\title{
Luka Ilić
}

\section{Theologian of Sin and Grace}

The Process of Radicalization in the Theology of Matthias Flacius Illyricus

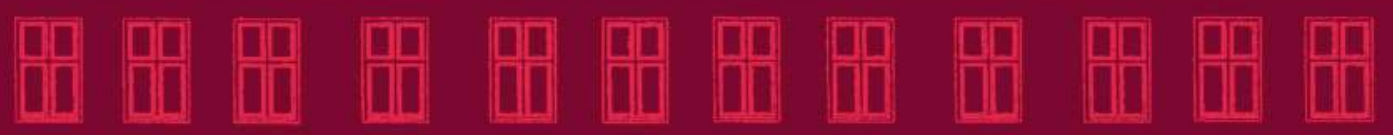 \\ 田田明明田田田田畞田

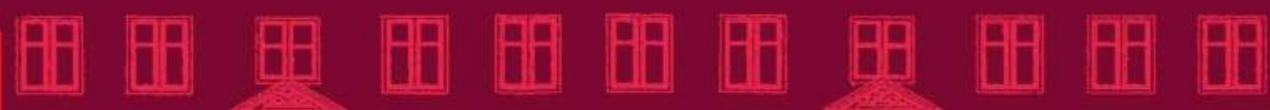

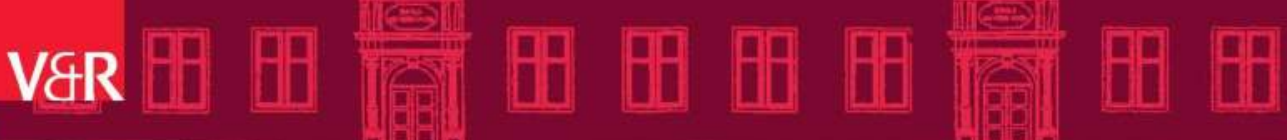




\section{V\&R}

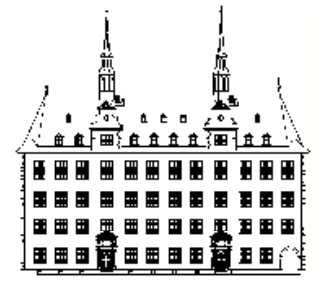




\title{
Veröffentlichungen des \\ Instituts für Europäische Geschichte Mainz
}

\author{
Abteilung für Abendländische Religionsgeschichte \\ Edited by Irene Dingel
}

Volume 225

Vandenhoeck \& Ruprecht 


\title{
Theologian of Sin and Grace
}

The Process of Radicalization in the Theology

of Matthias Flacius Illyricus

\author{
by \\ Luka Ilić
}

Vandenhoeck \& Ruprecht 


\section{With 11 figures}

Bibliographic information published by the Deutsche Nationalbibliothek The Deutsche Nationalbibliothek lists this publication in the Deutsche Nationalbibliografie; detailed bibliographic data available online: http://dnb.d-nb.de.

ISBN (Print) 978-3-525-10117-9

ISBN (OA) 978-3-666-10117-5

https://doi.org/10.13109/9783666101175

(C) 2014, Vandenhoeck \& Ruprecht GmbH \& Co. KG, Göttingen/ Vandenhoeck $\&$ Ruprecht LLC, Bristol, CT, U.S.A.

www.v-r.de

This work is licensed under the Creative Commons Attribution-

NonCommercial-NoDerivatives 4.0 International License. To view a copy of this license, visit http://creativecommons.org/licenses/by-nc-nd/4.0/.

Typesetting by Vanessa Brabsche 


\section{Table of Contents}

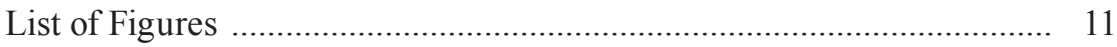

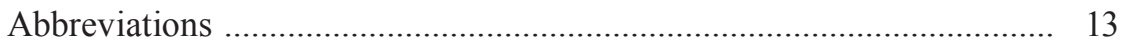

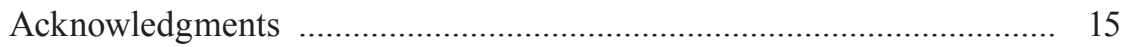

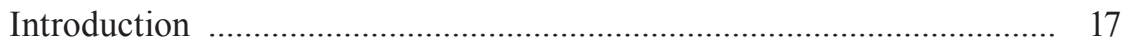

1. The Three Phases of Radicalization of Flacius' Theology .......... 19

2. Remarks on the Notions of Radicalism and Radicalization ......... 24

Chapter One:

Formative Years: The Pre-Radicalization Phase, 1536-1548 ….............. 29

1. Upbringing and Education within the Realm of La Serenissima Repubblica ....................................................... 30

2. North of the Alps: Peregrinatio academica and Early Network-Building ........................................................... 40

a) Augsburg ........................................................................ 40

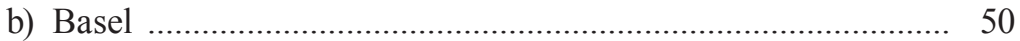

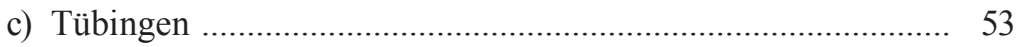

3. Wittenberg: Flacius' Theological Formation at the

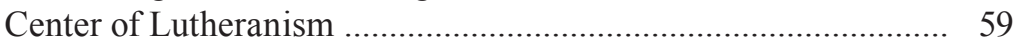

a) Flacius, A Disciple and Lifelong Follower of Luther ............... 61

b) A Complex Relationship: Philipp Melanchthon

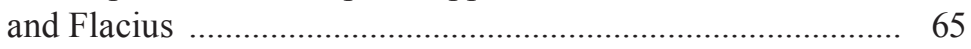

4. Concluding Remarks to Flacius' Early Years ……….................. 71

Chapter Two:

Phase One: The Shaping of Flacius' Theology

Through Controversies, 1548-1557 .................................................... 75

1. Flacius Becomes a Recognized Oppositional Figure,

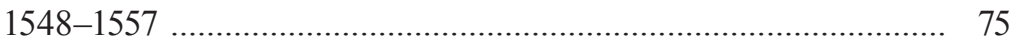

2. Intensification of the Persecution of Protestants under

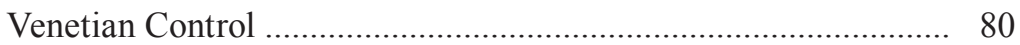

a) The Trial and Execution of Baldo Lupetino and its Impact on Flacius ........................................................... 82

3. Magdeburg, 1549-1557: Heading the Adiaphoristic Controversy 
4. Looking to Luther's Theology for Inspiration and Rationale to Resist the Augsburg Interim

5. The Majorist Controversy: The Role of Good Works in Salvation

6. Indecision Concerning the Future: Flacius' Intermediary Stop at Köthen

7. The Controversy with Andreas Osiander: The Nature of Divine Justification

8. The Debate between Schwenckfeld and Flacius: The Question of Scriptural Interpretation 115

9. Flacius' Church History Projects and Plans in Magdeburg ...... 118

a) Catalogus testium veritatis

b) The Magdeburg Centuries

10. The Second Eucharistic Controversy:

Flacius' Contribution to the Growing Distancing and Differentiation between Lutheran and Reformed Understandings

11. Summary of Flacius' Magdeburg Years

12. Excursus: Reception of Flacius' Concept of Adiaphora in the Twentieth Century

Chapter Three:

Phase Two: Flacius Within the Ecclesiastical

and Political Establishment in Ernestine Saxony, 1557-1562

1. An Academic Call: Flacius as Professor at the Newly Established University of Jena

2. A Dissenting Opinion: Flacius' Role in the Religious Colloquy of Worms

3. Flacius' Criticism of the Frankfurt Recess

4. Flacius' Attempt at Rooting Out »Particular Corruptions, Sects, and Errors«:

The Weimar Book of Confutation

5. The Synergistic Controversy:

The Role of the Human Free Will

6. The Weimar Disputation of 1560 and its Aftermath

7. Final Analysis of Flacius' Jena Years

Chapter Four:

Phase Three: Flacius' Attempts at Rehabilitation and Vindication, 1562-1575

1. A Wandering Scholar: Flacius' Time at Regensburg, 1562-1566 
a) Flacius' Missionary Plans: Endeavors at Establishing Theological Schools in Regensburg and Klagenfurt 163

2. Flacius against the Heidelberg Catechism, Erastus and Olevianus 166

3. Flacius and the Crypto-Calvinist Controversy in Nuremberg

4. Flacius Taking Sides in the Confessional Polemics Concerning the Eucharist in Royal and Ducal Prussia ............. 180

5. Evaluation of Flacius' Regensburg Years ................................. 184

6. A Tract in Clavis Scripturae: Flacius' Radical Exposition of Original Sin 188

7. Advising the Lutheran Church and Creating Antagonism: Antwerp, October 1566-March 1567

8. Finding Temporary Refuge in the Free Imperial City of Strasbourg, November 1567-June 1573

a) Flacius' Written Defense of His Doctrine on Sin ................ 201

b) Glossa: Flacius' New Testament Exegesis .......................... 213

9. Flacius' Desperate and Destitute Final Years: The Struggle to Clear His Name from Accusations of Heresy

10. Concluding Remarks on Flacius' Final Phase of Radicalization 228

Conclusion 229

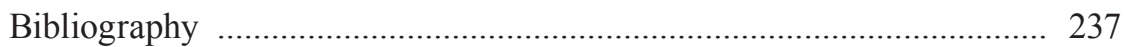

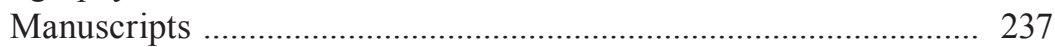

Primary Sources ..................................................................... 237

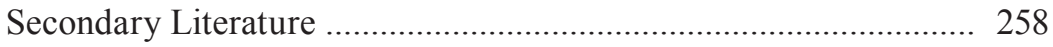

Website ............................................................................. 283

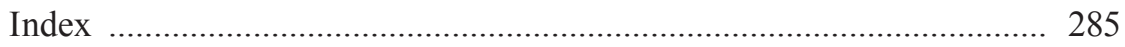

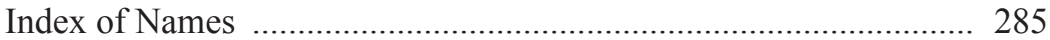

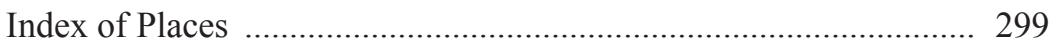





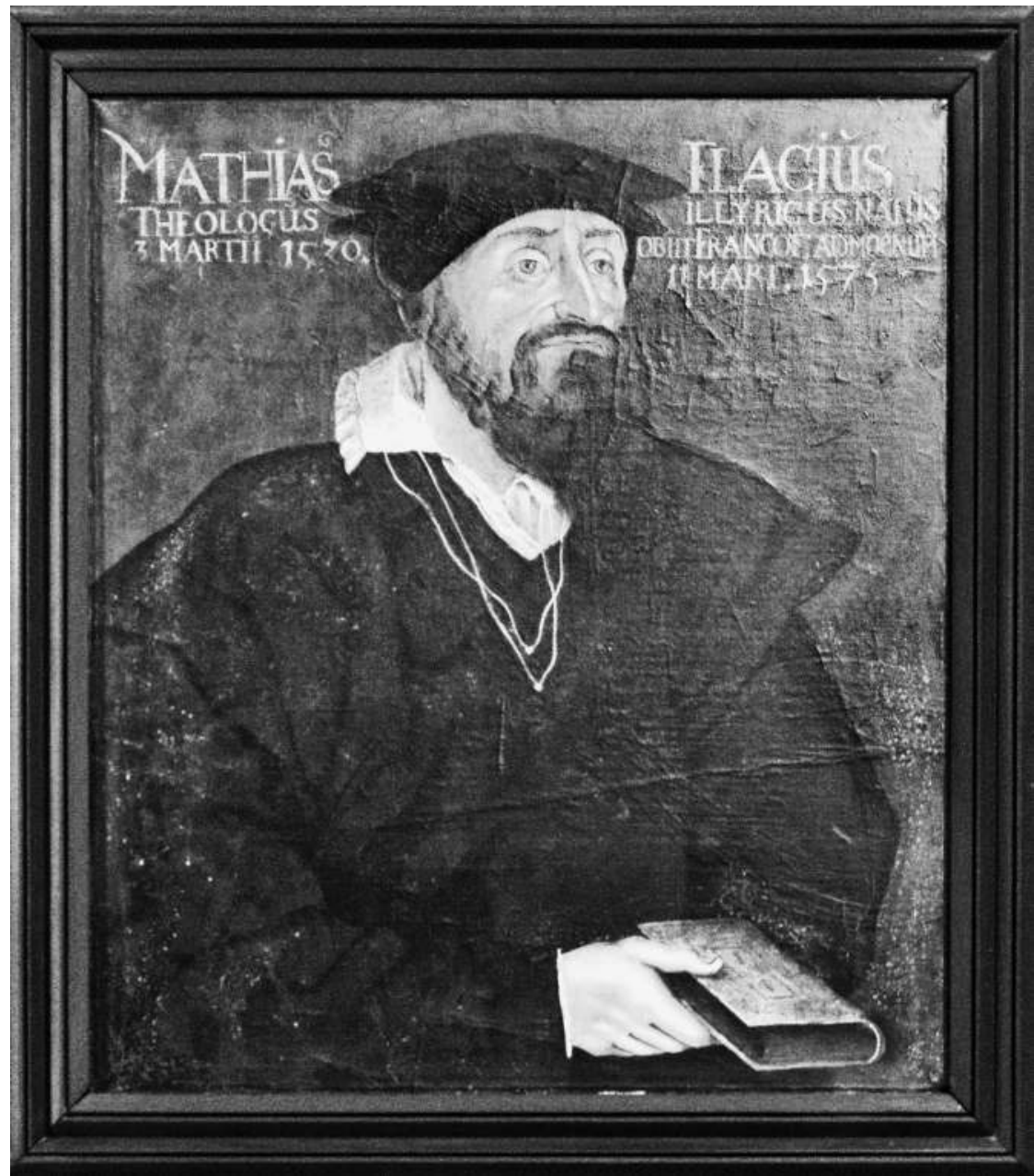

Figure 1: Portrait of Matthias Flacius Illyricus by Eugen Kokot from 1969, oil on canvas. Copy of the original by an anonymous sixteenth-century artist held at Friedrich Schiller University in Jena. Courtesy of Flacius Memorial Collection, National Museum Labin: shelfmark 510:LAB-102. 



\section{List of Figures}

1. Portrait of Matthias Flacius Illyricus by Eugen Kokot from 1969, oil on canvas

2. The title page of Vergerio's polemical work from 1563 against Ippolito Chizzola with Flacius' handwritten dedication to Wolfhart Herwart in Augsburg

3. Portrait of Achilles Pirmin Gasser from ca. 1571 drawn in red chalk

4. The title page of De voce et re Fidei from 1563 with Flacius' handwritten dedication to Ulrich Fugger in Augsburg

5. The title page of Nikolaus Medler's Ein wnnderlich gesicht newlich bey Braunschweig am hiemel gesehen from 1549 with Flacius' handwritten dedication to pastor Auctor Lampadius in Halberstadt

6. The title page of Flacius' Entschueldigung ... an einen Pfarher from 1549 with added information in sixteenth-century handwriting

7. The title page of Flacius' Dispvtatio de originali peccato et libero arbitrio from 1562 with his handwritten dedication to Georg Necker in Lindau

8. The title page of Flacius' Fidelis admonitio from 1562 with his handwritten dedication to Georg Necker in Lindau

9. A letter written in German in Flacius' handwriting from 1563

10. Flacius' Apologia ... contra Bezae cauillationes from 1566, dedicated to Wolfgang, Count of Palatinate-Zweibrücken

11. The title page of Flacius' Glossa Compendiaria from 1570 with his handwritten dedication to Achilles Pirmin Gasser 



\section{Abbreviations}

ADB Allgemeine Deutsche Biographie, ed. Historical Commission of the Bavarian Academy of Sciences, 56 vols. (Leipzig: Duncker \& Humblot, 1875-1912).

ARG Archiv für Reformationsgeschichte/Archive for Reformation History, 1903 -.

BBKL Biographisch-Bibliographisches Kirchenlexikon, ed. Friedrich Wilhelm Bautz, 34 vols. (Hamm/Nordhausen: Verlag Traugott Bautz, $1970-$ ).

BSB Bayerische Staatsbibliothek München.

CO Ioannis Calvini Opera Quae Supersunt Omnia, eds. Wilhelm Baum, Eduard Cunitz, and Eduard Reuss, 59 vols. (Braunschweig: Schwetschke \& Sons, 1834-1897).

CR Corpus Reformatorum: Philippi Melanthonis opera quae supersunt omnia, eds. Karl Gottlieb Bretschneider and Heinrich Ernst Bindseil, 28 vols. (Braunschweig: Schwetschke \& Sons, 1834-1860).

CS Corpus Schwenckfeldianorum: Letters and Treatises of Caspar Schwenckfeld von Ossig, eds. Chester Hartranft, Elmer Schultz Johnson, and Selina Gerhard Schultz, vols. 1-14 (Leipzig: Breitkopf \& Härtel, 1907-1936); vols. 15-19 (Pennsburg, PA: The Board of Publication of the Schwenckfelder Church, 1959-1961).

FBG Forschungsbibliothek Gotha.

HAB Herzog August Bibliothek Wolfenbüttel.

LW Luther's Works [American Edition], eds. Jaroslav Pelikan and Helmut T. Lehmann, 55 vols. (Philadelphia: Fortress and St. Louis: Concordia, 1955-1986). 
MBW Melanchthons Briefwechsel: Kritische und kommentierte Gesamtausgabe: Regesten and Personen, ed. Heinz Scheible et al., 25 vols. (Stuttgart-Bad Cannstatt: Frommann Holzboog, 1977-).

MBW T Melanchthons Briefwechsel: Kritische und kommentierte Gesamtausgabe: Texte, 12+ vols. (Stuttgart-Bad Cannstatt: Frommann Holzboog, 1991 -).

MSA Melanchthons Werke in Auswahl [Studienausgabe], ed. Robert Stupperich et al., 7 vols. (Gütersloh: Gerd Mohn, 1951-1975).

NDB Neue Deutsche Biographie, ed. Historical Commission of the Bavarian Academy of Sciences, 25 vols. (Berlin: Duncker \& Humblot, 1953 -).

StAR, Eccl. Stadtarchiv Regensburg, Ecclesiastica.

ThHStAW, Thüringisches Hauptstaatsarchiv Weimar, Ernestinisches GeEGA samtarchiv.

TRE Theologische Realenzyklopädie, ed. Gerhard Müller, Gerhard Krause et al., 36 vols. (Berlin: Walter De Gruyter, 1977-2004).

VD16 Verzeichnis der im deutschen Sprachbereich erschienenen Drucke des 16. Jahrhunderts.

WA Luthers Werke: Kritische Gesamtausgabe [Schriften], 80 vols. (Weimar: H. Böhlau, 1883-2009).

WA Br Luthers Werke: Kritische Gesamtausgabe: Briefwechsel, 18 vols. (Weimar: H. Böhlau, 1930-1985).

WA DB Luthers Werke. Kritische Gesamtausgabe: Deutsche Bibel, 15 vols. (Weimar: H. Böhlau, 1906-1961). 


\section{Acknowledgments}

This book is the fruit of many years of study and research that took me to countless libraries and archives. During this pursuit to learn more about Flacius' life and theology my wife often said that he had become an invisible but often present member of our family. As a dissertation this work was accepted by the faculty of the Lutheran Theological Seminary at Philadelphia and was defended on March 30, 2012. I owe my sincere gratitude to many people for helping me along the journey to this achievement.

Members of my dissertation committee deserve special mention: first and foremost my Doktorvater, Timothy J. Wengert, to whom I am thankful for all the insightful comments and thought-provoking conversations. Not only did he impart to me his thorough knowledge of the Reformation and particularly of Melanchthon but he always motivated me to do my best. Robert Kolb of Concordia Seminary, St. Louis posed perceptive questions that helped me move forward with the writing process. His encouragement at times was priceless. John Hoffmeyer provided further valuable feedback on my work.

Among the many others who shared their insights with me was Prof. Dr. Ann E. Moyer of the Department of History at the University of Pennsylvania. Her courses truly inspired me and the Latin reading group under her leadership with Daniel Cheely, Matthew Gaeteano and Martin Lohrmann was a further place of learning.

I am deeply indebted to Prof. Dr. Irene Dingel, Director of the LeibnizInstitut für Europäische Geschichte (IEG) in Mainz, for accepting this research for publication. Her discerning critique and constant reassurance helped this book receive its final form.

Several sources funded my doctoral studies in Philadelphia. I especially wish to thank the Northwest Ohio Synod of the Evangelical Lutheran Church in America (ELCA) with Bishop Marcus Lohrmann and the Rev. Dennis Maurer for their support. Professors Howard Louthan and Andrea Sterk from the University of Florida in Gainesville blessed me with their good advice as well as their resources. The four-month research stipend from the Forschungsbibliothek in Gotha in 2009 and the ten-month research grant I received from IEG 2010-2011 enabled me to continue with the work and complete the writing.

I further wish to thank the Rev. Dr. Henry Jansma of Haddon Heights, NJ for proofreading, my father-in-law, Dr. István Kontor for helping with the indexes, and Vanessa Brabsche for the layout of the text. My colleagues at IEG, Henning P. Jürgens, Christopher Voigt-Goy, Johannes Hund, Kęstutis 
Daugirdas and Marion Bechtold-Mayer deserve my gratitude for all the interaction and helpful comments they provided regarding this project. Former director of the National Museum and the Flacius Memorial Collection in Labin, Croatia and long-time friend, Tullio Vorano deserves special appreciation for all the practical help and encouragement with which he has supported my research on Flacius for many years. Another dear friend, ELCA Bishop of the Delaware-Maryland Synod, Wolfgang Herz-Lane was my conversation partner during many discussions about Lutheranism.

The illustrations in this book have been reproduced with permission of the following libraries and archives: Narodni Muzej Labin (1), Bayerische Staatsbibliothek München (2), Stadtarchiv Lindau (3, 7, 8), Universitätsbibliothek Heidelberg $(4,11)$, Universitäts- und Landesbibliothek Sachsen-Anhalt in Halle (5), Narodna in univerzitetna knjižnica Ljubljana (6), Stadtarchiv Regensburg (9), Sveučilišna knjižnica u Puli (10). I would especially like to thank the librarians and archivists Tijana Barbić-Domazet, Dr. Bruno Dobrić, Marijan Rupert and Heiner Stauder for their assistance.

The publication of the present volume has been funded from the following sources, to whom I wish to express my gratefulness: Vereinigte Evangelisch-Lutherische Kirche Deutschlands; Evangelisches Dekanat Mainz (especially Dekan Andreas Klodt); Evangelische Kirche in Mitteldeutschland; Evangelische Kirche in Hessen und Nassau; Selbständige Evangelisch-Lutherische Kirche; Evangelisches Dekanat Weinsberg (especially Dekan Georg Ottmar); Gustav-Adolf-Werk Württemberg (especially Ulrich Hirsch) and the Croatian Kulturgemeinschaft of Wiesbaden.

A profound debt of gratitude goes to my wife, Dr. Angela Ilić, who supported me unconditionally throughout the entire process, while working on her own dissertation. Thank you for sharing this exhausting but also exhilarating experience with me! While finishing this manuscript, my father, Velimir Ilić passed away and our daughter, Mattea Zoe Ilić was born. It is to his memory and to her life full of promise that this book is dedicated.

Mainz, on the day commemorating St. Elisabeth of Hungary, 2013

Luka Ilić 


\section{Introduction}

The focus of the present monograph is to offer a theological biography of the Croatian-born Lutheran theologian Matthias Flacius Illyricus, paying special attention to the way major life events impacted the course of his theology, which became increasingly radicalized with time. Concurrently, the book places Flacius and his written works within the broader context of the political and ecclesiastical power structures and developments of his day, including the process of confessionalization taking place in German-speaking territories at the time. The study does not aim to provide a comprehensive and detailed look at every single episode in Flacius' life; instead, it focuses on the major turning points, what led up to them and how they influenced Flacius' career and theological stances.

Flacius belonged to the second generation of evangelical theologians, who were students of Martin Luther and Philipp Melanchthon. He was theologically active during a challenging period in the history of the young Protestant church as it was trying to gain legitimacy and recognition in the Holy Roman Empire while attempting to solidify its theology and its practices and navigate the world of religious diplomacy. This was also a turbulent time in the Empire, accentuated by numerous upheavals. Some of these events, such as the Smalcaldic War, the siege of Magdeburg, and the occupation of Antwerp by Spanish troops impacted Flacius directly.

Considered to be one of the more controversial figures among sixteenthcentury theologians, Flacius has received some attention from scholars throughout the centuries but extensive study of significant parts of his large theological opus is still lacking. A cursory review of recently published literature reveals that there is renewed interest in Flacius. ${ }^{1}$ However, it can be noticed that there are only a few prevailing topics among researchers that are usually covered. Those are his historical works Catalogus testium veritatis and Ecclesiastica Historia (The Magdeburg Centuries), his contribution to hermeneutics and philosophy, and a biographical interest in his fascinating life. It seems that Flacius' legacy receives the greatest attention from historians, philosophers and linguists but significantly less from theologians. Since research has tended to label Flacius a pugnacious polemicist

1 Luka Ilić, »A Review of Publications About Matthias Flacius Illyricus between 1992 and 2007, in Marina Miladinov (ed.), Matija Vlačić Ilirik II: Proceedings of the Second International Conference on Matthias Flacius Illyricus, Labin/Croatia, 2006 (Labin: Grad Labin, 2008), 247-271. 
and an uncompromising Lutheran, the diversity of his theology, elements of which had been inspired by Melanchthon, has often been overlooked. His farreaching influence as a church historian and founder of Protestant historiography and his significance as a philologist, philosopher and polymath who, among others, was interested in politics, astrology and geography deserve further attention. A new and comprehensive academically oriented biography is therefore still needed. Since Flacius never published a systematic account of his theology or loci as such, for his understanding of Christian dogmas one must turn to the many disputations and controversies in which he was involved during his life. There are also no critical editions of his works or of his correspondence.

Scholarly study of Flacius is currently most prominent in Germany and Croatia, the two countries with the most personal ties to him. From the three influential and important biographies that have been written about Flacius so far, two stem from these countries. Wilhelm Preger, in his two-volume work Matthias Flacius Illyricus und seine Zeit ${ }^{2}$ was committed to the confessional Luther research of the mid-19 ${ }^{\text {th }}$ century, which accordingly made its theological mark on this account. Mijo Mirković, whose Croatian-language Matija Vlačić Ilirik first appeared in print in Yugoslavia in 1960, followed an approach influenced by socialist historians and presented his hero as a ProtoYugoslav, examining and evaluating Flacius in light of socialist concerns. ${ }^{3}$ Oliver Olson in Matthias Flacius and the Survival of Luther's Reform allows his biographical representation to be led at times by predispositions that are bolstered by the liberal-conservative disputes within contemporary American Lutheranism. ${ }^{4}$ In his biographical work Olson covers only the period from Flacius' birth in 1520 until his appointment to the chair of the New Testament studies at the University of Jena in 1557. Olson has also published a number of articles in his determined effort to promote the study of the man, whom he believes is to be credited with the continuation of the Reformation in accordance with Luther's theology.

2 Wilhelm Preger, Matthias Flacius Illyricus und seine Zeit (Erlangen: Theodor Bläsing, 18591861), 2 vols. Reprinted by Hildesheim: Georg Olms Verlag, and Nieuwkoop: B. de Graaf, 1964.

3 Mijo Mirković, Matija Vlačić Ilirik [Djela Jugoslovenske akademije znanosti i umjetnosti 50] (Zagreb: Izdavački zavod Jugoslovenske akademije, 1960). Reprinted as two volumes, [Istra kroz stoljeća II: 9-10] (Pula: Čakavski sabor - Istarska naklada; Rijeka: Liburnia, 1980).

4 Oliver K. Olson, Matthias Flacius and the Survival of Luther's Reform [Wolfenbütteler Abhandlungen zur Renaissanceforschung 20] (Wiesbaden: Harrassowitz, 2002). 


\section{The Three Phases of Radicalization of Flacius' Theology}

The in-depth inquiry into Flacius' life and works informs the formulation of the central thesis in this book, namely that Flacius became more and more theologically radicalized during his lifetime. The progression of his radicalization and his theological journey are therefore divided into three phases and are portrayed accordingly throughout the text. The three phases correspond to the stages in Flacius' academic and ecclesiastical career. Due to the biographically influenced nature of the book its overall structure follows a chronological format.

The principal argument behind developing the three phases is that certain external events and critical junctures in Flacius' life influenced his theology in a direct way and contributed to the process of its radicalization. The fundamental goal of the research is therefore to present a narrative bringing together the life and theology of Flacius, placing special emphasis on investigating how the political and ecclesiastical developments in his day together with the turning points in his own life played a role in shaping his theological positions. Although Jörg Baur has already observed that the nature of Flacius' theology was radical, ${ }^{5}$ no one has reconstructed this development sequentially and in detail before.

The different stages of Flacius' theological radicalization are recognized and divided after identifying key events and turning points that marked significant changes in his life and shifts in his theological formulations. The time period leading up to the first phase covers the years of young Flacius' studies, formation, and the influences he encountered first in Venice and then, after travelling north of the Alps, during his time in Augsburg, Basel, Tübingen, and finally in Wittenberg. This time concurrently marks the beginnings of Flacius developing his wide-ranging and diverse professional and personal network. The years between 1536 and 1548 have thus been identified as the pre-radicalization phase.

The first phase of radicalization began around 1548 and lasted until 1557, a time that Flacius spent mostly in Magdeburg. During those years he was presenting his theological arguments from a stance of opposition, for which he was recognized and consequently rose to leadership among those GnesioLutherans critical both of the imperial policies in the Augsburg Interim and of the Electoral Saxon counterproposals - the so-called Leipzig Interim, among others - which he was convinced were aimed at the re-catholicization

5 See his article written for the $400^{\text {th }}$ anniversary of Flacius' death, Jörg Baur, »Flacius - Radikale Theologie, « in Matthias Flacius Illyricus 1575-1975 [Schriftenreihe des Regensburger Osteuropainstituts 2] (Kallmünz: Lassleben, 1975), 37-49. Reprinted in Zeitschrift für Theologie und Kirche 72 (1975): 365-380. 
of the Protestant territories. ${ }^{6}$ Flacius was also becoming known as a polemicist, who was debating in print theologians such as Andreas Osiander, Caspar Schwenckfeld von Ossig, and Georg Major.

The second and relatively short phase of radicalization covers the time Flacius spent in Jena between 1557 and 1562. During this period, he acceded to positions of power and influence both within the church and at the university, which he used to continue his sharp criticism of those theologians and ecclesiastical leaders he disagreed with. He also issued written attacks and condemnation of groups he considered to be sects or opposed to Luther's teaching. Flacius used his newly attained leverage in Jena to contribute to the process of intra-Lutheran confessionalization and division, insisting upon adherence to the Unaltered Augsburg Confession of 1530 - as opposed to the later editions called Variata - along with its Apology and Luther's Smalcaldic Articles as the only norms for the true interpretation of the Wittenberg theology; documents that he understood to be both apostolic and prophetic.

The dismissal of Flacius and of his colleague Johannes Wigand from the University of Jena on December 10, 1561 and the ban on them from having any public involvement in churches or schools on the territory of Ernestine Saxony acted as the catalyst for ushering in the third phase of radicalization in Flacius' life. This final phase lasted from 1562 until his death in 1575. From 1562 onward he lived in exile, moving from place to place and finding refuge for limited periods of time in Regensburg, Antwerp, Strasbourg, and finally in Frankfurt am Main. When his exile began, Flacius published a work with the revealing title, Comforting Exhortations to Christians who are Persecuted because of God's Word? ' In it he used Luther's pastoral encouragement that he had provided to the persecuted Protestants in 1530 and applied it to his own situation, presenting himself as a victim of maltreatment by the political authorities incited by theologians who opposed him. He then dedicated the remaining thirteen years of his life to attempting to clear his name and justify his theological stances - albeit without readiness to compromise. The controversy over original sin that Flacius was heavily embroiled in played a central role in this phase. By refusing to rephrase his formulation that sin is the substance of the human being, Flacius was perpetuating the polemics through his long line of publications in defense of his position. The culmination of his

6 For the comparison of the texts of these two documents and their analysis, see Günther Wartenberg, »Das Augsburger Interim und die Leipziger Landtagsvorlage zum Interim, « in Irene Dingel and Günther Wartenberg (eds.), Politik und Bekenntnis. Die Reaktion auf das Interim von 1548 [Leucorea-Studien zur Geschichte der Reformation und der Lutherischen Orthodoxie 8] (Leipzig: Evangelische Verlagsanstalt, 2006), 15-32.

7 Flacius, Troestliche Vermanungen an die Christen/so vmb GOTTES Worts willen verfolgt werden. Durch / Doctor Martin Luther gestelt/Anno. 1530. (s.1.: 1562; VD16 L 3731). 
theological radicalization was signaled by his rejection to take the advice of his fellow theologians and friends, whom he alienated with his ever sharper words and eventually turned them into enemies.

Banishment from a number of cities in the Holy Roman Empire of the German Nation, coupled with the personal contacts he had cultivated in them, all played a key role in Flacius' theological development. His constant migration contributed to shaping Flacius' characteristic theological process, in which he did not first formulate his own positions, but rather the reverse: he would most often begin from a place of opposition, attacking the theological statements put forth by others and in the process of polemicizing against them eventually coming to articulate his own stances more clearly and thoroughly. It is not as though other theologians, including even Martin Luther, did not have their theologies sharpened by opposition. Flacius, however, almost always published his theology from a reactive position, with the possible exceptions of Catalogus testium veritatis and Clavis Scripturae.

In addition to the outward circumstances of his life, Flacius interpreted events taking place at that time from a strongly apocalyptic point of view. He saw the Protestant defeat in the Smalcaldic War and the arrest of Elector Johann Friedrich I as a sign and indication of the Last Days that were mere reflections of the struggle portrayed in the Book of Revelation. ${ }^{8}$ The resulting capitulation of Wittenberg, which impacted Flacius and his family directly as they were pressed to leave the city and move to Braunschweig, further contributed to his radical interpretation of his own situation. Concurrent to events within the Holy Roman Empire, Flacius was also receiving reports about the conquest of the Ottoman Turks in central and southern Europe and about the situation of the Protestants living in the territories under Ottoman dominion. ${ }^{9}$ The rapid Turkish advance through the Balkans and Hungary, together with their repeated attempts at taking Vienna, all contributed to

8 See for example direct quotes from chapters 16:2 and 18:2-3 on the title page of Wider Das INTERIM. Papistische Mess/Canonem/vnnd Meister Eissleuben/durch Christianum lauterwar/zu dieser zeit nützlich zu lesen. Anno. 1549 (Magdeburg: Michael Lotter, 1549; VD16 F 1554), where Flacius applies the Scripture verses to the Interim, equating the acceptance of the Augsburg Interim to the worship of the Beast.

9 A good example is a letter he received from Emerich Zigerius from Osijek in present-day eastern Croatia and which he published while in Magdeburg with his own seven-page-long preface. See, Epistola Cvivsdam Pii Concionatoris, ex Turcia, ad M. Illy. missa, qualis nam status Euangelij, \& Ecclesiarum sub Turco sit indicans, cum Praefatione Illyrici (Magdeburg: Christian Rödinger d.Ä., 1549; VD16 Z 464). A German edition was issued in the following year: Ein schrifft/eines fromen Predigers aus der Tuerckey an Jllyricum geschrieben/Darinnen angezeiget wird/wie es dort mit der Kirche vnd dem Euangelio zugehet (Magdeburg: Michael Lotter, 1550; VD16 Z 465). There is also a Hungarian translation of the letter. See, Mihály Bucsay, »Ein Brief von Imre Eszéki an Flacius, « in Tibor Bartha (ed.), Studia et Acta Ecclesiastica III (Budapest: A Magyarországi Református Egyház Zsinati Irodájának Sajtóosztálya, 1973), 905-910. Zigerius developed a friendship with Flacius in 1544-1545 while he was a 
creating an apocalyptic anxiety among the populations throughout the western part of Europe, including the German-speaking lands..$^{10}$ In addition to the growing circulation of printed materials, such as pamphlets and woodcuts that placed the Turkish threat into an eschatological context, the churches also played a role in spreading this fear through sermons. ${ }^{11}$ Luther himself contributed to the heightened awareness of the menacing Turks. ${ }^{12}$ An example is Luther's hymn, Lord, Keep Us Steadfast in thy Word that begins with the words,

Lord, keep us in thy Word and work,

Restrain the murderous Pope and Turk,

Who fain would tear from off thy throne

Christ Jesus, thy beloved Son. ${ }^{13}$

Casting the Turks into the role of infidels and enemies of Christ and placing them into the same category as the Pope, whom he viewed as the Antichrist, reveals how Luther saw these two powers as equally antithetical to the Gospel. ${ }^{14}$ The fall of Buda, the capital city of the Kingdom of Hungary, in 1541

student at Wittenberg. We learn from Flacius' preface that Zigerius was forced to suddenly leave Wittenberg due to illness. See also, Thomas Kaufmann, »Sendbrief: Epistola cuiusdam pii concionatoris ex Turcia ...« in Das Ende der Reformation. Magdeburgs »Herrgotts Kanzlei« (1548-1551/2) [Beiträge zur historischen Theologie 123] (Tübingen: Mohr Siebeck, 2003), 286-294 for the discussion of the Zigerius' letter to Flacius.

10 See, Robin Bruce Barnes, Prophecy and Gnosis: Apocalypticism in the Wake of the Lutheran Reformation (Stanford, CA: Stanford University Press, 1988).

11 See, Thomas Kaufmann, "Türckenbüchlein«: Zur christlichen Wahrnehmung »türkischer Religion « in Spätmittelalter und Reformation [Forschungen zur Kirchen- und Dogmengeschichte 97] (Göttingen: Vandenhoeck \& Ruprecht, 2008), especially chapter seven »Der eschatologische Horizont «; Gregory J. Miller, »Luther on the Turks and Islam,« in Timothy J. Wengert (ed.), Harvesting Martin Luther's Reflections on Theology, Ethics, and the Church [Lutheran Quarterly Books] (Grand Rapids: Eerdmans, 2004), 185-203.

12 For a very detailed study of all the Luther's writings against the Turks and Islam see a Habilitationsschrift by Johannes Ehmann, Luther, Türken und Islam. Eine Untersuchung zum Türken- und Islambild Martin Luthers (1515-1546) [Quellen und Forschungen zur Reformationsgeschichte 80] (Gütersloh: Gütersloher Verlagshaus, 2008).

13 Luther's hymn opens with the following stanza: »Erhalt uns, Herr, bey deinem Wort/und steur des Bapst und Türcken Mord/Die Jhesum Christum, deinen Son/Wolten stürtzen von deinem Thron.« WA 35: 467-468, see also the history of this song on pages 235-248. Flacius used the words of this song to write a prayer at the end of Etliche klare vnd treffliche Zeugnussen/ D. Martini Luthers/von dem bo(e)sen Wesen/Essentia, Bild/Form oder Gestalt des jrdischen todten Adams / vnd von der Wesentlichen transformation oder Verwandelung des Menschen: Aus welchen die Verkerung der Wo(e)rter/vnd der Sache/auch die falsche Lere der Sophisten/vnd des Papistischen Accidens kan vberaus wol ero(e)rtert werden. Matth. Flac: Illyr: (s.1.: 1574; VD16 L 3533), C3v: »Der Almechtige/Ewige vnd genedige Gott vnd gu(e)tige Vater wehre jnen/erhalte auch bey vns sein heylsames Wort/vnd stewre des Bapsts/seiner Schweirganten vnd Tu(e)rcken mord/vmb seines lieben Sons/vnsers Herrn Jesu Chisti willen/Amen."

14 See, Mark U. Edwards Jr., Luther's Last Battles: Politics and Polemics, 1531-46 (Ithaca/ 
added a new dimension of anxiety in the Empire as the Turks were coming ever closer. Luther's hymn Erhalt uns, Herr, bei deinem Wort (1542) was sung in the churches of Magdeburg during the city's siege in 1550-1551 and it was especially printed during that time in a collection of hymns and psalms for the purpose of strengthening the faith of the citizens. ${ }^{15}$ The siege was interpreted by Lutherans there as the battle between Christ and Belial. ${ }^{16}$

Such apocalyptic interpretations in Flacius' thinking contributed to heightening his perception of his own work's importance and added a sense of immediacy. By attempting to prove that he was the one who was being true to the Word of God and had the truth, he concurrently cast those with whom he disagreed as servants of the devil, standing on the same side as the Antichrist. According to Flacius, Rome and by extension the Pope was the Antichrist, predicted in the Old Testament book of the prophet Daniel. ${ }^{17}$ In light of his belief that the end times were nearing rapidly and that Christ was returning soon, he considered it of critical importance to ensure that the evangelical church held on to - what he considered to be - true doctrine.

Flacius was by no means alone in his apocalyptic emphasis: this worldview was particularly characteristic of those Lutherans who often described themselves as exiles for Christ, signing their letters and publications as »Exul,«»Exul Christi,«»Exul pro Nomine Christi,« or »Exul et Servus Jesu Christi. $\ll^{18}$ Most of them began using that term after they lost positions as pastors or deacons as a result of not being willing to comply with the stipulations of the Augsburg Interim. ${ }^{19}$

London: Cornell University Press, 1983), 97-114; Gottfried Seebass, »Antichrist IV: Reformation und Neuzeit, « TRE 3 (1978), 28-43.

15 Enchiridion Geistliker Leder vnd Psalmen/vppet nye gebetert. Mart. Luther. Mit einem nyen Calender schoen thogericht. Gedrueckt tho Magdeborch/Jn der Belagerung/Jn grother vahr/Dar ys dith vulendet gar/Den XXX. May/Dat ys war (Magdeburg: Hans Walther, 1550/51; VD16 G 939). Flacius quotes the first verse of the hymn in the conclusion of the preface. See, Ein register der hundert beschwerungen/damit Deudschland von dem Bapst vnd den seinen jemmerlich beschwert/vnd vberladen/ja gentzlich verterbt wird/auffm Reichstage zu Nu(e)rnberg Anno 1523. von dem Reich dem Bapst vbersendet. Mit einer kurtzen Vorrede Matth: Fla. Illyr: (Magdeburg: Christian Rödinger d.Ä., 1551; VD16 R 733), A2v.

16 The siege of Magdeburg lasted from September 22, 1550 until November 5, 1551.

17 Flacius even named his second son Daniel, who was born in Magdeburg [the first son received his name, Matthias] which shows how important the prophet was to him.

18 See the following two monographs for treatments of apocalyptic thought in sixteenth-century Lutheranism: Volker Leppin, Antichrist und Jüngster Tag. Das Profil apokalyptischer Flugschriftenpublizistik im deutschen Luthertum 1548-1618 [Quellen und Forschungen zur Reformationsgeschichte 69] (Gütersloh: Gütersloher Verlagshaus, 1999); Anja Moritz, Interim und Apokalypse. Die religösen Vereinheitlichungsversuche Karls V. im Spiegel der magdeburgischen Publizistik 1548-1551/52 [Spätmittelalter, Humanismus, Reformation 47] (Tübingen: Mohr Siebeck, 2009).

19 Evangelicals living in Magdeburg started identifying themselves as exiled believers already in 1548, with Nikolaus von Amsdorf as the first among them. For his first publication as »exul Christi« see, Kaufmann, Das Ende der Reformation, 86-90. Apart from von Amsdorf, 
Another pivotal argument in the book is that Flacius' understanding of original sin is the linchpin for his radicalization and for much of his work. This is shown through pointing out that in seemingly unrelated controversies, especially in the Majoristic and Osiandrist ones, the issue of human fallenness arose. A detailed examination of Flacius' Defense of the Sound Doctrine Concerning Original Righteousness and Unrighteousness, or Sin, ${ }^{20}$ penned five years before his death, provides the capstone of this argument. Moreover, through the recounting of the Defense it is demonstrated how Flacius related other controversies in the second half of the sixteenth century to the discussion on original sin, which eventually became the first article of the Formula of Concord.

\section{Remarks on the Notions of Radicalism and Radicalization}

There are two significant and potentially problematic issues connected to the use of the term »radicalism« to describe individual or group-related principles and practices in early modern Europe. First, it must be considered that radicalism is a modern-day term projected onto historical situations. The circumstances several centuries ago were governed by forms of social, political and ecclesiastical order that were very different from those experienced in modern-day societies. Therefore determining when and how to use it must be considered carefully. Second, so far no consistent definition of the term within the context of early modern European developments has been offered. Neither Baur, nor the authors in the edited volume on radicalism

Nikolaus Gallus and Erasmus Alber also used that description for themselves, joined later by Tilemann Heshusius in 1564 [VD16 H 3147], Petrus Eggerdes, Christoph Irenaeus, Joachim Magdeburg and a number of other Gnesio-Lutherans. This phenomenon was characteristic not only of Germany but also appeared elsewhere, used by individuals in separate instances and in an uncoordinated manner. After the Slovenian Reformers Primus Truber and Paul Wiener were banished from Laibach because of their opposition to the Augsburg Interim in 1548, they both began referring to themselves as »exul Christi.« Truber found refuge in Württemberg, while Wiener moved to Hermannstadt in Siebenbürgen. Pietro Paolo Vergerio also strongly identified with this epithet (the words exul Christi even appear on his tombstone in the Stiftskirche St. Georg in Tübingen). The last example is the Croatian-born Paul Skalich, who employed the words »exul Christi« for himself. For more about him, see Ludwig Theodor Elze, »Skalich, Paul,« in ADB 34 (1892), 443-444; Gerta Krabbel, Paul Skalich. Ein Lebensbild aus dem 16. Jahrhundert [Geschichtliche Darstellungen und Quellen 1] (Münster: Borgmeyer, 1916). For the »exul Christi« phenomenon see also, Irene Dingel's article »Die Kultivierung des Exulantentums im Luthertum am Beispiel des Nikolaus von Amsdorf, in Irene Dingel (ed.), Nikolaus von Amsdorf (1483-1565) zwischen Reformation und Politik [Leucorea-Studien zur Geschichte der Reformation und der Lutherischen Orthodoxie 9] (Leipzig: Evangelische Verlagsanstalt, 2008), 153-175.

20 Flacius, Defensio sanae doctrinae de originali ivstitia ac iniustitia, aut peccato, Matth. Flac. Illyr. (Basel: Pietro Perna, 1570; VD16 F 1336). 
in the early modern period have provided an explanation of the term that is precise enough and concurrently takes into consideration the specificities of the historical era to which it refers. ${ }^{21}$

While it does not fall within the scope of the present study to develop detailed theoretical definitions, a few observations connected to Flacius' radicalism and radicalization are to be made in order to help delineate an operational characterization of these phenomena. In Flacius' case the process of radicalization was not limited only to his theological positions but also included aspects of his stances against authorities. Thereby it was developing along parallel lines: theological and ecclesiastical-political. The former informed and inspired the latter and the latter impacted his views of the society he lived in and the specific events he experienced. At the same time, Flacius' gradual radicalization, as this monograph asserts, grew out of his varied reactions to what was happening in the establishment and it was fueled by his apocalyptic interpretation of events around him as signs of the approaching end times. Most of the time he was critical of the direction taken by the respective authorities, as they were making decisions based on theological stances that he was rejecting with increasing intensity. Flacius' way of radicalism was only one of many possible reactions to the developments in the second half of the sixteenth century and it was not limited to him but eventually found a following that cultivated his radical ideas even further.

One of the central elements of Flacius' radicalism, which was manifested already in the first phase and reached its peak in the third, was his attitude that lacked any willingness to compromise. Indeed, in the face of criticism and opposition, he refused to change his mind and even sharpened his theological formulations, signaling that he was not ready for any rapprochement. Such extreme behavior reaching well beyond non-conformity caused Flacius to be further and further removed from the theological and ecclesiastical mainstream, and his ideas therefore less acceptable to a broad audience. His stances concerning adiaphora and later, original sin, aptly illustrate this progression. In the end, he was cornered and was focusing all of his energy on the defense of his positions, constantly calling for a synod of the evangelical church so that he could defend himself in person in front of his accusers instead of only through writing.

Flacius' growing alienation manifested itself in the political realm as well: his theological radicalism was considered by most territorial rulers as dangerous, due to his reputation for refusing to compromise or make peace with people he disagreed with. In the era of Roman Catholic-Protestant differentiation and increasing intra-Protestant confessional conflicts rulers wanted

21 Günter Mühlpfordt and Ulman Weiß (eds.), Kryptoradikalität in der Frühneuzeit [FriedensteinForschungen 5] (Stuttgart: Franz Steiner Verlag, 2009). 
to achieve unity in their territories and to find broad consensus that all sides involved could agree to. As a result Flacius lost the little support he had from political leaders and made enemies, as nobody wanted him to live and work in places under their governance.

It is in light of the preceding considerations that the central questions guiding the research in this monograph have been formulated. First, the book sets out to explore what specific events and developments in Flacius' personal life and within the broader context of his day impacted his theological positions. Second, on the basis of the findings, it strives to map the radicalization process through his theological opus and through his actions. Third, it examines the personal and professional networks built by Flacius in order to determine how he utilized them for diverse purposes throughout his life.

In search for answers, the research turned to significant parts of Flacius' written legacy. From 1547 onward Flacius produced more than two hundred printed works, broadsheets and illustrated pamphlets, which were accompanied by an extensive correspondence. For the present monograph, a large number of Flacius' theological, philosophical and historical works were examined. His letters also served as an important source of information, as they allow - in addition to the printed literature - a valuable insight into the personal and intellectual horizons within which Flacius' works emerged.

During the first period of radicalization and in addition to the publication of numerous polemical writings Flacius began to strategically use his correspondence for shaping public opinion and for intervening in the course of the ongoing theological disputes. Eventually, Flacius' conceptual thinking and his targeted approach to building his Europe-wide network became reflected in his correspondence. As he was preparing his church history projects, he addressed in writing a number of important scholars at home and abroad to collect expert opinions on his plans. ${ }^{22} \mathrm{He}$ turned to potential patrons as he was searching throughout Europe to find original sources and painstakingly organized travel for his staff to numerous libraries - not least through writing letters of recommendation.

In the process of conducting research for this book many of Flacius' original publications were consulted. The fact that close to one hundred of Flacius' works and the content of a number of letters he wrote and received are currently available in digital format mainly through library networks in Germany has aided the work by making a large quantity of information readily and simultaneously available. Through studying the primary sources it

22 For a recent edition of a number of letters and other documents from that period, see Harald Bollbuck (ed.), Historische Methode und Arbeitstechnik der Magdeburger Zenturien. Edition ausgewählter Dokumente [Editiones Electronicae Guelferbytanae 11] (Wolfenbüttel: Herzog August Bibliothek, 2012). http://diglib.hab.de/wdb.php?dir=edoc/ed000086 (accessed June 3, 2013). 
became clear that much about Flacius' life is not yet fully known, as some of the elements and dimensions missing from previous accounts about Flacius emerged, prompting to place one of the main emphases in this work on presenting his biography with special attention paid to his writings. Furthermore, the present work references and interacts with the few existing biographies of Flacius throughout, along with a broad spectrum of secondary literature pertaining to the related subjects examined in the text. 



\section{Chapter One}

\section{Formative Years: The Pre-Radicalization Phase, 1536-1548}

This introductory chapter provides an overview of the early biography of Matthias Flacius Illyricus, focusing on both his Catholic upbringing in the Venetian-controlled part of the Istrian Peninsula ${ }^{1}$ and the experiences of his adulthood as a foreigner and immigrant north of the Alps in primarily Protestant milieux. In addition to taking into account the key events of his life, the chapter investigates the formative influences, including the political and cultural context of his familial background and childhood. Departing his native country and being uprooted also had an impact on Flacius, who after his conversion to Lutheranism could not return to his »sweetest homeland « (dulcissima patria $)^{2}$ of Istria any longer because of the Roman Catholic counter-reformation and can therefore be considered a true sixteenth-century religious refugee (Glaubensflüchtling).

Indeed, as an adult Flacius never settled in one place for a longer period of time but kept constantly moving from city to city. The scholarly networks that he built up served to facilitate the exchange of ideas and provided Flacius with a system of support that he lacked as a result of his not being settled in one location permanently. The purpose here is not to repeat what others have already written; but to point out the shortcomings by the main previous biographers of Flacius. On the one hand, Preger and Olson both place

1 Control over the Istrian Peninsula at the time of Flacius' childhood was divided between the Venetian Republic which ruled the coastal regions and the Habsburg Monarchy to which parts of the inland belonged. For a sixteenth century historical account of the region, contemporary to Flacius, written by an official historian of Venice, see Pietro Bembo, History of Venice, vol. 3, Books IX-XII, edited and translated by Robert W. Ulery, Jr. [The I Tatti Renaissance Library 37] (Cambridge, MA: Harvard University Press, 2009).

2 This is the term that Flacius often used when referring to his place of origin. In a letter written to the Senate of Venice, dated on June 26, 1570 and sent from Augsburg, he writes: »...quod mea dulcissima patria sub vostro dominio protectioneque est; ubi ego natus et ferme usque ad 20 aetatis annum educatus sum.« A copy of the letter is stored at the University Library of Pula, box XXII. See also a paragraph in Clavis Scriptvrae, seu de Sermone Sacrarum literarum, plurimas generales Regulas continens, Altera Pars. Avthore Matthia Flacio Illyrico Albonense (Basel: Eusebius Episcopius, 1581; VD16 F 1309), 336: »... in Istria, mea dulcissima patria.« The original publication of Clavis Scripturae dates to 1567 but I will be using the second edition from 1580/1 throughout the rest of the text because it is digitally available. 
minimal significance on Flacius' first twenty-one years, and thus begin their works with his arrival in Wittenberg in $1541 .{ }^{3}$ On the other hand, Mirković's standard Croatian interpretation of Flacius intentionally pays considerable attention to the young Flacius but avoids discussing his theology. ${ }^{4}$

The present chapter will also look at Flacius not only through the lens of the many theological controversies in which he was involved but also in light of his becoming an exile and a political and ecclesiastical refugee a number of times in his life. As will become clear throughout this book, by examining this constant interplay between his life and his theology one can more fully understand Flacius and his works.

\section{Upbringing and Education within the Realm of La Serenissima Repubblica}

Matija Vlačić (Matthias Flacius) was born on March 3, 1520 in Albona (now Labin), on the east coast of the Istrian peninsula, at the time under the control of Venice, La Serenissima Repubblica, approximately five kilometers from the Adriatic Sea in present-day Croatia. The town had once been part of the ancient Roman province of Illyria, which comprised largely the Western part of the Balkan Peninsula. People from Illyria were also referred to as Slavs. By the sixteenth century, Roman rule was long gone but many individuals, especially the well-educated, used the Latin epithet »Illyrian«/»Illyricus« in order to describe their place of origin, while hinting at their ethnic and linguistic identity. A few notable examples include the Franciscan friar Thomas Illyricus from Dalmatia, who lived most of his life in France and was one of the early literary opponents of Luther. ${ }^{5}$ Petar Gučetić [Gozze] from Dubrovnik in the Republic of Ragusa, who was professor at both the Universities of Paris and Louvain and later Bishop of Ston in Croatia, was known as »Doctor Illyricus«. Between 1537 and 1565 a number of students who matriculated at the University of Tübingen were listed as »Illyrian. $\ll^{6}$

3 Preger, Matthias Flacius Illyricus und seine Zeit, 1: 13-21; Olson, Matthias Flacius and the Survival of Luther's Reform, 25-38.

4 See in particular the foreword by Josip Bratulić in the reprinted edition of Mirković's Matija Vlačić Ilirik, 1980.

5 For his biography, see Wilhelm Kohl, »Thomas Illyricus (Th. v. Osimo, Th. Elysius, ital. Tommaso Illirico), « in BBKL 11 (1996), 1388-1390.

6 See Theodor Elze, Die Universität Tübingen und die Studenten aus Krain: Festschrift zur vierten Säcularfeier der Eberhard-Karls-Universität (Tübingen: Franz Fues, 1877; reprint [Geschichte, Kultur und Geisteswelt der Slowenen 14] München: Rudolf Trofenik, 1977), 64-67. 
Matija Grbac, or Matthias Garbitius, was the first known Protestant from the Balkans to place »Illyricus« after his name.

As for Flacius, others had been referring to him as the Illyrian when he was in Germany long before he began using the same designation for himself. ${ }^{8}$ Flacius, an undistinguished young man at the beginning of his career, was being called by the land of his origin, a reference that he later embraced, as is evident in how he signed his publications. In one early publication he listed his position as »reader of Hebrew at Wittenberg" on the title page after his name as additional information to identify himself. ${ }^{9}$ By late 1549 the term Illyricus appeared on all of his works while up to that point he hid his identity. ${ }^{10}$ During that year a large number of materials, bearing Flacius' name in the capacity of writer, editor, or author of a foreword, were made public. ${ }^{11}$

7 For more about Garbitius, see Karl August Klüpfel, »Garbitius, Matthias, « in ADB 8 (1878), 367; »Garbitius, Matthias, « in MBW 12: Personen F-K, 118; Đuro Körbler, »Humanista Matija Grbić (Mathias Garbitius Illyricus), in Rad Jugoslavenske akademije znanosti i umjetnosti, Knjiga 145 [Razredi filologijsko-historijski i filosofijsko-juridički 55] (Zagreb: Knjižara

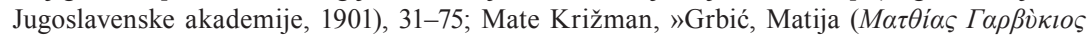

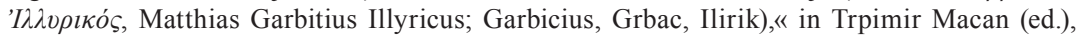
Hrvatski biografski leksikon 5: Gn-H (Zagreb: Leksikografski zavod Miroslav Krleža, 2002), 138-139; Otto Clemen, »Zwei Briefe von Tübinger Universitätsprofessoren an Melanchthon, « Zeitschrift für württembergische Landesgeschichte 4 (1940): 76-82.

8 One example is a letter by Chancellor Gregor von Brück to Elector of Saxony Johann Friedrich I written in 1544 and recommending Flacius for a teaching appointment at the University of Wittenberg. Throughout the letter Brück refers to Flacius five times, never using his Christian name or family name but only calling him Illyricus. However, it is clear from the introduction that he is writing about Flacius: »Gnedigster herr. E[ure] churf[ürstliche] g[nade] wissen sich gnediglich zu erinnern, das sie nehst alhie bewilligten, auch dem Philippo befehlen lassen, das dem Illirico das halbe stipendium von der Hebreischen lectio solt assignirt.« Later in the letter Brück makes an observation: »Zu diesem schreiben bewegt mich am allermeisten diss, das ich in der kirchen gesehen, wie sich feine junge gesellen umb gemelten Illiricum uf den feirtagen fugen mit hebreischen buchlein, die sie lesen, und wo sie mangel haben, so fragen sie inen, so gibt er inen bescheit und unterrichtet sie guetwillig, das ich achten kan, er wurde den schulern sehr nutz sein. « The edited letter was published by Walter Friedensburg as an appendix to the article »Die Anstellung des Flacius Illyricus an der Universität Wittenberg, « ARG 11 (1914): 308-309.

9 Flacius, Ein vermanung zur bestendigkeit/in bekentnis der warheit/Creutz/vnd Gebett/in dieser betruebten zeit sehr nuetzlich vnd troestlich/durch M. Matthiam Flacium Jllyricum/ Hebreischen leser zu Wittenberg (Magdeburg: Michael Lotter, ca. 1550; VD16 F 1522).

10 Another proof that in the period immediately after he relocated from Wittenberg to Magdeburg Flacius did not sign his name on the title page but identified himself as the author inside the treatise is found in Ein rechter lesteriger Rabsakes brieff/geschrieben von einem Bischoff an einen Christlichen Fuersten/in welchem er ihn vermanet das er sol von der erkanten warheit Christi zu dem Antichrist abfallen/Daraus man sehr woll kan mercken wie gut es die Antichristische Wolffe mit den armen Schefflein Christi meinen (Magdeburg: Christian Rödinger d.Ä., 1549; VD16 ZV 10271). This is a work against the Archbishop of Mainz, Sebastian von Heusenstamm, in which Flacius compares him to King Sennacherib of Assyria who wanted to destroy Jerusalem during the reign of King Hezekiah of Judah, see 2 Kings 19.

11 A simple search in the bibliographic database VD16 yields forty-five publications for the year 1549 . 
Up to that point he had been publishing anonymous pamphlets against the Augsburg Interim and the Papacy. ${ }^{12}$

Due to Flacius' increased visibility, by 1550 his name on the cover page of a penitential sermon by Georg Buchholzer appeared only as Matt. Fla. Illy. Flacius printed this sermon in Magdeburg through Christian Rödinger, ${ }^{13}$ and the abbreviation suggests that he had become known so that it was not necessary to spell out his full name any more, as readers would have recognized who the author was. ${ }^{14}$ As early as February 1551, a book was dedicated to

12 Several of Flacius' works were published under the following names: Johannes Waremundus (John the Truthful), Ein gemine protestation vnd Klagschrifft aller frommen Christen wieder das Jnterim vnnd andere geschwinde anschlege vnd grausame verfolgung der wiedersacher des Euangeli/allen Gotfuerchtigen gewissen/zu dieser betrübten zeit/vberaus sehr nuetzlich vnnd troestlich zu lesen. Durch Joannem waremundum (Magdeburg: Michael Lotter, 1548; VD16 F 1405); Theodorus Henetus (the Wend), Ein kurtzer bericht von Jnterim/darauss man leitlich kan die leer vnd Geist desselbigen Buchs erkennen/Durch Theodorum Henetum allen fromen Christen zu dieser zeit nützlich vnnd tröstlich (Magdeburg: Michael Lotter, 1548; VD16 F 1440); Johannes Hermanus, Das man in diesen geschwinden laufften/dem Teuffel vnd Antichrist zugefallen/nichts in den Kirchen Gottes vorendern soll. Durch Johannem Hermannum (Magdeburg: Michael Lotter, 1548; VD16 H 2352); Christianus Lauterwar (Christian the Pristine), Wider Das INTERIM. Papistische Mess /Canonem /vnnd Meister Eissleuben / [a nickname for Johannes Agricola ... (Magdeburg: Michael Lotter, 1549; VD16 F 1552)]; and Carolus Azarias [Azarias = Abednego, a name taken from the book of Daniel 1:7], Wider den Schnöden Teuffel/der sich jtzt abermals in einen Engel des liechtes verkleidet hat/das ist wider das newe INTERIM/Durch Carolum Azariam Gotsburgensem. M.D. XLIX (Magdeburg: Christian Rödinger d.Ä., 1549; VD16 F 1559). For a detailed discussion of these editions, see Andreas Waschbüsch, Alter Melanchthon: Muster theologischer Autoritätsstiftung bei Matthias Flacius Illyricus [Forschungen zur Kirchen- und Dogmengeschichte 96] (Göttingen: Vandenhoeck \& Ruprecht, 2008). The texts of three of these works (Henetus, Waremundus and Lauterwar) are now printed in a critical edition in Irene Dingel (ed.), Reaktionen auf das Augburger Interim: Der Interimistische Streit (1548-1549) [Controversia et Confessio. Theologische Kontroversen 1548-1577/80: Kritische Auswahledition, vol. 1] (Göttingen: Vandenhoeck \& Ruprecht, 2010), $88-113 ; 132-179 ; 742-770$. There is also another pseudonym attributed to Flacius, that of Publius Aesquillius, reminding the reader of the custom of attaching satirical writings to the Roman statue of Pasquil. The title of the work is Ein Sendbrieff/P. Aesquillij von dem tode Pauli/des dritten Babsts dieses namens, Jtem/Was jhm nach seinem tode/begegnet ist. Mit zweien Vorreden (Magdeburg: Christian Rödinger d.Ä., 1550; VD16 V 667). In the preface to this German translation issued by Flacius, however, he states that he is not author of this pasquinade, A3v. The original was written in Latin by Pietro Paolo Vergerio, the Younger shortly after Pope Paul III died and published in Basel in December 1549 [VD16 V 665]. The authorship of this anti-papal satire has for a long time been attributed to Flacius but it has recently been refuted by Anne Overell and Scott C. Lucas, „Whose wonderful news? Italian satire and William Baldwin's Wonderfull Newes of the Death of the Death of Paule the III, « Renaissance Studies 26/2 (2012): 180-196.

13 The publisher and the date of its printing do not appear on the work itself. Ulrich Kopp, an expert at identifying sixteenth-century prints from HAB determined the year and the exact publisher for VD16.

14 Georg Buchholzer and Flacius, Ein Prophetische/Buspredigt für die jenigen/So/den erkanten vnd bekanten Christum mit/dem Antichrist vnd seinem hauffen verfolget haben/oder noch verfolgen./Mit einer Vorrede Matt. Fla. Illy./G. B. Propst zu Berlin (Magdeburg: Christian Rödinger d.Ä., 1550; VD16 ZV 25014). Oliver Olson correctly states that the fact Flacius 
Flacius, ${ }^{15}$ and throughout the rest of his life he wrote forewords for others and many authors recognized him in their works.

Flacius kept signing his publications as Matthias Flacius Illyricus (albeit in a variety of combinations) but toward the end of his life there was a noticeable change to what had become his standard signature. After having been involved in a number of theological controversies, dismissed from the University of Jena and become a persona non grata in Regensburg, Flacius did not stay in one city for extended periods. The lack of a residence he could call home perhaps coupled with nostalgia for his place of origin prompted him to add »Albonensis« to his name. ${ }^{16}$

In the first part of his major hermeneutical work Clavis Scripturae Sacrae (Key to the Holy Scriptures) which he completed in February 1567 Flacius writes about his hometown: »My native city, the old town, which writers have in the past and also today call Albona, supposedly because of the

printed this sermon may be ascertained from Flacius’ own words: »... hab ich diese Buspredigt ... wollen druecken lassen, « A1r. However, Olson is mistaken in using the work to build an argument that Flacius published it in 1547 and that he opposed Johannes Agricola already then. It is true that the sermon is dated on Jubilate Sunday of 1547. Flacius' detailed critique of adiaphora in the foreword clearly suggests that he wrote it later, since the full blown adiaphoristic controversy had not yet begun at that time. Also, in 1547 Flacius was mostly in Braunschweig and was still on good terms with Melanchthon. This is one example of how Olson uses original texts he cites in a selective way in order to further his argument without carefully reading and presenting the sources. See Olson, Flacius and the Survival of Luther's Reform, 118.

15 Hevs Germani/Cognoscite ex hac epistola quid de uobis sentiat \& praedicet beatissimus Papa. Tum etiam uidete quale consilium/cum suis creaturis celebraturus sit. En tibe me hostem inquit Dominus exercituum, qui subducam fimbrias tibi supra faciem tuam, \& ostendam gentibus pudenda tua, renisque foeditatem tuam [Basel: Johannes Oporinus, 1551; VD16 ZV 15180]. This work was written by Pietro Paolo Vergerio, under the pseudonym Laurentius Millematius Histrius (Istrian), and dedicated to Flacius. Friedrich Hubert established that Vergerio is indeed the author of this publication against the Council of Trent. See, Vergerios publizistische Thätigkeit nebst einer bibliographischen Übersicht (Göttingen: Vandenhoeck \& Ruprecht, 1893), 84-86. The dedicatory foreword was dated on February 13, 1551 in Val Bregaglia, an alpine valley in Graubünden, Switzerland. The German translation, Was/vnnd wie man sich zue dem künftigen Concilium zue Trydent/versaehen moege. Auch was gůtts dauon zue verhoffen, was published in 1551 in Bern by Matthias Apiarius [VD16 ZV 22736].

16 The earliest occurrence that I have been able to find where he added his birthplace to his name is on the title page of the second part (Altera pars) of his work Clavis Scripturae ... as Matthia Flacio Illyrico Albonense (the preface dedicated to the Landgaves Wilhelm IV and Ludwig IV, the sons of Landgrave Philipp I of Hesse who had died earlier that year, is dated on August 1, 1567 in Frankfurt), (Basel: Paul Queck; VD16 F 1307). Two further examples are from 1570: the title page of his Glossa on the New Testament reads, Glossa compendiaria M. Matthiae Flacij Illyrici Albonensis in nouum Testamentum (Basel: Pietro Perna and Theobald Dietrich, 1570; VD16 B 4214); and a letter written to the Venetian senate with the date of June 26 which he signed as »magister Matthias Flacius Illyricus Albonensis«. The letter is kept at the State Archives of Venice, Sant'Ufficio, b. 162. According to Mijo Mirković, Flacius also signed a number of his unpublished works on which he worked in the last few years of his life as Albonensis and which are stored at HAB today. See, Mirković, Matija Vlačić Ilirik, 440. 
white ground on which it is situated, ${ }^{17}$ is called Labin in the language of the common people [...]. $\wedge^{18}$ In the twentieth century Mijo Mirković extensively researched population census results in Labin and its surrounding areas, cadasters, notary books and other primary documents that provided more details about Flacius' family. Matthias grew up as the youngest of six children, alongside two brothers and three sisters. His father was Andrija Vlačić, a small landowner, who died when Matthias was twelve years old. His mother was called Jacobea (Jakovica) Luciani, daughter of a wealthy and powerful Albonian civic family, who most likely died giving birth to Flacius. The Lucianis were related to the local Lupetino family through marriage Jacobea's brother, Luciano Luciani married Ivanka Lupetina, the sister of Baldo Lupetino [Lupetina in Croatian], who would later play an important role in Flacius' life. Most likely Flacius was baptized in the parish church of the Blessed Virgin Mary's Birth located in the heart of the old town of Labin. ${ }^{19}$ Upon his baptism he was given the name of the saint closest to his date of birth, that of St. Matthias.

The name Franković should also be mentioned, although scholars up to this day have not been able to agree about exactly how this family was related to Flacius (Mirković speculates that it may have been the result of a double last name resulting from marriage, or a family nickname). ${ }^{20}$ Flacius matriculated at the University of Basel in 1539 using the name Mattheus de Francistis [Franković] de Albona. ${ }^{21}$ The same family name appears on a payment slip at the University of Wittenberg from 1545 that he himself signed as Mathias Francovich Illyricus. ${ }^{22}$

17 Much of the terrain of the Istrian Peninsula consists of a limestone plateau. Flacius is most likely referring to the hill of white limestone that Labin sits atop. Even today the most mountainous part of Istria is commonly referred to as White Istria (Bijela Istra), due to its characteristically colored stone.

18 Flacius, Clavis Scriptvrae S., seu de Sermone Sacrarum literarum, Authore Matthia Flacio Illyrico. Pars Prima: in qva singvlarvm vocvm atqve locotionum S. Scripturae usus ac ratio Alphabetico ordine explicatur (Basel: Eusebius Episcopius, 1580; VD16 F 1309), 533 [under the explanation of the word Levana]: »Patria mea, vetus oppidum, vocatum tum olim à scriptoribus, tum \& nunc Albona, credo ab albedine soli, in quo situm est, vulgari lingua vocant Labin .....

19 Unfortunately, there are no existing baptism records. The church underwent major reconstruction in 1336 and was enlarged in 1420. For the history of the building, written by its parish priest, see Vilim Grbac, Crkva rođenja Blažene Djevice Marije (Labin: Župni ured i naklada Matthias Flacius, 1988).

20 Mirković, Matija Vlačić Ilirik, 7.

21 The full entry reads, »Matheus de Francistis de Albona Polensi Dioec. [esi] in Illirico, sub Venetorum dicione, pauper« in Hans Georg Wackernagel (ed.), Die Matrikel der Universität Basel im Auftrag der Universität Basel, vol. 2 (1532-1601), (Basel: Verlag der Universitätsbibliothek, 1956), 22, Nr. 4.

22 Friedensburg, »Die Anstellung des Flacius Illyricus, «307 n. 
It cannot be stated with absolute certainty when and where Flacius began his education. What is known is that from 1434 until ca. 1780 the San Francesco monastery of the Order of Friars Minor (Franciscans) existed in Lower Labin (Podlabin), where the monks also ran a school. ${ }^{23}$ It was established by the patrician families Lupetino and Luciani. ${ }^{24}$ Baldo Lupetino, a friar of the Franciscan Minorite order, had been living at this monastery, of which he became superior around 1535. It is highly likely that young Matthias received instruction from the friars and was a student there. However, some early biographers of Flacius offer another point of view, asserting that the Milanese scholar Franciscus Ascerius was Flacius' tutor in Albona for a period of time. Among them are Heinrich Pantaleon's book, Heroes of the German Nation, ${ }^{25}$ and Caspar Ulenberg, the early seventeenth-century Roman Catholic biographer of Flacius. ${ }^{26}$

Young Matthias arrived in La Serenissima Repubblica in 1536 at the age of sixteen, in the year Desiderius Erasmus of Rotterdam died. By that time, Venetian humanism, with its ties to Erasmus, had already become well-established. At the beginning of the sixteenth century, Aldus Manutius' publishing house had attracted a group of clerics and scholars in the so-called Aldine Academy, ${ }^{27}$ among whose founding members was the prominent Renaissance humanist Giovanni Battista Egnazio. ${ }^{28}$ Egnazio was a friend of

23 Herman Stemberger, Labinska povijesna kronika: povijesne skice Kožljaka, Čepića, Kršana, Šumbera (Labin: Radničko sveučilište, 1983), 27; Vedran Kos, »Podlabin, « Istarska Enciklopedija (Zagreb: Leksikografski zavod Miroslav Krleža, 2005), 603. Mirković states that the monastery was dissolved by Venice in 1794. Mirković, Matija Vlačić Ilirik, 18. In any case, the monastery closed shortly before the collapse of La Serenissima in 1797.

24 Stemberger, Labinska povijesna kronika, 27.

25 Heinrich Pantaleon, Der dritte vnd letste Theil Teutscher Nation Heldenbuch: Jn diesem werden aller Hochberuempten Teutschen Personen Geistlicher vnd Waelticher hohen vnd nideren staths Leben vnd nam̃haffte tathen gantz waarhafftig beschriben ... vnder den vier letsten Keyseren Maximilian I. Carolo V. Ferdinando vnd Maximilian II. von dem 1500 biss auff das lauffende 1570 jar ... Erstlich durch den Hochgelehrten Herren Heinrich Pantaleon zum theil auß vieler voelckeren Historien ... in Latein zusamen gebracht vnd mit sampt vieler personen bildnussen fürgestellet. Jetzmalen aber von dem Authore selbs verteutschet reichlich gemehret geenderet vnd gebesseret (Basel: Nikolaus Brylinger (Erben), 1570; VD16 P 234), 426-429, here 427: »... warde in dem Vatterland durch Franciscum Ascerium ein Meylender underrichtet.«

26 Caspar Ulenberg, Historia de vita, moribus, rebus gestis ac denique morte Praedicantium Lutheranorum, D. M. Lutheri, Ph. Melanchthonis, Matthiae Flacii Illyrici, Georgi Maioris et Andreae Osiandri (Köln: Gualterus, 1622), 373 [posthumously published by Arnold Meshov: VD17 23:249651M]. This work is also translated into German and published in two volumes as Geschichte der lutherischen Reformatoren Dr. Martin Luther's, Philipp Melanchthon's, Matthias Flacius Illyricus, Georg Major's und Andreas Osiander's (Mainz: Kirchheim, Schott und Thielman, 1836-1837). Flacius' biography can be found in volume two, on pages 308-373.

27 Martin Lowry, The World of Aldus Manutius: Business and Scholarship in Renaissance Venice (Ithaca: Cornell University Press, 1979), 113.

$28 \mathrm{He}$ also used the pseudonym »Cipelli« and the agnomen »Venetus, « referring to his city of origin. Pierre Bayle, »Egnatius (Jean Baptiste), « in Dictionnaire Historique et Critique, Par 
Erasmus, with whom he kept occasional correspondence until 1534. ${ }^{29}$ Egnazio also corresponded with Philipp Melanchthon. ${ }^{30}$ Egnazio collaborated on preparing many classical texts for publication, including works by Cicero and others, as well as the second enlarged edition of Erasmus' Adagia which was printed by the Aldine officina in $1508,{ }^{31}$ and also published brief biographies of Roman, Byzantine, and Medieval Western emperors, as well as a work on the origins of the Turks. ${ }^{32}$ From 1520 until 1549 Egnazio held the public chair of Greek at the school of San Marco. By the time he came to occupy this position, the school, founded in the mid-fifteenth century, had already developed an emphasis on philology and had appointed an official historiographer as well. ${ }^{33}$

Flacius came to study at the school of San Marco and was taught by Egnazio during his three-year-long stay. Egnazio introduced young Flacius to humanistic ideas and to Erasmus' works, including his translation of the New Testament into Latin from the original Greek. Furthermore, Flacius became familiar with the humanist emphasis to return to the study of original sources (ad fontes), as exemplified both by Manutius, who focused on collecting the Classics and publishing them, and by his own teacher Egnazio. The discipline

Mr. Pierre Bayle. Cinquieme Edition, Revue, Corrigée, et Augmentée. Avec la Vie de l'Auteur, Par Mr. Des Maizeaux, vol. 2: C-I (Amsterdam/Leiden/Den Haag/Utrecht, 1740), 345-346.

29 See R.A.B. Mynors and Douglas F.S. Thomson (eds.), The Correspondence of Erasmus: Letters 142-197 (1501-1514), vol. 2 (Toronto: University of Toronto Press, 1975), 243. For the relationship between Egnazio and Erasmus see Martin J.C. Lowry, »Giambattista Egnazio of Venice, 1478 - 4 July 1553, « in Peter G. Bietenholz (ed.), Contemporaries of Erasmus, 2 vols. (Toronto: University of Toronto Press, 1986), 1: 424-425. In the 1518 preface to a new edition of Suetonius' De Vita Caesarum, Erasmus wrote the following about Egnazio, who edited a volume of the same work by Suetonius after Manutius' death: »When I had just finished preparing this edition, there arrived a Suetonius printed by Aldus, but with the text emended by Egnazio, a man eminent for both character and learning, two qualities needed equally, in my opinion, by anyone who undertakes to edit or comment on the production of antiquity. For my part, I bear the death of my friend Aldus with greater resignation when I see that in this department of restoring the text of the classics he has a successor capable of overshadowing the dead man's reputation... « English translation by R.A.B. Mynors and D.F.S. Thomson, as published in Peter G. Bietenholz (ed.), The Correspondence of Erasmus: Letters 594 to 841 (1517 to 1518), vol. 5 (Toronto: University of Toronto Press, 1979), 98, Letter 648: »To The Reader, [Louvain 1517].

30 See MBW T 6 (1484: 191-192); MBW T 12 (3294: 293-295) for samples of their correspondence from 1534 (Egnazio to Melanchthon) and 1543 (Melanchthon to Egnazio). See also the German translation of Melanchthon's letter to Egnazio from August 1543 in Günther Frank and Martin Schneider (eds.), Melanchthon deutsch III: Von Wittenberg nach Europa (Leipzig: Evangelische Verlagsanstalt, 2011), 249-251.

31 James Bruce Ross, »Venetian Schools and Teachers Fourteenth to Early Sixteenth Century: A Survey and a Study of Giovanni Battista Egnazio, Renaissance Quarterly 29/4 (1976): 521-566, here 538-539.

32 A list of Egnazio's major published works [including translations and editions of classical authors] up until 1544 can be found in Waschbüsch, Alter Melanchthon, 13-14, n. 57.

33 J. B. Ross, »Venetian Schools and Teachers, « 534. 
of studying Ancient languages and collecting and publishing classical sources eventually became Flacius' lifelong pursuit, at which he excelled as an adult. ${ }^{34}$ Apart from studying at the school located near the central Piazza of San Marco, Flacius also attended open sessions of the city Senate and the Great Council, the major governing body of the Republic of Venice. He was interested in both the public life of the city and the state politics ${ }^{35}$ and later stated that from among the many speakers he had heard he still remembered a particular speech given by the Senator and later Cardinal, Gasparo Contarini, who spoke favorably about the Protestant Reformation. ${ }^{36}$

Although Flacius was now living away from his native land, it did not mean that he lost all contact with his fellow Istrians and other Slavs. In the sixteenth century the Venetian Republic ruled over large parts of Istria, the islands of the northern Adriatic and the Dalmatian littoral, with the exception of southern Dalmatia that belonged to the independent Republic of Ragusa (Dubrovnik). Considering that Venice also occupied a central place in Mediterranean trade, many Croats came to live there, and a significant colony grew up in the Castello district of the city. ${ }^{37}$ The fishermen, seafarers and merchants arriving at the harbor from the Eastern Adriatic coastline and the islands were collectively referred to as Schiavoni in the Venetian dialect. ${ }^{38}$ To satisfy the religious and social needs of the growing Croatian-speaking population, the School (also referred to as Confraternity, Guild Hall, and Church) of Saints George and Tryphon was founded in $1451 .{ }^{39}$ The building served as a central meeting place to both the local Croatian community and the other visiting Slavic speakers. There were also books in Croatian that

34 Martina Hartmann, Humanismus und Kirchenkritik: Matthias Flacius Illyricus als Erforscher des Mittelalters [Beiträge zur Geschichte und Quellenkunde des Mittelalters 19] (Ostfildern: Jan Thorbecke, 2001), 16.

35 Flacius himself mentioned those things in a letter written to the Senate of Venice on June 26, 1570 .

36 Flacius' teacher Egnazio belonged to the circle of close friends of Contarini and perhaps he advised his student to attend speeches of his highly admired patrician associate. For more about the friendship between Egnazio and Contarini, see James Bruce Ross, »Gasparo Contarini and His Friends, « Studies in the Renaissance 17 (1970): 192-232.

37 John Van Antwerp Fine, When Ethnicity Did Not Matter in the Balkans: A Study of Identity in Pre-Nationalist Croatia, Dalmatia, and Slavonia in the Medieval and Early-Modern Periods (Ann Arbor, MI: University of Michigan Press, 2006), 118-119.

38 The presence of Croats is evidenced by the names of islands, such as Brač (Bracia), Rab (Arbe), Cherso (Cres) and Hvar (Lesina) that have been carved into the Venetian docks. This is most probably how the waterfront immediately east of St. Mark's Square and the Palace of the Doge got the name it still bears today: Riva degli Schiavoni (the Dock of the Slavs).

39 The name of this primarily immigrant establishment is Scuola di San Giorgio degli Schiavoni. The main (lower) hall contains a cycle of paintings by Vittore Carpaccio, which he completed between 1502 and 1507, already as an accomplished local artist. This points to the wealth and prominence of this community. For the complete works of Carpaccio see http://www.vittore carpaccio.org/ (accessed December 22, 2011). 
were published in Venice before and during the time Flacius lived there. ${ }^{40}$ Since it was entirely conceivable that one could hear Croatian spoken at the docks and in the marketplace, receive news from home, get hold of books in Croatian, and have regular contact with fellow Slavs, living in the Republic of Saint Mark did not mean a complete break with Flacius' native culture and language. Flacius did learn to speak fluent Italian while in Venice, as he stated in 1548 when he offered to accompany Melanchthon if he were to attend the Roman Catholic Council of Trent. As one of the reasons making him fitting for this task, Flacius listed his Italian language skills. ${ }^{41}$

Already during his time in Venice, Flacius expressed interest in studying theology and asked Baldo Lupetino to be received into his order and sent to continue his studies at a monastery in either Padua or Bologna. ${ }^{42}$ Apparently while in Venice Flacius often attended church services and sang Psalms in a choir. ${ }^{43}$ As Caspar Heldelin, the Younger, stated in the funeral oration (Leichenpredigt) for Flacius, it was at this time, at the age of seventeen, that his zeal and love for theology were already manifested. ${ }^{44}$

40 For example, a work based on the Biblical story from the Deuterocanonical Book of Judith by the Croatian humanist Marko Marulić from Split (Marcus Marulus Spalatensis), was published in Venice in 1521. The facsimile of the whole publication can be found at www.bulaja.com/ Marulic/marul.htm (accessed January 2, 2011). For his biography, see Franz Posset, »Marulić, Marko (Marcus Marulus), « in BBKL 31 (2011), 942-47.

41 Flacius, Apologia Matthiae Flacij Illyrici ad Scholam Vitebergensem in Adiaphororum causa/Eiusdem Epistola de eadem materia ad Philip. Melantho./Item quaedam alia eiusdem/generis/... (Magdeburg: Michael Lotter, 1549; VD16 F 1264); see also MBW 5340 (Regesten 5: 376) and 5556 (Regesten 5: 481-482) for the context of Apologia which was written on August 10, 1549 and published in October), D3r-v: »... quod non minus amaverim Praeceptorem, quam quisquam alius, quod eo signo probo, quod cum ante annum et dimidium quotidie expectabatur, ut vocaretur ad Concilium Tridentinum, idque summo ac certo eius comitumque; periculo fieri existimaretur, non semel ei coram obtuli, me, quoniam Italicam linguam callerem, cuius ibi usus esset, libentissime ei sive liber, sive captus fuerit, famulaturum esse. « See also the German text, Entschueldigung Matthiae Flacij Jllyrici/geschrieben an die Vniuersitet zu Wittemberg/der Mittelding halben. Item sein brieff an Philip. Melanthonem/sampt etlichen andern schrifften dieselbige sach belangend. Verdeudscht (Magdeburg: Christian Rödinger d.Ä., 1549; VD16 F 1266): H5r »...das ich den H. Philippum mehr geliebt habe/denn irgent ein Ander/und will das hiemit Beweisen. Denn als man fur anderthalbem jare sich teglich versahe/das er gen Trent/auffs Concilium/wuerde gefordert werden/welchs (wie jederman meinte) on seine vnd seiner gefehrten/grosse vnd gewisse gefahr/nicht geschehen konnte/Da hab ich mich jm mehr denn ein mal angettragen/da ich jm/weil ich welsch [Italian] (welches man des orte gebraucht) konnte/herzlich gern famuliern wollte/er wuerde gefangen oder nicht.«

42 Flacius, Apologia ... ad Scholam Vitebergensem, B3r.

43 Heinrich Pantaleon, Teutscher Nation Heldenbuch, 427.

44 Heldelin, Eine Christliche predigt vber der Leiche des Ehrnwuerdigen vnd hochgelerten Herrn/M: Matthiae Flacij Jllyrici/Weiland getrewen Dieners vnd bestendigen Merterers Jesu Christi/fromen hertzen zu gut gestellet/Durch M. Gasparem Heldelinum Lindauiensem. 
Baldo, whom he calls the brother-in-law of his uncle (der Schwager meines Oheims $),{ }^{45}$ held the position of provincial at the monastery of San Francesco della Vigna ${ }^{46}$ in Venice at the time. Although Lupetino first seemed to agree with Flacius' intentions, as the two developed a closer relationship over time, the friar revealed his views about Reformation ideas and ended up giving Matthias different counsel:

[Baldo] told me how Luther has brought the Gospel back into honor, gave me his writings and advised me to go to Germany, not to a monastery, if I wanted to study theology. I was right away joyful and ready to do this and a few weeks later I traveled to Germany. ${ }^{47}$

Jtem/Summarischer Bericht/der Handlungen vnd Streitsachen Herrn Matthiae Flacij Jllyrici/von jm selbst verzeichnet (Oberursel: Nikolaus Henricus d.Ä., 1575; VD16 H 1563), G1r: »... da er noch ein junger Geselle von 17. Jaren war/Lust vnd Liebe zur Theologia hatte /...» Caspar Heldelin, the Younger was born in Lindau on Lake Constance ca. 1552. His father, Caspar Heldelin was a student in Wittenberg between 1522 and 1525 together with Achilles Pirmin Gasser, with whom he became friends. Gasser wrote an introductory section to the readers of the book (ad lectorem) to one of Heldelin's publications [VD16 H 1555]. In 1528 Heldelin became the first evangelical rector of the Latin school in Lindau. Paul Fagius dedicated his translation from Hebrew of the apocryphal books of Sirach and Tobit to Heldelin [VD16 B 4037]. For more about him, see »Heldelin, Caspar,« in MBW 12: Personen $F-K, 258$. Heldelin studied theology in Jena, where he enrolled in 1570 and obtained a master's degree. In September 1572 he acted as a notary during the Mansfeld colloquium between Flacius, Hieronymus Menzel and others. Heldelin was a staunch follower of Flacius', being called homo furiosus by Johannes Wigand. He published several works defending Flacian doctrine of original sin [VD16 H 1565; $\mathrm{H} \mathrm{1564;} \mathrm{H} \mathrm{1561]} \mathrm{and} \mathrm{also} \mathrm{issued} \mathrm{posthumously} \mathrm{Flacius'} \mathrm{work} \mathrm{against} \mathrm{Jakob} \mathrm{Andreae} \mathrm{[VD16}$ F 1337]. Heldelin was a pastor in Ebersbach and Kronberg im Taunus, where he died sometime after 1577. See two works written in honor of Heldelin's marriage to Magdalena Spangenberg (daughter of Cyriacus), one by Wilhelm Sarcerius, printed in Erfurt in 1577 [VD16 S 1793], and the other by Benedikt Thaurer, Speculum coniugis ex capite 31. Proverbiorum Salomonis, in honorem sacri nuptialis, reuerendi ac docti viri, D. magistri Caspari Heldelini pastoris ecclesiae Cronbergensis, et castissimae uirginis Magdalenae, clarissimi viri D. magistri Cyriaci Spangenbergii filiae, carmine politum (Eisleben: Andreas Petri, 1577, not in VD16).

45 Flacius, „Vertheidigungsschrift des Flacius Illyricus an die Schule zu Wittenberg, « text in August Detlev Twesten, Matthias Flacius Illyricus, eine Vorlesung. Mit autobiographischen Beilagen und einer Abhandlung über Melanchthons Verhalten zum Interim von Hermann Rossel (Berlin: G. Bethge, 1844), 35-63, here 37.

46 The monastery, which stands in the Castello district on the northern edge of the city, supposedly on the spot where the angel spoke the words »Pax tibi Marce Evangelista meus« to Mark the Evangelist, was founded in 1253.

47 Twesten, Matthias Flacius Illyricus, eine Vorlesung, 38: »[...] erzählte er mir, wie Luther das Evangelium wieder zu Ehren gebracht habe, wies mir einige Schriften und rieth mir, nach Deutschland, nicht ins Kloster zu gehen, wenn ich Theologie studiren wolle. Auf der Stelle war ich mit Freuden dazu bereit und reiste wenige Wochen darauf nach Deutschland." Latin text is in Apologia, B3r. See also Thomas Kaufmann, »'Erfahrungsmuster in der frühen Reformation, « in Paul Münch (ed.), »Erfahrung« als Kategorie der Frühneuzeitgeschichte [Historische Zeitschrift Beiheft 31] (München: Oldenbourg, 2001), 281-306, here 289. 
This short foray into Flacius' early life and education provide several important building blocks for an assessment of his theology and work. First, he always saw himself as something of an outsider north of the Alps. Second, born outside the Holy Roman Empire and orphaned at an early age, he was initially oriented toward Venice and the Italian humanism that it represented. His humanist training there and his concomitant interest in history, on which many studies of his thought have focused, arose not so much from his later exposure to Martin Luther and Philipp Melanchthon but from his much earlier education at the school of San Marco and in the shadow of the Aldine Press. His decision to leave the safe confines of Italian Catholicism and Venetian civic life had to have been a momentous one, inspired by his relative but also by the message emanating from Wittenberg and other centers of the Reformation.

\section{North of the Alps: Peregrinatio academica and Early Network-Building}

a) Augsburg

The first city outside of the Venetian realm where Flacius spent time was the Imperial free city of Augsburg. He arrived there sometime in early 1539. According to Flacius' own account written in 1568 for the Protestant clergy of Strasbourg, which is partly apologetical and partly autobiographical, he stayed with the city's Superintendent Bonifacius Wolfhart, also known as Lycostenes ${ }^{48}$ Wolfhart was a signatory of the Wittenberg Concord of 1536 for Augsburg, although he adhered more to the Zwinglian understanding of the Lord's Supper and had close relationships with Martin Bucer and Swiss theologians. ${ }^{49}$ Wolfhart was also a Hebraist, and perhaps it was already

48 Flacius, Erzehlunge der Handlungen/oder Religionsstreiten vnd Sachen Matthiae Fl: Jllyrici/von jm selbs trewlich vnd warhafftiglich/auff Beger der Prediger zu Strasburg/beschrieben/Anno 1568. zu Strasbourg [VD16 F 1379] in Heldelin, Eine Christliche predigt, T2v. Heldelin published the German text of Erzehlunge der Handlungen after the funeral oration, S4r-Ee2v. The original Latin version, entitled Narratio actionum et certaminum M. Matth. Fl. Illyrici, Bona fide conscripta a Flacio ipso (Strasbourg, 1568), is published in Conrad Schlüsselburg, Catalogi Haereticorum, Conradi Schlüsselbvrgii, SS. Theologiae Doctoris Et Professoris, ac in Ecclesia \& Gymnasio Stralesundensi, in Pomerania, Superintendentis, Liber XIII. \& vltimus. In qvo incredvlorvm Adiaphoristarum, \& fugitiuorum Interimistarum errores, apostasiae collusiones cum Antichristo Romano, \& argumenta repetuntur \& refutantur, cum assertione verae sententiae quam Catholica complextitur Ecclesia (Frankfurt: Johann Saurius, 1599; VD16 S 3038), vol. 13, 802-857. It is interesting to note that the Latin text, even though it is very similar to the German one, does not mention Augsburg and Bonifacius Wolfhart.

49 Already in the early 1530s Wolfhart had disagreements about Sacramental theology with the Lutheran preacher in Augsburg, Stephan Agricola. For more about Wolfhart, see Heinz-Peter 
in Augsburg that Flacius became acquainted with this Semitic language. Flacius also mentions Wolfhart Peter Herwart from Augsburg, who helped Baldo Lupetino in his Venetian imprisonment. ${ }^{50} \mathrm{He}$ also talks about the many German merchants (viel teutschen Kauffleuten) who were connected to the Germans' Inn (Teutsches Haus) in Venice. ${ }^{51}$ In the sixteenth century intensive trading connections existed between Venice and Augsburg, with merchants' caravans travelling between the two cities on a regular basis, which is most likely the way in which Flacius came to Augsburg.

Unfortunately, Flacius himself does not specify how long he stayed in Augsburg. However, the facts that throughout his life a number of prominent citizens of the city corresponded with him and that he received financial support from them, especially for the Magdeburg Centuries project, seems to suggest that he might have established a few key contacts already then.

Flacius' Augsburg connections have so far eluded all of his biographers, since none of them devotes any attention to his relationships with its residents or the church. ${ }^{52}$ Johann Baptist Haintzel, who was only four years younger than Flacius, played a role in supporting the church history project that Illyricus and his colleagues were working on in Magdeburg. ${ }^{53}$ A letter

Mielke, »Wolfhart, Bonifatius, in BBKL 29 (2008), 1575; Hermann Ehmer, »Bonifatius Wolfhart, ein reformatorischer Theologe aus Buchen, »in Rainer Trunk, Helmut Brosch, Karl Lehrer (eds.), 700 Jahre Stadt Buchen. Beiträge zur Stadtgeschichte (Buchen: Odenwälder, 1980), 211-231; »Wolfhart [Wolfart, Lycostenes] Bonifatius, « in Wolfgang Simon, Berndt Hamm and Reinhold Friedrich (eds.), Martin Bucer Correspondance 8 (April 1532 - August 1532), [Studies in Medieval and Reformation Traditions 153] (Leiden: Brill, 2011), 411-412.

50 Flacius, Erzehlunge der Handlungen, T2v. Herwart was from a wealthy patrician banking family from Augsburg. In 1553 he became a member of the city council. I have traced one of Vergerio's books printed in 1563 in Tübingen, which belonged to Herwart. The volume contained a hand-written inscription by Flacius, who was in Augsburg that year and most likely gave it to Herwart as a present. The inscription can be found at BSB, Polem. 3027, 17 (see Figure 2).

51 The building, known in Italian as Fondaco dei Tedeschi, still stands next to Rialto Bridge in the form in which it was rebuilt after a 1509 fire. See http://www.causa-nostra.com/Rueck blick/Fondaco-dei-Tedeschi--r1004a03.htm (accessed March 11, 2011). Two sources confirm that German merchants helped Fra Baldo and mention that the agent for the Fondaco, Johann Baier smuggled some money to Baldo from time to time. See, Henry Simonsfeld, Der Fondaco dei Tedeschi in Venedig und die deutsch-venetianischen Handelsbeziehungen. Quellen und Forschungen, 2 vols. (Stuttgart: Verlag der J.G. Cotta'schen Buchhandlung, 1887), 2: 158; Ludwig Theodor Elze, Geschichte der protestantischen Bewegungen und der Deutschen evangelischen Gemeinde in Venedig (Bielefeld: Druck von Velhagen und Klasing, 1883), 21.

52 See Preger, Flacius und seine Zeit, 1: 16 (three sentences), Mirković, Matija Vlačić Ilirik, 35 (one paragraph), Olson, Flacius and the Survival of Luther's Reform, 35 (two sentences) about Flacius and Augsburg.

53 Johann Baptist Haintzel was from an Augsburg patrician family. He studied in Basel and Wittenberg, where he was Melanchthon's student. He was in Wittenberg between January 1542 and May 1545, so it is possible that Flacius and Haintzel became friends there. For more about him, see »Haintzel, Johann Baptist, in MBW 12: Personen F-K, 215. For some of the details of Haintzel' time as mayor of Augsburg, see Katarina Sieh-Burens, Oligarchie, Konfession 


\section{Ä iFratelli d'Italia:}

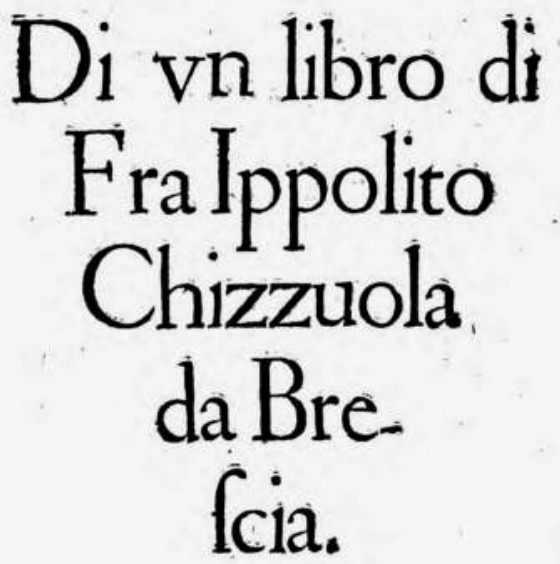

Verim lumeri iam luces I. IO A N cap.2s

\section{L' A N N O. L.XIII. nel thele di Febratio}

$4^{\circ}$

\section{tho Wolfento Hemoart,}

Figure 2: The title page of Vergerio's polemical work from 1563 against Ippolito Chizzola with Flacius' handwritten dedication to Wolfhart Herwart. Courtesy of the Bavarian State Library: shelfmark Polem. 3027, 17. 
from Flacius to Haintzel from 1559, a year after Haintzel became the mayor (Bürgermeister) of Augsburg, clearly shows that the two of them had known each other well. ${ }^{54}$ The previous year, in January 1558, Flacius dedicated his work Additions to Dialectics to Haintzel from Jena. ${ }^{55}$ They had corresponded with one another quite often. ${ }^{56}$ There are multiple references to Haintzel in Flacius' correspondence with Caspar von Niedbruck in Vienna. ${ }^{57}$ Niedbruck was neither on the Lutheran nor on the Reformed side but a sympathizer and helper of both churches. ${ }^{58}$ Alexandra Kess has called him »the undercover

und Politik im 16. Jahrhundert: zur socialen Verflechtung der Augsburger Bürgermeister und Stadtpfleger 1518-1618 [Schriften der Philosophischen Fakultäten der Universität Augsburg 29] (München: Ernst Vögel, 1986).

54 The letter is actually a supplication to Haintzel to lobby the Protestant princes of Germany for supporting the Gnesio-Lutheran party. The original is at BSB, Cod. Germ. 1315, 305-308 and is partly quoted in Preger, Flacius und seine Zeit, 2: 88-89.

55 Flacius, Paralipomena Dialectices. Libellus lectu dignissimus, \& ad Dialecticam Demonstrationem certius cognoscendam, cuius etiam in Praefatione prima quedam principia proponuntur, apprime utilis (Basel: Jakob Kündig, 1558; VD16 F 1465), A2r. For more on that work of Flacius, see Josip Talanga, »Paralipomena Dialectices des Matthias Flacius Illyricus, « in Josip Matešić (ed.), Matthias Flacius Illyricus - Leben \& Werk. Internationales Symposium, Mannheim, Februar 1991 [Südosteuropa-Studien 53] (München: Südosteuropa-Gesellschaft, 1993), 111-138.

56 At HAB there are at least eleven letters from Haintzel to Flacius written in the period between 1553 and 1558. They are catalogued under Cod. Guelf. 64.1; Helmst. 2 and Cod. Guelf. 361 Novi.

57 The correspondence was published by Viktor Bibl, »Der Briefwechsel zwischen Flacius und Niedbruck. Aus den Handschriften 9737 b, i und k der k. u. k. Hofbibliothek in Wien,« Jahrbuch der Gesellschaft für die Geschichte des Protestantismus in Oesterreich 17 (1896): 1-24; 18/3-4 (1897): 201-238, 19 (1898): 96-110; 20 (1899): 83-116. The earliest mention in the correspondence I found is in Flacius' letter to Niedbruck dated on October 1, 1553, where he instructs Niedbruck to send to Senator Haintzel in Augsburg books for the Magdeburg church history project, 17 (1896): 11. See also, Karl Schottenloher, »Handschriftenschätze zu Regensburg im Dienste der Zenturiatoren (1554-1562), « Zentralblatt für Bibliothekswesen 34 (1917): $65-82$, here 65.

58 For Niedbruck’s biography see Heinrich Holtzmann, »Niedbruck, Kaspar von,« in ADB 52 (1906), 621-29. Some of other Niedbruck's correspondence has been published: between Niedbruck and Johannes Sleidan from the years 1553-1557, see Hermann Baumgarten, Sleidans Briefwechsel (Strasbourg: Karl J. Trübner, 1881), 264-65; 272-274, 277-280, 283-295; 296-304; 307; 320-321; 324-325; 328-329; Hyperius' letter to Niedbruck from Marburg, dated September 11, 1555 is printed in Gerhard Krause, Andreas Gerhard Hyperius Briefe 1530-1563 [Beiträge zur historischen Theologie 64] (Tübingen: J.C.B. Mohr (Paul Siebeck), 1981), 50-52; Niedbruck's letter to Bonifacius Amerbach, dated in Strasbourg, on July 6, 1554 is in Beat Rudolf Jenny (ed.), Die Amerbachkorrespondenz IX/2: 1. Juli 1554 - Ende 1555 (Basel: Verlag der Universitätsbibliothek, 1983), 363-367; for the Niedbruck-Mathesius correspondence, see Georg Loesche, »Der Briefwechsel des Mathesius, « Jahrbuch der Gesellschaft für die Geschichte des Protestantismus in Oesterreich 11 (1890): 31-33; 49; 57-60; for Calvin's letter from Spring 1556 to Niedbruck, see CO 20: Nr. 4179, 445-447. The German translation of the letter is published in Rudolf Schwarz, Johannes Calvins Lebenswerk in seinen Briefen. Eine Auswahl von Briefen Calvins in deutscher Übersetzung. Zweiter Band: Die Briefe bis zum Jahre 1564 (Tübingen: J.C.B. Mohr [Paul Siebeck], 1909), 2: 138-139. Schwarz corrects the date of the letter in CR from April 13 to March 20, 1556, because Niedbruck wrote to Calvin on March 31. This letter is clearly a response to Calvin's writing; for Niedbruck's role in imperial 
Protestant with a vital influence at the Habsburg courts. $\ll^{59}$ Niedbruck collected sources for the Magdeburg Centuries with help from the diplomat Sigismund von Herberstein.

Haintzel himself also corresponded with Niedbruck regarding the Centuries. ${ }^{60}$ According to Ronald Diener, $»$ Haintzel was holding money in accounts for the history project, « including handling and distributing it. ${ }^{61}$ Haintzel also received a prominent place in the dedicatory letter published for the eighth volume of the Ecclesiastica Historia, where he is listed first among the eight people to whom the work is dedicated. ${ }^{62}$ Second on that list of dedicatees is another important man from Augsburg, namely Achilles Pirmin Gasser, a sixteenth-century polymath. By profession he was a medical doctor (surgeon) and pharmacist but he was also active as an astronomer, physicist, historian, theologian and cartographer. ${ }^{63}$ Prior to the 1564 dedication in volume eight of Centuria, Gasser had received a copy of the first published volume of

politics and his correspondence with Melanchthon, see Timothy J. Wengert, »Philip Melanchthon's Gift to Caspar von Niedbruck, « Lutheran Quarterly, n.s. 12 (1998): 485-489; and Viktor Bibl, »Melanchthon und Nidbruck. Aus der Handschriften 9737 i und k der k.k. Hofbibliothek in Wien, "Jahrbuch der Gesellschaft für die Geschichte des Protestantismus in Oesterreich 18/1-2 (1897): 34-47. For more about Niedbruck's activities see also, Ferdinand Menčik, »Caspar Nydbruck's Verhältnis zu den Calixtinern in Böhmen, « Jahrbuch der Gesellschaft für die Geschichte des Protestantismus in Oesterreich 18/1-2 (1897): 48-55; Otto Clemen, »Kaspar von Niedbruck als Büchersammler,« Zentralblatt für Bibliothekswesen 49 (1942): 168-169.

59 Alexandra Kess, Johann Sleidan and the Protestant Vision of History [St. Andrews studies in Reformation history] (Aldershot/Burlington, VT: Ashgate, 2008), 136.

60 Three letters from Haintzel to Niedbruck from the years 1556 and 1557 are printed in Josef Wilhelm Schulte, »Beiträge zur Entstehungsgeschichte der Magdeburger Centurien, « JahresBericht der Philomathie 19 (Neisse: Graveur, 1877), 51-154, here 110-111; 119-120 while Viktor Bibl quotes part of the letter from Niedbruck to Haintzel, dated on January 4, 1554 from Vienna, Jahrbuch der Gesellschaft für die Geschichte des Protestantismus in Oesterreich 18 (1897): 207.

61 Ronald Ernst Diener, The Magdeburg Centuries: A Bibliothecal and Historiographical Study, (Cambridge, MA: Harvard Divinity School, 1978; Th.D. Diss.), 92. Diener confuses Haintzel with Gasser and calls him a medical doctor.

62 Octaua Centuria Ecclesiasticae Historiae, Continens Descriptionem Amplissimarvm Rervm in Regno Christi, quae Octauo post eius natiuitatem seculo acciderunt: cum ... (Basel: Johannes Oporinus, 1564; VD16 E 231). The dedication reads: »Amplissimis, ornatissimis, et honestissimis viris, D[omino] Ioanni Bap[tistae] Heincelio Consuli Rei p[ublicae] Augustanae; D[omino] Achilli Gassaro Medicinae Doctori \& Augustanae Rei p[ublicae] Physico ...« A2r. See the German translation of the letter in Karl Heinz Burmeister, Achilles Pirmin Gasser 1505-1577: Arzt und Naturforscher, Historiker und Humanist. III. Briefwechsel (Wiesbaden: Guido Pressler, 1975), 271-284.

63 For an overview of Gasser's career, see Ferdinand Frensdorff, »Gasser, Achilles Pirmin, « in ADB 8 (1878), 396-397; Friedrich Blendinger, »Gasser (Gassarus), Achilles Pirminius, in NDB 6 (1964), 79-80; »Gasser, Achilles Pirminius,« in MBW 12: Personen F-K, 120-121; Karl Heinz Burmeister, »Gasser (Gassarus), Achilles Pirmin,« in Wilhelm Kühlmann et al (eds.), Frühe Neuzeit in Deutschland 1520-1620. Literaturwissenschftliches Verfasserlexikon, vol. 2 (Berlin/Boston: Walter de Gruyter, 2012), 528-535. His extensive biography and letters were 
the Centuries as a gift with an inscription in the handwriting of Johannes Wigand $^{64}$ dated April 17, 1559 calling Gasser "gubernatores operis Ecclesiastici. $\ll^{65}$

Gasser had also received numerous books as gifts from Flacius over the years, including the translation of the New Testament into Croatian from $1562,{ }^{66}$ the second edition of Catalogus testium veritatis from $1562,{ }^{67}$ the Glossa Compendiaria in novum Testamentum, ${ }^{68}$ which Flacius sent from Strasbourg in April $1570 .{ }^{69}$ In addition, Flacius dedicated another work of his to Gasser in $1570 .^{70}$ Gasser also co-operated with Flacius on the publication of Otfrid von Weissenburg's Gospel Book (Evangelienbuch) as the Illyrian acknowledges: »Indeed, the most eminent doctor Achilles Gasser has greatly

published in three volumes by Karl Heinz Burmeister as Achilles Pirmin Gasser 1505-1577: Artzt und Naturforscher, Historiker und Humanist (Wiesbaden: Guido Pressler, 1970-1975); Elmar Mittler, »Achilles Pirmin Gasser,« in Bibliotheca Palatina: Katalog zur Ausstellung vom 8. Juli bis 2. November 1986, Heiliggeistkirche Heidelberg (Heidelberg: Edition Braus, 1986), 398-399. See also Gasser's newly discovered portrait in Henning Wendland (ed.), Die Bibelsammlung der Ehemals Reichsstädischen Bibliothek Lindau (Bodensee) [Neujahrsblatt des Museumsvereins Lindau 48/49] (Lindenberg: Josef Fink, 2008), 22 and Figure 3 in this volume.

64 For Wigand's biography see Irene Dingel, »Wigand, Joachim, « in Gerhard Müller (ed.), in TRE 36 (2004), 33-38; Ronald E. Diener, »Johann Wigand, « in Jill Raitt (ed.), Shapers of Religious Traditions in Germany, Switzerland, and Poland: 1560-1600 (New Haven: Yale University Press, 1981), 19-38. For his later career in Prussia, see Irene Dingel, »Calvinism at the Borders of the Empire: Johannes Wigand and the Lutheran Reaction to Calvinism, « in Amy Nelson Burnett (ed.), John Calvin, Myth and Reality: Images and Impact of Geneva's Reformer (Eugene: Cascade Books, 2011), 139-161.

65 Heinz Scheible, »Die Magdeburger Zenturien mit Widmungen für Gasser,« in Bibliotheca Palatina, 410-411, here 411.

66 Tomislav Mrkonjić, »Slawische Bücher als Geschenke des Matthias Flacius Illyricus, « in Bibliotheca Palatina, 408-410.

67 Gerhard Kattermann, »Ein Buchgeschenk des Flacius Illyricus aus dem Kreis der OtfriedTextüberlieferung und andere Überreste der Bücherei A. P. Gassers in der Badischen Landesbibliothek, « Neue Heidelberger Jahrbücher, Neue Folge (1939), 84-89. The dedication reads: »Clarissimo eruditione ac pietate viro d. D. Achilli Gassaro, suo domino et fratri in Christo charissimo, Matthias Flacij Illyricus.«

68 Irene Dingel and Elmar Mittler, »Die Bibelausgabe des Matthias Flacius Illyricus - ein Geschenk an Gasser, « in Bibliotheca Palatina, 407-408. The text of Flacius' dedication to Gasser (see Figure 11) is not reproduced in the article. It reads: »Eruditione ac pietate clarissimo viro d[ono] d[edit] Achilli P.: Gassaro, suo domino \& fratri in Christo dilectissimo, Mathias Flacius Illyricus. 12 Aprilis anno salutis 1570 ex Argentorato Augsburgae mittebat.«

69 Among further titles that Flacius presented to Gasser was Otrozhia Biblia. Ein Handtbuechlein / Darinn ist vnter anderm der Catechismus Von fünfferlei sprachen (Regensburg: Johann Burger, 1566; VD16 O 1450). On the title page, written in Gasser's handwriting, is the inscription: »dono M. F. Illyri.« The original is held at the Bibliotheca Apostolica Vaticana, Pal. V 2008 (int. 1), 21385.

70 Flacius, Defensio sanae doctrinae, Ala-B8b. The dedications reads: »Clarissimis ervditione ac pietate viris, D.D. Achilli Gassaro, Matthiae Rot, Georgio Neckero, \& Thobiae Rupio, suis dominis, ac in Christo fratribus...« A2a. The other three Lindau preachers mentioned in this dedication, Roth, Necker and Rupp, will be discussed later. 
assisted this edition by his erudition and piety, both in copying out the original manuscript and in putting together a lexicon of the old words. " $^{71}$

Gasser took part in publicly supporting the Flacian theological movement. In late 1575 he received Tobias Rupp into his house, which was located behind St. Ulrich's Church, after Rupp was banished from Lindau on Lake Constance because of Flacianism. ${ }^{72}$ He wrote a number of letters to Lindau's Mayor and to the city council rebuking them for their actions against Flacian preachers. Gasser even gave asylum in his house to another one of Flacius' comrades, Cyriacus Spangenberg ${ }^{73}$ when he was exiled from Mansfeld. ${ }^{74}$ Because of this his relationships with the Augsburg city council and the local preachers were severely strained. ${ }^{75}$

Gasser's friendship with Flacius is an underresearched yet fascinating relationship of the sixteenth century. On December 4, 1577, six days before he died, Gasser composed with his own hand a theological last will and testament in the presence of the Augsburg lawyer Hieronymus Fröschel, who was also a Lutheran. ${ }^{76}$ His last words deserve to be quoted in full: »I, Achilles Pirmin Gasser from Lindau, who now stands before imminent death, hate and curse Heshusius, Wigand and Jakob Andreae, who hold that

71 Flacius (ed.), Otfridi Evangeliorvm Liber ... (Basel: Heinrich Petri, 1571; VD16 B 4664). See the dedicatory foreword to Baron Adolf Hermann Riedesel, dated in Strasbourg on September 1, 1571, B1r: »Plurimum sane hanc editionem adiuuit eruditione \& pietate clarissimus vir D. D. Achilles Gassarus, tum describendo, tum \& Lexicon ueterum huius sermonis uocum conficiendo...«. The English translation is quoted in John P. Considine, Dictionaries in Early Modern Europe: Lexicography and the Making of Heritage (New York: Cambridge University Press, 2008), 123.

72 Rupp [Ruppius] had been Flacius' student in Jena and had also lived in his house there - he had been recommended to Flacius by Matthias Roth. He matriculated at the University of Jena in the second semester of 1557 under the rectorship of Basilius Monner. See Georg Mentz and Reinhold Jauernig (eds.), Die Matrikel der Universität Jena: 1548 bis 1652 [Veröffentlichungen der Thüringischen Historischen Kommission 1] (Jena: Gustav Fischer, 1944), 271. Rupp was present at the Weimar Disputation in August 1560 and at the Naumburg Fürstentag in 1561, and in December 1561 he became a preacher in his hometown of Lindau. Later he emerged as a staunch supporter of Flacius' teaching on original sin.

73 For an overview of Spangenberg's career, see Robert Kolb, »Spangenberg, Cyriakus (15281604), « in Hans J. Hillerbrand (ed.), The Oxford Encyclopaedia of the Reformation 4 (Oxford/ New York: Oxford University Press, 1996), 99-100. Spangenberg has also been called »Flacian Apostle« by Johannes Schepff, preacher in Althausen [VD16 S 2644].

74 See Spangenberg's letter of May 14, 1577 to Gasser most likely written in his house in Augsburg in Burmeister, Achilles Pirmin Gasser. III. Briefwechsel, 531-532.

75 Klaus Niebler, Bücher aus der Bibliothek des Augsburger Humanisten Achilles Pirmin Gasser (1505-1577) in der Stadtbibliothek Mainz. Eine Untersuchung von Restbeständen der Bibliotheca Palatina (Köln, 1973), 12.

76 For more about him, see Friedrich Roth, »Der markgräfliche Kanzler Dr. Hieronymus Fröschel und sein Bericht über seine Kämpfe gegen die Konkordie und die Ansbacher Konkordisten (1577 und 1578), « Beitrage zur bayerischen Kirchengeschichte 17 (1911): 49-70 and 105-123; and also http:/www.geschkult.fu-berlin.de/e/jancke-quellenkunde/verzeichnis/f/froeschel/ index.html (accessed November 29, 2011). 


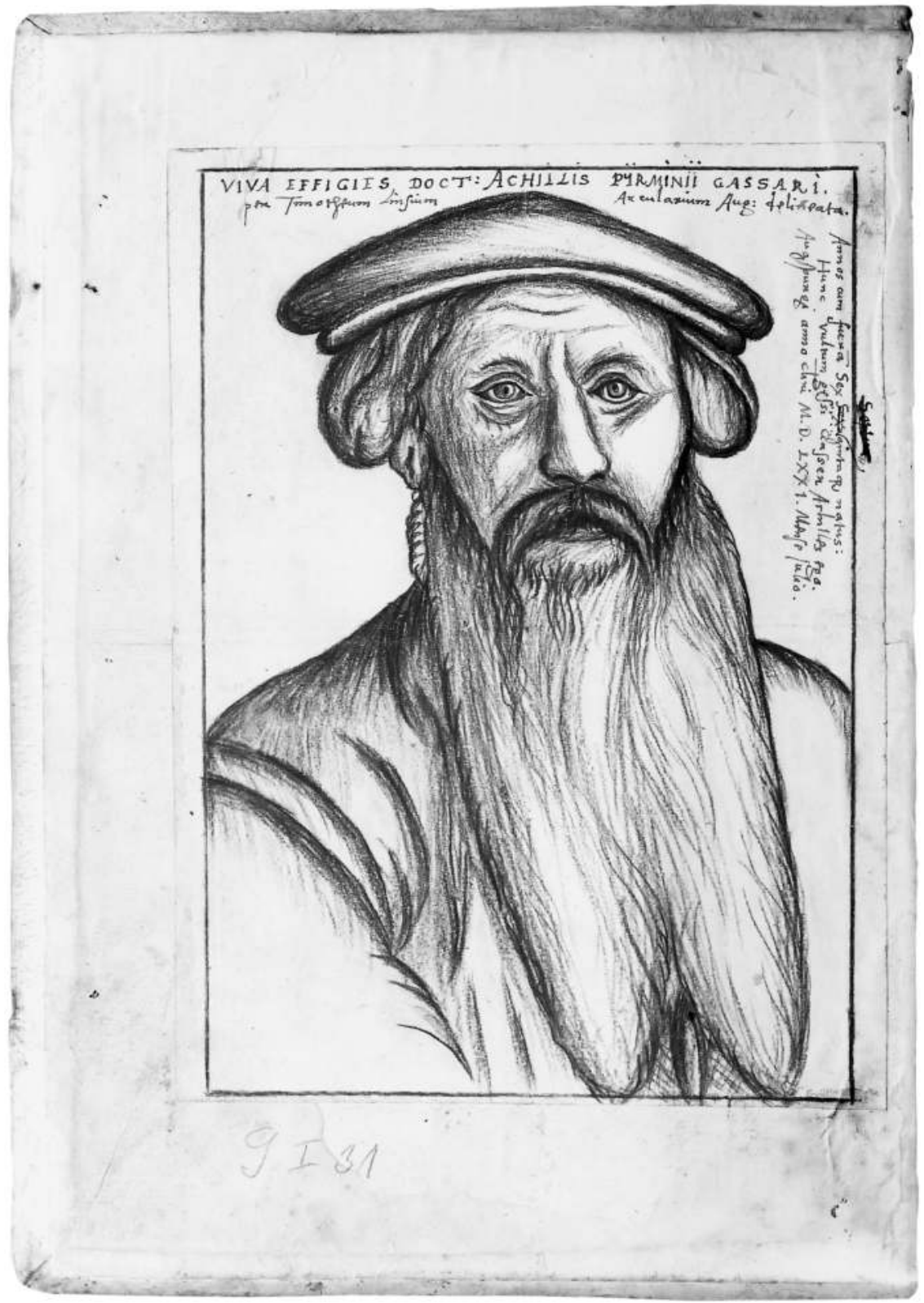

Figure 3: Portrait of Achilles Pirmin Gasser drawn in red chalk, found in the copy of the Antwerp Polyglott Bible that he gave as a gift to his home town of Lindau in 1571. Courtesy of Stadtarchiv Lindau: shelfmark G I 31. 
original sin is merely an accident, along with their accomplices. Cyriacus Spangenberg and [Flacius] Illyricus, together with the holy Luther, I embrace in my heart and confess that they are the true disciples of Christ and I cherish them. $\ll^{77}$ Such loyalty and commitment to Flacius and his ideas at the time when his followers were persecuted and banished is remarkable. ${ }^{78}$

Another man from Augsburg, connected to both Flacius and Gasser, was Hieronymus Wolf who in 1551 became secretary and librarian for Johann Jakob Fugger ${ }^{79}$ and later also Augsburg city librarian (Stadtbibliothekar) and principal of St. Anna-Gymnasium. ${ }^{80}$ Wolf corresponded with Flacius regarding The Magdeburg Centuries in the mid-1550s, as Flacius was particularly interested in sources from Fugger's library for the project. ${ }^{81}$

77 Friedrich Roth, »Der Augsburger Jurist Dr. Hieronymus Fröschel und seine Hauschronik von 1528-1600, Zeitschrift des Historischen Vereins für Schwaben und Neuburg 38 (1912): 1-82, here 34-35: »Ego Achilles Pirminius Gasserus Lindaviensis, jamjam moribundus Heshusium, Wigandum, Jacobum Andree, accidentis assertores, cum sociis odi et execror. Cyriacum Spangenbergium et Illyricum cum sancto Luthero conplector in fide et discipulos Christi profiteor et amplector. Anno 1577 die 28. Novembris. « Hieronymus Fröschel in his account of the death of Gasser writes that he passed away »im rechten, reinen, christlichen Glauben seines Alters im 72. Jahr als bestellter ältester Physicus der Stadt Augsburg daselbst christlich verschieden. [...] Der allmächtige Gott verleihe ihm eine selige, fröhliche Auferstehung,« 34. This strongly suggests that the lawyer Fröschel was a Crypto-Flacian himself; otherwise he would not have written such words about Gasser, who was a staunch supporter of Flacius. His attempts at opposing the Formula of Concord in 1577-1578 provide a further proof of that. Another fact that shows Gasser's commitment to Flacius is found in how he signed his letters. In 1568, he signed a letter to Hieronymus Wolf on »the feast day of the Apostle Matthias, who replaced Judas Iscariot.« Flacius himself signed many of his works on February 24, which in leap years fell on 25, the feast day of Saint Matthias. In 1570 Gasser signed a letter to Johannes Marbach, »Ex Flaciomastigica Augusta, « pointing out to Marbach that Augsburg is not a city favourable toward Flacianism, « Burmeister, Achilles Pirmin Gasser. III. Briefwechsel, 408, 430.

78 The city of Augsburg censured Gasser because of his Flacianism and forbade publication of Annales civitatis ac rei publicae Augstburgensis, which he completed in 1576. It was first published posthumously as a German translation in Frankfurt am Main in 1595 by pastor Wolfgang Hartmann from Ebersbach [VD16 G 507] and in the original Latin by Johann Burckhardt Mencke (ed.), Scriptores rerum Germanicarum, vol. 1 (Leipzig: Martini, 1728).

79 During his visit to Augsburg in 1563 Flacius gave Ulrich Fugger a copy of his newly republished De voce \& re fidei as a gift. The original is kept at the Bibliotheca Palatina at the Vatican and has the following dedicatory words written in Flacius' hand: »Nobili ac generoso d.d. Vlrico Fuggero Comiti in Weisenhorn, ac domino suo clementissimo.« (see Figure 4).

80 For more about him, see Georg Mezger, »Wolf, Hieronymus, « in ADB 43 (1898), 755-757; Hans-Georg Beck, Der Vater der deutschen Byzantinistik. Das Leben des Hieronymus Wolf von ihm selbst erzählt [Miscellanea Byzantina Monacensia 29] (München: Institut für Byzantinistik und Neugriechisch, 1984); Fritz Husner, »Die Editio princeps des »Corpus Historiae Byzantinae.« Johannes Oporin, Hieronymus Wolf und die Fugger, in Festschrift Karl Schwarber. Beiträge zur schweizerischen Bibliotheks-, Buch und Gelehrtengeschichte (Basel: B. Schwabe, 1949), 143-162. For Gasser's and Wolf's published epistolary exchange see Burmeister, Achilles Pirmin Gasser. III. Briefwechsel, 386-409.

81 Wolf is listed as Flacius' correspondent in a subdivision called »The Bibliophilic Network, « in Diener, The Magdeburg Centuries, 68. 
Among Flacius' other connections to Augsburg was a dedication to the Lutheran churches and preachers of the city of his work against the Philippist theologian Christoph Lasius ${ }^{82}$ written in July $1568 .^{83}$ The first time Flacius dedicated a work of his to the »Church of Christ« in Augsburg (Der kirche Christi zu Augspurg) was in $1550^{84}$ and the second time in $1553 .{ }^{85}$ Flacius also corresponded with Augsburg pastors, as is confirmed by the following letter. On September 27, 1556 Flacius wrote from Magdeburg to Joachim Westphal in Hamburg: »Dear Joachim, a certain pastor from Augsburg has asked me to send him your book about Baptism (De baptismo) ... Therefore, I kindly ask you to send me an extra copy of it, if you still have one. $\ll^{86}$

82 For more about Lasius, see Heinrich Holtzmann, »Lasius, Christoph, « ADB 17 (1883), 733. For Lasius' polemics against Flacius and the Flacianers, see chapter nine, »Matthias Flacius Illyrikus und Christoph Lasius, « in Ignaz von Dollinger, Die Reformation, ihre innere Entwicklung und ihre Wirkungen im Unfange des Lutherischen Bekenntnisess, vol. 2 (Regensburg: G. Joseph Manz, 1848), 224-267, here 262-265.

83 Flacius, Von der Erbsünde/Freyen Willen/Bekerung vnd Widergeburt/Antwort Matt. FI. Jllyrici auff etliche Schrifften Christophori Lasij des Jnterimisten (Oberursel: Nikolaus Henricus d.Ä., 1568; VD16 F 1537). The dedication is on A2r-B3r, where the Augsburg pastor of St. Ulrich's Church, Georg Meckhart is mentioned by name twice. This was Flacius' reply to the work by Lasius, which had been dedicated to the Augsburg preachers, called Fundament Warer vnnd Christlicher Bekerung/Wider die Flacianische Klotzbus/aus vier Jrthumen widers Fundament ersatz/klerlich erwisen/vnd gründlich widerlegt. Durch M. Christophorum Lasium (Frankfurt an der Oder: Johann Eichorn, 1568 [the preface is dated on March 7, 1568 in Küstrin]; VD16 L 567). It was reprinted later in the same year with additional comments by Lasius (Wittenberg: Peter Seitz d.J.; VD16 1 568). There is also a Latin edition called Praelibatio Flaciani dogmatis, de prodigios a conversione hominis, ad gustum totius contoversiae proposita (Wittenberg: Peter Seitz d.J., 1568; VD16 L 581). The first part of the foreword, dated in Augsburg on March 3, 1563, A5r (the second part was dated in Küstrin in January 1568, B3r), is most interesting for the connection between Flacius and the Augsburg Lutherans, since Lasius accuses Flacius of dishonoring him in the eyes of the clergy in 1563, A3r. The foreword is also intriguing for Slovenian Protestant history, since it mentions Sebastian Krell several times in relation to Flacius, calling him Flacius' secretary (amanuensis), A4r. During the last years of his life, Krell was Superintendent in Laibach. Prior to that he was a student at the Jena Academy, where he matriculated as »Sebast[ianus] Krelo Austriacus « in the first semester of 1557 under the rectorship of Erhard Schnepf. See, Die Matrikel der Universität Jena: 1548 bis 1652, 67. At Jena he lived in Flacius' house, and after Flacius was exiled he joined him in Regensburg. In 1562 he authored a polemical work to which Cyriacus Spangenberg wrote a foreword [VD16 K 2330]. He also translated a postil by Johann Spangenberg into Slovenian (Regensburg: Johann Burger, 1567; VD16 S 8006), issued a Children's Bible [VD16 O 1450], and wrote Slovenian Protestant songs [VD16 T 2101].

84 Flacius, Widderlegung der Predigten von der allerheiligsten Antichristische MISSA des frembden Bischoffs von Sydon/Meintzischen Weihbischoff. durch Matthiam Flacium Jllyricum (Magdeburg: Christian Rödinger d.Ä., 1550; VD16 F 1567).

85 Flacius, Des h. Hulrichs etwa vor sechshundert jaren Bischoffs zu Augspurg Schrifft (Magdeburg: Michael Lotter, 1553; VD16 U 17).

86 Carl Hieronymus Wilhelm Sillem (ed.), Briefsammlung des Hamburgischen Superintendenten Joachim Westphal aus dem Jahren 1530 bis 1575. Erste Abteilung. Briefe aus den Jahren 1530 bis 1558 (Hamburg: Lucas Gräfe \& Sillem, 1903), 238; Letter Nr. 127: »Carissime Joachime, 
b) Basel

According to his own testimony, Flacius journeyed from Augsburg to Basel upon the advice and recommendation of Lycostenes. ${ }^{87}$ Flacius' education continued in Basel, where he enrolled at the University on May 1, 1539 under the rectorship of Nikolaus Briefer ${ }^{88}$ as a pauper. ${ }^{89}$ Professor of the New Testament, Simon Grynaeus, who was a successor to Erasmus, took him into his home and according to Flacius, treated him as if he were his own son. ${ }^{90}$ Even though Flacius' stay in Basel was not long, it proved to be fruitful academically and personally. Johannes Oporinus taught him Greek, and the two of them developed a relationship that resulted in ongoing cooperation and life-long friendship, with Oporinus later printing many of Flacius' works. ${ }^{91}$ According to Martin Steinmann, Oporinus wrote to Joachim Camerarius in

oravit me maximopere quidam Augustae pastor, ut sibi tuum libellum de Baptismo mitterem ... Quaeso, si habes ejus scripti superfluum exemplar, ut mihi mittas.« The book in question is Loci Praecipvi, de VI, vsv, et Dignitate Salvtiferi Baptismi ex Euangelistis \& Apostolis collecti à Magistro Ioachimo Vuestphalo, Ecclesiae Hamburgensis Pastore (Strasbourg: Blasius Fabricius, 1556; VD16 W 2298).

87 It is important to distinguish Lycostenes of Augsburg from Conrad Wolffhart of Basel, who also used the Greek translation of his family name, Lycosthenes. He was married to the sister of the Basel printer Johannes Herbst (Oporinus), Chrétienne Herbst. Mijo Mirković makes this mistake and confuses these two people with identical names, Mirković, Matija Vlačić Ilirik, 35, n. 34. Lycosthenes of Basel is named as the author of the short three-page biography of Flacius that appeared in the German edition of Pantaleon's Book of Heroes, printed in Basel in 1570. However, someone else must have updated the biography, perhaps Wolffhart's son-in-law, Theodor Zwinger d.Ä., since Lycosthenes died in 1561, while Flacius' life is described in the period afterwards, covering his departure from Jena and stays in Regensburg and Strasbourg.

88 The typical mandate of a rector at the University of Basel began on May 1 and ended on April 30 the following year. Briefer was rector in 1520, 1523 and 1539 . He also took part in the 1528 Bern disputations. For more about him, see Richard Newald, »Briefer, Nikolaus, « in NDB 2 (1955), 611.

89 When a poor student registered at the University, he was listed as a pauper in contrast to the nobiles who could pay their own way. Therefore, Flacius was exempt from paying registration and tuition fees. See Lewis William Spitz and Barbara Sher Tinsley, Johann Sturm on Education: the Reformation and Humanist Learning (St. Louis: Concordia, 1995), 15.

90 Flacius, Erzehlunge der Handlungen, T2v: »... zu Basel studieret vnd gewohnet beij dem Hochgelerten Herrn Simone Grynaeus, Leser der heijligen Schrifft daselbs / der mich auch an seinen Tisch genomen hat/vnd nicht anders gehalten/als wenn ich sein Leiblicher Son were gewesen.« For Grynaeus see Peter G. Bietenholz, »Simon Grynaeus of Veringendorf, c 1494 - 1 August 1541, « in Peter G. Bietenholz (ed.), Contemporaries of Erasmus, 2 vols. (Toronto: University of Toronto Press, 1986), 1: 142-146; Paul L. Nyhus, »Grynaeus, Simon (1493 - 1541), « in The Oxford Encyclopedia of the Reformation, 200-201; »Grynaeus, Simon, « in MBW 12: Personen F-K, 192-193.

91 Flacius, Erzehlunge der Handlungen, T3r. In 1538 Oporinus stopped being a professor of Latin and began teaching Greek Classics in the building of a former Augustinian monastery in Basel, where he also lived. See, Martin Steinmann, Johannes Oporinus. Ein Basler Buchdrucker um die Mitte des 16. Jahrhunderts [Basler Beiträge zur Geschichtswissenschaft 105] (Basel/Stuttgart: Helbing \& Lichtenhahn, 1967), 17. Oporinus later became the most important publisher 
Tübingen on November 30, 1539 asking him to greet Flacius. ${ }^{92}$ This particular letter has not been published but it suggests that Flacius spent only one semester at Basel. Up until now all literature on Flacius' life has stated that he went on to Tübingen in 1540. Since there is no record at the University of Tübingen for Flacius' enrollment it is difficult to establish exactly when he moved there. In the aforementioned autobiographical writing by Flacius from 1568 , he uses the words »folgende $\mathrm{Ja}[\mathrm{h}] \mathrm{r} \ll$ to refer to his relocation from Basel to Tübingen. ${ }^{93}$ However, the purpose of the Erzehlunge der Handlungen was not to establish an exact chronology of his life but rather to provide a narrative account without specific dates or details. Since not much attention has been dedicated to reconstructing Flacius' early years, as I have already argued, the existence of such an ambiguity underscores the great need for producing a detailed itinerary of his life as well as gathering and publishing a critical edition of his correspondence. ${ }^{94}$ A complete bibliography of all of Flacius' works as author, editor, translator and contributor does not exist, either. ${ }^{95}$

Next to Grynaeus and Oporinus, Flacius' other professors were Oswald Myconius, Sebastian Münster, who taught him Hebrew, and others. There is no record of Flacius having contact with Andreas Bodenstein von Karlstadt who was Johannes Oecolampadius' successor and was in Basel until

of Flacius' historical works and remained a loyal friend to Flacius until his death in July 1568. »Dass Basel ... zum Druckort der Magdeburger Centurien und der historischen Schriften des Flacius geworden ist, beruht zunächst auf der Bekentschaft, die der junge Student Flacius einst 1539 mit Oporin in Basel geschlossen hatte... in Andreas Burckhardt, Johannes Basilius Herold. Kaiser und Reich im protestantischen Schrifttum des Basler Buchdrucks um die Mitte des 16. Jahrhunderts [Basler Beiträge zur Geschichtswissenschaft 104] (Basel/Stuttgart: Helbing \& Lichtenhahn, 1967), 20. Only an excerpt of the correspondence between Flacius and Oporinus has been published thus far. See, Martin Steinmann, »Aus dem Briefwechsel des Basler Druckers Johannes Oporinus, « Basler Zeitschrift für Geschichte und Altertumskunde 69 (1969): 104-203. Flacius' letter to Oporinus from May 1, 1565, which he wrote from Regensburg concerning the publication of the Taborite Confession and his Clavis Scripturae, is on pages 182-184. The facsimile of the letter and that of one from October 29, 1566, as well as a letter Flacius wrote from Strasbourg on August 28, 1568, shortly after Oporinus' death, asking his successor to return unprinted manuscripts, are published in Mirković, Matija Vlačić Ilirik, Appendix 10-13.

92 Steinmann, Johannes Oporinus. Ein Basler Buchdrucker, 69.

93 Flacius, Erzehlunge der Handlungen, T3r.

94 The itinerary of Melanchthon's life put together by Heinz Scheible and his team at the Heidelberg Academy of Sciences could serve as a template for a similar project on Flacius. See, MBW 10: Orte A-Z und Itinerar (1998).

95 Various attempts at creating a Flacius bibliography have been made, with the first one already compiled during his life time by Conrad Gessner and after Gessner's death continued by Josias Simler. See Bibliotheca Institvta et collecta primvm a Conrado Gesnero, Deinde in Epitomen redacta \& nouorum Librorum accessione locupletata, iam vero postremo recognita, \& in duplum post priores editiones aucta, per Iosiam Simlerum Tigurinum (Zurich: Christoph Froschauer d.J., 1574; VD16 G 1704), 494-495. 
his death on December 24, 1541. ${ }^{96}$ Flacius also met Conrad Gessner, known as the »Father of bibliography «, during his stay in Basel. ${ }^{97}$ While living in Grynaeus' home Matthias had roommates, two of whom are known: Johannes Cellarius from Frankfurt and Johann Wilhelm von Reiffenstein, later counsellor to the duke Ludwig of Stolberg. ${ }^{98} \mathrm{He}$ also met and befriended Michael Bäris, who later became a medical doctor in Mülhausen (Mulhouse), ${ }^{99}$ and Heinrich Pantaleon. ${ }^{100}$ Pantaleon's recollection of those student days, published in his work Heroes of the German Nation (Teutscher Nation Heldenbuch), is an important source for confirming Flacius' claims. ${ }^{101}$ In that work Flacius was listed along with the Reformers who were active in Basel, including Oecolampadius, Oswald Myconius, Martin Cellarius, and Simon Sulzer. ${ }^{102}$

Another person whom Flacius met in Basel was pastor and theologian Wolfgang Wissenburg. Wissenburg was later a key contact between Basel, Niedbruck in Vienna and Flacius in Magdeburg. ${ }^{103}$ In March 1555 Wissenburg wrote a foreword to the edition of late medieval texts that Flacius put together as an anthology of anti-papal statements, which Oporinus published in Basel. ${ }^{104}$

96 Simon Grynaeus, Flacius' landlord and mentor was not on good personal terms with Karlstadt; therefore it is not surprising that Flacius did not get in contact with Karlstadt. See a letter of Karlstadt against Grynaeus from that period in Herbert Rädle, »Simon Grynaeus (1493-1541): Briefe,« Basler Zeitschrift für Geschichte und Altertumskunde 90 (1990): 35-118, here 101-102.

97 Olson, Flacius and the Survival of Luther's Reform, 36. For more about Gessner, see »Gessner, Konrad, « in MBW 12: Personen F-K, 140-142; Urs B. Leu, Conrad Gesner als Theologe. Ein Beitrag zur Zürcher Geistesgeschichte des 16. Jahrhunderts [Zürcher Beiträge zur Reformationsgeschichte 14] (Bern: Herbert Lang, 1990).

98 For more about him and his family, see Eduard Jacobs, »Reiffenstein, « in ADB 27 (1888), 691-693, esp. 693.

99 Flacius, Erzehlunge der Handlungen, T3r.

100 Hans Buscher, Heinrich Pantaleon und sein Heldenbuch [Basler Beiträge zur Geschichtswissenschaft 26] (Basel: Helbing und Lichtenhahn, 1946), 5: »Im Hause des Simon Grynäus, ... lernte er den Feuerkopf Matthias Flaccius [sic!] kennen, der ihn zutiefst beinflußte und zu literarischen Arbeiten anregte. « See also, Burckhardt, Johannes Basilius Herold, 92, n. 73.

101 Heinrich Pantaleon, Teutscher Nation Heldenbuch, 427. I am using a German translation but it is important to note that the original Latin edition was already published in 1566 as Prosopographiae Herorvm atque Illustrivm Virorvm Totius Germaniae, Pars Tertia... (Basel: Nikolaus Brylinger (Erben); VD16 P 230), 438.

102 The reason why Pantaleon decided to include Flacius among German heroes is most interesting. On page 426 of Teutscher Nation Heldenbuch he writes: »Ob wol dieser ausserhalbe den Teutschen grenzen haerkommen/vnd aber von jugent an in Teutschen land erzogen/darzu in dieser spraach etliche buecher geschrieben/auch durch sein hohen verstand vnd bestendiger lehr Teutschland beziret/solle er billich vnder die beruempte teutschen personen gezellet werden.«

103 Burckhardt, Johannes Basilius Herold, 22 n. 10. Wissenburg wrote a dedication to Niedbruck in Dominici Marii Nigri Veneti Geographiae Commentariorum... (Basel: Heinrich Petri, March 1557; VD16 N 1751), A2r-6r.

104 Flacius and Wissenburg, Antilogia Papae: hoc est, de corrupto Ecclesiae statu, \& totius cleri Papistici peruersitate, Scripta aliquot ueterum authorum, ante annos plus minus CCC, \& 


\section{c) Tübingen}

From Basel Flacius moved on to study at Tübingen. There he was received into the house of Matthias Garbitius Illyricus, who was a professor of Greek at the university. Garbitius was the first known Protestant from the Balkans and is counted among the humanists of the sixteenth century. We do not know the exact place of his birth, only that he came from Istria. ${ }^{105}$ Melanchthon referred to him as a compatriot of the church father St. Jerome, ${ }^{106}$ who is believed to have been born on the Istrian Peninsula. ${ }^{107}$ Flacius called Garbitius his fellow countryman (conterraneus/Landsmann) in his writings. ${ }^{108}$ After hearing only German and Latin for months, Flacius was now able to converse in his mother tongue and to talk about his childhood and beloved homeland.

Garbitius' life foreshadowed Flacius' later path in many ways. He came to Germany as a young boy around 1520 and enrolled in the monastery-based school St. Egidien (where Friedrich Pistorius was abbot) in Nuremberg as a pauper. In 1526 he continued his studies at the newly founded and first evangelical Gymnasium ${ }^{109}$ under the leadership of Joachim Camerarius, who was to become the first biographer of Melanchthon and a close friend of Garbitius. ${ }^{110}$ Melanchthon delivered a speech at the official opening ceremony of

interea: nunc primùm in lucem eruta, \& ab interitu uindicata. Cum praefatione D. Vvolfgani Vuissenburgij Theologi Basiliensis (Basel: Johannes Oporinus, 1555; VD16 F 1255).

105 Heinz Scheible in his brief biographical entry on Garbitius names Pićan (Pedena) as the place of birth but does not state the source of this information. See, MBW 12: Personen F-K, 118.

106 Melanchthon to Erhard Schnepf (October 12, 1537): MBW T 7 (1955: 538-539; cf. CR 3: 425f.): „Conterraneus est Divi Hieronymi; nomen est ei, Magistro Matthiae Garbicio Illyrico.« See also Melanchthon's speech concerning St. Jerome delivered in $1546 » O r a t i o$ de vita D. Hieronymi Stridonensis, « from 1546 in CR 11: 734-741, esp. 736.

107 Flacius referred to Jerome as a man from the same community as himself: »Vnus popularus meus HIERONYMVS (emphasis by Flacius) « in Clavis Scriptvrae, Pars Prima, A4r.

108 Flacius, Erzehlunge der Handlungen, T3r: »Das folgende Jar/... hab ich studieret zu Tu(e) bingen beij meinem Landsmann Matthia Garbitio Illyrico, Griechischem Leser/vnd hab mit seinen Discipeln die Lectiones repetiert /...« Christian Friedrich Schnurrer later also claimed that Garbitius came from Istria. See Christian Friedrich Schnurrer, Erläuterungen der Würtembergischen Kirchen- Reformations- und Gelehrten Geschichte (Tübingen: J. G. Cotta'schen Buchhandlung, 1798), 388: „Garbiz war in Histerreich (ehemals Jllyricum) im niedrigem Stand gebohren.«

109 In the previous year, 1525, the imperial free city of Nuremberg officially accepted the Protestant Reformation.

110 His biography of Melanchthon was published in 1566, just six years after the death of the Wittenberg humanist and reformer, as De Philippi Melanchthonis ortu, totius vitae curriculo et morte de Philippi Melanchthonis ortv, Totivs Vitae Cvrricvlo et Morte, Implicata Rervm Memorabilivm Temporis Illivs Hominumque mentione atque indicio, cum expositionis serie cohaeentium: Narratio Diligens est Accvrata Ioachimi Camerarii Pabeperg (Leipzig: Ernst Vögelin, 1566; VD16 C 502). In the biography itself there is a short chapter with the title »Praise for Matthias Garbitius.« For more about the biography, see Timothy J. Wengert, »With Friends Like This ... The Biography of Philip Melanchthon by Joachim Camerarius, « in Thomas F. Mayer and D.R. Woolf (eds.), The Rhetorics of Life-Writing in Early Modern 
the school in May of that year, ${ }^{111}$ and this was the first time young Garbitius met Praeceptor humanissimus. The two were to later develop a friendship that is reflected in Melanchthon's correspondence and from which young Flacius was to also benefit. ${ }^{12}$

During the coming years, Garbitius had the opportunity to meet many powerful local residents in Camerarius' home where he was living, among them Melanchthon's friend, Hieronymus Baumgartner, patrician and a member of the city council in Nuremberg. ${ }^{113}$ Garbitius already showed an interest and a talent for Latin and Greek during his years of study in Nuremberg. In 1533 he went to Heidelberg, where he worked as a tutor and also enrolled at the University as a student. ${ }^{114}$

After only a year-long stay, Garbitius moved to Wittenberg in 1534 and was matriculated at the University on May 6. There he met Martin Luther, who helped him, and he also became Melanchthon's student. On August 28 of that year Garbitius received the degree of Master of Arts (magister artium).$^{115}$ The following day, Melanchthon wrote to Camerarius in Nuremberg about his student and warmly recommended him, saying: »Matthias has completed the usual education and has earned school degrees. [...] For he is, as I indeed reckon, [endowed] with upstanding morals and well educated,

Europe: Forms of Biography from Cassandra Fedele to Louis XIV [Studies in Medieval and early Modern Civilization] (Ann Arbor: University of Michigan Press, 1995), 115-131.

111 CR 11: 106-111, Nr. 12. This school in Nuremberg today bears the name MelanchthonGymnasium.

112 For the relationship between Melanchthon, Garbitius and Flacius, see Luka Ilić, »Praeceptor Humanissimus et duo Illyri: Garbitius et Flacius, « in Irene Dingel and Armin Kohnle (eds.), Philipp Melanchthon. Lehrer Deutschlands, Reformator Europas [Leucorea-Studien zur Geschichte der Reformation und der Lutherischen Orthodoxie 13] (Leipzig: Evangelische Verlagsanstalt, 2011), 65-79.

113 Garbitius later wrote a 34-page dedication to his edition of Aeschylus' Prometheus to Baumgartner (Baumgärtner); Aeschyli Prometheus, cum interpretatione Mathiae Garbitii Illyrici, Graecae linguae \& Moralis philosophiae professoris ordinarij in Academia Tubingensi... (Basel: Johannes Oporinus, February 1559; VD16 A 408). For more about him, see »Baumgartner, Hieronymus, « in MBW 11: Personen A-E, 124-125.

114 He enrolled on April 30, 1533 when Johann Stopler was rector. See Gustav Toepke (ed.), Die Matrikel der Universität Heidelberg. Vol. 1: von 1386-1553. (Heidelberg: Carl Winter, 1884), 554: »Matthias Illyricus dioeceseos Weiden vltimo Aprilis.« Scheible draws the conclusion that Garbitius was most likely born in Pedena/Pićan, based on the fact that the Bishopric of Weiden is sometimes referred to as Pedena. However, in old German the Bishopric of Udine in Italy is also called Weyden. Therefore, Garbitius' exact place of birth cannot be established based only on this enrollment record from the University of Heidelberg. Garbitius' enrollment at the University coincided with the arrival of Jacob Micyllus, the noted Greek scholar, who took up a teaching post there.

115 Julius Köstlin, Die Baccalaurei und Magistri der Wittenberger philosophischen Facultät 1518-1537 und die ordentlichen Disputationen 1536-1537. Aus der Facultätsmatrikel veröffentlicht (Halle: Max Niemeyer, 1888), 21. 
and recommended by you to me. $«{ }^{116}$ According to Tübingen professor Georg Liebler, ${ }^{117}$ who delivered Garbitius' funeral oration, Melanchthon had developed great respect for his talented student and was especially proud of his thorough knowledge of Greek. ${ }^{118}$ As was normal practice, Melanchthon wrote »Gratiarum actio in promotione Magistrorum, « the response read by a graduating student, on the occasion of Garbitius' graduation. ${ }^{119}$ Garbitius was also often a guest in the homes of Luther and Melanchthon during his stay in Wittenberg. ${ }^{120}$

Melanchthon helped the Illyrian get a position at the University of Wittenberg, teaching Greek literature. In his classes, Garbitius interpreted the works of Homer, Sophocles, and Aristotle's ethics, and became increasingly interested in ethics. Apart from lecturing on the Greek classics, Garbitius himself composed and published poetry in Greek and Latin. His longest poem in Greek was an epithalamium of 82 couplets for the occasion of the wedding of Melanchthon's daughter Anna to Georg Sabinus in November 1536. ${ }^{121}$

116 MBW T 6 (1483: 190-191; cf. CR 2: 783): »Matthiam ornavimus usitatis scholae titulis. Nec ei in posterum mea officia defutura sunt maiora his usitatis rebus, modo ut possim aliqua ei in re prodesse. Est enim, ut ego quidem iudico, probis moribus et bene literatus, et a te mihi commendatus."

117 For more about Liebler's and Garbitius's role at the University of Tübingen, see Norbert Hofmann, Die Artistenfakultät an der Universität Tübingen, 1534-1601 [Contubernium: Beiträge zur Geschichte Eberhard-Karls-Univesität Tübingen 28] (Tübingen: Mohr Siebeck, 1982).

118 Georg Liebler, Oratio lugubris, Post funerationem Clarissimi, \& omni Virtutum \& Doctrinarum genere spectatissimi viri, Dn. M. Matthiae Garbitii Illyrici, vtrivsqve lingvae, et philosophiae moralis, in inclyra Tubingensi Academia Professoris celebratissimi fidelissimique: in Ferijs DD. Apostolorum Philippi \& Jacobi, Anno 1559. cum Discipulis suis, insigni dexteritate, zeloque; plane divino, summa cum admiratione explicaret Textum, Jo: 14. (Tübingen: Johann Alexander Cellius, 1614; not in VD17), 11. The funeral oration (Leichenpredigt) delivered by Liebler was published by his student, pastor Israel Wieland fifty-five years later. The original manuscript of the speech is stored at Universitätsbibliothek Tübingen, Mh 196, 1r-31v. Liebler also held the funeral oration for Sabina, Duchess of Württemberg [VD16 L 1652] as well as for Jakob Schegk [VD16 L 1653]. Garbitius wrote a short poem in Greek which appeared on the title page of Schegk's work Philosophiae Natvralis ... (Tübingen: Ulrich Morhardt, 1538; VD16 S 2484).

119 CR 10: 923-924, Nr. 9.

120 Liebler, Oratio lugubris, 12.

121 Verses 79 through 84 talk about how Sabinus is blessed because he is not only marrying a much sought after bride but is also gaining a famous father-in-law, who exceeds Orpheus and Pericles in his rhetorical skills. »De nuptiis Georgii Sabini et Annae, filiae Melanchthonis, « was published in Melchior Acontius and Matthias Garbitius Illyricus, Erotica/Georgii Sabini Brandeburgensis. Dvo Epithalamaia. Alterum Latinis versibus a Melchiore Acontio, Alterum Graecis a Matthia Illyrico scriptum (Wittenberg: Josef Klug, 1536; VD16 F 1763), D1r-D4r. Garbitius was to later write a poem for Melanchthon's young granddaughter, which he published in an edited volume Epitaphia/qvaedam non inscita partim graeca partim/latina iam primum Tubingae aedita. Anno M.D.XL.III. die Augusti VI. (Tübingen, 1543; VD16 ZV 5130), 16. 
On September 13, 1537 Garbitius was received into the senate of the Faculty of Liberal Arts at the University of Wittenberg. ${ }^{122}$ However, soon afterwards he moved to Tübingen where he took a post as a professor and in 1541 he inherited the chair in Greek of his previous teacher Camerarius, who had left for Leipzig. ${ }^{123}$ Melanchthon had already written to Camerarius in April 1537 about the possibility of Garbitius moving to the University of Tübingen (founded in 1477) and sent the Illyrian with a glowing recommendation letter to the university senate in October ${ }^{124}$ Garbitius was a part of the reconstruction of the University of Tübingen as an Evangelical university in which Wittenberg was very involved by sending several people to teach there after 1535, when Duke Ulrich I of Württemberg officially introduced the Protestant reformation into the theological faculty.

In Tübingen Garbitius became professor of Greek language and Latin literature and poetry and in July 1544 also professor of ethics. ${ }^{125}$ Soon after arriving in Tübingen, he married his first wife but she died not much later. ${ }^{126}$ In 1540 Garbitius remarried, and had four sons and two daughters with his second wife. ${ }^{127}$ Garbitius continued writing, translating and publishing with some of his works being published by Johannes Oporinus in Basel, the same publisher that Flacius would use throughout his career. Garbitius was also well known as a poet; Melanchthon, in the recommendation letter he wrote for him, referred to poems written by Garbitius in Latin. ${ }^{128}$

122 Köstlin, Die Baccalaurei und Magistri (1888), 26.

123 The two of them corresponded with each other. Some of those letters were published in Libellus nouus, Epistolas et alia qvaedam Monvmenta Doctorvm Superioris et huius Aetatis Complectens. Editus studio Joachimi Camerarij Pabeperg. Anno Christi. M. D. LXIII (Leipzig: Hans Rambau d.Ä., 1568; VD16 C 411). See for example a letter from Garbitius to Camerarius on February 2, 1546, consoling Camerarius about his brother's death and telling him about his new rectorship, O 5-6; or an undated letter from Camerarius to Garbitius, 5-6.

124 MBW T 7 (1951: 529-533; cf. CR 3: 421-425). See also letters written to Camerarius and Veit Dietrich on October 11-13, 1537 praising and recommending Garbitius; MBW T 7 (1953: 535-537; 539-541; cf. CR 3: 419-421; 428-430).

125 Combining a number of interests and disciplines was a typical trait of humanists of the sixteenth century. See Helmuth Maier, »Der Humanist Mathias Garbitius Illyricus, « Blätter für Württembergische Familienkunde 5, Heft 11/12 (1934): 105ff.

126 They married in February 1538. Her name was Margarete and she was the daughter of the professor of law and rector of the Tübingen University, Johannes Kingsattler.

127 Their first-born son was named Matthias in honor of Garbitius. Garbitius' other son appears on the student list at the University of Tübingen in April of 1554 as »Christoph Garbitz Tubingensis.« The second wife, Magdalene Röser, died in Calw in July 1555, soon after giving birth to their daughter, who was named Magdalene.

128 See also Iva Karabaić, Posvetno pismo Matije Grbića prijevodu Eshilova Okovanog Prometeja (Undergraduate Thesis, Department of Philosophy, The University of Zagreb, 1996), 4. 
During the period between 1545 and 1557 Garbitius was the dean of the philosophical faculty (facultas artium) at the University in Tübingen three times. ${ }^{129}$ He apparently died of a stroke while expounding the Gospel of John, 14:1: »Do not let your heart be troubled; believe in God, believe also in Me. ${ }^{130}$ Garbitius' successor at the university was Martin Crusius, ${ }^{131}$ who also wrote a short biography of Garbitius in his most important work, Swabian Annals (Annales Suevici). ${ }^{132}$ There are conflicting claims about whether Garbitius remained a Lutheran until the end of his life. ${ }^{133}$

Garbitius and Melanchthon not only shared an intellectual connection and a common fascination with ancient philosophy and language. Their friendship and mutual respect went beyond the usual relationship between teacher and student, and they seemed to have a very personal bond. The warm tone and abundant compliments concerning Garbitius in Melanchthon's recommendation letter to Tübingen and in his personal letters to Camerarius and others demonstrate this. Melanchthon must have had a lot of respect for his student and confidence in Garbitius' abilities in Greek and other subjects.

129 In that role Garbitius was also required to hold funeral orations for fellow professors; an example is a published speech (Leichenrede) he held in remembrance of Johannes Sichard [VD16 G 2981]. See Horst Schmidt-Grave, Leichenreden und Leichenpredigten Tübinger Professoren (1550-1750): Untersuchungen zur biographischen Geschichtsschreibung in der frühen Neuzeit [Contubernium 6] (Tübingen: Mohr, 1974), 42. For an overview of Garbitius' career, see Đuro Körbler, »Humanista Matija Grbić (Mathias Garbitius Illyricus), in Rad Jugoslavenske akademije znanosti i umjetnosti, Knjiga 145 [Razredi filologijsko-historijski i filosofijsko-juridički 55] (Zagreb, 1901), 31-75. Garbitius' collection of books was acquired by the library of the Tübingen Evangelischer Stift in 1563. In 2009, the University of Tübingen listed the $450^{\text {th }}$ anniversary of Garbitius' death (May 1) on its official list of commemorations (Gedenkkalender). http://www.uni-tuebingen.de/UAT/archiva.htm (accessed November 22, 2011).

130 See Pietro Paolo Vergerio's letter to Duke Christoph of Württemberg, dated on May 2 (only one day after the event took place) in Eduard von Kausler and Theodor Schott (eds.), Briefwechsel zwischen Christoph, Herzog von Württemberg und Petrus Paulus Vergerius [Bibliothek des litterarischen Vereins in Stuttgart 74] (Tübingen: H. Laupp, 1875), 209-211, here 210. Albert Westermayer Emil Wagner, and Theodor Demmler (eds.), Die Grabdenkmäler der Stiftskirche zu St. Georg in Tubingen (Tübingen: Weil, 1912), 207.

131 For his biography, see Thomas Wilhelmi, »Crusius (Kraus), Martin, in Kühlmann et al. (eds.), Frühe Neuzeit in Deutschland, 58-63.

132 During the years 1595-1596 two Latin volumes consisting of four parts were published in Frankfurt am Main by Nikolaus Basse [VD16 C 1603]. I have used the German translation from Johann Jakob Moser, Martin Crusii Schwaebischer Chronick (Frankfurt: Metzler und Erhard, 1733), vol. 2: 290; 296.

133 Mijo Mirković refers to the regulation of the University of Tübingen that professors had to be Lutheran. He rejects Körbler's claim that Garbitius returned to Catholicism after the Augsburg Interim and maintains that he remained a loyal follower of Melanchthon, as opposed to taking Flacius' side. See Mirković, Matija Vlačić Ilirik, 40 n. Also, Garbitius' daughter Magdalene married a Lutheran pastor, Johannes Weickersreutter in 1572, which supports the thesis that Garbitius remained a Lutheran. Another proof might be that all four sons of Garbitius were buried in a family tomb in the main evangelical church in Tübingen. For the tomb epitaph, see Westermayer et al. (eds.), Die Grabdenkmäler der Stiftskirche zu St. Georg, 206. 
Garbitius did not take sides in the polemics between Melanchthon and Flacius during the $1550 \mathrm{~s}$ but rather stayed neutral and therefore exercised a more irenic spirit. ${ }^{134}$

Relying upon his personal relationships and network of connections, Garbitius tried to assist his young protégé and fellow countryman, Flacius, in the same way as Melanchthon and Camerarius had done for him. In Tübingen he introduced Flacius to many important people, including Leonhart Fuchs, who was the University rector at the time, and according to Flacius the two formed a friendship that lasted until Fuchs' death. ${ }^{135}$ Among the other new acquaintances Flacius acquired via Garbitius were Jakob Schegk, Ludwig Gremp von Freudenstein, professor of Roman and canon law and previous rector, ${ }^{136}$ and Johannes Forster, who taught Flacius Hebrew in Tübingen. Later they exchanged roles as Forster succeeded Flacius as professor of Hebrew in Wittenberg. ${ }^{137}$ Both Garbitius and Camerarius saw potential in Flacius, and together they decided to send him to Wittenberg to continue

134 Križman, »Grbić, Matija,« 138.

135 Flacius, Erzehlunge der Handlungen, T3r: »...D. Leonhardo Fuchsio, welcher als ein trefflicher Liebhaber der reinen Lere/vnd feind aller Secten bis in seinen Todt/mein guter Freund gewesen ist.« For the theory that Fuchs' statement that sickness is the substance of the human being (morbum esse substantiam) might have influenced Flacius' theological anthropology, see Olson, Flacius and the Survival of Luther's Reform, 37-38.

136 For more about Gremp, see Albert Teichmann, »Gremp von Freudenstein, Ludwig, in ADB 9 (1879), 637-638; Hans Erich Feine, »Gremp von Freudenstein, Ludwig,« in NDB 7 (1966), 44-45. Flacius says that he himself visited Gremp a few times while living in Tübingen. See, Twesten, Matthias Flacius Illyricus, eine Vorlesung, 66. The same Gremp later became Strasbourg's chief attorney (Advokat) and helped Flacius legally to stay in the city between 1567-1572. See, James Kittelson, Toward an Established Church: Strasbourg from 1500 to the Dawn of the Seventeenth Century [Veröffentlichungen des Instituts für Europäische Geschichte 182: Abteilung für Religionsgeschichte] (Mainz: Philipp von Zabern, 2000), 146150, here 147: »There is nonethless good evidence to suggest that Gremp, working through his network of fellow attorneys in other places, smuggled him [Flacius] into the city, « and 148: »Gremp in all likelihood - arranged for Flaccius [sic!] to be received into the city ...« It seems that Kittelson is not aware that Gremp and Flacius had known each other personally already for almost twenty years. Flacius' son, Matthias, the Younger dedicated his humanistic poem in Latin, an allegory on fever and medicine, Elegia de febri. Scripta à Matthia Flacio Illyrici filio (s.1. 1571; VD16 F 1577), to Gremp, calling him »patrono« on page A2a, suggesting that Gremp helped with financing the younger Flacius' education in Strasbourg.

137 Christina Beatrice Melanie Frank, Untersuchungen zum Catalogus testium veritatis des Matthias Flacius Illyricus (Eberhard-Karls-Universität zu Tübingen, 1990, doctoral dissertation, selbstverlag), 12. Frank states that Forster was Flacius' Hebrew teacher in Tübingen. For more about Forster see Reinhold Jauernig, »Forster, Johann, « in NDB 5 (1961), 304; Helmar Junghans, »Verzeichnis der Rektoren, Prorektoren, Dekane, Professoren und Schloßkirchenprediger der Leucorea vom Sommersemester 1536 bis zum Wintersemester 1574/75, « in Irene Dingel and Günther Wartenberg (eds.), Georg Major (1502-1574) - Ein Theologe der Wittenberger Reformation [Leucoreastudien zur Geschichte der Reformation und der Lutherischen Orthodoxie 7] (Leipzig: Evangelische Verlagsanstalt, 2005), 235-270, here 244; »Forster, Johannes, « MBW 12: Personen F-K, 76-77. 
his studies there. ${ }^{138}$ It was not only that other people recognized the gift for ministry in Flacius, but he also experienced it personally at an early age as he himself later testified. ${ }^{139}$

Flacius' connections in Augsburg, Basel and Tübingen are examples of how his personal networks formed and how they functioned. On one level, at least, it seems that Flacius was lonely enough in different locales of his lifejourney, so that he did strive to establish friendships. ${ }^{140}$ On the other hand, it is undeniable that he was also driven by a desire to create connections from which he could later benefit, seeking out individuals who would be willing to finance his projects or lobby political and religious leaders in his favor.

Flacius traveled to Wittenberg via Regensburg during the time of the Imperial Diet (Reichstag). ${ }^{141}$ The religious colloquy at the Diet took place between April 5 and July 29, 1541. It is known that Melanchthon arrived there on March 25 and returned to Wittenberg on August 5. ${ }^{142}$ Since Flacius enrolled at the University in Wittenberg on May 1, his journey through Regensburg must have occurred sometime in April. It is plausible to think that Flacius might have seen Melanchthon in Regensburg for the first time.

\section{Wittenberg: \\ Flacius' Theological Formation at the Center of Lutheranism}

The next stop for Flacius was to become a decisive one, signaling a major turning point in his life. He was now heading to the heart and hub of Protestantism: Wittenberg. His stay in the city was to bring both hoped-for and unexpected changes: first a crisis and then the solidification of his faith; the conclusion of his studies and his first teaching position at the University; his

138 Camerarius states this in his biography of Melanchthon. I have used the new translation into German published on the occasion of the $450^{\text {th }}$ anniversary of Melanchthon's death. Joachim Camerarius, Das Leben Philipp Melanchthons, trans. by Volker Werner [Schriften der Stiftung Luthergedenkstätten in Saschen-Anhalt 12] (Leipzig: Evangelische Verlagsanstalt, 2010), 206: »...begab er sich [Flacius] 1541 nach Wittenberg, wo ihn Philipp Melanchthon, weil er von uns gekommen war, mit noch größer Freundlichkeit aufnahm.«

139 Flacius, Entschueldigung JIlyrici, D5v.

140 As Heinz Scheible once observed, Flacius was well-skilled in making both friends and enemies: »Flacius war ein Genie der Freundschaft und des Hasses, « in Bibliotheca Palatina, 411; Jürgen Diestelmann also made a similar conclusion: »Flacius, der durchaus charmant sein konnte und sich einen ausgedehnten Freundeskreis zu schaffen verstand, bildete ..., « in Joachim Mörlin: Luthers Kaplan - „Papst der Lutheraner. "Ein Zeit- und Lebensbild aus dem 16. Jahrhundert (Neuendettelsau: Freimun, 2003), 221.

141 Flacius, Erzehlunge der Handlungen, T3r.

142 Wibke Janssen, »Wir sind zum wechselseitigen Gespräch geboren« Philipp Melanchthon und die Reichsreligionsgespräche von 1540/41 [Forschungen zur Kirchen- und Dogmengeschichte 98] (Göttingen: Vandenhoeck \& Ruprecht, 2009), 204. 
first marriage; his initial theological disagreements; and the forging of relationships with the two most important men for the Wittenberg Reformation - Luther and Melanchthon. The time that Flacius spent in Wittenberg marked an important stage in his pre-radicalization phase, while he also continued developing sensitivity to theological issues. At the same time, the effects of living as a foreigner, away from home and family, were contributing to his tendency toward spiritual struggle and insecurity. In spite of the challenges he was facing, however, the path young Flacius was setting out on was on one level not yet much different from that of other Wittenberg students, although on another level he did begin to distinguish himself above others academically. The pre-radicalization phase in Flacius' life was characterized by inquisitiveness and eagerness to learn, but certain elements, such as his internal conflicts, were already foreshadowing his vulnerability and were to contribute to ushering in the first phase of his theological radicalization. The following sections focus not only on Flacius' experiences and accomplishments in Wittenberg but also examine them through the lense of his association with Luther and Melanchthon, both of whom were to have a life-long impact on him, albeit in very different ways.

While the significance of the Wittenberg years for the formation of Flacius' personal faith and theology should not be discounted, it is also important to keep in mind that the young Illyrian arrived there already after years of educational broadness, particularly influenced by Venetian humanism, and with an already budding interest in classical literature, biblical exegesis and languages. Furthermore, he established relationships that were to play an important role later in the forming of his professional and personal networks. In Basel and in Tübingen Flacius also encountered streams of Protestant thought different from the Wittenberg Reformation. He continued familiarizing himself with these ideas even while in Wittenberg, which is demonstrated by the books that he was reading and studying during that time. This observation is based on a partial reconstruction of the tomes that Flacius possessed and read during his Wittenberg years, kept today at Herzog August Bibliothek in Wolfenbüttel..$^{143}$ The identification of these works is possible because he marked the books that he owned with his initials and the year in which he either purchased or received them as gifts. Several of the books also contain his personal annotations and comments relating to the text. Among the volumes that Flacius read are commentaries on the Gospel of Matthew and the Book of Acts by Heinrich Bullinger ${ }^{144}$ Commentaries on the Four

143 Martina Hartmann's reconstruction of Flacius' library in her Humanismus und Kirchenkritik does not contain the books of contemporaries he owned but is instead focused primarily on the manuscripts he possessed.

144 In Acta Apostolorum Heinrychi Bullingeri Commentariorum libri VI (Zurich: Christoph Froschauer d.Ä., 1540; VD16 B 4955); In Sacrosanctvm Iesu Christi Domini nostri Euangelium 
Holy Gospels by Martin Bucer, ${ }^{145}$ Erasmus' New Testament, ${ }^{146}$ Autores Historiae Ecclesiasticae by Beatus Rhenanus, ${ }^{147}$ Institutionum Linguae Graecae by Urbano Bolzanio, ${ }^{148}$ numerous commentaries by Erasmus Sarcerius, ${ }^{149}$ a commentary on the epistles of St. Paul by Ambrosiaster issued by Erasmus ${ }^{150}$ and a Hebrew lexicon by Santes Pagnino. ${ }^{151}$

\section{a) Flacius, A Disciple and Lifelong Follower of Luther}

Matthias Flacius arrived in Wittenberg as a student in 1541 to study for a Master of Arts degree. He matriculated at the University in the Summer Semester (May 1) under the rectorship of Killian Goldstein the Elder as a pauper (gratis inscriptus). ${ }^{152}$ By that time, Flacius already knew the classical languages, having learned Greek from Egnazio, Oporinus and Garbitius, and Hebrew from Münster and Forster. However, he continued learning Greek

secundum Matthaeum Commentariorum libri XII (Zurich: Christoph Froschauer d.Ä.,1542; VD16 B 4889). Both books were obtained by Flacius in 1545 and contain notes in his hand on the margins. HAB, C 206c. $2^{\circ}$ Helmst. (1); C 241. $2^{\circ}$ Helmst. (1).

145 In Sacra Qvatvor Evangelia, Enarrationes Perpetvae... (Basel: Johannes Herwagen d.Ä., 1536; VD16 B 8873). HAB, C 229.2 Helmst. (1).

146 NEA $\triangle I \Theta H K H$. Novvm Testanementvm (Basel: Hieronymus Froben, 1545; VD16 B 4185), HAB, A 78.4 Helmst. Des Erasmi Rot. Opervm Sextus Tomvs Novvm Testamentvm Complactens ... (Basel: Hieronymus Froben and Nicolaus Episcopius, 1542; VD16 E 1869), HAB, C $205.2^{\circ}$ Helmst. (1). These volumes contain numerous notes, marginalia and even an index in Flacius' hand. Most likely Flacius used them when he was working on his Glossa. For more on that work see the section Glossa: Flacius' New Testament Exegesis later in this book.

147 Avtores Historiae Ecclesiasticae ... (Basel: Hieronymus Froben and Nicolaus Episcopius, 1544; VD16 E 4277), HAB, S $21.2^{\circ}$ Helmst. (1).

148 Vrbani Bellvnensis, Institvtionum Linguae Graecae libri Dvo ... (Basel: Hieronymus Curio and Heinrich Petri, 1548; VD16 B 6533), HAB, P $830.8^{\circ}$ Helmst. (1).

149 Flacius owned commentaries on Matthew, Mark, Luke and the epistles to the Corinthians by Sarcerius. In Matthaevm Evangelistam ivsta docta Scholia, per omnes rhetoricae artis ... (Basel: Bartholomaeus Westheimer, 1544; VD16 S 1733), HAB, C 300.8 Helmst.; In Marcum evangelistam iusta scholia ... (Basel: Bartholomaeus Westheimer, 1541; VD16 S 1730), C $324.8^{\circ}$ Helmst. (1); Lvcae Evangelion cvm ivstis scholijs, per omnes circumstantias, Methodica forma consriptum ... (Basel: Bartholomaeus Westheimer, 1540; VD16 ZV 13717); C 336.8 Helmst. (1); In D. Pavli Epistolas Ad Corinthios, eruditae ac piae meditationes (Strasbourg: Wendel Rihel, 1544; VD16 S 1711), C $455.8^{\circ}$ Helmst.

150 Diui Ambrosii episcopi Mediolanensis, Comentarii in omnes Diui Pauli epistolas, ex restitution Desiderii Erasmi Roterodami diligenter recogniti. Adiecta Est Avtem Noviter inuenta ad Hebraeos epistola, eisduem Autoris comentariis illustrata (Antwerp: Johannes Steelsius and Johannes Grapheus, 1540), HAB, S $21.2^{\circ}$ Helmst. (1).

151 In 1545 Flacius purchased Pagnino's work, Hoc Est, Thesavrvs Linvae Sanctae: Sic Enim Inscribere placuit lexicon hoc Hebraicum ... (Lyon: Sebastian Gryphius, 1529). Below the initials »M I 1545« he marked the price of 3 daleris and 6 grossis, HAB, P $396.2^{\circ}$ Helmst.

152 Karl Eduard Förstemann (ed.), Album Academiae Vitebergensis, vol. 1: 1502-1560 (Tübingen: Max Niemeyer, 1976 [reprint of the original 1841 Leipzig edition], 191. In the enrolment records of the Wittenberg University Flacius is listed as »Mattheus Watzer ex Dalmatia.« 
in Wittenberg where his professor was Veit Oertel from Bad Windsheim. ${ }^{153}$ It was then, at the age of twenty-one that he met Martin Luther and Philipp Melanchthon. As a student, Flacius's life was limited to his room, the University and the church, and he became known for his utter devotion to research and serious scholarship.

After Flacius had already been in German-speaking territories for three years, far away from his beloved Istria, learning German and struggling to adjust to a completely different culture and climate, he had many doubts about his newly acquired Lutheran faith. He did not share his internal struggles with anyone and as a result, grew disillusioned. By his own account, a deep struggle with sin tormented him, causing depression and even thoughts of suicide. He kept thinking that God was angry with him and wanted only to judge him because of his sin. In his autobiographical writing Flacius says that he thought constantly of death and felt the wrath of God upon himself, also experiencing the power of the devil. He explains what happened when, in the midst of his personal crisis, he had a face-to-face meeting with Luther: ${ }^{154}$

[...] Luther then comforted me by sharing his own example, as well as through the word of God, and when the congregation [at St. Mary's Church in Wittenberg] had prayed for me, the torment lessened from day to day until a year later I was well again. ${ }^{155}$

In Luther, Flacius recognized a man like himself, with human doubts and insecurities, different from what he seemed to be behind the pulpit or in the classroom. Later in life, Flacius said that this very personal discussion with Luther in his study changed him completely - it was his breakthrough experience. August Twesten, Friedrich Schleiermacher's successor in Berlin, even

153 This information is found in a short biography of Flacius published by Pantaleon and also in Preger, Flacius und seine Zeit, 1: 21. Camerarius does mention that Flacius' knowledge of Greek was average at that time and states that Flacius devoted much more time to perfecting his Hebrew language skills. Das Leben Philipp Melanchthons, 206: »Flacius, der im Griechischen nur mittelmäßige Kenntnise besaß, verlegte sich damals ganz und gar auf das Erlernen der hebräischen Sprache.«

154 This encounter with Luther - something Flacius in a preface from 1549 said he remembered often - took place in 1542: »Ich gedencke offt/do ich vor sieben jaren in grosse anfechtung vnd Teuffels plagen war/des trostes D. Martini Luthers seliger gedechnis/der vnter andern auch also zu mir sagte /... in Ein rechter lesteriger Rabsakes brieff/geschrieben von einem Bischoff an einen Christlichen Fürsten/in welchem er ihn vermanet das er sol von der erkanten warheit Christi zu dem Antichrist abfallen/Daraus man sehr woll kann mercken wie gut es die Antichristische Wolffe mit dem armen Schefflein Christi meinen (Magdeburg: Christian Rödinger d.Ä., 1549; VD16 ZV 10271), A2r.

155 Flacius, Apologia ... ad Scholam Vitebergensem, B4r: »... D. D. Martinum Luth. Qui, cum proprio exemplo aliorumque et verbo DEI me consolatus esset, Ecclesiaque pro me preces fecisset, coepi indies melius habere, ita ut in uno anno mediocriter convaluerim.« 
called this event the key to understanding Flacius' life. ${ }^{156}$ The two most wellknown Flacius biographers, Wilhelm Preger and Oliver Olson followed the same interpretation, and it is this thesis that has prevailed in much of Western scholarship until today, influencing perceptions of Flacius and his legacy. ${ }^{157}$ Wittenberg was indeed a turning point for Flacius' Evangelical faith, as Twesten had pointed out: it was here that his Lutheran beliefs became consolidated. However, by focusing on this development, his previous experiences, both academic and within the Protestant milieux in Augsburg, Basel and Tübingen, received less attention. For example, Olson devotes only fourteen pages of his 428-page biography to Flacius' life before Wittenberg, and Preger's account is even shorter. ${ }^{158}$ Therefore, a new narrative of Flacius' life is needed that will avoid overemphasizing one aspect at the expense of the others, and will instead present a more encompassing and impartial account, as Irene Dingel has recently asserted. ${ }^{159}$

The encounter with God that Flacius underwent in the midst of suffering is reminiscent of what Luther himself had gone through and what he called »Anfechtung« or »Tentatio." Although the comfort Flacius received from Luther made him feel delivered and renewed, he kept returning to the theme of human sinfulness throughout the rest of his theological career, reformulating his own understanding of the doctrine of sin. He came to believe that the real problem of original sin fundamentally defines the human being's personal relationship with God. A letter of recommendation in which Luther wrote favorably about Flacius in 1543 stating $»$ nostris homo notissimus et magnæ fidei« (he is a man well-known to us and of great faith), ${ }^{160}$ confirms the personal bond between the Reformer and the young Illyrian. In another letter from November 1544 Luther referred to Flacius' academic devotion, calling him »studiosissimus. ${ }^{161}$

156 Twesten, Matthias Flacius Illyricus, eine Vorlesung, 6: »Wir haben hierin den Schlüssel seines ganzen Lebens..."

157 See Preger, Flacius und seine Zeit, 1: 23; Oliver K. Olson, »Matthias Flacius Illyricus, « in Jill Raitt (ed.), Shapers of Religious Tradition in Germany, Switzerland and Poland, 1560-1600 (New Haven and London: Yale University Press, 1981), 1-17, here 2.

158 See Olson, Flacius and the Survival of Luther's Reform, 25-38.

159 See, Dingel (ed.), Reaktionen auf das Augburger Interim, »Historische Einleitung, « 3-34, here 15, n. 53: »Trotz dieser umfangreichen biografischen Studien [i.e. Preger and Olson] wäre eine neue, unvoreingenommene wissenschaftliche Sichtung des gelehrten Illyrers und seines Werks wünschenswert.«

160 Luther wrote to Veit Dietrich in Nuremberg on June 13, 1543, informing him that he gave a letter he had written to Flacius for the Italian evangelicals to carry and that on his way to Venice, Flacius will stop in Nuremberg. WA Br 10: 328, Nr. 3884: »Accepit a me literas illas ad Italos fratres, quas toties a me flagitasti, Hic Matthias Illyricus, nostris homo notissimus \& magne fidei."

161 WA Br 10: 679-682, here 681, Nr. 4041: „Cum vero Matthias Illyricus vestri studiosissimus..." 
In 1544 Flacius received a teaching appointment for Hebrew language at the Faculty of Arts at Wittenberg University. ${ }^{162}$ A year later he married Elisabeth, the daughter of the evangelical pastor Michael Faust ${ }^{163}$ from Dabrun, a village close to Kemberg, southeast of Wittenberg. Luther, who attended Flacius' November 1545 wedding, died four months later. ${ }^{164}$ On February 25, 1546, only seven days after Luther's death in Eisleben and three days after Melanchthon and Johannes Bugenhagen had delivered funeral orations, Flacius received a master's degree. He graduated as the best in his class of thirty-nine students. ${ }^{165}$

Beyond Flacius' strong personal connection to and identification with Luther, he also recognized Luther's emphasis on human fallenness and on original sin as central to the great Reformer's theology. This was later to play a significant role of legitimation in his argumentations at the theological controversies he was involved in. Flacius' perception was that this emphasis was lessening among the second generation of Lutheran Reformers, and so he strove to preserve and emphasize (and in the process perhaps even over-emphasize) this doctrine. He wanted to follow what Luther had earlier articulated in his preface to the commentary on the Epistle to the Romans: ॥Sin, in the Scripture, means [...] the inmost heart, with all its powers; [...] before good or bad works take place, as the good or bad fruits, there must be in the heart

162 For details about Flacius' appointment as professor, see Friedensburg, »Die Anstellung des Flacius Illyricus, «302-310. It is also interesting to note that Camerarius mentions how Flacius passionately studied Hebrew while in Tübingen. See, Joachim Camerarius, De vita Philippi Melanchthonis Narratio. I have used a reprinted edition of the work by Georg Theodor Strobel (Halle: Johann Gebauer, 1777). See chapter LXXXII, entitled »Matth. Garbii laus. Matth. Flacii turbulentum ingeniut, «274: »Flacius in cognoscendam linguam Hebreicam tunc totius incubit."

163 For more about him, see »Faust, Michael,« in MBW 12: Personen $F-K$, 50. Melanchthon mentions pastor Faust a number of times in his correspondence between 1553 and 1558 in a positive manner (MBW 6984, 7500, and 7870 (Regesten 7:124, 314, 449); and MBW 8549 (Regesten 8: 203), suggesting that Faust stayed loyal to Wittenberg and to Praeceptor Philipp. See Flacius' letter to Simon Musaeus, dated in Jena on September 2, 1557, in which he refers to Faust as »my father-in-law« (meus socer) and further talks about Faust's annual pension, in Otto Clemen, Kleine Schriften zur Reformationsgeschichte (1897-1944), vol. 6, in Ernst Koch (ed.), (Leipzig: Zentralantiquariat der DDR, 1985), 240-243, here 240.

164 Flacius, Erzehlunge der Handlungen, T3v: »Habe auch etliche mal mit dem Ehrwu(e)rdigen Herrn D. Luther seliger geredt /... Es ist auch der Man Gottes auff meiner Hochzeit gewesen im Herbst des 1545. Jars."

165 Julius Köstlin, Die Baccalaurei und Magistri der Wittenberger philosophischen Fakultät 1538-1546 und die öffentlichen Disputationen derselben Jahre. Aus der Facultätsmatrikel veröffentlicht (Halle: Max Niemeyer, 1890), 18. See also the speech written by Melanchthon and delivered by the Dean of the Faculty of Philosophy, Johann Stoltz, in CR 11: 716-721, Nr. 89. 
faith or unbelief. $^{166}$ According to Robert Kolb, »Luther viewed the freedom and bondage of the human will, as critical for a proper interpretation of the entire biblical message $\ll{ }^{167}$ Luther also stated in his lecture on Psalm 51 from 1532 that $»$ without [the doctrine of original sin] it is impossible to understand Scriptures correctly. ${ }^{168}$ It was exactly this issue that Flacius would take very seriously and that with time emerged as the central focal point of his theology. At this point, though, the centrality of the issue of sin for Flacius was being only foreshadowed but not yet expressed in radical terms.

\section{b) A Complex Relationship: Philipp Melanchthon and Flacius}

In contrast to both Flacius' admiration of Luther and to Melanchthon's amicable relationship with Garbitius, the association between Matthias Flacius and Melanchthon went through sharply opposing phases, through both friendship and enmity. Flacius was at first Melanchthon's student in Wittenberg and later on the two became colleagues at the University. Flacius admired Praeceptor Germaniae as a teacher and considered his work Loci communes theologici ${ }^{169}$ to be of outstanding scholarship. ${ }^{170} \mathrm{He}$ recommended and cited

166 WA DB 7: 7. English translation in Preface to the Epistle of St. Paul to the Romans (1546), LW 35: 369.

167 Robert Kolb, »Nikolaus Gallus' Critique of Philip Melanchthon's Teaching on the Freedom of the Will,« ARG 91 (2000): 87-109, here 87. In support of his statement Kolb cites De servo arbitrio, WA 18: 614, 3-6 and 786, 26-35.

168 WA 40/2: 351; LW 12: 351 [Luther's lecture on Psalm 51:4, 1532].

169 A story has been published of Flacius lifting up a copy of the Loci and kissing it fondly (exosculari), then recommending it in a weeping voice in front of some students while teaching at the church of St. Ulrich in Magdeburg. Since Flacius was definitely an emotional character and he did indeed think highly of Loci, it is probable that this event could have taken place. On the other hand, there are several factors pointing to the possibility that this episode is only apocryphal. First, the author(s) of the publication remained anonymous. Second, the volume had been edited with the purpose of praising Melanchthon's work and contained testimonies in particular about the Loci. Third, it was published after Flacius' death and at the time when there were disagreements about the role of the Loci. Lastly, this book was likely trying to weigh in on the ongoing debate about whether the Loci should be included in the Formula of Concord. For the background of the drafting of the Formula of Concord and the reasons why the Loci was eventually excluded from it, see Irene Dingel, »The Preface of The Book of Concord as a Reflection of Sixteenth-Century Confessional Development, Lutheran Quarterly 15/4 (2001): 373-395. De Locorvm Theologicorvm D. Philippi Melanthonis Orthodoxa Pvritate et Vtilitate, adsertio \& subscriptio praecipuorum aliquot Doctorum (Frankfurt: Paul Reffeler, 1579; VD16 L 2253), A4r. See also the anonymous edition with the same title from 1580, which may have been edited by Joachim Meister, rector of Gymnasium illustre in Görlitz (Görlitz: Ambrosius Fritsch; VD16 L 2254) for an almost identical version of the story with only one small variation and an additional sentence stating that there are still living witnesses of this event, C5v-D1r. Meister also published Metamorphosis Flacii Illyrici in truncum (Görlitz: Ambrosius Fritsch, 1578; VD16 L 2254).

170 In 1551, when Flacius published a work defending himself from the attacks by Georg Major 
its first edition, which he described in 1559 as wwritten with more Spirit and less philosophy than the last version of the Loci ${ }^{171}$ Later, however, their relationship turned sour as praise by Flacius was replaced by disagreement and criticism, which was expressed in his letters and publications as well. One of the aims in this work is to try to challenge the stereotype held about these two people, namely that Flacius and Melanchthon were bitter enemies at all times, and to show that their relationship was much more nuanced and more complex than that. ${ }^{172}$

A number of articles have already appeared focusing on Flacius as a student of Melanchthon's, most notably those by Heinz Scheible and Irene Dingel. Scheible asserts that he has come to the conclusion during the writing of his doctoral dissertation that Flacius' understanding of history seen through a theological lens was without question influenced by Melanchthon. ${ }^{173} \mathrm{By}$ stating this he attempts to prove previous scholarship wrong, which had held that Flacius as a Gnesio-Lutheran opponent of the Philippist party had not been influenced by Melanchthon but only by Luther. ${ }^{174}$ Dingel, on the other hand emphasizes that both Luther and Melanchthon were important for Flacius' formation but that he followed Luther's model of leadership and prophetic authority. ${ }^{175}$ Flacius was welcomed at Wittenberg in 1541 by Philipp

and Johannes Bugenhagen, he clearly cited a section from the Loci Communes about the worldly authorities (Von weltlicher Obrigkeit) on the title page of his reply. See, Antwort Matth. Fl. Jllyr. auff etliche Beschueldigung D. Gei. Maiors/vnd D. Pomers (Magdeburg: Christian Rödinger d.Ä., 1551; VD16 ZV 5895).

171 Flacius, Bericht M. Fla. Jllyrici/Von etlichen Artikeln der Christlichen Lehr/vnd von seinem Leben/vnd endlich auch von den Adiaphorischen Handlungen/wider die falschen Geticht der Adiaphoristen. Lutherus spricht... (Jena: Thomas Rebart, 1559; VD16 F 1280), D2v: »... seinen ersten Loci (Da mehr Geist/ vnd weniger Philosophia/ denn in den letzten ist) ..."

172 Robert Kolb has demonstrated that Melanchthon's former students, including Flacius, who have theologically disagreed with their former teacher on certain issues, still continued to use methodological tools that they had learned in Wittenberg, such as rhetoric, dialectic, study of grammar, and »topical arrangement which Melanchthon had pioneered for learning in general and theology in particular.« See, »Philipp's Foes, but Followers Nonetheless: Late Humanism among the Gnesio-Lutherans, « in Manfred P. Fleischer (ed.), The Harvest of Humanism in Central Europe: Essays in Honor of Lewis W. Spitz (St. Louis: Concordia, 1992), 159-177, here $164-165$.

173 Heinz Scheible, $»$ Der Catalogus Testium Veritatis. Flacius als Schüler Melanchthons, « Blätter für pfälzische Kirchengeschichte und religiöse Volkskunde 63/30 (1996): 343-357, here 352: »In meiner machineschriftlichen Dissertation von 1960 und in dem 1966 publizierten Auszug daraus bin ich zu dem Ergebnis gekommen, daß Flacius geschichtstheologisch von seinem Lehrer Melanchthon ... beeinflußt ist.«

174 Ibid., 355: »Ich bestreite nicht, daß Luther ein ähnliches Verständnis der Kirchengeschichte hatte. Aber nicht er hat es auf dem Wittenberger Katheder vertreten, jedenfalls nicht thematisch, sondern Melanchthon, und ich behaupte, daß Flacius es von Melanchthon gelernt hat, denn es wurde in den Jahren 1542 bis 1548, als Flacius - unterbrochen vom Schmalkaldischen Krieg - in Wittenberg lernte und lehrte, immer wieder ... öffentlich vorgetragen.«

175 Irene Dingel, »Flacius als Schüler Luthers und Melanchthons, « in Gerhard Graf et al. (eds.), Vestigia Pietatis. Studien zur Geschichte der Frömmigkeit in Thüringen und Sachsen. 
Melanchthon on account of references from Camerarius and Garbitius. According to Joachim Camerarius, in the beginning Melanchthon helped him financially from his own funds because Flacius was poor. ${ }^{176} \mathrm{He}$ also later found students that Flacius could tutor in Greek and Hebrew, so that he could earn some money. Mirković also states that, in addition to the university classes, Melanchthon taught Greek to Flacius privately. ${ }^{177}$ During this time a friendship evolved between them, to which Melanchthon referred in 1556: »I used to enjoy friendship and familiarity with Illyricus «. ${ }^{178}$

The events of the fatal year of 1546 for the Protestants in Germany affected the young Flacius family greatly. In July of that year the emperor Charles $\mathrm{V}$ issued the ban against the two Protestant leaders, Johann Friedrich the Magnanimous, Elector of Saxony, and Philipp, Landgrave of Hesse. This was the beginning of the Smalcaldic War which soon impacted Wittenberg. As a result the University closed on November 6 because the troops of Duke Mauritz of Saxony occupied the city.

Matthias and his wife Elisabeth moved immediately, first to Köthen in Anhalt. They later went to Braunschweig, where Melanchthon helped secure a post for him through a personal recommendation to Nikolaus Medler, the superintendent of Braunschweig. ${ }^{179}$ Melanchthon's letter of reference dated 22 November stated, »The learned M. Illyricus is coming to you, who surpasses Epiphanius of Salamis ${ }^{180}$ who spoke five languages, not only in his

Festschrift für Ernst Koch [Herbergen der Christenheit. Sonderband 5] (Leipzig: Evangelische Verlagsanstalt, 2000), 77-93, here 92.

176 Camerarius, Das Leben Philipp Melanchthons, 206: »Deshalb half er [Melanchthon] dem Flacius in allem und verhalf ihm zu Aufstieg und Ansehen, wobei er, was er ja bereitwillig für alle tat, ihn auch mit seinem eigen Geld unterstützte.«

177 Mijo Mirković, Matija Vlačić [Biblioteka portreti] (Beograd: Nolit, 1957), 252.

178 MBW 7890 (Regesten 6: 456; cf. CR 8: 797-799, esp. 797). Melanchthon to Hubert Languet (July 15, 1556): »Fuit mihi dulcis et amicitia et familiaritas cum Illyrico.«

179 For more about Medler see Axel Herrmann and Arnd Kluge (eds.), Nikolaus Medler (15021551): Reformator-Pädagoge-Mathematiker (Hof (Saale): Nordostoberfränkischer Verein für Natur-, Geschichts- und Landeskunde, 2003). Medler was of the same mind as Flacius concerning the Augsburg Interim and criticized it openly in his preaching. It is actually very possible that Medler did indeed influence Flacius' view regarding the Interim, since he was older and had a leadership position in the church. On September 23, 1548 Medler preached a sermon on the Gospel of Luke chapter fourteen against the Interim and published it for the same publisher in Magdeburg where Flacius' anti-Interim pamphlets were issued. See, Eine Predigt vber Das Euangelion Luce xiiij. Von dem Wassersuechtigen/So man list den Siebenzehenden Sontag nach Trinitatis wieder das INTERIM. Geschrieben an einem guden freundt. Durch Doctorem Nicolaum Medlerum (Magdeburg: Michael Lotter, 1548; VD16 M 1887). The text of the pamphlet is available in a modern critical edition done by Hans-Otto Schneider, see Dingel (ed.), Reaktionen auf das Augsburger Interim, 694-711.

180 Saint Epiphanius, Bishop of Salamis on the Island of Cyprus had a great reputation for learning and in his youth (because of his zeal for the Scriptures) he learned the Hebrew, the Egyptian, the Syriac, the Greek and the Latin languages. 
knowledge of languages but also in his broader knowledge. (181 $^{18}$ A few weeks later, on December 5, 1546, Melanchthon wrote again to Medler, this time from Magdeburg, thanking him for receiving Flacius in a friendly manner. ${ }^{182}$ As a result of Melanchthon's commendation, Flacius was able to lecture at the Braunschweig Paedagogium during his exile from Wittenberg. In the autumn of 1547 his first child, Matthias Flacius, the Younger was born. ${ }^{183}$

When the University of Wittenberg reopened October 16, 1547, Flacius returned to his professorship there sometime in early 1548 and had a heavier teaching schedule than before, adding Greek and lectures on Aristotle to the classes he was teaching. ${ }^{184}$ A quote by Flacius from this time period reflects how he regarded the Greek philosophers:

Plato was the greatest philosopher, and Socrates the most holy and most pious, as we read from the ancient Greeks; nevertheless, they praise Aristotle for having stood against Plato (who was his teacher) because of the truth, and he did not approve everything from Socrates, either. Moreover, learned people consider Aristotle's words to be sublime and divine, since he said that one should regard the truth to be higher and greater than even his/her most beloved friends. ${ }^{185}$

This statement is important in showing that concerning Aristotle, Flacius' thinking was more in line with Melanchthon, rather than with Luther. Luther objected to Aristotle's anthropology not having a place for a Creator God as it did not fit with his own definition of humanity as fearing, loving and trusting

181 MBW 4456 (Regesten 4: 446; cf. CR 6: 286): »Venit autem istuc M. Illyr. vir doctus, qui

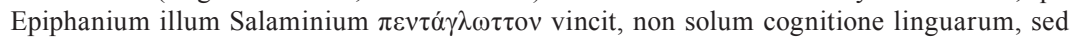
etiam rerum scientia.«

182 MBW 4484 (Regesten 4: 457; cf. CR 6: 303-304): »De Illyrico gratiam tibi habeo, quod eum tam liberaliter complexus es.«

183 Matthias Flacius, the Younger (Braunschweig, September 12, 1547 - Rostock, April 27, 1593) was a philosopher, theologian and doctor of medicine.

184 At the Austrian National Library (Österreichische Nationalbibliothek) in Vienna exists a manuscript of 768 pages, which are notes taken during the lectures by Georg Tanner, who was Flacius' student, under the title Scholia in Aristotelis librum II Posteriorum, in libros Topicorum, Elenchorum et Rhetericorum a G. Tannero collecta a 1547. Cod. 10570. For more about Tanner, see Johann August Ritter von Eisenhart, »Tanner, Georg, « in ADB 37 (1894), 382-383; "Tanner, Georg, « in Deutsche biographische Enzyklopädie 9: SchlumbergerThiersch, Rudolf Vierhaus (ed.), 2nd edition (München: Saur, 1998), 866-867.

185 Flacius, Entschueldigung Jllyrici, A3v (section »to the Christian reader«): »Plato ist der groessest Philosophus gewesen/vnd Socrates der heiligest vnd froemest/wie man von jhnen lieset/dennoch lobet man Aristotelem/das er vmb der warheit willen sich wider Platonem (der sein schulmeister gewesen) gelegt hat/vnd auch Socrati nicht alles hat lassen gutt sein/Ja man helt es fur eine himelische Goettliche rede/bey den gelerten/ das Aristoteles schreibet/da er spricht/Man sol die warheit viel hoeher vnd groesser achten/denn vnsere allerliebsten freunde.« 
in God above all things, and therefore opposed the use of his philosophy in theology. ${ }^{186}$ Melanchthon, on the contrary, held that it was precisely Aristotle's philosophy and methodology that were the most fitting for the task of the study of theology. ${ }^{187}$ This is certainly an area in which Melanchthon's influence upon Flacius was greater than Luther's. However, Flacius later critiqued use of philosophy and logic in studying theology, stating that they corrupt our opinion (iudicium) and obscure the language of the Bible. ${ }^{188}$

While in Braunschweig, Flacius had befriended one of his students, Albert Rolevinck from Magdeburg. Rolevinck followed Flacius to Wittenberg in 1548 and first became a student there, while later Flacius employed him as an amanuensis (secretary) and translator of his works into German. ${ }^{189}$ At that time, according to Camerarius, the Illyrian still struggled with German: »Flacius himself did not possess such a broad knowledge of the German language that allowed him to speak or write in a well-formulated way. 190 $^{190}$

Flacius' first theological work appeared in print when he was 29 years old. The title was De vocabulo fidei (On the Word »Faith«), a linguistic treatment of the term on the basis of its Hebrew derivation, following basic

186 See, Wilhelm H. Neuser, »Luther und Melanchthon - Ein Herr, verschiedene Gaben, « Luther Digest: An Annual Abridgment of Luther Studies 3 (1995): 60-64, here 62. For more on Luther and Aristotle, see Theodor Dieter, Der junge Luther und Aristoteles. Eine historischsystematische Untersuchung zum Verhältnis von Theologie und Philosophie [Theologische Bibliothek Töpelmann 105] (Berlin: Walter de Gruyter, 2001).

187 See for example his work De Philosophia oratio pronunciata ... from 1536, CR 11: 278-284, Nr. 38.

188 Flacius, Clavis Scripturae, A3v: »Illa vero vel maxima pernicies totius verae pietatis studijogue sacri fuit, quod plerioque recentiores Theologi aut Monachi, primum fuerunt ita corrupta quadam Philosophia \& Logica, atque adeo etiam barbarissima Grammatica corrupti et veluti dementati, ut inde male praeconceptas opiniones, corruptumque iudicium, etiam in ipsam Theologiam Sacrasque literas intulerint..."

189 Johann Heinrich Zedler, Grosses vollständiges Universal-Lexicon aller Wissenschaften und Kunste (Halle/Leipzig, 1742), vol. 32: Ro-Rz, 594: »Im Jahr 1548 begab er [Roelinck] sich nach Wittenberg, um sich da vorerst zu besehen, sein Vater aber wolte aus vielen bedencklichen Ursachen ihn nicht weiter studiren lassen, deswegen er Flacii Illyrici amenuensis worden, viel seiner Schriften, die er drucken lassen, verdeutscht, auch was er drucken lassen, corrigieret und zum Druck befordert.« Oliver Olson also states that Rolevinck followed Flacius to Magdeburg. See Olson, Flacius and the Survival of Luther's Reform, 182. However, that was only for a short period of time, since according to Zedler, Rolevinck moved to Jena in April of 1550. For more about Rolevinck see Friedrich Adolf Hülße, »Selbstbiographie eines Magdeburgers aus dem 16. Jahrhundert (Albert Rolevink), «Archiv des Vereins für Geschichte und Alterthümer der Herzogthümer Bremen und Verden und des Landes Hadeln zu Stade 10 (1884): 86-104.

190 Camerarius, Das Leben Philipp Melanchthons, 206: »Bei Flacius selbst ging die Kenntnis der deutschen Sprache nicht so weit, dass er jemals die Fähigkeit erreichte, wohl-formuliert zu sprechen oder zu schreiben.« It needs to be stated that Camerarius's biography was a defense of Melanchthon and attack on his Lutheran opponents, especially Flacius, so that his report might be exaggerated. 
Melanchthonian grammatical principles. ${ }^{191}$ Melanchthon himself wrote the fourteen-page foreword for his young colleague. Dated March 1, 1549, Melanchthon dedicated it to Thomas Cranmer, the Archbishop of Canterbury. ${ }^{192}$ The publication was a modest work, which Flacius kept revising and to which he kept adding new materials. Both the second edition of $1555^{193}$ and the third edition from $1563^{194}$ were later reprinted in Corpus Reformatorum 7 and included a few personal words of praise for Flacius by Melanchthon. This prompted Wilhelm Preger to exclaim, »Who could have thought and wished that such a beautiful bond between teacher and student would dissolve so quickly and so painfully! « ${ }^{195}$ Soon after De vocabulo fidei was published, just before Easter 1549, Flacius resigned from his position and left Wittenberg for Magdeburg.

During 1548 and 1549, while Flacius was still in Wittenberg, he sent a number of his works against the Augsburg Interim to Magdeburg to be

191 Flacius, De Vocabvlo Fidei/Et Aliis Quibvsdam/Vocabvlis, Explicatio uera \& utilis, sum[p]ta ex/fontibus Ebraicis. Scripta a Matthia Flacio Illyrico. Cum praefatione Phil[ippi] Mel[anchthonis]. Abacuc 2. Anno M.D. XLIX (Wittenberg: Veit Kreutzer, 1549; VD16 F 1525).

192 MBW 5466 (Regesten 5: 437-438; cf. CR 7: 345-349). See the translation of Melanchthon's preface into German by Irene Dingel, »Vorrede zur Schrift des Matthias Flacius Illyricus »De voce et re fidei« ('Vom Wort und der Sache des Glaubens`) 1549/1563, « in Michael Beyer, Armin Kohnle and Volker Leppin (eds.), Melanchthon, die Universität und ihre Fakultäten [Melanchthon deutsch 4] (Leipzig: Evangelisches Verlagsanstalt, 2012), 175-184.

193 Flacius, De Voce et re Fidei, contra Pharisaicvm Hypocritarum fermentum. Autore Matthia Flacio Illyrico. Cum praefatione Philippi Melanchthonis. Abacuc 2. Iustus fide sua uiuet. (Basel: Johannes Oporinus, 1555; VD16 F 1526). This edition contains a dedicatory letter by Flacius to Vergerio. Vergerio was the Catholic bishop of Capodistria (Koper) who converted to Protestantism and at the time that this Epistola by Flacius was written was a counselor to Duke Christoph in Württemberg. The letter contains Flacius' concern for his »dulcissima patria « of Istria and laments the persecutions against Protestants there as carried out by Venice. For his later years as a Protestant see Angelika Hauser, Pietro Paolo Vergerios protestantische Zeit (Tübingen: Diss. Phil., 1980). See also, Robert A. Pierce, Pier Paolo Vergerio the Propagandist [Uomini e dottrine 40] (Rome: Edizioni di storia e letteratura, 2003).

194 Flacius, Matthiae Flacij Illyrici, de voce \& re Fidei, quodque sola fide iustificemur, contra Pharisaicum hypocritarum fermentum, Liber. Eivsdem, De Ivsticia Christiana, Sive Iustificatione, \& noua obedientia, Disputatio: multa accuratius alijs quibusdam explicans. Item, De Velamine Mosis, eiusque detractione. De uestigijs ueri usus Legis. De nomine IEHOVA. Cum rerum \& verborum in his omnibus praecipue memorabilium copioso Indice (Basel: Johannes Oporinus, 1563; VD16 F 1527). This third edition also contains a dedicatory letter from February 1 to the City Council and Senate of Lindau and Melanchthon's preface is also republished. The edition is enlarged with an additional text about justification by faith, 99-190; seven concluding articles against Justus Menius from the Eisenach Synod of August 1556, 192-204; Menius' revocation, 205; Menius' letter to Melanchthon from 1555, 206-207; and Flacius' and Wigand's expert opinion about the Eisenach Synod under the title »Sententia M. Iohan. Wigandi \& Illyrici, de scripto Synodi Isanacensis, Anno Domini 1556, « dated in Magdeburg on September 24, 1556, 208-218; and other texts. The volume concludes with a letter from Cardinal Contarini to Pope Paul III from 1541, 268-272.

195 Preger, Flacius und seine Zeit, 1, 29: »Wer hätte ahnen und wünschen können, daß der schöne Bund zwischen Lehrer und Schüler so bald und so schmerzlich sich lösen würde!« 
published under pseudonyms. ${ }^{196}$ At that time Magdeburg was the exception among the German cities since it allowed their two printing presses to issue publications critical of the imperial decrees promulgated at the Augsburg Diet of $1548 .{ }^{197}$

\section{Concluding Remarks to Flacius' Early Years}

A few overarching themes emerge when one examines the young Flacius' life in detail. First, his contacts in Venice, Augsburg, Basel and Tübingen immersed him fully in the humanist method of returning to the sources, an approach that would serve him well throughout his career. ${ }^{198}$ Second, he had also had meaningful exposure to the Protestant Reformation and its theology before arriving in Wittenberg. Thus, his encounter with Melanchthon and Luther in Wittenberg sharpened his philological and theological skills, but it did not create them. The way in which he related to the theology of the two Reformers, however, accompanied and impacted him to the end of his life.

One of the most important themes may be the presence of certain father figures in his life, something fueled not only by the experience of having lost his parents - and particularly his father - at an early age but was also connected to his quest for a place where he could feel loved, accepted and at home. The way that young Illyricus writes about some of the men who played important roles of encouragement and support at critical junctures of his life indicates that they filled the hole caused by the absence of his father. The way he related to his relative, Baldo Lupetino; the words he wrote about Grynaeus $^{199}$ and Garbitius, all highlight the longing in his heart that was eventually filled by what he ultimately experienced in the person of Martin

196 Using pseudonyms was not something that was uncommon to Flacius as he signed many of his letters during that same period and later in the 1550 s with pseudonyms, such as Petrus Pan, Theodorus Henetus, Andreas Petri, Joannes Tullius or different combinations with the name Hoppius, including Titius, Johannes and Petrus.

197 The printing shops that printed works against the Interim in Magdeburg were owned by Michael Lotter and Christian Rödinger d.Ä. See, Ernst-Otto Reichert, Amsdorff und das Interim. Kommentierte Quellenedition mit ausführlicher historischer Einleitung. Nach dem maschinenschriftlichen Manuskript der Dissertation aus dem Jahre 1955 digital erfasst, für den Druck eingerichtet und um Register und bibliographische Nachträge ergänzt von HansOtto Schneider [Leucorea-Studien zur Geschichte der Reformation und der Lutherischen Orthodoxie 14] (Leipzig: Evangelische Verlagsanstalt, 2011), 132.

198 Matthias Pohlig provides an interesting discussion of whether Flacius was indeed a humanist or not in his article, »War Flacius Humanist? « in Arno Mentzel-Reuters and Martina Hartmann (eds.), Catalogus und Centurien. Interdisciplinäre Studien zu Matthias Flacius und den Magdeburger Centurien [Spätmittelalter, Humanismus, Reformation 45] (Tübingen: Mohr Siebeck, 2008), 19-52.

199 In one place he remembers him with the following words: »Simon Grynaeus, once upon a time my dear illustrious teacher, (Simons Grynaei, olim praceptoris mei charissimi). See 


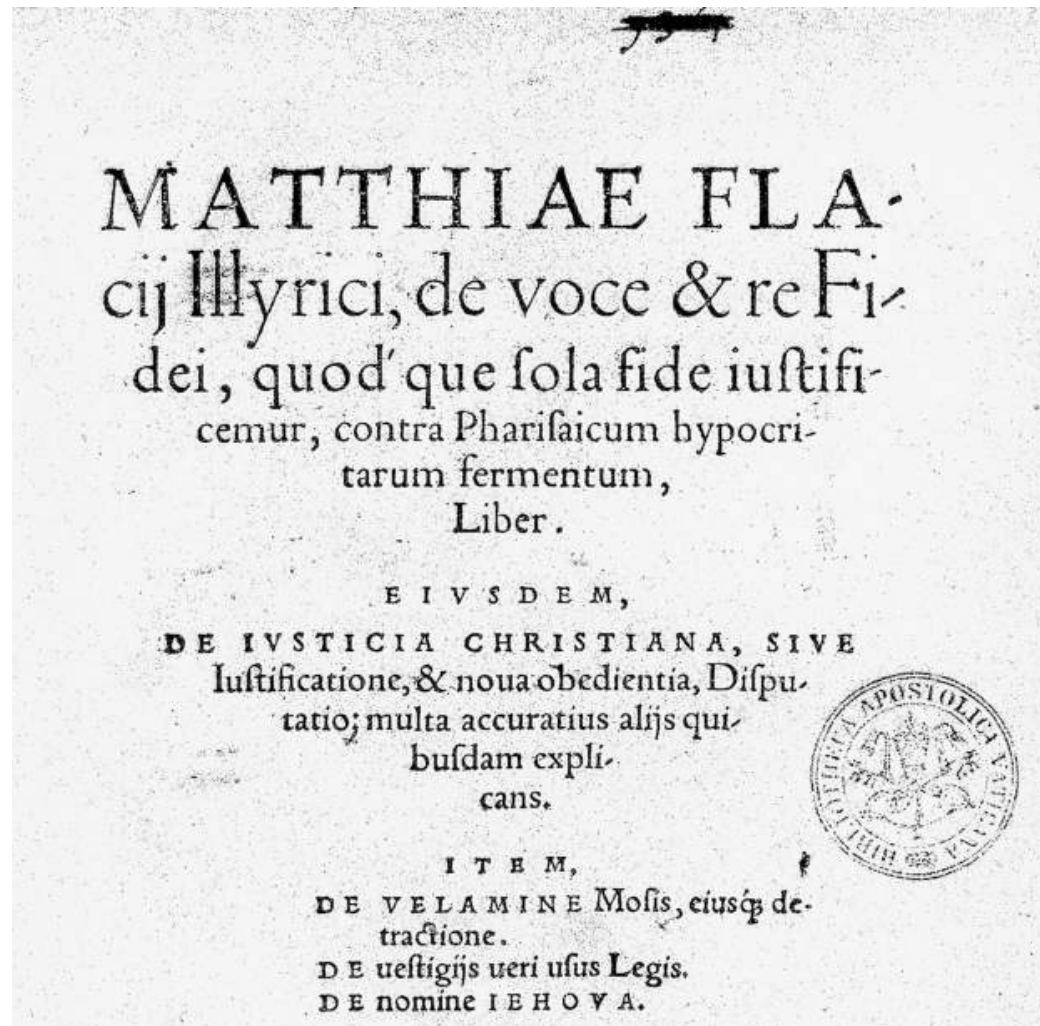

Cum rerum o uerborum in his ormibusprecipuè memorabilium copiofo

INDICE.

1563 .

Nobili a generopo d. A. Wrico Ings:

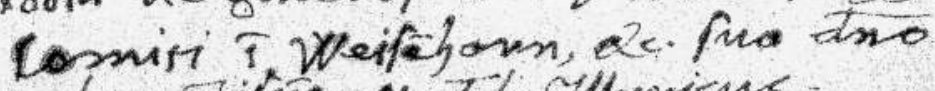
clemerifsio m.7\% ymyrians

Figure 4: The title page of Flacius' De voce \& re Fidei of 1563 with his handwritten dedication to Ulrich Fugger. Courtesy of University Library of Heidelberg, Biblioteca Palatina, Microfiche, shelfmark 89 MA 246:: M477/M478 (477,1). 
Luther. Flacius may not have even realized this yet but he was to remain a permanent outsider. He would spend the rest of his life away from his native land and knowing that due to his Protestant faith he would not be able to return, he had to contend with staying abroad. This period marked Flacius' pre-radicalization phase, during which some of the themes and emphases that were to emerge later as central to his life decisions and to his theology were already visible. His anthropological concern for example, which would come to dominate much of what he wrote, had already emerged during the Wittenberg period and was beginning to shape his understanding of the grace of God and the sinfulness of the human being. Flacius' own experience of a deep struggle with sin that tormented him was instrumental in making original sin central to his theology. The full extent of his radicalization would begin during his time in Jena and progress from then onward.

Flacius' formative years laid the foundations for his quest and zeal of pursuing »the Truth, « which may explain why already during this time it was becoming a necessity for him to respond to and correct each and every doctrine he considered to be heretical, i.e. not in accordance with his interpretation of Lutheranism. Flacius' love for details and his thoroughness were also reflected in his early written output and these were to characterize much of his work that would follow later.

Flacius' preface to Landgrave Philipp II of Hesse-Rheinfels in Gregorii Tvronici Historiae Francorvum. Libri Decem (Basel: Pietro Perna, 1568; VD16 G 3144), A2r. 



\title{
Chapter Two
}

\author{
Phase One: \\ The Shaping of Flacius' Theology \\ Through Controversies, 1548-1557
}

\section{Flacius Becomes a Recognized Oppositional Figure, $1548-1557$}

The beginnings of the first phase can be dated to Flacius' return to Wittenberg in 1548, after the university had reopened in October 1547. Flacius moved back from Braunschweig, where he and his wife had found refuge after the university closed due to the siege and occupation by the troops of the new Elector of Saxony, Maurice. Soon after his return, and at the latest by June 1548, Flacius began an anonymous campaign against the Augsburg Interim. During 1548 and early 1549 he sent a series of pamphlets and Flugschriften opposing the Augsburg Interim to Magdeburg, where they were published under various pseudonyms. In this he joined a host of other Evangelical theologians, including Philipp Melanchthon, Nikolaus von Amsdorf and Caspar Aquila. ${ }^{1}$

Following the military defeat of the Smalcaldic League in 1547, and during the time that the Imperial forces were trying to impose the Interim throughout the Empire, the city of Magdeburg emerged as the center for publishing materials in opposition to the emperor's policy of re-catholicization. At that time, Magdeburg was the only city in Germany where such documents were being printed.

Flacius feared that the Pope and the Emperor were trying to obliterate the churches that adhered to the Augsburg Confession and to eradicate the Protestant Reformation completely. He had the impression that Johannes Agricola, theological advisor to the Elector Joachim I of Brandenburg and coauthor of the Augsburg Interim, had completely capitulated to the Roman position by his support of the Augsburg Interim.

Then, later (toward the end of 1548 and into 1549), he came to the conclusion that Melanchthon, Bugenhagen and others had been too accepting of the Catholic positions in their preparation of counterproposals to (among

1 For more about different political and theological reactions to the Augsburg Interim, see Dingel and Wartenberg (eds.), Politik und Bekenntnis. Die Reaktion auf das Interim von 1548. 
others) the new Roman bishop of Naumburg-Zeitz, Julius von Pflug, and the Brandenburgers. He also took offence at the lack of transparency concerning the negotiations with Catholic theologians. Furthermore, he became disturbed by the broad interpretation of adiaphora that was promoted in Wittenberg. For Flacius, the concessions made on liturgical issues regarding the celebration of the Mass, the wearing of vestments, the use of candles or religious litany processions had gone too far. These were among the reasons that eventually led Flacius to resign from his teaching position and leave Wittenberg - a decision he later explained as a matter of conscience and a defense of the freedom of the church. Since the Interim ceremonies and rituals were imposed from the outside they constituted a serious violation of the Church's liberty claimed Flacius. ${ }^{2}$ This step already indicated signs of his intransigence.

Flacius moved to Magdeburg around Easter 1549, where he was now publishing without pseudonyms. With this began his open resistance against his former Wittenberg colleagues. At the same time, a group of like-minded theologians was gathering and forming in Magdeburg. Throughout the midsixteenth century, theologians and sympathizers of that initial Magdeburg circle opposing the Augsburg Interim and the so-called Leipzig Interim, which had its height of activity between 1548 and 1552, were dubbed GnesioLutherans. ${ }^{3}$ Robert Kolb has rightly defined Gnesio-Lutherans as »those who supported positions which represented a more radical interpretation of Luther's legacy, in areas of doctrine and practice, in the relationship of church and state and in style of churchmanship. $\ll^{4}$

2 Flacius, Omnia Latina Scripta Matthiae Flacii Illyrici, hactenus sparsim contra Adiaphoricas fraudes \& errores aedita, \& quaedam prius non excusa, catalogum uersa pagina indicabit (Magdeburg: Michael Lotter, 1550; VD16 F 1296), Y7v-Y8r: »Prima, quia non habent causam efficentem Adiaphororum, quam superius dixi, esse tripliceni, generale Dei mandatum, liberam eamquae piam tum Ecclesiae, tum ministrorum uoluntatem. « This is just a beginning of Flacius argument. For a discussion of what constitutes a true and false ing to Flacius, see Bernard J. Verkamp, »The Limits upon Adiaphoristic Freedom: Luther and Melanchthon,« Theological Studies 36/1 (1975): 52-76, here 66-69.

3 Keller, Rudolf, »Gnesiolutheraner,« in TRE 13 (1984), 512. See also Ernst Koch, »Gnesiolutheraner, « in Religion in Geschichte und Gegenwart: Handwörterbuch für Theologie und Religionswissenschaft, 4. Auflage, vol. 3, F-H (Tübingen: Mohr Siebeck, 2000), 1043; (2010), 29-36. By contrast, these theologians were not called »Amsdorfers « or »Gallists, « after two of the other important leaders. Björn Slenczka, Das Wormser Schisma der Augsburger Konfessionsverwandten von 1557. Protestantische Konfessionspolitik und Theologie im Zusammenhang des zweiten Wormser Religionsgesprächs [Beiträge zur historischen Theologie 155] (Tübingen: Mohr Siebeck, 2010), 150-153.

4 Robert Kolb, »Philipp's Foes, but Followers Nonetheless: Late Humanism among the GnesioLutherans, «159, n. 1 . 
During his time in Magdeburg Flacius was beginning to distinguish himself as a polemicist and an anti-Roman Catholic voice. In late 1548, when Flacius became aware of proposals being made by Wittenberg and Leipzig's theologians concerning the so-called Interim Leipzig, he also attacked them with the same fervor he had already turned on the Roman imperial party and Johannes Agricola. However, in his criticism of the Interim he lumped both Roman Catholic and Protestant supporters of the Interim into the same category, as the following quote reflects: »The Papists and Interimists (Interimisten) talk a lot about sacrifices and thus want to preserve their Mass, to eventually lead [all] into blindness and folly, by approving of the Gentiles' sacrifice and using it as a means of validating their Mass. $\ll^{5}$ By Interimists, Flacius was thinking of Johannes Agricola and at least one other Lutheran who did support the Augsburg Interim, while the later term that he often employed, Adiaphorists (Adiaphoristen), was reserved for the supporters of the Leipzig Proposal for the Diet.

Flacius' polemics soon spread to addressing other intra-Protestant theological disputes as well, so that he published works against the theologians from the Wittenberg circle, like Georg Major, Justus Menius, and Paul Eber, ${ }^{6}$ and also against Caspar von Schwenckfeld, Andreas Osiander, Calvinists, Anti-Trinitarians and others. The spectrum of his opponents was constantly broadening. Through his writings Flacius' name became known and he was recognized by his contemporaries (theologians and pastors alike) for his abilities to understand and analyze the arguments of others. At the same time he was seen as specially gifted at formulating his responses by pointing out the weaknesses in the argumentation of the opposing side, while also expressing his own views in a way that many others could identify with. He also gained notoriety as someone with a sharp tongue and pen.

When Flacius began his anonymous publishing campaign against the Augsburg Interim, it is very plausible to think that his views had been influenced by the older pastor and doctor of theology, Nikolaus Medler, during his stay in Braunschweig in 1547-1548. Superintendent Medler preached against

5 Flacius [Lauterwahr], Wider Das Interim (1549), text in Irene Dingel (ed.), Reaktionen auf das Augsburger Interim, Nr. 15 (2010), 753: »Die Papisten vnnd Jnterimisten plaudern viel von Opffern vnd wollen dadurch jhre Meß erhalten, geraten auch entlich in die narrheit vnd blindheit, das sie der Heiden opffer billichen vnd zum behelff, jhre Meß damit zu bestettigen, füren.«

6 For Eber's biography, see Christian Heinrich Sixt, Dr. Paul Eber, der Schüler, Freund und Amtsgenosse der Reformatoren. Ein Beitrag zur Geschichte des Reformations-Zeitalters, mit XLIX Original-Urkunden (Heidelberg: Karl Winter, 1843); Stefan Rhein, »Paul Eber aus Kitzingen: Schüler und Kollege Philipp Melantchthons, Zeitschrift für bayerische Kirchengeschichte 80 (2011): 239-259, and Daniel Gehrt and Volker Leppin (eds.), Paul Eber (1511-1569): Humanist und Theologe der zweiten Generation der Wittenberger Reformation [Leucorea-Studien zur Geschichte der Reformation und der Lutherischen Orthodoxie 16] (Leipzig: Evangelische Verlagsanstalt, 2014). 
the Interim and also issued in print his stand of resistance. Furthermore, the two of them obviously stayed in contact even after Flacius returned to Wittenberg, since in 1549 they jointly published a tract, A Miraculous Sign Recently Seen in the Sky above Braunschweig, ${ }^{7}$ revealing their eschatology and interpreting the Augsburg Interim as the Antichrist's work. »An analysis of the contents of this tract shows that it was part of Flacius' propaganda campaign against the two Interims, the Roman Church, and the emperor's religious policy. $\ll^{8}$ On page two the image of former Elector of Saxony, Johann Friedrich I was printed, dressed in his full electoral regalia, with the year 1549 prominently marked on the single-leaf woodcut. ${ }^{9}$ At the time of the publication Johann Friedrich, stripped of his electoral dignity, was still being held in prison under a sentence of death because he refused to acknowledge the Interim. Flacius and Medler viewed him as faithful and unswerving in his faith and therefore as presenting a model for other Christians. By adding the year 1549 next to Johann Friedrich's portrait they were indicating their loyalty to him and that they viewed him as the legitimate ruler of Electoral Saxony, instead of his cousin Maurice of Albertine Saxony, upon whom the Emperor Charles V had bestowed the electoral dignity. By doing this and by portraying Maurice as Judas Iscariot, the one who betrayed them and had generally hurt the Protestant cause, Flacius and Medler issued a clear political statement.

One other interesting aspect related to the development of Flacius' theology is found on page two of his five-and-a-half-page long preface, where he states: »While we still have the old corrupt Adam in us and out of weakness still commit sins daily, therefore we can never claim that we have no $\sin . \ll^{10}$ This is one of the first appearances of Flacius expounding in print his explanation of the role sin plays in the life of a Christian and using the phrase »old corrupt Adam. «It is exactly his understanding of sin that would later become the most radical and controversial feature of his theology and

7 Medler and Flacius, Ein wunderlich gesicht newlich bey Braunschweig am hiemel gesehen/ beschrieben durch den hochgelerten hern Doctorem Nicolaum Medlerum/Superattendententem zu Braunschweig (see Figure 5). What is interesting to note is that Flacius' name does not appear on the title page of the work itself but instead only after his preface as M[agistar] M[atthias] Illyricus (Magdeburg: Pankratz Kempff, 1549; VD16 M 1893), A4v.

8 Ken Kurihara, Wunderzeichen and Society in Late Reformation Germany: Lutheran Clergy and Celestial Wonders (Fordham University, New York, 2010), 110. I am grateful to Ken Kurihara for providing me with a manuscript copy of his thus far unpublished doctoral dissertation. The detailed analysis of the Medler/Flacius tract is provided on pages 119-141.

9 There are four different print versions of this tract. In some of them, the year next to the portrait of the Elector is 1548. For a discussion of this and of the approximate dating of the work see, Thomas Kaufmann, Das Ende der Reformation, 60-61.

10 Flacius, Ein wunderlich gesicht, Vorrede (preface), A2v: „Weil wir aber noch den alten verderbten Adam an vns haben/vnd aus schwacheit noch teglich suendigen/also das wir nie kuennen leugnen/das wir nicht suend haben.« 


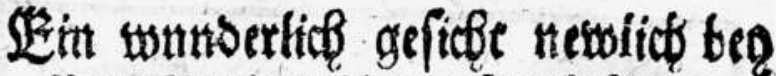 Brausfabseig am biemel gefeben/befcbriben oureb oen bochgelerten bern Doctorem nif colaum LDeolerum / fuperattenoententem 3น 2B raun çอerig.}

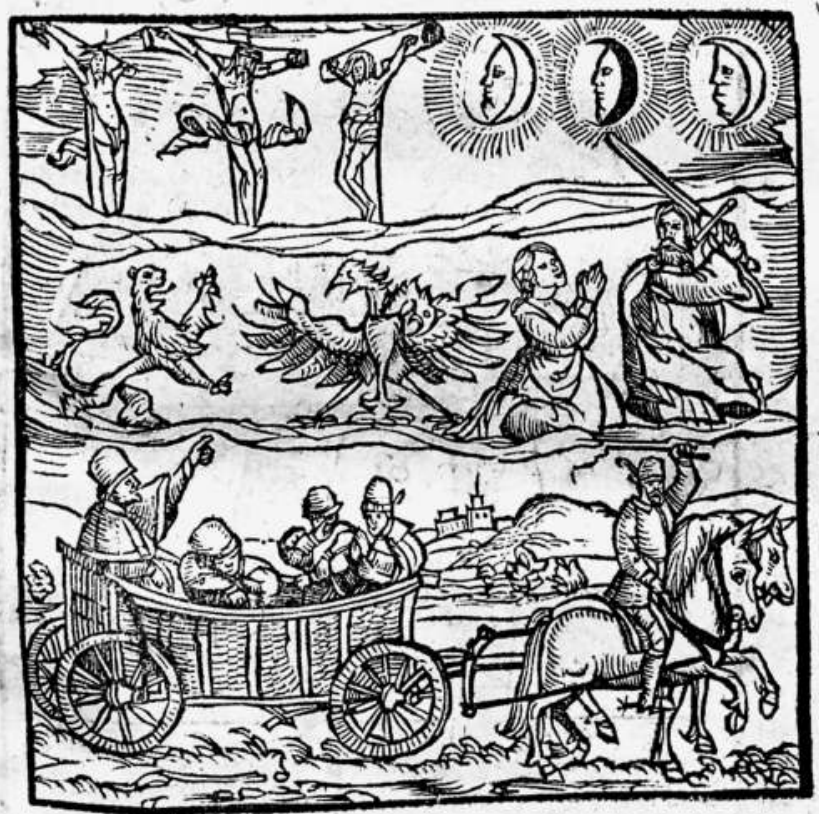

Ruce am $2+$ wenn oifs anfobet 34 gefebebn fo Felgee off/pno bebt ewer bedbter of / Oarumb ocs ficb exos? stilofung napet.

$$
\begin{aligned}
& \text { D:2. Aertors apadio protio } \\
& \text { Math. flacio fyric-evij }
\end{aligned}
$$

Figure 5: The title page of Nikolaus Medler's Ein wnnderlich gesicht of 1549 with Flacius' handwritten dedication to pastor Auctor Lampadius in Halberstadt. Courtesy of Universitäts- und Landesbibliothek Sachsen-Anhalt in Halle: shelfmark AB 44 19/i, $13(7)$ 
play a pivotal role in his career. Bringing attention to this initial formulation helps in retracing the trajectory of how Flacius was to develop his particular doctrine of original sin.

Forming theological and political positions in opposition to the views and policies of others can be considered a radical way of entering the public sphere of theology and politics and yet it is exactly in this way that Flacius began establishing himself as a voice of resistance and opposition. The following pages and chapters will show how Flacius' theology continued to be shaped by arguing in both print and public disputations against others and how this turned into a radicalization process that became increasingly extreme with the passing of time and ultimately led to an unhappy end.

\section{Intensification of the Persecution of Protestants under Venetian Control}

Among the reasons that stood in the background of the beginnings of Flacius' radicalization process and undoubtedly influenced his way of thinking, lending his statements more urgency and importance, was the situation of Protestant sympathizers in the territories under Venetian control, including his homeland, which started to change in the 1540 s. It is hard to ascertain exactly when Flacius began to harbor thoughts of resistance toward Emperor Charles V, Duke Maurice of Albertine Saxony and the Catholic princes and bishops in Germany. Certainly after the Smalcaldic League lost the decisive battle at Mühlberg, Flacius' hopes for a peaceful future for the Reformation in Germany were crushed. At the same time, he became aware of the increasing Roman Catholic persecution of Protestants in his native land.

The Reformation had already had a considerable impact on Istria, which during the sixteenth century was divided between Austria and Venice. ${ }^{11}$ Two bishops in particular contributed to the spreading of the Reformation in the Venetian part of the peninsula by openly embracing the new ideas it represented: Bishop Giovanni Battista Vergerio of Pola (today's Pula in Croatia) and his brother, Bishop Pietro Paolo Vergerio, the Younger from Capodistria (today's Koper in Slovenia). In Trieste, humanistically oriented Bishop Pietro Bonomo was also favorable to Protestant ideas. Further south, in the Gulf of Quarnaro (Kvarner) Flacius' relative Baldo Lupetino was bringing Protestant elements into his homilies on the Island of Cherso (Cres). A letter from Pietro

11 For more on the history and impact of the Reformation in Istria see the book by Antonio Miculian, Protestantizam u Istri, XVI. i XVII. stoljeće u svjetlu novih arhivističkih istraživanja/ Protestantismus in Istrien (XVI. und XVII. Jahrhundert) im Lichte der neuesten archivistischen Forschungen (Pula: Zavičajna naklada Žakan Juri, 2006). 
Lando, who was the Venetian doge from 1538 onward, to Aloysius Pisano, guardian on the island of Veglia (Krk), mentions that most of the inhabitants of Krk »follow Luther's sect«. Furthermore, merchants from Fiume (Rijeka), who conducted business with cities such as Sebenico (Šibenik) and Tragurium (Trogir), contributed to the spread of the Reformation and the distribution of Protestant literature in Dalmatia.

On April 1, 1543 Pope Paul III issued a bull naming six cardinals as »Inquisitors of the Faith « and charged them with the task of reviewing the judgments of the ecclesiastical courts concerning heresy and re-examining all such cases on both sides of the Alps. This move led to the intensification of the harassment and imprisonment of many people who read Protestant literature and embraced its ideas. In addition to the establishment of the Holy Office (the Inquisition), the defeat of the Smalcaldic League also resulted in a change of policies in the territories ruled by the Venetian Republic, where Doge Francesco Donà allowed the death penalty to be carried out by order of the Inquisition and gave his full support to the Inquisitor and Apostolic Nuncio Giovanni della Casa.

The Council of Trent, called together by Pope Paul III in order to address the deepening crisis within the Roman Catholic Church caused by the spread of Protestantism, was first convoked in December 1545. Justification was among the central issues discussed and in January 1547 the Council issued a decree in which it reaffirmed the necessity of both faith and good works for achieving it - in contrast to the Protestant understanding of sola fide. The Council (which convened for twenty-five sessions between 1545 and 1563) rejected and declared heretical many other Protestant beliefs, while establishing among other things that the Scriptures and ancient church tradition possessed equal authority, and that the Church's interpretation of the Bible was final. ${ }^{12}$

Bishop Vergerio of Pula died in early August of $1548 .{ }^{13}$ Rumors were circulating that he had been assassinated by the Inquisition - his death and the nature of his funeral were surrounded by controversy. According to some reports, »his funeral ceremony had been conducted in a »Lutheran manner. $1^{14}$ Francesco Spiera, a well-respected jurist from Citadella near Padua, was forced by the Inquisition to recant his Protestant views on St.

12 When Pope Paul III died on November 10, 1549, Flacius immediately wrote and published a pamphlet with the satirical title Wonderful News of the Death of Pope Paul III - translated into English by William Baldwin in 1552 from the Latin original of Flacius (Magdeburg, 1550; VD16 V 666/7). See VD16 K 400 for another pamphlet written by Flacius against Paul III while he was still alive in 1549.

13 Vergerio had been appointed as Bishop on January 15, 1532.

14 Anne Jacobson Schutte, Pier Paolo Vergerio: The Making of an Italian Reformer [Travaux D’humanisme et Renaissance 160] (Genève: Droz, 1977), 236. 
Mark's Square in Venice on June 20, 1548 and the following Sunday he was forced to repeat his renunciation during the Mass at the Cathedral in his home town. After denying under pressure what he still believed to be the truth, Spiera was convinced that he had committed the gravest sin against the Holy Spirit and became tormented, allegedly suffering from recurring seizures, and died soon afterwards.${ }^{15}$ Early during his sojourn in Magdeburg, Flacius then published an account of the end of Spiera's life and added a preface to it. ${ }^{16}$

\section{a) The Trial and Execution of Baldo Lupetino and its Impact on Flacius}

In late 1542, Baldo Lupetino was arrested on the island of Cherso after a local friar, Jacopo Curzolo, had accused him of having preached heretical ideas during Lent. Among the teachings deviating from Roman Catholic doctrines were Lupetino's denunciation of purgatory and his claim that Christ had redeemed humankind completely, so that good deeds were unnecessary for salvation. Lupetino was subsequently transferred to Venice, where he was imprisoned.

From the time of Lupetino's arrest, various efforts were undertaken at garnering support from Protestant ecclesiastical and political leaders in the German-speaking territories and urging them to appeal to the Venetian authorities to free Lupetino and other Protestants imprisoned for their beliefs. One such request was issued by the layperson Baldassare Altieri from L'Aquila, ${ }^{17}$

15 For Vergerio's account of the end of Spiera's life translated into English, see John H. Bernheim (ed.), A Brief Narrative of the Last Days and Awful Death of Francis Speira, Counsellor at Law. By the Right Rev: Peter Paul Vergerius, Bishop of Justinopolis (Elizabethtown, PA: W. M. Baxter, 1834), 3-21. For a critique of Vergerio's version of the account see, Silvana Seidel Menchi, »Theorie und Wirklichkeit der Verfolgung in norditalienischen evangelischen Kreisen 1540-1570« in Silvana Seidel Menchi (ed.), Ketzerverfolgung im 16. und frühen 17. Jahrhundert [Wolfenbütteler Forschungen 51] (Wiesbaden: Harrassowitz, 1992), 193-212, here 204-208.

16 Flacius (ed.), Eine Erschreckliche Historia von einem/[Francesco Spiera] den die feinde des Evangelij inn welsch Land gezwungen haben/den erkanten Chrjstum zuvorleugnen (Magdeburg: Michael Lotter, 1549; VD16 G 3303). The publication contains four pages of Flacius' preface to the Christian reader [A2r-A3v] and twenty-four pages of text. See also a variant of the same preface by Flacius in Ein erschreckliche Historia/von Francisco Spira/Wie er in grausame verzweifflung gefallen ist/nach dem er muendlich vnd schrifftlich/die erkandte warheit des heiligen Euangelij/von wegen des zeitlichen/vnnd aus forcht der Menschen/widerumb verleugnet hat (Frankfurt: Martin Lechler, 1565; VD16 E 3833), A2r-A6v. Flacius' account was based on the report of Matteo Gribaldi Moffa, a jurist from Padua, who witnessed Spiera's death. His account begins on page E6v of the 1565 Frankfurt edition. Gribaldi was later also persecuted by the Inquisition for his Anti-Trinitarian views.

17 For more about him, see »Altieri, Baldassarre« in MBW 11: Personen A-E, 61. 
who was the secretary of the English diplomat and King Henry VIII's ambassador to Venice, Edmund (alias »Sigismund«) Harvell, between 1540 and 1548. Altieri was sympathetic to the Reformation and he wrote to Luther on November 26, 1542 on behalf of the evangelicals in Venice, Vicenza and Treviso, urging him to use his influence with German Protestant princes and convince them to pressure the Venetian Senate in support of the evangelicals imprisoned there. ${ }^{18}$ Luther did write a letter in response to Altieri's request to the evangelical believers in north Italy in June $1543 .{ }^{19}$ Others, including Melanchthon, got involved in the correspondence concerning the situation of Protestants in these territories. ${ }^{20}$ Altieri also wrote to Heinrich Bullinger in Zurich and to the pastors in Geneva, with the same goal, to garner the support and help from the Swiss Protestants. ${ }^{21}$

In a second letter from the evangelical believers in Italy written to Luther on August 30,1543, there is evidence that Flacius had become personally involved in the efforts at freeing Baldo. ${ }^{22}$ The text referred to young Matthias having traveled to Venice earlier that year in order to deliver a letter signed by Smalcaldic princes Elector Johann Friedrich I of Saxony and Landgrave Philipp I of Hesse to Doge Pietro Lando ${ }^{23}$ and to the Venetian Senate. ${ }^{24}$ The letter had been composed anonymously by Melanchthon. ${ }^{25}$ The two rulers were requesting that Baldo, whom the text referred to as $»$ a man endowed with remarkable piety and sound doctrine, « be released from prison. ${ }^{26}$ The letter was read out publicly but the Senate responded negatively to the appeal, being suspicious of its authenticity due to a problem with the date and location of its signing. ${ }^{27}$ That is, the letter contained no indication of its place of origin,

18 WA Br 10: 197-208, Nr. 3817.

19 WA Br 10: 328-333, Nr. 3885.

20 For details on Melanchthon's, Veit Dietrich's and others' involvement, see the notes by the editor of WA Br 10: 200-201.

21 See Altieri's letter to Bullinger from Venice on August 11, 1543 signed as »Balthassar Alterius, secretaries oratoris Anglie, « and from December 6, 1543, in which he sends Bullinger greetings from the two arrested men [Baldo Lupetina and Pietro Speziale] in Rainer Henrich, Alexandra Kess and Christian Moser (eds.), Heinrich Bullinger Briefwechsel 13: Briefe des Jahres 1543 (Zurich: Theologischer Verlag, 2008), 186-189; 330-330.

22 Letter written to Luther by the evangelical brothers of Venice, Vicenza and Treviso on August 30, 1543. WA Br 10: 376-384, Nr. 3907.

23 Lando held the position of doge from 1538 until 1545.

24 WA Br 10: 379, Nr. 3907: »...ut Matthias diligenter inquireret de quodam Baldo, cuius mentionem fecerant Principum literae...«

25 MBW T 12: 253-256, Nr. 3268; CR 6: 761-763, Nr. 4108. A contemporary German translation by Martin Schneider can be found in Melanchthon deutsch III, 252-254. See also the letter from Matthias Guttich to Melanchthon, dated on February 15, 1544 in Venice, informing him about Pietro Speziale's and Baldo's situation in prison. MBW T 13: 88-90, Nr. 3456.

26 MBW T 12: 24, Nr. 3268: »...Baldum Lupedium, hominem singulari pietate et doctrina praeditum...« Letter from June 26, 1543.

27 WA Br 10: 379, Nr. 3907: »Primum conati sunt, quoquo modo possent, efficere, ne Principum 
and the Venetians also knew that Johann Friedrich I and Philipp of Hesse were not in the same place on the day on which both of them had apparently signed the document. ${ }^{28}$ The doubt raised by this discrepancy resulted in the rejection of the letter by the Senate. While in Venice, Flacius was able to visit Baldo as well as at least one other person imprisoned along with him for his faith. ${ }^{29}$

Concerning the authorship of the letter from the evangelical believers in Italy on August 30, 1543 it is evident from the text that Altieri wrote it, even in the absence of his personal signature. This becomes particularly clear when the letter is compared to the previous one by the same senders from November 26, 1542, which Altieri did sign. In another letter to Altieri and believers in Venice and Vicenza, which Luther wrote from Wittenberg on November 12, 1544, he said that Flacius had urged him to influence Smalcaldic princes to write another letter to the Senate of Venice on behalf of those who are persecuted because of confessing Christ (especially Baldo). ${ }^{30}$ Altieri eventually had to leave Venice in 1549 after the defeat of the Smalcaldic League, to which he also had connections. ${ }^{31}$

At Baldo's first trial, which took place in 1543, he was handed a life sentence and was required to pay a fine. With the intensification of Venetian efforts at exposing and punishing heretics, Baldo's fate took a turn for the worse at the hands of the Inquisition. A second trial followed, at which the authorities pronounced a death sentence. During all these years Lupetino was being held in prison in the city and as a result of the conditions, particularly the dampness, his health began to deteriorate. There is also evidence pointing to the fact that the bishop of nearby Capodistria, Vergerio »persuaded the Venetian government not to burn Baldo Lupetino, $\$^{32}$ as the Franciscan Bishop Dionisio de Zanettini (known as »il Grechetto, « the little Greek) reported with disappointment in a letter to Cardinal Alessandro Farnese the Younger, ${ }^{33}$ dated April 26, 1547. Even Flacius' former teacher and mentor,

literae quicquam apud eos essent ponderis habiturae, dicentes, quod locum datae non haberent, idque non parvam suspicionem ipsis afferre..."

28 The letter bore the date of August 26, 1543.

29 WA Br 10: 379, Nr. 3907: »Triduo post reversus Matthias renunciavit, invenisse se non solum hunc Baldum, sed sexagenarium quoque senem, homines sane pios ambos propter euangelium teterrimo ac diutino carcere..."

30 WA Br 10: 679-682, here 681, Nr. 4041: »Cum vero Matthias Illyricus vestri studiosissimus non desineret exigere litteras saltem salutatorias, ne vobis in affectione positis suspicio aliqua oriretur, quasi vestri nos cepisset negligentia vel oblivio, coactus sum istas breviores scribere. Admonuit autem me de scribendis denuo litteris per Principes nostros ad Senatum Venetum pro vinctis confessoribus Christi.«

31 Silvano Cavazza, »Pier Paolo Vergerio e Flacio Illirico per Baldo Lupetino, « Quaderni giuliani di storia 26/1 (2005): 137-141, here 129.

32 Schutte, Pier Paolo Vergerio, 229.

33 Cardinal Farnese's grandfather, Alessandro Farnese the Elder reined as Pope Paul III from 1534 onward. Alessandro was later in two instances a candidate for Pope, in 1566 and 1585. 
Egnazio was indirectly involved in this process through his connection to Vergerio. It is known that the Capodistrian bishop lodged in Egnazio's house in Venice in early 1548 and gave open readings from his own works. ${ }^{34}$ At that time an inquisitorial investigation was taking place against Vergerio because of suspicions that he had become a Protestant heretic and was gathering a large following.

Others attempted to help Baldo too; among them Princess Renata of France, who was also Duchess of Ferrara by marriage. Caspar von Schwenckfeld collected some money among his friends for Baldo and his fellowprisoner Pietro Speziale from Citadella, as he reports in several of his letters during 1550 and $1551 .{ }^{35}$ This is even more remarkable, given that in February 1548 Schwenckfeld penned a refutation of Baldo's »Confession of Faith." That document consisted of sixteen answers to the inquisitors that Baldo had compiled and given to the court during his second trial in1547 and was titled, Articulations of faith proposed by friar Baldo, a captive in the prison of St. Mark, with the answers given by this very friar. ${ }^{36}$

In July 1553, Duke Christoph of Württemberg wrote to newly elected Doge Marc Antonio Trevisano with an appeal for clemency for Baldo, and offered to let Baldo spend the remainder of his life in Württemberg. ${ }^{37}$ Trevisano's reply stated that this matter was in the hands of the ecclesiastical and not the political authorities to decide and therefore did not fall under his jurisdiction..$^{38}$ Pietro Paolo Vergerio was also involved in the efforts at trying to free Lupetino and wrote a letter in support of Duke Christoph's request, in which he also refuted the allegation from the Doge's response. ${ }^{39}$ In January 1555 he again urged the Duke to take action to help free sbrother Baldo. ${ }^{40}$ So, the Duke wrote a memorandum in April that was given to the

34 This was reported in a letter from Girolamo Muzio to the notary of Capodistria, Ottonello Vida, dated in Milan on May 23, 1548 and published in Le Vergeriane del Mvtio Ivstinopolitano. Discorso se si convenga ragvnar concilio. Trattato della Comvnione de' Laici et delle mogli de' Cherici (Venice: Gabriel Giolitto de Ferrari e fratelli, 1551), 34v-37v [E1r-E 4v]. Cited in Schutte, Pier Paolo Vergerio, 230 n. 69.

35 CS 12: 34-35; 40-41; 99; 623: »Denn gefangnen zu Venedig haben wir newlich 20. Gulden geschickt..." (Letter from May 7, 1551).

36 The title of the Schwenckfeld's text is Iudicium ueber die Bepstische Artickel der Ketzer Jnquisitoren/N. Baldo/zue Venedig im Gefencknus fuergehalten. It is reprinted in CS 11: 490-498. See also pages 487-489 written by the editor for an explanation of how Baldo's confession reached Schwenckfeld via Philipp Walther.

37 The letter is dated on July 31, 1553 in Tübingen. It is reprinted in Eduard von Kausler and Theodor Schott (eds.), Briefwechsel zwischen Christoph, Herzog von Württemberg und Petrus Paulus Vergerius [Bibliothek des litterarischen Vereins in Stuttgart 74] (Tübingen: H. Laupp, 1875), 85-86.

38 Ibid., 86-87. The letter from September 9, 1553 dated in Venice.

39 Ibid., 87-88.

40 See his letter from Göppingen dated on January 15, 1555 in Kausler and Schott (eds.), Briefwechsel zwischen Christoph, Herzog von Württemberg und Petrus Paulus Vergerius, 
Venetian ambassador to deliver to the Venetian Senate. ${ }^{41}$ However, it seems that those attempts at influencing the Venetian government to pardon and issue clemency for Baldo did not succeed. According to the final verdict, ${ }^{42}$ Baldo Lupetino, following a ceremony of degradation, was drowned in one of the lagoons of Venice in September 1556. ${ }^{43}$

The martyrdom of Baldo within the larger context of growing persecution of Protestants under Venetian control, carried out by the Roman Catholic Church and civil authorities following its orders, was a natural progression when observed through an apocalyptic lens. If the Pope was truly the Antichrist, it was expected that his persecution of »true believers « would begin sooner or later and continue to become worse. Such rationalization would, in turn, provide justification to Rome's opponents for resisting the authority of the Pope and the authority of political figures who embraced Catholicism.

Flacius took this logical progression one step further and began advocating resistance even to those Protestants whom he thought were associating themselves with the Roman Church too much and thereby allowed themselves to be influenced by it.

There had already been much talk about disobedience to the authorities, self-defense and outright resistance in Wittenberg, before the university closed in November 1546. Major, Caspar Cruciger the Elder, Eber, Menius, and Melanchthon all took part in those discussions. During early 1547 the Wittenberg printer Veit Kreutzer published at least three versions of a pamphlet with the title Instructions on Legitimate Self-Defense (Von der Notwehr Unterricht), which argued that evangelicals had a right to actively resist the government on the basis of the Lutheran teaching on the order of creation. ${ }^{44}$

80-84, here 82: »... in causa fratris Baldi de Albona, qui per duodecim annos patitur martyrium deterrimorum carcerum apud Venetos ob confessionem jesu Christi.« In another letter to the Duke written from Chiavenna on September 17, 1553 he is also asking for help in »liberating the brother in Christ« (...pro liberation illius fratris Christiani) from a Venetian jail, 56-59, here 58 .

41 Ibid., 108-109. Dated in Augsburg on April 20, 1555.

$42 »$ The verdict states the following: he must be defrocked in St. Theodore's Chapel and then he must be secretly thrown into the deep sea, so that he drowns and suffocates completely and dies. This cruel verdict was followed by its cruel execution. Baldo was put into a sack laden with heavy stones and laid down tied to a board across two gondolas floating next to each other. During the dark night, the two gondolas separated on the open sea of the Venetian Lido and the poor convict disappeared in the waves... « Emilio Comba, I nostri protestanti II: Durante la riforma nell Veneto e nell' Istria (Florence: Claudiana, 1897), 325-357, here 356; Cavazza, »Vergerio e Flacio«, 127.

43 Oliver K. Olson, »Baldo Lupetino, Venetian Martyr,« Lutheran Quarterly 7 (1993): 7-18, here 14.

44 For a detailed treatment of this pamphlet including the first edition printed in January and its subsequent revision by Melanchthon in March 1547, and its authorship, see Luther D. Peterson, 
As shall be shown later in this chapter, in the Magdeburg Confession Flacius and his fellow authors focused on rightful resistance to the authorities, thereby joining an already ongoing discussion on this topic.

\section{Magdeburg, 1549-1557: \\ Heading the Adiaphoristic Controversy}

When Flacius moved to Magdeburg just before Easter 1549, his wife, Elisabeth and their young son, Matthias, the Younger stayed behind. As she was in the late stages of pregnancy, it is most likely that they stayed with Elisabeth's parents who lived in the village of Dabrun near Wittenberg. Flacius entrusted his former student of Hebrew and also a colleague at the faculty, Johannes Aurifaber from Breslau, with taking over his lectures at the university. Among the well-known persons who had also studied Hebrew under Flacius, were Paul Eber, Friedrich Staphylus and Johannes Mathesius. ${ }^{45}$

It is plausible to think that by making these arrangements concerning his family and workplace Flacius thought that his stay in Magdeburg would only be a transitory stop and not an irreversible move. Perhaps he was hoping that those in the academic and ecclesiastical leadership of Wittenberg would come to see the situation regarding the Interim from his point of view, in which case he would come back and return to teaching. However, soon after Flacius left, Aurifaber wrote to him from Wittenberg on April 19, 1549 informing him about the increasing resentment against him by Melanchthon and others and in a mild tone suggested reconciliation between them. ${ }^{46}$ As Walter Friedensburg has observed, this letter likely bore fruit, as Flacius wrote a pamphlet in defense of his decision (apologia) to the University on July 23, 1549. ${ }^{47}$ In his

»Justus Menius, Philipp Melanchthon, and the 1547 Treatise, Von der Notwehr Unterricht, « ARG 81 (1990): 138-157.

45 Flacius, Erzehlunge der Handlungen, X2r: »Bin derwegen hart vor Ostern allein hinweg gezogen/denn meine Hausfraw war grosschwanger/Die Lection befahle ich M. Johanni Aurifabro von Preslaw/der dazumal die Sphaeram lase/vnd von mir Hebreisch gelernet hatte/wie auch Eberus/Staphylus/Mathesius/vnd andere mehr.« Based on Mathesius' biography, he studied Hebrew with Flacius in Wittenberg in 1545. For more about Aurifaber, see Gustav Kawerau, »Aurifaber, Johannes (Vratislaviensis), Realenzyklopädie für protestantische Theologie und Kirche 3/2 (1897), 288-290 and »Aurifaber Vratislaviensis, Johannes« in MBW 11: Personen $A-E, 98-99$. Henceforth referred to as Johannes Aurifaber [Vratislaviensis].

46 Walter Friedensburg, »Ein Brief Aurifabers an Flacius (1549)., ARG 20 (1923): 62-65. The letter is dated on Palm Sunday (dominica palmarum anno 1549), suggesting that Flacius left Wittenberg prior to Holy Week.

47 Ibid., 62: „Ganz ohne Frucht ist der Brief des wohlmeinden Vermittlers vielleicht nicht geblieben; er mag dazu beigetragen haben, daß Flacius sowohl eine ausführliche Schrift zur Rechtfertigung seiner Handlungsweise gegenüber den Wittenbergern ausgehen ließ..." 
open and published text issued in both Latin and German Flacius explained his reasons for leaving and tried to justify his actions. ${ }^{48}$

In contrast to what he had in Wittenberg (an appointment at the university with a regular salary and a generally well-established and respectable life), it seems that Flacius had laid out no clear plans for the future as he left for Magdeburg, nor was there a better job waiting for him. He claimed that he went to the city upon the invitation of Amsdorf, Erasmus Alber, ${ }^{49}$ Stephan Tucher, who was Alber's son-in-law, ${ }^{50}$ the city secretary of Magdeburg, Heinrich Merckel, who was Nikolaus Gallus' brother-in-law, ${ }^{51}$ and Andreas Birkicht, ${ }^{52}$ so that he could help them in their dispute against the Interim with his writings. ${ }^{53}$

48 Flacius, Apologia Matthiae Flacij Illyrici ad Scholam Vitebergensem; Entschueldigung Jllyrici/geschrieben an die Vniuersitet zu Wittemberg. See footnote 41 in Chapter 1.

49 For details of his career and publications, see Herfried Vögel, »Alberus, Erasmus, « in Kühlmann et al. (eds.), Frühe Neuzeit in Deutschland, 87-99.

50 Oliver Olson states that Flacius lodged in Tucher's house and that they were brothers-in-law. While the first claim is plausible, Tucher was actually not married to the sister of Flacius' wife Elisabeth Faust but to the daughter of Erasmus Alber. See Olson, Flacius and the Survival of Luther's Reform, 147. Tucher was an assistant pastor at St. Ulrich's church in Magdeburg. He died on April 13, 1550. Tucher and Flacius knew each other from Wittenberg.

51 Merckel became a city secretary in 1547 after his studies in Wittenberg, as he stated in his published history of Magdeburg's siege in 1550-1551, Warhafftiger Avssfuerlicher vnd gruendlicher Bericht/von der Altenstadt Magdeburgk Belagerung/so die Roem: Key: May: Carolus Quintus /sampt Churfuersten/Fuersten vnd Stenden des Heiligen Roemischen Reichs etc. Anno 50 am 16 Septembris angefangen/vnd bis auff den 9. Nouembris Anno 51 Continuirt: Vnd wie endlich die Stadt vortragen vnd zur Aussoenung wieder kommen/Durch Heinrichen Merckeln/Secretarium der Altenstadt Magdeburgk beschrieben (Magdeburg: Paul Donat, 1587; VD16 M 4798), )*(. I have located one letter dated January 28, 1585 and signed in Magdeburg as »Heinrich Merckel Secretari der alten Stadt Magdeburg. « This points to a long career and makes a contribution toward Merckel's biography. The letter is printed in Marcus Wagner, Thüringer Königreichs/Das es für vnd nach Christi geburth in Pagos getheilet gewesen/wahrhafftiger/ ... Mit einer beglaubten Vorrede/M. Cyriaci Spangenberg, Durch Marcvm VVagnervm Frimariensem Historicvm... (Jena: Tobias Steinmann, 1593; VD16 W 132), M3r. Gallus' letter to Merckel and his sister Margarethe in Magdeburg from December 1564 is reprinted in Gustav Hertel, »Zur Geschichte der heshusianischen Bewegung in Magdeburg, « Geschichts-Blätter für Stadt und Land Magdeburg: Mitteilungen des Vereins für Geschichte und Altertumskunde des Herzogtums und Erzstifts Magdeburg 34 (1899): 72-151, here 112-113.

52 Also known as Bürkicht. He was a merchant and the husband of Anna Tucher, Stephan Tucher's sister. This shows how family relations played an important role in bringing this group of people together. Burkicht is mentioned during the Magdeburg siege in Wilhelm Raabe's novel Unseres Herrgotts Canzlei (Braunschweig: Georg Westermann, 1862).

53 Flacius himself reports the details of his journey and talks about the Magdeburg invitation in Erzehlunge der Handlungen, X3r. 
The theory that Flacius lacked long-term plans is supported by the fact that soon after he arrived in Magdeburg, he set out on the road again, traveling first to Braunschweig, then to Lüneburg, where he met with the pastors and the superintendent of the city and discussed the situation regarding the Interim and the problem of adiaphora. ${ }^{54} \mathrm{He}$ continued his journey to Hamburg where he had a series of meetings with the superintendent Johannes Aepinus and the pastor of St. Catherine's Church, Joachim Westphal. He then returned to Magdeburg.

Another fact reinforcing the claim that Flacius had not made any concrete plans when he left Wittenberg is that his years in the city were marked by constant financial insecurities. He worked as an editor for the publisher Michael Lotter ${ }^{55}$ and privately tutored students in order to earn enough so that he could provide for himself and his growing family. A further source of irregular income originated from dedicating a number of his works to influential and well-to-do individuals and at times even to cities, which in turn donated some money to him. Some funds were even provided by friends. In addition, he was drawn into the book trade, which included selling his own books. This activity led him to involvement at the Frankfurt and Leipzig book fairs. Claiming later in his life that his departure from Wittenberg and relocation to Magdeburg had been an act of conscience was possibly Flacius' attempt at justifying his abrupt move and giving up job security for a life of uncertainty. His decision, however, was also likely the result of his obstinacy and inflexibility, especially on matters of doctrine - traits that were to characterize him for the rest of his life.

In Magdeburg, Flacius met a number of other like-minded Lutherans, who shared his disappointment and bitterness. Finding others sympathetic to the cause of resistance encouraged him to continue his literary attacks against those involved with the Interim and the Saxon counter-proposals. Opposition to the Interim also included theologians outside the German-speaking territories. Thus, it is very likely that Flacius convinced Michael Lotter to print the German translation of one such work written by John Calvin in Geneva in 1548. Flacius wrote the section "to the reader « to Calvin's Interim Adultero Germanum in Magdeburg, »Unseres Herrgotts Kanzlei, «56

54 Even though Flacius does not mention his name, it was Friedrich Henninges who wrote Lüneburg's Confession against the Interim and later supported Flacius and Gallus in their struggle against adiaphora and against Georg Major. For more about him, see Karl Ernst Hermann Krause, »Henninges, Friedrich,« in ADB 11 (1880), 778.

55 For more about Lotter's printing activity, see Maren Ballerstedt, Peter Petsch and Matthias Puhle (eds.), Magdeburger Drucke des 16. Jahrhunderts. Ein Bestandeverzeichnis mit einer Einleitung von Michael Schilling (Halle: Mitteldeutscher Verlag, 2009), 35-37.

56 For the origins and usage of this term, see Thomas Kaufmann, »Our Lord God's Chancery« in Magdeburg and Its Fight against the Interim, « Church History: Studies in Christianity and Culture 73 (2004): 566-582. 
in $1549 .{ }^{57}$ Calvin was not only critical of the Augsburg Interim but also of the Philipp Melanchthon, since "when in mid-1549 Melanchthon became embroiled in the adiaphoristic controversy, Calvin sent Melanchthon a less than friendly letter. Calvin insisted that so many things ought not to be conceded to the papists. $\ll^{58}$

Flacius published materials critical both of those involved in leading the negotiations for the Augsburg Interim (for example, Johannes Agricola) and of the Roman Catholic theologians who authored the Augsburg Interim. An example was a work he wrote condemning the Interim, the Mass Canon and Johannes Agricola, whom he referred to as $»$ Meister Eisleben. $\aleph^{59}$ His publications critical of Pope Paul $\mathrm{III}^{60}$ and of the Archbishop-Elector of Mainz, Sebastian van Heusenstamm followed. ${ }^{61}$

Flacius did not spare others involved in the Interim, either. He attacked Michael Helding's sermons on the Mass in 1549 and $1550 .{ }^{62}$ Helding had been

57 Calvin, Erklaerung, wie es der Religion halben im Heiligen Reich bis zu Austrag des gemeinen Concilii gehalten werden soll/Interim/Advltero/Germanvm./Cui adiecta est./Vera Christianae pacificationis/\& Ecclesiae reformandae ratio./Per Iohannem Caluinium (Magdeburg: Michael Lotter, 1549; VD16 D 954). Calvin's text is reprinted in CO 35: 509-544. Flacius' text with the title Typographus ad Lectorem is actually a critique of Calvin's teaching on infant baptism and can be found in the section Prolegomena by the editors of the volume, XXXIX-XLIV.

58 Timothy J. Wengert, »We Will Feast Together in Heaven Forever: The Epistolary Friendship of John Calvin and Philip Melanchthon, « in Karin Maag (ed.), Melanchthon in Europe: His Work and Influence Beyond Wittenberg [Texts and Studies in Reformation and Post-Reformation Thought] (Grand Rapids: Baker, 1999), 19-44, here 35-36.

59 Flacius, Wider Das Interim. Papistische Mess Canonem vnnd Meister Eissleuben durch Christianum Lauterwar zu dieser zeit nuetzlich zu lesen (Magdeburg: Michael Lotter, 1549; VD16 F1554). Already in 1548, Flacius published an anonymous eleven-page pamphlet against Agricola. See, Von der Messe vnd jhrem Canone Magistri Johannis Agricolae Eysleben/Lhere vnd schrifft/Welche er auff dem Reichstag zu Speyer in der Epistel zu den Collossern geprediget/vnd folgend Anno M.D.XXVII. zu Wittenbergk im Druck offentlich hat ausgehen lassen/ Dem Interim so er ytzt hat helffen stellen/gantz entgegen/Daraus sein geyst zuuermercken (Magdeburg: Christian Rödinger d.Ä., 1548; VD16 F 1543). Flacius, following Caspar Aquila, later also gave an unflattering nickname to Johannes Agricola, by making a play of words on his town of origin and referring to him in a vulgar way as »Scheissleben«.

60 Flacius, Bvlla Antichristi de Retrahendo populo Dei in ferream Aegiptiacae seruitutis fornacem, Maguntini Rabsaces blasphemis literis consona, Ex qua facile animaduerti potest, quid Satan per utranque suam uirtutem, scilicet, per parricidiale bellum contra Ecclesiam Dei susceptum, \& per mendacia Concilium, Interim, Adiaphora \& Chorrook efficere conetur (Magdeburg: Michael Lotter, 1549; VD16 K 400).

61 Flacius, Ein rechter lesteriger Rabsakes brieff geschrieben von einem Bischoff an einen Christlichen Fuersten in welchem er ihn vermanet das er sol von der erkanten warheit Christi zu dem Antichrist abfallen Daraus man sehr woll kan mercken wie gut es die Antichristische Wolffe mit den armen Schefflein Christi meinen (Magdeburg: Christian Rödinger d.Ä., 1549; VD16 ZV 10271).

62 Flacius, Confvtatio Catechismi laruati Sydonis Episcopi, Autore Matthia Flacio Illyrico (Magdeburg: Michael Lotter, 1549; VD16 F 1319), and in 1550 two in German: Widderlegung des Catechismi des Larven Bischoffes von Sidon/durch Matthiam Flacium Jllyricum (Magdeburg: Michael Lotter, 1550; VD16 F 1320); Widderlegung der Predigten (as in note 84, Chapter 1). Helding replied to Flacius in Brevis institvtio ad pietatem Christianam secundum 
co-author of the text of the Augsburg Interim. ${ }^{63}$ Other works followed: against the Roman Catholic Bishop Julius von Pflug, ${ }^{64}$ who had been involved in the negotiations leading up to the Augsburg Interim, in the formulation of the document and in the negotiations surrounding the first draft for what became known as the Leipzig Interim; and against the evangelical superintendent of Leipzig, Johann Pfeffinger, who had also taken part in the deliberations concerning the Augsburg Interim. ${ }^{65}$ Georg Witzel, a former Wittenberg student and an evangelical for a short time before returning to the Church of Rome, also defended the Interim ${ }^{66}$ and published a work against Flacius in Cologne in 1551 in response to the Illyrian's writings concerning the Mass. ${ }^{67}$ Witzel was perhaps the most important apostate who had deserted Wittenberg and returned to Rome up to this time. ${ }^{68}$

Doctrinam Catholicam continens. ... Defensio adversus calumnias cuiusdam Matthiae Illyrici (Mainz: Ivo Schöffer, 1552; VD16 H 1582). For more on Helding's Defensio see, Peter M. Seidel, »Defensio adversus Matthiam Flacium Illyricum, « in Michael Helding (1506-1561). Ein Bischof im Dienst von Kirche und Reich [Reformationsgeschichtliche Studien und Texte 157] (Münster: Aschendorff, 2012), 341-349. Flacius followed with Verlegung der Apologiae Sydonij/damit er seinen Catechismus verteidinget. Matth. Flacius Jllyricus (Magdeburg: Christian Rödinger d.Ä., 1553; VD16 F 1512) and Kurtze antwort M. Fla. Jllyr. auff des Laruen Bischoffs von Sydon Holhiplerey/Damit er seinen Antichristischen Catechismum verteidingen wil. Jtem etliche oeffentliche verfelschung Gottes worts aus des Sidonij Buechern. Jtem ein stueck aus einer schrifft des hochgelarten Gersonis (Magdeburg: Christian Rödinger d.Ä., 1553; VD16 F 1432-1434).

63 On May 28 1549, Emperor Charles V appointed Michael Helding, coadjutor bishop of Mainz, also known as Sidonius, as bishop of Merseburg.

64 Flacius, Widder die vnchristliche Vermanungschrifft/des Bisthumbs zu Naumburg/Durch Matth. Flacium Jllyricum (Magdeburg: Christian Rödinger d.Ä., 1550; VD16 F 1565).

65 Flacius, Widder die newe Reformation D. Pfeffingers/des Meisnischen Thumbherrn. Durch Matth. Fl. Jllyr. (Magdeburg: Christian Rödinger d.Ä., 1550; VD16 F 1561); Gruendliche verlegung aller Sophisterey so Juncker Jssleb D. Jnterim Morus Pfeffinger D. Geitz in seinem gruendlichen bericht vnd jhre gesellen die andere Adiaphoristen das Leipsische Jnterim zu beschoenen gebrauchen. Durch Matth. Fla. Illyricum (Magdeburg: Christian Rödinger d.Ä., 1550; VD16 F 1410); Gruendliche verlegung aller Sophisterey so D. Pfeffinger mit den andern Adiaphoristen das Leiptzigsche Jnterim zubeschoenen gebraucht. Durch Matth. Fla. Jllyricum (Magdeburg: Christian Rödinger d.Ä., 1551; VD16 F 1411). For Pfeffinger's work, see Luther D. Peterson, »Johann Pfeffinger's Treatise of 1550 in Defense of Adiaphora: `High Church Lutheranism and Confessionalization in Albertine Saxony, in John M. Headley, Hans Joachim Hillerbrand and Anthony J. Papalas (eds.), Confessionalization in Europe, 1555-1700. Essays in Honor and Memory of Bodo Nischan (Burlington, VT: Ashgate, 2004), 91-105.

66 For Witzel's role in defending the Interim, see Heribert Smolinsky, »Altgläubige Kontoverstheologen und das Interim, « in Dingel and Wartenberg (eds.), Politik und Bekenntnis, 51-64, esp. 56-58.

67 Georg Witzel, Pvblicvm Ecclesiae Sacrvm. Von der Warheit der Altkyrchischen Liturgy vnd Opfferung das ist Catholischer Missen Antwort Georgij Wicelij Orthodoxi wider den Matthis Jllyric. zu Magdenburg (Cologne: Johann Quentel, 1551; VD16 W 4007).

68 In 1564 Witzel published another polemical work defending Roman Catholic liturgy against Flacius and others. See Defensio Ecclesiasticae Litvrgiae, Qva Scismaticorum quorundam eruditorum confutationes summa breuitate refutantur (Cologne: Arnold Birckamm d.Ä. 
Flacius also disagreed fundamentally with those who tried to negotiate a way around the Augsburg Interim by compromising in matters of adiaphora. This topic was to emerge as a central issue in many of his publications during the Magdeburg years. ${ }^{69}$ Flacius' statement from 1549, $»$ in the situation of confession and scandal, there is no such thing as an indifferent practice ${ }^{70}$ (»nihil esse $\alpha \delta \delta_{\alpha} \varphi \rho \rho \rho v$ in casu confessionis et scandali $\ll$ ), reflected his convictions clearly and later became widely known and quoted by others. ${ }^{71} \mathrm{He}$ was convinced that the very heart of the Protestant message, justification by faith, would be compromised as a result of the Saxon negotiations. In such a situation, he claimed, even normally inconsequential issues surrounding the liturgy, church leadership, membership and so on gain a notably more significant meaning either pointing to or away from the Gospel. Therefore, they could no longer be regarded as adiaphora. Flacius argued that under such circumstances the church should raise its voice in protest to the political authorities of the day.

Flacius' apocalyptic point of reference in interpreting the events around him, the persecution of Christians from his homeland and the precariousness of his personal life all led him to understand the situation resulting from the Augsburg Interim and the Saxon counter-proposals as constituting a status confessionis. Viewing them from this standpoint raised the stakes much higher and consequently every small detail mattered, which led him to argue that absolutely no concessions or compromises should be made with the Roman Church. The rigidity of this conviction resulted in an increasing radicalization of his theology, parallel to his publishing activities against an ever-widening circle of theologians, political figures and church leaders. In 1550 Flacius participated with the pastors of Magdeburg in drafting a confession that contained a doctrine of resistance to the superior magistrates. Lowell Zuck states that »the Magdeburg Confession thus was the first formal

(Erben), 1564; VD16 W 3905). The section contra Flacius is titled »Plvra svper eodem negocio Sacro, ad. M. Illyricum, « B5r-B 21r.

69 Among his many publications dedicated to this topic was a book defining what is a true and a false adiaphora: Ein buch/von waren vnd falschen Mitteldingen/Darin fast der gantze handel von Mitteldingen erkleret wird/widder die schedliche Rotte der Adiaphoristen. Durch Matth. Flacium Jllyr. (Magdeburg: Christian Rödinger d.Ä., 1550; VD16 F 1447).

70 Despite the fact that Kolb and Wengert in The Book of Concord also translate it »indifferent, « the term in English that best matches is "undifferentiated « matters or things, since they are not unimportant (the way »indifferent, « is usually understood) but rather neither right nor wrong/good or bad in and of themselves. Robert Kolb and Timothy J. Wengert (eds.), The Book of Concord: The Confessions of the Evangelical Lutheran Church (Minneapolis: Fortress, 2000), 515, 635. Another possible formulation is »a practice that does not make a decisive difference, « according to John F. Hoffmeyer.

71 Flacius, Qvod hoc tempore nvlla penitvs mvtatio in Religione sit in gratiam impiorum facienda. Per Matth. Flacium Illiric. ... (Magdeburg: Hans Walther, 1549; VD16 F 1471), A5v [under Argument XV]. 
assertion of a theory of rightful resistance issued by orthodox Protestants. $\ll^{72}$ While Zuck's claim of the Magdeburg Confession being the first document to tackle the issue of rightful resistance is certainly flattering, it is not fully accurate. The memoranda and the disputation from Luther and Melanchthon at the end of the 1530s, together with the literature produced by the Smalcaldic League theologians already in 1546-1547 were definitely precursors to the Magdeburg Confession concerning the treatment of this topic. ${ }^{73}$

In addition to debating in print questions directly connected to the Augsburg Interim, Flacius also wrote a number of anti-Roman works. For example, he debated issues surrounding the Mass and the primacy of the Pope with the Dominican monk and the preacher at the Augsburg cathedral church, Johannes Fabri of Heilbronn. ${ }^{74}$ In this, he was still acting in consort with Wittenberg theologians, such as Major and Melanchthon, who also attacked aspects of the Council of Trent at this time.

Considering the number of works Flacius wrote and published while in Magdeburg, it may be argued that the time he spent in the city was very fruitful. It is true that he was becoming known to a growing audience through his publications, especially as a polemicist, but also as a premier theologian of the next generation of Evangelical leaders.

Apart from Flacius' works being read within Protestant circles in the German-speaking territories, at least one of his writings also caught the

72 Lowell H. Zuck (ed.), Documents in Free Church History Christianity and Revolution: Radical Christian Testimonies 1520-1650 (Philadelphia: Temple University Press, 1975), 136.

73 See Oskar Waldeck, »Die Publizistik des Schmalkaldischen Krieges, « ARG 7 (1909-1910): 1-55; »Die Publizistik des Schmalkaldischen Krieges, «ARG 8 (1911-1912): 44-133. The pamphlet Instructions on Legitimate Self-Defense (Von der Notwehr Unterricht) discussed earlier in the text also belongs to this body of literature.

74 Flacius, Beweisung das nicht die vnsere Christi/Sonder die Papistische Religion/new vnd auffruerisch/vnd ein vrsach alles vngluecks sey. Wider das Gotteslesterisch buch Marani, oder des schwartzen Munchs zu Augspurg, von dem itzigen krieg geschrieben. Durch Matth. Flacium Jllyricum (Magdeburg: Christian Rödinger d.Ä., 1553; VD16 F 1287); Refvtatio Missae. Widerlegung des Sophistischen Buechs des Schwartzen Münchs von der Opffer Meß/Anno 1555. außgangen. Jtem die beschreibung der Mesz oder Communion dreyer alten vaetter/als Justini/welcher zue Rhom vngefaehr 150. Jar nach Christo gelebt/Clementis/... Dionisij/... Durch Matth. Flac. Jllyricum ... (Strasbourg: Samuel Emmel, 1557; VD16 1476). Flacius referred to Fabri by using his German name, Hans Schmidt. This work of Flacius was a critique of Fabri's: Was die Euangelisch Mesz sey/Grundtliche vnnd Christenliche anzaigung/auß der hailigen geschrifft/vnnd auß den alten hayligen Kirchen lerern/zue trost vnd sterckung der Glaubigen. Durch D. Johannem Fabri von Hailbrun/Thumbprediger zue Augspurg (Dillingen: Sebald Mayer, 1555; VD16 F 182). See also Fabri's work against Flacius, Antwort/Auff das vnnuetz/vnrain/jrrig geschwetz Mathie Flaccij Jlyrici/so er geschriben wider das buechlein/genant Rechter weg. Vnd auff seine dreyvndzwaintzig sectische Argument/so er geschriben an Osterreich vnnd Bayern/wider die Euangelische Meß. Mit einer vorgehenden Epistel/... Durch D. Johannem Fabri von Hailbrunn/Thumprediger zu Augspurg/mit bestendigem grund/allen Christglaubigen zu trost/ganz trewlich beschrieben (Dillingen: Sebald Mayer, 1558; VD16 F 147). Fabri was also a professor of theology at the University of Ingolstadt, where in 1552 he received a doctorate. 
attention of the Slovenian evangelical pastor, Primus Truber. ${ }^{75}$ In 1550, while working in Rothenburg ob der Tauber as a preacher in exile, Truber published the first edition of Catechismus, the first book in the Slovenian language. ${ }^{76}$ Drawing on a variety of sources, including Martin Luther and Johannes Brenz, the volume contained a litany, hymns, Bible expositions and also a text on the true faith - a translation from Flacius' Wittenberg master's thesis De vocabulo fidei, which first appeared in print the previous year. ${ }^{77}$ Truber published the book under the pseudonym »Philopatridus Illiricus « (Illyrian Patriot) and in this work he referred to himself as »exul Christi« and »martyr Christi,« and blamed the Augsburg Interim that led to his religiously motivated persecution. ${ }^{78}$

\section{Looking to Luther's Theology for Inspiration and Rationale to Resist the Augsburg Interim}

In the midst of his growing disappointment and frustration with the situation caused by the Augsburg Interim, Flacius also reached back to Luther's own words and began publishing the Reformer's works. In addition to wishing to preserve Luther's theological legacy, Flacius also wanted to justify and defend his own stances through these publications.

For example, Flacius wrote the foreword and an epilogue to a collection of Luther's letters written at Coburg during the summer of 1530, while attempts at ensuring peace between the Protestants and the Emperor, Charles V were taking place at the Imperial Diet in Augsburg. ${ }^{79}$ Luther could not attend

75 For his brief biography, see Luka Ilić, »Primus Truber (1508-1586), the Slovenian Luther,« Lutheran Quarterly 22/3 (Autumn 2008): 268-277.

76 Truber, Catechismus/In der Windischenn Sprach/sambt einer kürzten Außlegung/in gesang weiß. Item die Litanai/ vnd ein predig vom rechten/Glauben, gestelt, durch/Philopatridum/ Illiricum./Anu kratku Poduuzhene skaterim/vsaki zhlouik more vnebu/pryti (Tübingen: Ulrich Morhart d.Ä., 1550; VD16 T 2104). The publisher used a pseudonym (Jernei Skurayniz) and instead of Tübingen as the place of publishing, he listed Sybenburgen. See Rolf-Dieter Kluge, »Zum 500. Geburtstag des slowenischen Reformators Primus Truber,« Tübinger Blätter 94 (2007/2008): 26-34, here 27.

77 For a discussion on how Truber employed Flacius' text, see Jochen Raecke, »Primus Truber als Autor und Übersetzer. Betrachtungen zum Thema literarische Originalität,« in Sönke Lorenz, Anton Schindling and Wilfried Setzler (eds.), Primus Truber 1508-1586: Der slowenische Reformator und Württemberg [Veröffentlichung der Komission für geschichtliche Landeskunde in Baden-Württemberg] (Stuttgart: W. Kohlhammer, 2011), 119-144, here 143.

78 Truber, Catechismus/In der Windischenn Sprach, 145.

79 Etliche Brieffe/des Ehrwirdigen Herrn D. Martini Luthers seliger gedechtnis/an die Theologos auff den Reichstag zu Augspurg geschrieben/Anno M.D.XXX. Von der vereinigung Christi vnd Belials/Aufs welchen man viel nützlicher Lehr in gegenwertiger gefahr der Kirchen nemen kan. Verdeutscht. Item, etliche andere schrifften, nuetzlich vnd troestlich zu Lesen (Magdeburg: Christian Rödinger d.Ä., 1549; VD16 L 3727). The Latin edition is not 
the Diet due to his status as an outlaw of the Empire, and therefore he corresponded with Melanchthon, Justus Jonas and others who were present at Augsburg and were engaged in writing the Lutheran confession that came to be known as Confessio Augustana and concurrently negotiating with the Protestant princes to bring about a consensus. ${ }^{80}$ The publication of the Coburg letters served to underscore Flacius' criticism of the Augsburg Interim and his position in the ensuing adiaphoristic controversy. Writing against the theologians who supported the Interim, either directly (like Johannes Agricola) or through compromise (like the Wittenbergers), Flacius drew parallels to Luther's warnings from 1530 against making too many compromises with both the secular and the Roman Catholic ecclesiastical powers. After all, Flacius lived in Wittenberg during the last five years of Luther's life, »the period during which Luther leveled his most virulent attacks against the papacy, and the proximity of the Reformer must have had a hardening effect on the already cultivated anti-Catholic attitude of Flacius. $\ll^{81}$ This illustrates that Flacius saw himself as following in Luther's footsteps, not only in the content of his theology but also in his use of polemical methods of communicating it.

Two years after issuing Luther's Coburg letters, Flacius attempted to legitimate his own theological position from them with the following, apocalyptically charged words:

You know very well that nobody has argued more vehemently against such a union of Christ and Belial than Doctor Luther did. I am not stating any falsehood. Read his letters that he wrote in the year [15]30 (since, as they say, he supposedly was an Adiaphorist) to Philipp [Melanchthon] and the other theologians in Augsburg, which we had printed in German and Latin. ${ }^{82}$

identical, Aliqvot epistolae reverendi patris piae memoriae D. Martini Lutheri quibusdam Theologis ad Augustana comitia. Anno 1530. scriptae, de conciliationibus Christi et Belial disserentes, ex quibus multa remedia praesentibus Ecclesiae morbis salutaria, peti possunt. Et quedam alia lectu digna (Magdeburg: Michael Lotter, 1549; VD16 L 3724). The German edition was reprinted in Jena with additional letters in 1558 [VD16 L 3728]. For more about this publication, see Johannes Haußleiter, »Matthias Flacius als Herausgeber von Luthers Koburger Briefen und Trostsprüchen (1530),« Neue Kirchliche Zeitschrift 28 (1917): 149-187.

80 Apart from Luthers letters to Melanchthon and Jonas the collection Flacius published also includes Luther's correspondence with Johannes Brenz, Georg Spalatin, Johannes Bugenhagen and Caspar Cruciger the Elder.

81 Cyriac K. Pullapilly, Caesar Baronius, Counter-Reformation Historian (Notre Dame/London: University of Notre Dame Press, 1975), 50.

82 Flacius, Gruendliche verlegung aller Sophisterey/so D. Pfeffinger mit den andern Adiaphoristen/das Leiptzigsche Jnterim zu beschoenen, gebraucht. Durch Matth. Fla. Jllyricum (Magdeburg: Christian Rödinger d.Ä., 1551; VD16 F 1411), B1r: »Sie wissen sehr wohl, daß 
In another foreword that Flacius wrote for a collection of Luther's pastoral advice, Illyricus referred to him as a »holy man « and a »true hero; « words that point to his admiration of Luther. ${ }^{83}$ For Flacius, Luther was »the last apostle « and he referred to him as »the third Elijah of blessed memory, « emphasizing his prophetic role and placing him in the same category as the Old Testament prophet and John the Baptist, who was considered to be the second Elijah. ${ }^{84}$ This language and imagery were already being used in Wittenberg, such as in Michael Stifel's hymn ${ }^{85}$ or in Melanchthon's and Bugenhagen's funeral addresses for Luther, held on February 22, 1546 in the Castle Church, which Flacius undoubtedly heard. ${ }^{86}$ In another writing Flacius described Luther as »...our old venerable father in Christ, the authentic man of God and true Elijah, who, as an undaunted hero, fought confidently and blessedly against the Antichrist and all heretics and idolaters [literally: followers of Baal]. ${ }^{87}$

niemand heftiger wider solche Christi und Belials Vereinigung gestritten hat, denn D. Luther. Ich sag keine Unwahrheit. Lies seine Briefe, die er Anno 30 (da er vornemlich, wie sie vorgeben, ein Adiaphorist soll gewest sein) gen Augspurg an Philippum und andere Theologen geschrieben hat. Welche wir die Deudsch und Lateinisch haben drucken lassen.«

83 Flacius, Etliche troestliche vermanungen/in Sachen das heilige Goettliche Wort betreffend: $\mathrm{Zu}$ dieser betruebten Zeit/sehr nuetzlich vnd troestlich zu lesen/D. Martinus Luther/Anno. M.D.XXX. Wieder aussgelegt zu Magdeburg An. 1550 (Magdeburg: Christian Rödinger d.Ä., 1550; VD16 L 3729; reprinted by Thomas Rebart in Jena in 1558; VD16 L 3730), Tittle page: »Zum Christlichen Leser. Mit diesem Sprüchen hat sich der heilige Mann und thewre held D. Martinus Luther getröstet... « For more on this, see WA 30/2: 697f. but with WA 30/2: 153 Revisions - Nachtrag and WA 48: (324) 327-333. Rev. Nachtrag 1972.

84 See the title page of: Erklerung der schendlichen Suende der jenigen/die durch das Concilium/Jnterim/vnd Adiaphora/von Christo zum Antichrist fallen/aus diesem Prophetischen gemelde/des 3. Eliae seliger gedechtnis/D. M. Luth. genomen. Durch Matth. Fla. Illyr. (Magdeburg: Christian Rödinger d.Ä., 1550; VD16 L 3730).

85 Stifel, Von der Christfermigen/rechtgegründten leer Doctoris Martini Luthers/ain überuß schoen kunstlich Lied/sampt seyner neben außlegung. / Bruder Michael Styfel, Augustiner von Esszlingen (Augsburg: Erhard Oeglin, 1522; VD16 S 9019), A2r-B1r. For more about the hymn, see Robert Kolb, For All the Saints: Changing Perceptions of Martyrdom and Sainthood in the Lutheran Reformation (Macon, GA: Mercer University Press, 1987), 125.

86 Bugenhagen, Eine Christliche Predigt/vber der Leich vnd begrebnis/des Ehrwirdigen D. Martini Luthers/durch Ern Johan Bugenhagen Pomern/Doctor/vnd Pfarrher der Kirchen $z u$ Wittemberg/gethan (Wittenberg: Georg Rhau, 1546; VD16 B 9274). For the facsimile of Bugenhagen's homily and its translation into English by Kurt K. Hendel, A Christian Sermon Over the Body and At the Funeral of the Venerable Dr. Martin Luther, Preached by Mr. Johann Bugenhagen Pomeranus, Doctor and Pastor of the Churches in Wittenberg (Atlanta: Pitts Theological Library, 1996), see http://beck.library.emory.edu/luther/luther_site/luther_text. $\mathrm{html}$ (accessed December 19, 2011). Melanchthon, Oratio in fvnere Reverendi viri D. Martini Lvtheri, recitata Vitebergae a Philippo Melanchthone (Wittenberg: Josef Klug 1546; VD16 M 3853) in CR 11: 726-734, Nr. 89.

87 Flacius, Etliche greiffliche gewisse vnnd scheinbarliche warzeichen/Daraus ein jeder wie geringes verstands er sey/Wo er nur zu erforschung der warheit geneiget ist/vormercken kan/das die Lehre der Euangelischen des Herrn Christi Leher selbst ist/vnd das der Papisten Lehr falsch/Gottloss vnd vom Antichrist erfunden ist. Auss einer lateinischen schrifft M. Matthie Flacij Jllyrici verdeutschet (Magdeburg: Christian Rödinger d.Ä., 1549; VD16 F 
In a pamphlet Flacius published against the Council of Trent in 1551, during its second session, he returned to the words Luther said about the Council at its beginning in 1545 , and presented them as prophetic utterances in that they foresaw the developments that were to take place during the proceedings. ${ }^{88}$ Building on Luther's warnings about how papal theologians and others would distort the truth, Flacius portrayed them as enemies of the true religion.

In a number of Flacius' writings he affectionately called him $»$ Father Luther« or sometimes »Reverend Father Martin Luther of blessed memory. « ${ }^{89}$ Although Flacius was certainly not the only person in the sixteenth century to ascribe to Luther epithets of a German hero, holy man, prophet and father, ${ }^{90}$ his view of Luther certainly contributed to shaping a posthumous depiction and remembrance of Luther as surpassing the ordinary and making him larger than life. ${ }^{91}$

\section{The Majorist Controversy: The Role of Good Works in Salvation}

One of the people who participated in the composition of the so-called Leipzig Interim of December 1548 was the preacher and Wittenberg professor Georg Major. ${ }^{92}$ As public disapproval arose within Protestant Germany concerning the Saxon proposals, Major began publishing sermons and writing

1305), A3r: »... unser Alter Ehrwirdiger Vater in Christo/der getrewe Gottes man vnd rechte Elias/welcher als ein vnvertzagter Heldt getrost und glueckselig wider den Antichrist/allerley Ketzer und Baaliten gekempffet hat.« English translation taken from Thomas A. Brady, Jr., German Histories in the Age of Reformations, 1400-1650 (Cambridge: Cambridge University Press, 2009), 266.

88 Flacius, Eine prophetische abkonterfeiung des Tridentischen Conciliabuli. Durch D. Martinum Lutherum. Mit einer erklerung M. Fl. Jllyr. (Magdeburg: Christian Rödinger d.Ä., 1551; VD16 F 1375).

89 Flacius, Qvod hoc tempore nvlla penitvs mvtatio in Religione sit in gratiam impiorum facienda. Per Matth. Flacium Illiric. ... (Magdeburg: Hans Walther, 1549; VD16 F 1471), A2r: »Reuerendi Patris Martini Lutheri, piae memoriae.«

90 Robert Kolb's book, Martin Luther as Prophet, Teacher, and Hero: Images of the Reformer, 1520-1620 [Texts and Studies in Reformation and Post-Reformation Thought] (Grand Rapids: Baker, 1999), discusses how images of Luther were used among his followers, creating a legend out of him. Flacius played an important role by contributing to an almost idealized view of Luther that became part of German Protestantism.

91 Luka Ilić, »Der heilige Mann und thewre held«: Flacius’ View of Luther, in Marina Miladinov in cooperation with Luka Ilić (eds.), Matija Vlačić Ilirik III: Proceedings of the Third International Conference on Matthias Flacius Illyricus, Labin/Croatia, 2010 (Labin: Grad Labin, 2012), 294-314.

92 For more about him, see Helmar Junghans, »Major (Maier), Georg, i in NDB 15 (1987), 718-719; Irene Dingel and Günther Wartenberg (eds.), Georg Major (1502-1574). Ein Theologe der Wittenberger Reformation [Leucorea-Studien zur Geschichte der Reformation und der Lutherischen Orthodoxie 7] (Leipzig: Evangelische Verlagsanstalt, 2005). 
letters trying "to reassure people that nothing had changed in Wittenberg's teaching. Convinced that simply attacking Rome and attesting to the purity of one's own teaching would not suffice, Major also began a systematic attack on Wittenberg's opponents, especially Matthias Flacius Illyricus. ${ }^{93}$

Major was particularly concerned with Lutherans residing in Magdeburg, like Gallus and Nikolaus von Amsdorf, but it is significant that he recognized Flacius as the intellectual leader and as someone whom he especially needed to refute. Timothy J. Wengert corrects a view held by some Reformation scholars that the beginning of the Majoristic controversy was a publication by von Amsdorf in 1551 against Major and Bugenhagen, ${ }^{94}$ with the title The Doctor Pomer ${ }^{95}$ and Doctor Major with their Adiaphorists Have Brought About Nuisance and Division and Have Done Insurmountable Damage to the Churches of Christ. ${ }^{96}$ Wengert states that the start of the long-drawn debate was actually Major's personal attack upon Flacius in the preface to the first edition of his work Auslegung des Glaubens, where he also »announced that he would refute Flacius' teaching in a discussion of the nature of the church in sermon nineteen. ${ }^{97}$ The first edition of Auslegung des Glaubens, which consisted of twenty sermons Major preached in Merseburg between August 1547 and February 1548 when he was Superintendent there, was published in early October $1550 .{ }^{98}$ As Robert Kolb has observed, Major disliked Flacius

93 Timothy J. Wengert, »Georg Major (1502-1574). Defender of Wittenberg's Faith and Melanchthonian exegete, « in Heinz Scheible (ed.), Melanchthon in seinen Schülern [Wolfenbütteler Forschungen 73] (Wiesbaden: Harrassowitz, 1997), 129-156, here 135-136.

94 Ibid., 136. For example, that view is presented by Heinz Scheible in TRE 21 (1991), 725-730 and still widely cited, including in the recent short biography of Major for the Database Controversia et Confessio. Quellenedition zur Bekenntnisbildung und Konfessionalisierung (1548-1580), Irene Dingel (ed.). See http://www.controversia-et-confessio.adwmainz.de/ index.php?id=1181 (accessed July 5, 2011). For details of this project, see Johannes Hund and Henning P. Jürgens, »Pamphlets in the Theological Debates of the Later Sixteenth Century: The Mainz Editorial Project >Controversia et Confessio, « in Malcolm Walsby and Graeme Kemp (eds.), The Book Triumphant. Print in Transition in the Sixteenth and Seventeenth Centuries [Library of the Written Word 15 - The Handpress World 9] (Leiden/Boston: Brill, 2011), 158-177 and Henning P. Jürgens, »Druckschriften in den theologischen Debatten des späteren 16. Jahrhunderts: Die Datenbank der Mainzer Quellenedition zur Bekenntnisbildung und Konfessionalisierung (1458-1580), « in Dingel and Wartenberg (eds.), Politik und Bekenntnis, 125-138. Oliver Olson also makes the mistake by stating that »Major's Answer set off the »Majorist Controversy.« See, Flacius and the Survival of Luther's Reform, 282.

95 »Pomer« or »Pommer« was the nickname for Johannes Bugenhagen who came from Pomerania.

96 Von Amsdorf, Das Doctor Pomer vnd Doctor Maior mit jren Adiaphoristen ergernis vnnd zurtrennung angericht/Vnnd den Kirchen Christi vnueberwintlichen schaden gethan haben. Derhalben sie vnd nicht wir zu Magdeburg vom Teuffel erwegt sein/wie sie vns schmehen vnd lestern. Niclas von Amsdorff Exul (Magdeburg: Michael Lotter, 1551; VD16 ZV 1543).

97 Wengert, »Georg Major,« 136. Wengert also points out that sermon nineteen was written much later than others.

98 Major, Auslegung des Glaubens/Welcher das Symbolum Apostolicum genand wird/den einfeltigen Pfarherrn vnd allen Hausuetern zu dienste in XX. Predig verfasset. Durch D. Georg. 
because he was a foreigner and did not possess any ecclesiastical office »and thus could not speak on theological matters. $\ll{ }^{99}$

Part of Major's argument is curious and reveals a double standard, since Melanchthon, whom Major supported strongly, was not ordained either, just like Flacius, and did not hold any official ministerial position in a congregation. (Of course, he was called as professor of the arts [humanities] and theology faculties.) The other side of Major's argument, discrediting Flacius because he was a foreigner, was also done by others, including Michael Helding, who made fun of Flacius' homeland by giving him the derogatory nickname »Dellyricus« (the delirious one). Schwenckfeld, on the other hand, attempted to discredit Flacius by equating him to the Jews and naming him »Rabbi Illyricus, « which was definitely not a flattering nickname by sixteenth-century standards. ${ }^{100}$

Flacius' reply to Major was issued in print in late 1551, where on the title page Flacius cited a passage from Melanchthon's Loci Communes that has to do with the magistrates (Weltliche Obrigkeit). This incidentally shows not only Flacius' familiarity with this work but also how he used it in order to prove that his interpretation of it was correct. On the opening page, Flacius first establishes that Major singled him out by name and that he would now reply to his accusations. ${ }^{101} \mathrm{He}$ also says that he was prevented from replying immediately because at the time of Major's publication he was in Magdeburg under siege, and he points out that Major published his work soon after the siege began. ${ }^{102}$ That indeed this is Flacius' reply to the preface found in Major's Auslegung and to sermon nineteen found in it including a section called "von den Adiaphoris oder Mitteldingen" is clear from the following three quotations by Flacius: »[Major] writes in a German preface that we,

Maior. Mit einer Vorrede/des M. Flacij Jllyrici schreien vnd schreiben belangend (Wittenberg: Georg Rhau, 1550; VD16 M 2003). The foreword dedicated to the city of Merseburg where the published twenty sermons were originally preached is dated on October 4, 1550, $1 \mathrm{v}-\mathrm{A} 4 \mathrm{v}$. The second edition with a new preface was issued in Wittenberg by Veit Kreutzer in February 1554 (VD16 M 2004).

99 Robert Kolb, Nikolaus von Amsdorf (1483-1565): Popular Polemics in the Preservation of Luther's Legacy [Bibliotheca Humanistica \& Reformatorica 26] (Nieuwkoop: B. De Graaf, 1978), 125.

100 CS 13: 483: »Rabj Illyricus hat mit den Juden allein einen buchstebischen verstand Von der Schrifft.« It is possible that Schwenckfeld gave this name to Flacius because he knew that the Illyrian was a scholar of the Hebrew language.

101 Flacius, Antwort auff etliche Beschueldigung Maiors, A1v: „Vnter andern aber hat vornemlich widder vns [Magdeburgers] geschrieben G. Maior/vnd mich sonderlich mit namen angegriffen/Demselben fromen Manne mus ich ein wenig antworten.«

102 Flacius points that out in the following words: »In der Deudschen Praefation/im anfang vnserer belagerung ausgegangen/schreibt er ...« A3v. The siege of Magdeburg began on September 19, 1550 while Major dated his preface on October 4, 1550. 
and especially I, out of ignorance...fight against the Adiaphora ...; $\left\langle 1^{103} » I n\right.$ the nineteenth sermon he says .... ${ }^{104} »$ Although in the same sermon he takes on the whole disputation on the Adiaphora, he still does not consider the most important rule..., namely that the Adiaphora, in case of offense, coercion, confession and fallacy, ceases to be an indifferent thing... $\ll^{105}$

It seems that nothing escaped Flacius' notice in those days. The fact that in the same work Flacius replies to Major's attack in print and responds to Bugenhagen's sermons preached in Wittenberg, in which he had named Flacius several times in front of the congregation, shows that Flacius had a good network of informants who provided him with the reports. ${ }^{106}$ It is also revealing to see that Flacius considered Major as a more significant opponent and of heavier theological weight than Bugenhagen, since his answer to Major takes up thirteenth and a half pages, while the Antwort auff $D$. Pomers Beschueldigung is only eight and a half pages long. Perhaps the most significant thing that reveals how Flacius functioned in those days is that by responding to Major's criticism he was not only formulating his answers but his theology was being molded through defense and by countering the arguments of others.

Flacius writes that already in 1548 he personally spoke with Major in Wittenberg several times regarding what constitutes adiaphora and that Major supported Flacius' view of not wearing chasubles. He also said that he gave Major some of his not yet published writings against the Augsburg Interim and that Major approved them. Flacius also claims that Major influenced Paul Eber into taking a position against the Augsburg Interim ${ }^{107}$ and that he encouraged Flacius in his idea to write a letter to Georg III, prince of Anhalt-Dessau and Lutheran coadjutor of the Bishopric of

103 Flacius, Antwort auff etliche Beschueldigung Maiors, A2r: »Er schreibt in einer Deudschen Prefation/das wir/vnd vornemlich Jch/aus vnuerstande/vnd weis nicht was fu(e)r Teuflisher bewegung angezu(e)ndet werden/widder die Mittelding zu streitten.«

104 Ibid., A3r: »In der Neunzehenden predigt sagt er/das wir inen nach Leib vnd Leben stehen/Daraus vnser geist zuuermercken sey.«

105 Ibid., A3v: »Wiewol er auch in derselben predigt/die ganze Disputation von Mitteldingen fu(e)r sich nimpt/so denckt er doch nirgent der vornempsten Regel/die sie zuuor/allezeit im maul hatten/nemlich/Das die Mittelding, im fall, da ergernis, zwang, bekentnis, und anfang zum Irthumb dran hengt, keine Mittelding sein, sonder Gottlos werden.«

106 Apart from responding to the sermons Flacius also mentions Bugenhagen's writing against Magdeburgers but does not specifically name it: »Die Adiaphoristen/vnd sonderlich Pomer in seinen predigten/vnd jezt in einer Schrifft/beschu(e)ldigen vns hefftig...« B4r. For Flacius’ critique of the content of one of Bugenhagen's sermons see page C3v: »Pomer hat vor etlichen Monden in einer predigt gesagt... I It is also evident that Flacius had even less respect for Bugenhagen than for Major since indirectly in his conclusion he refers to Bugenhagen as a »Gemeine Mann« and says that what he said is nothing but »Dreck«.

107 Flacius, Antwort auff etliche Beschueldigung Maiors, A2r. 
Merseburg. ${ }^{108}$ Obviously Flacius wrote all this to show how Major had changed his position since his participation at the meeting with Duke Maurice's advisors at the Cistercian monastery at Altzelle near Meissen in November 1548. According to Flacius, Major had become a proponent of the liturgical and doctrinal changes after that meeting and supported the signing of the so-called »Celle Interim« that was indeed a forerunner to the so-called Leipzig Interim, which was proposed but not adopted in Leipzig by the Saxon estates the following month.

Flacius also wanted to point out that he was not the first one to issue a public attack but that instead it was his former professor. He then asked a rhetorical question with a dose of sarcasm: $\gg$ Did this great Doctor not notice at the same time that I was going astray? Why did he not teach me differently and correct me? «109

Flacius' reply shows that he was deeply hurt and disappointed that Major had attacked him in print. It seems that he had spent a considerable amount of personal time with Major while in Wittenberg and that he thought highly of him. Flacius also referred to Major's preface to the work on the history of the Bohemians, showing that he read Major's writing and that he respected it. ${ }^{110}$ Flacius himself later published works of Jan Hus and of Jerome of Prague and was interested in the Hussite movement and its legacy, which he interpreted as a form of true witness to Christ. ${ }^{111}$ Apart from responding to Major's

108 Flacius, Antwort auff etliche Beschueldigung Maiors, A2r. Flacius actually published his lengthy letter to Prince Georg of Anhalt-Dessau dated on November 24, 1549. See, Etliche Brieffe/des Ehrwirdigen Herrn D. Martini Luthers seliger Gedechtnis, G2r-H2v.

109 Flacius, Antwort auff etliche Beschueldigung Maiors, A2v: »Hat nu dieser grosser Doctor zur selben Zeit gesehen/das ich jrret/Warumb hat er mich nicht vnterrichtet?«

110 Ibid., A4r: »Vor fu(e)nf jaren aber schreib er viel anders/inn der Vorrede der Behemischen Historia /... Da er aber seinen namen nicht wolte dazu setzen/... Even though Major's name does not appear anywhere inside Historia we can actually attribute the preface of the work to Major through Flacius' above statement. Historia vnnd erzelung der Handlung/so in dem loeblichen vnnd Hochberuembtem Koeningreich Behem/auff ihres Koenings Mandat/den Churfuersten zu Sachssen Hertzog Johans Fridrichen... (Magdeburg: Michael Lotter, 1547; VD16 H 3937). Major had a number of students from Bohemia throughout his career as a professor in Wittenberg. In 1568 Major, together with his son-in-law, Paul Crell and Paul Eber wrote an expert opinion (Gutachten) for the work of one of the leading preachers of the Czech Brethren, Georg Israel. See Anton Gindely, Böhmen und Mähren im Zeitalter der Reformation I: Geschichte der Böhmischen Brüder, vol. 2 (1564-1609.), (Prague: Carl Bellmann, 1858), 81-82.

111 Flacius, Ioannis Hus, et Hieronymi Pragensis Confessorvm Christi Historia er Monvmenta, Partim Annis Svperioribvs Pvblicta, Partim Nvnc demum in lucem prolata \& edita, cum scriptis \& testimonijs multorum ... (Altera Pars. Additae svnt Narrationes de Condemnatione Inivsta, et Indign Svpplicio Ioannis Hvs, et Hieronymi Pragensis, ab incertis Avthoribus ...) Narrationes de condemnatione iniusta et indigno supplicio Johannis Hus et Hieronymi Pragensis (Nurenberg: Johann vom Berg and Ulrich Neuber, 1558; VD16 H 3901), A4r. For more on Flacius involvment in publishing Hus see, Dušan Coufal »Einletung, « in Jana Nechutová et al (eds.), Magistri Iohannis Hus Enarratio Psalmorum (Ps. 109-118) [Corpvs Christianorvm: Continuatio Mediaeulis 253] (Turnhout: Brepols, 2013), IX-LXXI, here XXXVIII-LXVIII. 
preface and particularly to sermon nineteen, Flacius also referred to Major's »letter to the King, «112 showing that he was also familiar with Major's latest work Refutatio coenae Domini, ${ }^{113}$ where the preface was addressed to the young monarch of the Tudor dynasty, King Edward VI of England. This, too, showed his appreciation for Major's opposition to Roman Catholic theology.

As previously demonstrated, Major's attack on Flacius in October 1550 produced counter-attacks by Flacius and by von Amsdorf in 1551. Major followed up with a rebuttal in early $1552,{ }^{114}$ while he was a superintendent in Eisleben, a position in which he spent only one year, when he was dismissed by Count Albrecht VII of Mansfeld-Hinterort. ${ }^{115}$ Even though the title of his work mentioned only von Amsdorf, in reality »Major's reply to von Amsdorf's tract focused its criticism on Flacius. $\ll^{116}$

In his Antwort Major made the following statement, which he considered an attack on Amsdorf but which was to ignite the actual Majoristic controversy:

This I confess: I have previously taught and still teach and want to teach my whole life, that good works are necessary for salvation; and I say openly and with clear and plain words, that no one will be saved through evil works, and no one will be saved without good works, and I say further that whoever teaches otherwise, even an angel from heaven [Gal 1:8-9], is accursed. ${ }^{117}$

112 Flacius, Antwort auff etliche Beschueldigung Maiors, B2v: »Maior schreibt im Briefe an den Ko(e)ning von Engelland [Edward VI]..."

113 Major, Refvtatio horrendae prophanationis coenae Domini, collecta ex Evangelio et sinceris antiqvae ecclesiae testimoniis a Georgio Maiore. Cum praefacione Philip. Melanth. (Wittenberg: Veit Kreutzer, 1551; VD16 M 2156). Three more editions of this work were published in Wittenberg: one in 1555 (VD16 M 2157), another one in 1557 (VD16 M 2158), and in 1561 (VD16 M 2159) with a revised preface but with the same foreword by Philipp Melanchthon.

114 Major, Auff des Ehrenwirdigen Herren Niclas von Ambsdorff schrifft, so jtzundt neulich Mense Nouembri Anno 1551. wider Georgen Maior oeffentlich im Druck ausgegangen. Antwort Georg: Maior (henceforth: Major, Antwort), (Wittenberg: Georg Rhau, 1552; VD16 M 1996). Amsdorf's work referred to in this title could not have been published before November 1551, since the siege of Magdeburg, where he was, was only lifted on November 4.

115 Major took the position of superintendent for the territory of Mansfeld that had been vacant following the death of Johannes Spangenberg on June 13, 1550. Because there was a plague in the city, Major began his appointment only in December 1551, or as Gustav Kawerau claims, in January 1552. See, Kawerau, »Eine Episode aus dem Kampfe der Flacianer mit den Melanchthonianern, «Theologische Studien und Kritiken. Eine Zeitschrift für das gesamte Gebiet der Theologie 55/1 (Gotha: Friedrich Andreas Perthes, 1882): 324-343, here 341, n. 3. Major was fired by Duke Albrecht the following December because of the controversy surrounding the topic of good works.

116 Robert Kolb, »Georg Major as Controversialist: Polemics in the Late Reformation, « Church History 45/4 (1976): 455-468, here 459.

117 Major, Antwort: C1v-C2r: »Das bekene ich aber/das ich also vormals geleret/vnd noch lere/vnd foereder alle meine lebtag also leren will/Das gute werck zur seligkeit noetig sind/vnd sage oeffentlichen vnd mit klaren vnd deutlichen worten/das niemands duch boese werck selig werde/vnd das auch niemands one gute werck selig werde/vnd sage mehr/das 
The central issue in the ensuing debate, which became known as the »Majorist controversy, « was about the necessity of good works for salvation. In his desire to defend himself for his actions and to prove that he was teaching pure doctrine, Major assigned to the human will the possibility to apply itself to the grace of God. His emphasis was on the good deeds of a Christian. He believed that these must be done out of obedience to God and that they played a role in salvation.

Major's claims convinced Flacius that Major was departing from Luther's teaching, so the Illyrian wrote a response entitling it Wider den Evangelisten des heiligen Chorroks D. Geitz Maior (Against the Evangelist of the Holy Gown, Dr. Avaricious Major). Even though Flacius was not a preacher himself, he clearly saw how teaching that good works were necessary and that they in themselves were a cause of salvation would influence people listening to the sermons in the pews. He thundered:

If therefore good works are necessary to salvation, and if it is impossible for any one to be saved without them, then tell us, Dr. Major, how can a man be saved who all his life till his last breath has led a sinful life, but now, when about to die, desires to apprehend Christ, as is the case with many on their deathbed or hanging on the gallows? How will Major comfort such a poor sinner? ${ }^{118}$

Once again, note the crucial place that sin plays in this rebuke. As the controversy was heating up, Melanchthon distanced himself from Major's theology in 1552 and refused him permission to publish his sermon on the Conversion of St. Paul in Wittenberg. ${ }^{119}$ Nikolaus Gallus published a condemnation of Major's statement immediately after it was issued, ${ }^{120}$ while Justus Menius joined in defending Major's view first in $1554 .{ }^{121}$ It is interesting to notice

wer anders leret/auch ein Engel von Himel/der sey verflucht.« Quoted in Kolb, »Major as Controversialist, « 459 and Wengert, »Major: Defender of Wittenberg’s Faith,« 139.

118 Flacius, Wider den Euangelisten des heiligen Chorroks/D. Geitz Maior. Matth. Flac. Jlly. (»Basel« [Magdeburg: Michael Lotter], 1552; VD16 F 1558), C1r: »Sind nu die guten werck zur seligkeit noetig/vnnd ist nit moeglich das iemand ohn sie selig werde, so sage an D. Maior/wie will der selig werden/der all sein leben lang bis auff den letzten adem suendlich gelebt hat/vnnd nu so er ietzt sterben sol Christum gern ergreiffen wolt/wie vielen auff dem todbedt vnnd am Galgen geschieht? Wie will Maior nu solchen armen suender oder suenderin troesten?«

119 Wengert, »Major. Defender of Wittenberg’s Faith,« 140-141. See also Wengert's explanation for the theological differences between Melanchthon and Major.

120 Gallus, Auff des Herrn D. Maiors verantwortung vnd Declaration der Leiptzigischen Proposition/wie gute werck zur seligkeit noetig sind/zum zeugnis seiner vnschult/das er mit der Leiptzigischen handlung nichts zu thun habe. Antwort. Nicolai Galli [henceforth Gallus, Antwort] (»Basel« [Magdeburg: Michael Lotter], 1552; VD16 G 255).

121 Flacius was also involved in a theological debate with Menius. In 1554 they had a disputation in Eisenach at a time when Menius was still Superintendent in Gotha. Menius later published 
that in his closing argument against Major, Gallus cited his former teacher Melanchthon. ${ }^{122}$ Thus, the debate went on with more and more people embroiled in it. Reactions were published as far away as Transylvania, where a court preacher, Ferenc Dávid, and an Italian anti-Trinitarian, Giorgio Biandrata, jointly issued a refutation of Major's work. ${ }^{123}$ Their publication is relevant for the discussion in the present chapter because they stated that Flacius was correct in pointing out that Major's insistence on bona opera was misguided and was according to them the doctrine of the papists. ${ }^{124}$ Their support of Flacius' position is even more significant in light of the fact that Flacius had written a work against Biandrata, in which he branded him an Arian and a Mohamedan. ${ }^{125}$

A few years later Flacius tried to reconcile with Melanchthon over the adiaphoristic and Majoristic battles, but was apparently dumb-founded by Melanchthon's refusal. He wrote in a personal letter to Hubert Languet, a

two works against Flacius to which he replied with a work dedicated to the king of Denmark and Norway, Christian III in early 1558, namely Apologia M. Fl. Jllyrici/auff zwo vnchristliche Schrifften Justi Menij/Darinnen von den grewlichen Verfelschungen der Adiaphoristerey vnd Maioristerey allerley nuetzlichs angezeigt wird. Gebessert (Erfurt: Merten von Dolgen, 1558; VD16 F 1270). An overview of the controversy between Menius and Flacius is found in Gustav Lebrecht Schmidt, Justus Menius, Der Reformator Thüringens. Nach archivalichen und andern gleichzeitigen Quellen (Gotha: Friedrich Andreas Perthes, 1867), 2 vols. See Chapter »Streit mit Flacius, « found in the second volume, 255-286.

122 Gallus, Antwort, E3v.

123 Ferenc Dávid and Giorgio Biandrata, Refvtatio scripti Georgii Maioris, in qvo Devm Trinvm in Personis, et Vnvm in Essentia: Vnicum deinde eius Filium in persona, \& duplicem in naturis, ex lacunis Antichristi probate conatus est. Avthoribvs. Francisco Dauidis, Superintendente, et Georgio Blandrata, Doctore (Klausenburg (Kolozsvár): Kaspar Heltus, 1569; VD16 ZV 25355), F4v-F8r. This refutation by Dávid and Biandrata was a reply to a previous work published by Georg Major (Wittenberg: Hans Lufft, 1569). See also Major's Commonefactio...ad ecclesiam catholicam [VD16 M 2015]. The fact that Dávid and Biandrata responded so fast could be explained by the fact that a number of Hungarians were studying at the University in Wittenberg at that time, which made the exchange of information, letters and new books through individuals traveling between their homeland and Wittenberg possible. It is also probable that Dávid and Biandrata wrote their refutation of Major's theses in part out of concern for those students, so that they would not be affected by what they considered to be erroneous teaching.

124 For the discussion of this work, see Mihály Balázs, Ungarländische Antitrinitarier IV: Ferenc Dávid [Bibliotheca Dissidentium XXVI] (Baden-Baden/Bouxwiller: Valentin Koerner, 2008), 224-228.

125 Flacius, Refutatio Confessionis aut potius proprii baptismi abnegationis georgii Blanderatae Ariani per M. Matthiam Flacium Illyricum. Biandrata's anti-Trinitarian confession is definitely composed after 1567 when he was already in Transylvania since he quotes from Beza's work written about the death of Valentin Gentili, which points to a later date for the refutation by Flacius. I am grateful to Kęstutis Daugirdas for pointing this out to me. The texts by Biandrata and Flacius are reprinted by Heinrich Philipp Conrad Henke under the title Georgii Blandratae confession Antitrinitaria, eisqve confvtatio, avctore Matthia Flacio, e MS. primvm editae. It was published first in Helmstedt in 1794 and then again in Leipzig in 1802 . 
Huguenot diplomat and a lay-theologian: »What in the world are we trying to do, or in what does he [Melanchthon] resist us, if not in the condemnation of adiaphorism and of Majorism? $\ll^{126}$

\section{Indecision Concerning the Future: Flacius' Intermediary Stop in Köthen}

Sometime in November or early December 1551 Flacius and his family moved to Köthen in Anhalt for a period of time. Köthen was the hometown of Nikolaus Gallus, whose father was the mayor there, and through him Gallus arranged for the Flacius family to stay in the city as refugees. ${ }^{127}$ Flacius and Gallus had become friends in Wittenberg, where Gallus arrived in 1548, after he needed to leave his post as preacher in Regensburg because of his role in the opposition to the Augsburg Interim. ${ }^{128}$ Their bond of friendship lasted until Gallus' death in $1570 .{ }^{129}$

The reason for the move was Flacius' fear for his safety in Magdeburg after the siege had been lifted. Even though the contract between the city of Magdeburg and Maurice of Saxony about the surrender of the city explicitly stated that Flacius and Gallus could continue to live in Magdeburg, Flacius did not trust Maurice, whom he considered to be a Judas, a betrayer of the evangelical cause. ${ }^{130}$ Gallus evidently perceived things differently and remained in Magdeburg. One of the revealing things about Flacius' state of mind at this time could be found in his letter to the assistant pastor of

126 Flacius, »Letter to Hubert Languet, June 21, 1556.« The whole letter is reprinted in CR 8: 801-803, cited by Hans-Werner Gensichen in We Condemn: How Luther and $16^{\text {th }}$-Century Lutheranism Condemned False Doctrine, translated by Herbert J.A. Bouman (St. Louis: Concordia, 1967), 150.

127 For a biography of Gallus' early life, see Hartmut Voit, Nikolaus Gallus, Ein Beitrag zur Reformationsgeschichte der nachlutherische Zeit [Einzelarbeit zur Kirchengeschichte Bayerns 54] (Neustadt a.d. Aisch: Degener, 1977). A detailed biography of Gallus' second Regensburg period between September 1553 and July 1570, highlighting his relationship with Flacius while the latter lived in the same city, is yet to be written.

128 Nikolaus Gallus, Einer Christlichen Stad vnthertenigk antwort/auff das von Key. Ma. vberschickt Jnterim. Vnnd ein Radtschlag der Predicanten der selbigen Stadt (Magdeburg: Michael Lotter, 1548; VD16 C 2379). See the critical version of the text edited by Johannes Hund in Controversia et Confessio 1: 114-130.

129 Camerarius wrote about the beginning of their friendship soon after Gallus had arrived in Wittenberg. See, Camerarius, Das Leben Philipp Melanchthons, 206: »Mit ihm [Gallus] schloss Flacius in kürzester Zeit enge Freundschaft.«

130 See, Flacius, Erzählung der Verhandlungen und Streitigkeiten des Flacius Illyricus (Text in Twesten, Matthias Flacius Illyricus, eine Vorlesung, 77-78): »... Aufenthalt in Köthen, wohin ich mich vor dem feindlichen Hausen, der damals Magdeburg bezetzt hielt, geflüchtet hatte...« 
St. Catherine's Church in Hamburg, Conrad Gerlach. ${ }^{131}$ The letter was dated November 8, 1551, one day after the siege of Magdeburg was lifted and the day when Maurice's troops marched into town, and in it Flacius was asking Gerlach for his opinion on whether he should leave Magdeburg or stay. ${ }^{132}$ The dilemma whether "to stay or to leave« seemed to reflect the issue that had occupied Flacius already two years earlier. At that time he was wondering what the right ethical decision was: to leave the evangelical church or to continue to be a part of it. The subtitle of one of Flacius' pamphlets from 1549 that read »Which One Should It Be: To Leave the Church or Not?« is indicative of the internal struggle that he was facing. ${ }^{133}$

Flacius stayed in Köthen for approximately half a year. ${ }^{134}$ Not much is known about the details of his time there but what can be established is that in the evening of December 8, 1551 Flacius had a meeting with Theodore Fabricius, superintendent from Zerbst, in the city of Barby on the river Elbe. ${ }^{135}$ Previously during that week, Fabricius had held a discussion in Magdeburg with the theologians there in an attempt to reconcile the conflicting positions of Wittenberg and Magdeburg over adiaphora. ${ }^{136}$ Since Flacius was already in

131 »Gerlach, Konrad,« in MBW 12: Personen F-K, 138. Flacius most likely knew Gerlach personally from Braunschweig where both of them lived in 1546-1547. Gerlach was rector of the St. Catherine's School until 1548.

132 Sillem (ed.), Briefsammlung des hamburgischen Superintendenten Joachim Westphal, 1: 118-119.

133 Flacius, Eine entschueldigun(n)g Mathiae Flacij Jllirici/an einen Pfarher. Jtem desselben/was da sey die Kirchen verlassen/odder nicht verlassen. Durch M. Fla. Illy. Jtem zween Trewme Philippi. (Magdeburg: Christian Rödinger d.Ä., 1549: VD16 F 1370), B2r-B3r. The copy of the book, which is preserved at the National and University Library in Ljubljana, R 138986 (see Figure 6), bears in sixteenth-century handwriting the date »mense Julio« after 1549 on the title page and under the word »Pfarher« it is written »Iohannvm Pomer.« From these inscriptions it appears that the unknown owner of the book knew the exact date of publication and that the unnamed pastor to whom Flacius was issuing an apology was Johannes Bugenhagen. The Latin title reads, Quid sit Ecclesiam deferere aut non deferere per Math. Flacium Illyricum (Magdeburg: Michael Lotter, 1549).

134 In Erzehlunge der Handlungen, Flacius says: »...war ich etliche Monat gehn Ko(e)then im Anhaltischen Lande gewichen/..., U Ualv, while in Narratio actionum et certaminum Matth. Flacii Illyrici bona fide conscripta a Flacio ipso [1568] he is a little more precise by stating that he withdrew to Köthen for one semester: »... Goten ... ad semester exceseram, « in Schlüsselburg, Catalogi Haereticorum, vol. 13: 828.

135 In 1544 Flacius actually succeded Fabricius as a teacher of Hebrew at the University of Wittenberg as Fabricius vacated his post in order to become a superintendent in Zerbst upon Luther's recommendation. See, Friedensburg, »Die Anstellung des Flacius Illyricus an der Universität Wittenberg,« 302-308. For an overview of Fabricius’ career, see Franz Münnich, »Theodor Fabricius. Lebensbeschreibung des ersten anhaltischen Superintendenten. Unter Hinzufügung einer deutschen Übersetzung,« Zerbster Jahrbuch 16 (1931/32): 37-94; »Fabricius, Theodor, « in MBW 12: Personen F-K, 42-43.

136 For the details of that meeting, where Gallus acted as a spokesperson for the Magdeburgers, see Gustav Kawerau, »Eine Episode aus dem Kampfe der Flacianer mit den Melanchthonianern, «324-343. On pages 336-337 Kawerau quotes a letter from Flacius to the Magdeburg clergy dated on December 15, 1551 in Köthen. He also mentions the letter from Gallus to 


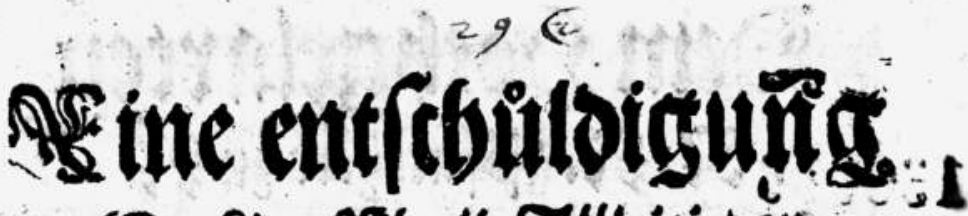

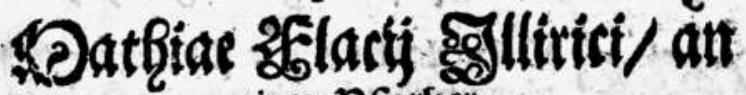 einen $\mathcal{P}$ farber. ban- \\ poms:}

Jtemisefselben/was ba fey sie suírchent vers laffen osoer nicbt verlaffen. aist<smiles>C#CC1C#CC1</smiles>

Jtein jwoen orreomeme philippi.

1. Corinth. 1.

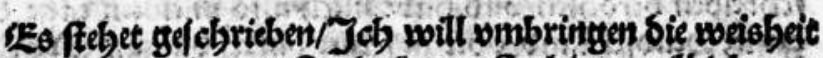

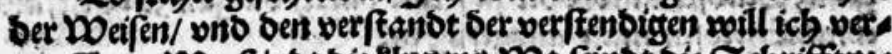

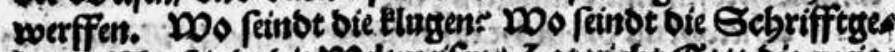

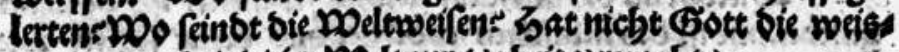
beit biefer Doelt 3ur torbeit geminebte.

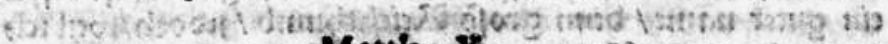

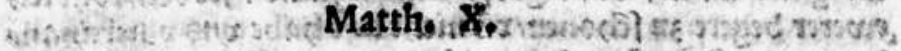

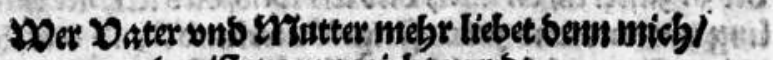

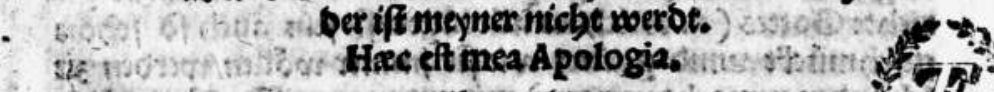

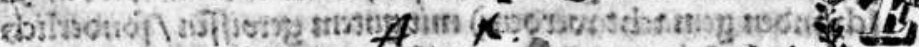

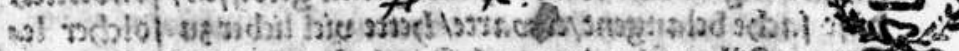

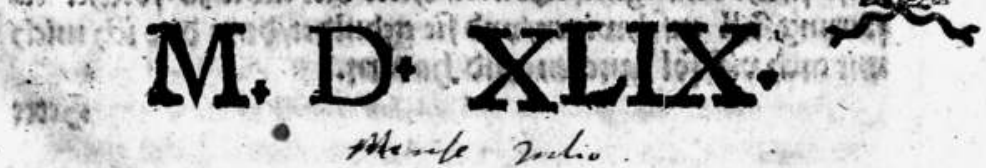

Figure 6: The title page of Flacius' Entschueldigung ... an einen Pfarher from 1549 with added information in sixteenth-century handwriting, Courtesy of the National and University Library, Ljubljana: shelfmark R138986. 
Köthen, Fabricius invited Flacius for a consultation in Barby, approximately half-way between Magdeburg and Köthen, because the Magdeburgians did not want to proceed without Flacius being involved in this process of negotiations. This episode illustrates how important Flacius and his opinions were for pastors and theologians in Magdeburg.

While the soteriological polemics about the relationship between faith and works with Major were still going on, Flacius also became involved in another theological quarrel, concerning the doctrine of justification by faith. It was against a man he knew, namely the former Nuremberg reformer, Andreas Osiander. ${ }^{137}$ Flacius wrote his first confutation of Osiander from Köthen and dated the ten-page-long dedicatory letter to Albrecht of Brandenburg-Ansbach, Duke of Prussia on March 1, 1552. ${ }^{138}$ The work came out in print that same month under the title Refutation of the Confession of Osiander on the Justification of the Poor Sinners through the Essential Righteousness of the High Majesty of God Alone. ${ }^{139}$

\section{The Controversy with Andreas Osiander: The Nature of Divine Justification}

In April 1549, Osiander delivered his inaugural disputation as chair of theology at the newly founded University of Königsberg. Osiander had moved to the northern town from Nuremberg soon after the Augsburg Interim took effect in the southern German territories. He left Nuremberg because of his opposition to the Augsburg Interim and was offered this position by Duke Albrecht. ${ }^{140}$ His views concerning justification and grace, which he expanded

Flacius, dated on the same day, just traveling in the opposite direction, where Gallus is informing Flacius about the negotiations with Fabricius.

137 Flacius referred to him as a friend prior to their public disagreement. See, Erzehlunge der Handlungen, Ualv: »...mit Osiandro/der dazumal mein Freund war...«

138 This was not the first work by Flacius dedicated to Duke Albrecht. Already in 1550 Flacius dedicated to him his book Omnia Latina scripta Matthiae Flacii Illyrici, hactenus sparsim contra Adiaphoricas fraudes \& errores aedita, \& qucedam prius non excusa catalogum uersa pagina indicabit (Magdeburg: Michael Lotter, 1550; VD16 F 1296).

139 Flacius and Gallus, Verlegung des Bekentnis Osiandri von der Rechtfertigung der armen sunder durch die wesentliche Gerechtigkeit der Hohen Maiestet Gottes allein. Durch Matth. Fla. Jllyr. Mit vnterschreibung Nicolai Gallj/darin der grund des jrthums Osiandri sampt seiner verlegung auffs kuertzest verfast ist (Magdeburg: Christian Rödinger d.Ä., 1552; VD16 F 1514), A2r-B2v.

140 Duke Albrecht was actually the Margrave of Brandenburg by birth. He founded the University of Königsberg in 1544. For his involvement in the Osiandrian controversy, see Jörg Rainer Fligge, Herzog Albrecht von Preussen und der Osiandrismus, 1522-1568 (Bonn: Friedrich Wilhelm University, 1972). 
at his second disputation in October 1550, unleashed a lengthy controversy and were eventually condemned by Lutheran and Calvinist theologians alike. $^{141}$

Apparently Osiander had long disagreed with Luther's concept of forensic justification, according to which the sinner is pronounced righteous by a just God, but his position had never appeared in print before. It was only when he was given a professorship in theology that he mustered the courage to announce his views publicly. It is believed that he even said, »The lion is dead, now I have to do only with foxes and hares. ${ }^{142}$ However, he seems to have misjudged the strength of his opponents. Osiander originally thought that Gnesio-Lutherans and particularly Flacius would come over to his side because they were also resisting the Interim and the Wittenberg theologians, but his expectations were miscalculated. ${ }^{143}$

During this period of time Flacius was receiving job offers from political rulers for positions in academia and in ecclesiastical hierarchy. Duke Albrecht had invited Flacius to come to Ducal Prussia and made him an offer to become Bishop of Samland. ${ }^{144}$ Flacius chose not to move and instead decided to issue his refutation of Osiander's theology in print. ${ }^{145}$ Around the same time the Illyrian turned down another invitation, this one from the Duke of Mecklenburg, Johann Albrecht I, ${ }^{146}$ who had asked him to become

141 For an overview of the Osiandrian controversy, see Bernhard Lohse, »Dogma und Bekenntnis in der Reformation: Von Luther bis zum Konkordienbuch, in Carl Andresen (ed.), Handbuch der Dogmen- und Theologiegeschichte (Göttingen: Vandenhoeck \& Ruprecht, 1980): 2: 125-129; Gottfried Seebass, »Andreas Osiander d.Ä. und der Osiandrische Streit: Ein Stück preußischer Landes- und reformatorischer Theologiegeschichte, « in Dietrich Rauschning and Donata von Nerée (eds.), Die Albertus-Universität zu Königsberg und ihre Professoren: Aus Anlaß der Gründung der Albertus-Universität vor 450 Jahren, Jahrbuch der Albertus-Universität zu Königsberg 29 (Berlin: Duncker \& Humbolt, 1995), 33-48.

142 »Der Löwe ist tot, jetzt habe ich nur noch mit Füchsen und Hasen zu tun. « Cited in Götz von Selle, Geschichte der Albertus-Universität zu Königsberg in Preussen (Königsberg: Kanter, 1944), 36.

143 Thomas Kaufmann, »Theologische Auseinandersetzungen an der Universität Königsberg im 16. und 17. Jahrhundert, « in Klaus Gerber, Manfred Komorowski and Axel E. Walter (eds.) Kulturgeschichte Ostpreußens in der Frühen Neuzeit [Studien und Dokumente zur deutschen Literatur und Kultur im europäischen Kontext; Frühe Neuzeit 56] (Tübingen: Max Niemeyer, 2001), 243-318, here 299.

144 Preger, Flacius und seine Zeit, 1: 217. About the attempts of Duke Albrecht to win Flacius over, see Martin Stupperich, »Die Werbung Herzog Albrechts um Matthias Flacius Illyricus, « in Osiander in Preussen 1549 - 1552 [Arbeiten zur Kirchengeschichte 44] (Berlin: Walter de Gruyter, 1973), 276-281.

145 Flacius saw Albrecht's offer as something of a bribe.

146 Flacius later attended the wedding of Johann Albrecht I with Anna Sophia of Prussia, daughter of Duke Albrecht on February 24, 1555 in Wismar. The main reason for Flacius' travel on foot from Magdeburg north was not to enjoy the marriage festivities but instead to discuss the Osiandrian problem. Flacius and Albrecht also exchanged correspondence regarding the continuing theological conflicts between the supporters of Osiander on the one side and those who opposed his teachings on the other. Flacius even published one letter from Johann 
a professor of Hebrew at the University of Rostock. ${ }^{147}$ Even though these prospective appointments and the security that they represented must have been appealing to Flacius and his ever-growing family and reflected the recognition of his skills and leadership abilities, he still declined them both. This choice, similar to the one he made to leave Wittenberg, was indicative of a pattern already emerging in Flacius' decision-making process. Believing that his own theological convictions were correct, he made every effort to express them to as wide an audience as possible, even if it meant remaining without steady employment, gaining more enemies, and leading his family into insecurity. His choice may have been additionally influenced by his reluctance to move from the center to the periphery, where he would have been far removed from the decision-makers and those he wanted to impact with his theology.

Just as before, Flacius returned to employing the words of Luther and in 1552, he edited the booklet titled Comforting Counter-Statements of the Reverend Doctor Martin Luther and Matthias Flacius Illyricus against the Statements of the Raven, Osiander, which also contained quotes from his other refutations of Osiander. ${ }^{148}$

Osiander was claiming that justification comes to human beings by God's indwelling or infusion - instead of imputation. He wrote:

Since we are in Christ through faith and he is in us, we also became the righteousness of God in him, just as he became sin for us [2 Cor. 5:21]. That is, he showered us and filled us with his divine righteousness, as we showered him with our sins, so

Albrecht to him, dated on April 1, 1556 in Schwerin [VD16 M 1820; see also VD16 M 1821 for the German version]. See also, Otto Krabbe, David Chyträus (Rostock: Adler's Erben, 1870), 68-74.

147 Melanchthon, in his letter dated in Wittenberg on March 12, 1553 to Aurifaber [Vratislaviensis] who had been pastor at St. Nicholas' Church and professor in Rostock since 1550, asked if the Duke had decided to employ Andreas Wesling as a professor of Hebrew since Flacius had not accepted the position. MBW 6761 (Regesten 7: 43-44). Wessling did indeed get the job in July 1553. For more about him, see Paul Bahlmann, »Wesling, Andreas, « in ADB 42 (1897), 139.

148 Flacius, Troestliche Gegenspruech des Ernwirdigen Herren Doctoris Martini Lutheri/vnd Matthie Jllyrici/wider des Rabe Osiandri Primarij spruch (Wittenberg: Hans Lufft, 1552; VD16 L 3477). The booklet also contains one quote from Nikolaus von Amsdorf, B1r. This work was also published in Magdeburg by Christian Rödinger d.̈̈. in the same year [VD16 L 3476]. Even though Flacius' name does not appear as the author on the title page, it is almost certain that Flacius himself stood behind it as the editor. See also, Thomas Kaufmann, "')Wie die Bücher und Schrifften ... Lutheri nützlich zu lesen.< Joachim Mörlins Anweisung zum Lutherstudium von 1565 und ihr historischer Kontext, « in Notger Slenczka and Walter Sparn (eds.), Luthers Erben: Studien zur Rezeptionsgeschichte der reformatorischen Theologie Luthers [Festschrift für Jörg Baur zum 75. Geburtstag] (Tübingen: Mohr Siebeck, 2005), 25-72, here 48, footnote 85: »Flacius selbst war Osianders Inanspruchnahme Luthers mit einer Sammlung von Lutherzitaten, die er allerdings um eigene >Sprüche` erweitert hatte, entgegengetreten.« 
that God himself and all the angels see only righteousness in us on account of the highest, eternal, and infinite righteousness of Christ, which is His Godhead itself dwelling in us. ${ }^{149}$

\section{Osiander went on to state,}

By the fulfilment of the law and by his suffering and death, Christ merited and acquired from God, his heavenly Father, this great and exalted grace: he has not only forgiven our sin and taken the unbearable burden of the law away from us, but also wishes to justify us through faith in Christ, to infuse justification or righteousness, and, through the working of His Holy Spirit and the death of Christ into which we are incorporated by Baptism, to kill, wipe out, and entirely exterminate sin that, though already forgiven, still dwells in our flesh and clings to us. ${ }^{150}$

It was this teaching that Flacius attacked in his first publication of the controversy, namely that justification comes to human beings essentially by God's indwelling or transfusion instead of forensic imputation. ${ }^{151}$ It was obvious to Flacius that Osiander had misunderstood what righteousness meant according to Luther, so immediately on the first page under the title True and Foundational Description of the Righteousness of Faith (Ware/Grundliche beschreibung der Gerechtigkeit des Glaubens) he offered his definition of the term:

Our righteousness ... is the fulfillment of God's law, which not we, but Christ, true God and true man, accomplished surpassingly and overwhelmingly through his absolute obedience, both by doing that which the law required of us to do, and suffering that which we because of our sins should have suffered, all of this [what Christ did] is given and imputed [accredited] to us by God through faith. ${ }^{152}$

149 Andreas Osiander, Von dem Einigen Mjtler Jhesu Christo vnd Rechtfertigung des Glaubens. Bekantnus Andreas Osiander (Königsberg: Hans Lufft, September 8, 1551; VD16 O 1220), $\mathrm{X} 4 \mathrm{~b}$. The critical edition of the text is in Gerhard Müller and Gottfried Seebass (eds.), Andreas Osiander d. A. Gesamtausgabe 10. Schriften und Briefe September 1551 bis Oktober 1552 sowie Posthumes und Nachträge (Gütersloh: Gütersloher Verlagshaus, 1997), 78-300, here 268-269. English translation taken from Eric Lund (ed.), Documents from the History of Lutheranism 1517-1750 (Minneapolis: Fortress, 2002), 206.

150 Ibid., 206.

151 For more on how Flacius employed and further developed the imputation theory that he learned from Melanchthon in his doctrine of justification as a response to Osiander and to the Roman Catholic decree on justification from the Council of Trent, see Friederike Nüssel, »Die Rechtfertigungslehre als Imputationstheorie bei Matthias Flacius Illyricus, « in Allein aus Glauben: zur Entwicklung der Rechtfertigungslehre in der konkordistischen und frühen nachkonkordistischen Theologie [Forschungen zur systematischen und ökumenischen Theologie 95] (Göttingen: Vandenhoeck \& Ruprecht, 2000), 71-111.

152 Flacius, Verlegung des Bekentnis Osiandri, Alv: „Vnsere Gerechtigkeit ... ist die 
In the same way Flacius had tried to discredit the theologians who accepted the Interim, by considering them to be just like the Papists, so he also likened Osiander to the Roman Catholics in his criticism. He equated their positions concerning justification: »... they both say that through the infused love that God is in himself, we become justified, and as far as we become justified through faith, so far faith takes form through such love. That is, the word iustificare (to justify) for both Osiander and the Papists means to make one just, « and warned, »they both say that we completely and thoroughly become righteous and they minimize the [importance of] original sin, which still remains in us. $\ll^{153}$

Not only did Flacius draw parallels between the positions held by Osiander and the Catholics but what is even more important for our purposes is that Flacius accused both of not understanding original sin correctly. This was an example of an emerging pattern: Flacius would accuse his opponents with increasing frequency that they did not understand or interpret original, inherited sin properly since this particular topic was coming to dominate his theology more and more. Clearly, since justification of human beings by God was an act in which God was neither counting nor charging us for our sins but instead imputing to us the righteousness of Christ, Flacius saw this doctrine as very important exactly because of the exchange taking place, i.e. sins for perfect righteousness.

In spite of their differences, Melanchthon must have been impressed by what Flacius had written because already on April 6, 1552 he sent Flacius' Verlegung des Bekentnis Osiandri to Friedrich Pistorius in Nuremberg, together with another work against Osiander written by a superintendent in Weißenfels, Johannes Pollicarius. ${ }^{154}$ Less than two months later Melanchthon, in a letter to Johannes Brenz about Osiander, praised Flacius for the way he expressed his views on justification, ${ }^{155}$ which shows that Melanchthon was

ERFVLLUNG des Gesetzes Gottes, welche nicht wir, sondern Christus warer Gott vnd mensch, durch seinen allervolkomensten gehorsam gantz vberschwencklich vnd vberreichlich geleistet hat, beide mit THVN des ienigen, so das Gesetz von vns zuthun hat erfordert, vnd mit LEIDEN des, das wir von wegen vnser Suenden hetten leiden sollen, Vns aber durch den glauben von Gott geschenckt vnd zugerechnet wird...« Also cited in Andreas Osiander d. Ä. Gesamtausgabe 10, 750 .

153 Ibid., N3r: »Denn sie sagen beyde/das wir durch die eingegossene liebe/die da Gott selbs ist/gerecht sein/vnd so fern durch den glauben Gerechtfertigt werden/so fern der glaub durch solche liebe eine gestalt bekompt. Denn das wort iustificare rechtfertigen bedeutet beiden dem Osiandro vnd Papisten mit der that gerecht machen/Sie sagen beyde das wir gantz vnd gar vnd mit der that gerecht werden/vnd verkleinen die Erbsuende/die noch vbrig bleibet."

154 See Melanchthon's letter to Hieronymus Besold from Wittenberg, dated 6 April 1552, CR 7: 976, Nr. 5088; MBW 6403 (Regesten 6: 289).

155 See the description of Melanchthon's unpublished letter to Johannes Brenz from Wittenberg dated, June 3, 1552 in MBW 6464 (Regesten 6: 312): »Während M[elanchthon], >um Christi 
still closely reading what Flacius was saying, so that Flacius and Melanchthon had become »improbable allies « $^{156}$ in the cause against Osiander.

It is difficult to establish the exact date when Flacius left Köthen and returned to Magdeburg. The textual evidence from Melanchthon's correspondence calls into question the claim made by Oliver Olson, who, without mentioning his source of information, writes that $\gg I n$ 1551, he [Melanchthon] succeeded in persuading the dukes to expel Flacius from his refuge in Cothen [sic!]. $\ll^{157}$ Mirković states that Flacius went back to Magdeburg in the spring of $1552 .^{158}$

In a publication from September 1552, Flacius expanded his argument and further defined what he meant by passive and active obedience. ${ }^{159}$ During the following years Flacius wrote a series of works against Osiander and his followers in Prussia, with an opus consisting of at least thirty publications in both German and Latin, together with the forewords and prefaces he wrote for other authors. ${ }^{160}$ In his criticism of Osiander, Flacius joined Johannes

willen angenehm sein sagt, legt Flacius Wert auf die Formulierung, daß uns Christi Gerechtigkeit zugerechnet wird, was auch M. nicht ablehnt.« I am grateful to Timothy J. Wengert, for bringing this letter to my attention.

156 Lewis W. Spitz, review of Martin Stupperich's book, Osiander in Preusen, 1549-1552 in Church History 43/3 (September 1974): 403-404, here 404. Another example of Flacius and Melanchthon as »improbable allies« is when both of them wrote a recommendation letter to the Count Bernhard of Lippe VIII on behalf of Hermann Hamelmann, who published them together. See, Sententiae Omnivm Fere Patrvm, tam recentiorum, quam antiquiorum, de primarijs Augustanae Confessionis articulis, in primis uero de sola fide iustificante. Autore \& collectore Hermanno Hamelmanno. Cum Praefatione Philippi Melanthonis, \& Matthiae Flacij Illyrici (Marburg: Andreas Kolb, August 1, 1557), A3r-A6v. See also MBW 7940 (Regesten 7: 476).

157 Olson, Flacius and the Survival of Luther's Reform, 194. A little bit later in the book Olson states: "sometime about March 10, having been expelled from Cöthen [sic!] by the prince of Anhalt at Melanchthon's urging, Flacius returned to Magdeburg...« 219.

158 Mirković, Matija Vlačić Ilirik, 118. As of March 20, 1552 Flacius was still in Köthen since on that day he wrote a letter to Duke Albrecht of Prussia. A copy of the letter is stored in Berlin, Geheimes Staatsarchiv, Preußischer Kulturbesitz, Konzepte A4 228, 1r-4v.

159 Flacius, Von der Gerechtigkeit wider Osiandrum/nuetzlich zu lesen. Durch Matth. Flacium Illyr. (Magdeburg: Christian Rödinger d.Ä., 1552; VD16 F 1538). The last page of the publication states the date of September 24, 1552, F1v.

160 According to Jörg Fligge there were at least twenty-four publications. See Fligge, Herzog Albrecht von Preussen und der Osiandrismus, 138. However, the same author then lists twenty-six publications by Flacius in his bibliography, 886-894. In addition to Fligge's list of works, which is the most comprehensive one up to date, I have indentified several more: Troestliche Gegenspruech des Ernwirdigen Herren Doctoris Martini Lutheri/vnd Matthie Jlyrici/wider des Rabe Osiandri Primarij spruch (Magdeburg: Christian Rödinger d.Ä., 1552; VD16 L 3476). There is also an identical publication issued in the same year but by Hans Lufft in Wittenberg (VD16 L 3477); Brenz, Gallus and Flacius, Bekentnis Brentij vnd andern Wirtebergischen Theologen von der Rechtfertigung. Mit einer Vorreden M. Illyr. vnd Nic. Galli an die Preusische Kirchen (Magdeburg: Christian Rödinger d.Ä., 1553; VD16 B 7589); Widder drei Gottislesterische vnnd Sophistische Argumenta des Funckens/welche er newlich in Preussen widder das tewre blut Christi vnter die Leute gestrewet hat. Matth. 
Aepinus, Erasmus Alber, von Amsdorf, Gallus, Melanchthon, Joachim Mörlin, and his younger brother, Maximilian Mörlin, David Chytraeus, Andreas Musculus, Anton Otto, Erhard Schnepf, Johannes Pollicarius, Wolfgang Waldner, Michael Roting, Bernhard Ziegler and several other authors against him. ${ }^{161}$ Even John Calvin opposed Osiander.

The agreement of most of the Lutherans on the doctrine of justification by faith was remarkable, since a broad theological consensus was rarely reached in the polemics of the sixteenth century. According to Seebass, apart from some theologians in Prussia and Swabia, the latter including Jakob Andreae and Brenz, almost no one else sided with Osiander's position. ${ }^{162}$ On the other hand, Wengert shows that Brenz and following him, Andreae did not so much side with Osiander's doctrinal position as with his person and tried to reinterpret his message in a Wittenberg-Magdeburg acceptable manner, pointing to a more nuanced response from the Württemberg theologians. ${ }^{163}$ Therefore, a recent assertion from Olli-Pekka Vainio does not reflect the historical reality:

Fl. Jllyr. (Magdeburg: Michael Lotter, 1555; VD16 ZV 5897); Joachim Mörlin and Flacius, Antwort auff das Buch des Osiandrischen schwermers in Preussen/M. Vogels/darinnen er sein beduncken anzeiget von der fürgefallenen zwispalt/vnd meinen Brieff an jn. Joachimus Moerlin D. Jtem Matth. Fl. Jllyrici von dem Gebet einer Osiandrischen Person/vber den lxxj. Psalm (Magdeburg: Ambrosius Kirchner d.Ä., 1557; VD16 ZV 11072).

161 See the chapter by Timothy J. Wengert, »True Lutherans, All: Joachim Mörlin, Matthias Flacius and Nicholas Gallus against the 〉Prussian Gods «« in Defending Faith: Lutheran Responses to Andreas Osiander's Doctrine of Justification, 1551-1559 [Spätmittelalter, Humanismus, Reformation 65] (Tübingen: Mohr Siebeck, 2012), 101-190. It needs to be mentioned that not only evangelical theologians issued refutations against Osiander. Some Roman Catholics also wrote against him, like bishop of Ermland, Stanislaus Hosius. Staphylus' 1553 publication against Osiander Synodus Sanctorum Patrum Antiquorum contra nova dogmata Andreae Osiandri (Nuremberg: Paul Fabricius, September 1553; VD16 S 8594) can also be counted among Roman Catholic ones since it was issued at the time that he converted from Protestant faith to Catholic. For more about his conversion and life, see Ute Mennecke-Haustein, Conversio ad Ecclesiam. Der Weg des Friedrich Staphylus zurück zur vortridentinischen Katholischen Kirche [Quellen und Forschungen zur Reformationsgeschichte 74] (Gütersloh: Gütersloher Verlagshaus, 2003). Stahpylus also wrote a lengthy attack against Flacius. See Defensio Pro Trimembri Theologia M. Lutheri, Contra Aedificatores Babylonicae Turris: Phil. Melanthonem, Shwenckfeldianum, Longinum, And. Musculum, Mat. Flacc. Illyricum, Iacobum Andream Shmidelinum. Authore Friderico Staphylo (Dillingen: Sebald Mayer, 1559 [dated May 1, 1559 in Augsburg]; VD16 S 8581), Q3r-E3r.

162 See Gottfried Seebass, »Johannes Brenz und Andreas Osiander, Blätter für württembergische Kirchengeschichte 100 (2000): 162-185. Fligge lists Jakob Andreae and Duke Christoph of Württemberg under »neutral« but lists Johannes Brenz as an »Osiander friendly author« (Osianderfreundliche Autor), 864. Lucas Osiander the Older, another important theologian from Swabia, is listed by Fligge under Osiandrists, 994. This shows how Osiander's teachings were carried on by his son, Lucas, who was also a son-in-law of Jakob Andreae.

163 Wengert, Defending Faith, 208-220, shows that both Melanchthon and Flacius approved of Brenz and Württemberg's theologians confession of faith regarding Osiander's doctrine of justification. 
»Despite the apparent weaknesses in Osiander's thought, particularly on the issue of the nature of faith, his position was more congruent with Luther than that of Flacius. $\ll^{164}$ Certainly none of the opponents of Osiander would have agreed.

\section{The Debate between Schwenckfeld and Flacius: The Question of Scriptural Interpretation}

According to Flacius' own account, he got involved in a written debate with Caspar Schwenckfeld von Ossig at the request of preachers and laypersons in Silesia and Swabia in 1553, who were worried about the growing number of followers Schwenckfeld was attracting ${ }^{165}$ Even though Flacius does not name the people who wrote to him, the editors of Schwenckfeld's collected works believe that among them were Aegidius Faber, ${ }^{166}$ the former court preacher to Duke Friedrich II of Brieg and Liegnitz, and Hieronymus Wittich from Breslau ${ }^{167}$ superintendent in Brieg, with additional support from a nobleman Sebastian von Zedlitz, ${ }^{168}$ on the Silesian side; and Brenz, Andreae, Martin Frecht and preachers from Augsburg on the Swabian side. ${ }^{169}$ The fact that

164 Olli-Pekka Vainio, Justification and Participation in Christ: The Development of the Lutheran Doctrine of Justification from Luther to the Formula of Concord (1580) [Studies in Medieval and Reformation Traditions 130] (Leiden/Boston: Brill, 2008), 117.

165 Flacius, Erzehlunge der Handlungen, Aa3r: »Anno 1553. haben etliche Schlesische Prediger/ vnd andere frome Christen/dergleichen auch etliche aus Schwabenland begeret/ich wolte etwas wider Schwenckfeld schreiben/denn sein Jrrthumb von Goettlichs Worts vnd Sacramenten neme allenthalben vberhand/welchs ich auch/in Ansehen der hochwichtigkeit der Sachen/nicht hab vnterlassen koennen. Dieser Streitt hat auch etliche Jar geweret/denn er auch widerumb viel wider mich geschrieben hat.«

166 For an overview of his career, see »Faber, Ägidius, « in MBW 12: Personen $F-K, 33$.

167 Flacius published Wittich's work against the Schwenckfeldian Johann Sigismund Werner posthumously. See, Kurtze vnnd gruendtliche widderlegung der vier Schlusreden die Johan Sigmund/Werner/etwa Pfarherr zu Lignitz aus Schwenckfeldts Buechern gezogen/gestalt/vnd gericht hat wider die Christliche lehre vom dienst des Goettlichen worts vnd der hochwirdigen Sacrament Jesu Christi des Sons Gottes. durch Hieronymum Wittich. Jtem eine kurtze schrifft Matth. Flacij Illyrici (Magdeburg, July 1, 1555; VD16 W 3789). In the book there are three dedications to the Duke Georg II. First by Sebastian von Zedlitz dated in Neukirch an der Katzbach on March 25, 1555, then by Wittich, dated in Brieg on Nov. 25, 1553 and lastly at the end of the book undated one by Flacius, J2v-K3r. For more about this work, see CS 13: 965; Rudolf Keller, Der Schlüssel zur Schrift: Die Lehre vom Wort Gottes bei Matthias Flacius Illyricus [Arbeiten zur Geschichte und Theologie des Luthertums, Neue Folge 5] (Hannover: Lutherisches Verlagshaus, 1984), 69-70.

168 Sebastian von Zedlitz was a student in Wittenberg at the same time as Flacius and later also took classes as Flacius' student. He matriculated on September 26, 1540 in Wittenberg as »Sebastianus Zedlitz a Newnkirch [Neukirch an der Katzbach; Nowy Kościół nad Kaczawa in present-day Poland] Silesius.«

169 See, CS 13: 362-363. 
he was invited to respond underscores the growing recognition among Protestants from different geographical areas of Flacius' polemical abilities and theological skills.

Schwenckfeld had earlier criticized the Augsburg Confession on the issues of infant baptism and free will as well as Luther's commentary on Genesis, earning Luther's contempt. What concerned many theologians, however, was the publication sometime in the summer of 1551 of his On the Holy Scriptures..$^{170}$ According to a twentieth-century Schwenckfeld biographer and editor of his works, Schwenckfeld contended there »that the inner word of the spirit must be differentiated from the external word spoken by the preacher; that the living Word of God is not the Scriptures, but Christ and that the Scriptures must be interpreted spiritually« ${ }^{171}$

It did not take much convincing by others for Flacius to write a refutation of Schwenckfeld's theology. After Flacius had read Schwenckfeld's works he completely disagreed with the spiritualistic approach to the Bible and even made a comment: »Spiritual exegesis fits scripture like a fist fits into an eye. $\ll^{172} \mathrm{He}$ got to work immediately and published On the Holy Scripture and its Effect sometime in the first half of 1553 (it was already in Schwenckfeld's hands in the beginning of August).$^{173}$ Nikolaus Gallus, at that time Lutheran Superintendent of Regensburg, provided a preface and conclusion. ${ }^{174}$ This work appeared in three editions: two in Magdeburg and one in Strasbourg in 1554, where the preachers of that city published it in order to combat the growing threat from radical followers of Schwenckfeld and added their marginalia to Flacius' text, in which they defamed Schwenckfeld..$^{175}$ Over

170 Schwenckfeld, Von der hailigen Schrifft/jrem Jnnhalt/Ampt/rechtem Nutz/Brauch vnd miszbrauch. Jtem/Vom vnderschaide der diener vnd prediger der hailigen Schrifft/vnd des worts Gottes. Was auch recht aigentlich Gottes wort sei (Hagenau: Sigmund Bund, 1551; VD16 S 5052).

171 Selina Gerhard Schultz, Caspar Schwenckfeld von Ossig (1484-1561) (Pennsburg: The Board of Publication of the Schwenkfelder Church, 1977 [4 $4^{\text {th }}$ edition]), 330.

172 Olson, Flacius and the Survival of Luther's Reform, 302.

173 CS 13 [Letter to Hans Weichßner in Nuremberg. Beginning of August 1553]: 217-218.

174 Flacius, Von der h. Schrifft vnd jrer wirckung/widder Caspar Schwenckfeld/Durch Matthiam Flacium Jllyricum. Mit einer vermanung Nicolai Galli das ampt Gottlichs worts in ehren zuhaben (Magdeburg: Michael Lotter, 1553; VD16 F 1540 and 1554; VD16 F 1541). In CS 13: 397-448.

175 Flacius, Von der h. Schrifft... (Strasbourg: Samuel Emmel, 1554; VD16 F 1554). The same publisher also issued Flacius' second pamphlet against Schwenckfeld, Von dem fürnembsten stücke/punct/oder artickel der Schwenckfeldischen schwermerey. Durch Matthiam Flacium Jllyricum (Strasbourg: Samuel Emmel, 1554; VD16 F 1529). In May 1557 Flacius dedicated another work he wrote against Schwenckfeld to the city council of Strasbourg, which points out that Schwenckfeldian ideas were still being circulated in that free imperial city. See, Gruendliche verlegung aller schedlichen Schwermereyen des Stenckfelds/zur vnterricht vnd warnung der einfeltigen Christen. Geschrieben durch Matthiam Flacium Illyricum, M. D. LVII. (Nuremberg: Johann vom Berg und Ulrich Neuber, 1557; VD16 F 1409). 
the course of the following years Flacius wrote many books against the Silesian nobleman. Topics of the written polemical exchange between them included the role of the Bible and the preached word; Law and Gospel; sin and the nature of forgiveness; and the person of Christ. Flacius rejected »not only [Schwenckfeld's] subversive hermeneutics but also his anthropology and his epistemology. ${ }^{176}$ The exchange between Flacius and Schwenckfeld lasted from 1553 until Schwenckfeld's death in 1561. Flacius even published one work against Schwenckfeld's followers, nicknamed Schwenckfeldians, in $1564 .{ }^{177}$

The early strategy used by Schwenckfeld in attempting to refute Flacius and Gallus was to spread further the negative opinions expressed publicly by some evangelical professors in Wittenberg and Leipzig in order to discredit the two theologians. Part of his propaganda was republishing excerpts from Major and Pfeffinger's sermons and writings, in which they said things such as: »Illyricus and his associates are all possessed by the devil« and »they are bitter and poisonous liars and claim that good works are not necessary for salvation. $\ll^{178}$

In essence, Flacius' criticism of Schwenckfeld concerned the Silesian's statement that the Bible is not clear, that one cannot use historical and literary approaches in order to understand the Scriptures, but that instead the word of God comes to one inwardly and mystically. Schwenckfeld argued that the Ten Commandments cannot be God's word because they were written on a stone or that the words »This is my beloved Son, « in Matthew's Gospel are not God's. Flacius replied that »the word is God's whether it is on stone, tablets, paper, parchment, or the human memory, registered, composed, written, or spoken by the human voice. «179

Schwenckfeld made a differentiation between written word and internal word, the first having been written by human beings, the second by God

176 Claire Gantet, »Dreams, Standards of Knowledge and >Orthodoxy< in Germany in the Sixteenth Century, « in Randolph C. Head and Daniel Christensen (eds.), Orthodoxies and Heterodoxies in Early Modern German Culture: Order and Creativity 1500-1750 [Studies in Central European Histories 42] (Leiden/Boston: Brill, 2007), 69-87, here 82.

177 Flacius, Widerlegung vier Predigten eines Sacramentirers/mit zunamen Oleuianus. Jtem/Beweisung/Das auch die vnwirdigen den Leib vnd Blut Jesu Christi im Abendmal empfahen/Wider ein Schwenckfeldisch Buechlein/so newlich ohne Namen durch den Druck ausgestrewet worden (Oberursel: Nikolaus Henricus d.Ä., 1564; VD16 F 1398).

178 Schwenckfeld, Der Wittenbergischen vnd Leiptzischen Theologen Judicium vnd zeügknus von dem frommen manne Jllyricus vnnd seinem gesellen N. Gallus. Mit auffdeckung ettlicher jhrer jrrthumb/Vnd widerlegung des buechlins wider Chaspar Schwenckfelden geschrieben. (Ulm: Hans Varnier, December 1553; VD16 S 5069), A2r: »Illyricum... vnd seine gesellen alle vom teufel besessen ... da sie sagen: Das die gueten werck nit von noeten sein zuer seligkait.«

179 Flacius, Von der h. Schrifft, C2r: »...Gottes wort sein wort bleibet/es sey gleich in steinerne Tafel/Papir/Pergament/oder menschliche gedechtnis verzeichnet/verfasset oder geschrieben/oder durch menschliche stim ausgesprochen...« in CS 13: 396. 
himself inside of our hearts. Because of this, the preached word of God has less value and no saving power. A church ceremony like the Lord's Supper, which by this time Schwenckfeld refused to receive and practice, is of no use to Christians, he stated. On the other hand, Flacius insisted that God deals with human beings only through God's external word and sacraments. It is obvious that they were worlds apart in their hermeneutics and as the debate progressed it was more apparent that their theology differed fundamentally as well.

However, some of the criticisms leveled by Flacius, such as the claim that Schwenckfeld taught Christian perfection, were exaggerated. In 1554, Schwenckfeld refuted that charge by stating: »Illyricus criticizes me falsely and unjustly when he writes that I teach of the perfect, complete fullness of God and his whole divine being, as if one were able to receive this here fully or might keep God's law perfectly (volkomlich) and had no longer any need to pray the Lord's prayer [cf. the fifth petition]. ( $^{180}$ Yet, despite Schwenckfeld's claim, one can understand why Flacius would be particularly sensitive to what he saw as a denigration of the sinful condition of human beings.

\section{Flacius' Church History Projects and Plans in Magdeburg}

While still in Magdeburg, Flacius began developing an idea for a history project that would later result in two works: Catalogus testium veritatis and Historia Ecclesiastica. The latter, commonly referred to as »The Magdeburg Centuries, « was intended to be a »summation of the history of the church from the time of Christ >to the present timer, the first of its kind since Eusebius. $\ll^{181}$ One of the earliest recorded mentions of a plan for this work on church history from a Protestant viewpoint can be found in a letter Flacius sent to Caspar von Niedbruck on November 10, $1552 .{ }^{182}$ Flacius further elaborated on his ideas for what such a work should look like in a letter he wrote

180 Caspar Schwenckfeld, Vom worte Gottes. Das khein ander wort Gottes sei/aigentlich zureden/denn der Suen Gottes Jesus Christus/Bewerung. Damit auch auff Matthie Flacij Jlyrici schmachbuechlen/mit auffeckung seiner vilfaltigen Jrrthumb wirt geanthwurt. Jtem/Judicium vber Osianders leere von der Iustification. Durch Caspar Schwenckfeldt von Ossing (Augsburg: Hans Gegler, 1554; VD16 S 5035), Eelv (under the section »Vom Gerechtmachenden Glauben«): »Drumb so beschuldiget mich Jllyrick felschlich vnd vnrecht das ich von der volkomnen gantzen vo(e)lle gottes vnnd seines gantzen Go(e)ttlichen wesens schreibe/alls ob der mensch solchs alhie gentzlich mo(e)g erlangen/gotes gebot VOLKOMLICH/hallten vnd nicht mehr das vatter vnser dürffe beethen. « Reprinted text in CS 13, Nr. 889: 732-899, here 857, lines 6-10; the English translation is taken from Horst Weigelt, The Schwenkfelders in Silesia (Pennsburg: Schwenkfelder Library, 1985), 21.

181 Diener, The Magdeburg Centuries, 51-52.

182 See the entire letter in Bibl, »Der Briefwechsel zwischen Flacius und Niedbruck, « Jahrbuch der Gesellschaft für die Geschichte des Protestantismus in Oesterreich 17 (1896), 6-8. 
from Magdeburg to Hartmann Beyer, ${ }^{183}$ the superintendent of the church in Frankfurt am Main, on March 7, 1553. In it Flacius expounded his approach and voiced some of his rationale:

I am going about with a great plan, which of course, reaches beyond my own powers, but which, if it is carried out, could be extraordinarily useful for the church. First, a catalogue of all those who before the Reverend Lord Doctor Martin Luther, of pious memory, wrote, said, or thought anything against the Pope and his errors. Then I would wish that a church history would be written, from Christ onward until our time, as my attached plan (scheda) more clearly explains. ${ }^{184}$

From the brief descriptions of his concepts for both works that Flacius provided in this letter it is clear that a two-fold goal was emerging from his initial idea. On the one hand, these projects would aim to serve as legitimation for

183 Beyer's first biographer was a pastor in Frankfurt, Peter Gedult[d]ig, alias Petrus Patiens, who published a work about Beyer together with Heinrich Petreus and a poet, Christian Egenolff, Accesit Narratio de vita \& obitu M. Hartmanni Beyeri, Ecclesiastis Francofurtensis Primarii. Avthore Petro Patiente, Ecclesiaste Francofurtensi (Frankfurt: Franz and Nikolaus Basse, 1577; VD16 G 674; ZV 6435). See also a German translation done by Patiens, Historia Mag. Hartmann Beyers/seligen/weylandt Euangelischen Predicanten zu Franckfort am Mayn/wie es vmb sein gantzes Leben vnd Wesen gethan/vnd wie er von diesem Jammerthal seliglich abgeschieden. Vor diser zeit in Latein beschriben/durch Petrum Patientem/Euangelischen Predicanten daselbst/vnd nun durch denselben auch verteutsch/vnd gemehret. In der Vorrede wirt auch das Christlich Leben vnnd Ende Frauw Marien/Herrn Antony Elers /alten Burgermeisters Haußfrauwen/seligen/kürtzlich vnd gantz troestlich beschrieben (Frankfurt: Paul Reffeler, 1578; VD16 G 672). See also the following works for more contemporary biographies of Beyer, Georg Eduard Steitz, »Der lutherische Prädicant Hartmann Beyer. Ein Zeitbild aus Frankfurts Kirchengeschichte im Jahrhundert der Reformation, « Archiv für Frankfurts Geschichte und Kunst 4 (1847): 100-146; 5 (1853): 49-110; also the article by G. E. Steitz in ADB 2 (1875), 597-598; Dietrich Andernach, »Beyer, Hartmann, « in NDB 2 (1955), 203; Reinhard Frost, »Beyer, Hartmann, « in Wolfgang Klötzer (ed.), Frankfurter Biographie 1: A-L Personengeschichliches Lexikon [Veröffentlichungen der Frankfurter Historischen Kommission 19/1] (Frankfurt: Waldemar Kramer, 1994), 68-69 - contains also a short biography of his son, Johann Hartmann Beyer, who was a medical doctor and senator. For more about Patiens, see Theodor Kaul, »Peter Patiens, der hierzulande >unübliche Papst‘,« Blätter für pfälzische Kirchengeschichte und religiöse Volkskunde 37/ 38 (1970-1971): 373-443.

184 The letter is printed in Johann Balthasar Ritter, Eigentliche und umstaendliche/ Beschreibung/Des/Lebens/Handels und Wandels/der Streiten und Schrifften, wie auch/ endlich des Todes/M. Mat. Flacii/Illyrici,/Ehemals beruehmten und sehr gelaehrten/Theologi in Teutschland:/Aus theils bekannten, theils bißher unbekannten/Uhrkunden, Schrifften und Brieffen, anderer/und seiner selbst/Zur Beleuchtung der Kirchen-Historie/Des XVI. Seculi, /Derfertiget, auch auff verschiedener Begehr.../zum Druck ueberlassen/Von/Johann Balthasar Ritter/Evangelischen Predigern in Franckfurth am Mayn (Frankfurt: Wolffgang Christoph Multzen, 1723), 51-53, here 52: »Non autem sine causa id à te peto, magna enim quaedam \& sane longe supra meas vires cono, quae tamen eximiam utilitatem Ecclesiae Dei asserre possint. Primùm cupio Catalogum conscribi omnium eorum qui ante R. D. D. Mart. Luth. piae memoriae aliquid scripserunt, dixerunt aut senserunt, contra Papam ejusque errores. Deinde etiam optarim scribi integram historiam Ecclesiae inde à Christo usque ad nos sicut consilium meum aliquanto clarius in hac scheda exposui.« 
the Protestant Reformation and its theology. By showing that there have been constant efforts at renewal and reform within the church, regardless of how strongly the individuals or groups proposing them may have been persecuted by the authorities, he aimed to establish clear doctrinal continuity from the first Christians all the way to Luther and his sixteenth-century followers. Luther and Melanchthon had already initiated such work in their 1539 tracts, and Georg Major continued on this path in his Origin and Authority of the Word of God. ${ }^{185}$

On the other hand, by presenting anti-Papal attitudes as expressions of the truth and standing up for the Gospel, Flacius was just as determined to prove that the Roman Catholic Church, the Pope, and its clergy, had become so corrupt and had developed erroneous teachings and practices, including Purgatory, celibacy, the primacy of the pope, and many others, that they now stood for the opposite of the true and pure Christianity proclaimed by Jesus Christ in the first Century.

\section{a) Catalogus testium veritatis}

Catalogue of the Witnesses of the Truth was written between 1553 and 1555 and was first published in Basel in March 1556, ${ }^{186}$ with many more editions to follow later. ${ }^{187}$ The Catalogus consisted of a series of brief biographies

185 Major, De Origine et Avtoritate Verbi Dei, \& quae Pontificum, Patrum \& Conciliorum sit autoritas, admonitio hoc tempore, quo de Concilio congregando agitur, ualde necessaria. Additvs est Catalogus Doctorum Ecclesiae Dei, a mundi initio, usque ad haec tempora. Georgio Maiore Avtore (Basel, 1551; VD16 M 2122). The first edition was published in Wittenberg in 1550 by Hans Lufft. For the treatment of this work, see Irene Dingel, »An patres et concilia possint errare. Georg Majors Umgang mit den Vätern, « in Leif Grane, Alfred Schindler and Markus Wriedt (eds.), Auctoritas Patrum II, Neue Beiträge zur Rezeption der Kirchenväter im 15. und 16. Jahrhundert [Veröffentlichungen des Instituts für Europäische Geschichte Mainz. Abteilung für Abendländische Religionsgeschichte 44] (Mainz: Philipp von Zabern, 1998), 51-66 ; Rudolf Keller, »Das Schriftverständnis bei Georg Major,« in Reinhold Mokrosch and Helmut Merkel (eds.), Humanismus und Reformation: Historische, theologische und pädagogische Beiträge zur deren Wechselwirkung [Arbeiten zur Historischen und Systematischen Theologie 3] (Münster: Lit, 2001), 123-135.

186 Flacius, Catalogus testivm veritatis, qvi ante nostram aetatem reclamarunt Papae. Opus uaria rerum, hoc praesertim tempore scitu dignissimarum, cognitione refertum, ac lectucum primis utile atque necessarium. Cum Praefatione Mathiae Flacii Illyrici, qua operis huius \& ratio \& usus exponitur (Basel: Johannes Oporinus and Michael Martin Stella, 1556; VD16 F 1293).

187 For the revised editions published by the Calvinist Simon Goulart in 1597 and 1608, see Matthias Pohlig, »Matthias Flacius, Simon Goulart and the Catalogus testium veritatis: Protestant History in an Age of inner-Protestant Struggle, « ARG 101 (2010): 263-274. In 1628 the faculty of theology at Leiden University authorized a Dutch translation of Catalogus to be done on the basis of Goulart's expanded edition from 1608. The work of translation was entrusted to pastor Marcus Boerhave and was printed in Hoorn in 1632-1633. 
and stories, accompanied by Flacius' commentary describing the plight of people throughout history who were striving to preserve the New Testament faith and resisted the Antichrist (Rome). ${ }^{188}$ Through enumerating close to four hundred such witnesses Flacius tried to show that the Reformation was not something that Luther started but that there had always been people who wanted to be free from central authority and the politics of Rome and who longed to be able to read and interpret Scriptures in their own homes and communities instead of being given a set of dogmas from Rome to follow. ${ }^{189}$

Saint Peter the Apostle is the first of the »witnesses. «It is significant to recognize that in Flacius' rendering of church history, Luther is presented as the legitimate and true successor of St. Peter's and not the current Roman Pope. In that way Flacius was trying to prove his main purpose for the Catalogus, namely the succession of the doctrine (successio doctrinae), which has nothing to do with the so-called apostolic succession (successio apostolicae).

Among other witnesses were a number of ecclesiastical leaders and priests, such as Photius I, Patriarch of Constantinople who refused to accept the Pope's supremacy in matters of the Eastern church; and theologian and mystic, Abbot Joachim Fiore from Calabria. Renewers and reformers of the church, such as Jan Hus, as well as groups of believers (among them the Bulgarians converting to Christianity; or the Church of England, for breaking with Rome), were also named.

Several political leaders also appeared as witnesses: among them were Holy Roman Emperors Charles IV and Sigismund. Poets and writers, including Dante Alighieri for his criticism of papal power and the Pope's involvement in political life, Francesco Petrarca, and even Niccolò Machiavelli made the list. ${ }^{190}$ The witnesses of truth represented a variety of countries and were people who in one way or another had stood against papal power and its financial, moral and political excesses. Such a socio-political interpretation is visible in this work when one closely examines the list of witnesses, some of whom were not known for any type of spiritual devotion or initiating ecclesiastical reform, but simply resisted central authority. Among them are jurists, theologians, historians and humanists. It was not only individual human

188 For literature about the Catalogus, see Frank, Untersuchungen zum Catalogus testium veritatis des Matthias Flacius; Thomas Haye, »Der Catalogus testium veritatis des Matthias Flacius Illyricus - eine Einführung in die Literatur des Mittelalters, « ARG 83 (1992): 31-48.

189 Flacius, Catalogus, b. The title on the first page of text, following the thirteen-page-long dedicatory epistle from March 1556 (A2r-A8r) to to the Ernestinian dukes, Johann Friedrich II (maiori), Johann Wilhelm and Johann Friedrich III (minori) and the preface to the reader consisting of eight pages, actually reads: »Testes veritatis, qvi ante nostram aetatem uixerunt: siue Catalogus scriptorum, qui Papae ante Lutherum reclamarunt.«

190 Some of the other witnesses include Hildegard of Bingen, Bridget (Birgitta) of Sweden, Johannes Tauler, John Duns Scotus, Johannes de Rupescissa, Lorenzo Valla, Johann Hilten, and Girolamo Savonarola. 
beings who received a place on Flacius' list; doctrinal documents and decisions in line with the Bible (such as some of the church councils) were also among his witnesses. The Catalogus has also been labeled as a »controversial theological polemic. $\ll^{191}$

Through doing research for the Catalogus, Flacius became familiar with the history of the Waldensians, the spiritual movement founded by Peter Waldo, and the theological tenets of this group seem to have particularly fascinated him. In his letter to Beyer from 1553 cited above Flacius was requesting his help in negotiating with merchants from Lyons in order to procure any sources that existed there. ${ }^{192}$ In comparison to other entries, Flacius dedicated one of the lengthier sections in Catalogus to the Waldensians, stretching over fifty-seven pages. ${ }^{193}$ Apart from recounting their history, Flacius also included a long discussion of their central theological beliefs (with a list titled Articuli Vualdensium), placing an emphasis on their anti-Papal and anti-Roman stances, and explained how they had been declared heretical and were persecuted by Rome, even adding portions from original documents to his text.

What is also evident from his entry on the Waldensians is Flacius' view that the Hussites were theological and spiritual successors to the Waldensian movement, as in the same place he included documents on the persecution of believers in Bohemia. Flacius' fascination with those individuals and movements that had been persecuted for diverging from centrally held church dogmas and traditions was yet another aspect revealing his growing radicalization. In addition to validating the Lutheran Reformation and placing it within historical continuity, Flacius' intentions with the Catalogus and the enumeration of witnesses of truth included providing legitimation of his own theological stances and illustrating his camaraderie with like-minded, persecuted and often exiled Christians throughout the centuries. As part of his self-validation, he was presenting through the Catalogus an image of himself among the »true believers « who had invariably and unjustly suffered at the hands of those in ecclesiastical and political power throughout history.

191 Wilhelm Schmidt-Biggemann, »Flacius Illyricus’ »Catalogus testium veritatis« als kontroverstheologische Polemik, « in Günther Frank and Friedrich Niewöhner (eds.), Reformer als Ketzer: Heterodoxe Bewegungen von Vorreformatoren [Melanchthon-Schriften der Stadt Bretten 8] (Stuttgart/Bad Cannstatt: Frommann-Holzboog, 2004), 263-291.

192 Flacius to Beyer, March 7, 1553, in Ritter, Eigentliche und umstaendliche, 51: »... ut te oraret per litteras, ut diligenter velles cum Lugdunensibus Mercatoribus agere, si qui istuc ad nundinas ventitarent, ac pii essent, ut velint curare sedulo inquiri in suis Bibliothecis, si quae vel historia de Waldensibus vel aliqua scripta eorum illic reperiri possint. Nam ibi primum orti sunt ante 400. annos.《

193 Flacius, Catalogus, 704-761. 


\section{b) The Magdeburg Centuries}

Although clearly driven by a great amount of ideological zeal and personal motives, Flacius gave a lot of attention to making proper organizational and methodological preparations for his proposed overview of church history. Recognizing the enormity of the project, he indicated a division of labor among a group of coworkers, and explained the source of his inspiration for that from nature in his letter to Beyer from 1553:

I wish that the writing be commended to some rather learned person of capable style - rather, not one but three people or four: two to seek out and gather materials from wherever, a third to compose those collected materials in writing, as it were, imitating some of the organization and honey making of bees. ${ }^{194}$

Already early on in his process of preparation, Flacius began developing a master plan for the historiographical approach for The Centuries (called Scheda), which he kept on revising and perfecting. Flacius (later together with the team he gathered around himself) also wrote other working papers and documents that outlined various aspects of this plan. ${ }^{195}$ According to the Methodus historiae ecclesiasticae, the material would be arranged according to centuries, and each of them would be further divided into a fixed range of topics. These included sections on the persecution of the church, doctrines, errors and heresies, church councils, and martyrs. Arrangement of the material by centuries, Martina Hartmann claims, was a completely new way of dividing up history. The »Lokalmethode, « which was another characteristic of this approach, had on the other hand been inspired by Melanchthon's Loci communes. ${ }^{196}$

The method in Catalogus had been chronological and focused on personal histories, and through conducting research for it Flacius had acquired a vast knowledge of medieval sources. This later proved to be the foundation upon

194 Flacius to Beyer, March 7, 1553, in Ritter, Eigentliche und umstaendliche, 52: »Caeterum historiae scriptionem alicui doctiori, styloque valenti commendari velim, vel non uni potius sed tribus, aut quatuor, ruorum duo materias undiquaque congererent $\&$ comportatent, tertius omni ailla congesta scriptione pertexeret, ut ita quasi Apum quandam politiam melificationemque imitarentur.« English translation by Diener, The Magdeburg Centuries, 45.

195 A treatment of this plan can be found in Heinz Scheible, Die Entstehung der Magdeburger Zenturien. Ein Beitrag zur Geschichte der Methode [Schriften des Vereins für Reformationsgeschichte 183] (Gütersloh: Gerd Mohn, 1966), 13-40. Scheible had investigated the plan of The Centuries in his 1960 Heidelberg doctoral dissertation, »Der Plan der Magdeburger Zenturien und ihre ungedruckte Reformationsgeschichte,« which served as the basis for this book.

196 Martina Hartmann, »Die Magdeburger Centurien und ihre wissenschaftliche Bedeutung, « in Eckhart W. Peters (ed.), Die Magdeburger Centurien, I: Die Kirchengeschichtsschreibung des Flacius Illyricus (Dössel, Saalkreis: Janos Stekovics, 2007), 55-80, here 62-63. 
which he could begin constructing the Centuries, as this work was also based on working with primary documents. The division of responsibilities within the team of authors included the positions of »collector, « »scriptor, « and »inspector." Flacius began gathering a group of Evangelical scholars around him, who would be carrying out the actual work of collecting and analysing sources, writing materials, editing, and other functions, while Flacius still remained the intellectual motor behind the project - or its spiritus rector, as Hartmann calls him. ${ }^{197}$ The group, called the Collegium, included five men: Johannes Wigand, Matthaeus Judex, ${ }^{198}$ Martin Copus, Abdias Praetorius, ${ }^{199}$ and Marcus Wagner. ${ }^{200}$ Numerous other

197 Martina Hartmann, »Matthias Flacius Illyricus, die Magdeburger Centuriatoren und die Anfänge der quellenbezogenen Geschichtsforschung, « in Arno Mentzel-Reuters and Martina Hartmann (eds.), Catalogus und Centurien: Interdisziplinäre Studien zu Matthias Flacius und den Magdeburger Centurien [Spätmittelalter, Humanismus, Reformation 45] (Tübingen: Mohr Siebeck, 2008), 1-17, here 1, n. 1.

198 His family name was Richter. For more about him, see Ernst Koch, »Judex (Richter), Matthäus, « in Religion in Geschichte und Gegenwart $4^{4}$ (2001), 643; »Judex, Matthäus« in MBW 12: Personen $F-K$, 374. Judex's important publications are: $\Sigma v v \tau \alpha \gamma \mu \alpha$, seu Corpus doctrinae Christi, ex novo Testamento Tantum, Methodica ratione, singulari fide \& diligentia congestum: per Iohannem Vvigandvm, et Matthaevm Ivdicem (Basel: Johannes Oporinus, 1558 [August]; VD16 W 2817). This is the first edition of Syntagma on which Judex collaborated with Wigand and is almost identical to Locus IV of the first volume of The Magdeburg Centuries. See Keller, Der Schlüssel zur Schrirft, 95. For more about this work see Robert Kolb, »The First Protestant `Biblical Theology.く The Syntagma of Johannes Wigand and Matthaeus Judex, « in Torbjörn Johansson, Robert Kolb and Johann Anselm Steiger (eds.), Hermeneutica Sacra. Studien zur Auslegung der Heiligen Schrift im 16. und 17. Jahrhundert-Studies of the Interpretation of Holy Scripture in the Sixteenth and Seventeenth Centuries [Historia Hermeneutica. Series Studia 9] (Berlin: Walter de Gruyter, 2010), 189-206; Das Kleine Corpvs Doctrinae. Das ist/Die Heuptstuecke vnnd summa Christlicher lere/fuer die Kinder in Schulen vnd Heusern ... gestellet/durch Matthaevm Ivdicem (Rostock: Stephan Möllemann, 1564; VD16 ZV 13254). This catechism was reprinted numerous times between the sixteenth and nineteenth centuries (the VD16 catalogue lists twenty-eight reprints, even though many more were printed). It was also translated into Dutch as Dat cleyne Corpus Doctrinae. Dat is: Die hooftstucken en Somma der Christelijcke leereinge voor die kinderen in den Scholen ende buysen opt Simpleste gbestelt, door: Mattheum Iudicem (Wesel: Hans de Braeker, 1564; not in VD16). It is counted as one of the oldest teaching books that were used in the Dutch Lutheran Church. For the critical edition, see Johannes Wilhelm Pont, »Het kleine Corpus Doctrinae van D. Mattheus Judex opnieuw uitgegeven en van een inleiding en aantekenigen vorzien door Dr. J.W. Pont, «Nieuwe bijdragen tot kennis van de geschiedenis en het wezen van het Lutheranisme in de Nederlanden 4 (Amsterdam, 1911), 1-47. For the different editions and the reception of the Corpus Doctrinae, see Daniel Gehrt, »Zum besseren vnd gründtlicheren verstandt des Catechismi Lutheri. Das Kleine Corpus Doctrinae des Matthäus Judex, « in Gerlinde Huber-Rebenich (ed.), Lehren und Lernen im Zeitalter der Reformation [Spätmittelalter und Reformation 68] (Tübingen: Mohr Siebeck, 2012), 149-199.

199 His German name was Gottschalk Schultze.

200 For Wagner's travels in order to collect primary documents for the Centuries and particularly his trip to Scotland via Denmark, see Heinrich Schneider, »Die Bibliotheksreisen des Marcus Wagner,« Zentralblatt für Bibliothekswesen 50 (1933): 678-682. In 1557 Wagner was in Vienna, searching for original sources in the libraries. See the letter by Paul Skalich to Melanchthon dated on May 21, 1557 from Vienna in MBW 8225 (Regesten 8: 72). The whole 
coworkers, supporters, and assistants were also involved. In the process of drawing up the plans for the Centuries, Flacius decided to ask for the opinions of others as well. Among those that replied to his request for input were François Baudoin, a Flemish jurist, who approved the plan and the loci arrangement; 201 the Marburg theologian Andreas Gerhard Hyperius [from Ypres], who suggested periods of fifty years would be more appropriate; ${ }^{202}$ and the professor of Greek from Vienna, Georg Tanner, who recommended the traditional four-monarchy order from the book of Daniel. ${ }^{203}$ Conrad Gessner, by contrast, did not approve the method. Hubert Languet was also helpful to Flacius and his collaborators for The Magdeburg Centuries. ${ }^{204}$ John Calvin was also among those whom Flacius had chosen to consult. They exchanged letters via Caspar von Niedbruck, Flacius' former student in Wittenberg, and Calvin's former student in Strasbourg, who acted as an intermediary in the correspondence. ${ }^{205}$ Instead of devoting a separate volume

letter is reprinted in Krabbel, Paul Skalich, 196-197. Skalich also corresponded directly with Wagner as is evidenced by a reprinted letter in Thüringer Königreichs, M1v-M2r. For Wagner's biography, see Johann Christian Schöttgen, »Leben Marcus Wagners, eines bekannten Thüringischen Historici und Pfarrers zu Bussleben, « Sammlung verschiedener Nachrichten zu einer Beschreibung des Kirchen- und Schulenstaats im Herzogthum Gotha 12 (Gotha: Christian Mevius, 1757), 56-91.

201 See Gregory B. Lyon, »Baudoin, Flacius and the Plan for the Magdeburg Centuries, « Journal of the History of Ideas 64/2 (2003): 253-272. For Bauduin's biography, see Michael Erbe, François Bauduin (1520-1573). Biographie eines Humanisten [Quellen und Forschungen zur Reformationsgeschichte 46] (Gütersloh: Gerd Mohn, 1978). Bauduin's three letters to Copus, Wigand, Flacius, Praetorius and Judex, dated June 13, August 5, and September 20, 1556 are reprinted on pages $262-276$.

202 See Hyperius' letter to Niedbruck from Marburg, dated September 11, 1555 in Gerhard Krause, Andreas Gerhard Hyperius Briefe 1530-1563 [Beiträge zur historischen Theologie 64] (Tübingen: Mohr Siebeck, 1981), 50-52. In this letter Hyperius states that he had already sent his opinion on the plan of The Magdeburg Centuries to Flacius. For Hyperius' biography, see Gerhard Krause, Andreas Gerhard Hyperius. Leben-Bilder-Schriften [Beiträge zur historischen Theologie 56] (Tübingen: Mohr Siebeck, 1977).

203 Viktor Bibl, »Nidbruck und Tanner. Ein Beitrag zur Entstehungsgeschichte der Magdeburger Centurien und zur Charakteristik König Maximilians II., Archiv für österreichische Geschichte 85 (1898): 379-430. For the only published Tanner correspondence, see Roderich von Stintzing, Georg Tanners Briefe an Bonifacius und Basilius Amerbach 1554-1567. Ein Beitrag zur Geschichte der Novellen-Editionen (Bonn: Adolph Marcus, 1879), 3-71, here 6-10.

204 In December 1553 Flacius gave a hand-written copy of Catalogus to Hubert Languet asking him to send it to Niedbruck. See Mirković, Matija Vlačić Ilirik, 261. Languet also traveled around Europe and collected manuscripts for The Magdeburg Centuries. On this point, see Béatrice Nicollier-De Weck, Hubert Languet (1518-1581): Un Réseau politique international de Melanchthon à Guillaume d'Orange [Travaux d'Humanisme et Renaissance 293] (Genève: Droz, 1995). This work also contains an episode about Flacius and Languet in relation to The Magdeburg Centuries as well as information about the relationships between Melanchthon and Flacius, and Duke August of Saxony and Flacius.

205 See Förstemann (ed.), Album Academiae Vitebergensis. Vol. 1: 1502-1560, where he matriculated as »Caspar a Neytbruck Lottaringus« in July 1546, 235a. He attended Flacius' lectures on the Politics of Aristotle in Wittenberg in that year, see Erzehlunge der Handlungen, Aa3r: 
to each century, Calvin suggested a topical approach. ${ }^{206}$ It took a long time for Calvin to respond and by the time his reply reached Magdeburg a large part of the work for the first three centuries had already been completed, according to the division Flacius had originally suggested. The first three volumes of The Centuries were published in Basel by Oporinus in 1559, while volume XIII came out in 1574 . Volumes XIV and XV were never published, although they had already been partly prepared.

\section{The Second Eucharistic Controversy: \\ Flacius' Contribution to the \\ Growing Distancing and Differentiation between \\ Lutheran and Reformed Understandings}

In the Eucharistic [also referred to as Sacramentarian] controversies of the 1550 s, Flacius took the side of Joachim Westphal, a pastor from Hamburg, ${ }^{207}$ against John Calvin. ${ }^{208}$ The polemics began in 1552 with Westphal's attack upon Calvin, Bullinger in Zurich and Johannes à Lasco, who was in Frankfurt at the time. ${ }^{209}$ The reason for Westphal's pamphlet, called $A$ Hodgepodge (Farrago) of Confused and Dissenting Opinions on the Lord's Supper, ${ }^{210}$ was a 1551 publication of Consensus Tigurinus, a document of agreement on the question of the Lord's Supper between the churches of Zurich and Geneva. ${ }^{211}$

»...D. Caspar Nidbruck/Key: May: Rhat/welcher zuuor zu Witemberg von mir die Politica Aristotelis / Anno 1546. Geho(e)ret hatte /...«

206 See Calvin's letter to Niedbruck, dated February 13, 1557 in Geneva in CR 20 [Supplementum]: 448-450, Nr. 4181. The original is at the National Library in Vienna, Cod. 10.364, $12 \mathrm{v}-13 \mathrm{v}$. This letter is also translated into German in Schwarz, Johannes Calvins Lebenswerk in seinen Briefen, 2: 164-165.

207 For details of his biography, see Irene Dingel, »Westphal, Joachim,« in TRE 35 (2003), 712-715.

208 For an overview of the controversy, see Wilhelm H. Neuser, »Der zweite Abendmahlsstreit, « in Carl Andresen (ed.), Handbuch der Dogmen- und Theologiegeschichte: Die Lehrentwicklung im Rahmen der Konfessionalität (Göttingen: Vandenhoeck \& Ruprecht, 1988), 272-285; Wim Janse, » The Controversy between Westphal and Calvin on Infant Baptism, 1555-1556., « Perichoresis 6/1 (2008): 3-43; »Joachim Westphal's Sacramentology, Lutheran Quarterly 22/2 (2008): 137-160.

209 For his biography, see Henning P. Jürgens, Johannes a Lasco, 1499-1560 - Ein Europaer des Reformationszeitalters (Wuppertal: Foedus, 2004); Johannes a Lasco in Ostfriesland. Der Werdegang eines europäischen Reformators [Spätmittelalter und Reformation 18] (Tübingen: Mohr Siebeck, 2002).

210 Westphal, Farrago Confvsanearvm et inter se Dissidentivm Opinionum De Coena Domini, ex Sacramentariorum libris congesta, Per. M. Ioachimum westphalum, Past. Hamb. (Magdeburg: Christian Rödinger d.Ä., 1552; VD16 W 2287). The work is dedicated to the city of Frankfurt am Main.

211 The Latin text of the Zurich Consensus (Consensio mutua de re sacramentaria...) can be found in CO 7: 733-748. A German translation by Heinrich Bullinger followed: Einhaelligkeit 
In his work on the Consensus, published in Magdeburg, Westphal accused the Reformed theologians of $»$ reaffirming the sacramentarianism of Zwingli, and he especially objected to their rejection of the Lutheran explanation of Christ's presence in the Supper. ${ }^{212}$

Westphal continued his assault with a second longer polemical and dogmatical pamphlet published in Magdeburg in 1553 called The Right Faith about the Lord's Supper. ${ }^{213}$ The German translation was issued in the following year and added the word »undistorted « in the title of the work. ${ }^{214}$ Calvin responded to Westphal with his Defense of the Sound and Orthodox Doctrine of the Sacrament (Defensio) of the Consensus Tigurinus in January of 1555. ${ }^{215}$ It is evident from the correspondence between Flacius and Westphal that Flacius was supporting Westphal's position. ${ }^{216}$

Der Dienern der Kilchen zue Zürich vnd herren Joannis Caluinj dieners der Kilchen zue Genff/deren sy sich im handel der heyligen Sacramenten gaegen andern erklaert vnd vereinbared habend (Zurich: Rudolf Wyssenbach, 1551; VD16 C 4920). Calvin then translated the Consensus into French: L'Accord passe et conclvd Tovchant la Matiere des Sacraments, entre les Ministre de l'Eglise de Zurich, \& Maistre Iohan Caluin Ministre de l'Eglise de Geneue. (Geneve: Johann Crespin, 1551). An English translation by Ian D. Bunting was published in the Journal of Presbyterian History 44 (1966): 45-61. See also the historical-critical edition by Emidio Campi and Ruedi Reich (eds.), Consensus Tigurinus (1549). Die Eingung zwischen Heinrich Bullinger und Johannes Calvin über das Abendmahl. Werden - Wertung - Bedeutung (Zurich: Theologischer Verlag, 2009). Although its text was first published only 1551, the Consensus Tigurinus was already reached and ratified in May 1549.

212 Joseph N. Tylenda, »The Calvin - Westphal Exchange. The Genesis of Calvin's Treatises against Westphal,« Calvin Theological Journal 9/2 (1974): 182-209, here 183. See also Tylenda's article »Calvin and Westphal: Two Eucharistic Theologies in Conflict, « in Wilhelm H. Neuser, Herman J. Selderhuis and Willem Van't Spijker (eds.), Calvin's Books: Festschrift Dedicated to Peter De Klerk on the Occasion of His Seventieth Birthday (Heerenveen: J.J. Groen, 1997), 9-21.

213 Westphal, Recta Fides de Coena Domini, ex verbis Apostoli Pauli, \& Euangelistarum demonstrata ac communita, per Magistrum Ioachimum Vvestphalum Ecclesiae Hamburgensis Pastorem (Magdeburg: Michael Lotter, 1553; VD16 W 2308).

214 Westphal/Waldner, Der rechte vngefelschte Glaub/von dem Hochwirdigen Sacrament des waren leybs vnd bluts vnsers Herrn Jesu Christi/bede auß den worten der heyligen Euangelisten/vnd des lieben Apostels Pauli/erstlich im Latein angezeyget vnd beschrieben. Durch. M. Joachimum Westphalum/Pfarrhern zu Hamburg. Jetzt aber aufs treulichste verdeutscht/von Wolffgango Waldner/der Christlichen Kirchen diener zu Nuernberg (Nuremberg: Georg Merkel, 1554; VD16 W 2310).

215 Calvin, Defensio Sanae et Orthodoxae Doctrinae de Sacramentis, eorumque natura, ui, fine, usu, \& fructu: quam pastores \& ministri Tigurinae Ecclesiae \& Geneuensis antehac breui Consensionis mutuae formula complexi sunt: unà cum refutatione probrorum quibus eam indocti \& clamosi homines infamant. Iohanne Calvino authore (Zurich: Christoph Froschauer d.Ä., 1555; VD16 C 4919). The reprinted text of the Defensio can be found in CO 9: 15-36.

216 The part of their correspondence relating directly to this controversy has been published by Sillem (ed.), Briefsammlung des hamburgischen Superintendenten Joachim Westphal, vol. 1. In Flacius' letter to Westphal from 1554 he is asking him to provide him copies (exemplaria) of the German translation of the Recta Fides. It is not clear from the letter if Flacius would be the mentioned book seller (bibliopolae) at the Leipzig Book Fair or someone else, but the purpose is clear, Flacius is approving of the work and would like to distribute it, 181-182. 
By that time, many other pastors and theologians had also become involved in writing and explaining their understanding of the words $\gg$ This is my body." An example was the Lutheran pastor from Bremen, Johann Timann called Amsterdamus, who in 1555 published his Farrago consisting of more than six hundred pages in an attempt to prove »a true and catholic doctrine of the Lord Supper. ${ }^{217}$ In Timann's compendium Flacius also found his place, as he was one of the authors Amsterdamus marshaled to support his cause against the Reformed interpretation, ${ }^{218}$ particularly by Johannes à Lasco and Albert Hardenberg. ${ }^{219}$

In 1557, Westphal published a collection of twenty-five letters and confessions on Holy Communion from the evangelical churches called The Confession of Faith on the Sacrament of the Eucharist, in which the Ministers of the Church of Saxony Defend the Presence of the Body and Blood of the Lord Jesus Christ in the Supper by Solid Argument of Sacred Scripture in Answer to the Book Dedicated to them by John Calvin. ${ }^{220}$ The volume contained writings that opposed the Swiss Reformed interpretation of the Sacrament of the Eucharist by pastors from a number of cities. ${ }^{221}$ Among the documents was the Magdeburg declaration on the Holy Supper, which had been signed by fifteen of that city's pastors. ${ }^{22}$ Flacius also agreed to the declaration, although

217 Johann Timann, Farrago Sententiarvm Consentientivm In Vera Et Catholica doctrina, de Coena Domini, quam firma assensione, \& uno spiritu, iuxta diuinam uocem, Ecclesiae Augustanae confessionis amplexae sunt, sonant \& profitentur: Ex Apostolicis scriptis: Praeterea ex Orthodoxorum tam ueterum, quam recentium perspicuis testimonijs, contra Sacramentariorum dissidentes inter se opiniones, diligenter \& bona fide collecta. Per Ioannem Timmanvm Amsterodamum, Pastorem Bremensem, in Ecclesia Martiniana. Vnà cum Indice rerum memorabilium (Frankfurt: Peter Brubach, 1555; VD16 T 1313).

218 Ibid., 498-500.

219 See Wim Janse, »Timanns Farrago und Hardenbergs Defensive, 1554-September 1556, « in Albert Hardenberg als Theologe: Profil eines Bucer-Schülers [Studies in the History of Christian Thought 57] (Leiden: Brill, 1994), 45-52. For a biography of Hardenberg, see Henning P. Jürgens, »Hardenberg, Albert (Rizaeus),« in Martin Tielke (ed.), Biographisches Lexikon für Ostfriesland 4 (Aurich: Ostfriesische Landschaft, 2007), 182-186.

220 Confessio Fidei de Evcharistiae Sacramento, in qva Ministri Ecclesiarum Saxoniae solidis Argumentis sacrarum Literarum astruunt Corporis et Sanguinis Domini nostri Iesv Christi, praesentiam in Coena sancta, et de libro Ioannis Caluini ipsis dedicato respondent (Magdeburg: Ambrosius Kirchner d.Ä., 1557; VD16 W 2274).

221 Ibid., H4r-T5v: Mansfeld, Eisleben [Erasmus Sarcerius], Bremen [Superintendent Jakob Probst, Johann Timman, Johann Selst, Anton Grevenstein, Christian Havemann, Ditmar Timann, Elard Segebade and others], Hildesheim [Tilemann Krage and others], Hamburg, Lübeck, Lüneburg, Braunschweig [Joachim Mörlin, Martin Chemnitz and Heinrich Osteradt], Hannover, Wismar, Schwerin, Husum in Holstein, the Region of Dithmarschen, Nordhausen [Anton Otto and others], Johannes Bodeker, Johannes Brenz, Hartmann Beyer, Johannes Balsaráti Vitus, Joachim Magdeburg and others.

222 Ibid., H3r: »Pastores ac Ministri Ecclesiae Magdebvrgensis proprijs manibus subscripferunt: Iohannes Vuigandus Pastor ad D. Huldrichum, Sebastianus Vuerner, Matthaeus Iudex, [H3v:] Lucas Rosenthal Pastor ad D. Iohannemi, Ioachimus Bonus, Chilianus Fridericus, Iohannes Meyer, Henningus Frede, Pastor ad D. Catharinam, Iohannes Conon, Ambrosius Hidfeld, 
he attached his own theological statement to it. ${ }^{223}$ By writing his Subscriptio, published in Westphal's collection, Flacius actively entered the Eucharistic debate. The entire volume was translated into German by an Austrian-born evangelical pastor from Nuremberg, Wolfgang Waldner, ${ }^{224}$ and published in Regensburg in 1558 with a preface by Waldner addressed to his previous church in Steyr in Upper Austria, from where Waldner had been exiled in $1548 .^{225}$ By 1558 the second Eucharistic controversy had spread further from

Pastor ad D. Petrum, Martinus Lesscher, Iohannes Baumgartnerus, Pastor ad D. Spiritum sanctum, Iacobus Bolderberch, Otto Ohmes, Pastor ad D. Iacobum, Bartolomeus Strele.«

223 Ibid., H3v: »Svbscriptio Matthiae Flacij Illyrici. Ego qvo qve Matthias Flacius Illyricus, sentio hanc Magdeburgensium Doctorum, meorum charissimorum in Domino Fratrum, sententiam de Coena Domini sanam piamque esse.

Non enim credo Typis, Allegorijs, aut prouerbijs Dominum in extrema hora, condendo sacrosanctum suum Testamentum, sententiam suam inuoluere, et abscondere suis dilectis Discipulis omnibusque pijs uoluisse, ut et illi audieentes non audirent, et uidentes non uiderent, seu non [H4r:] intelligerent nec crederent, ut de reprobis Dominus inquit.

Sed sentio Dominum Iesum simpliciter, clare ac distincte, primum indicasse quid det illis manducandum ac bibendum, nempe panem ac uinum, suum Corpus ac Sanguinem, addita in super declaratione, quod Corpus det, nempe nom spirituale, non Allegoricum, Figuratum, Typicum, Symbolicum, Vmbratile, Phantasticum, significatum, etc. sed uerum, quod scilicet etiam pro eis crucifigebatur. Deinde etiam ad quem usum, nempe, ut esset memoriale sacrificij sui, non ociosum scilicet, nudum aut uacuum, sed applicans credentibus fructus omnes inde prouenientes.

Credo etiam eos omnes sibi iudicium ac damnationem fumere, qui non credentes dilecto Dei Filio, cum tanta grauitate ac maiestate asseueranti, HOC EST Corpus meum, HIC EST Sanguis meus, etc. aut ea contemptim eludentes, tantum panem quendam Symbolicum aut Typicum se fumere in Coena Domini sentiunt: Eo quod non solum non dijudicent Corpus Domini, sed etiam plane nullum ibi esse, contra manifestam Christi asseuerationem, statuunt ac contendunt. Magdeburgi, Anno Domini. M.D.LVII.«

224 A complete biography of Waldner's does not exist even though he played an important role among second generation Lutherans, especially in the Osiandrian, Majoristic and Sacramentarian controversies and in the one concerning original sin. He published two separate works against Osiander: Christlicher vnd Gruendtlicher bericht, Von der Rechtfertigung des Glaubens, Einwonung Gottes vnd Christi in vns. Der Ehrwirdigen, Gottseligen Herrn vnnd Euangelischer warheyt Lehrern. D. Martini Luthers heyliger gedechtnuß/Johannis Brentzij/vnnd Vrbani Regij Seligen ... (Nurenberg: Hans Daubman, 1551; VD16 L 4991); and Antwort auff des Osianders Schmeckbier (Magdeburg: Christian Rödinger, 1552; VD16 W 867). For Osiander's reply to Waldner's critique of Schmeckbier, see Andreas Osiander d. $\ddot{A}$. Gesamtausgabe 10, 746-747. In this work Osiander nicknamed Waldner »Nurmbergischer Uhu« (The Nuremberg Night Owl). Using bird names to mock or flatter each other was a common practice in sixteenth century polemics. Waldner and others called Osiander the Night Raven or a Crow (Rabe), Flacius was sometimes referred to as a Cuckoo (Kuckuck), Gallus as a Rooster (Hahn), von Amsdorf as a Blackbird (Amsel), David Chytraeus as a Wren (Zaunkönig), Melanchthon as a Nightingale (Nachtigall) and Luther was a Swan (Schwan). Waldner corresponded with Flacius and translated into German some of Flacius' works. The only existing longer life-sketch of Waldner's is written by Eduard Böhl, Beiträge zur Geschichte der Reformation in Österreich. Hauptsächlich nach bisher unbenutzten Aktenstücken des Regensburger Stadtarchivs (Jena: Gustav Vischer, 1902), 205-221.

225 Westphal/Waldner, Confessio/oder Bekantnuss dess Glaubens vnd der Lehr/von dem Hochwirdigen Sacrament/dess waren Leibs vnnd Bluts Jhesu Christi/gestellet vnnd geschriben von den Christlichen Lehrern der Saechsischen Kirchen/auff das Buch Johannis Caluini/das 
the Swiss and German territories, impacting Denmark, Poland, Holland and the southern Habsburg territories. ${ }^{226}$ In the following years, Flacius published many works against the Reformed understanding of the Lord's Supper.

\section{Summary of Flacius' Magdeburg Years}

Considering the written output Flacius produced during his Magdeburg years, it may be argued that this period of time was the most fruitful one of his life. His impressive Magdeburg opus included publications against the Interim and the many texts he authored as he got involved in a growing number of theological disputes. It was also in this city that Flacius conceived two major church history projects, Catalogus testium veritatis and The Magdeburg Centuries. Additionally, his extensive correspondence, in addition to the prefaces, forewords, dedicatory epistles and other texts he wrote for works by others, testify to his indefatigable creative work.

The diversity found among these writings also reveals Flacius' multi-faceted interests, which during this period nonetheless began to be streamlined, and certain patterns could already be observed as becoming of central importance for him. The emergence of his emphasis on sin can already be noticed in his early polemical works ${ }^{227}$ and in the way he appropriated Luther's own words to support his theology. ${ }^{228}$ Growing recognition by others must have also strengthened Flacius' confidence and fueled his zeal to formulate his thoughts ever more boldly in writing.

Flacius' time in Magdeburg signaled the first phase of the radicalization of his theology, which arose out of opposition to the Augsburg Interim and the Wittenberg theologians. The specific issue of adiaphora together with his rigid and wholly uncompromising way of defining and using that term in critique of his opponents indicated the beginning of his radicalization.

er jnen dedicirt vnd zugeschriben hat. Erstlichen im Druck Lateinisch ausgegangen/jetzt aber trewlichen verteutschet. Durch Walffgangum Waldner (Regensburg: Heinrich Geißler, 1558; VD16 W 2275), S1r-V.

226 For example, the Slovenian reformer Primus Truber was accused of being Zwinglian by Jakob Andreae and needed to defend his views about the Eucharist in a public trial. See, Luka Ilić, »Bullingerjev vpliv na slovensko reformacijo « [Bullinger's Influence on the Reformation in Slovenia], Stati inu obstati. Revija za vprašanja protestantizma 1-2 (2005): 72-81.

227 For example in a 1552 tract against Osiander Flacius' accent on sin can be observed on the bottom of the front page of the publication, Widder die Goetter in Preussen... Ein kurtzer/heller vnnd klarer bericht von verdienst vnd gerechtigkeit Christi. Durch M. Fla. Jlly... (Magdeburg: Michael Lotter, 1552; VD16 F 1560).

228 As an example, see how Flacius employs Luther while criticizing Schwenckfeld's understanding of faith and righteousness and accusing him of twisting and misinterpreting Luther's words, see Von der h. Schrifft, K2v-L2r. 
These two characteristics would later come to reach their peak in the way he employed his definition of original sin. Flacius gaining a name for himself and being acknowledged as a leader of a circle of people opposing the imperial laws during these crucial years in Magdeburg may have also assured him in his belief that he was perceiving and interpreting events correctly and in a way that was true to Luther's legacy.

The Magdeburg years turned out to be a springboard for Flacius'. Overall, this time period was decisive in shaping him both theologically and personally. They also signaled the beginnings of his active involvement in religious politics both at the micro-level, such as trying to influence the Prussian court during the Osiandrian controversy, and at the macro-level, within the Empire. He would often formulate his theological stances in reaction to specific religious-political developments, which was clearly illustrated by his fierce opposition to the imperial Interim law. Reacting to something he disagreed with and coming up with his own position in the process of providing a retort would become characteristic of his method in the coming years. Additionally, the time spent in Magdeburg impacted his personal life through the physical challenges he faced, among them the siege of the city and the challenges associated with supporting a growing family in that situation without a steady income. The experiences of adversity intensified not only his zeal but also his apocalyptic emphasis.

\section{Excursus:}

Reception of Flacius' Concept of Adiaphora in the Twentieth Century

When examining the history of the reception (Rezeptionsgeschichte) of Flacius' theological ouvre, it can be noted that his notion of status confessionis received fresh relevance in the twentieth century, at the time when National Socialism was gaining strength in Germany. ${ }^{229}$ Most notably, Hans Christoph von Hase, Dietrich Bonhoeffer's first cousin, dedicated his Master of Sacred Theology thesis, The status confessionis in the Polemical Literature Surrounding the Augsburg Interim of 1548, written in 1934, to this topic. ${ }^{230}$

229 Luka Ilić, »Flacius' Status Confessionis as an Inspiration for von Hase, Bonhoeffer and the Confessing Church in the Third Reich, « paper presented at Session A3-308: History of Christianity Section and Martin Luther and Global Lutheran Traditions Consultation at the American Academy of Religion Annual Meeting in Chicago on November 3, 2008.

230 Hans Christoph von Hase, Der status confessionis in den Streitschriften um das Augsburger Interim von 1548 (New York: Union Theological Seminary, unpublished STM thesis dated June 12, 1934). This work has not been featured in almost any scholarly literature. In subsequent footnotes quotes from the text appear in their original form, which excludes Umlauts due to the fact that the thesis had been typed on an American typewriter. 
Von Hase completed his thesis as part of his studies at Union Theological Seminary in New York only one year after Adolf Hitler had come to power as German chancellor.

The thesis began with a theological introduction, followed by a historical overview of what was put at stake by the Augsburg Interim Law of 1548 . Von Hase then dedicated a chapter to the adiaphora and to the role it played with regard to the unity of the church. The fourth chapter was titled »Against Church Politics for the Freedom of the Gospel, « and it was here that von Hase discussed Flacius and his role in detail. In the final chapter the focus was on the adiaphora and its relation to confession and to status confessionis.

Flacius' definition of the so-called middle-things (adiaphora or Mitteldinge) that von Hase used was the following: »things, arrangements, acts, the existence of which is intended and arranged by God but which are not expressly commanded [by God]. $^{231}$ Von Hase proceeded to expound on Flacius' views regarding adiaphora, its relation to the confession and to the Scriptures, as well as its meaning as a symbol. This was achieved through using ample quotes from Flacius himself. ${ }^{232}$

Von Hase cited Flacius, for example, responding to the proponents of the Interim by stating that $»$ the Gospel does not only have a content, a spure doctrine, $<$ but also a form and it is precisely this formal character of the Gospel with which it formatively and constructively intrudes into the world of the Mitteldinge. ${ }^{233}$ Flacius also rebutted his opponents' statement that the confession is not in the adiaphora by stating that »it is true and overly true that the confession lies in the Mitteldingen. $1^{234}$

The thesis by von Hase also explored the correlation between status confessionis and the freedom of the Church - an issue which was very important for Flacius and which was becoming a growing concern for Christians in Germany in the 1930s, too. Von Hase wrote,

If we proceed from the realization that the shape given to the ecclesiastical Mitteldinge is always either a confession or a denial of the faith, then we have to conclude that the Church never in principle steps out of the »status confessionis; « that their Mitteldinge

231 Von Hase, Der status confessionis, 54: »Unter >Mitteldingenく versteht Flacius Dinge, Ordnungen, Handlungen, deren E x i s t e n z von Gott gewollt und geordnet ist, die aber nicht ausdruecklich von geboten sind.«

232 Von Hase relied in large part on Flacius' work, Ein buch/von waren vnd falschen Mitteldingen.

233 Von Hase, Der status confessionis, 51: »Flacius zeigt dagegen in seiner These vom >status confessionis $\prec$, dass das Evangelium nicht nur einen inhalt, eine `reine Lehre`, sondern auch eine Form hat, und dass es gerade dieser for $\mathrm{m}$ a $1 \mathrm{e} \mathrm{C} \mathrm{h}$ a $\mathrm{rak}$ t e $\mathrm{r}$ des Evangeliums ist, mit dem es in die Welt der >Mitteldinge < formend und gestaltend eingreift.«

234 Ibid., 52: »es ist wahr unueberwahr, dass das Bekenntnis in Mitteldingen stehet.« 
are indeed always a confession; that Christ and the liberty of His Gospel in Kultus and condition are always somehow confessed or are renounced. ${ }^{235}$

The conclusion von Hase drew at the end of his thesis was that status confessionis does and should eventually lead to uncompromising resistance. ${ }^{236} \mathrm{He}$ commented on the fact that by 1555 , Flacius' thesis about status confessionis had been forgotten and the Peace of Augsburg, based on the principle of cuius regio, eius religio, came into force, allowing the political leaders of the time to exercise control over the Church - which was precisely what Flacius had been campaigning against, as von Hase said.

Although von Hase did not make any explicit mention of the National Socialist regime throughout his work, one cannot but notice that it was nonetheless meant to be a clandestine warning to Christians of contemporary relevance in twentieth-century Europe. Neither was this von Hase's only work in which Flacius was mentioned, nor was he the only person making reference to the Illyrian during this critical time period with the intention of drawing parallels to the contemporary situation in Germany.

Dietrich Bonhoeffer discussed the concept of adiaphora in False Teaching in the Confessing Church? [Opinions], a piece composed during his time at the Finkenwalde Seminary in June $1936 .{ }^{237}$ In this work Bonhoeffer provided examples from three different eras (New Testament times, the Reformation period and the present) as justifications for action in status confessionis. Examining the era of the confessional writings, Bonhoeffer cited passages from the Confessio Augustana and the Formula of Concord, and quoted Flacius directly, stating, $\gg$ The poor people look mainly at the ceremonies, for those fill the eyes, but doctrine cannot be seen. [...] The people recognize the inroad of false doctrine by the surrender of the order! « ${ }^{238}$ Through his analysis concerning ceremonies and how they impact the average believers, Bonhoeffer was drawing a parallel to the contemporary German situation and the danger of embracing ceremonies and outward expressions of faith

235 Ibid., 61-62: „Gehen wir von der Erkenntnis aus, dass die den kirchlichen Mitteldingen gegebene Gestalt i m m e r entweder ein Bekenntnis oder eine Verleugnung des Glaubens ist, so haben wir zu schliessen, dass die Kirche grundsaetzlich aus dem sstatus confessionis nie heraustritt, dass ihre Mitteldinge tatsaechlich immer ein Bekenntnis sind, dass Christus und die Freiheit seines Evangeliums in Kultus und Verfassung immer irgendwie bekannt oder verleugnet wird.«

236 Ibid., 63: »Der status confessionis ist da, es kann nur darum gehen, kompromisslosen Widerstand zu leisten."

237 Dietrich Bonhoeffer, Irrlehre in der Bekennenden Kirche? Gutachten, Stettin, Juni 1936 in Eberhard Bethge (ed.), Dietrich Bonhoeffer, Gesammelte Schriften II: Kirchenkampf und Finkenwalde. Resolutionen, Aufsätze, Rundbriefe 1933 bis 1943 (München: Christian Kaiser, 1959), 246-275, here 270-271.

238 Flacius, Ein buch/von waren vnd falschen Mitteldingen. Quoted in Dietrich Bonhoeffer, Irrlehre in der Bekennenden Kirche?, 271. 
while forgetting about pursuing true doctrine. In 1940, von Hase's much better known work, The Shape of Luther's Church, was published, in which he focused on Flacius' resistance to the imperial religious law (the Interim). ${ }^{239}$

The above mentioned examples illustrate how Flacius' ideas were received and rediscovered at a time of turbulence and a noticeable growth of restrictions on the freedom of belief in Germany. The fact that Flacius' ideas from the mid-sixteenth century resonated with Protestant theologians almost four hundred years later, suggests that they may have contained observations and theological argumentation that rose above differences in time.

239 Hans Christoph von Hase, Die Gestalt der Kirche Luthers: Der casus confessionis im Kampf des Matthias Flacius gegen das Interim von 1548 (Göttingen: Vandenhoeck \& Ruprecht, 1940). Incidentally, this book was the last one under the Nazi government that the Ministry of Propaganda allowed the long-standing theological publishing house of Vandenhoeck \& Ruprecht to print. Vandenhoeck \& Ruprecht was the publisher of the journal Junge Kirche, the mouthpiece of the Confessing Church during the Nazi years. The authorities shut the periodical down in 1941. Until the end of World War II the company was not allowed to publish anything related to theology - previously their main profile. 


\title{
Chapter Three
}

\section{Phase Two: \\ Flacius within the Ecclesiastical and Political Establishment in Ernestine Saxony, $1557-1562$}

\author{
1. An Academic Call: \\ Flacius as Professor at the Newly Established \\ University of Jena
}

The second phase of Flacius' theological radicalization covers the shortest period out of the three - approximately four years and eight months. However, several crucial events and changes took place in his life during this time, all of which impacted him in significant ways. This stage therefore warrants an examination that is separate from that of the other phases.

On July 17, 1556, while still in Magdeburg, Flacius received a letter of call from Duke Johann Friedrich II to Jena, which outlined his duties, were he to accept the position:

That he [Flacius] together with the honorable and learned, our beloved doctor of the Holy Scriptures, Erhard Schnepf, should be a General Superintendent and should exercise supervision over all superintendents, pastors and church employees of all the churches in the principality, that no one should introduce new doctrines and ceremonies, and that each pastor persevere in the religion established in the land. Beyond that, he should lecture one hour each day - three days a week in Greek on the New Testament and on the other days in Latin on a Gospel or an epistle of St. Paul. ${ }^{1}$

1 Johann Friedrich I, Ad lectionem publicam \& Superintendentiam universalem, HAB, Guelf. 79 Helmst., 117r-v: »Das ihr sampt dem Erwirdigen und hochgelarten unsern lieben andechtigen Erhardten Schneppen der heiligen schriefft doctorn ain Obersuperintendent ueber alle Superintendentten pfarherr und Kirchen diener aller Kirchen unsers Fürstenthumbs Lande unnd Herrschafften sein/ und darauff ein getrewen fleissigen auffsehen haben sollen, dass niemand Newe lehr und Ceremonien einführe, und das ein jeder pfarherr bei der im Lande aufgerichteten Religion verharre. Ueber das solle er auch in Jena alle tage ein stunde als in der woche drey tage im Neuen Testament in Griechischer sprach und in den andern tagen in Lateinischer sprach ein Euangelion oder Epistel Pauli.« The English translation above is based on Olson, Flacius and the Survival of Luther's Reform, 327-328. Olson attributes this letter 
Before the end of July 1556 Flacius already made a commitment to the Ernestinian dukes, Johann Friedrich II, Johann Wilhelm and Johann Friedrich III that he would move to Jena by Easter 1557 in order to assume the professorship and the position of general superintendent (Obersuperintendent) of Thuringia that had been offered to him. ${ }^{2}$ Soon afterwards Flacius received another invitation in September 1556 from the Elector of the Palatinate, Ottheinrich, to assume a professorial chair at the University of Heidelberg and a position in the church. ${ }^{3}$ This is what Flacius said in his own words about his decision:

About the end of 1556 the younger Saxon princes began to insist strongly that I move to Jena for public lectures and for the »Obersuperintendent« position. To them I soon committed my efforts, moreover with a half-year's time allowed for the completion of Historia ecclesiastica, the Catalogus testium veritatis, and the last book against Schwenckfeld, sufficiently long and dedicated to the most excellent Council of Strasbourg. At the same time, Elector Ottheinrich was asking that I come to Heidelberg. I made a promise to His Excellency with this condition; if he could ask that the Saxon princes agree, to whom I had committed my work. When they did not agree, I went to Jena about Easter time $1557 .{ }^{4}$

to von Amsdorf even though he quotes it from Preger, Flacius und seine Zeit, 2: 106, who correctly identifies the author. See also Thomas Kaufmann, »Die Anfänge der Theologischen Fakultät Jena im Kontext der innerlutherischen Kontroversen zwischen 1548 und 1561, in Leppin et al. (eds.), Johann Friedrich I. - der lutherische Kurfürst, 209-258, here 244 n. 125.

2 Flacius' letter dated on July 6, 1556 in Magdeburg is kept at ThHStAW, EGA, Reg. O 908, $1 \mathrm{r}-\mathrm{v}, 4 \mathrm{r}-\mathrm{v}$. For the details of this invitation, see Daniel Gehrt, »Die Berufung von Flacius nach Jena," in Ernestinische Konfessionspolitik. Bekenntnisbildung, Herrschaftskonsolidierung und dynastische Identitätsstiftung vom Augsburger Interim 1548 bis zur Konkordienformel 1577 [Arbeiten zur Kirchen- und Theologiegeschichte 34] (Leipzig: Evangelische Verlagsanstalt, 2011), 109-114. Based on archival research in Weimar, Gehrt has shown that the Ernestian dukes began negotiations with Flacius already in March 1555.

3 The invitation letter from Elector Ottheinrich dated September 19, 1556 in Amberg is kept at StAR with the title: »Othonis epistola vocatoria ad D. Illyricum, « under Eccl. I, 14, 121, 8726-8727. Part of the letter is reprinted in Karl Schottenloher, Pfalzgraf Ottheinrich und das Buch. Ein Beitrag zur Geschichte der evangelischen Publizistik. Mit Anhang: Das Reformationsschrifttum in der Palatina (Münster: Aschendorffschen Verlagsbuchhandlung, 1927), 168-169. See also the letter by Nikolaus Gallus to the Elector regarding the call issued to Flacius to come to Heidelberg. Gallus acted as an intermediary and in the letter stated that he had received a leter of call (Vocationschrifft) for Flacius from the Elector, which he had forwarded to Magdeburg. He then told Ottheinrich that »two days ago « he had received a written answer from Flacius and explained apologetically how Flacius had already accepted the invitation from the young Duke of Saxony. The letter was written from Regensburg on October 26, 1556; See Schottenloher, Pfalzgraf Ottheinrich, 169-170.

4 Flacius, Narratio actionum, in Schlüsselburg, Catalogi Haereticorum, 832-833: „Sub finem anni 1556. coeperunt vehementer instare iuniores Saxonici principes, vt Ienam ad lectionem publicam \& Superintendentiam vniuersalem migrarent. 
After celebrating his last Easter in Magdeburg, Flacius set out on a journey and arrived in Jena on April 27, 1557. ${ }^{5}$ The following day he announced that he would hold lectures on St. Paul's epistle to the Romans during the summer semester. ${ }^{6}$ On May 1, he dedicated a publication of the old Roman missal to Ottheinrich, prince elector of the Palatinate. ${ }^{7}$ His inaugural university lecture was held on May 17, $1557 .{ }^{8}$

The history of the founding of the University of Jena had begun in the aftermath of the defeat of the Smalcaldic League, as a result of which Duke Johann Friedrich I lost two thirds of his territory, including Wittenberg and its university. As an attempt at establishing a new school that would continue to preserve the true Lutheran teaching in his shrunken territory, the Collegium Jenense, an academy was set up in March 1548, when around 170 students moved into a former Dominican monastery. The first two professors at the new establishment were Johannes Stigel from Gotha, a humanist, poet laureate, personal friend of Melanchthon's and former professor at Wittenberg, ${ }^{9}$ and Victorin Strigel. ${ }^{10}$ Stigel was the founding rector; thereafter

Quibus etiam mox operam meam condixi, petito tamen spacio semestri ad dilationem perfectionis ob historiam Ecclesiasticam, catalogum testium veritatis \& vltimum librum contra Svvenckfeldium satis longum \& amplissimo senatui Argentinensi inscriptum.

Eodem tempore etiam Ottho Henricus elector postulabat, vt Heidelbergam venirem, quod ei Celsitudini promittebam, ea conditione, si posset impetrare, vt Saxonici principes consentirent, quibus iam meam operam condixeram: quibus non consentientibus veni circa Pascha anni 57. Ienam.« English translation taken from Diener, The Magdeburg Centuries, 145.

5 According to Paul Eber he arrived in Jena on April 27, 1557. See Calendarivm historicvm conscriptvm (Wittenberg: Johannes Kraft d.Ä., 1571; VD16 E 19), 155.

6 See the manuscript dated on April 28, 1557 in Jena with the official announcement to the theological faculty, at FBG, Chart. B 213, 331r-332r.

7 Flacius, Missa Latina, quae olim ante Romanam circa 700. Domini annum in usu fuit, bona fide ex uetusto authenticoque Codice descripta. Item quedam de uetustatibus Missae scitu ualde digna. Adivncta est Beati Rhenani Praefatio in Missam Chrysostomi à Leone Tusco, Anno Domini 1070. Uersam (Strasbourg: Christian Mylius, 1557; VD16 M 5497), A2r-A4v. This publication also contains a dedicatory epistle of Beatus Rhenanus to the Augustinian general vicar Johannes Hoffmeister dated in February 1545 in Sélestat, and Flacius comments about it, G5r-H4r. The dedication to Ottheinrich was perhaps motivated as a sign of gratitude for the invitation to Heidelberg and as an attempt to keep good relationship with the Palatinate duke. Flacius had previously dedicated his Catalogus testivm veritatis to the young Ernestinian dukes in March 1556, A2r-A8r.

8 A critical edition of the original Latin text has been recently published. See, Waschbüsch, Alter Melanchthon, 171-189.

9 For an overview of Stigel's career, see Stefan Rhein, »Johannes Stigel (1515/1562). Dichtung im Umkreis Melanchthons, « in Scheible (ed.), Melanchthon in seinen Schülern, 31-49. For the relationship between Stigel and Flacius see chapter fourteen, »Stigel und Flacius, « of the doctoral dissertation by Hans-Henning Pflanz, Johann Stigel als Theologe (1515-1562) (Breslau, 1936), 105-112. Stigel and Flacius knew each other from Wittenberg: in 1546 Stigel was academic dean of the Faculty of Arts, where Flacius was teaching.

10 For his biography, see Ernst Koch, »Strigel, Victorin(us), « in TRE 32 (2001), 252-255; Ernst Koch, »Victorin Strigel (1524-1569). Von Jena nach Heidelberg, « in Scheible (ed.), Melanchthon in seinen Schülern, 391-404. 
he and Strigel traded places occupying this post. In January 1557 Erhard Schnepf, who had been teaching Hebrew since 1549, was named rector. ${ }^{11}$

In addition to their professional association, the three professors were connected to one another through personal ties as well; for example Schnepf's daughter was married to Strigel. Having all lived in Jena for a while, they had also built up their own professional and personal networks in the city. Flacius walked into this tight-knit circle in late April 1557 and his new professorial appointment was not welcomed by everyone at the Collegium. Most notably, Stigel, who was looking to Wittenberg for theological direction, was opposed from the beginning to the Duke's idea of inviting Flacius to Jena: the Illyrian had already acquired a controversial reputation for his criticism of Melanchthon and for his polemics against a wide range of people and groups with whom he theologically disagreed. At the newly formed theological faculty Flacius was assigned to teach alongside Strigel and Schnepf. There Flacius was »immediately attacked by Viktorin Strigel, who viewed him as a personal rival and some of his ideas as antithetical to his own theology. $\ll^{12}$

Apart from deep-seated theological differences, another dimension adding to tensions between the newcomer and the already established faculty members concerned Flacius' salary. Namely, before accepting the position in Jena, Illyricus negotiated with the ducal court in Weimar an annual salary of 342 thalar for himself, to be paid twice a year. ${ }^{13}$ His colleagues were earning considerably less, even though they had been teaching at the school for almost a decade: Stigel was receiving 170 thalar (supplemented by ten thalar for heating wood and twenty gulden for rent) and Strigel 180 thalar (170 plus ten for heating wood) a year. ${ }^{14}$

On August 31, 1557 the Collegium Jenense was promoted to the status of university through an imperial privilege issued by Emperor Ferdinand I. A festivity celebrating the advancement to university was held on February 2, 1558 with more than six hundred people in attendance. The academic procession (Festzug) that wound through the town to the celebratory sound of bells and trumpets was headed by the three Ernestinian dukes, Johann Friedrich II, Johann Wilhelm and Johann Friedrich III and representatives of the nobility, including a number of counts as their guests. Behind them

11 In addition to his academic duties Schnepf also held ecclesiastical posts as pastor of St. Michael's church and superintendent. For more about him, see Hermann Ehmer, »Erhard Schnepf(f), « in NDB 23 (2007), 320-321; Hermann Ehmer, »Erhard Schnepf. Ein Lebensbild, « Blätter für württembergische Kirchengeschichte 87 (1987): 72-126.

12 Kolb, Nikolaus von Amsdorf, 213.

13 As the result of a good annual salary, Flacius was able to purchase a house in the immediate vicinity of the Collegium already in July 1557.

14 Mirković, Matija Vlačić Ilirik, 155, referring to sources at ThHStAW, EGA, Reg. O 590. 
came Corpus academicum led by the first rector of the new university, professor of medicine Johannes Schröter, accompanied by Count Phillip IV of Nassau-Weilburg, who was a student in Jena at the time. They were followed by Strigel, then Stigel, each flanked by two other professors, while Flacius was walking in the fourth row of the academic section next to Jena Superintendent Andreas Hügel. ${ }^{15}$ The academic procession, according to tradition, was arranged in an order that reflected the participants' positions within the hierarchy of the university. Flacius' place indicated that almost ten months after being hired as a rising star and taking up his professorial post, he had not ascended to the top rank at the faculty of theology. ${ }^{16}$

\section{A Dissenting Opinion:}

\section{Flacius' Role in the Religious Colloquy of Worms}

The theological differences between Flacius and his new colleagues became apparent relatively soon after Flacius' arrival in Jena through their involvement in the preparations for the upcoming religious colloquy in Worms. Following the Diet of Regensburg of 1556/57 a decision was made to continue the talks between Roman Catholic and evangelical theologians concerning controversial religious issues. The second imperial Colloquy of Worms, which took place in the autumn of 1557 , was meant to provide such a platform for discussing questions causing disagreement, with the hope of finding consensus and reaching unity. The evangelical representation of the adherents of the Augsburg Confession was far from being homogenous: it included delegates from Albertine and Ernestine Saxony, Württemberg, Hesse and other places, who held diverse positions on a number of theological matters that were to be addressed at Worms.

Flacius got appointed by Duke Johann Friedrich II as a member of the committee to write recommendations for the Ernestinian Saxon delegates at the colloquy, together with Strigel and Schnepf. Their first recommendation was submitted on July 9 and the second on July 20. On July 23, three days after the second joint opinion was handed in, Flacius wrote a twenty-two-page

15 For a detailed description of the celebrations marking the elevation of the Collegium Jenense to the rank of university, see Johann Adolph Leopold Faselius, Neueste Beschreibung der herzoglich Sächsischen Residenz- und Universitäts-Stadt Jena (Jena: Prager, 1805), 95-96.

16 The reasoning that Flacius did not have a doctorate and was therefore placed in the fourth row may be challenged, since out of all the people preceeding him only Johannes Schröter possessed a doctorate, which he had earned at the University of Vienna in 1552. It is also true that Stigel held the prestigious title of Poet Laureate granted to him by Emperor Charles V, which might explain why he was placed before Flacius. Strigel, on the other hand, had the same level of education as Flacius, which supports the argument that at that stage, Flacius was not seen by the ducal court as a leading faculty member. 
memorandum to the Duke that showed Flacius' theological differences with the other two colleagues on the faculty. Björn Slenczka examines this document, in which Flacius warned of Melanchthon's adiaphoristic tendencies, and by the content of the letter we can see that Flacius did not have the last word in forming the expert opinion (Gutachten). ${ }^{17}$ Slenczka attributes this to the fact that Flacius was not yet fully established but was still solidifying his base in Ernestine Saxony, and that his theological opinions did not prevail at that time, either at the theological faculty in Jena, or at the ducal court in Weimar. $^{18}$

Without the knowledge of his two colleagues, Flacius went to urge the Duke to condemn explicitly in his final instructions to the delegates, the Augsburg Interim and the so-called Leipzig Interim or all adiaphoristic alliances formed on their basis. ${ }^{19}$ As Markus Friedrich has observed, for Flacius »the adiaphoristic controversy was about the nature of orthodox Lutheranism. $\ll^{20}$ This episode illustrates how Flacius was unwilling to accept that his radical and less accommodating theological position was not embraced by others and therefore turned to other means of getting his message across. Such behavior is indicative of his modus operandi in dealing with theological disagreement: not tending to unity but producing an ever-growing number of enemies, alienating even his allies in the process.

On July 27 the Duke issued the so-called »Weimar Instructions, « a directive for the deputies who were going to Worms, namely Schnepf, Strigel, Johann Stössel, who was superintendent in Heldburg, and the jurist Basilius Monner. ${ }^{21}$ The Weimar Instructions did not contain Flacius' staunch anti-adiaphoristic position, which indicates that Flacius was unsuccessful in trying to convince Johann Friedrich II and his circle of advisers to make this stance

17 »Flacius' Privatgutachten von 23. Juli und die Weimarer Instruktionen, « in Slenczka, Das Wormser Schisma, 150-153.

18 Ibid., 487: „Offendkundig ist aber, daß Flacius zu dieser Zeit in Jena noch nicht etabliert war und um seinen Stand innerhalb der Fakultät zu ringen hatte. Ebenso kämpfte er auch um seinen Einfluß bei Hof.»

19 Ibid., 151. Flacius to Duke Johann Friedrich II, Jena, July 23, 1557: »Ich rate außerdem Euren Hoheiten an ..., daß sie klar und ausdrüklich verdammen das große Interim und alle kleinen [Interims] oder alle adiaphorischen Vereinigungen, die aus dem Interim entsprungen sind.« The original letter is kept at ThHStAW, EGA, Reg. N 235, 14r-25v.

20 Markus Friedrich, »Orthodoxy and Variation: The Role of Adiaphorism in Early Modern Protestantism, « in Randolph C. Head and Daniel Christensen (eds.), Orthodoxies and Heterodoxies in Early Modern German Culture: Order and Creativity 1500-1750 [Studies in Central European Histories 42] (Leiden/Boston: Brill, 2007), 45-68, here 58.

21 During the winter semester of 1557/58 Monner became rector of the University of Jena. $\mathrm{He}$ was the first professor of jurisprudence at the newly established faculty of law in 1554. See Max Vollert, »Basilius Monner, der erste Rechtslehrer an der Universität Jena, Zeitschrift des Vereins für Thüringische Geschichte und Altertumskunde 30 (1933): 41-51. 
central to the instructions. He still attempted to influence the Ernestinian delegates, though, by continuing to write letters to them as well as to the Duke from Jena.

Right at the opening of the colloquy the Jesuit Petrus Canisius and the bishop of Merseburg Michael Helding issued a calculated verbal assault against their counterparts for the lack of consensus and multitude of internal disagreements within the evangelical representation on issues such as justification, adiaphora and the Eucharist. The other side responded by formulating responses at the same time as launching a counterattack, criticizing decisions made by the still ongoing Council of Trent. At the same time, the deep-seated division between the Gnesio-Lutheran party and the other group represented by Melanchthon (who was present in Worms), the so-called Philippist party, became prevalent, with neither side wanting to make compromises, leading to a dead-end in the internal search for consensus. After many days of theological quarreling in Worms, the frustrated Weimar delegation, joined by Joachim Mörlin from Braunschweig and Erasmus Sarcerius from Mansfeld, walked out. ${ }^{22}$ The colloquy eventually dissolved without having achieved any of its purposes, but provided grounds for each side to blame the other for being responsible for this failure. Not only did the Worms Colloquy not bring the Catholic and evangelical sides any closer to reaching at least some level of consensus on certain issues; it actually served to make clear and to perpetuate the chasm between the two divided Lutheran groups. This was the last imperial religious colloquy in the sixteenth century.

Slenczka's new research into the preparations preceding the Colloquy of Worms not only shows that the so-called »Weimar Instructions « were not the work of Flacius as previous scholarship had held, ${ }^{23}$ but it further underscores that Flacius' role in Worms was not as significant as formerly assessed. ${ }^{24}$ Therefore the critique raised against Flacius for being the sole person responsible for the failure of the colloquy does not stand. For example, Georg Major accused Flacius in his writing in 1567 that it was only because of Flacius that

22 They handed in a note of protestation to the moderator and to the notaries of the Colloquy of Worms (Forma protestationis) on September 20, 1557. Reprinted in CR 9: 284-295, Nr. 6350. Heinrich Heppe, Geschichte des deutschen Protestanismus in den Jahren 1555-1581: Die Geschichte des deutschen Protestantismus von 1555-1562 enthaltend, vol 1 (Marburg: Elwert, 1852), 12-24 [appendix 6], mentions the date of September 27.

23 Heppe, Geschichte des deutschen Protestanismus, 486-494.

24 An example is Wilhelm Preger, who stated that Flacius' influence on the decisions made by the ducal court became almost limitless from the day of his arrival in Jena and that the behavior of the Thuringian delegation at Worms was determined in part by Flacius. See Flacius und seine Zeit, 2: 119: »Flacius' Einfluß auf die Entschließungen des Hofes war mit seiner Ankunft in Jena ein fast unbeschränkter geworden. Das Verhalten der Thüringer bei dem Colloquium zu Worms war durch ihn mitbestimmt.« 
the Protestants did not succeed. ${ }^{25}$ On the other hand, those who praise Flacius for not achieving ecumenical unity err, too, by overestimating his role. Oliver Olson has credited Flacius with saving the Lutheran Reformation in his dramatic depiction of the events at Worms in the concluding section of his book which he titled Matthias Flacius and the Survival of Luther's Reform. The final sentence from the book is a good illustration of how he has built his entire thesis on this assumption: »in 1557, once again - thanks in large part to Matthias Flacius - Luther's reform had survived. ${ }^{26}$ Since Olson does not explain what exactly he means by the survival of Luther's reform, I will argue that at least on two levels his thesis is not correct. First, to claim that Lutheranism survived in 1557 implies that its very existence was conceivably threatened by imminent extinction. The fact is that only two years prior to Worms Lutheranism did become an officially recognized religion within the Holy Roman Empire as it was promulgated at the Imperial Diet of Augsburg. After having survived serious challenges since its founder's death in 1546, Lutheranism had been granted institutional status and had spread in many territories. On another level, if Olson means that $»$ Lutheranism according to Flacius « or the ideas he held had prevailed in Worms, this cannot be established from the facts since Flacius' agenda of condemning the adiaphorists and everything else he considered to be deviating from pure Lutheranism did not take place.

\section{Flacius' Criticism of the Frankfurt Recess}

On February 25, 1558 a number of German territorial princes participated in the Frankfurt electoral congress (Kurfürstentag) that marked the transfer of imperial title and responsibilities for the Holy Roman Empire from Charles $\mathrm{V}$ to his younger brother, Ferdinand I. While in Frankfurt, the rulers also discussed the religious situation, with the goal of trying to reach confessional unity. Melanchthon, who was also present, helped in drawing up a document, which became known as the Frankfurter Rezess, on four doctrinal issues: justification, good works or new obedience, the Lord's Supper, and adiaphora. ${ }^{27}$ In addition to the four articles, the agreement defined pure doctrine as

25 See Hans-Peter Hasse, »Georg Major als Professor der Leucorea. Identifikation mit der Wittenberger Reformation, « in Dingel and Wartenberg (eds.), Georg Major (1502-1574), 41-68, here $65-66$.

26 Olson, Flacius and the Survival of Luther's Reform, 333.

27 For Melanchthon's involvement, see Irene Dingel, »Melanchthons Einigungsbemühungen zwischen den Fronten: der Frankfurter Rezeß, in Jörg Haustein (ed.), Philipp Melanchthon. Ein Wegbereiter für die Ökumene [Bensheimer Hefte 82] (Göttingen: Vandenhoeck \& Ruprecht, 1997), 119-141. 
the three ecumenical creeds (Apostles', Nicene, and Athanasian), the Augsburg Confession, and its Apology. The following rulers signed the Rezess on March 18: Ottheinrich of the Palatinate, August I of Saxony, Joachim II Hector of Brandenburg, Wolfgang of the Palatinate-Zweibrücken, Christoph of Württemberg, and Philipp I of Hesse. ${ }^{28}$

Soon after Flacius learned about the agreement reached in Frankfurt am Main, he began sharply criticizing the document, dubbing it »the Samaritan Interim." Already in May 1558 he wrote Refutation of the Samaritan Interim, in which true religion is criminally and perniciously confounded with the sects $^{29}$ in Latin and another version in German, Reason and Cause why the Frankfurt Interim must not be Adopted..$^{30}$ Both of these papers became widely circulated. Flacius objected to the fact that neither Osiander, nor Major was mentioned by name for what he considered to be erroneous teaching on justification and good works. A further point of criticism was that he considered the article on the Lord's Supper worded in a way that was too Calvinistic. Lastly, he completely disagreed with the interpretation of the adiaphora in the document. On top of finding something wrong with each article, he condemned the Rezess for not including the Smalcald Articles within the corpus of doctrine accepted.

After being signed by the initial group in Frankfurt, the Rezess was sent around to other territorial rulers, seeking their support and signature of the document - among them was Duke Johann Friedrich II. As a result, three different expert opinions were written and sent to the Duke for consideration by groups of theologians in the Ernestinian territories in reaction to the $R e$ zess. One group, including Caspar Aquila, Maximilian Mörlin and Stössel, expressed mild criticism of the Rezess but did not reject the document $a$ priori. Another expert opinion came from Jena, authored by Schnepf, Strigel and Hügel. Flacius did not join his colleagues at the theological faculty and the city superintendent in signing this expert opinion. Instead, he composed, together with several others, a third document for Duke Johann Friedrich II, advising him not to sign. The authors/signatories involved along with Flacius in this process were: Simon Musaeus, superintendent in Eisfeld; Johannes Grau, superintendent in Weimar; Johannes Aurifaber, court preacher in

28 For more on the Recess, see Thomas Kaufmann, »Recess of Frankfurt, « in Klaus Ganzer and Bruno Steimer (eds.), Dictionary of the Reformation, translated by Brian McNeil [The Encyclopedia of Theology and Church] (New York: Crossroad, 2004), 119-120.

29 Flacius, Refvtatio Samaritani Interim, in quo vera Religio cum Sectis \& Corruptelis scelerate et perniciose confunditur (1558). The manuscript is located at BSB, Cod. Germ. 1315, 30-35; at HAB, Cod. Guelf. Helmst. 81, 139r-144v; at ThHStAW, EGA, Reg. N 266, 1r-18v and at Staatsarchiv Amberg, Pfalz-Sulzbach, Geheime Registratur 24/2.

30 Flacius, Grund und Ursach warumb das Frankfurdische Interim in keinem Wege anzunemen sey (1558). The manuscript is located at the HAB, Cod. Guelf. Helmst. 79, 384v-391r. See Preger, Flacius und seine Zeit, 2: 74. 
Weimar, ${ }^{31}$ Alexius Bresnitzer, superintendent in Altenburg; Wolfgang Möstel, superintendent from Weida; and Martin Wolff, pastor in Kahla. ${ }^{32}$

On June 27, 1558 the Duke informed others about his decision to reject the Frankfurt agreement. ${ }^{33}$ This development illustrates how by that time Flacius had already found like-minded thinkers and was building up a network among the theologians and churchmen from various regions of Ernestine Saxony. Not siding with his Jena colleagues, Flacius approached the situation in his own way by gathering people around him who thought similarly and among whom his opinions could prevail. This time his strategy paid off as the Duke did follow the opinion of Flacius' group, which shows that he was becoming more theologically influential in shaping confessional politics.

\section{Flacius' Attempt at Rooting Out »Particular Corruptions, Sects, and Errors«: The Weimar Book of Confutation}

In a letter dated January 17, 1558 Flacius wrote from Jena to Duke Johann Friedrich II in Weimar expressing his disappointment with the lack of clear formulation regarding the new university's theological mandate. He stated that he had been called to oversee what doctrines were being taught at the school and in the churches. Therefore, he requested that the Duke, in his official speech at the upcoming official proclamation scheduled for February 2, clearly list by name the false teachings that the university should reject. Additionally, Flacius asked him to include this list in the written statute of privileges so that all professors and students would know which erroneous and sectarian teachings they should refute and protect themselves from. ${ }^{34}$

31 Aurifaber was from Weimar (= Vimariensis) and should not be confused with the Aurifaber who came from Breslau (= Vratislaviensis) and was Flacius' student in Wittenberg. For his biography, see Helmar Junghans, »Aurifaber, Johannes, « in TRE 4 (1979), 752-755; William R. Russel, »Aurifaber, Johannes, « in The Oxford Encyclopedia of the Reformation 1: 101-102. For the sake of clarity, in future references I will employ the derivations of the names of the two towns from their Latin form in order to distuingish between the two persons. It should be mentioned that Vimariensis remained a loyal Gnesio-Lutheran, while Vratislaviensis sympathized with and somewhat embraced the Osiandrian position.

32 Ein ander Bedencken der Theologen auff den Franckfurdischen abschiedt. The original manuscript in Johannes Aurifaber's hand is located at the University Library in Heidelberg, Codex Palatinus Germanicus 155, 86v-90v. The expert opinion of the Jena theologians can be found in the same manuscript, 83r-86r, while the opinion by Caspar Aquila, Maximilian Mörlin, Johann Stössel, and Adam Rudiger, superintendent in Römhild, is on folios 52r-53v.

33 Der Fvrsten zv Sachsen Recvsation schriefft widder den Franckfordisschen Abschiedt. Anno 1558. Cod. Pal. Germ. 155, 56r-60v.

34 For a transcription of the letter, see Mirković, Matija Vlačić Ilirik, 169-170. 
The Duke did not heed Flacius' request in the way Flacius had advised. Instead, he decided to form a committee made up of Schnepf, Strigel and Hügel and charged them with compiling a document refuting all the false doctrines, which would then be enforced as a law on the territory of Ducal Saxony. The three drafters handed over their confessional statement to the Duke on April 3, 1558. Johann Friedrich II then invited superintendents, pastors and theologians from his territories for a meeting in Weimar in midMay to discuss the drafted document. By that time, the Frankfurt Recess was looming in the background, causing diverse reactions from theologians, and Flacius had already written against it. At the Weimar meeting Flacius laid out his polemical arguments against the draft and its three authors, demanding that not only Major's claim that good works are necessary for salvation be condemned, but also Menius' position in support of Major. Flacius furthermore wanted a clear rejection of adiaphorism and pointed out that the position on free will in the draft was not in line with Luther's. As a result, a verbally intense dispute broke out among those present. ${ }^{35}$

In response to these developments, the Duke appointed a different committee, consisting of Maximilian Mörlin, Stössel, and Musaeus, and charged them with improving the document. The three of them first met in Coburg and then in Weimar, where they completed the work and submitted it to the ducal court. Subsequently, on October 30 Johann Friedrich II gave authority to Flacius, Aurifaber [Vimariensis] and the Mansfeld superintendent, Sarcerius, to finalize the text. This group met at the ducal palace in Weimar, revised the arguments, added new ones, and wrote conclusions for each chapter. They handed in the final version on November $25 .{ }^{36}$

The Duke then wrote the concluding words to the book, dating them on November 28, 1558 in Coburg. The publication of the original Latin and the German translation done by Maximilian Mörlin followed in early $1559 .{ }^{37}$ The German edition ${ }^{38}$ differed somewhat in its text from the

35 For a description of the meeting with its polemics, see Gehrt, Ernestinische Konfessionspolitik, 129.

36 Ibid., 130-131.

37 The Book of Confutation was published in seven different editions in 1559 (three Latin and four German) by two different publishing houses in Jena (Thomas Rebart's and Christian Rödinger's). See Gehrt, Ernestinische Konfessionspolitik, 130 n. 152.

38 Johann Friedrich II, Des Durchleuchtigen Hochgebornen Fuersten vnd Herrn/Herrn Johans Friderichen des Mittlern/Hertzogen zu Sachssen/Landgrauen in Dueringen/vnd Marggrauen zu Meissen/fuer sich selbs/Vnd von wegen seiner F[ürstlichen] G[nad] Bruedere/Hertzog Johans Wilhelmen/vnd Hertzog Johans Friderichen des Juengern zu Sachssen etc. in Gottes wort/Prophetischer vnnd Apostolischer schrifft/gegruendete Confutationes/Widerlegungen vnd verdammung etlicher ein zeit her/zu wider demselben Gottes wort/vnd heiliger Schrifft/auch der Augspurgischen Confession Apologien/vnd den Schmalkaldischen Artickeln/Aber zu fuerderung vnd wider anrichtung des Antichristischen Bapstums eingeschlichenen/vnd eingerissenen Corruptelen/Secten vnd Jrrthumen/Wie 
Latin. ${ }^{39}$ For example, the Latin title of Article Five read, »Refutation of the Erroneous Teaching of Zwingli and Calvin concerning the Lord's Supper, « ${ }^{40}$ while the German avoided including Calvin by name and instead referred to »old and new Zwinglians. ${ }^{41}$ Another difference between the original and the translation was that the Latin contained an additional ordinance aimed specifically at all current and future professors of the University in Jena. The document reiterated that the school had been founded by Elector of Saxony, Johann Friedrich I the Magnanimous, father of the current Duke, with the purpose of »defending the divinely commanded saving truths of the Gospel and combating erroneous teachings and sectarianism. $\aleph^{42}$ By this time, the late Johann Friedrich I was being revered among Gnesio-Lutherans as a hero, martyr and defender of the faith, and his memory was meant to serve as an example that all professors should follow. This ordinance, which demanded that the refutation of fallacies be carried out according to the Konfutationsbuch, clearly reflected Flacius' agenda, as the formulations were almost identical to the request he delivered in his letter to the Duke in January 1558.

The Book of Confutation and Condemnations of the Particular Corruptions, Sects, and Errors, contained nine articles, each addressing one cluster of erroneous teachings. Six of these were also generally recognized as such by Wittenberg theologians, although the wording and the language employed might have been too exclusive for them. The six groups condemned were: Anti-Trinitarians; Schwenckfeldians; Antinomians; Anabaptists;

dieselben vnterschiedlich/vnd in Specie/namhafftig angezeigt werden/An ihrer F. G. getrewe Landstende/Vnterthanen vnd Verwanten ausgangen/Damit sie sich durch Goetliche verleihung/dafuer zu hueten/Auch in Gottes worts/vnd der Christlichen Religion Sachen/gemelter Auspurgischen Confession/Apologien/Vnd den Schmalkaldischen Artickeln gemes (dabey denn ihre F. G. durch Goettliche gnad/bis an derselben ende zuuerharren willens vnd entschlossen) zu halten wissen vnd haben (Jena: Thomas Rebart, 1559; VD16 S 1096).

39 Johann Friedrich II, Illvstrissimi Principis Ac Domini, Domini Iohannis Friderici Secvndi, Dvcis Saxoniae, Landgrauij Thuringiae, \& Marchionis Misniae, suo ac Fratrum D. Iohannis Vuilhelmi, et D. Iohannis Friderici natu Iunioris nomine, solida \& ex Verbo Dei sumpta Confutatio \& condemnatio praecipuarum Corruptelarum, Sectarum, \& errorum, hoc tempore ad instaurationem \& propagationem Regni Antichristi Rom. Pontificis aliarumque fanaticarum opinionum, ingruentium \& grassantium, contra ueram sacrae Scripturae, Confeßionis Augustanae \& Schmalkaldicorum Articulorum Religionem, ad suae Celsit. \& Fratrum suorum subditos cuiuscunque Ordinis scripta \& edita, ut auxiliante deo illas satane technas cauere, \& in puritate Verbi Dei praedictaque Christiana agnita, recepta, \& confessa Religione in cutus Confessione \& ipsorum Celsitudines, Dei beneficio, constants ad extremum usque altae spiritum perseuerare decreuerunt) illi quoque permanere possint, quemadmodum et debent (Jena: Thomas Rebart, 1559; VD16 S 1100).

40 Ibid., E2r (18): »Confvtatio corrvptelarvm Zvvinglii et Calvini de Coena Domini.«

41 Johann Friedrich II, ...Widerlegungen vnd verdammung, G2r (42b): »Widerlegung des Irrthums der alten vnd newen Zwinglianer vom Abendmal des Herrn.«

42 Mirković, Matija Vlačić Ilirik, 172. 
»Sacramentarians; « Osiandrianists and Francesco Stancaro; but the other three refutations were aimed at the Philippists, concerning the role of free will in salvation; Majorism; and adiaphorism. ${ }^{43}$

As can be observed from the title of the book, Flacius' sharp formulations found their way even there: confutation and condemnation of all particular misleading sectarian errors; furthermore, the Smalcald Articles are also mentioned on the title page (even twice in the German version) together with the Augsburg Confession and its Apology, as forming together a corpus of doctrine. This should be seen as a reaction to the Frankurt Recess where Melanchthon did not include the Smalcald Articles. At the same time this revals their importance for the Gnesio-Lutheran camp.

As the Book of Confutation was in its final stages Erhard Schnepf died on his birthday in Jena on November 1, 1558. Schnepf's death, due to the prominent academic and ecclesiastical positions he held, signaled a change in the power dynamics at the university and within the church. This meant that the number of Flacius' most vocal opponents in Jena was reduced to two, namely Strigel and Hügel.

\section{The Synergistic Controversy: The Role of the Human Free Will ${ }^{44}$}

As soon as it was published, the Book of Confutation became a doctrinal standard for Christian teaching and law in Ducal Saxony. All pastors were required to regularly read and preach from it, superintendents needed to use it in examing candidates for the ordained ministry and everybody else needed to adhere to it. There were protests against the book, and it was the sixth locus on the freedom of the will, or so-called synergism, that caused the most controversy. ${ }^{45}$ This was almost to be expected, since there had already been an ongoing debate for a number of years on this issue. In 1555, Johann

43 For more on the contents of the book, see Volker Leppin, »Bekenntnisbildung als Katastrophenverarbeitung. Das Konfutationsbuch als ernestinische Ortsbestimmung nach dem Tode Johann Friedrichs I., in Volker Leppin, Georg Schmidt, and Sabine Wefers (eds.), Johann Friedrich I. - der lutherische Kurfürst [Schriften des Vereins für Reformationsgeschichte 204] (Gütersloh: Gütersloher Verlaghaus, 2006), 295-306, here 299-304.

44 For more on this controversy, see Luther D. Peterson, »Synergist Controversy, « in The Oxford Encyclopedia of the Reformation 4: 133-135; Robert Kolb, Bound Choice, Election, and Wittenberg Theological Method: from Martin Luther to the Formula of Concord [Lutheran Quarterly Books] (Grand Rapids/Cambridge: Eerdmans, 2005), 106-127; Irene Dingel, »The Culture of Conflict in the Controversies Leading to the Formula of Concord (1548-1580), « in Robert Kolb (ed.), Lutheran Ecclesiastical Culture, 1550-1675 [Brill Companions to the Christian Tradition 11] (Leiden/Boston: Brill, 2008), 15-64, here 45-50.

45 The Latin edition (see n. 39) consists of ten folios under the title Confvtatio corrvptelarvm in Articulo de libero Arbitrio, seu de Viribus humanis, H4v-K1r (32b-37), while the German 
Pfeffinger, professor in Leipzig, stirred up public attention with his work »Five Questions Concerning the Liberty of the Human Will. ${ }^{46} \mathrm{He}$ contended that humans must play their part in conversion. Flacius responded by writing Refutation of Pfeffinger's Propositions Concerning Free Will. ${ }^{47}$ The Weimar court preacher, Aurifaber also edited a book against Pfeffinger's proposition, dating his preface on October 1, 1558. Aurifaber actually published a posthumous work written by his predecessor Johann Stoltz, and also included Flacius' Refutation of Pfeffinger. ${ }^{48}$

Superintendent Hügel refused to read the Book of Confutation from the pulpit, while Strigel criticized it before his students in the classroom. Strigel's main objection was directed at the passivity of the will in salvation, as stated in the Konfutationsbuch. Instead, he defended Melanchthon's position from the third edition of Loci communes, namely that the human will cooperates in conversion with the Word and the Holy Spirit. Because of their public opposition, the Duke ordered that Strigel and Hügel be arrested in Jena on the morning of Easter Monday, March 27, 1559, and he kept them in prison until September and November, respectively. Flacius was accused of being behind the arrest, but he denied the charges.

In the meantime a Gnesio-Lutheran pastor, Balthasar Winter, took Andreas Hügel's position as a city superintendent. Flacius then succeeded in persuading the ducal court to invite superintendent Simon Musaeus ${ }^{49}$ to become a professor of theology instead of Johann Stössel, who was apparently the first choice for the position by some members of the court. It was also negotiated that Musaeus' salary be equal to Flacius'. The fact that Flacius had such an influence on the court in the appointment of a professor and that he wrote the final and authoritative version of the Book of Confutation, demonstrate that he was now established in Ernestine Saxony and that his theological stances were prevailing. Lastly, Wigand and Judex were hired as professors of theology in April $1560 .^{50}$

edition (see n. 38) has twenty-two folios, Widerlegung der Irrthum im Artikel vom freien Willen/vnd des Menschen Krefften, L2v-M5r (74b-85).

46 Johannes Pfeffinger, De libertate voluntatis humanae qvaestiones qvinqve. D. Iohannes Pfeffinger (Leipzig: Georg Hantzsch, 1555; VD16 P 2327).

47 Flacius, Refvtatio propositionum Pfeffingeri de Libero arbitrio ... M. Fla. Illyrici de eadem materia controversia (Jena: Thomas Rebart, 1558; VD16 F 1478), D4v-L4r.

48 Aurifaber [Vimariensis] (ed.), Ioannis Stolsii Concionatoris Avlici Ducum Saxoniae Refutatio propositionum Pfeffingeri de Libero arbitrio, cum Praefatione M. Ioannis Aurifabri. Matth: Fla: Illyrici de eadam controuersia (Jena: Thomas Rebart, 1558; VD16 S 9267).

49 For Musaeus' biography, see Theodor Mahlmann, »Musäus, Simon, « in Religion in Geschichte und Gegenwart $5^{4}$ (2002), 1591.

50 Preger, Flacius und seine Zeit, 2: 126. Ronald Diener has located a document written in Wigand's hand also on behalf of Judex to the city senate of Magdeburg, bidding them farewell, dated on November 23, 1559. Diener, The Magdeburg Centuries, 189. This poses a question about their whereabouts in-between. 
According to Kurt Hannemann, on April 28, 1560 in Jena, Flacius ordained Andreas Fabricius to the office of pastor. ${ }^{51}$ Fabricius received a master's degree in Wittenberg in July 1554 and later that year he became the school rector in Nordhausen upon Melanchthon's recommendation. ${ }^{52}$ Following his ordination Fabricius first served the Church of St. Nicholas in Nordhausen as an assistant pastor and in March 1564 became senior pastor of St. Peter in Nordhausen. The question is how Flacius could become a general superintendent in the first place without previously having been ordained and whether there was an installation ceremony at which some kind of dispensation and authority were granted to him. This is an area of Flacius studies that has not been researched and explored thus far but could provide an interesting contribution to how the regional churches in Germany functioned in the sixteenth century and could shed light on yet another aspect of Flacius' role within the church structures. The fact that Stigel, in a letter he wrote in 1558, complained about the doctrinal rigidity within what he called the »Ecclesia Flaciana," points to the fact that Flacius indeed had exercised a leadership role over the life and teaching of the church..$^{53}$

The arrival of Wigand and Judex from Magdeburg signaled that the power dynamics at the theological faculty have been completely changed. Even though Strigel was allowed to return to teaching at the university after his release, he was transferred to the philosophical faculty, leaving the theological education in Jena now to Flacius, Musaeus, Wigand and Judex. However, the tensions caused by disagreements concerning monergism versus synergism were not resolved and they still lingered on. A public disputation between Flacius and Strigel was therefore organized to address the issue.

51 Kurt Hannemann, »Der Humanist Georg Fabricius in Meissen, das Luthermonotessaron in Wittenberg und Leipzig und der Heilandpreaefatiokodex aus Naumburg a.d. Saale,« Annali Sezione Germanica 17: Filologica Germanica (Napels, 1974): 7-109, here 89: »Am 28.4.1560 in Jena von Flacius zum Pfarrer ordiniert.«

52 See Melanchthon's letter from 5 April 1554 to the mayor of the free imperial city of Nordhausen, Michael Meyenburg, in MBW 7141 (Regesten 7: 179); CR 8: 264, Nr. 5578.

53 Pflanz, Johann Stigel als Theologe, 107. In a letter to Caspar Peucer in Wittenberg dated October 26, 1558, Stigel complained that in the »Ecclessia Flaciana« it is a capital crime not to read writings by Flacius and like-minded theologians, letter Nr. 19, 139-140, here 140. In another letter to Melanchthon he referred to Flacius as »Pope Illyricus« (Papatus Illyricus), letter Nr. 17 in Pflanz, 136-137; MBW 8091 (Regesten 8: 23-24). Christian Schütz, a pastor in Albertine Saxony, once referred mockingly to the Illyrian's growing circle of followers as the »Flacian Synagogue« (Flazianer Synagoga). 


\section{The Weimar Disputation of 1560 and its Aftermath}

The purpose of the colloquium at Weimar was to clarify the role of the human being's free will in salvation. In preparation for the debate each participant wrote seven theses about free will ahead of time. Flacius composed his theses together with Musaeus, while Strigel wrote his own. ${ }^{54}$ These theses were approved by Christian Brück, who then drew up the rules of conduct for the public disputation and decided on the form it would take. The Saxon disputation lasted thirteen sessions which were spread over seven days in the morning and the afternoon (with the exception of Sunday morning) from August 2 to 8, 1560. Immediately at the first session Flacius began to make a case for a relationship between free will and original sin. He stated that human beings had lost all their powers to do good because original sin had corrupted their free will to such an extent that they had no choice left to them in matters of conversion. Flacius presented this in a form of a syllogism:

»Major: Something that has lost its positive energy cannot produce any good (as an example Flacius used the biblical story of a bad tree that cannot bear good fruit).

Minor: Following the testimony of the Holy Scriptures, humankind did not only lose their God-given power toward good works, but on the contrary they received powers inclined toward evil.

Conclusion: Therefore it is impossible that human beings can contribute to their salvation through their good works. Can anyone pick grapes from a thornbush? [Matthew $7: 16], \varkappa^{55}$ he asked.

Strigel replied with an analogy of a man robbed by thieves, who not only stole their victim's possessions but left him sorely injured. He wanted to explain that even though humans were left without their good powers because the devil had robbed them, they were still alive and possessed their intellect, heart and will. Flacius attacked this analogy by saying:

I know that those individuals who defend human powers (just as you are now doing) are in the habit of fleeing to this comparison of the wound, as if it meant that human nature was ruined in its entirety; but that is not it at all. For that poor man, even if he

54 Simon Musaeus (ed.), Dispvtatio de originali peccato et libero arbitrio, inter Matthiam Flacium Illyricum et Victorinum Strigelium publice Vinariae per integram hebdomadam, praesentibus Illustriss. Saxoniae Princibus, Anno 1560. initio mensis Augusti habita... (Basel: Johannes Oporinus, 1562; VD16 F 1354), 1-4. All fourteen theses are reprinted in Eduard Schmid, »Des Flacius Erbsünde - Streit. Historisch-literarisch dargestellt: bis zum weimarischen Convent 1571, « Zeitschrift für die Historische Theologie 19/1 (1849): 3-78, here 24-25.

55 Musaeus (ed.), Dispvtatio de originali peccato et libero arbitrio, 10: »... Num de spinis uvae colliguntur?« 


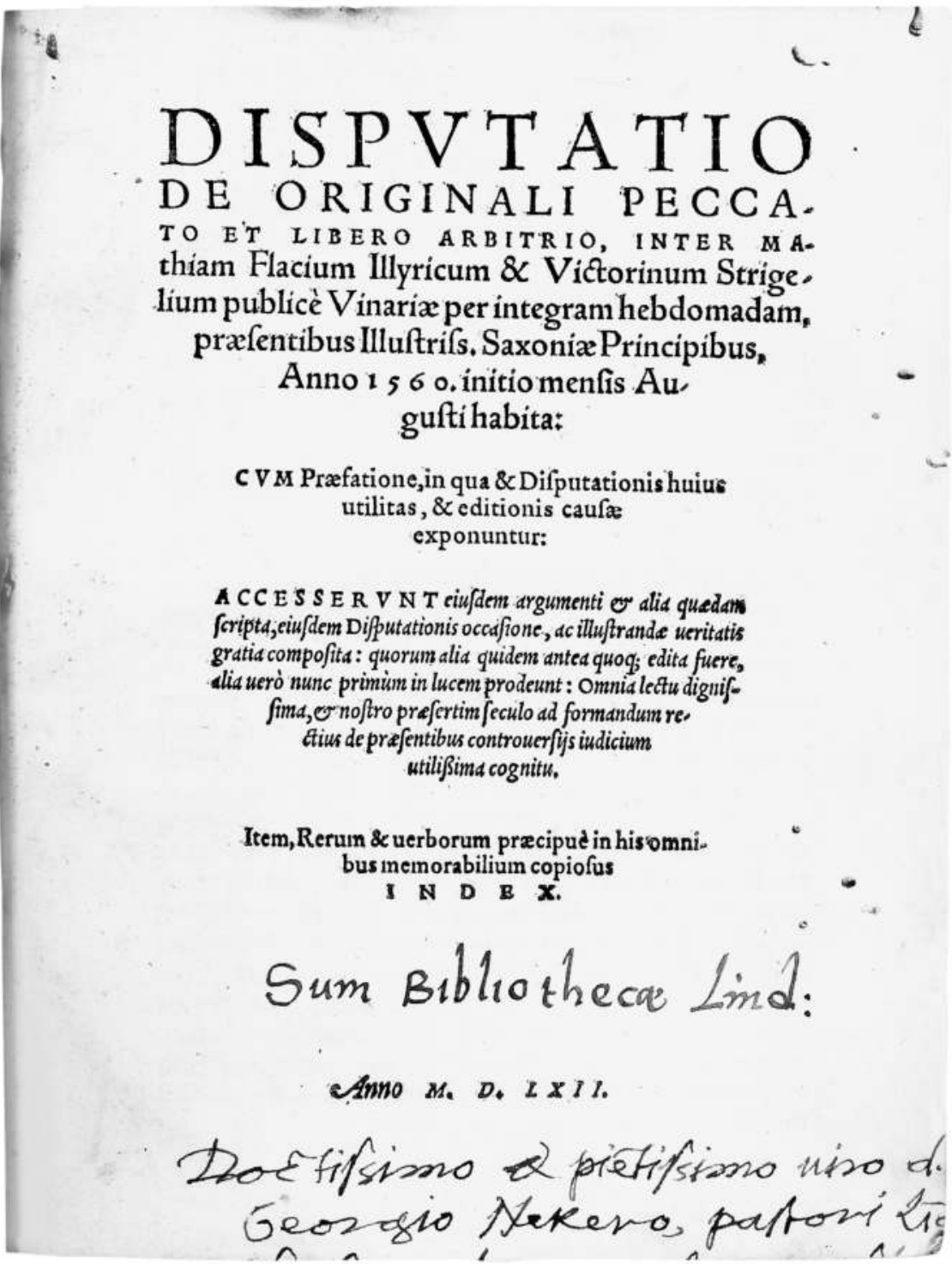

Figure 7: The title page Flacius' Dispvtatio de originali peccato from 1562 with his handwritten dedication to Georg Necker in Lindau. Courtesy of Ehemals Reichsstädtische Bibliothek Lindau: shelfmark ERB-Lindau N III 195. 
was critically wounded by the thieves, nevertheless did not lose all sparks and flashes of life, nor was he completely killed. Otherwise he could not have been revived and healed. Therefore, I assert that man in the original fall was not only wounded but (as Scripture confirms) was completely killed, extinguished and incapacitated to do good in all spiritual things. And in its place was added animation and activity inclined toward evil. I believe that you wish to demonstrate by this comparison the gravely wounded human nature. But if any help or medicine is administered to him then that synergy is able to be healed and convalesce. ${ }^{56}$

In the second session after lunch on the first day Strigel rejected this explanation by Flacius but admitted that humankind was affected by the fall to such an extent that their body and soul had become polluted. However, according to him, the human being's powers were only injured by sin and the original substance that they possessed at the creation had not been destroyed, transformed or removed, but only incapacitated. Strigel's main argument was that the substance of humans must have remained, because if it had been transformed then the species would have become something completely different than originally intended. At that point, Strigel declared that original sin is a quality (accidens) that is combined with free will.

After Flacius objected to this statement, Strigel addressed him with the direct question, $»$ Do you deny that original sin is an accident (quality)? $\ll^{57}$ Flacius responded by employing Luther and the Apostle Paul, »Luther eloquently denied it to be an accident. Scripture too testifies that a person in their intellect is not only dead, killed and removed as regards divine things, but is also transformed into the image of Satan. Colossians 2. ( $^{58}$ Flacius' argument was that sin has depraved and corrupted human beings so that they have become an enemy of God. In his understanding, the Scripture teaches

56 Musaeus (ed.), Disputatio de originali peccato et libero arbitrio, 11-12: »Scio eo confugere solere illos qui vires humanas defendunt, (ut \& tu iam id facis) ad illam similitudinem de sauciato, tanquam prorsus res ita se haberet in ruina humanae naturae: cum plurimum differat. Ille enim miser, etsi fuerat a latronibus sauciatus horribiliter, non tamen prorsus omnes scintillas ac micas vitae amiserat: nec erat totaliter extinctus, alioqui non potuisset reviviscere \& sanari. Ego vero affero hominem originali lapsu non tantum sauciatum, sed (ut Scriptura affirmat) esse penitus mortuum, extinctum \& interfectum ad bonum in spiritualibus: \& contra insuper vivum ac vigentem, ad malum. Illud igitur desidero, quod hoc simili vis ostendere, esse quidem graviter sauciatam naturam humanam: sed si addatur ei aliquid opis \& medicaminis, tum posse synergiam illam convalescere \& sanari.«

57 Ibid., 25: »An negas peccatum originis esse accidens?«

58 Ibid., 25: »Lutherus diserte negat esse accidens. Contra Scriptura testatur, in intellectu hominem non modo mortuum, intersectum \& sublatum, quo ad divina: sed etiam ad imaginem Satanae, transformatum esse. Colos. 2.« Quoted in Heinrich J. Vogel, »The Flacian Controversy on Original Sin, « in Arnold J. Koelpin (ed.), No Other Gospel: Essays in Commemoration of the 400 ${ }^{\text {th }}$ Anniversary of the Formula of Concord 1580-1980 (Milwaukee, WI: Northwestern Publishing House, 1980), 1-15, here 4. 
that the change that took place after the fall was that sin became the substance and the very essence of a person and because of it the person's ability to know God has been lost.

Flacius also created a distinction between the person's formal and material substance. He explained that the formal substance of a person was their original essence, which was made up of their unique righteousness and holiness, really free and in the right relationship with God. In other words, the image of God is the formal essence of a person, which has been changed by original sin into a contrary image, namely into the image of Satan himself. Other gifts that God bestowed upon humanity in creation were not lost in the fall and those gifts Flacius described as material substance. Only the best part of a person has been corrupted, namely their soul. Thus, he distinguished between the sinless condition of Adam and Eve in the garden before they sinned, which he called formal substance, and their state after committing sin, which is the material substance or sinful nature. ${ }^{59}$

The disputation ended on August 8 not because Flacius lost the debate, as some sources suggest, but mainly because the son of the Saxon Duke, Johann Friedrich II, who was presiding at the colloquium, Prince Johann Friedrich IV died (at nine months old) on that day in the castle where the disputation was being held. The burial needed to be done immediately since it was summer and they did not have ways to preserve the body. ${ }^{60} \mathrm{Schmid}$ wrongly states that the prince died on August 2, the day the disputation began ${ }^{61}$ No official outcome of the disputation was issued by the ducal court so that there was not apparent winner or loser. Perhaps such a decision was made in order to allow time for the already heated situation in Jena, caused by the Book of Confutation and Strigel's and Hügel's arrest, to cool down. ${ }^{62}$

Soon after the end of the disputation a new controversy broke out in Jena. In September 1560 Superintendent Winter refused to allow professor Christoph Dürfeld to partake of the Lord's Supper because he had apparently said that theology could be learned from Seneca. Winter also accused Dürfeld of heretical teaching concerning free will. Prior to that event, Winter forbade

59 For an explanation of the usage of the term »formal substance« (forma substantialis) by Flacius, see Hans Kropatscheck, Das Problem theologischer Anthropologie auf dem Weimarer Gespräch von 1560 zwischen Matthias Flacius Illyricus und Viktorin Strigel (Göttingen: Georg-August-Universität, Th.D. Diss., 1943), 86-90.

60 For the Latin funeral epitaph by the Poet lauerate Paul Siber, see Epitaphivm Illvstrissimi Principis, ac Domini, D. Ioannis Friderici IIII. Filii Illvstriss: Principis, D. Ioan: Fridericii II. Dvcis Saxoniae, Landgravii Thvringae, Marchionis Misniae, Scriptvm a. Pavlo Sibero (Jena: Donat Richtzenhan, August 1560; VD16 S 6242).

61 Schmid, »Des Flacius Erbsünde - Streit, « 26 n. 54.

62 For more on the Weimar Disputation, see Luka Ilić, The Understanding of Sin in the Theology of Matthias Flacius Illyricus (Amsterdam: Vrije Universiteit, Master of Arts thesis, 2005), 40-45. 
another professor from the university, jurist Matthias Wesenbeck, from being the baptismal sponsor to Johann Stiegel's baby boy on July 8 because Wesenbeck had refused to express an opinion on the Konfutationsbuch. Such ecclesiastical rigidity angered many of Jena's prominent citizens who complained to the ducal court. Flacius, Musaeus, Wigand and Judex, representing the theological faculty, stood on Winter's side arguing that the Duke should not intervene in the affairs of the church - but to no avail, as on October 29, 1560 Winter was removed from office. This was clearly a sign that Flacius and his party were beginning to lose favor with the courtiers and with the Duke himself.

During 1561 it became obvious to Duke Johann Friedrich II and his advisors that it was becoming difficult to control the Jena theologians. They were refusing to submit their manuscripts for review before publication and rejected the censorship regulations in place..$^{63}$ Therefore, a consistorial order was established and approved in July. ${ }^{64}$ The consistory was given the highest instance of decision-making in matters of censorship and doctrinal conflicts, and all theologians were required to subordinate themselves to its authority. It was presided over by the Duke himself and composed of four political advisors: Chancellor Christian Brück, Matthes von Wallenrod, Heinrich Schneidewein, and Lukas Thangel, and four superintendents: Maximilian Mörlin from Coburg, Johann Stössel from Jena and Heldburg, Bartholomäus Rosinus from Weimar and Caspar Molitor from Orlamünde, who were supposed to meet four times a year in Weimar. Flacius and his like-minded colleuagues from the Jena theological faculty or any of his sympathizers were excluded from the consistory.

The establishment of the consistory was aimed at curbing the power and the activities of Flacius and his three colleagues. Sensing that the situation was changing to their disadvantage, on September 10, 1561 Musaeus left Jena to take the position of superintendent of Bremen vacated by Albert Hardenberg at the cathedral. On October 1 Judex was fired from Jena University and was ordered to leave the city with his wife and five children. The four reasons for his expulsion named in the official document were: ${ }^{65}$

63 As an example of resistance to ducal censorship by Judex, see Robert Kolb, »Matthaeus Judex’s Condemnation of Princely Censorship of Theologians' Publications, « Church History 50 (1991): 401-414.

64 The printed version is dated on St. Kilian's Day (July 8), 1561. Ordenung vnd summarischer Process des Fuerstlichen Sechsischen Consistorij. Auffgerichtet in dem jar. M.D.LXI. (Jena: Thomas Rebart, 1561; VD16 S 1105), C3r. For more on the consistorial order, see Gehrt, Ernestinische Konfessionspolitik, 196-201.

65 See the document »Ursachen, Warumb der Hoff M. Judicem zu Jhena enturlaubet hatt, « in Carl Hieronymus Wilhelm Sillem (ed.), Briefsammlung des Hamburgischen Superintendenten Joachim Westphal aus dem Jahren 1530 bis 1575. Zweite Abteilung. Briefe aus den Jahren 1559 bis 1575 (Hamburg: Lucas Gräfe \& Sillem, 1903), 456-458. 
1. disobedience to the mandate of the Consistory (Konsistorialordnung);

2. publishing a book without approval; $; 6$

3. openly criticizing the ducal court in Weimar; and

4. writing against religious peace and particularly against the Treaty of Passau.

After Judex's dismissal, Aurifaber [Vimariensis] was let go from his position later in October. Flacius and Wigand wrote a letter to Stössel, who had become superintendent in Jena in the meantime, complaining about Johann Friedrich II's church politics. Instead of responding directly to them, Stössel showed the letter to a number of professors, who then wrote a list of accusations against the theologians, which, along with Stössel's own charges against Flacius and his colleagues, was sent to the ducal court. As a result, Flacius and Wigand had to stand trial on November 25, at which they tried to defend themselves in the face of a long list of charges. In the end, they lost their case before the ducal court in Weimar and the negative decision was announced on December 10, 1561 ordering them to be dismissed from their professorial posts at the university. ${ }^{67}$ Furthermore, an ecclesiastical ban was pronounced prohibiting them from teaching further in the territory of Ducal Saxony.

\section{Final Analysis of Flacius' Jena Years}

Slenczka's new findings add to the thesis already established by Mijo Mirković that Flacius' Jena years were the least productive ones in his whole career in terms of literary output. ${ }^{68}$ On the other hand, Flacius' rise within the ranks of the ecclesiastical and academic hierarchies meant greater recognition of his contributions, but along with increased influence also came a greater workload. His intense involvement in church affairs and politics was one of the reasons for not having time for writing, researching and publishing as before.

The sources for frictions with his colleagues and fellow churchmen varied, but rivalry, money, doctrine and even nationalism, all played a role and fueled criticism. One of the issues upsetting people was that Flacius' salary, as

66 The book in question is Der Ewigen/Allmechtigen Goettlichenn Mayest. Mandat/vnd ernstlicher befelch/wes sich ein yeder Christ/nach seinem berueff vind stande/gegen dem offenbarrten Antichrist/das gantze Babstumb/halten solle/widerholet vnd erkleret/Durch Mattheum Judicem (s.1.: 1561; VD16 R 2246). It was Judex's direct attack on the decree by Duke Johann Friedrich II issued on July 8, 1561 forbidding all theologians to publish anything without his prior approval, so that Judex's crime was breaking the censorship law and exercising free speech in print.

67 Preger, Flacius und seine Zeit, 2: 173-174; Mirković, Matija Vlačić Ilirik, 194-196.

68 Mirković, Matija Vlačić Ilirik, 209-213. 
well as that of his three friends for whom he was instrumental in securing positions at the theological faculty, was almost double than what the local lecturers were earning. They were outsiders whose perceived success and recognition did not please everyone. A recurring charge used by Flacius' critics and enemies was the fact that he was a Slav ${ }^{69}$ i.e. a foreigner. This was only one side of the coin. The other side of the story was that Flacius failed to effectively address and soothe the criticisms leveled against him by not expressing a conciliatory tone. His behavior was exacerbated by the fact that he was now in a position from where he could use his authority to force others to agree with him. Naturally, he was neither the first, nor the last churchman to use such methods but this time his lack of a thought-out strategy and short-sightedness backfired. In the end, starting a new faculty of theology, which he had been asked to do by the dukes of Weimar, and contributing to establishing a university that would match the one in Wittenberg proved to be too big of a challenge for Flacius.

In addition, the limitations of his influence within the ecclesiastical and political power structures in Ernestine Saxony had been revealed when his radical theological stances did not prevail over those of others at the Colloquy of Worms. Although with the breakdown of talks and the dissolution of the colloquy Flacius may have achieved what he originally desired, it did not happen the way he wanted it. After all, his call to condemn "all adiaphoristic alliances « was not accepted - in spite of repeated attempts through various channels. This may have been the reason why Flacius turned to writing and compiling a Book of Confutation (Konfutationsbuch), a normative confessional document for the Ernestine territories, through which he was hoping to achieve his goals.

His reputation was damaged and he quickly lost his standing with other imperial estates, too. One such example is reflected in the letter Elector August I of Saxony wrote to Baron Hans Ungnad von Sonnegg on January 7, 1562, to whom he had given 200 Gulden for the work of a Slavic printing press in Urach, »... I graciously ask you to persist diligently in ensuring that the Bible and Dr. Luther's Hauspostil should get printed and produced as a priority, unadulterated in the aforementioned languages, and not the pamphlets and excesses [Schwärmerei] of that rabble-rouser Illyricus. $\aleph^{70}$ As a

69 Rudolf Herrmann, Thüringische Kirchengeschichte, 2 vols. (Weimar: Hermann Böhlaus Nachfolger, 1947, [reprint, Waltrop: Hartmut Spenner, 2000]), 2: 146: »Er war ein Slave, was ihm von seinen Gegnern häufig vorgehalten wurde.«

$70 \gg \ldots$ vnd begeren gnedigst, ir wollet mit vleiss anhalten, dass die biblia vnnd doctor Lutheri hausspostill vnd nit etwa dess rottengeists Illirici tractetlein vnnd schwermerei förderlichst möcht inn berurten sprachen vnuerfelscht gedruckt vnnd gefertigt werdenn.« Ivan Kostrenčić, Urkundliche Beiträge zur Geschichte der protestantischen Literatur der Südslaven in den Jahren 1559-1565 (Wien: Carl Gerold's Sohn, 1874), 67-8, here 68. Ernst Benz, Wittenberg und 
growing number of influential people, such as Elector August I, were distancing themselves from his theological immoderation, Flacius was losing their support and any influence over the causes he had considered important at a rapid pace.

As previously argued, Flacius' radicalization reached its full extent during this time period. Not only was he adamant about holding on to his theological positions by not showing any willingness to re-think or modify them but this rigidity also began to rapidly influence his personal and professional relationships in a negative manner. Through his statements and behavior he was polarizing an ever growing circle of people. In the final phase of his radicalization during the last years of his life he would have to face the consequences of the controversies he was causing. 



\title{
Chapter Four
}

\author{
Phase Three: \\ Flacius' Attempts at Rehabilitation \\ and Vindication, 1562-1575
}

During the four years and eight months Flacius spent in Jena he did not write any significant work and almost everything that he tried to accomplish failed, including the goal he was trying to achieve via the Book of Confutation. He continued to struggle with a lack of confidence in speaking German; at the Weimar disputation in August 1560 he openly admitted that his pronunciation of German was not good. ${ }^{1}$ Also, during the trial in Weimar on November 25, 1561 he spoke Latin, while Wigand used German.

The unequivocal pronouncement of the ducal court meant that Flacius and his family would have to be uprooted once again. This time the transition was all the more difficult due to a number of different factors. It was the beginning of winter, with Christmas approaching. It also seems that there was not sufficient time given to Flacius to put his affairs in order before leaving and to make arrangements for his wife and many children or regarding the house he had purchased, including his personal library and furniture.

A letter written by Johannes Aurifaber [Vimariensis], to Gaspar Achilles in Augsburg dated on January 9, 1562, tells us that Flacius left Jena in midDecember, and for three weeks he moved around secretly in the territories from which he was banned. He was in Naumburg (Saale) and in other towns, among which was Bufleben north of Gotha, where Flacius was given refuge for two days by his friend Marcus Wagner, who had been pastor there since 1559. ${ }^{2} \mathrm{He}$ was hidden by brothers ( fratri) and peasants at other times.

Aurifaber explained in his letter that Flacius was waiting for his wife and children to leave Jena and that he eventually was reunited with the family in Rudolstadt. From there they began their journey to Nuremberg on January 7 , 1562 and first made a stop in Fulda. ${ }^{3}$ Flacius' plan was to travel from Nuremberg to Regensburg, where he had decided to settle and live as a private

1 Flacius wrote the overwhelming majority of his works and letters in Latin but there is at least one letter in German in his handwriting from 1563, revealing a good command of the written language (see Figure 9). StAR, Eccl. I, 59, 29, 35191-35193.

2 Preger, Flacius und seine Zeit, 2: 179.

3 Ibid. 
citizen. ${ }^{4}$ This letter by Aurifaber is of importance because it sheds new light on Flacius' whereabouts after his dismissal from Jena. For example, Preger presented no exact timeframe for the various stages of Flacius' transition, and offered only the approximation that he left Jena before February 2, 1562. ${ }^{5}$ Mijo Mirković made a much closer guess by writing that Flacius left Jena immediately after December 10 , but he did not cite any sources to support his statement. ${ }^{6}$

During the period of Flacius' secret travels, his friend, Nikolaus Gallus, superintendent in Regensburg, negotiated with the local authorities there in order to procure from the city council a residency permit for Flacius. Flacius wrote to Gallus from Nuremberg, stating that he had arrived there on February 9 and asked him to find an adequate house or apartment with at least two rooms of medium size and the possibility of heating since it was winter?

Flacius' first-born son, Matthias, the Younger stayed behind in Jena and matriculated at the university in the Summer Semester of 1562 under the rectorship of Mathias Colerus. ${ }^{8}$ The Slovenian Sebastian Krell, who had been Flacius' student, also remained a little longer in Jena and kept Flacius informed of the events in the city before joining him in Regensburg. ${ }^{9}$

4 Aurifaber [Vratislaviensis] to Gasser, Weimar, January 9, 1562, in Burmeister, Achilles Pirmin Gasser. III. Briefwechsel, 186-192, here 187: »Dominus Illiricus ex ea urbe ante tres septimanas discesserat, nam insidiae et vincula a quibusdam ipsi struebantur. Clam igitur inde auxilio fratrum aufugit et Naumburgi ac in aliis locis apud contiones paganos hinc et inde latitavit, donec ipsius coniunx et liberi etiam ex Ihena emigrarent ipsumque Rudelstadii convenirent. Cum quibus ante biduum discessit Norimbergam, inde Ratisbonam petet, ubi aliquandiu privatam vitam agere statuit.« The letter further mentioned that Judex left Jena on January 1, 1562 for Magdeburg; that Wigand would most likely follow him during the week since they planned to continue working together on The Magdeburg Centuries; and that Aurifaber was also negotiating about his own relocation to Magdeburg.

5 Preger, Flacius und seine Zeit, 2: 179: »Aber schon vor dem 2. Februar scheint er Jena verlassen zu haben.«

6 Mirković, Matija Vlačić Ilirik, 196 (Croatian text) and 515:»Schon im Dezember 1561 flüchtete Flacius von Jena zunächst nach einem Nachbarorte in Thüringen, dann nach Nürnberg und im Februar 1562 nach Regensburg."

7 Flacius to Gallus, February 10, 1562: „Veni iam Norib: nono februari ... Quare maximeque te oro et obsecro ut mihi conduces aliquod mediocre domicilium in quo praecipue spectes salubritatem. Si omnino non posset haberi duo hypocausta, possam forte contentus esse pro me aliquot mediocri, sed tamen non inamoeno cocnclavi, cum iam hyeme propteriisse videatur.« StAR, Eccl. I, 21, 309, 12666. Letter cited in Mirković, Matija Vlačić Ilirik, 216-217.

8 Mentz (ed.), Die Matrikel der Universität Jena, 103: »Flacius, Mathi., Illyricus, junior.«

9 Mirković, Matija Vlačić Ilirik, 196. 


\section{FIDELIS ADMO"}

NITIO DE RETINENDO SACRO. SANCTO IESV CHRISTI TESTAMEN

TO INCORRVPTO, ACIN SVO natiuo fenfu, contra omnes impolturås \&

Sophismata feductorum

$\because$

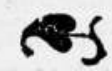

$\because$

c.

\section{PER MATTHIAM FLACIVM ILLYRICVM.}

\section{Gala. 3.}

Fratres, fecundum hominem dico, Hominis licet Teftamentum, tamen, fifit comprobatum, nemo reijcit aut addit aliquid. Multo ergo minus licet Teftamentum filij Dei humanis additamentis peruertere. Omnis quifumit corpus domini indignè, iudicium \& exitium fibimet fumit:Sed omnis non eredens Chrifto dicenti,Hoc, hoc eft corpus \& fanguis meus, fumit indigne, Igitur fibimet in exitium

\section{D. LXII.}

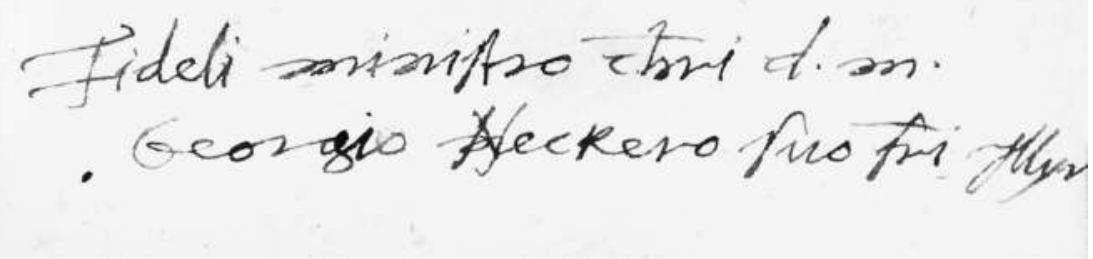

Figure 8: The title page Flacius' Fidelis admonitio from 1562 with his handwritten dedication to Georg Necker in Lindau. Courtesy of Ehemals Reichsstädtische Bibliothek Lindau: shelfmark ERB-Lindau K II 110-2. 


\section{A Wandering Scholar: \\ Flacius' Time at Regensburg, 1562-1566}

When the councilors of Regensburg made a favorable decision allowing Flacius to reside in their city, he then relocated there sometime in February 1562 . Soon afterwards complaints about the city's decision to permit Flacius to live in Regensburg began to arrive, among them a letter from the imperial secretary Wolfgang Haller, ${ }^{10}$ who wrote from Prague on April 13, ${ }^{11}$ informing the city lawyer and advisor to the city council Johannes Hiltner ${ }^{12}$ of his displeasure. However, the permit contained certain limitations, such as forbidding Flacius to get involved in further controversies. ${ }^{13}$ Duke Johann Friedrich II wrote from Weimar on May 25, 1562 to the city council of Regensburg requesting that they forbid Flacius and Gallus to publish "Lästerschriften « in the city. ${ }^{14}$ The city leadership replied on 9 June, in the handwriting of Johannes Hiltner. ${ }^{15}$

Amsdorf's favorable testimony at this crucial period in early 1562 about Flacius' »innocence and pure teaching " (unschuld und reine Lehre) was important in the sense that Amsdorf was seen as a Gnesio-Lutheran Praeceptor and therefore had the authority to clear Flacius' name from the accusations. ${ }^{16}$

One of the conditions of the asylum granted to Flacius by the city council was a prohibition of him printing anything in the city. However, while living in Regensburg, an account of his Weimar disputation with Strigel was issued in print by Simon Musaeus in 1562, containing Flacius' positions on original

10 MBW 12: Personen F-K, 219.

11 The original letter written in German is stored at StAR, Eccl. I, 17, 14, 10480-10487. Haller is startled by the residence granted to Illyricus in Regensburg and provides a very unfavorable judgment of this development.

12 Kuhr, Georg, »Hiltner, Johannes, « in NDB 9 (1972), 165. See also Hiltner's reply to Haller dated on May 16, 1562, StAR, Eccl. I, 17, 17, 10488-10507.

13 See the council minutes from March 9. Ratsprotokoll über die Verhandlung mit Fl. Illyrikus, welcher ein »Trostbüchlein für die verfolgten und geplagten Christen« hier drucken lassen wollte. StAR, Eccl. I, 17, 21, 10508-10515.

14 StAR, Eccl. I, 17, 42, 10538-10541. The letter is printed in Karl Schottenloher (ed.), Das Regensburger Buchgewerbe im 15. und 16 Jahrhundert mit Akten und Druckverzeichnis [Veröffentlichungen der Gutenberg-Gesellschaft 14-19] (Mainz: Verlag der GutenbergGesellschaft, 1920), 141-142.

15 StAR, Eccl. I, 17, 43, 10542-10547. Schottenloher, Das Regensburger Buchgewerbe, 142-144.

16 Von Amsdorf, »Sendbrieff Herrn Nicolai Ambsdorffij von der vnschuld vnd reiner ler M. F1. Ill.« The open letter was signed in Eisenach on the first Sunday of Lent (Invocavit) 1562. BSB, Collectio Waldneriana III, toms b, Cod. Germ. 4110b, 9r-12v. Printed in: Matthias Flacius (ed.), Erzehlung. Wie der Hochwichtig vnnd langwirige Religionstreit/Victorini in Thueringen/endlich geschlichtet worden sey/durch die Mitler beschriben/Allen liebhabern der Warheit/ sehr nützlich zulesen. Jetzo vonn newem mit fleis Corrigirt/vnnd an vilen orthen gemehrt vnd gebesert (Regensburg: Heinrich Geißler, 1563; VD16 F 1383), G3r-G4r. 
sin and free will under the title Disputatio de Originali Peccato et Libero Arbitrio. Flacius also dedicated the second edition of the Catalogus, which was significantly expanded compared to the first edition, to the city senate and the Church of Lübeck. ${ }^{17}$ The German translation was completed by Conrad Lautenbach and issued in Frankfurt in 1573. Flacius was consulted during the translation and therefore this edition can be counted as the last one authorized by him. ${ }^{18}$

\section{a) Flacius' Missionary Plans: Endeavors at Establishing Theological Schools in Regensburg and Klagenfurt}

Flacius wrote a letter to Bartholomaeus Schober on December 12, 1561, only two days after the court decision in Weimar, in which he laid out his plans for the founding of a theological school (Academie) ${ }^{19}$ In this letter Flacius

17 Flacius, Catalogvs Testium ueritatis, qui ante nostram aetatem Pontifici Romano, eiusque erroribus reclamarunt: iam denuo longe quam antea, \& emendatior \& auctior editus. Opus varia rerum... Cum Praefatione Matthiae Flacii Illyrici, qua Operis huius \& ratio \& usus exponitur (Strasbourg [Basel]: Paul Messerschmidt and Johannes Oporinus, 1562; VD16 F 1294. The second edition contained four hundred and thirty witnesses.

18 Catalogvs Testivm Veritatis: Historia der zeugen/Bekenner vnd Maerterer/so Christum vnd die Euangelische warheit biss hieher /auch etwa mitten im Reich der finsternus /warhafftig erkennet/Christlich vnd auffrichtig bekennet/vnd dem Baepstlichen vermeinten Primat/jrrthumen lergerlichem leben vnd lastern lerstlich widersprochen /Auch mehrertheils uber solchem Christlichen kampff/unbillichem Hasz/grewliche verfolgung/harte gefencknus/vnd den todt selber/ritterlich außgestanden vnd erlidten haben. Jetzt neulich dem teutschen Leser zu gutem / ... auß dem Latein in vnsere gemeine Teutsche sprach gebracht vnd verfertigt/Durch Conradum Lautenbach von Mutißlar/Pfarherrn zu Hunaweiler (Frankfurt: Johann Schmidt, 1573: VD16 1295). In the seventeeth century several Latin and German editions of Catalogus were also printed.

19 Preger, Flacius und seine Zeit, 2: 175. Preger refers to him only as »Schober,« without identifying him. Schober is also mentioned in a 1564 dedication to volume eight of The Magdeburg Centuries as »exuli Christi« (for more about that dedication see Chapter One, note 62): »... et domino Bartolomeo Schober, exuli Christi.« He was from Austria and was exiled by the Roman Catholic bishop of Salzburg and found religious asylum in Nuremberg. In 1563 he was exiled from Nuremberg because of providing accommodation for Flacius. He then moved to Regensburg, where he was granted citizenship. Burmeister states that he could not identify who he is, Achilles Pirmin Gasser. III. Briefwechsel, 284. Schober later published a work supporting Flacius' teaching regarding the original sin. See, Kurtze vnd klare richtige Antwort/des Herrn Bartel Schoebers/weiland Burgers zu Regenspurg/Auff D. Caspars Melisanders/Pfarherrs zu Aldenburg/etc. vnklaren Bericht von der Erbsuende/damit Melisander die Einfeltigen je lenger je mehr verirret vnnd verwirret. Anno/1581. (s.1.; VD16 S 3341). This was a reply to Caspar Melissander's work, Klarer Bericht Von der Erbsuende/Ob sie ein Substantz, oder ein Accidens sey/vnd was fuer ein Accidens sie eigentlich sey? Daraus der einfeltige Deudsche Mann den rechten Grund des gantzen Handels/sowol wider das Pelagianische vnd Synergistische Accidens, Als wider die Manicheische Gottslesterliche Substantz/auffs deutlichste zuuernemen ... Jtzt in Druck gegeben Durch D. Casparum Melisandrum, Pfarrern vnd Superintendentem zu Aldenburg in Meissen (Wittenberg: Simon Gronenberg, 1581; VD16 B 5439). 
explained that he wanted to establish an Academie in Regensburg, which would train people for the ministry in their vernacular »[llyrian« [Slavic] languages, who would then return to their cities and spread Lutheran doctrines there. He saw the need for establishing an institution in the southeastern German and Slavic-speaking border region of the Empire, which lacked such schools but could attract students from neighboring lands and even beyond. As he noted, from Ingolstadt to Vienna and from Vienna to Padua, no Protestant academies existed.

Already the following day, on December 13, 1561 Sebastian Krell sent a letter to Schober from Jena, at Flacius' request. ${ }^{20}$ This letter contained an appeal to Schober and to the senate of Regensburg to consider a proposal for establishing a theological training institution in the city. Although the relationship between Schober and the Regensburg senate was not explained in the text, it was suggesting that Schober may have been in Regensburg at that time and that he was believed to possess some authority and influence either with the political or the ecclesiastical leadership of the city. In his letter, Krell presented eight reasons that supported the founding of an Academie, where "many [students] would come from the neighboring regions of Austria, Bavaria, Carinthia, Bohemia and others $\aleph^{21}$ to study, and he enumerated the many ways in which such a school would benefit the city and the Church.

Confirming Flacius' intentions was a letter written to Hans Ungnad on May 7, 1562 by the Slovenian Matija Klombner from Laibach (Ljubljana). Klombner referred to the school Flacius wanted to establish in Regensburg as a preliminary basic school that consisted not of a full four-year curriculum but presumably of only a two-year program (halbe hoche schuel; semiacademiola) that would train good and learned people. ${ }^{22}$ In this same letter, Klombner corroborated the fact that by this time Flacius was living in

20 Sebastian Krell to Bartholomaeus Schober, December 13, 1561, in Jože Rajhman, Pisma slovenskih protestantov/Briefe der slowenischen Protestanten [Razred za filološke in literarne vede/Classis II: Philologia et Litterae. Korespondence pomembnih Slovencev/Epistulae Slovenorum illustrium 11] (Ljubljana: Slovenska akademija znanosti in umetnosti, 1997), 31-34. Mijo Mirković operates with the assumption that this particular letter written by Krell's hand was dictated by Flacius since it contains Flacius' plans that he had previously expressed in a letter to Gallus. Mirković's theory is that Flacius was concerned that the letter could be intercepted and he wanted to protect himself since he had already been dismissed from his positions in Jena and was in hiding. Mirković, Matija Vlačić Ilirik, 420.

21 Rajhman, Pisma slovenskih protestantov, 32: »Accurrent multi ex vicinis regionibus, Austria, Bauaria, et Carinthia, Bohemia etc."

22 Klombner to Hans Freiherrn von Ungnad, Laibach am Tag der Himelfarth Christi [May 7], 1562, in Kostrenčić (ed.), Urkundliche Beiträge, 73-76, here 75: »Der herr Illiricus vermaint zu Regenspurg ein halbe hoche schuel anzurichten, dess furwar ein gross werkh vnd ein hoche furderung wer dissem werkh gottes, damit guet vnd gelehrt leuth erzogen wurden..." 
Regensburg together with his wife and children. ${ }^{23}$ However, Ungnad was not too enthusiastic about Flacius and the theological direction he was taking, and he mentioned some of the conflicts the two of them had had in a letter from November 1562 to Stephan Consul from Istria and Anton Dalmata, both of whom were working with the Urach printing press, and to Philipp Gugger, his secretary. ${ }^{24}$

Parallel to aiming at establishing the Regensburg Academie, Flacius was also hoping to start a similar but smaller school in Inner Austria, namely in the capital city of Carinthia, Klagenfurt. ${ }^{25}$ Klagenfurt had a significant Slovenian-speaking minority and was located not far from Italy and Istria, an ideal location for Flacius' plan. ${ }^{26}$ This particular effort was in many ways parallel to the missionary activities of Primus Truber and the people gathered around Baron Ungnad. ${ }^{27}$ Flacius also had an idea about moving the already existing Slavic printing press, which was located in Urach, ${ }^{28}$ to Regensburg, so that Regensburg could become the intellectual center for the Slavic Reformation. $^{29}$

During this time Flacius also published some works in Croatian and Slovenian together with Krell. ${ }^{30}$ Flacius' ambition to start a Protestant theological

23 Ibid., 75: »Nun ist er aber mit weib vnd kindt hinauf auf Regenspurg.« In the letter Klombner refers to Flacius as »Illirico Albano [sic!], « an Illyrian from Albona (Labin).

24 Kostrenčić, Urkundliche Beiträge, 130-132, here 131.

25 Wilhelm Baum, »Der Klagenfurter Universitätsplan des Flacius Illyricus (1562) und der Flacianismus in Kärnten, « in Wilhelm Baum (ed.), Kollegium, Lyzeum, Gymnasium. Vom »Collegium Sapientiae et Pietatis« zum Bundesgymnasium Völkermarkter Ring, Klagenfurt. Die Geschichte des ältesten Gymansiums Österreiches (Klagenfurt: Kärtner Druck- und Verlag, 1991), 33-44; reprinted in Wilhelm Baum, Remigius Bäumer, Stephan Meier-Oeser and Rudolf Palme (eds.), Konziliarismus und Humanismus: Kirchliche Demokratisierungbestrebungen im Spätmittelalterlichen Österreich (Wien: Turia und Kant, 1996), 192-205.

26 Rudolf Leeb, »Regensburg und das evangelische Österreich,« in Peter Schmid and Heinrich Wanderwitz (eds.), Die Geburt Österreiches. 850 Jahre Privilegium minus [Regensburger Kulturleben 4] (Regensburg: Schnell und Steiner, 2007), 229-249, here 239. For the spread of Flacius' theology and ideas in Carinthia see, Rudolf Leeb, »Die Reformation in Kärnten, « in Wilhelm Wadl (ed.), Glaubwürdig bleiben: 500 Jahre protestantisches Abenteuer. Wissenschaftlicher Begleitband zur Kärntner Landesausstellung 2011 in Fresach [Archiv für vaterländische Geschichte und Topographie 101] (Klagenfurt am Wörthersee: Geschichtsverein für Kärnten, 2011), 83-105, here 97-101.

27 Rudolf Leeb, »Der Missionsgedanke bei Hans Ungnad von Sonneck, Primus Truber und in der lutherischen Reformation, « in Sašo Jerše (ed.), Vera in hotenja: študije o Primožu Trubarju in njegovem času (Ljubljana: Slovenska matica, 2008), 256-72, here 267-268.

28 In 1561 the Slovenian and Croatian printing press was founded in Tübingen and was then moved to Urach in the province of Württemberg.

29 Mijo Mirković, Pokušaj Matije Vlačića Ilirika da osnuje sveučilište u Regensburgu i u Celovcu, [Poseban otisak iz 300. knjige rada Jugoslovenske akademije znanosti i umjetnosti] (Zagreb, 1954), 537-573, here 540.

30 Vlado Deutsch, »Flacijevci u slovenskoj reformaciji,« in Branko Lovrec (ed.), Blizu ti je riječ: spomen zbornik uz 75. obljetnicu života Josipa Horaka (Zagreb: Duhovna stvarnost, 1988), 105-124, here 113. 
seminary in the close proximity of the Jesuit center of Ingolstadt as a way to curtail their expansion did not materialize in the end. His missionary zeal, however, to spread the Reformation south and east of the Alps, which was reflected in his plan, showed no signs of abating. Flacius' enthusiasm for reaching out to his fellow Slavs, along with his work on hermeneutics, biblical commentary, and history demonstrate that he was not reducing himself to being just a one-sided polemicist. Instead, his growing theological radicalization took place without any loss to his desire to be a churchman of larger dimensions.

\section{Flacius against the Heidelberg Catechism, Erastus and Olevianus}

Flacius' reaction to the Heidelberg Catechism ${ }^{31}$ under the title Refutation of a Small German Calvinist Catechism was issued only a few months after the Catechism had been adopted and published in January $1563 .^{32}$ This publication by Flacius was the first response from among evangelicals adhering to the Augsburg Confession ${ }^{33}$ to what was taking place in the Palatinate, where Friedrich III had become elector in $1559 .{ }^{34}$ That not only Protestants took notice of Flacius' pamphlet is shown by a letter from the Jesuit Peter

31 Catechismus Oder Christlicher Vnderricht/wie der in Kirchen vnd Schulen der Churfuerstlichen Pfaltz getrieben wirdt (Heidelberg: Johann Mayer, 1563; VD16 P 2166). The preface of the Catechism was dated on January 19, 1563, A6r. For the background of the Catechism and for the new critical edition of it, see Wilhelm H. Neuser, »Heidelberger Katechismus von 1563, « in Mihály Bucsay, Emidio Campi et al. (eds.), Reformierte Bekenntnisschriften 2/2: 1562-1569 (Neukirchen-Vluyn: Neukirchner, 2009), 167-212.

32 Flacius, Widerlegung/eines kleinen Deutschen/Calvinischen Catechismi/so in disem M.D.Lxiij. Jar/sampt ethlichen andern jrrigen Tractetlin ausgangen. Item/Beweisung/Das auch die vnwirdigen den waren Leib vnd Blut Jesu Christi im Abendmal empfahen /Wider ein Schwennckfeldisch Buechlein /so newlich on namen durch den Druck ausgestrewet worden. M. Flacius Jllyricus (Regensburg: Heinrich Geißler, 1563; VD16 F 1568), A2r-v [Preface]; A3r-D3v [text].

33 Another work against the Heidelberg Catechism was issued in early 1564 by Heshusius, Trewe Warnung fuer den Heidelbergischen Caluinischen Catechissmum/sampt wierderlegung etlicher jrthumen desselben. D. Tilemannus Hesshusius Exul Christi (Eisleben: Urban Gaubisch, 1564; VD16 H 3147). Many more works followed, including Joachim Mörlin's, Wider die Landluegen der Heidelbergischen Theologen. Joachimus Moerlin D. (Eisleben: Andreas Petri, 1565; VD16 M 5894). Johannes Marbach from Strasbourg also wrote against the Heidelberg Catechism in 1565 and 1566 [VD16 M 902; M 903]. Zacharias Ursinus and Josua Lagus replied to Marbach and Mörlin in 1565 [VD16 U 298]. Theologians from Württemberg also censured the Heidelberg Catechism.

34 For the relationship between Lutherans and Heidelberg, see Lyle D. Bierma, »What Hath Wittenberg to do with Heidelberg? Philip Melanchthon and the Heidelberg Catechism, « in Karin Maag (ed.), Melanchthon in Europe: His Work and Influence beyond Wittenberg [Texts and Studies in Reformation and Post-Reformation Thought] (Grand Rapids: Baker, 1999), 103-121. 
Canisius $^{35}$ who wrote to Cardinal Stanislaus Hosius on October 7, 1563 from Augsburg, informing him that Flacius had issued an attack on the Heidelberg Catechism. ${ }^{36}$

When initial strife concerning the nature of Christ's presence in the Holy Communion had broken out in Heidelberg in 1559 between the general superintendent of the Palatinate, Tilemann Heshusius, ${ }^{37}$ and Wilhelm Klebitz, Elector Friedrich III decided to dismiss them both. ${ }^{38}$ At that time Heshusius belonged to the Gnesio-Lutheran party and has been labeled in current scholarship as »ultra-orthodox « ${ }^{39}$ and also »a second Flacius« because of the polarizing effect he had on others. ${ }^{40}$ Klebitz was a preacher with Reformed

35 Canisius was asked by Pope Pius V to refute The Magdeburg Centuries. He did publish two works in response and the third one concerning Flacius' criticism of the primacy of the Pope never saw the light of day but the original text is in the manuscript collection of Munich city library. I am grateful to Patrizio Foresta for bringing this to my attention. For more on Canisius and Flacius, see James Brodrick, Saint Petrus Canisius (Chicago: Loyola Press, 1988), 664711; Siegfried Hofmann, »Petrus Canisius und die Widerlegung der Magdeburger Centurien, « in Karl Batz (ed.), Die Jesuiten in Ingolstadt: 1549-1773. Ausstellung des Stadtarchivs, der Wissenschaftlichen Stadtbibliothek und des Stadtmuseums Ingolstadt [12. Oktober 1991 bis 12. Januar 1992] (Ingolstadt: Stadtarchiv, 1991), 20-28.

36 Canisius to Hosius. Letter 960 in Otto Braunsberger (ed.), Beati Petri Canisii, Societatis Iesu, Epistulae et Acta, Volumen Quartum. 1563-1565 (Freiburg in Breisgau: Herder, 1905), 349-352, here 350: »J1liricus Catechismum Heidelbergensem oppugnat.« In the same letter Canisius was informing Hosius in Poland of the activities of other Protestants, i.e. Wigand, Major, Brenz, Bullinger but also of Andreae's attack upon Friedrich Staphylus. It is interesting to note that Canisius refers to Andreae as »Smidelinus, « a nickname that was given to Andreae because he was the son of a blacksmith.

37 Heshusius was a good student of Melanchthon's whom he abandoned in the late 1550s and »turned sharply against his former [Philippist] position.« See, Robert Kolb, »Dynamics of Party Conflict in the Saxon Late Reformation: Gnesio-Lutherans vs. Philippists, « The Journal of Modern History 49/3 (1977): 1289-1305, here 1290-1291. According to Thilo Krüger, Heshusius' three-week-long stay in Magdeburg in May 1556, where he met Flacius, Wigand and Judex, was a turning point for him. See, Empfangene Allmacht: die Christologie Tilemann Heshusens (1527-1588) [Forschungen zur Kirchen und Dogmengeschichte 87] (Göttingen: Vandenhoeck \& Ruprecht, 2004), 29. Melanchthon in return abandoned Heshusius in his memorandum to Friedrich III dated on November 1, 1559, in which he clearly distanced himself from Heshusius' position on the Lord's Supper. See, Ivdicivm D. Philippi Melanchthonis, de controuersia Coenae Domini, ad Illustrisimum Princepem, ac D. D. Fridericum, Comitem Palatinum Rheni, Sacri Romani Imperij Archidapiferum, Electorem, Bauariae Ducem, \&c. (Heidelberg: Ludwig Lucius, 1560; VD16 M 3531), now in MSA 6: 482-486. For an overview of Heshusius' early career, see Peter F. Barton, Um Luthers Erbe. Studien und Texte zur Spätreformation, Tilemann Heshusius (1527-1559) [Untersuchungen zur Kirchengeschichte 6] (Witten: Luther Verlag, 1972).

38 They were removed from their positions on September 16. Heshusius' view of the Lord's Supper penned in Heidelberg on September 1, 1559 was published only in 1562 as Bekandtnus vom heiligen Nachtmal des Herrn Jhesu Christi in a work edited by Nikolaus Gallus (Jena: Thomas Rebart/Donat Richtzenhan, 1562; VD16 H 3003), C6v-E5v.

39 Wim Janse, Albert Hardenberg als Theologe, 78.

40 Gerhard Zschäbitz, »Die Auswirkungen der Lehren Philipp Melanchthons auf die fürstenstaatliche Politik in der zweiten Hälfte des 16. Jahrhunderts, « in Philipp Melanchthon 1497-1560. Humanist, Reformator, Praceptor Germaniae (Berlin: Akademie-Verlag, 1963), 
adherences. ${ }^{41}$ In 1562 Friedrich III invited Caspar Olevianus and Zacharias Ursinus, both newly appointed to the theological faculty, to write a confession of faith together with a few other members of the university, which later became known as The Heidelberg Catechism..$^{42}$

Flacius' relatively short work of only twenty-nine pages centered around nine points or errors as he called them, which he had selected from the many he claimed to have found in the Catechism. The main points of disagreement were directed against the interpretation of the Lord's Supper in the Heidelberg Catechism although Flacius also did not like the document's statements on baptism and how it interpreted the Second Commandment. In his introductory remarks Flacius warned that even though this catechism was trying to present itself as truly Evangelisch in line with the Augsburg Confession, it clearly was not because it contained many grave mistakes.

Flacius' first section of attacks dealt with the second part within the threefold division of the Heidelberg Catechism titled »Deliverance«. He began by challenging the Catechism's position regarding Christ's locality, namely that $\mathrm{He}$ is sitting on the right hand of God in heaven and therefore is not able to be present bodily in the Sacrament. Flacius countered this by stating that according to the Scriptures, Luther and other learned men: »God is infinite, inconceivable and is present everywhere. $\kappa^{43}$ The request by the sons of Zebedee, James and John and their mother to sit on Christ's right and left was viewed by Flacius not as something to be understood literally, but as the expression of their longing for a position of honor, power and might in a worldly kingdom.

Upon observing the first point of contention with the Catechism in Flacius' text, it becomes evident that just as he had done many times before, right at the start the Illyrian invoked not only the Augsburg Confession but also Luther and his authority in support of what he believed to be true doctrine. By

190-226, here 215: »Als übler Vertreter der lutherischen Orthodoxie trat der Generalsuperintendent Thielmann Heßhus auf und füllte als ein zweiter Flacius die Kirchen mit seinem Gepoltere.«

41 For more on the debate see Wim Janse, »Non-conformist Eucharist Theology: The case of the alleged `Zwinglian Polemicist< Wilhelm Klebitz (c. 1533-68), «Nederlands Archief voor Kerkgeschiedenis/Dutch Review of Church History 81/1 (2001): 5-25. For Melanchthon's influence upon Klebitz see Wim Janse, »Die Melanchthonrezeption des Nonkonformisten Wilhelm Klebitz (ca. 1533-1568), « in Günter Frank and Herman J. Selderhuis (eds.), Melanchthon und der Calvinismus [Melanchthon-Schriften der Stadt Bretten 9] (Stuttgart-Bad Cannstatt: Frommann-Holzboog, 2005), 257-289.

42 See Lyle D. Bierma, »The Purpose and Authorship of the Heidelberg Catechism, in Lyle D. Bierma (ed.), An Introduction to the Heidelberg Catechism: Sources, History and Theology with a Translation of the Smaller and Larger Catechisms of Zacharias Ursinus [Texts and Studies in Reformation and Post-Reformation Thought] (Grand Rapids: Baker, 2005), 49-74.

43 Flacius, Widerlegung, A3v: »Gott [ist] vnentlich, unbegreiflich vnd allenthalben.« 
putting this as the first step of his argumentation, Flacius made it clear at the very beginning against which standard he was going to judge the Catechism.

According to Flacius, the second error concerned the definition of the Sacraments found in question sixty-six of the Catechism. ${ }^{44}$ Flacius laid out his disagreement with the understanding that the »sacraments are holy signs and seals for us to see« (as the answer to question sixty-six formulated it). For Flacius, this view meant that the best part or core of the Sacrament itself, namely the Word and promise, which human beings cannot see, was being taken away. ${ }^{45}$ Flacius said that according to Saint Augustine and the practice in Christian churches, when the words of institution are pronounced over the elements they become the true Sacrament at that point.

Flacius did not agree with the answer to question eighty-two either, which stated that the people who with their words and actions show their unbelief and ungodliness should not be admitted to the Lord's Supper because »that would dishonor God's covenant.« Aiming to prove that the Heidelberg Catechism was inconsistent, Flacius here cited the answer to question seventyfour, which said that baptism is a sign of the covenant, while in eighty-two the Supper was referred to as the covenant with God. Flacius concluded that the authors of the Catechism were discrediting themselves by presenting such contradictory statements.

Thirdly, Flacius saw a problem in the Catechism's section on baptism, particularly in question seventy-two: »Does the outward washing with water itself wash away sins? « to which the authors of the Catechism answered, »No, only Jesus Christ's blood and the Holy Spirit cleanse us from all sins.» Flacius accused the authors of »this booklet« of despising Luther and wanting to follow Calvin only, which for him was evident from the Heidelberg Catechism itself: Flacius asserted that parts of the document had been taken word for word from Calvin. ${ }^{46}$ In light of much scholarly discussion about the source of influence behind the Heidelberg Catechism, Flacius' statement should be considered since he did not accuse the authors of the Catechism

44 Catechismus oder Christlicher Vnderricht/wie der in Kirchen vnd Schulen der Churfuerstlichen Pfalz getrieben wirdt, 45. For the purposes of the present work the English translation of the Heidelberg Catechism was used (Grand Rapids: Christian Reformed Church, 1988). I have consulted the original German version and in the footnotes first mention the original page numbers, while in the text I use the question numbers from the English translation.

45 Flacius, Widerlegung, A4r-v: »... das die Sacrament sein sichtbare zeichen, schleust ganzlich aus den Sacramenten den besten theil, ja auch den kern der Sacramenten, nemlich das Wort vnd verheissung, welches theil man nicht sehen kan.«

46 Flacius, Widerlegung, B2v-3r: »Weil aber die Meister dieses Büchleins, Lutherum seliger verachten, vnd woellen allein Calvino folgen, wie dann sehr vil eben in disem Catechismo, von wort zu wort aus des Calvini Catechismo genommen und gesetze ist, so woellen wir beweisen mit etlichen spruechen desselbigen...« 
of being Melanchthonian. ${ }^{47}$ However, this particular charge also carried political significance since Elector Friedrich III's desired that the territory he ruled be under the Augsburg Confession. The Peace of Augsburg from 1555 recognized only adherents of the Augsburg Confession and did not extend to groups that followed other doctrines. Therefore, an imperial ban could have been imposed upon the Palatinate if it could be shown that they were Calvinist and not Lutheran. By charging that the Heidelbergers were not even following their own Praeceptor, Calvin, but instead were like the Schwärmer and Schwenckfeldians, he once again employed a similar way of argumentation to discredit his opponents as he had done by lumping Interimists, Adiaphorists and Papist together.

The fourth point with which Flacius disagreed concerned the answer to question seventy-four, which used the concept of the covenant as a symbol to support the practice of pedo-baptism but made a distinction between the infants of Christian parents and the children of unbelievers. As Flacius contended, "with this they clearly demonstrate that they believe that little children are Christians not because they have been baptized but because they have been born of Christian parents. $\aleph^{48}$ Flacius thundered, by not practicing obligatory baptism in their churches they were greatly diminishing original sin; and that was a Pelagian heresy. ${ }^{49}$ Moreover, he criticized the fact that the Heidelberg Catechism saw baptism as only a sign of the covenant with God, while according to him »baptism is a true and complete covenant or treaty with God, within which both sides, God towards us and on the other hand we towards Him, declare and oblige ourselves $«{ }^{50}$ Flacius used the image of a contract, in which both parties commit to fulfill their promises and seal it with a stamp. He stated, »The washing with water is both a seal and a confirmation of the covenant. $\ll^{51}$

In the seventh section Flacius named and addressed a few errors he found in the third part of the Heidelberg Catechism titled Gratitude. He criticized that the section (questions eighty-eight to ninety-one) explained genuine

47 Burchill's claim that »the principal model was that of the Genevan Catechism drawn up by Calvin in 1542« might find support in Flacius' statement. See Christopher J. Burchill, »On the Consolation of a Christian Scholar: Zacharias Ursinus (1534-83) and the Reformation in Heidelberg, « Journal of Ecclesiastical History 37/4 (1986): 1-20, here 6. For the other theory that Melanchthon had a considerable influence upon the Heidelberg Catechism, see Bierma, "What Hath Wittenberg to do with Heidelberg?»

48 Flacius, Widerlegung, B3v: »...so zeigen sie klar an, das sie glauben, das die kleine Kinder nicht darumb Christen sein, das sie getaufft worden, sondern darumb, das sie von Christlichen eltern geboren sein."

49 Ibid., B3v: »Darumb sie auch die nottauff in iren Kirchen abschaffen. Dieser Irthumb aber vernichtet sehr die erbsünde ist Pelagianisch, vnd verkleinert die massen sehr die heilige Tauff.«

50 Ibid., B3v: »So doch die Tauf ein warer vnd volkomener bund oder vertrag mit Gott ist, darinn sich beide Gott gegen vns vnd widerumb wir gegen Gott erkleren und verpflichten."

51 Ibid., B3v: »Hierzu kompt das Wasserbad als ein sigil und bestetigung des bunds.« 
repentance or conversion as the dying away of the old self and the resurrection of the new. Flacius saw this part of the text as being too human-centered, assigning to the human being the capacity to have sorrow for sin, hatred of it, and eventually to run from it, as the effect of the dying to the old self; and the ability to do good works and live according to the will of God as the result of the resurrection of the new person. In truth, Flacius argued, good works, expressed by the reborn human being were actually the work of God through the Holy Spirit. ${ }^{22}$ Quoting Ephesians 2:10 - »For we are God's handiwork, created in Christ Jesus to do good works, which God prepared in advance for us to do « Flacius stated that it is not wise to leave out the fact that God through the Holy Spirit is the One who brings about change. It is the Holy Spirit that does the work, not placing human capacity in the center.

Responding to the Heidelberg Catechism's interpretation of »what is God's will for us in the second commandment?« in questions ninety-seven and ninety-eight made up the eighth section of Flacius' refutation. ${ }^{53} \mathrm{He}$ stated that the Heidelberg Catechism's insistence that no images should be permitted in the churches only encouraged the fanatics [Bildstürmer] who like Andreas Bodenstein von Karlstadt and the »heavenly prophets « wanted to remove all objects from the churches when instead the emphasis should have been put more on not making idols in our hearts and thoughts. The point that also needs to be observed is that the Heidelberg Catechism inserted the rejection of graven images as a second commandment where for Lutherans the second commandment was on false witness.

The ninth point Flacius made in his work $^{54}$ was devoted to answering a short booklet about the breaking of bread ${ }^{55}$ issued anonymously by a member of the medical faculty of the Heidelberg University and lay theologian,

52 Ibid., C3r: »Entlich so beschreibet es nicht recht weder die absterbung des alten, noch die aufferstehung des newen Menschen/Dann es saget, das die absterbung des alten Menschen sey hassen die Sünde, vnd die aufferstehung des newen Menschen sey leben nach dem willen Gottes in allen guten wercken, so doch solche actiones, opera oder thaten seind eigentlich nur fructus, effectus oder wirckung der toedtung des alten, vnd aufferstehung des newen Menschen, welche gute fruechte der vernewerte Mensch thut, so doch dagegen die toedtung des alten vnd die lebendig machung des newen Menschen, eigentlich ein pur lauter werck Gottes ist, durch den H. Geist geschehen.«

53 Ibid., C3r-D1r.

54 The title of this section on page D1v is »Von dem neunden Irthumb/oder von der Brotbrechung.«

55 For more about that debate see Oliver K. Olson, »The >Fractio Panis` In Heidelberg and Antwerp, « in Derk Visser (ed.), Controversy and Conciliation: The Reformation and the Palatinate 1559-1583 [Pittsburgh Theological Monographs New Series 18] (Allison Park, PA: Pickwick Publications, 1986), 147-53. For the background of the fraction rite and the controversy surrounding it in late Reformation Germany, see Bodo Nischan, »The \Fractio Panis:〈 A Reformed Communion Practice in Late Reformation Germany, « Church History 53/1 (1984): 17-29. 
Thomas Erastus..$^{56}$ The Booklet on Bread-Breaking was published in Heidelberg at the same time as the Heidelberg Catechism. ${ }^{57}$ In it Erastus insisted on a ceremonial breaking of bread before the distribution of the Sacrament (the Fraction), while Flacius opposed this practice by using his knowledge of the Hebrew Scriptures, saying that this rite was unnecessary and should not be obligatory during the Lord's Supper. Actually, the practice of breaking bread became a point of division between Lutherans and Reformed in the late sixteenth and early seventeenth century. Evangelical pastors who thought that fractio panis was just an adiaphoron and performed it were accused of being Calvinists and sometimes even threatened verbally and attacked physically. ${ }^{58}$ Of all the things Flacius could have criticized, it needs to be noted that the concept of sin played a crucial role in Flacius' responses to the Heidelberg Catechism, particularly concerning baptism and repentance.

A year later Flacius wrote critically of Caspar Olevianus, ${ }^{59}$ a Reformed Protestant and a former student of Calvin and Theodore Beza, who by that time had become the senior pastor in the Church of the Holy Spirit in Heidelberg and, in addition to the Heidelberg Catechism, had published some of his sermons concerning the Lord's Supper. ${ }^{60}$ As a response Flacius wrote a

56 For his biography and career, see Charles D. Gunnoe, Jr., Thomas Erastus and the Palatinate: A Renaissance Physician in the Second Reformation [Brill's Series in Church History 48] (Leiden: Brill, 2011).

57 Erzelung Etlicher vrsachen/warumb das hochwirdig Sacrament des Nachtmals vnsers Herrn und Heylandts Jesu Christi, nicht solle ohne das Brotbrechen gehalten werden (Heidelberg: Johannes Mayer, 1563; VD16 E 3914). VD16 does not mention Erastus as author. The proof of authorship can be found in a refutation of the booklet by Johannes Marbach, Christlicher/vnd warhaffter vnderricht/von den worten der einsatzung des heyligen Abendmals Jesu Christi/vnsers Heylandts/sampt gruendtlicher widerlegung der Sacramentierer hieuon jrrigen Lehr/vnd meynung. Gestellet durch Johan Marbach/der h. Schrifft Doctorn/vnd der Kirchen zu Straßburg Superintendenten (Strasbourg: Christian Müller d.Ä., 1565; VD16 M 902). Erastus then issued a rebuttal, Bestendige Ableinung der Vngegruendten beschuldigung/damit D. Johann Marbach/das buechlein Thomae Erasti Medici, vom verstand der wort Christi/Das ist mein Leib/etc. vnterstehet verdechtig zu machen (Heidelberg: Johann Mayer, 1565; VD16 E 3670).

58 See, Bodo Nischan, Prince, People, and Confession. The Second Reformation in Brandenburg (Philadelphia: University of Pennsylvania Press, 1994), 87-88 for a story of Solomon Finck, a preacher in Berlin, who suggested to his congregation in a sermon in October 1613 that »we should simply use regular, natural bread and, in accordance with Christ's words, break and distribute it.« After the church service »a large crowd of screaming and restless youth gathered outside the cathedral, shouting obscenities and taunting him, ")Come out, come out, you damn Calvinist! When Finck actually did emerge, the noise grew even louder; several of the onlookers hurled rocks at him and at least two found their target."

59 For a detailed bibliography of works by and about Olevianus, see J.F. Gerhard Goeters, »Caspar Olevianus als Theologe, Monatshefte für Evangelische Kirchengeschichte des Rheinlandes 37/38 (1988/1989): 287-344, here 320-337 (»Bibliographia Oleviana«).

60 Olevianus, Kurtze Summ vnd jnnhalt Ettlicher Predigten vom H. Abendmal vnsers Heilands Jesu Christi. Darinn allein auß Gottes wort vnd nicht auß der vernunfft noch menschen 
short book under the title Refutation of the Four Sermons Preached by the Sacramentarian Named Olevianus. ${ }^{61}$ On April 5, 1564, Olevianus wrote from Heidelberg to Bullinger in Zurich asking for advice on whether he should reply to Flacius' Streitschrift. ${ }^{62}$ In the end it seems that the task of replying to Flacius was given to Ursinus who in his work also answered attacks by Heshusius. ${ }^{63}$ In his pamphlet Ursinus stated that Flacius was his most important opponent. ${ }^{64}$

There was much more at stake in this dispute than just a divergence in theology, otherwise this debate would not have differed from any other. All participants understood well that the secular authorities were defining which territory would follow a certain religion since after the religious peace of Augsburg in 1555 the principle of cuius regio eius religio was in place. ${ }^{65}$ Consequently the significance of this debate reached beyond the question of proper doctrinal understanding. Flacius saw Calvinism as responsible for

Lehr/der rechte einfeltige verstandt/frucht vnd nutz des H. Abendmals/one alle bitterheyt vnnd gezaenck wirdtfürgetragen. Gepredigt zu Heidelberg/durch Casparum Oleuianum/Anno 1563 (Heidelberg: Johannes Mayer, 1563; VD16 O 705).

61 Flacius, Trewe Warnung vnd Vermanung/das man das heilige Testament des hochwirdigen Nachtmals/vnsers Herrn Jesu Christi vnuerfelscht/vnd in seinem rechten eigentlichen verstande/rein behalten sol/Jn dieser vnserer zeit wider so manicherley Verfuerer/Sophisterey vnd Betriegerey/Sehr nuetzlich zu lesen. Jtem/Widerlegung vier Predigten eines Sacramentirers/ mit zunamen Oleuianus. Jtem/Beweisung/Das auch die vnwirdigen den Leib vnd Blut Jesu Christi im Abendmal empfahen/Wider ein Schwenckfeldisch Buechlein/so newlich ohne Namen durch den Druck ausgestrewet worden. M. Flacius Illyricus (Oberursel: Nikolaus Henricus d.Ä., 1564; VD16 F 1398), O2v-Q5r. The dedicatory preface is dated February 2, 1564.

62 The original letter is stored at Zentralbibliothek Zurich, Ms. F 39, fol. 382-383 and is reprinted by Goeters, »Caspar Olevianus als Theologe, « 344: »Illyricus nominatim contra me scripsit, an ei respondendum iudices cupio ex te intelligere. Si respondendum sit, faciam modeste et graviter, quantum Dominus dederit, et eo consilio faciam, ut ipsius nomine pro larva utar et occasione ad propagandum veritatem. Cum enim exosus sit multis per germaniam, in ipsus contemptum volent plerique, quae adversus ipsum scribuntur, legere. Nollem etiam affixus esse ipsius scripto, sed mea methodo causam totam tractare atque suo quaeque loco refutare. Quid suaderis rogo, ut paucis rescribas.«

63 Zacharias Ursinus, Antapokrisis ad D. Tilemanni Heshusii et Flacii sectae responsa (s.1.: 1564; not in VD16), republished in Quirinus Reuter and David Pareus (eds.), Zacahriae Ursini ... Professoris in Academia Heidelberg et Neustadiana. Operum Theologicorum Tomi Duo (Frankfurt: Jonah Rosa, 1612; VD17 1:048644U), 1431-1450, and Gründtlicher bericht Vom heiligen Abendmal vnsers Herren Jesu Christi/aus einhelliger Lere/der heiligen Schrift/der alten rechtglaeubigen Christlichen kirchen/Vnd auch der Augspurgischen Confession. Gestellt Durch der Vniuersitet Heydelberg Theologen. Bedencken Herrn Philippi Melachthonis/vber der spaltung vom Abendmal (Heidelberg: Johann Mayer, 1564; VD16 U 328).

64 Derk Visser, Zacharias Ursinus: The Reluctant Reformer, His Life and Times (New York: United Church Press, 1983), 133.

65 For different aspects of the Peace of Augsburg, see Heinz Schilling and Heribert Smolinsky (eds.), Der Augsburger Religionsfrieden 1555. Wissenschaftilches Symposium aus Anlaß des 450. Jahrestages des Friedensschlusses, Augsburg 21. Bis 25. September 2005 [Schriften des Vereins für Reformationsgeschichte 206] (Gütersloh: Gütersloher Verlagshaus, 2007). 
the changes on the German religious scene. No wonder that during that same period Flacius was involved in the controversies regarding the Sacrament of the Lord's Supper in at least two more cities, Nuremberg and Danzig.

\section{Flacius and the Crypto-Calvinist Controversy in Nuremberg}

In 1562 a theological disagreement developed in the free imperial city of Nuremberg, in which Joachim Heller, ${ }^{66}$ an astronomer, printer and rector of the evangelical Gymnasium St. Egidien, accused two evangelical preachers in the city, Moritz Heling, ${ }^{67}$ pastor of St. Sebald, ${ }^{68}$ and newly installed pastor at St. Lorenz, Johannes Schelhammer, ${ }^{69}$ of being Crypto-Calvinists ${ }^{70}$ and

66 For his brief biography, see Leppin, Antichrist und Jüngster Tag, 299-300, who calls him an »apocalyptically oriented mathematician, « 50; »Heller, Joachim, « in MBW 12: Personen F-K, 262. For more on his printing activities see, Christoph Reske, Die Buchdrucker des 16. und 17. Jahrhunderts im deutschen Sprachgebiet. Auf der Grundlage des gleichnamigen Werkes von Josef Benzing [Beiträge zum Buch- und Bibliothekswesen 51] (Wiesbaden: Harrassowitz, 2007), 682-683. Heller needs to be differentiated from his Nuremberg contemporary with an almost identical name, Joachim Haller. Haller was from the patrician family von Hallerstein and was a prominent member of the city council. He was part of the second Nuremberg church visitation (the first took place in 1528) of 1560-1561. For his role in the visitation, see Gerhard Hirschmann, »Die zweite Nürnberger Kirchenvisitation 1560/61, « Zeitschrift für bayerische Kirchengeschichte 32 (1963): 111-132; Kirchenvisitation im Landgebiet der Reichsstadt Nürnberg 1560/1. Quellenedition [Einzelarbeiten aus der Kirchengeschichte Bayerns 68] (Neustadt a.d. Aisch: Degener, 1994).

67 Julius August Wagenmann, »Heling, Moritz,« in ADB 11 (1880), 690; »Heling, Moritz,« in MBW 12: Personen F-K, 260-261.

68 The Reformer of Nuremberg, Veit Dietrich was pastor at St. Sebald from 1535 until 1547.

69 Schelhammer was from Staffelstein in Franken. In 1555 he matriculated at the University of Wittenberg where he was befriended by Melanchthon. Upon receiving his Master of Arts degree he worked as an adjunct instructor at the university before moving to Nuremberg, where he later became a pastor. See Melanchthon's recommendation letters for him from 1559, MBW 8927, 8928, and 8949 (Regesten 8: 340, 348). The city of Nuremberg purchased Schellhammer's library after his death, consisting of 379 works, which are kept at the Stadtbibliothek today. See paragraph 1.7: http://134.76.163.162/fabian?Stadtbibliothek_(Nuernberg) (accessed October 18, 2011).

70 For a historical discussion of the origins of the term »Crypto-Calvinism« and when it came into use, see Theodor Mahlmann, »Melanchthon als Vorläufer des Wittenberger Kryptocalvinismus, « in Günter Frank and Herman J. Selderhuis (eds.), Melanchthon und der Calvinismus [Melanchthon-Schriften der Stadt Bretten 9] (Stuttgart-Bad Cannstatt: Frommann-Holzboog, 2005), 173-230. For a general discussion of the term, see Helmar Junghans, »Kryptocalvinismus, « in TRE 20 (1990), 123-129. Johannes Hund has argued extensively that the term »Crypto-Philippism《 is more appropriate instead of »Crypto-Calvinism. Das Wort ward Fleisch: Eine systematisch-theologische Untersuchung zur Debatte um die Wittenberger Christologie und Abendmahlslehre in den Jahren 1567 bis 1574 [Forschungen zur systematische und ökumenischen Theologie 114] (Göttingen: Vandenhoeck \& Ruprecht, 2006), 66-96; 674-694 and also »Kryptocalvinismus oder Kryptophilippismus? Die Wittenberger Abendmahlslehre und Christologie in den Jahren 1567-1574,« in Dingel and Kohnle (eds.), 


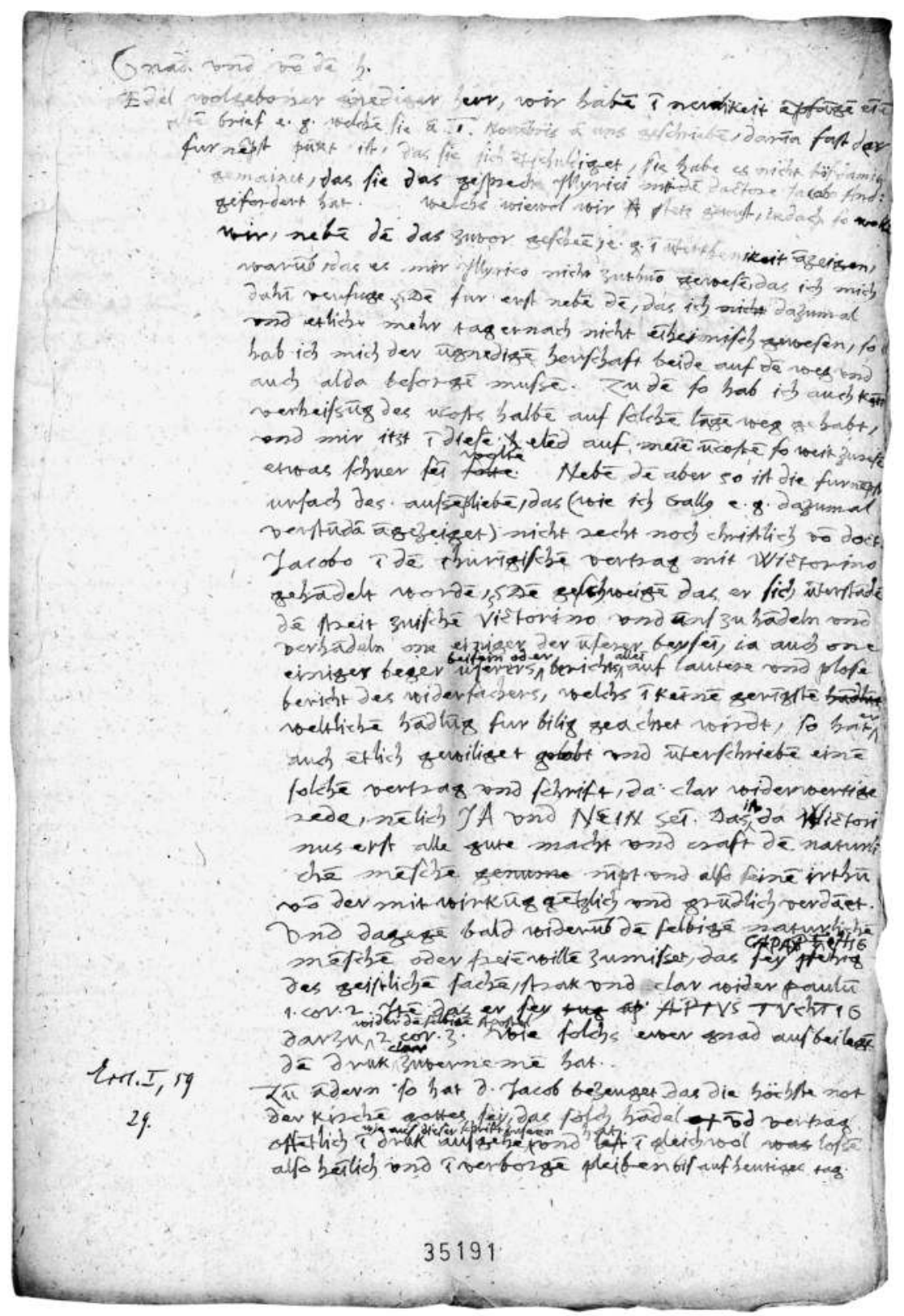

Figure 9: A draft of the letter written in German in Flacius' handwriting from 1563. Courtesy of Stadtarchiv Regensburg: shelfmark Eccl. I, 59, 29, 35191. 
reported them in writing to the city council on December $30 .{ }^{71}$ Immediately following that accusation other city preachers joined Heller, confirming that the theology of Heling and Schelhammer was indeed leaning toward Calvinism. Among them were Conrad Klingenbeck ${ }^{72}$ pastor of St. Egidien, Michael Besler, ${ }^{73}$ preacher at St. Marien and the Franciscan church, and others.

This episode culminated in a public trial conducted by the city council of Nuremberg. Already on February 5, 1563 there was a first hearing to investigate Heling and Schelhammer, where several different subjects were discussed, including the Lord's Supper, the Gospel, good works, and free will. ${ }^{74}$ In one of Heling's replies he accused Flacius of not understanding the Sacraments and being directly responsible for the disagreement going on in Nuremberg. ${ }^{75}$ Following Heling's lead, Schelhammer then went on to attack Flacius and his theological writings in ten different points. ${ }^{76}$ This tactic

Philipp Melanchthon. Lehrer Deutschlands, Reformator Europas, 271-88. The thought that "Crypto-Philippism《 is a better term than »Crypto-Calvinism« can be traced back to Irene Dingel, Concordia controversa. Die öffentlichen Diskussionen um das lutherische Konkordienwerk am Ende des 16. Jahrhunderts [Quellen und Forschungen zur Reformationsgeschichte 63] (Gütersloh: Gütersloher Verlagshaus, 1996), 104.

71 Heller, Relation vnd bericht M. Joachim Hellers in Causa Sacramenti is actually dated on December 15, 1562 but it seems that Heller submitted it to the city council fifteen days later. The original source for this debate is found in an unpaginated file called the $»$ Heller Dossier, « located at the state archive (Staatsarchiv) in Nuremberg under the following signature: Reichsstadt, Repertorium 15a, Ratskanzlei A-Laden, S.I.L 182, Nr. 2. I am grateful to Jacob M. Baum for providing me with a copy of the »Heller Dossier, « including the transcriptions of some of Flacius' letters in that file.

72 See, »Klingenbeck, Konrad, « in MBW 12: Personen $F-K$, 426. After Klingenbeck died on August 27, 1567 his replacement was Laurentius Dürnhofer, who was a Philippist. Dürnhofer's appointment contributed to changing the pastoral equation in Nuremberg, reducing the proportion of Flacians. For an overview of Dürnhofer's career, see MBW 12: Personen A-E, 375-376.

73 Ibid., »Besler, Michael,« 149; also referred to as Peßler. In 1569, Besler found himself in conflict with the Nuremberg city council because of being pro-Flacian and using the pulpit to propagate his views. That was the reason for his suspension after having served the Nuremberg church for twenty-two years (1547-1569). In January of that year the city issued a prohibition to all of its printers on issuing any »Flacianische Schmachschriften. Printer Christoph Heußler and his son Leonhard defied the ban by publishing Flacius' critique of the Altenburg Colloquium, WJe das Aldenburgisch Colloquium zergangen (VD16 W 2504). See, Reske, Die Buchdrucker, 688; Irmgard Bezzel, Leonhard Heußler (1548-1597), Ein vielseitiger Nürnberger Drucker und Verbreiter von Neuigkeitsberichten [Buchwissenschaftliche Beiträge aus dem Deutschen Bucharchiv München 62] (Wiesbaden: Harrassowitz, 1999), 4-5.

74 Here is the list of headings Heling discussed: »1. Beweis das im nicht geburet hat, solche anklag wider mich furzubring vil weniger mich zuuerdamen; 2. Vor meinem bekhantnus in gemein; 3. Erkhlerung etlicher punt halben, darinn er mich in sonderheit beschediget; 4. Vom Abentmal des Herren; 5. Widerhollung meines bekhantnus vom Abendmal; 6. Vonn guten werkhen; 7. Vom Euangelio; 8. Vom freyen willen; 9. Von Schmeche vnnd Lesterwortten.«

$75 » .$. macht er [Flacius] aus den Sacramenten, nur ein gauckhelspil, vnnd gespott.«

$76 »$ Flacius Illyricus versicht in seinen buechern wider die Christliche kirchen diese irrthumb: 1. wie das Evangelion proprie vnnd eigentlich in seinem ambt kein buesbredig sey, sunder nur das gesetze, eben das verfichtet Heller auch, darumb ist er in diesem punct ein Flacianer; 2. Illyricus will nicht zugeben, das das Euangelion in seinem ambt die suende strafe, sunder 
succeeded in turning the dynamics of the debate around, since from that point onward Heller, the accuser, became accused of Flacianism.

In addition to analyzing Flacius' theological influence in this particular episode it is also important to mention that the disagreement among the Nuremberg Lutherans regarding the Eucharist had previously come up. That is why Wolfgang Waldner, who was a preacher in Nuremberg for the decade from 1548 until 1558 at the former Dominican monastery (Dominikanerkloster) before he was called to Regensburg as a replacement for Martin Schalling, ${ }^{77}$ had translated Westphal's work against Calvin into German and published it in the city in $1554 .^{78}$

It is significant to see and reconstruct how Flacius' theological influence played a part in this case. Already while living in Jena, Flacius corresponded with Waldner, who also helped with the collection of books and manuscripts for the project of The Magdeburg Centuries. ${ }^{79}$ Apart from Waldner, Flacius exchanged letters with Heller, who was his financial supporter and a follower

nur das gesetze; 3. Flacius greiffet herren Philippum vnnd alle alten kirchen an in dem, das er verleugnet, das Logos [in Greek], das ist, das wort gottes Son, cogitatione interna patris geboren sey; 4. Flacius verdammet Philippi Melanchtonis Definition, die auch in vnserm agend buechlein gesetzet ist, di also lautet: Lex Moralis est aeterna et immota sapientia Dei, et radius transfusus in creaturam rationale [CR 16: 168]: das ist, das Gottliche gesetz, ist die vnwandelbar, vnnd vnnverrukte weisheit Gottes selbs, ein glanz vnnd funklein der weisheit Gottes in vnsere natur eingepflantzet; 5. Phillipus Melanchton vnnd die Wittenbergisch Kirch leren: quod hic sit dei ordo immotus et aeternus, ut creatura rationalis obediat Creatori: das ist, das ist gottes ewiger, vnnd vnbeweglicher will vnd ordnung, das die vernunfftige Creatur schuldig sey gehorsam zu leisten Gott irren Schoepfer, das verleuguent Heller mitt Flacio Illyrico; 6. Flacius schreibet, Gott wirke durch das gesetz buese vnnd den glauben, das verteidiget mit im Heller. 7. Illyricus sagt, das mensch sey in der bekehrung wie ein stokh vnnd stein, quod habeat se pure passive, ante, in, et post connversionem, dergleichen gibet auch Heller fuer; 8. Illyricus schreibet, das Gott bekehre den menschen wider seinen willen, mit gewalt genotiget vnnd gezogen: eben dieser Schwarm stellet in des Hellers hirn, darumb ist er auch in diesem punct ein Flacianer; 9. Flacius kan nicht leiden, das in der bekehrung diese drey causae oder vrsachen zusamen komen/das wort Gottes, der heilige Geist der durch das wort kreftig ist, vnnd der wille des Menschen, der von Gott gezogen durch das predigampt, Gottes genade annemen koennen; 10. Flacius leret, Got bekehre allein die, so er im zu gefesen, in seiner ewigen versehung versehen vnnd erwelet hatt, er erbarme sich, des er erbarmen woell, die andern beraite er in zu gefesen seines Zorns, das sie nicht koennen bekehret werden/ob sie schon wollten.«

77 Schalling corresponded with Calvin in Geneva secretly and had Reformed theological tendencies. When Superintendent Gallus found out about that, he managed to fire him from his post in Regensburg in 1558. For Schalling's biography, see Joachim Stalmann, »Schalling, Martin, « in BBKL 8 (1994), 1583-1585.

78 Westphal/Waldner, Der rechte vngefelschte Glaub... See also the second updated edition from 1555 that is: Widerumb mit fleis vbersehen vnd gebessert (Nuremberg: Georg Merkel, 1555; VD16 W 2311).

79 At FBG there are four letters from Flacius to Waldner in Nuremberg: Chart. A 127, 3r-V (August 13, 1557); 4r-v (September 6, 1557); 1r-v (October 22, 1557); 2r-v (November 15, 1557). Waldner's letters to Gallus from the same period are at StAR. See, Böhl, Beiträge zur Geschichte der Reformation in Österreich, 452-460 for the reprint of the letter from January 7, 1557. Böhl, 209, also refers to Waldner's letter to Gallus from April 28, 1558. 
of his theology ${ }^{80}$ and with Gregor Forwerck, assistant pastor at St. Egidien. ${ }^{81}$ Flacius also had a supporting network among Nuremberg merchants, patricians and people in the city council as is evident from several book dedications. Among them were Senator Christoph Harsdörfer, ${ }^{82}$ Thomas Irtenberger, ${ }^{83}$ Jacob Peck ${ }^{84}$ and others. ${ }^{85}$ Flacius was known in the city through publications of several of his polemical works against Osiander and Schwenckfeld between 1554 and 1557. ${ }^{86}$ Furthermore, Flacius visited Nuremberg on his way from Rudolstadt to Regensburg in February 1562 and spent some time in the city. Then, on the Friday after St. Bartholomew's Day (August 28) 1562, Gallus and Flacius wrote from Regensburg a nineteenpage open letter ${ }^{87}$ to Hieronymus Besold, ${ }^{88}$ then superintendent and preacher

80 In the »Heller Dossier « there are also letters by Flacius to Heller. One is dated on March 9, 1559, in which Flacius thanks Heller for the donation of one hundred florins; the other bears the date of May 17, 1559. Heller is also mentioned in two letters addressed to Waldner by Flacius in 1557.

81 Two letters written from Jena in 1560 are stored at FBG, Chart. A 123, $278 \mathrm{r}-\mathrm{v}$ (May 6) and Chart A 123, 279r-v (December 26).

82 Flacius dedicated a work to Christoph Harsdörfer (Harsdorf) on November 1, 1555 from Magdeburg. See, Eine vberaus nuetzliche Historien/wie zur zeit des H. Augustini/die Bepste mit dem VI. Carthaginensischen Concilio/von jrem Primat oder Gewalt haben gestritten/vnd vberwunden sind worden/aus warhafftigen alten schrifften zusamen gelesen/Durch Matth. Flac. Jllyr. (Magdeburg: Michael Lotter, 1555; VD16 ZV 5905; Reprint: Oberursel: Nikolaus Henricus d. Ä., 1562; VD16 F 1417). In 1569 Harsdörfer was jailed for two days in a tower because of advocating Flacius' ideas in Nuremberg.

83 Christoph Irenaeus (whose son, Wolfgang married Flacius' daughter Anna in 1577) dedicated his work Contrafet/Vnd Spiegel des Menschen... (Oberursel: Nikolaus Henricus d. Ä., 1582; VD16 I 288) to Irtenberger. He refers to him as a Nuremberg linen merchant: »Meinem grosegu(e)nstigen Herrn vnd Patronen, « A2r. This shows that Irtenberger supported the Flacian party financially and remained favorable to their theological convictions even after Flacius' death.

84 Wolfgang Waldner dedicated the work Ein Historia: Wie der Antichrist zu Rhom in diesem 1553. jar/abermal zween Christen jaemerlich ermoerdet hat. verdeutscht durch $\mathrm{H}$. Wolfgangum Waldner (Coburg: Cyriacus Schnauß, 1554; VD16 H 3890) to Peck, A2r-v. Peck was married to Senator Harsdörfer's daughter, Maria. After his death she married Sigmund Gamersfelder in 1572 .

85 The dedicatory letter of volume eight of Historia ecclesiastica (Basel, 1564) lists the following Nurembergers: Christoph Harsdörfer, Johann Meienschein, Jacob Peck, Thomas Irtenberger and Andreas Örtel as »civibus rei publicae Nornbergensis."

86 At least five of Flacius' works were produced at the local printing house run by Johann vom Berg and Ulrich Neuber.

87 A copy of the letter under the title »Sendbrief Nicolai Galli...« is in the Heller Dossier. It opens with the following words: »Reverendis et Clarissimis viris D. Hieronymo Besoldo, Michaeli Beslero, et Conrado Klingenbeckio concionatoribus in ecclesia Norimbergensi. D. Michaeli Rotingo et Joachimo Hellero, artium et philosophiae professoribus, Dominis et amicis observandis.«

88 Besold (Petzolt) studied in Wittenberg. In 1547 he became a preacher at the Heilig-Geist-Spital. He married Andreas Osiander's oldest daughter, Katharina in January 1548, while Osiander was still in Nuremberg. Later Besold opposed his father-in-law's teaching regarding justification together with other Nuremberg preachers Waldner, Besler and Rotting. For his correspondence with Osiander prior to their theological disagreement that started in December 1550, see 
at the Hospital of the Holy Spirit (Heilig-Geist-Spital), Besler, Klingenbeck, Michael Roting, ${ }^{89}$ and Joachim Heller.

At his trial, Heller was questioned specifically about his connections with Flacius. At one of the hearings on May 5, 1563 Heller stated that he listened to Flacius with joy. ${ }^{90}$ Flacius came from Regensburg to visit Nuremberg at the end of Heller's trial on May 11, 1563 and stayed in the home of the preacher Bartholomaeus Schober for two days. ${ }^{91}$ In the end, Heller was condemned for stepping out of place as city astronomer when he had entered the theological debate. The other accusation against him was that he was a Flacian. Flacius' books and personal letters from him that Heller had in his possession were used against him as evidence. Finally, his sentence was pronounced: a lifelong banishment from Nuremberg for him and his family and it was handed down on June $1,1563 .^{92}$ Schober was also exiled from Nuremberg for having provided hospitality to Flacius without prior permission from the city and for insisting on replying to the charges in written form only while refusing verbally to answer the prosecutor during the trial. ${ }^{93}$

GA 8, 681-682 and GA 9, 67-73; 299-308; 337-339; 407-410; 516-18; 553-556. Besold was a prominent Gnesio-Lutheran and was involved in collecting materials for the Jena edition of Luther's Works. For his short biography, see Karl Schornbaum, »Besold, Hieronymus, « in NDB 2 (1955), 179; »Besold, Hieronymus, « in MBW 11: Personen A-E, 149-150. Besold is also referred to in Flacius' correspondence with Waldner in 1557.

89 Roting went by the Latin version of his name, Rotingius. He was from Sülzfeld in Franken. Between 1519 and 1526 he was a student of Luther's and Melanchthon's in Wittenberg and became a magister there. In 1526 he came with Camerarius to Nuremberg where he became a teacher at a Latin school St. Egidien. In the following year he married in Nuremberg. Roting wrote a work against Andreas Osiander in 1551 [VD16 R 3326]. After Osiander wrote his Schmeckbier [VD16 O 1094] refuting Roting and others who attacked him, including Flacius, Roting published another work in 1552 in Magdeburg together with Wolfgang Waldner and Hieronymus Besold [VD16 R 3325]. http:/www.merkelstiftung.de/Familie/familiendaten/ getperson.php?personID=I5658\&tree=PWMerkel (accessed September 16, 2011).

90 Unpaginated Heller Dossier, »...hab nun Illyricus mit freuden gehoert.«

91 See, Karl Schornbaum, »Die brandenburgisch-nürnbergische Norma doctrinae 1573., ARG 19 (1922): 161-193, here 184.

92 Heller eventually ended up in Mansfeld, were he worked as a town astronomer. He published some of his works in Eisleben, including Prognosticon [VD16 ZV 21928]. Irmgard Bezzel, »Joachim Heller (ca. 1520-1580) als Drucker in Nürnberg und Eisleben, « Archiv für die Geschichte des Buchwesens 37 (1992): 295-330.

93 Schornbaum, »Die brandenburgisch-nürnbergische Norma doctrinae, «184 n. 1. See the letter from Josef Fröschl von Marzoll to Count Joachim von Ortenburg, sent on July 17, 1563, about the details of Schober's ordeal, in Walter Goetz and Leonhard Theobald (eds.), Beiträge zur Geschichte Herzog Albrechts V. und der sog. Adelsverschwörung von 1563 [Briefe und Akten zur Geschichte des sechzehnten Jahrhunderts mit besonderer Rücksicht auf Baierns Fürstenhaus 6] (Leipzig: Tuebner, 1913), 111-114, here 112. 


\title{
4. Flacius Taking Sides in the Confessional Polemics Concerning the Eucharist in Royal and Ducal Prussia
}

\begin{abstract}
Another Crypto-Calvinist controversy took place in Danzig (Gdańsk), located on the Baltic Sea in Royal Prussia, ${ }^{94}$ where two city pastors appointed at the church of St. Mary, Veit Nuber ${ }^{95}$ and Erhard Sperber, ${ }^{96}$ started a public disagreement regarding the Eucharist in 1561. The particular issue they were arguing about concerned the leftover elements of consecrated bread and wine in the Lord's Supper, the so-called reliquiae Sacramenti.$^{97}$ Nuber leaned toward the Wittenberg theology and also claimed that Aurifaber (Vratislaviensis) agreed with him. He employed Melanchthon's formulation that $»$ nothing can be a Sacrament outside the divinely ordained use. $\mathrm{K}^{98}$ According to Nuber, the leftovers were nothing other than bread and wine, while Sperber argued that the reliquiae remained Christ's flesh and blood even after the celebration of the Eucharistic meal..$^{99}$
\end{abstract}

94 Royal Prussia was also called »Polish Prussia« because it was under the rule of the Polish king, as opposed to Ducal Prussia in the East, which had been a Protestant (Lutheran) Duchy since 1525, with Königsberg as its capital and Albertina University as its primary educational institution. In Royal Prussia evangelical preaching was allowed only in 1557 by a royal privilege. Both Royal and Ducal Prussia are referred to as Pruthenia in Latin, which makes it somewhat confusing and difficult to differentiate between the two. For example, a doctrinal statement written in 1567 by Joachim Mörlin and Martin Chemnitz, commonly referred to as Corpus doctrinae Prutenicum, was adopted by the Synod in ducal Prussia and intended for use only in that territory. For details of this document composed in order to end controversies, and particularly the Osiandrian one, see Robert Kolb, »The Braunschweig Resolution: The Corpus Doctrinae Prutenicum of Joachim Morlin and Martin Chemnitz as an Interpretation of Wittenberg Theology, « in John M. Headley et al. (eds.), Confessionalization in Europe, 1555-1700: Essays in Honour of Bodo Nischan (Aldershot/Burlington: Ashgate, 2004), 64-89.

95 In some sources he is referred to by the Latin version of his name, Vitus. See, for example Gustav Kötz, Die Danziger Konkordienformel über das Heilige Abendmahl, Notel genannt, und ihre Apologie (1561-1567), Diss. from Albertina Univesity of Königsberg (Königsberg: H. Jaeger, 1901). Nuber was recommended to Danzig by the Wittenberg theological faculty to fill one of the pastoral positions that became vacant as a result of the firing of four pastors. He arrived in Danzig in August 1561.

96 Sperber was responsible for the evening services (Vespers).

97 For more about this particular controversy, »the range of worship practices within the early Reformation, « and how they were resolved in the Formula of Concord's Solid Declaration, see Timothy J. Wengert, »Luther and Melanchthon on Consecrated Communion Wine (Eisleben 1542-43), « in Philip Melanchthon, Speaker of the Reformation: Wittenberg's Other Reformer [Variorum Collected Studies Series 963] (Farnham: Ashgate, 2010), VIII; Originally published in Lutheran Quarterly 17 (2003): 24-42.

98 Melanchthon first employed this statement, »nihil habet rationem Sacramenti extra usum divinitus institutum, « at the Regensburg Colloquy on May 8, 1541 when debating about the Eucharist with Johannes Eck and Nicolas Perrenot Granvella. He included it later in his »Bedencken vom Synodo aller Chur und Fürsten und Stände Augsburgischer Confession«; see CR 9: 403-411, here 409, Nr. 6425; MBW 8494 (Regesten 8: 179); CR 9: 462-478, here 471, Nr. 6471; MBW 8543 (Regesten 8: 199-201, here 200).

99 Kötz, Die Danziger Konkordienformel, 12-13 and 47 mentions that Flacius opposed Nuber 
Since the same pulpit was being used to express the sharply opposing opinions of the two pastors the controversy spread, and both the city of Danzig and the region around became embroiled in it. Benedict Morgenstern, ${ }^{100}$ who had been a pastor of St. Catharine's in Danzig for a short period before being expelled on April 29, 1560, also got involved. Morgenstern had found a pastoral position in Thorn (Toruń) on the Vistula River and from there supported Sperber starting in 1562, while accusing Nuber of Calvinism and Schwärmerei. ${ }^{101}$ The city council of Danzig then decided to involve a jurist, Jakob von Barthen, ${ }^{102}$ who was already in the service of the city as a legal advisor. Barthen had also studied theology in Wittenberg and therefore had competence for the assignment he received, namely the drafting of a document in order to reach a compromise and end the polemics in Danzig between the parties leaning toward either Luther's or Calvin's understanding of the Eucharist. This process resulted in the confessional document called Notula, also referred to as the Formula of Concord (Formula Concordiae), which was signed on July 17, 1562 by preachers of both adherences and was later issued in print. ${ }^{103}$

The Notula did not bring peace among the divided city preachers, and the Danzig city council then approached a number of theological faculties for their expert opinions, including those of Wittenberg and Rostock. Other

and refers to a letter and libelous writing (Lästerschrift) against him, in which Flacius called Nuber »a godless Epicurian monk, who has taken many wives, « accusing him of polygamy (...diesen Nuberum einen gottlosen Epicurischen münchen, der da mehr weiber genommen habe); a document that stirred up the citizens of Danzig. Namely, during 1564 a plague was raging in Danzig that people interpreted as a punishment from God (24,000 people died), so that Flacius' defamatory text against Nuber created further religiously inspired fear in the city.

100 Karl Alfred von Hase, »Morgenstern, Benedict,« in ADB 22 (1885), 228-230.

101 Henning P. Jürgens, »Inner-Protestant Conflicts in $16^{\text {th }}$ Century Poland and Prussia The Case of Benedict Morgenstern, « in R. Ward Holder (ed.), Calvin and Luther: The Continuing Relationship [Refo500 Academic Studies 12] (Göttingen: Vandenhoeck \& Ruprecht, 2013), 143-164. The Thorn pastor Anton Bodenstein had corresponded with Flacius since 1556, which shows that Flacius was already having contacts and developing a network in Royal Prussia. See, Theodor Wotschke, Geschichte der Reformation in Polen [Studien zur Kultur und Geschichte der Reformation 1] (Leipzig: Verein für Reformationsgeschichte, 1911), 236. For more about Bodenstein, see MBW 11: Personen A-E, 170-171.

102 »Barthen, Jakob von, in MBW 11: Personen A-E, 116.

103 Formula Concordiae oder Notel der Kirchen Zu Dantzigk (s.1.:1652; VD17 14:072654K). For the critique of the Notel, see Gruendlicher Gegenbericht... Widerlegung der Formulae Concordiae oder Notel/so alle Prediger zu Dantzigk... (Danzig: Jakob Rhode, 1567; VD16 A 3149); Benedict Morgenstern, Johannes Wigand et al., Widerlegung der Notel/damit die Sacramentirer zu Dantzig/jhren Jrthumb vnd Verfolgung/verkleistern vnd bedecken wollen (Eisleben: Andreas Petri, 1567; VD16 M 6341). One of the objections against the Notel was that it was composed from the writings of Johannes à Lasco and Melanchthon. 
theologians were also asked to write their responses. Joachim Mörlin sent his opinion from Braunschweig on October 24, 1562. ${ }^{104}$

In Königsberg there was also a religious discussion on the theme of the Lord's Supper in 1562, ignited by the developments in Danzig. As university professor and president of the Samland diocese, ${ }^{105}$ Aurifaber (Vratislaviensis) sent a report to Duke Albrecht concerning the Croatian-born Paul Skalich, who was at that time a professor of Logic and Metaphysics at Königsberg University and the Duke's privy councilor. ${ }^{106}$ Skalich had introduced his own »third way« of resolving the Notula controversy by suggesting that the words corpus and sanguis be interpreted in an allegorical way relating to the mystical Christ. ${ }^{107}$ The court preacher, Johannes Funck, who was a friend of Skalich, supported him. ${ }^{108}$ It is needless to say that this attempt only caused even greater division and added fuel to the already raging fire of the Eucharistic controversy in both Ducal and Royal Prussia.

Morgenstern apparently contacted Flacius for his advice and support in resolving the conflict. In response, Flacius dedicated his book about the Sacrament of the Lord's Body and Blood, which also contained his writings against Olevianus and Schwenckfeld's supporters, specifically to the mayor Johann Brandes, ${ }^{109}$ city and the evangelical church of Danzig. The dedicatory preface was signed in Regensburg and dated on the day of the Purification of Mary (February 2) $1564 .{ }^{110}$ The preface consisted of twenty-six pages, which,

104 See the chapter »Mörlins Gutachten für Danzig,« in Diestelmann, Joachim Mörlin: Luthers Kaplan, 291-293.

105 Königsberg was the seat of the Samland Bishopric. The first evangelical bishop of the see of Samland was Georg von Polentz. The Bishopric of Pomesania was seated in Marienwerder and Riesenburg, where Paul Speratus was bishop. After the death of these two bishops, Duke Johann Albrecht I decided not to replace them after he failed to convince either Brenz or Flacius to become the new bishop of Samland so that these two bishoprics were unoccupied throughout the Osiandrian controversy in Prussia. Only in 1567 was Joachim Mörlin appointed as the new bishop of Samland. Aurifaber was technically just an administrator of the diocese in addition to the professorship he held at the University of Königsberg.

106 For more about Skalich's time in Königsberg and Prussia see the chapter »Paulus Scalichius, der falsche Markgraf von Verona (1561-1565), « in Karl Alfred von Hase, Herzog Albrecht von Preussen und sein Hofprediger: eine Königsberger Tragödie aus dem Zeitalter der Reformation (Leipzig: Breitkopf und Härtel, 1879), 287-330; Fligge, »Paul Scalich in Preußen,« in Herzog Albrecht von Preussen und der Osiandrismus, 474-501.

107 Parts of Aurifaber's letter to Duke Albrecht are quoted in Krabbel, Paul Skalich, 138-39. The letter is dated in Königsberg on February 26, 1563.

108 Funck was Osiander's son-in-law, just like Hieronymus Besold in Nuremberg. For more about Funck, see http://www.controversia-et-confessio.adwmainz.de/index.php?id=1243 (accessed September 25, 2011); Hase, Herzog Albrecht von Preussen und sein Hofprediger, 80-120; 205-286.

109 Ernst Bahr, »Brandes, Johann,« in NDB 2 (1955), 521.

110 Flacius, Trewe Warnung, Vorrede A2r: »Den Erbaren vnd Hochweisen Herrn/Burgermeistern/Rhat vnd Gemein der Statt Dantzig/meinen grossguenstigen Herrn/Wuenscht M. Flacius Jllyr. die ware vnd reine Religion Jesu Christi/sampt einem ernsten Eyffer vnd bestendigkeit in derselben.« 
as Flacius claimed, he had been »instructed by the Holy Spirit« to write. ${ }^{111} \mathrm{He}$ reported that he had been informed orally and in written form by two bishops and by the preachers Franz Burchard, ${ }^{112}$ pastor of St. Mary's Church, and Benedict Morgenstern, about the situation in the city. ${ }^{113}$

What is interesting to note is that in the middle of the preface to the city of Danzig, Flacius began to talk about the controversy in Nuremberg without mentioning the name of the place but calling it a "great big city« and going on in great detail about what took place there and how some good Christians were banned as a result. ${ }^{114}$ Flacius' intention was to use Nuremberg as a bad example to serve as a warning for Danzig not to do the same. That Flacius was referring to Nuremberg is confirmed by the existence of a document at the state archive in Nuremberg, written by the city magistrate condemning Flacius' preface and its critique, dated on May 5, 1564 with the title: Advice concerning the several calumnies by the fraudulent and inflammatory man, Matthias Flacius Illyricus, against the honorable city council and the city of Nuremberg. ${ }^{115}$ Nuremberg's response to the dedication written to Danzig in

111 Ibid., A3r: »Mein ansprechen vnd zuschreiben des Buches steht ... in dem befehl des Heyligen Geystes /...«

112 Burchard was from Löwenberg in Silesia and once signed his work as »Franciscus Burchardus Leobergensis minister ecclesiae Thoronicensis Prussiae.« He was a pastor in Riesenburg and in 1557 he relocated to St. Mary's in Rostock. Soon afterwards he moved to Danzig and was exiled from there in April 1560, together with Morgenstern and two other pastors because they had openly criticized the city council from their pulpits. Following his banishment, he and Morgenstern found new employment and were installed as pastors of St. Mary's in the old city of Thorn on July 30, 1560. See a letter by Flacius to Anton Bodenstein in Thorn, dated in Magdeburg on April 1, 1556 in which he asked him to pass on his greetings to »Franciscus Burcardus, pastor Riesenburgensis.« The letter is reprinted in Anton Gindely, Quellen zur Geschichte der Böhmischen Brüder vornemlich ihren Zusammenhang mit Deutschland betreffend, vol. 2 (Wien: Kaiserlich-Königlich Hof- und Staatsdruckerei, 1859), 281-283, here 283.

113 Flacius, Trewe Warnung, A2v: »...in dem/das ich/beide mit ewren Bischoff auffs vleissigest/beide Mündlich vnd schrifftlich/vnd auch mit ewren trewen Predigern M. Francisco Burchardo/Benedicto Morgenstern/vnd andern /... « Flacius does not name the two bishops but most likely he was referring to then empty positions of Bishops of Pomesania and Samland, which were filled by two administrators at the time. The other possibility is that Flacius did not really know the current ecclesiastical situation and was only saying that he spoke to the two bishops in order to add credibility to his writing.

114 Ibid., A5v: »Es hat sich vor zweien jaren im Winter des LXI. [1561] Jars in einer grossen vnd gewaltigen statt zugetragen/das fast drey Monat so gar ein grosser mangel der liecht gewesen / ... so sein etliche dergleichen Christliche Personen verjagt worden.«

115 Ratschlag etliche des verlognen, auffruehrischen Manns Matthaei Flacii Jlliricj Caluminias wider ein Erbarn Rath vnd gemeine Statt allhie betreffendt. For more about the document, see Georg Theodor Strobel, »Nuernbergischer Ratschlag den unruhigen Flacium betreffend vom Jahr 1564., in Beyträge zur Litteratur besonders des sechzehnten Jahrhunderts 1/20 (Nuremberg/Altdorf: George Peter Monath, 1785), 405-412. It is interesting to note that the Nuremberg city council had another grievance with Flacius in the same year. In the already mentioned volume eight of The Magdeburg Centuries there was a section against the cult of Saint Sebaldus, pointing out that he was sent by the Pope to Germany. Since St. Sebaldus 
1564 sheds light on how Flacius used his prefaces to influence political and confessional situations as well as theological controversies in various places and how important his publications and opinion really were.

Prior to this particular conflict, Flacius had written a foreword for Johann Serrarius' pamphlet against the Danzig preacher, Bonaventura Knorr, and the latter's sermons about good works and had dedicated it to the people in Danzig. This shows that already prior to the debate over the Lord's Supper he had tried to indirectly influence the theological landscape of that city. ${ }^{116}$ The outbreak of this theological Streit was also part of other Crypto-Calvinistic controversies taking place in many cities at the time. ${ }^{117}$ This is why Flacius attacked Theodore Beza, who was Calvin's successor, as soon as he took over the leadership of the Genevan Church and issued a first publication against him in $1565 .{ }^{118}$ Flacius namely considered Geneva to be the center of the Reformed interpretation of the Eucharist that was spreading throughout Europe. He did not issue a similar attack against Bullinger or the Zurich church.

\section{Evaluation of Flacius' Regensburg Years}

Even though the time spent in Regensburg was probably the academically most productive for Flacius after Magdeburg, it also marked the most tragic years in his private life. In 1564 his wife died giving birth to their twelfth child and Matthias was left alone to take care of his big family. Nine months

was the patron saint of Nuremberg and the shrine with his tomb and relics was one of the most visited sites by pilgrims, especially on St. Sebaldus' feast day in August when his relics were carried in procession, the city council blamed Flacius for fewer visitors to the shrine and therefore the loss of income. See, Fritz Schnelbögl, "Sankt Sebald in Nürnberg nach der Reformation, « Zeitschrift für bayerische Kirchengeschichte 32 (1963): 155-172, here 161. For Flacius' stand against the veneration and invocation of the saints, see Marina Miladinov, »Mittelding or Idolatry? Veneration of Saints in Matthias Flacius Illyricus, in Miladinov (ed.), Matija Vlačić Ilirik II, 75-107.

116 Serrarius, Das die Euangelischen Prediger gute wercke nicht verbieten noch verwerffen/wie sich Herr Boneuentur, Thomasprediger zu Dantzk in seinen Predigten zum oftermal hoeren lesst/ein kurtzer Bericht durch Joannem Serrarium. Mit einer Vorrede Matth. Flac. Jlli. (Magdeburg: Michael Lotter, ca. 1555; VD16 S 6061), A1v-3v, A2r: »An die Liebhabber Gottes Worts/zu Dantzk. Vorrede Matth. Flac. J1li.«

117 For the controveries (Osiandrian, Majoristic and Crypto-Calvinistic) in Royal and Ducal Prussia following the Augsburg Interim, see Henning P. Jürgens, »Die Beteiligung der beiden Preußen an den nachinterimistischen Streitigkeiten, « Zeitschrift für Geschichte und Altertumskunde Ermlands: Beiträge zur Kirchen- und Kulturgeschichte des Preussenlands 55 (2011): 30-63.

118 For Flacius' involvement in a dispute with Beza, see Luka Ilić, »Beza and Flacius in the Sacramentarian Controversy, « in Irena Backus (ed.), Théodore de Bèze (1519-1605): Actes du colloque de Genève (septembre 2005) [Travaux d'Humanisme et Renaissance 424] (Genève: Droz, 2007), 353-365. 


\section{APOLO IIA, MATH \\ APOLOGIA, MATHIÆ}

FLACII ILLYRICI PRO SVIS DE. monltrationibus, in controuerfia Sacramen= tarid, contra, Beze cauillationes.

\section{ILLVSTRISSIMO PRIN.}

CIPIAC D. D. VVOLFGANGO, PA XATINO RHENI, DYCI BAYARIAE, \&C. fuo Domino clementifsimo optat ardentem zelum Euangelij с н R IS T I \& perpetuam foelicitatem Mathias Fl. Illyr?

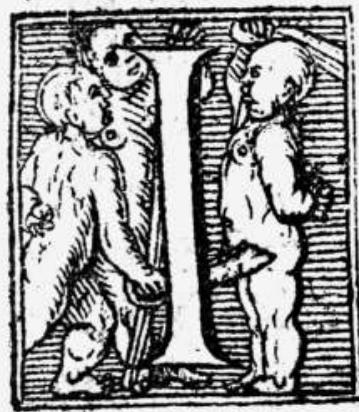

LLVETRISSIME ET RY entifsimePrinceps ac Domine longè clementifs, omnique ob feruantia colende, op tandum profecto o, minibus modis effet, ut, cừm controuerfia Religionis exoriuntur, prafertim uerò in Ecclefia \& inter eos,qui de plerisç capitibas arti cullifue inter fe confentiunt, omnia ibi

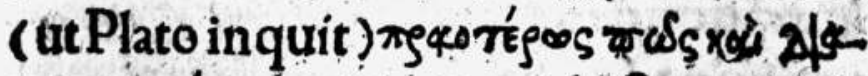

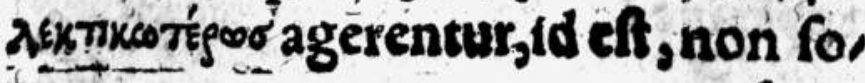

Figure 10: Flacius' Apologia ... contra Bezae cauillationes, dedicated to Wolfgang, Count of Palatinate-Zweibrücken. Courtesy of The University Library of Pula: shelfmark R-F 582. 
after his wife's death his oldest daughter died, too. Matthias was very sick, his stomach was not able to digest anything, his legs were shaking and he was on the brink of a nervous breakdown. When he could not effectively take care of his household any more, his friend Gallus persuaded Flacius to marry again and acted as a marriage broker. It must not have been easy to convince the widow of pastor Ilbeck to give her young daughter Magdalena ${ }^{119}$ in marriage to a sick foreigner with many children, who was also a refugee without a job or financial means to support his family. ${ }^{120}$ Soon after Flacius' second wedding Emperor Maximilian II ordered the city of Regensburg to cancel their asylum for Flacius, so he took to the road once again. ${ }^{121}$ This time, however, his family stayed behind.

The fact that Flacius took time to write against the Heidelberg Catechism and Olevianus in the year when his wife died and when he was left alone to take care of his eight surviving children shows just how seriously he took the developments in the Palatinate. After all, at that time he was living less than 200 miles away in Regensburg and was most likely concerned that Calvinism might spread even further.

Flacius left Regensburg in 1566 but his indirect theological influence in the city was felt long after he was gone. ${ }^{122}$ In 1568 Superintendent Gallus attempted to defend Flacius from accusations by publishing A True Vindication of Matthias Flacius Illyricus against a Certain New Attack Launched by the Adiaphorists. ${ }^{123}$ Even after Gallus died in May 1570, ${ }^{124}$ the disagreements continued, with Joshua Opitz, who became the Regensburg superintendent at the young age of twenty-nine and was a Flacian, taking on a leading role in the controversy over original $\sin .{ }^{125}$

119 She had a brother named Erasmus. One book purchased by him for ten creutzers in Frankfurt in 1567 can be found at HAB, C $21.12^{\circ}$ Helmst. His ownership signature reads: Erasmus Ilpeck Ratisbonensis.

120 See Mirković, Matija Vlačić Ilirik, 214-223.

121 Ibid., 228. Mirković argues that the reason was the so-called Grumbach affair, a rebellion led by the knight Wilhelm von Grumbach, who was supported by Duke Johann Friedrich II of Saxony against the Emperor. Even though this same Duke had dismissed Flacius from Jena in December 1561, the imperial court in Vienna believed that the insurrection was influenced by supporters of Flacius.

122 The city of Regensburg issued a letter of recommendation and testimony for Flacius on August 9, 1566. A copy of the document can be found at HAB, Helmst. 71c, 309, referred to in Mirković, 228, n. 435.

123 Nikolaus Gallus, Vera excusatio M. Fl. Ill. contra novam quandam criminationem ab Adiaphorists sparsam (Regensburg, 1568), Preger, Flacius und seine Zeit, 2: 332.

124 On the continuing Flacian controversy in Regensburg after Gallus' death, see Friedrich Loy-Bayreuth, »Der Flacianische Streit in Regensburg, « Zeitschrift für bayerische Kirchengeschichte 1 (1926): 6-29; 67-93.

125 Gustav Frank, »Opitz, Josua, « in ADB 24 (1886), 369-370; Josef Karl Mayr, »Vom Geist des Hauses: der lutherische Landhausprediger Josua Opitz, « and »Michael Eichlers Leichenpredigt auf den Magister Josua Opitz,« Jahrbuch der Gesellschaft für die Geschichte des 
This particular controversy, which took place in Regensburg and alienated its clergy, is a good example of how Flacius' theology often led to division and caused strong partisanship. Opitz was eventually expelled from the town by the city council in February 1574, together with pastors Hieronymus Peristerius, ${ }^{126}$ Wolfgang Viereckel ${ }^{127}$ and the Gymnasium rector, Hieronymus Haubold, ${ }^{128}$ because of their adherence to Flacius and for propagating his views on original sin from the pulpit and in the classroom. ${ }^{129}$ All of them went into exile in Austria, where they continued their polemical activities

Protestantismus in Österreich 71 (1955): 9-13; 68-72. Opitz published his Leichenpredigt for Gallus, Eine Christliche Leichpredigt. Bey dem Begrebnuß des Ehrwirdigen vnnd Hochgelehrten Herrn Nicolai Galli/Pfarrhers/vnd Superintendenten der Christlichen Gemein zu Regenspurg/gethan am tag Johannis Baptistae. Durch M. Iosvam Opitivm/Predigern in der Newen Pfarr daselbst (Regensburg: Johann Burger, 1570; VD16 O 778).

126 In the year he was exiled, Peristerius published his position regarding original sin, which mirrored the Flacian definition of it. The twenty-three-page-long preface to the book was written by Flacius himself, A2r-B1v. See Christliche Confession vnd Bekentnus/auch Antwort vnd Bericht/auff den fuergelegten Extract eines Erbarn Camerer vnd Rhats der loeblichen Stadt Regenspurg von dem gegenwertigen Streitte/der Erbsuende/gezogen vnd genomen aus den Schrifften der Propheten vnd der Apostel. M. Hieronymus Peristerius. Jtem/Matthiae Flacij Jllyrici von der besten Schlichtung dieses Streitts von der Erbsuende/sampt seinem Beschlus (Oberursel: Nikolaus Henricus d.Ä., 1574; VD16 D 663). Four years later, Peristerius published his renouncement of that work and of his Flacian position and claimed that instead he followed Wigand. See, Retractation Gentzliche Auffhebung vnnd verwerffung. Der Anno 1574 gestelten vnd getruckten kurtzen Antwort vnd Berichts. M. Hieronymi Peristerii. Von der Hauptfrage des gegenwertigen Streits von der Erbsuende. Vnd Wie er sich mit der Euangelischen Kirchen vnd Gemeine/des heiligen Roeomischen Reichs Freystat Regenspurg Christlich versoenet vnd mit derselben Bekantnu $\beta$ wider die newen Manicheer gentzlich vereiniget habe (Regensburg: Hans Burger, 1578; VD16 D 663). Opitz then wrote an objection and critique of Retractation. See, Protestation wider den unseligen Abfall M. Hieronymi Pereisterij/von erkanter vnd bekanter warheit/vnd seine durch den Druck außgegangene Retraction/oder Widerruff. Von M. Iosua Opitio. Zu rettung seiner Christlichen Lehre vnd Bekantnis/vnd seinem Zuhoeren zur warnung gestelt (s.1.: 1578; VD16 ZV 11989).

127 Viereckel was from Bohemia. Prior to his pastorate in Regensburg he had been in Mansfeld and after 1574 he was in Obersulz in Lower Austria.

128 Theodor Distel, »Haubold, Hieronymus, « in ADB 11 (1880), 42-43. See also Distel's book about Haubold's Flacian activities in Geringswalde in Saxony, where he was a school rector between 1566 and 1568 and then exiled by Elector August I, Der Flacianismus und die Schönburg'sche Landesschule zu Geringswalde (Leipzig: Johann Ambrosius Barth, 1879). Haubold himself published a number of works. One was issued while he was a school rector in Klagenfurt together with a pastor there, Andreas Lang, see Richtige vnd in Gottes Wort gegruendte Bekentnis von der ERBSVNDE. Herrn Andree Langen/ etwan Pfarrers zu Clagenfurd in Kaerndten/Vnd/ M.Hieronymi Hauboldi/ auch etwan Rectoris der Landtschafft Schulen daselbst. Der warheit zum Zeugnuss/vnd fromen Christen zum unterricht/ in druck verfertiget (s.1.: 1576; VD16 L 274). Haubold's work Formvla Veritatis. Warhafftige vnd gruuendliche Außfuehrung/des hohen vnnd wichtigen Religionsstreits von der Erbsuende: ... (Nuremberg: Nikolaus Knorr, 1582; VD16 F 1875) was composed in Efferdingen and published posthumously. It contained the signatures of forty Flacian pastors in Upper Austria, among whom eleven were described as »Exules Jesu Christi,« B2r-B3r.

129 Johannes Wigand wrote his account of the controversy in Regensburg. See, »Acta Ratisponensia in Controversia de Peccato Originis, « in De Manichaeismo Renovato. D. Iohannes VVigandvs Episcopus Pomezaniensis (Leipzig: Henning Grosse, 1587; VD16 W 2795), 
countering Andreae's attempts at bringing the unity among the evangelicals and against The Book of Concord. ${ }^{130}$ They all insisted on the Flacian definition of $\sin .^{131}$ For example, Opitz carried on the controversy from his place of refuge with Wolfgang Waldner, who had become his successor as superintendent in Regensburg. ${ }^{132}$

\section{A Tract in Clavis Scripturae: Flacius' Radical Exposition of Original Sin}

During his time in Regensburg Flacius completed the majority of the work on what was perhaps his most systematic opus, Clavis Scripturae Sacrae, about which philosopher Wilhelm Dilthey said that it is the »first scientific work of biblical interpretation since the days of disputes between Alexandrian and Antiochian theologians, ${ }^{133}$ while Hans-Georg Gadamer called it »the first important work of hermeneutics. ${ }^{134}$

In the Clavis, Flacius criticized those theologians who in his view had been corrupted by Aristotelian logic and were no longer able to comprehend the language of the Bible: »They disapprove of examining the Hebrew and Greek sources, contending that they give rise to heresies.« This was contrary to the practice of the Fathers, Flacius continued, - especially Jerome, who

526-534. See also his Von Zweyen Grewlichen/ Gottslesterlichen Jrrthuemben/ der Newen Manicheer... (Regensburg: Johann Burger, 1574; VD16 W 2905).

130 See Andreae's work dedicated to the city council and the evangelical church of Regensburg, meant to win them over to his position, Bericht von der Erbsünde. Darinn der vnderscheid zwischen der verderbten Natur deß Menschen nach dem fahl vnnd der Erbsünde bewisen vnd erklert/Vnd dem einfaltigen Layen ein richtiger weg angezeigt wie er sich vermög Gottes Worts ... Durch Jacobum Andree/D. Probst zu Tübingen (Tübingen: Georg Grupenbach, 1575; VD16 A 2499).

131 See Rudolf Leeb, »Der Einfluss von Cyriakus Spangenberg auf die habsburgischen Erblande und das Erzstift Salzburg,« in Stefan Rhein and Günther Wartenberg (eds.), Reformatoren im Mansfelder Land: Erasmus Sarcerius und Cyriakus Spangenberg [Schriften der Stiftung Luthergedenkstätten in Sachsen-Anhalt 4] (Leipzig: Evangelische Verlagsanstalt, 2006), 259-277, here 266-273; Dingel, Concordia controversa, 472-476.

132 Waldner, Abfertigung/vnd gruendliche Widerlegung des vngegruendten Gegenberichts M. Josue Opitij/so er von der Erbsuende/seiner enturlaubung/von etlichen Specialhendeln/wider eines Erbarn Camerer vnd Raths der Stadt Regenspurg warhafften Bericht/am ende des 1578. Jars/hat meuchelisch in Druck außgehen lassen. Wolffgangus Waldner Kirchendiener zu Regenspurg (Regensburg: Johann Burger, 1580; VD16 W 866).

133 Wilhelm Dilthey, Studien zur Geschichte des deutschen Geistes. Gesammelte Schriften. Book III (Leipzig/Berlin: Tuebner, 1927), 219. See also Ivan Kordić, Hermeneutika Matije Vlačića Ilirika (Zagreb: August Šenoa, 1992), 161.

134 Hans-Georg Gadamer, »Die Universalität des hermeneutischen Problems, « Philosophisches Jahrbuch 73 (1966): 215-225. 
»excelled in languages, « and Augustine, who recommended linguistic studies in De doctrina christiana. ${ }^{135}$

As has already been mentioned, during the Weimar Colloquium Flacius said that original sin is the person's substance. In his tract On the Appellations and Essence of Original Sin or the Old Adam, Flacius explained this claim in greater detail and tried to distinguish between the lower and the higher formal substance. For him, »forma substantialis« (substantial form) represented the basic or lower form, which included the difference between body and soul, our senses (hearing, smell, taste, sight and touch), as well as the ability to think. The higher form he termed »forma substantialis formalis [nobilissime] in summo gradu« (substantial form in its highest grade), which consisted of our reason and will, and had been part of our original divine image before the fall. Here is how Flacius explained the nature of humankind as it was originally created out of nothing (creatio ex nihilo):

But I speak concerning the most noble substantial form according to which especially the heart, or rather the rational soul, had been formed, so that this same essence would be the image of God, and that as man's substantial powers, the reason, will, and affections, would be conformed toward the properties of God, and would both represent and truly know Him. ${ }^{136}$

Flacius insisted that the substantial form in its highest grade was the component of humankind's substance that made the person into what their creator desired them to be. ${ }^{137}$ That higher substantial form, which is only one part of us, has been completely destroyed and transformed into the image of Satan, according to Flacius. On the other hand, the lower form remains the same as our principal created matter (in the body). Even though through the higher substantial corruption of our soul the lower part has been affected as well, in that part something has still been left of the original perfection and order. ${ }^{138}$

By making these statements, Flacius attempted to respond to his critics who were accusing him of making the human being seem as if he were a creature of Satan. His reply was that the transformation that took place, through which the highest part of the form was completely changed, does not prove

135 Flacius, Preface to Clavis Scriptvrae... Pars Prima, A3v-A4v.

136 Flacius, Clavis Scriptvrae..., Altera Pars. Tractatus VI: De peccati originalis, avt veteris Adami appellationibus \& essentia, 368-382, here 370: »...sed loquor de ea nobilissima substantiali forma, ad quam praecipuem ipsum cor, aut potius anima rationalis formata erat, ita ut ipsa sua essentia esset Dei imago eumquem repraesentaret, utque suae substantiales potentiae intellectus ac voluntas affectusque; ad Dei proprietates essent conformatae, eumque tum repraesentarent, tum vere agnoscerent."

137 Ibid., 370: »Forma substantialis summa gradus, qui praecipue dat homini esse eius rei, quam esse eum suus creator voluit."

138 See Ante Bilokapić, »Die Erbsünde in der Lehre des Matthias Flacius Illyricus,« in Josip Matešić (ed.), Matthias Flacius Illyricus - Leben \& Werk [Internationales Symposium, Mannheim, Februar 1991; Südosteuropa-Studien 53] (München: Südosteuropa-Gesellschaft, 1993), 43-52, here 48. 
that Satan is the maker of the new person, but only shows that he is the one who has fully corrupted the God-given substance and therefore responsible for the total depravity in humankind:

Therefore, this inverted substantial form or formal substance in the highest grade, which provides the human being chiefly with that thing that the creator desired him to be, that now changes him according to its formal cause so that he is the image and son of the devil, and provides him that horrible fate to become the old Adam - - this thing, which we call original sin, I assert to be the true and sole font of $\sin .{ }^{139}$

Flacius' division of substantiality is the best way to portray his understanding of anthropology. He describes the human being as the one who possesses the lower form as the earthly (carnal) and philosophical person that is different from the spiritual and theological person: only the latter can stand in the presence of God (coram Deo). At this point he introduces the term imago, which is in some sense similar to the term forma and from which his theology of humanity is derived. Because the image of the human being has been changed from that of God to that of Satan, he develops a triplex status hominis (threefold standing of the human being) based on: imago Dei, imago Satanae and a new birth ex nihilo in Jesus Christ. ${ }^{140}$ The ground for this threefold partition of the human being is found in five domains: 1. God; 2. Adam; 3. Christ; 4. Antichrist; 5. End-time; where numbers two and four, as well as three and five, belong together.

Triplex status $\left\{\begin{array}{l}\text { Libertas } \\ \text { Servitus } \\ \text { Liberatio }\end{array}\right.$

Hominis $\left\{\begin{array}{l}\text { Integri } \\ \text { Lapsi } \\ \text { Redempti }\end{array}\right.$

139 Flacius, Clavis Scriptvrae, 370: »Hanc igitur inversam substantiam formalem, aut formam substantialem summi gradus (qui praecipuem dat homini esse eius rei, quam esse eum suus creator voluit), quae iam eum, ut causa formalis, facie imaginem et filium diaboli, et dat ei illud horrendum esse veteris Adami: statuo esse verum et quasi unicum fontem omnis peccati,... et idipsum quod vocamus originale peccatum.«

140 For the concept of Imago Dei by Flacius, see Lauri Haikola, Gesetz und Evangelium bei Matthias Flacius Illyricus: Eine Untersuchung zur lutherischen Theologie vor der Konkordienformel [Studia Theologica Lundensia 1] (Lund: CWK Gleerup, 1952), 60-75. 
As illustrated in the diagram above, Homo integrus is the one who is free from unrighteousness and punishment; Homo Lapsus is a servant of guilt and punishment, while Homo Redemptus has been set free from unrighteousness and punishment, which is death. ${ }^{141}$

This is how Flacius described the terrible effect of sin, which attacked humanity's being and nature and changed it in such a way that human beings have become dehumanized or demonized, i.e. they do not portray the image given to them by their Creator any more:

In this manner, therefore, I have recently realized and asserted that original sin, in its first rank, is a substance because the rational soul and especially its most noble and substantial powers, namely reason and will (which were created so wondrously that they were the true image of God, the fount of all justice, honesty and piety and clearly, essentially, just as gold or gems) are now, by the trick of Satan, precisely and utterly inverted. Thus they have become the true and living image of Satan and are like manure or rather the unchanging hellish flames. [This transformation] is as if some completely sweet and pure mass is infected by a most venomous leaven and is deeply and substantially changed and transformed through the fermentation of that mass. ${ }^{142}$

In this vividly worded paragraph Flacius only described the results that original sin has produced but failed to define the sin itself. Instead, he turned directly to the words of Luther in order to support and legitimate his own position:

Regarding Psalm 51: In fact, if you wish to define sin according to the psalm, you must say that $\sin$ is everything that is born from father and mother, before man is old enough to speak, act, or think anything. ${ }^{143}$

141 See Günter Moldaenke, Schriftverständnis und Schriftdeutung im Zeitalter der Reformation, Teil I: Matthias Flacius Illyricus [Forschungen zur Kirchen- und Geistesgeschichte 9] (Stuttgart: W. Kohlhammer, 1936), 88.

142 Flacius, Clavis Scriptvrae, 370: »Hoc igitur modo sentio et assero, primarium peccatum originale esse substantia, quia anima rationalis, et praesertim eius nobilissimae substantialesque potentiae, nempe intellectus et voluntas, quae anrea erant ita praeclarem formatae, ut essent vera imago Dei, fonsque omnis iusticiae, honestatis ac pietatis, et planem essentialiter veluti aureae ac gemmeae: nunc sunt fraude satanae adeo prorsus inversae, ut sint vera ac viva imago satanae, et sint veluti stercorae aut potius ex gehennali flamma constantes, non aliter ac si dulcissima ac sincerissima quaepiam massa, venenatissimo fermento infecta, in eiusdem fermenti molem penitus substantialiterque immutata ac transformata esset."

143 Ibid., 371: »Quin tu sic definias secundum hunc Psal[mum] peccatum esse hoc totum, quod natum est ex patre et matre, antequam homo per aetatem aliquid possit dicere, facere aut cogitare." Quoted in Robert J. Christman, Doctrinal Controversy and Lay Religiosity in Late Reformation Germany: The Case of Mansfeld [Studies in Medieval and Reformation Traditions] (Leiden/Boston: Brill, 2012), 56. 
Behold it is so true that I am a sinner before you, that also sin is my nature, my original nature, and my conception, not to mention the word, deed, thought, and life that follows. I am an evil tree ... and therefore as long as this same nature and essence remains in and on us, so long are we sinners, until the body dies and deteriorates. ${ }^{144}$

In these passages Luther stated that $\sin$ is the inborn nature of the human being. He also used the illustration of a bad tree that can only bear bad fruits. Flacius later took this imagery and used it in his detailed descriptions of the fallen nature of humans.

Regarding free will, Flacius made the following statements: »Free will is the intellect and will of the human being as far as it applies to religion and the mandates of God; furthermore, it is the human being's rational soul. Therefore, free will, at the point it was created in the beginning, was the principal part of the image of God and the cause of all good. (145 $^{14}$ It is clear from this definition provided by Flacius that he taught that the image of God resided in the human being. The word arbitrium signifies also the ability and power which the human being had to do everything that the intellect and the will decide (either good or bad). This means that the human being can de facto and not only de jure give itself over to good or to evil, or to the middle road, whenever it likes. Flacius extends his definition of the term liberum arbitrium compared to the way it is applied in what he calls »common usage.« In this sense, it is the power, ability or strength of the intellect, will and actions, with which human lead their intellectual life, especially as it relates to religion.

Flacius' argument continues, human beings do not have power to use these things, as they are carnal. Matter, body and flesh impact human decisions, and because of them, they are always more ready to do evil than to do good. As we are all born of Adam's seed, on the one hand we are dead. This means that we are not able to do anything that is acceptable by God, that is, good things that are thought of, spoken and done from the heart. Because of that no one will, by their own strength, i.e. his own free will, or through good deeds (either great or small), be able to justify themselves before God.

144 Ibid., 372: „Vol. 1, fol. 29 [of the Jena edition of Luther's works]: »...Sihe so war ists / das ich für dir ein sünder bin/ das auch sünd mein natur/ mein anhebends wesen/vnd mein empfengnuß ist/ schweige dann die wort/ werck vnd gedancken/ vnd nachfolgendt leben. Ein böser baum bin ich/ . . vnd darumb so lang als dieselb natur vnd wesen in und an vns/ etc. bleibet/ also lang sind wir sünder/... Biß das der leichnam sterbe vnd undergehe.«

145 Ibid., 373: »Liberum arbitrium, est ipsemet intellectus ac voluntas hominis, quatenus circa religionem et mandata Dei versatur: seu etiam est ipsamet anima rationalis. Id igitur liberum arbitrium, quatenus olim initio sanum conditum est, fuit potissima pars imaginis Dei, et causa omnis boni.» 
In view of the fact that one of the main purposes of the tract $\mathrm{DePec}$ cati originalis, aut veteris Adami appellationibus et essentia was to refute the opinion held by many Philippists that original sin is an accident, Flacius returned to the Weimar Colloquium for a moment, recounting his opponent's position:

Therefore, according to [Strigel], the human being was not killed in the original fall, much less substantially transformed from the image of God into the image of Satan, but only polluted with a certain evil accident. If, therefore, that accident is wiped away, the human being will perfectly practice those first powers, just like Adam in the beginning. It will, therefore, not need resurrection from the dead, regeneration, the creation of a new heart so that it might be restored as a new creature. Rather, it will exercise its innate powers as prior to the fall and it will do so happily. ${ }^{146}$

In order to make his point and to probably also caricature the synergists' beliefs, Flacius used very strong language here. He did this to make clear for his readers that original evil was not just a temporary and reversible thing, to be understood lightly, but affected every part of human nature. By this, he emphasized the need of the human being for dependence on God. He went on describing the makeup of human being:

Finally, what else is the human being except a completely corrupt body and soul - even if a third thing were added to it? I do not truly believe anybody is so crazy as to assert differently. Since only these two worst and most depraved parts are in human being, they themselves must be that natural evil that fights with God... Let those who will not concede this show some other third part of human being, which is as powerful and elaborate as that original evil. ${ }^{147}$

Flacius returned to this topic several pages later and continued:

Others disagree, insisting there are still many good and excellent things remaining in the human being's creation. I respond: Even in the devil there are still many excellent characteristics of creation and indeed many more excellent than in this carnal human,

146 Ibid., 376: »Sic igitur secundum istos, homo in primo lapsu non est mortuus, multo minus substantialiter transformatus, ex imagine Dei in imaginem satanae: sed tantum malo quodam accidente conspurcatus. Si igitur illud accidens extergatur, homo illas primas vires exercebit perfecte, sicut initio Adamus. Non ergo indigebit resuscitatione ex mortuis, regeneratione, creatione novi cordis, et ut in novam creaturam condatur: sed illa prima suas nativas vires exercet, et feliciter exercebit.«

147 Ibid., 376: »Quid vero aliud tandem in homine est, praeter corpus et animam corruptiss. Num etiam aliquid tertium illis assidet, quod etiam sit in homine? Non credo sane quenquam esse tam vecordem, qui id asserat. Cum igitur tantum istae duae pessimae et depravatissimae partes in homine sint, necesse est eas ipsas esse illud nativum malum, quod cum Deo pugnet... Qui 
but has nevertheless, because all fight against God, all are evil and pure sin. For what else are they than weapons of unrighteousness? $?^{148}$

Since the body and soul of post-lapsarian humankind are ruled by sin, this makes them one and inseparable, claimed Flacius. Here he was challenging the contention that humankind needs to be distinguished from sin. His argument was that in the original creation humanity was of God but after the horrible transformation (horrenda metamorphosis) humanity came under the dominion of the devil. In this way, God's words to Adam, "You shall surely die, «(Genesis 1:17) were fulfilled and humanity as a whole became a servant of sin. Flacius insisted that good characteristics instilled by God were not enough by themselves to redeem the human being.

For there is nothing in human beings distinct from that evil mind or heart of stone that destroys them spiritually, as sickness kills them bodily. Rather, it was all his ruined and devastated nature. The original malice is not infused in Adam from outside, as many now think, in such a way as if someone would pour poison or some other bad substance into good liquor, so that due to added bad substance, what remained became itself harmful. But it is as if someone transmuted the same good liquor or food, so that by its own means, it became evil and poisonous or simply poison itself. ${ }^{149}$

Original sin did not enter man from the outside but corrupted his very substance itself from within. Therefore, according to Flacius, it is not a removable element or part but a non-detachable ingredient of human nature, which leads man toward death and destruction. Through statements like this, the tract $D e$ Peccato originali did not only provide a detailed explanation of Flacius' theological anthropology but also revealed the very pessimistic view he held of human nature. It is an interesting signal of Flacius' continuing radicalization that he did not use this chance of publishing in print his thoughts on original sin to present a perhaps less threatening formulation in order to quiet some

hoc non concedunt, illi monstrent aliquam tertiam partem hominis, aut in homine existentem, et quae insuper sit tam potens ac operosa, ut est istud originarium malum.«

148 Ibid., 380: »Objiciunt aliqui: multa esse in homine adhuc bona et praestantia ex reliquijs creationis Dei. Respondeo: Etiam in diabolis sunt adhuc multae praestantes creationis dotes, et quidem multo excellentiores quam in hoc carnali homine: sed tamen quia omnes contra Deum militant, ideo sunt male et mera peccata. Quid enim aliud sunt, quam iniustitia armata?

149 Ibid., 380: „Non est in homine aliquid diversum ab ipsa mala mente aut lapideo corde, quod eum spiritualiter destruat, sicut morbus eum corporaliter conficit: sed est tantum ipsa perditissima, et iam destructissima natura. Originalis malicia non est ita ab extra infusa Adamo, ut multi nunc sentiunt, sicut si quis in bonum liquorem venenum aut aliud aliquod malum inijciat aut infundat, ut propter illud affusum malum, etiam reliquum sit noxium: sed ita, sicut si quis ipsum bonum liquorem aut cibum invertat, ut illud per se iam malum ac venenatum, aut potius venenum sit.« 
of his critics and restore his reputation, but instead he went even further in defending his views and supporting them by painting very vivid images with his words, which made his claims impossible to misunderstand.

\section{Advising the Lutheran Church and Creating Antagonism: Antwerp, October 1566-March 1567}

During the so-called Wonderyear (het Wonderjaar or Annus mirabilis; spring 1566 through spring 1567) Flacius arrived in Antwerp, ${ }^{150}$ where he became an advisor to the Lutheran movement in church matters. ${ }^{151}$ He came by invitation of the city's senate, and with the knowledge of William I, Prince of Orange, but his stay in Antwerp lasted only a short time. ${ }^{152}$ In December of that year a Latin publication of the »Antwerp Confession, « which was an evangelical statement of faith modeled after the Augsburg Confession invariata of 1530 and its Apology, ${ }^{153}$ Smalcald Articles, the Saxon Konfutationsbuch of 1559 and the Mansfeld Confession from $1565,{ }^{154}$ saw the light. ${ }^{155}$ Loosjes states

150 He must have arrived after October 14 since on that date Hartmann Beyer in Frankfurt dated a letter of testimony (Zeugnis) stating that Flacius was suitable as a preacher for the church in Antwerp and that he was doctrinally correct. See Karl Bauer, »Der Bekenntnisstand der Reichsstadt Frankfurt a. M. im Zeitalter der Reformation. V., ARG 22 (1924): 39-101, here 89.

151 The most detailed study regarding the religious and political life of the city on the Scheldt River in the second half of the sixteenth century is Guido Marnef, Antwerp in the Age of Reformation: Underground Protestantism in a Commercial Metropolis, 1550-1577 [Johns Hopkins University Studies in Historical and Political Science 114] (Baltimore/London: Johns Hopkins University Press, 1996). See particularly the second chapter »The Rise of Protestantism in Antwerp, 1550-1567,« 61-105.

152 Flacius arrived in October and a few months later as a gesture of gratitude, he wrote a dedicatory epistle to William I, Prince of Orange and to William, Duke of Jülich-Cleves-Berg dated in Antwerp on February 1, 1567. See, Omnes Libelli Mathiae Fl. Illrici, hactenvs in sacramentaria controversia editi. Quibus accessit valde copiosa Appendix nouarum demonstrationum. In hoc opere multae admodum arduae quaestiones dilucide explicantur, in quibus plaerique disputantes hactenus haesitarunt (Frankfurt: Peter Braubach, 1567; VD16 F 1397), A2r-A8r.

153 The Dutch translation of the Confessio Augustana was also published in 1566 in Antwerp, Die Confessie oft Belydinghe des Gheloofs/die den onuerwinlycken Keyser Carolus de. V. inden Rijcxdach van Ausborch ouerghegheuen is / Int Jaer M.D.XXX. Nu eerst wten latine int nederduytsch op daldernerstichste ende ghetrouwelycste ouerghesedt. Psal. CXIX. Ick sprack van uwe ghetuygenissen voor die Coningen/ende ick en werde niet bechaemt. 1566. For a reprint of the title page see, Willem Heijting, Profijtelijke boekskens. Boekcultuur, geloof en gewin. Historische Studies (Hilversum: Verloren, 2007), 121. Heijting states that it was printed by Hans de Laet and Gillis Coppens from Diest and issued in September 1566.

154 For the involvement of Mansfeld theologians in Antwerp, see Lothar Berndorff, »Das Engagement der Mansfelder Kirche in Antwerpen, « in Die Prediger der Grafschaft Mansfeld. Eine Untersuchung zum geistlichen Sonderbewusstsein in der zweiten Hälfte des 16. Jahrhunderts (Potsdam: Universitätsverlag, 2010), 301-306.

155 The Antwerp Confession was translated into three languages soon after the original Latin version was published. See the versions in, High German: Bekendtnus Derer Kirchen binnen 
that Flacius was the principal author of the confession. ${ }^{156}$ According to Klaas Zwanepol the Antwerp Confession later influenced the Dutch congregations of Woerden and Amsterdam, as well as the German ones in Cologne and Aachen. ${ }^{157}$ Parallel to the Confession an Antwerp church order was also written and published. ${ }^{158}$

Flacius also wrote the foreword to the Clavis Scripturae in Antwerp, dated on St. Matthias' Day, February 24, 1567 dedicated to Duke Christoph of Württemberg and printed in March in Basel. He also kept an active correspondence. ${ }^{159}$

Flacius' invitation to Antwerp and the fact that he was asked to advise the local Lutherans indicated that he was still receiving some recognition as an evangelican leader, and it may have seemed that things would turn out for the better for him. However, while he went to Frankfurt to collect his family in the early spring of 1567 so that they could join him, Antwerp was taken over by a Roman Catholic army, loyal to Margaret, Duchess of Parma, governor of

Antorff/so der waren Augspurgischen Confession zugethan. Aus dem Lateinischen ins hoch Deutsch gebracht. Sampt einer Vorrhede M. Cyria: Spangenberg (Schmalkalden: Michael Schmuck, 1567; VD16 F 1317); French: Confession des Ministres de Iesv Christ, en Eglise d'Anuers, qui consent à la Confession d'Ausbourg (s.1.: 1567; VD16 ZV 3810), and Dutch: Confessie oft Bekentenisse der Dienaren Jesu Christi in de Kercke binnen Antwerpen die welcke der Confessie van Ausborch toeghedaen is. Beter ouersien ende gheemendeert nae de latijnsche copije (s.1.: 1567). Reprinted in Johannes Wilhelm Pont, De Luthersche kerken in Nederland, vol. 2 (Amsterdam: Swets \& Zeitlinger, 1929), 1-131.

156 Jakob Loosjes, Geschiedenis der Luthersche kerk in der Nederlanden ('s-Gravenhage: Martinus Nijhoff, 1921), 43: »De voornaamste opsteller der Confessie schijnt Flacius geweest te zijn.«

157 See Klaas Zwanepol, »Lutheran-Reformed Unity in the Netherlands, « Lutheran Quarterly 11/4 (1995): 419-451.

158 Kirchenagend/oder Form vnd Gestalt/Wie es mit den Sacramenten vnd Ceremonien gehalten wird/in der Kirchen der Augspurgischen Confession zu Andorff. Durch die Ehrwirdigen Herrn vnd Predicanten daselbst gestelt/Welcher Namen am Ende gesetzt werden (s.1.: 1567; VD16 A 659). This church agenda was signed by six local pastors. Among them were Frans Alard, Johannes Saliger, also known as Beatus, and Balthasar Houwaert; five German preachers, Hermann Hamelmann, Johannes Vorstius, and three from the county of Mansfeld, Cyriacus Spangenberg, Martin Wolff, pastor in Helfta, and Joachim Hartmann, pastor in Helbra. Flacius appeared as the last signatory, I6r. Another version of this church order was published by Cyriacus Spangenberg, who dated the foreword on February 27, 1567 in Antwerp, Agenda. Christliche Kirchenordnung der Gemeine Gottes/so in Antdorff der waren/reinen/vnuerfelschten Augspurgischen Confession zugethan (Schmalkalden: Michael Schmuck, 1567; VD16 A 660).

159 See for example Flacius' letter from December 13, 1566 to Count Hermann of Neuenahr and Moers referred to in Johann Friedrich Gerhard Goeters, »Ein Brief des Grafen Hermann von Neuenahr an den lutherischen Theologen Matthias Flacius Illyricus, « Monatshefte für evangelische Kirchengeschichte des Rheinlandes 9 (1960): 54-58. Two letters from Flacius to Westphal in Hamburg from that period (November 28, 1566 and January 27, 1567) were printed in Sillem (ed.), Briefsammlung des Hamburgischen Superintendenten Joachim Westphal, 2: 524; 530-531. 
the Habsburg Netherlands. ${ }^{160}$ As a result many Protestants went into exile in order to avoid staged trials for heresy and certain death. ${ }^{161}$ The last Lutheran service in Antwerp took place on the Octave of Easter (Quasimodogenesis), Sunday, April 9, »and two days later William I of Orange and many Calvinists and Lutherans left the city. ¿162 $^{16}$

During 1567 Flacius published two works together with Balthasar Houwaert. ${ }^{163}$ One was a validation of the Antwerp Confession, as a response to Confutatio Confessionis by Josse van Ravesteyn, called Tiletanus, a Roman Catholic theologian and professor at Leuven University, ${ }^{164}$ and was issued in August. ${ }^{165}$ The other theological treatise was aimed at the Roman Catholic Bishop of Roermond, William Damasus van der Lindt, called Lindanus, ${ }^{166}$

160 Already on March 23, 1567 Flacius wrote a letter to Nikolaus Gallus from Frankfurt, referring to the sad situation in the Netherlands. StAR, Eccl. I, 59, 33, 35203.

161 General Fernando Álvarez de Toledo y Pimentel, the third Duke of Alba, arrived with the Spanish army in the Netherlands in August 1567 and replaced Margaret of Parma as Governor. Under his rule the remaining Protestants were harshly persecuted.

162 Guido Marnef, »Multiconfessionalism in a Commercial Metropolis: The Case of $16^{\text {th }}$-Century Antwerp, in Thomas Max Safely (ed.), A Companion to Multiconfessionalism in the Early Modern World [Brill Companions to the Christian Tradition 28] (Leiden/Boston: Brill, 2011), 75-97, here 80. On April 13, 1567 William I of Orange wrote a letter of attestation from Breda to the good behavior of Lutheran preachers in Antwerp. For the edition of the letter see, H. de Jager, »Attestatie voor de predikanten van de Augsburgsche Confessie te Antwerpen, afgegeven door prins Willem I, « Studiën en Bijdragen op 't gebied der historische theologie 3 (1876): 550-551.

163 The only article about Houwaert that I was able to locate is by Egbert Smedes, »De Lutherse predikant Balthasar Houwaert als vermoedelijk dichter van het Wilhelmus [1525-1578?],« Tijdschrift voor geschiedenis 60/2-3 (1947): 129-155.

164 Ravesteyn was present at the religious colloquy of Worms in 1557. For more about him, see Walter Troxler, »Ravesteyn, Josse od. Jodokus Tiletanus, Kontroverstheologe, « in BBKL 7 (1994), 1422-1424.

165 Flacius and Houwaert, Defensio Confessionis Ministrorvm Iesv Christi, Ecclesiae Antuerpiensis, quae Augustanae Confessioni adsentitur, contra Ivdoci Tiletani uaria Sophismata. Cvm Praevia Adhortatione ad seriam poenitentiam, et ardentes preces, in praesentibus difficultatibus et periculis. Addita est in fine et Altera Adhortatio ad piam constantiam in praesenti cruce, ac Satanae cribratione (Basel: Bartholomaeus Franck, 1567; VD16 F 1334). The Dutch and French translations of this work were also printed. See also Ravesteyn's attack on the Antwerp Confession from 1567: Confessionis Siue doctrinae, quae nuper edita est a Ministris, qui in Ecclesiam Antwerpiensem irrepserunt, \& Augustanae Confessioni se assentiri profitentur, succincta Confutatio and his 1568 reply to Flacius, Catholicae confvtationis prophanae illivs et pestilentis confessionis, (quam Antuerpiensem Confessionem appellant Pseudoministri quidam) contra varias \& inanes cauillationes Mat. Flacci Illyrici, APOLOGIA seu defensio. Authore Ivdoco Ravesteyn Tiletano, Doctore Theologo in Academia Lovaniensi. Both works were published in Leuven by Pierre Zangre and contain a preface dedicated to the Antwerp senate [A2r-B2v; A2r-A5v]. They can be found at HAB, originating from Flacius' personal library with his notes, in the 1568 book, $\mathrm{H} 63.8^{\circ} \mathrm{Helmst}$.

166 For his biography, see Petrus Theodorus van Beuningen, Wilhelmus Lindanus als inquisiteur en Bisschop: Bijdrage tot zijn biografie (1525-1576) (Assen: van Gorcum, 1966). 
which was published in Dutch. ${ }^{167}$ That Flacius caused a significant theological stir in Antwerp during his brief stay is further manifested by the publication of an attack on Flacius' interpretation of the Eucharist. The work in question, for which the Antwerp publisher Tronaesius secured a royal privilege from Brussels in 1567, was written by the French Roman Catholic Franciscan theologian Jean Porthaise, who, while defending the position taken by the Council of Trent, dedicated his book to Philipp II of Spain. ${ }^{168}$ In the following year, Flacius issued a defense against the accusations that were being leveled against him in the churches of the Low Countries and particularly by the Spaniard Antonio del Corro. ${ }^{169}$

\section{Finding Temporary Refuge in the Free Imperial City of Strasbourg, November 1567-June 1573}

The months of March through November 1567 Flacius spent in Frankfurt am Main. During this time he completed the second part of Clavis (Altera pars) in August and signed it as Albonese. From there he moved westward, hoping to find a new home in the imperial city of Strasbourg. Along the way he first stopped in Stuttgart where he spent several days meeting with Brenz,

167 Flacius and Houwaert, Corte verantwoordinghe, oft bescherminghe der confessien oft christelijcker ghemeinten van Antwerpen der Ausborchser confessien toegedaen, tegen het venijnisch schimpboeck Wilhelmi Lindani van Dordrecht, Bisschop (Titulotenus) van Rueremunde (Basel: Bartholomaeus Franck, 1567; not in VD16). A copy is kept at Utrecht University Library, E oct 457 (Rariora) dl 1-4 Con.

168 Jean Porthaise, De Verbis Domini, Hoc Facite, Pro Oecvmenico Concilio Tridentino, aduersus Sophisticas nebulas Matthiae Flaccij Illyrici (Antwerp: Emanuel Philips Tronaesius, 1567). The dedication is dated in Antwerp on August 10, 1567. Flacius in the already mentioned Defensio Confessionis makes a reference to »monachus Gallus, « who is none other than Porthaise with whom he says he had a theological debate in Antwerp. Porthaise also talks about »en plaine dispute 1566 en Anvers« with Flacius. See Vermaseren, »The Life of del Corro«, 229.

169 Flacius, Excvsatio Matthiae Flacij Illyrici, contra calvmnias adversariorvm, qvod praesentivm calamitatvm Ecclesiae Brabantiae cavsa fverit (s.1.: 1568; VD16 F 1391). This pamphlet contains only five pages. For more about Corro see, A. Gordon Kidner, »Antonio del Corro, « in André Séguenny (ed.), Éloy Pruystinck, Sebastian Franck, Antonio del Corro [Bibliotheca Dissidentium: Répertoire des non-conformistes religieux des seizième et dix-septième siécles 7] (Baden-Baden: Valentin Koerner, 1986), 121-176; Bernard Antoon Vermaseren, "The Life of Antonio del Corro (1527-1591) Before His Stay in England. I. In Spain and France « and »II. Minister in Antwerp (Nov. 1566 - April 1567), « Archives et Bibliothèques de Belgique. Archief-en Bibliotheekwezen in België 57 (1986): 530-568 and 59 (1990): 175-275. See especially part three, »Corro's Conflict with the Lutheran Pastors. Connexions [sic!] with Matthias Flacius Illyricus, « 213-242. I am grateful to Guido Marnef for bringing this work to my attention and making it available to me. See also, Rady Roldan-Figueroa, »Antonio del Corro and Paul as the Apostle of the Universal Redemption, « in R. Ward Holder (ed.), $A$ Companion to Paul in the Reformation [Brill's Companions to the Christian Tradition 15] (Leiden/Boston: Brill, 2009), 389-425. 
Andreae and Wilhelm Bidenbach. Their discussions centered mainly on the topic of the Lord's Supper. ${ }^{170}$

Flacius arrived in Strasbourg on November 14, $1567 .{ }^{171}$ In the beginning he stayed in the house of the pastor Johannes Flinner who was Flacius' ardent supporter. ${ }^{172}$ It is recorded that Flinner called Flacius a »true Athanasius « (verus Attanasius). ${ }^{173}$ The significance of this designation is that Flinner was comparing Flacius to the church father Athanasius of Alexandria, also known as St. Athanasius the Great or St. Athanasius the Confessor, who was exiled for defending orthodox Christian teaching against Arianism five times in his career.

Flacius' family joined him in the spring of 1568 together with their furniture and private library. The city senate refused to give Flacius citizen's rights but allowed the entire family residency permits on the condition that Flacius should not interfere with church and school matters in the city. ${ }^{174}$ Before they moved into their own house the family lived at the home of the professor of theology and Hebrew language at the city school (Academie) and assistant pastor of Strasbourg Cathedral (Cathédrale Notre-Dame-deStrasbourg), magister Elias Kyber. ${ }^{175}$

The church in Strasbourg at that time was led by a Gnesio-Lutheran, Johannes Marbach. ${ }^{176}$ Four years prior to Flacius' arrival, Marbach had

170 Preger, Flacius und seine Zeit, 2: 295, 300.

171 Ibid., 2: 296.

172 Traugott Bautz (ed.), »Flimmer [sic!], Johannes, « in BBKL 2, 60. At the Strasbourg city archives (Archives Municipales de Strasbourg) there are eleven preserved letters from Flacius to Flinner; Codex Nr. 156 »Epistolae ad historiam ecclesiasticam« III. F., 310-337. Mirković, Matija Vlačić Ilirik, 407.

173 See, Johannes Ficker and Otto Winckelmann, Handschriftenproben des sechzehnten Jahrhunderts nach Strassburger Originalen. Zweiter Band. Tafel 47-102. Zur geistigen Geschichte (Strasbourg: Karl J. Trübner, 1905), 91. Repeated in Kleine Ausgabe: 35 Tafeln in Lichtdruck mit Transcriptionen und biographischen Skizzen (Strasbourg: Karl J. Trübner, 1906), 31.

174 Alcuin Hollaender, »Der Theologe Matthias Flacius Illyricus in Strassburg in den Jahren 1567-1573, « Deutsche Zeitschrift für Geschichtswissenschaft, Neue Folge II (1898): 203-224, here 204-205, the decision was dated on May 22, 1568.

175 For an overview of his career at the Strasbourg academy (Gymnasium illustre) between 1565 and 1569, see Anton Schindling, Humanistische Hochschule und Freie Reichstadt: Gymnasium und Akademie in Strassburg 1538-1621 [Veröffentlichungen des Instituts für Europäische Geschichte Mainz 77] (Wiesbaden: Franz Steiner, 1977). Elias’ father, Lucius Kyber was an evangelical pastor in Gengenbach in Baden, where Elias and his older brother, David, were born. David Kyber was a professor of Hebrew in Strasbourg. See, »Kyberus, Lucius, « in MBW 12: Personen $F-K, 477$. At HAB there is a copy of the book that has an ex libris bookplate by »Elias Kyberus Gengebacensis« and the notes in the book are in Flacius' hand, signature G $117.4^{\circ}$ Helmst. (1).

176 Heinrich Holtzmann, »Marbach, Johann, in ADB 20 (1884), 289-290; Wilhelm Horning, Dr. Johannes Marbach, Pfarrer zu St. Nikolai, Münsterprediger, Professor und Präsident des lutherischen Kirchenkonvents in Straßburg 1545-1581 (Strasbourg, 1887); Christopher J. Burchill, «)In the Shadow of a Titan<: Johann Marbach and the origins of confessional orthodoxy in Strasbourg, 1553-1563, « Paper presented at the Sixth International Congress of 
succeeded in expelling from the city an Italian refugee from Lucca, Girolamo Zanchi who was a professor of Old Testament at the Strasbourg Academy, ${ }^{177}$ because his teachings on predestination and the Eucharist were deemed to be Calvinistic. ${ }^{178}$

Soon after settling in Strasbourg Flacius began to experience antagonism from the city senate, which wanted to expel him because of his controversial doctrine of sin. ${ }^{179}$ Already in 1568 Emperor Maximilian II writing from Vienna stirred up the city authorities by complaining to them about having given asylum to Flacius. In 1570 Elector August I of Saxony, together with the Palatine Elector Friedrich III, asked the city to banish the Flacius family. ${ }^{180}$ This was the reason behind Flacius writing his doctrinal defense in September of that year. ${ }^{181}$ He dedicated the book to four men from Lindau on the Lake Constance, ${ }^{182}$ the city where he hoped to find asylum in case Strasbourg decided to deny him a visa. Strasbourg superintendent Marbach was also from Lindau, as was a young professor of Hebrew at the Strasbourg Academy, Johannes Pappus, who looked up to Flacius because of his knowledge of Hebrew. ${ }^{183}$ Apart from these individuals, Flacius had strong support

Luther Research in Erfurt, 1983. Available at: http://www74.homepage.villanova.edu/christo pher.burchill/my\%20papers/Shadow\%20of\%20a\%20Titan.pdf (accessed October 10, 2011).

177 Emidio Campi, »Zanchi, Hieronymus, « in Hans Dieter Betz et al. (eds.), Religion in Geschichte und Gegenwart, $4^{\text {th }}$ ed. (Tübingen: Mohr Siebeck, 2005), 8: 1780.

178 For the details of the controversy, see James M. Kittelson, »Marbach vs Zanchi: The Resolution of Controversy in Late Reformation Strasbourg, « Sixteenth Century Journal 8 (1977): $31-44$.

179 See Hollaender, »Der Theologe Matthias Flacius, « 203-224.

180 See Flacius' letter from June 6,1570 to the city senate of Lindau in F. Wilhelm E. Roth, »Des M. Flacius Illyricus Beziehungen zu den Städten Straßburg und Lindau. 1570 -1572. Nach Briefwechsel in der Ulmer Stadtbibliothek bearbeitet, «Zeitschrift für wissenschaftliche Theologie 54 (1912): 244-255, here 245.

181 Flacius, Defensio sanae doctrinae.

182 The thirty-two-page-long dedicatory epistle on page A2r reads: „Clarissimis ervditione ac pietate viris, D. D. Achilli Gassaro, Matthiae Rot, Georgio Neckero, \& Thobiae Rupio, suis dominis, ac in Christo fratribus... « Roth, Necker and Rupp were Lindau preachers, who were all good friends of Flacius' and ardent supporters of his teachings.

183 Pappus arrived in Strasbourg in 1570 in order to replace Elias Kyber, who died on November 19 from the plague. In the beginning Pappus had a good relationship with Flacius. Some time later, however, he took a position against Flacius' teaching on sin. Georg Kreutzer stated: »Pappus war ein starcker Flaccianer/es konnte schier niemand fuer jme bey Jllyrico zu kommen.« See, Consensvs, Das ist/Vereinigung der Prediger zu Strasburg/im streittigen Artickel von der Erbsuende/von D. Johan Marbach geschrieben/vnd von den Pfarherrn vnterschrieben/Anno 1571. Welchen Consens Der Schreiber/vnd die Vnterschreiber steiff leugnen/vnd andere drueber verfolgen.Verdeutscht aus dem Latein/zu rettung der Warheit/Durch Georgium Creuzern/etwan Pfarherrn zu Schilckenheim/Exulem Christi (Oberursel: Nikolaus Henricus d.Ä., 1581; VD16 M 907), A3r. For Pappus' biography, see Richard Otto Zoepffel, »Pappus, Johannes, « in ADB 25 (1887), 163-164; Wilhelm Horning, Dr. Johann Pappus von Lindau: 1549 -1610: Münsterprediger, Universitätsprofessor und Präsident des Kirchenkonvents zu Straßburg; aus unbenuetzen Urkunden und Manuskripten (Strasbourg: J.H.E. Heitz, 1891); Ingeborg Dorchenas, »Johannes Pappus,« in BBKL 6 (1993), 1497-1502. 
among the four evangelical pastors in Lindau, Matthias Roth, ${ }^{184}$ Georg Necker, Tobias Rupp and Sebald Scheffler. By attempting to build up a lobby in this free imperial city on the lake Constance that became evangelisch in 1528 , Flacius was hoping to establish a backup plan in case he was asked to leave Strasbourg. This episode again highlights the ways in which Flacius was using his networking skills, in this particular case in order to secure refuge for himself and his family.

\section{a) Flacius' Written Defense of His Doctrine on Sin}

The purpose of Flacius writing Defensio sanae doctrinae de originali iustitia ac iniustitia, aut peccato was yet another attempt at establishing or defending, as he stated in the title, »Sound Doctrine Concerning Original Righteousness and Unrighteousness, or Sin. ${ }^{185}$ Apart from expounding his theological anthropology and original sin in great detail, he also incorporated responses to questions posed by his opponents and critics throughout the work. ${ }^{186}$ This was the crystallization in carefully written form of his thoughts regarding those concepts he considered to be of crucial importance, reflecting the late stages of radicalization of his ideas. At the same time it served as an effort at presenting legitimation from the church fathers, reformers, and other theologians for his own central emphasis on original sin.

Through the publication of Defensio sanae doctrinae, Flacius also aimed at gaining further support among Lindau's leading clergy. Even though he never moved to live on the island town of Lindau (he only spent a few weeks there during the summer of 1570), ${ }^{187}$ the preachers in the city remained loyal

184 Roth was ordained in Wittenberg by Luther in 1545, when Flacius was a professor there. He was one among 51 signatories of a supplication against Melanchthon and the adiaphorists, addressed to the German nobility. See, Svpplicatio qvorvndam Theologorvm, qvi, post obitvm Lvtheri $P$ [hilipp]. M[elanchthon]. corruptelis \& Sectis, voce aut scriptis contradixerunt, pro libera, Christiana, \& legitima Synodo, ad Illustrissimum Principem, D.D. Iohannem Fridericum II. Ducem Saxoniae \&c. eiusque C. Fratres, ac alios pios Principes \& Status Angustanam Confessionem amplectentes (s.1., 1560; VD16 ZV 25707).

185 See footnote 20 in the Introduction.

186 For example, Flacius replied to Heshusius' critique of his teaching contained in Epistola D. Tilemani Heshvsii ad M.Matthiam Flacivm Illyricvm De controuersia. An peccatum Originis sit substantia. Item analysis argvmentorvm quibus D. Illyricus nititur (Jena: Christian Rödinger d.J., 1570; VD16 H 3034).

187 See Georg Karo, »Das Lindauer Gespräch. Ein Beitrag zur Geschichte der Concordienformel,« Zeitschrift für wissenschaftliche Theologie 45 (1902): 513-564. According to Karo, 519, Flacius stayed in the house of Georg Necker during the summer of 1570. Before arriving in Lindau Flacius had stayed in Basel for a while in June 1570, where Sulzer and his brotherin-law, pastor Huldrich Koch tried to convince the Basel city senate to allow Flacius and his family to reside there. See, Preger, Flacius und seine Zeit, 2: 307-308. See also Bullinger's letter to Beza from August 3, 1570, in which he calls Sulzer a hypocrite for hosting Flacius, 
to his theology even after his death, and they opposed Andreae's plans for the Formula of Concord. ${ }^{188}$ The formula was an attempt to find a middle ground among the quarrelling groups of Lutheran theologians, namely Philippists, Gnesio-Lutherans (those who had distanced themselves from the teaching and leadership of Flacius) and Flacians.

One of the preachers, Caspar Heldelin also made sure that the details of Flacius' final days in Frankfurt am Main were recorded and he published them together with an account of Flacius' last words and the funeral oration

in, Claire Chimelli, Alain Dufour, Béatrice Nicollier-de Weck (eds.), Correspondance de Théodore de Bèze (Genève: Droz, 1983), vol. 11: 249-252, here 251. Bullinger further accused Sulzer of being a complete adherent of the ubiquitarian sacramentology taught by Brenz and Andreae (»Sulcerus alioqui totus adhaeret Brentio, Jekelino, id est Jacobo Andreae et Ubiquiitaris, « 251). Amy Nelson Burnett in her otherwise excellent study Teaching the Reformation: Ministers and Their Message in Basel, 1529-1629 [Oxford Studies in Historical Theology] (New York: Oxford University Press, 2006), 23, claims that Sulzer »tried to maintain Basel's middle course between the increasingly strident positions expressed in Lutheran Germany and Reformed Switzerland « and portrays him as Bucerian. However, taking into account Sulzer's support for Flacius and also the accusations leveled at him by Bullinger, Burnett's view of Sulzer needs to be reexamined.

188 Between August 3 and 8, 1575 a colloquium was held at the Lindau city hall, where Tobias Rupp and Sebald Scheffler supported Flacius' rendering of the doctrine of sin against Andreae and Ludwig Rabus, Superintendent of Ulm. For the details and the protocol of the colloquium see Karo, »Das Lindauer Gespräch,« 529-542. Several renderings of the colloguium have been published, expressing different point of view. See first the publication by the city itself, which clearly saw this theological quarrel as a political danger. If they were accused of supporting Flacius and therefore harboring a heretical doctrine this could have had consequences on their standing in the Holy Roman Empire of the German Nation and they could lose their status as a free imperial city since according to the Peace of Augsburg any deviance from the Augsburg Confession could be punished. Therefore, the mayor himself and the city council issued the Bericht Burgermeister vnd Rhat/der Statt Lindaw. I. Von wegen ettlicher daselbsten/enturlaubten Predicanten. II. Sampt dem Gespraech/vom Artickel der Erbsuende ... III. Mit angehengten/vnnd darueber ergangnen/reiner Christlichen Kirchen/Augspurgischer Confession/Vrtheiln vnnd Erkanntnussen. IIII. Auch gantzen Proceß/wie mit den jrrigen Predicanten/von anfang/bis zur irer Enturlaubung gehandelt. In woelchem die Lehre von der Erbsuende... (Tübingen: Georg Gruppenbach, 1576; VD16 L 1863). In the following year Cyriacus Spangenberg published a differing account, Von dem Lindauwischen Colloquio/zwischen Doctor Jacob Andreen/vnd Herrn Tobia Ruppio/Anno 1575. Jm Augusto gehalten. M. Cyriacus Spangenberg (Oberursel: Nikolaus Henricus d.Ä., 1577; VD16 S 7712). Six years later, Christoph Irenaeus issued another version of the colloqium. See, Erzehlung vnd widerlegung etlicher vnchristlichen/ergerlichen vnd abschewlichen Reden D. Jacobs vnd seiner Accidens Brueder, in Examen Des ersten Artickels vnd des Wirbel Geists/Jm newen Concordien Buch. Vnd Einfeltiger Beweis/das darinne der Artickel von der Erbsüde [sic!] wider sich selbs ist/vnd sich selbs widerlegt. M. Christoph: Jreneus exul Christi (s.1., 1581; VD16 I 283), P3r-Aa2v. This publication is mentioned in Dingel, Concordia controversa, 510 n.191. However, Dingel provides no discussion of the aftermath of the Lindau colloquium. Robert Kolb states that Andreae failed to grasp the central concern of the Flacians, see »Andreae, Jakob, « in The Oxford Encyclopedia of the Reformation 1: 36-38, here 37. 
that he wrote. In the preface to his funeral sermon, dedicated to Adolf Hermann Riedesel zu Eisenbach, Heldelin referred to Flacius as »my beloved teacher (mein lieber Praeceptor) several times. ${ }^{189}$

In the text of the book Flacius set out to defend his understanding of the doctrine concerning original sin. In order to provide a context and also legitimation for his own theological stances, he intentionally presented his beliefs within the framework of other authors and sources. These included the Biblical book of Isaiah, the Gospels of Matthew and John, some of Paul's epistles, as well as St. Augustine, Luther, Bucer, Martin Chemnitz, Peter Martyr Vermigli and Melanchthon. Flacius frequently made references to Greek mythological figures (for example the Hydra of Lerna and Glaukos) in his text and mentioned persons from antiquity, such as Thucydides. Occasionally Flacius included quotes by various authors in the original Greek, which shows his wide-ranging and thorough knowledge of that language, culture, and philosophy. Furthermore, he made reference to Plato, and his argumentation followed Aristotelian logic. In addition to Flacius' use of Greek, at times even a few phrases in German appeared in the middle of his text. In this work, however, he did not use Hebrew at all - a language at which he was considered to be an expert, and one he occasionally employed in his other writings.

Flacius' Latin text is characterized by rhetorical complexity. Concerning his writing style and the employment of figures of speech, it can be noted that Flacius relied on many metaphors and provided vivid descriptions, especially in instances when he described the nature and consequences of sin. It is also evident that Flacius had meticulously planned the way in which he would develop his line of reasoning in this particular disputation. He set out by describing the issue, and then moved on to discuss the consequences of such a position, while drawing on a wide range of disciplines to illustrate his points.

189 Heldelin, Eine Christliche predigt, )( 3. It should be stated that the funeral sermon was not held, only its text was published. For more about Adolf Hermann Riedesel, see Eduard Edwin Becker, Die Riedesel zu Eisenbach: Geschichte des Geschlechts der Riedesel Freiherrn zu Eisenbach, Erbmarschälle zu Hessen, vol. 3: Vom Tode Hermanns III. Riedesel 1501 bis zum Tode Konrads II. 1593 (Offenbach am Main: Wilhelm Gerstung, 1927), 347-364, 406-408, 459-461. Flacius dedicated two of his works to Riedesel (VD16 F 1385; VD16 B 4664). The eleventh volume of the Magdeburg Centuries was also dedicated to Riedesel in 1567 (VD16 ZV 23968). A number of other works also included dedications to Riedesel, who seems to have been a generous sponsor of scholars. For example, Nikolaus Asclepius Barbatus [VD16 A 3989], Adam Lonicer [VD16 L 2420] and Lucas Lossius [VD16 E 4284] wrote Widmungen to Riedesel. 
Flacius began Defensio sanae doctrinae with a lengthy introduction, in which he referred to three of his previous works on the same topic, namely

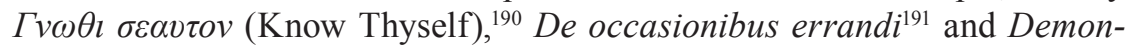
strationes. ${ }^{192}$ The reason for providing these quotes is not entirely clear: either he assumed that his readership already knew them or he was actually encouraging them to read them and become familiar with his argumentative defense; or this may have simply been an example of self-promotion. In other disputes, such as the Osiandrian controversy, he also on occasion referred the reader back to previous writings on the subject.

Flacius then reiterated one of the foundational points of his argumentation, stating, »I have already shown with the three principal causes that the heart or ratio of the human being and free will itself can be called, and is sin, original unrighteousness or the devil's image, by reason of the efficient, formal and final cause. $\ll^{193}$

Firstly, he explained, because of the efficient cause, the depraved human being is named after its father the devil, and man's seed comes from the progeny of the old serpent. ${ }^{194}$ This is because the devil transformed the human

190 Flacius, $\Gamma v \omega \theta$ r $\sigma \varepsilon \alpha v \tau o v$. De essentia originalis iustitiae et iniustitiae seu Imaginis Dei et contrariae. Avthore Matth. Flacio Illyrico (Basel: Pietro Perna, 1568; VD16 F 1385). For a discussion of this work, see Ivan Kordić, »Vlačićev Gnothi seauton [Flacius' Gnōthi seauton],« Prilozi za istraživanje hrvatske filozofske baštine 39-40 (1994): 137-155. Johannes Wigand published a work based on his lectures held at the University of Jena with the same title, $\Gamma \nu \omega \theta l \sigma \varepsilon \alpha v \tau o v$, referring to the ancient Greek aphorism (Frankfurt: Peter Braubach, 1562; VD16 W 2769), and a translation into German by Basilius Faber, Erkenne dich selbst! (Erfurt: Georg Baumann d.Ä., 1563; VD16 W 2771).

191 Flacius, De occasionibvs vitandi errorem in essentia iniustitiae originalis. Item, de eximia vtilitate summaque necessitate doctrinae de essentia imaginis Dei ac diaboli, iustitiaeque ac iniustitiae originalis. Per Matth. Flaccium Illyricum. Nunc primùm in lucem edita (Basel: Pietro Perna, 1569; VD16 F 1548).

192 Flacius and Reinecker, Demonstrationes evidentissimae doctrinae de essentia imaginis dei \& Diaboli, iustitiaeeque ac iniustitiae originalis, vna cum testimonijs veterum ac recentium theologorum. Per Matthiam Flacivm Illiricvm. Additus est et alius libellus alterius autoris, ... (Methodica probatio propositionis, Quod peccatum originale sit substantia, Per D. M. Pau [lum]. Rei [necker]. D. VV.) Cum indice copioso (Basel: Pietro Perna, 1570; the dedicatory preface to Count Vollrad V of Mansfeld is dated January 1 in Strasbourg; VD16 F 1339). Paul Reinecker had been dismissed from his pastoral office in Teutleben in 1562 because of his refusal to sign Declaratio Victorini Strigelii. Between 1563 and 1565 he was pastor in Oettingen and later in Weimar, from where he was forced into exile together with the court preacher Christoph Irenaeus in August 1571 because of Flacianism. Reinecker was present at the colloquium in Mansfeld on September 3-4, 1572 between Flacius and some of the theologians from Mansfeld and Eisleben. Later he was pastor in Bienbach and Gross Kreuzhausen.

193 Flacius, Defensio sanae doctrinae, A4b-5a: »Ostendi igitur ibi tribus potissimum de causis, cor aut rationem hominis ipsumque liberum arbitrium dici \& esse peccatum iniustitiamve originalem, aut imaginem diaboli, ratione causae efficientis, formalis, ac finalis."

194 Ibid., A5a: »Primum quidem ratione efficientis, quia homo corruptus dicitur ex patre diabolo, \& semen eius ac genimen illius antiqui serpentis. « Flacius' use of the term »ratio« would seem to indicate that he may be using the technical term »causa« in a broader sense. Thus, these are the grounds for original sin. 
being in the first fall, from the best into the worst, as a result of the human's own fault and disobedience to God's command not to eat of the fruit of the tree (Genesis 2:17). ${ }^{195}$ Following the same pattern traceable in many of his other works, Flacius also began his argumentation here by presenting support for his own claims regarding original sin and the fallenness of humankind through reference to Luther and claiming that he was following Luther's interpretation.

Secondly, Flacius explained what he meant by formal cause, or factor, concerning the human being. He stated, »[the human being] is completely flesh, the old and animal-like Adam, who has a blind mind, and a particularly perverse heart of stone as hard as steel, and that the human being is full of darkness and all kinds of evil. ${ }^{196} »$ Their whole mass [refers to the lump of clay from which Adam was formed] ${ }^{197}$ and image, « he continued, »is only evil, conceived and formed in the mother's womb in sin or a sinner, or, as Luther states, conception itself and mass is sin. Finally, [the human being] is some horrible, smelly and abominable spiritual corpse. ${ }^{198}$

As his third point, Flacius elaborated on the final cause. He stated that the human being is an enemy of God by intention and is not able to do otherwise because, $»$ From the worst and most abundant treasure of [the human being's] heart come forth sins of all kinds. It is a grave full of corpses and rottenness. From here all kinds of the most poisonous smells are evaporating abundantly, which corrupt and pollute earth, air and sky. ${ }^{199}$

As a conclusion to this three-fold line of philosophical reasoning, Flacius summed up his position in the following way: »God's law and strict justice detests above all this worst and saddest form, or essence of our soul, or this

195 Ibid., A5a: »Ille enim eum illae horrenda primi lapsus caede in hoc triste foetidumque ac detestandum cadaver sic transformavit, ipsius sane propria culpa, non tamen sine iustissima ira, poena ac maledictione Dei, illam horribilem sententiam ferentis: Quacunque die comederis, morte morieris: quae maledictio, teste Luthero, de hac ipsa re agente, res optimas in pessimas transformat.«

196 Ibid., A5a: »Totus est caro, vetus animalisque Adamus, habens mentem coecam et cor lapideum ac plane adamantinum perversumque: plenus est tenebris \& omni malitia.«

197 The use of the term »massa« goes back to St. Augustine (»massa perditionis« or simply $»$ massa «) and was used throughout the Middle Ages, to talk about fallen humanity, meaning »lump of perdition, « literally. God takes from this »massa« those whom he deigned to save.

198 Ibid., A5a: »Ipsamet massa figmentumque, eius est tantum malum, conceptus formatusque est in utero matris in peccatis seu peccator, seu, ut Lutherus pronunciat, ipsa conceptio ipsaque massa est peccatum. Est denique horrendum quoddam foetidumque \& abominabile cadaver spirituale.«

199 Ibid., A5b: »Ex cordis eius pessimo \& copiosissimo thesauro omnis generis peccata prodeunt. Est sepulchrum plenum cadaveribus \& putredinibus. Unde sine intermissione omnis generis venenatissimi foetores terram, aerem, coelumque spiritualiter inficientes ac conspurcantes, ubertim exhalant.« 
most wicked tree, weed and the planting by Satan, as extremely incompatible with God, certainly much more than individual fruits, or as leaves or effect of this worst tree. $\ll^{200}$

After having defined the three causes that led to sin becoming the very heart of the human being, Flacius continued his argumentation with an exposition of the role of God's law in relation to sin. The right relationship of God's law to grace as represented in the Gospels was a frequent theme in Lutheran writings in the sixteenth century. Flacius, however, did not deal with the civil usage of the law here, nor did he mention Melanchthon's concept of the »third use of the law, « which applied to moral instruction of a Christian life, something with which Flacius agreed even though he did not use much ink expounding it. ${ }^{201}$ Instead, he described the second use of the law, where the two spheres of law and sin interact and guided his readers to the Scriptures: »It is not in vain that Paul says that through the law itself there is, or comes, recognition of sin. Therefore, it is from this [the law] and not from human dreams, fantasies or fallacies that we must learn and become acquainted with the true nature and essence of $\sin . \ll^{202}$

Flacius enumerated four different types of people or ways of thinking about God's law. First, he wrote, »some people think that God's moral law demands only proper outer works and forbids misbehavior, just as many understand civil law, according to the saying: Thoughts are exempt from censorship. The Church does not judge secret things: no one is punished for his thoughts. $\ll^{203}$ Among those he considered to hold such a view he listed the Pharisees and monks, who thought of themselves as righteous if only they followed external rituals and did not break the law by committing murder,

200 Ibid., A5b-A6a: »Hanc igitur pessimam tristissimamque formam, aut essentiam cordis nostri, seu hanc pessimam arborem, zizania \& plantationem Satanae, \& omnium maxime detestatur lex et severa Dei iustitia, tanquam sibi extreme in conformem, multo certe magis quam singulos fructus, aut quasi folia seu effectus huius pessimae arboris."

201 That is why Flacius could endorse the thesis that "good works are theoretically necessary for salvation in the doctrine of the law « from the Eisenach Synod held in August of 1556. For Flacius' understanding of the third use of the law, see Matthias Richter, »Matthias Flacius: Iudicium de tertio legis usu, « in Gesetz und Heil: Eine Untersuchung zur Vorgeschichte und zum Verlauf des sogenannten Zweiten Antinomische Streits [Forschungen zur Kirchenund Dogmengeschichte 67] (Göttingen: Vandenhoeck \& Ruprecht, 1996), 319-325. For Flacius' opposition to Andreas Poach during the second antinomian controversy, see pages 196-202.

202 Flacius, Defensio sanae doctrinae, A6a: »Non enim frustra dicit Paulus per legam ipsam esse, aut fieri cognitionem peccati. Ex ipsa igitur, non ex humanis somniis, phantasiis aut sophismatibus veram naturam essentiamque, peccati discere cognoscereque debemus."

203 Ibid., A7a: »Quadruplices autem homines, aut opiniones de lege sunt: Alii putant legem Dei moralem tantum externa recta opera postulare, \& prava prohibere: sicut plaerique de civilibus legibus sentiunt, iuxta dictum: Gedanchen seindt zolfrey: De occultis non iudicat Ecclesia: nemo de cogitationibus punitur.« 
stealing, or behaving promiscuously. At this level, he reflected the teaching of his preceptor, Philipp Melanchthon. ${ }^{204}$

Describing the second group, Flacius stated, »Some go one step further, establishing that God's law judges even the internal evil thoughts, actions and emotions, especially if the will approves of it. $\mathbb{1}^{205}$ Flacius then claimed that these people mostly considered only the second stone tablet of God's Ten Commandments (numbers four through ten), and they did that without respecting God, God's word, and not giving God the full honor. Those in the third camp, Flacius continued, »concede that the law itself judges even both the good and the evil accidents of the soul, especially its characteristics, and it examines the good and considers it justice and good works, but rejects evil, considering it sins or unrighteousness. $\ll^{206}$ It was apparent to Flacius that out of the three groups mentioned so far, this one had the most developed understanding of the function of the law and believed that thoughts and habits of the mind are also subject to God's scrutiny.

However, the fourth and only correct way of thinking is that of the Scriptures, according to Flacius. He proceeded to portray this understanding extensively on the following several pages, setting out by establishing the details and implications of the fact that the totality of the human being, including especially their reason, was created in God's image and reflected God's character. The following reflects Luther's Genesis commentary:

Finally, the last and correct understanding is that of the sacred Scriptures and of those who follow it, that God and his law describe and depict the human creature in its entirety and that he creates for himself its essence together with its accidents, its inclinations with all movements and internal as well as external actions: [God] wants all this to be as perfect as it was in the beginning, but especially God most clearly formed, shaped and conformed to himself that very human creature in its substance and accidents, and foremost in its spirit or rational soul at its highest level or free choice, where it ought to manifest itself most strongly and to express itself as by some living image, and act toward him and serve him. ${ }^{207}$

204 See the third edition of Loci Communes from 1543 on the law or on righteousness or free will in MSA 2/1: 307-359.

205 Ibid., A7a: »Alii paulo longius progrediuntur, statuentes legem Dei etiam internas pravas cogitationes \& motus affectusque damnare, praesertim si assensus voluntatis accedat."

206 Ibid., A7a-b: »Tertio alii concedunt, quod lex etiam ipsa bona malaque accidentia animae, praesertim autem qualitates iudicet, \& bonas exigat, habeatque pro iustitia ac bonis operibus, pravas autem vetet habeatque pro peccatis vel iniustitia."

207 Ibid., A7b: „Denique ultima ac vera sententia est Scripturae sacrae, eorumque qui eam sequuntur, quod Deus eiusque lex totum hominem describat $\&$ depingat, sibique poscat essentiam eius cum accidentibus, inclinationes cum omnibus motibus actionibusque internis \& externis: 
Here, the use of the word »substance « was precisely where the debate was joined. Although Flacius was using the Aristotelian categories of substance and accident, it is clear that he was not thinking in dualistic (Manichaean) terms, i.e. he was not setting them against one another as contrasting entities. What he meant was that the core of the human being (»substantia«), not just its superficial aspects (»accidentia«) were corrupt.

Flacius launched into a discussion of sin and its consequences on the human being at this point, moving somewhat circularly towards establishing his case regarding original sin. He first presented the concept of sin and how it has affected the nature of the human being, and then returned to elaborating on further details of the original creation of the human being by God. He summarized what God wants from humans and what the humans' attitude should be towards their Maker:

For when the law and God himself asserts, putting forward the purpose and sum of his entire will: »Be holy just as I am holy« and »Love God with all your heart and all your soul, and from all your strength«, he does not only require good fruit and external and internal deeds as some divine from the simple sound of the words but above all he requires the cause itself and the good tree or root and the primary source, so that [the heart and soul] would be the best according to its own nature and essence as it was in the beginning when God created it and looked at with the greatest delight; and it was very good according to his judgment. ${ }^{208}$

Flacius went to great lengths to explain and assert that God is the creator of the human being. God formed the human's soul to be eternal and breathed into it God's own image at the beginning of creation, to be in harmony and agreement with God. It is God who implanted in us a clear and holy mind (puram sanctamque mentem inspiravit), which is our best part (substance), especially in its highest grade, namely our free will (which, like Melanchthon, Flacius would have defined as the combination of intellect and will). Since Flacius' opponents were accusing him of teaching that Satan created and

eaque omnia prorsus \& perfecte talia esse velit, ut initio ipse ea, praesertim autem ipsum hominem in substantia \& accidentibus, in primisque ipsam mentem seu animam rationalem, in suo summo gradu seu libero arbitrio, quo potissimum se repraesentare, ac tanquam viva quaedam imago exprimere, secumque agere, \& sibi servire debuit, praeclarissime formavit, finxit ac sibimet penitus conformavit.«

208 Ibid., B1v: "Cum enim lex \& Deus ipse dicit, scopum summamque totius suae voluntatis proponens, Sancti estote, sicut \& ego sanctus sum, \& Diligite Deum ex toto corde totaque anima, \& omnibus viribus vestris: non tantum bonos fructus effectusve externos \& internos postulat, ut aliqui ex solo verborum sono divinant: sed ante omnia ipsammet causam arboremque bonam aut radicem scaturiginemque primariam flagitat, ut illa sit per sese suaque natura ac essentia optima, ut fuit initio cum Deus eam condidit, viditque eam cum summo gaudio, \& erat iudicio ipsius valde bona.« 
made the human being, or that the devil is the human being's potter, implying that God is the author of evil, he took even great pains to prove in this work that this was not what he meant and that he had been misunderstood. ${ }^{209}$

Although humans were made to reflect God's original righteousness, at the same time they fell short of the glory of God:

When God and his law do not find in us this greatest good and dignity of the best essence (which is in conformity to God and his law), or original or inborn righteousness, so much aspired to, then He becomes exceedingly angry, and is furious and shouts, saying everything contrary to [what was said] before about us: ॥You are the brood of vipers, the seed of the serpent, from the father devil, sons of the devil, sons of inferior stock: You are of Satan, flesh, an old and animal-like man, body of sin, the worst and venomous trees, Satan's planting, weed, wild vine, Sodom's vine, dross, alienated from me and my enemies: You have a heart of stone, hard as steel, perverse, blind and hardened, which is a treasury of all evil. ${ }^{210}$

Illyricus connected these striking images of the worst of human nature with the metaphors found throughout Scripture but especially in Romans 3:10-18. The reasoning behind employing such dramatic descriptions was in line with his assertion that the best in human beings turns into the worst in them. As the person falls short of fulfilling God's law, he or she becomes the antithesis of all the Ten Commandments. Moreover, this could best be seen in light of the law itself, which Flacius called the only standard of justice and all holiness. This is a crucial part of Flacius' argument, because it demonstrates that he was not simply arguing from some sort of philosophical belief in human evil but in the brutal judgment of God's law.

Although humans live with this inner tension, God requires more from them: God wants their whole being, their full devotion. Using the analogy of a lord and his tenants, Flacius described how God has placed the human being as overseer of God's property and has entrusted humans with land in order to produce good and abundant fruit (cf. Genesis 2). God wants humans to reflect the image of their lord: to whom they belong and whom they serve. Continuing with the analogy, Flacius stated that keeping our end of the

209 Among his accusers were his former friends and supporters Heshusius, Wigand, Joachim Mörlin, Chemnitz, Musäus and others.

210 Flacius, Defensio sanae doctrinae, B3a: »Hoc ipsum summum bonum aut decus optimae, Deoque ac legi eius conformis essentiae, seu iustitiam originariam aut innatam, tantopere expetitam, cum Deus \& eius lex in nobis non reperiat, vehementer irascitur, \& furit clamatque, omnia contraria praecedentibus de nobis dicens, Vos estis genimina viperarum, semen serpentis, ex patre diabolo, filii diaboli, filii degeneres: Vos estis Satanae, caro, vetus animalisque homo, corpus peccati, pessimae veneniferaeque arbores, plantationes Satanae, zizania, labrusque, vites Sodomiticae, scoria, alieni a me, ac hostes mei: Habetis cor lapideum, adamantinum, perversum, coecum, induratum, quodque est thesaurus omnis mali.« 
lord-tenant contract meant that we owed service and accountability to God: »God and his entire law require in us and from us only the best essence of a good tree, far more than leaves and fruits. $\ll^{211}$

From this point onward, Flacius continued with an explanation and practical application, in which he made references to Scripture verses, Greek mythology, and God's law in order to describe what God expects from the human being and how the human being can be of God's image. He first quoted the Old Testament passages that call us to love and praise God with all our heart, mind, and soul. Flacius continued by emphasizing that God above all wants us to have a good and solid foundation, from which good fruit can spring up: »When requiring good fruit, He will surely always ask above all for a good tree and root. $\mathbb{1}^{212}$ The importance of a good and healthy base for a person - so that they can bear good fruit - appears several more times in the text, as do the levels of importance in the eyes of God, which begin on the inside and decrease as they move toward the outer appearance and behavior of a person. As Flacius stated, God is more concerned about sin present in the inner being of humans:

If He detests or condemns these individual quasi-leaves and fruits just as some sorrowful sins or unrighteousness, surely much more does He condemn that most evil essence itself of the bad tree or the worst treasure or scum of all filthiness as the worst sin and unrighteousness. ${ }^{213}$

It is only after establishing his arguments regarding the human being's created nature and the characteristics and consequences of sin that Flacius began discussing the concepts of free will and original sin, in light of God's law:

Likewise, on the other hand He hates above all else the hostile perverse essence of the internal man as truly original unrighteousness, from where all unrighteousness and actual sin gushes forth, shouting: »Inside you are ravenous wolves, from the outside you are whitewashed tombs, full of corpses within: the Lord knows your hearts: whatever is lofty in you is an abomination before (in the presence of) God. $\ll^{214}$

211 Ibid., B3a-b: »Multo profecto magis Deus \& tota eius lex flagitat exigitque in nobis \& a nobis ipsam optimam essentiam bonae arboris, quam foliorum ac fructuum.«

212 Ibid., B4a-b: »Semper certe ille flagitando bonos fructus, ante omnia ipsam bonam arborem radicemque flagitat.«

213 Ibid., B4b: »Sin ille haec singula quasi folia aut fructus idem pervenientes detestatur aut damnat, tanquam quaedam tristia peccata, aut iniustitiam, multo certe magis damnat illam ipsam pessimam essentiam malae arboris aut pessimi thesauri vel sentinae omnium spurcitiarum, tanquam summum quoddam peccatum \& iniustitiam."

214 Ibid., B5a: »Idem quoque vicissim contrariam pravam essentiam interni hominis omnium maxime odit, tanquam vere originalem iniustitiam, unde scaturiat omnis iniustitia aut peccatum actuale, clamans: Intus estis lupi rapaces, estis sepulchra foris dealbata, intus plenae 
Using the imagery and sharp words that echo Matthew 23:27-28, Flacius described the internal rottenness of the human being; the completely perverted condition of their very substance. This is one of the key passages of Defensio sanae doctrinae, where Flacius provided a summary of his beliefs, to which he held tenaciously. He continued by addressing the issue of the human will: »The will, together with all the desires of the heart according to its nature as it is now, with all its feelings is total hostility towards God, (Romans 8). Rightly therefore, Scripture calls this work and this restoration of man a new creation in Christ, also a New creature, indeed a new Human. $\ll^{215}$ In this passage Flacius described the nature of human beings after the fall, stressing their sinfulness and the conflict in which they find themselves with God. In light of such a state, Christ's redemptive work indeed gains an added emphasis of creating something entirely new out of the sinful human being.

On the last few pages, Flacius returns to the central focus of his work. He addressed those whose stance on the question of original sin differed from his and criticized them heavily: »In fact they always contend that this original evil is something totally different from nature, that it is poured into or stuck onto the human creature by Satan, and that in all ways it should be separated from man's good nature itself, which has been made by God alone. $\aleph^{216}$

He then turned to the Scriptures and his theological predecessor St. Augustine to prove his own understanding: »However, Scripture asserts otherwise, that man's nature by itself, by means of its changeability, is already perverted and transformed, that it is evil in itself, from where all evil comes, just as Augustine discusses it against the Manicheans. ${ }^{217}$ In other words, humans are corrupted from the inside out, not as a result of an infusion from the outside. Of course, it is not without irony that Flacius here should refer to Augustine's writings against the Manicheans, since many of his own opponents had labeled his approach to original sin as Manichean.

At the end of the publication Flacius appealed to be heard before an impartial church synod, claiming that he had never had any affiliation with any sect that held beliefs contrary to the Augsburg Confession, and he denied the false

cadaveribus: Dominus novit corda vestra: nam quod est sublime in vobis, abominatio est coram Deo.«

215 Ibid., B6b: »Voluntas cum omnibus suis appetitionibus cordis secundum naturam suam, qualis nunc est, tota cum omnibus sensibus est inimicitia adversus Deum, Rom. 8. Recte igitur vocat Scriptura hoc opus \& hanc reparationem hominis novam in Christo creationem, Novam item creaturam, Hominem denique novum.«

216 Ibid., B 6b: »Semper enim isti contendunt, originale illud malum esse quiddam plane a natura diversum, a Satana homini affusum aut agglutinatum, \& omnibus modis separandum ab ipsa bona hominis natura, quae sit a solo Deo condita.«

217 Ibid., B6b-B7a: »Sed Scriptura contra contendit, ipsammet naturam hominis iam ita esse per suam mutabilitatem inversam \& transformatam, ut sit illud ipsum malum, unde omne malum veniat, sicut \& Augustin, contra Manicheos disserit.« 
accusations of his opponents, who believed that he desired to establish a new faction within Lutheranism. He challenged those who thought differently from him to settle their conflicting theological opinions on an intellectual level, with arguments from the Scriptures. Stating that his conscience was clean, Flacius was willing to face opposition in order to defend himself, hoping that this would afford him an opportunity to prove that his life and teaching were dedicated to the Lutheran church: $\gg I$ am saying, testifying and declaring now only this: that I have always presented myself to the legitimate inquiries of our Churches... I also offer myself to a political investigation, if anyone has an outward crime or case against me and does not want to or cannot dismiss me. $\ll^{218}$

Flacius had written about himself in a similar manner and tone a few years earlier, in a foreword he dedicated to Emperor Maximilian II in February 1566 from Regensburg: »How much care, seriousness and labor I have invested against all kinds of false beliefs and what follows from them for God's honor, for the true religion and church and for dear Germany, as well as for the sake of all Christianity, my writings and this booklet will testify about sufficiently. $\ll^{219}$

Although Flacius was ready and willing to face his adversaries, it is clear from the text of Defensio sanae doctrinae that he was fully convinced that his position was true to the Scriptures and to Luther's understanding and that he was not prepared to compromise them and change his mind. From the way Illyricus wrote so vividly about the ugliness of sin, its consequences and the polluted nature of the human being, it is evident that he had not changed his position in comparison to his previous works. Instead, he continued to represent the understanding that original sin had infected humans completely, and by taking this stance he remained in opposition to those who in his opinion wished to diminish human fallenness and the depraved state of human nature and, hence, the true miracle of salvation.

218 Ibid., B7a: »nunc illud unum solum dico, testor \& protestor, me semper obtulisse me ad legitimam cognitionem nostrarum Ecclesiarum... Offero etiam me ad politicum iudicium, si quis quod externum crimen causamve contra me habet, nec me missum facere vult aut potest.«

219 Flacius, »Foreword to Maximilian II,« in De Translatione Imperii Romani ad Germanos. Item de Electione Episcoporum, quod aequem ad plebem pertineat. Matthia Flaccio Illyrico Avtore (Basel: Pietro Perna, 1566; VD16 F 1502), A2r. See also the German translation, Von Ankunfft des Roemischen Keyserthumbs an die Deudschen. Von der Herkunft der Sieben Churtfuersten. Verdeudschet durch M. Wolffgang Waldner. Jtem/Von der Wahl der Prelaten. Ob Petrus zu Rohm gewesen sey. Durch M. Matth. Flacium Jllyricum (Oberursel: Nikolaus Henricus d.Ä., 1567; VD16 F 1504). The Foreword has been translated into Croatian by Dragica Đujić in Zbornik radova trinaestog znanstvenog skupa »Susreti na dragom kamenu« Matija Vlačić Ilirik i njegova doba. Labin i Istra danas (Pula: Viša ekonomska škola »Dr Mijo Mirković,« 1985), 3-18, here 17. 
In spite of all the trials and difficulties he had experienced, which may have prompted others to formulate their theology in more conciliatory terms in order to clear up misunderstandings, Flacius refused to show any hint of compromise. Although he obviously wished to clear his name, he wanted to do it only on his own terms. His conviction of the correctness of his position made the price he had to pay worth it: being excommunicated and even being called heretical for the sake of confessing and defending this emphasis until his death. This attitude of complete intransigence and lack of interest in maintaining unity among his fellow evangelicals marked the third and final phase of Flacius' theological radicalization.

This attitude was manifested again in August 1571 when Jakob Andreae stopped in Strasbourg on his way from Montbéliard (Mömpelgard) to Württemberg. The city preachers requested that Andreae have a theological disputation with Flacius in their presence, which took place on the day of St. Lawrence (August 10). They debated the doctrine of original sin and agreed that there was not enough time to discuss everything and therefore they would continue their polemics in writing, which ended in misunderstanding and mutual recriminations. ${ }^{220}$ Apart from the above mentioned colloquium Flacius had a few other public debates concerning original sin before his death but never had the chance to present his views before the general Lutheran synod.

\section{b) Glossa: Flacius' New Testament Exegesis}

Flacius' last major work, published in Basel in 1570, was his Gloss on the New Testament. Flacius began his colossal project in Antwerp at the end of 1566 and finished it in three years. Completing the Glossa was of utmost importance to Flacius, and he kept working on it in the midst of all the upheavals he was experiencing. He wrote the dedication of his monumental work (occupying 18 large folio pages) to the senate of Strasbourg, dated February 24,1570 , which was St. Matthias' feast day [his name day]. ${ }^{221}$

220 Andreae published an account of this disputation long after Flacius was exiled from Strasbourg. The dedicatory epistle to the Austrian lands of Styria and Carinthia was dated on December 1, 1574 in Tübingen. See, Colloquium de Peccato originis. Inter D. Iacobvm Andreae, et M. Matthiam Flaccivm Illyricum Argentorati Anno 1571. institutum. Cvi Adivncta svnt allia quoque, Scripta, sicut sequens pagina docebit. In qvibvs Doctrina et Controversia de Peccato originis perspicuem explicata, \& compendiaria via ad piam pacem, \& litis huius expeditam compositionem monstratur (Tübingen: Georg Gruppenbach, 1574; VD16 A 2258).

221 On March 11, 1570 he personally presented a copy of the Glossa bound in red silk and garmented with blue ribbons to the city council of Strasbourg. See Hollaender, »Der Theologe Matthias Flacius,« 210, n. 4. 


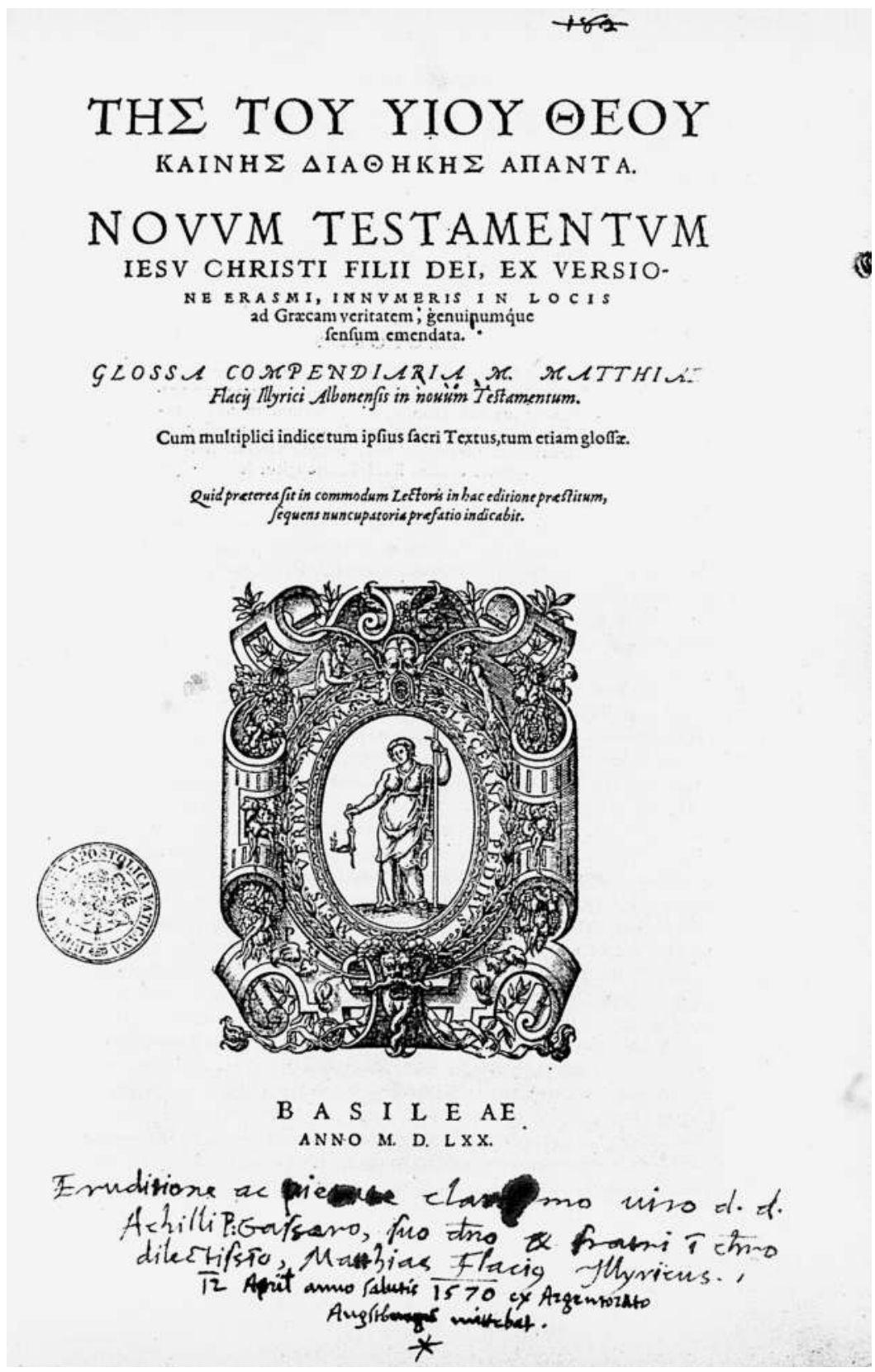

Figure 11: The title page of Flacius' Glossa Compendiaria of 1570 with his handwritten dedication to Achilles Pirmin Gasser. Courtesy of University Library Heidelberg, Biblioteca Palatina, Microfiche, shelfmark 89 MA 246:: B1163 / B1176 $(1163,1)$. 
This publication was the result and reflection of Flacius' love for the Scriptures - something that he had developed as a young student while he was in Venice. In his autobiographical reflection, Flacius described how this passion was awakened in him:

Even before I learned Luther's doctrine I felt in myself the peace of conscience and the joy in the Holy Spirit, loved the religion and the Holy Scripture and often with my whole heart wished to contribute something in theology, so that I could advance in the Holy Scripture and serve the church of Christ some time and then be able to return to the Lord. ${ }^{222}$

The reason for keeping Glossa a priority was that Flacius held the Holy Scriptures in the highest esteem and to be the main source of knowledge as he stated in the Preface to Clavis Scripturae: »the Holy Scriptures are divine inspiration because the Holy Spirit spoke them through the mouth of holy instruments of God and wrote them through the hands of these instruments. $\ll^{223}$

The title of the work, Glossa compendiaria, already gives a clear indication of what Flacius was trying to accomplish in his tome. According to medieval tradition, glossa denoted words of explanation or clarification that were incorporated into a certain text by way of making notes in between the lines or on the margins. This stood in contrast to the later loci method, applied for example by Melanchthon, which concentrated on highlighting only certain portions of Scripture and did not address each segment in detail but rather was more topically arranged. The gloss is actually a predecessor of the annotation or perhaps of one-volume commentaries of the whole Bible. The fact that Flacius worked feverishly in the last years of his life on the Glossa of the Old Testament, which unfortunately never saw the light of publication due to his death, shows this connection to biblical commenting exemplified in things like Erasmus' Annotationes in Novum Testamentum, Johann Albrecht Bengel's Gnomon Novi Testamenti or the Oxford Annotated Bible. ${ }^{224}$

222 Flacius, Entschueldigung Jllyrici, D5v: »Ich hab (Gott weis) ehe ich des Luthers lehr erkant hatte/fried meines gewissens/vnd grosse freud im heiligen Geist gefuelet/hab auch die heilige Schrifft lieb gehabt/vnd offt von ganzem hertzen gewuendscht/das ich in der heiligen schrifft moechte zunemen/damit ich ein mal der Kirche Christi dienen/vnd darnach zum Herrn wandern moechte.«

223 Flacius, Preface to Clavis Scriptvrae... Pars Prima, A2v: »Quae sacra Scriptura ideo $\Theta \varepsilon o ́ \pi v \varepsilon v \varsigma$ et divinitus inspirata dicitur, quia Spiritus sanctus eam per os sanctorum Dei organorum locutus est, et per eorundem manus conscripsit.«

224 See also Timothy J. Wengert, Philip Melanchthon's »Annotationes in Johannem« in Relation to its Predecessors and Contemporaries [Travaux d'Humanisme et Renaissance 220] (Genève: Droz, 1987). 
Some thirty years after Flacius first studied Erasmus' edition of the New Testament, which was accompanied by a volume of annotations, he decided to correct Erasmus' text as well as to augment it. He compared the Greek original and Erasmus' Latin translation to the Vulgata. Flacius also added his own annotations, and as a result the work grew to 1,394 folio pages (not counting the dedication, the preface, or the two indexes at the end), making it a very large and heavy (in weight) book. ${ }^{225}$ According to Pierre Fraenkel, Flacius' Glossa of the New Testament has been one of the least studied commentaries of Scripture through history and has received little attention even from those scholars who have dedicated much time to studying Flacius and his works. ${ }^{226}$ On each page of the Glossa, there were two columns of approximately seventy lines each: the Greek text was on the left, ${ }^{227}$ the corrected Latin text of Erasmus on the right, ${ }^{228}$ and then Flacius' commentary followed. His text was so detailed and thorough that it took up as much space as the entire New Testament.

From Flacius' commentary it seems that there were various underlying motivations that prompted him to get involved in such an enormous undertaking. First, it is clear that by offering corrections of Erasmus' translation, Flacius believed that he was providing a better translation and a more accurate understanding of Scripture. In this, he was being true to Erasmus' own goals, namely to return to the original Biblical texts, cherished by humanists of all stripes. However, beyond working closely with the texts, Flacius' abundant annotations also allowed him to present interpretations of Biblical passages reflecting his own theological convictions. Finally, Wilhelm Preger claims that the Illyrian's aim in the Glossa was to show how ideas and books in the New Testament are linked together, ${ }^{229}$ in other words, to present the inner coherence of Scripture.

225 Flacius, Tès tou Hyiou Theou Kainēs Diathēkēs hapanta. Novvm Testamentvm Iesv Christi Filii Dei, ex versione Erasmi, innvmeris in locis ad Graecam veritatem, genuinumque sensum emendata. Glossa compendiaria M. Matthiae Flacij Illyrici Albonensis in nouum Testamentum. Cum multiplici indice tum ipsius sacri Textus, tum etiam glossae (Basel: Pietro Perna and Theobald Dietrich, 1570; VD16 B 4214).

226 See Pierre Fraenkel, »Matthias Flacius Illyricus and his Gloss on Hebrews 9, « The Journal of Medieval and Renaissance Studies 14/1 (Spring 1984): 97-111, here 99. This is a paper presented at a seminar held at the Institut d'Histoire de la Réformation in Geneva, June 14-15, 1982.

227 Flacius used the Greek text with a critical apparatus published in 1550 by Robert Estienne in Paris.

228 Flacius says about Erasmus' translation, Glossa compendiaria, **2r: »We have done our best to improve it by bringing it in many ways closer to the true sense of the greek original, the genuine import of a particular passage and its clear meaning and to the proper signification and the finer shades of meaning of the Greek and Hebrew terms.« English quote taken from Fraenkel, »Flacius Illyricus and his Gloss, 101.

229 Preger, Flacius und seine Zeit, 2: 509. 
Even though the Glossa was first of all a Biblical commentary, portions of it reflect the dogmatic and polemical interests of Flacius. These included his arguments regarding what constitutes adiaphora, for which Flacius cited Apostle Paul from Romans 14 and 15 and 1 Corinthians 7, 8, 10 and 14 for a sufficient proof that there is such a thing as adiaphora in the church; his disagreement with Georg Major over the latter's emphasis on Christian good deeds playing a role in salvation; the Synergistic controversy against those who had contended that humans must play their part in conversion; his polemics against Schwenckfeld and many more. In addition to references to these theological disputes, statements against Catholic and Calvinist teaching can also be found in Glossa.

Flacius presented some hermeneutical reflections in both the dedication and the preface to the reader, as he explained part of his approach to studying and interpreting Biblical texts. As Flacius stated in the title of his preface to his readers (totaling 23 pages), he wanted to present an uncorrupted text of the Gospel of Jesus Christ. ${ }^{230}$ In this statement lay an indirect reference to the imperfections in Erasmus' text. Making use of his expertise in languages, Flacius immediately delved into his views on the use of Hebrew phrases in the New Testament.

Among the first issues he wanted to clarify at the beginning concerned ת ת תירֶב (b'rith) and the Greek $\delta \alpha \alpha \theta \eta$ кү (diatheke) and words in different Biblical texts and translations to describe covenant or contract, he first commented on the differences in their meanings.

One of the main arguments that Flacius made on this point came from him contrasting various examples of testaments throughout the Bible (the so-called Adamic, Abrahamic, and Mosaic covenants, which he grouped together as representations of the old »testament «) with the new covenant (pactum) through Christ. Flacius wanted to show that he differed from Theodore Beza's interpretation of the New Covenant, which for Calvinists was only the continuation and sealing (by death) of the Old Covenant. On the contrary, Flacius argued that Christ is presented as the mediator of the new covenant, seen as the only way to salvation, and that he restores God's covenant to its original state. This is why Christ's blood is covenantal blood. For Flacius Christ is the center of the Scriptures, and his Christology still deserves intensive study.

230 Flacius, Glossa compendiaria, **5r: »Christiano lectori, gratiam et pacem una cum ardentissimo studio retinendi coelestis depositi incontaminati evangelii Iesu Christi, optat Matth. Flacius Illyricus.« 
Flacius aimed to dissolve the tension between the old and new covenants by pointing out both their similarities and differences and by looking at them through the Lutheran paradigm of Law and Gospel. ${ }^{231}$ The fact that Flacius later returned to the same topic in his commentary on Hebrews, and especially to discussing the relationship between the Old and New Testaments and the Words of the Institution, demonstrated the importance he attached to this subject. Flacius argued, following Luther, that these words needed to be interpreted literally and not figuratively exactly because the Testament rather than the Covenant is the dominant idea of $\delta 1 \alpha \theta \eta \dot{\kappa} \kappa$, so that the cup of wine is not a sign of the blood of the New Covenant but instead Christ's last will and Testament.

Apart from the line-by-line commentary in the main body of the Glossa, Flacius introduced each New Testament book or group of books with a preface, often quoting from works by the Church Fathers. Flacius' zeal for compiling materials showed even here, as he relied on incorporating previous works by others into his glossa. It is interesting to note that in his introduction to the book of James, Flacius follows Luther in dismissing the canonicity of the Epistle because of the lack of teaching on justification by faith and too much emphasis on good works, concluding that James differs from the Pauline corpus.

The timing for the publishing of Glossa could not have been worse, since by 1570 Flacius' reputation had been irreparably damaged. The publication of an enormous, and therefore very expensive, book by someone whom many theologians held to be a heretic certainly meant that very few people bought let alone wanted to read the Glossa. By the time of its printing, the number of Flacius' supporters had dwindled, mostly as a result of being persecuted due to their association with him. Therefore, there was almost no market for such a work - even though Flacius may have been hoping to clear his name with this publication. The Glossa received little attention during Flacius' lifetime and was reprinted only once, almost a century after the original edition. ${ }^{232}$

However, the work does deserve attention for several different reasons. First, it marks $»$ the beginning, or prehistory, of scientific biblical criticism $\ll{ }^{233}$ Second, the Glossa was one of the first Protestant commentaries on

231 Keller, Der Schlüssel zur Schrift, 166.

232 The second edition of Flacius' Glossa was published almost a century later in Frankfurt am Main by Johannes Beyer in 1659 [VD17 23:231193N].

233 Kenneth G. Hagen, »De Exegetica Methodo Steinmetz (ed.), The Bible in the Sixteenth Century [Duke Monographs in Medieval and Renaissance Studies] (Durham, NC: Duke University Press, 1996), 181-196, here 195. Hagen examines different arguments presented by Flacius in favor of the Pauline authorship of the Book of Hebrews. See Hebrews Commenting from Erasmus to Bèze, 1516-1598 [Beiträge zur Geschichte der biblischen Exegese 23] (Tübingen: Mohr Siebeck, 1981), 83-86. 
the entire New Testament. (Both Luther and Calvin had avoided producing commentaries on the Apocalypse of John). ${ }^{234}$ Thirdly, in this work Flacius put into practice the hermeneutical principles that he had articulated and systematized in Clavis Scripturae. As Robert Kolb has observed, »On the basis of these two works Matthias Flacius had contributed in unique and significant ways to the history of Wittenberg exegesis. (235 $^{23}$

\section{Flacius' Desperate and Destitute Final Years: The Struggle to Clear His Name from Accusations of Heresy}

While living in Strasbourg, Flacius faced antagonism from the city senate. This spurred him on to pen his doctrinal defense, Defensio sanae doctrinae which was issued in print in 1570 .

Since Flacius had been accused of Manichean heresy by many Lutheran theologians, the city council of Strasbourg asked Flacius to defend his teaching on original sin in writing. At first the authorities were satisfied with Flacius' explanation of his doctrine, but when Flacius refused to sign the so-called »Five Union Articles (Fünf Unionsartikel), « a brief statements of controversial issues: »justification, good works, freedom of the will, adiaphora, and the Lord's Supper, $\ll^{236}$ meant to bring unity among divided evangelical theologians, it was decided that Flacius should explain his beliefs personally to Jakob Andreae, the leading theologian from Württemberg. The »Five Articles« were drawn up by Andreae after the Colloquy of Altenburg, which had been organized by Ernestine and Albertine dukes, ended with failure in March of $1569 . .^{237}$

On August 10, 1571 a colloquium between Andreae, the chancellor of Tübingen University, and Flacius was held in superintendent Marbach's house near the church of St. Thomas. During that exchange Andreae called original sin an »accidentia" while Flacius stayed with the term »substantia, « claiming that the principal part of the human being is corrupt. Flacius

234 Another example is Rudolf Gwalther, Zwingli's and Bullinger's successor in Zurich who wrote Latin homilies on the entire New Testament except on Revelation. See, John Lee Thompson, Reading the Bible with the Dead: What You Can Learn from the History of Exegesis That You Can't Learn from Exegesis Alone (Grand Rapids/Cambridge: Eerdmans, 2007), 268. See also, Irena Backus, Reformation Readings of the Apocalypse: Geneva, Zurich, and Wittenberg [Oxford Studies in Historical Theology] (New York: Oxford University Press, 2000). She discusses the odd distribution of commentaries on Revelation by people such as Leo Jud, Theodor Bibliander, Nikolaus Selnecker, David Chytreaus, and a few others.

235 Robert Kolb, »Matthias Flacius' Glossa Compendiaria: The Wittenberg Way of Exegesis in Its Second Generation, « in Miladinov and Ilić (eds.), Matija Vlačić Ilirik III, 72-89, here 89.

236 See, Dingel, »The Culture of Conflict, « 61-62.

237 For more on those articles, see Hans Christian Brandy, »Jakob Andreaes Fünf Artikel von 1568/69, « Zeitschrift fur Kirchengeschichte 98 (1987): 338-351. 
also participated in a disputation with Jesuit monks in Fulda ${ }^{238}$ May 17-22, $1573,{ }^{239}$ and then returned to Strasbourg.

As a result of the theological controversies that surrounded him, the Strasbourg city council decided to refuse further hospitality to Flacius in 1573 and he was expelled. He left the city with his wife and children on June 8. ${ }^{240}$

Flacius and his family found refuge at a convent in Frankfurt am Main, where prioress Meerfeld offered them protection. ${ }^{241}$ Since Frankfurt was officially a Protestant city, this convent was used in order to offer refuge primarily to evangelical widows but also to persecuted French-speaking religious refugees and others. Even though the Lutheran superintendent in the city, Hartmann Beyer, was a personal friend of Flacius, he did not have much influence on the city senate. Elector August I of Saxony, ${ }^{242}$ who was a formidable adversary of Flacius, managed to pressure the town council to issue a decision on December 22, 1573 ordering Flacius, his wife and his children to leave the city in twenty-four hours. ${ }^{243}$ Flacius immediately left Frankfurt but his family stayed in the Monastery of White Ladies. ${ }^{244}$

238 Flacius, Von der Disputation/oder Religionstreit/zwischen M. Matthia Flacio Jllyrico/vnd den Jesuitischen Doctoren zu Fulda/dieses 1573. Jar geschehen ... Jtem/von Vneynigkeit der Papisten vnter sich selbs (Oberursel: Nikolaus Henricus d.Ä., 1574; VD16 F 1547).

239 Gerrit Walther, »Die Disputation des Flacius Illyricus, in Abt Balthasars Mission. Politische Mentalitäten, Gegenreformation und eine Adelsverschwörung im Hochstift Fulda [Schriftenreihe der Historischen Kommission bei der Bayerischen Akademie der Wissenschaften 67] (Göttingen: Vandenhoeck und Ruprecht, 2002), 268-279.

240 Preger, Flacius und seine Zeit, 2: 381. According to Döllinger, Flacius first stayed in Basel at the house of the superintendent Simon Sulzer and wanted to arrange for asylum in the city but was not able to. See, Ignaz von Döllinger, Die Reformation, ihre innere Entwicklung und ihre Wirkungen im Umfange des Lutherischen Bekenntnisses (Regensburg: Georg Joseph Manz, 1848), vol. 2: 252, n 698.

241 The Sisters of the Order of St. Mary Magdalene of Repentance (Ordo Sanctae Mariae Magdalenae de poenitentia), or »Magdalenerinnen, « were commonly referred to as »Weißfrauen« (White Ladies) because of the simple white clothing they wore. The order followed the rules of St. Augustine. The cloister in Frankfurt does not exist anymore, although a street called Weißfrauenstraße in the vicinity of the old city center indicates where it had been located.

242 August I was the younger brother of Maurice, whom he succeeded as Elector when Maurice died on July 11, 1553 at the age of thirty-two. It is interesting to note that August I was at first very favorable toward Flacius and then changed his mind sometime in the early 1560s and became one of his worst adversaries.

243 Institut für Stadtgeschichte Frankfurt am Main, Ratsprotokoll und Bürgermeisterbuch, Dienst b. 22. Dec. 1573, cited in Preger, Flacius und seine Zeit, 2: 518, n**. It seems that the city of Frankfurt showed mercy to Flacius' wife and children since it was already wintertime, so they did not get expelled, Preger, 2: 520, $\mathrm{n}^{* * *}$.

244 On December 24, 1573 when the city official came to look for him he was already gone. His wife, Magdalena told him the story that Flacius had gone to visit a nobleman in Franken. This might have been Flacius' supporter, Adolf Hermann Riedesel zu Eisenbach, who owned a castle in Upper Hesse, according to Preger, Flacius und seine Zeit, 2: 518. It is also possible that he visited Johannes von Crailsheim in his castle in Morstein in the region of Hohenlohe, as Helmut Neumaier suggests in »Exules Christi< in Franken - die Herren von Stetten und der Flacianismus. Das Zeugnis des Cyriacus Spangenberg, Blätter für württembergische 
During most of 1574 Flacius travelled throughout Germany in an attempt to clear his name of the »Flacian heresy«. He was also feverishly writing letters - among others to Duke Julius of Braunschweig-Lüneburg, on January 10 and February 12, 1574. In early 1574 he visited Count Vollrad V in Mansfeld, who then arranged a meeting for Flacius in Berlin with the new Elector of Brandenburg, Johann Georg, ${ }^{245}$ and the general superintendent of the Brandenburg church, Andreas Musculus from Frankfurt an der Oder, at which Flacius was warmly received. ${ }^{246}$ Apparently at that time Musculus agreed with Flacius' teaching on original sin. ${ }^{247}$ Flacius also met with another supporter, Barthold von Mandelsloh, Captain of Cottbus who gave him money for his further travel to Silesia. While visiting Cottbus he stayed with the church superintendent there, Johannes Teckler, whom he knew from his Wittenberg days. ${ }^{248}$

In Lower Silesia (Dolnośląskie) ${ }^{249}$ on May 7 and 12, 1574 Flacius held two colloquiums on the topic of original $\sin ,{ }^{250}$ organized by Count Sebastian

Kirchengeschichte 101 (2001): 13-48, here 17 and in »Zum konfessionellen Verhalten der fränkischen Reichsritterschaft: Ort Odenwald im späten 16. Jahrhundert, «Zeitschrift für Württembergische Landesgeschichte 55 (1996): 109-130, here 115-116. The plausibility of this theory is further supported by the fact that Flacius dedicated his work »The Angel of Darkness [Devil] Discovered, « to von Crailsheim. See, Angelvs tenebrarum detectus. Qvod Accidentarii, Scholasticorvm pelagianismum, a Luthero P. M. destructum, reaedificent instaurentque. Qvod Scholastici Ivsticiam illam essentialem, homini in creatione inditam, eiusque contrariam iniustitiam animaduerterint: sed per suas ratiocinationes euanescentes, temere ad comminiscendam accidentariam iustitiam aberrauerint (Oberursel: Nikolaus Henricus d.Ä., 1572; VD16 F 1252), A2r-3r. Flacius' oldest son, Matthias, the Younger also dedicated his work to von Crailsheim in the same year, further proving the existence of a Flacius family connection to this nobleman and that he was sponsoring them. The twenty-five-yearold Matthias, the Younger wrote in defense of his father's theology concerning original sin in the face of the attacks by Heshusius and Musaeus. The dedication is dated in Eisleben on July 22, 1572. See, Amolitio XX. Errorvm, qvos Heshvsivs Illyrico falso obiicit. Examen novae D. Mvsaei de peccato originali sententiae (Eisleben: Andreas Petri, 1572; VD16 ZV 5908), A1v.

245 In the same year Flacius dedicated to Johann Georg, De mystica sacramentalique seu externa praesentia et manducatione corporis et sanguinis Christi in sacra coena. Avtore Matthia Flacio Illyrico (Oberursel: Nikolaus Henricus d.Ä., 1574; VD16 F 1451).

246 For a biography of Musculus, see Christian Wilhelm Spieker, Lebensgeschichte des Andreas Musculus, General-Superintendent der Mark Brandenburg, Consistorialrath, Doctor und erster Professor der Theologie und Pfarrer zu Frankfurt an der Oder. Ein Beitrag zur Reformations- und Sittengeschichte des 16ten Jahrhunderts (Nieuwkoop: B. de Graaf, 1964; reprint of the original 1858 edition). For an overview of his career, see Robert Kolb, »Musculus, Andreas, « in The Oxford Encyclopedia of the Reformation 3: 103.

247 Preger, Flacius und seine Zeit, 2: 385-386.

248 Gustav Bauch, Valentin Trozendorf und die Goldberger Schule [Monumenta Germaniae Paedagogica 57] (Berlin: Weidmann, 1921), 222.

249 Since the mentioned places are all located in today's Poland, I am using the present-day names in parentheses.

250 See the melodramatic statement, without evidential support, written by the editors of the CS 13: 362: »Flacius' visit to Sebastian von Zedlitz in Neukirch, Silesia, in 1574 is significant for their relationship and for the persecution of the Silesian Schwenckfelders in the latter part of the 
von Zedlitz ${ }^{251}$ in Castle Lähnhaus (Zamek Wleń) and Langenau (Czernica), against five local pastors and theologians: Jacob Colerus, ${ }^{252}$ Georg Bezold from Goldberg (Ztotoryja), Michael von Stabenau from Lähn (Wleń), Georg Willer from Leipe (Lipin), and Peter Gromann from Langenau. In defending the proposition that the original sin is a substance (peccatum est substantia), Flacius claimed that this particular phrase was not his invention but that it has been used throughout church history and first by Dionysius the Areopagite.

Flacius only came back to Frankfurt on August 17, 1574. These travels demonstrate that Flacius was working intensely to rehabilitate himself in the eyes of political and ecclesiastical leaders. ${ }^{253}$ When Flacius returned to Frankfurt he was exhausted from his travels and became ill.

$16^{\text {th }}$ century.« For the details of the colloquium, see Augustin Knoblich, »Die Disputation von Flacius über die Erbsünde, « in Chronik von Lähn und Burg Lähnhaus am Bober: Urkundliche Beiträge zur Geschichte der Städte, Ritterburgen, Fürsten und Adelsgeschlechter Schlesiens (Breslau: Aderholz, 1863), 121-126. Knoblich states that Flacius wanted to secure long-term asylum in Silesia, 122. For more details about the colloquium, see Hermann Bushbeck, »Des Matthias Flacius Illyricus Religionsgespräche auf Burg Lehnhaus und Schloß Langenau im Jahre 1574,« Jahrbuch des Vereins für schlesische Kirchengeschichte 24 (1934): 3-23.

251 Zedlitz was from Neukirch an der Katzbach (Nowy Kościół). He matriculated at the University of Wittenberg on September 26, 1540 as a student and later also attended lectures by Flacius. Their friendship can therefore be traced back to the years that both of them spent in the city. Later Zedlitz was supporting Flacius during his theological debate against Schwenckfeld in the 1550s. Flacius dedicated two of his works to Zedlitz. See, Confessio Waldensium... (Basel: Johannes Oporinus, 1568; VD16 C 4835) and secondly, a work written primarily in response to Heshusius' accusations, Solida Refvtatio vanissimorum Sophismatum, calumniarum \& figmentorum, atquem adeo etiam deterrimorum errorum Antidoti, \& aliorum Neopelagianorum Scriptorum. Avthore Math. Flac. llyrico (s.1.: 1573; VD16 F 1500), dated on the day of the Apostle St. Matthias (February 24) in Strasbourg. After Flacius died, Zedlitz donated 300 Talers for establishing a hospital in the little valley town of Lähn in honor of Flacius. This particular hospital was renovated in 1871 as the plaque states: »... im Jahre des Hernn 1575 dieses Haus von Herrn Freiherrn Sebastian v. Zedlitz gestiftet, 1871 von der Stadt Lähn renoviert und dem Vaterländischen Frauenverein zur Verwaltung übergeben.« Bushbeck, »Des Matthias Flacius Illyricus Religionsgespräche,«3-4.

252 For an overview of his career, see Adolf von Schimmelpfennig, »Colerus, Jacobus, « in ADB 4 (1876), 401-402. Colerus published his version of the disputation with Flacius. See, Historia Dispvtationis sev potivs Colloqvii, inter Iacobvm Colervm et Mathiam Flacivm Illyricvm, de Peccato originis, habitae in arce Langenavv Silesiorum 12. Maij Anno 1574. Pavlo ante Obitvm Illyrici (Berlin: Nikolaus Voltz, 1585; VD16 C 4512). This work was reprinted by Gregor Langemak, who added his own preface to it (Stralsund: Samuel Gottlieb Lochmann, 1726).

253 Daniel travelled with his father in 1574 and was present at the disputations between Flacius and Jacob Coler in Lower Silesia, where he recorded the proceedings. According to Daniel's enrollment records at the University of Basel, he was matriculated in May 1579 as »Daniel Flaccius Magdeburgensis, Mathiae Ilirici filius.» See Hans Georg Wackernagel (ed.), Die Matrikel der Universität Basel II.,1532/33-1600/01 (Basel: Verlag der Universitätsbibliothek, 1956), 267, Nr. 123. Daniel enrolled at the Faculty of Arts (facultatis artium) as a student at the time when the rector of the University was Johannes Nikolaus Stupanus and the dean of the medical faculty was Heinrich Pantaleon, a good friend of his father's. In 1581 Daniel received both his bachelor and master's degrees. Flacius had eighteen children. In one attempt of the author (see http://www.flacius.net/index. 
Toward the end of his life Flacius wrote a Catechism for young adults, to be used together with Luther's Small Catechism, and he dedicated it to the Frankfurt monastery prioress Katharina von Meerfeld. ${ }^{254}$ Even though the dedication had no date, it was without a doubt written during the period that Flacius resided in the monastery, thus sometimes after June 1573 and before the end of $1574 . .^{255}$ The dedicatory letter reveals Flacius' gratefulness for the shelter provided by the prioress, but it also shows his respect toward her, calling her his »graceful Mother. ${ }^{256}$

The Catechism is the only work written by him that was primarily meant for teaching teenagers the tenets of the Christian faith. ${ }^{257}$ Since Flacius himself had a number of teenage children at the time it is plausible that it was written for the use of his household in the first place. It was posthumously printed in 1577. As far as can be established, no single biographer of Flacius' has been aware of its existence. The whole catechism is structured in a way that first the son asks a question and then the father replies.

This particular Catechism is very unusual in the sense that it contained Flacius' teaching regarding original sin especially in the fifth and ninth

php?option $=$ com_content\&view $=$ category\&id $=53$ :druga-vlaieva-djeca\&layout $=$ blog\&Item$\mathrm{id}=63 \&$ lang=en), I had traced eight. It is to be assumed that some died at birth or as infants.

254 Her family name is at times also spelled as Mörfeld or Mehrfeld. Flacius, Eine Einfeltige Christliche Vnterweisunge der gewachssenen Jugend in den noetigsten Stuecken des Christichen Glaubens/so auff den kleinen Catechismum folgen solt/Sampt Anzeigung der jetzigen widerwertigen Jrthumen/auff das sie erkenne beide das Gute/zur erwehlung/vnd auch das Boese/zur vermeidung. M. Matthias Flacius Jllyricus. Anno 1577 (Oberursel: Nikolaus Henricus d.Ä., 1577; VD16 F 1362), A2r-6v. The publisher of this work has been established by Manfred Kopp, Die Druckerei zu Ursel 1557-1623 (Oberursel im Taunus: Stadt Oberursel, 1990), print Nr. 151; VD16 does not have the place and the name of the publisher. For more about that important printing press for Flacius and other Gnesio-Lutherans, see Manfred Kopp, Nicolaus Henricus und Cornelius Sutor: Bürger und Drucker zu Ursel (Oberursel: Pharma-Druck Inge Hartmann, 1964). This particular Catechism by Flacius is briefly discussed by Friederike Fricke in a chapter called »Sonstige evangelische Katechismen, « in Luthers Kleiner Katechismus in seiner Einwirkung auf die katechetische Litteratur des Reformationsjahrhunderts (Göttingen: Vandenhoeck und Ruprecht, 1898), 167-171.

255 Sections of the Catechism are reprinted in Johann Michael Reu (ed.), Quellen zur Geschichte des Katechismus-Unterrichts: Mitteldeutsche Katechismen. Vol 2/2: Texte [Quellen zur Geschichte des kirchlichen Unterrichts in der evangelischen Kirche Deutschlands zwischen 1530 und 1600] (Gütersloh: C. Bertelsmann, 1911), 1114-1126.

256 The title of the dedication affectionately reads: »Der Ehrwu(e)rdigen, Andechtigen, vnd Gottsfuerchtigen Frawen, Katharina Mo(e)rfeldin, Mutter zur weissen Frawen, meiner gu(e)nstigen Frawmutter.« Flacius, Eine Einfeltige Christliche Vnterweisunge, A2r.

257 Ibid., A2v: »So hab ichs fu(e)r Christlich geachtet, das ich beyde, meine Danckbarkeit gegen E. E. zu beweisen/vnd sie jres Christlichen Fu(e)rnemen zu fo(e)rdern, eine klare vnd eine einfeltige Summa der Christlichen Lere fu(e)r die junge Leute, die da numehr ein wenig gewachssen sein, aus der H. Schrifft trewlich fassete/vnd mit demselbigen E. E. verehre.« There is a discussion among Croatian and Slovenian scholars whether Flacius also wrote a catechism for children, which was printed anonymously in the »Children's Bible« (Otrozhia Biblia) edited by Sebastian Krell. See the facsimile edition of Otrozhia Biblia [Monumenta Litterarum Slovenicarum 20] (Ljubljana: Mladinska knjiga, 1987). 
questions of the second section [part]. The controversial word ssubstantia once again appears in this teaching. The answers by the father are important to quote, since this is probably the last written statement by Flacius regarding his teaching on human nature and original sin and also reveals which biblical texts were key to Flacius for such an interpretation of his doctrine:

5. Son: What is the human being like now? Father. The human creature, since having fallen from God to Devil, is after the serious verdict and threats of God [stating] that the day you eat thereof you will surely die; spiritually, by that same first death thus indeed and abominably deceased, that it particularly has changed completely into [being] repulsive in its highest part and power: namely, that it has become an evil tree or vine and image of the devil, who now has a such a soul that is entirely unequal to God and to his laws. Yes, it is contrary [to God] in the highest form of its nature and substance, including incidental or appended fruits or effects, which is all sin and is called $\sin .^{258}$

\section{Section nine focuses on defining original sin:}

9. Son: What is original sin? Father. That evil, or that thing in us, reigns as [something] bad against God and his law, and its spirit is raging and abuses our bodies to [commit] all actual sins, and in summary it is the origin, or fountain and treasury of all evil (Romans 6, 7 and 8). This is precisely our evil nature and our evil heart that is a fountain and treasury of all actual sin, or the evil flesh that lusts and fights against the spirit (Genesis 6, 8; Matthew 12, 15; Romans 6, 7 and 8; Galatians 5). ${ }^{259}$

There was also an anti-Manichean section in the Catechism, under questions fourteen through sixteen, clearly recognizable from their formulation:

15. Son. Are you saying, then, that at the same time there are two creators in the world, through whom all is made: that is, the good is the creator of good and on the other hand, the bad is the creator of bad? Father. By no means: the Manicheans have taught

258 »5. Son. Wie ist der Mensch jetzunder? Vater. Der Mensch, da er ist von Gott zum Teufel abgefallen, ist er nach dem ernsten Sententz vnd Drewunge Gottes, Welches Tages du darvon issest, wirstu des Todes sterben, Geistlich durch denselbigen Ersten Todt also gar vnd grewlich gestorben, das er sonderlich in seinem höchsten Theil vnd Krafft gantz vnd gar in das Widerwertige verendert ist: das er nemlich worden ist ein böser Baum oder Weinstock vnd Bild des Teufels, der da hat nunmehr eine solche Seel, die Gott vnd seinem Gesetze gantz vnd gar vngleichformig ist, Ja zum höchsten zuwider mit seinem Wesen oder Substantz, auch zufelligen oder anhangenden Früchten oder Wirckungen, welches alles Sünde ist vnd geheissen wird.«

259 »9. Son. Was heisset die Erbsünde? Vater. Dasjenige böse,oder das Ding in vns, so vbel regiret, wider Gott vnd sein Gesetz vnd Geist wütet, vnd vnsere Glieder zu allen wirkclichen Sünden misbrauchet, vnd in Summa ein vrsprung, Brun oder Schatz alles bösen ist, Rom. 6. 7. 8. Welches ist eben vnsere böse Natur, vnd vnser böses Hertz, das ein Brunne vnd Schatz ist 
and said the malicious God or the Devil have made something of his own, a poison as it were, or something very harmful, which he mixed into the good nature, essence and life of the human being that is created by God, and only that, which the evil Enemy has done, is $\sin .^{260}$

In this section Flacius was attempting to respond to the accusation often levelled against him that he was teaching that the devil was the creator of the human beings, and he tried to distance himself clearly from Manichean dualism.

Five days before he died, Flacius wrote a foreword dedicated to Duke Ludwig of Württemberg, successor of Duke Christoph, ${ }^{261}$ dated March 6, 1575 in Frankfurt. ${ }^{262}$ Flacius' very last theological work, written against Jacob Andreae was published posthumously. ${ }^{263}$

aller wircklichen Sünden, oder auch das böse Fleisch, das wider den Geist gelüstet vnd fichtet, Gen. 6. 8. Matth. 12. 15. Rom. 6. 7. 8. Gal. 5.«

260 »15. Son. Sagt jr denn, das gleichsam zween Schepffer sein aller Dinge in der Welt, durch welche alles gemacht sey: Also das der gute sey ein Stiffter des guten vnd dargegen der böse ein Stiffter sey des Bösen? Vater. Mit nichten. Die Manicheer haben also geleret und gesagt, Das der böse Gott oder der Teufel etwas eigenes gemacht hab, gleichsam ein Gifft, Bulatranck oder etwas hochschedlichs, das er der gute Natur, Wesen vnd Leben des Menschens, welche von Gott erschaffen ist, eyngemischet habe, vnd nur dasselbige, das der böse Feind gemacht habe, sey Sünde.«

261 Duke Ludwig, nicknamed the Pious (der Fromme), was the only surviving son out of twelve children. He unresevedly supported Andreae's initiative for unity among the divided evangelicals, which ultimately resulted in the Formula of Concord. For an overview of Ludwig's career as a Lutheran territorial ruler and the consolidation of the evangelical church in Württemberg under his leadership, see Manfred Rudersdorf, »Herzog Ludwig (1568-1593), « in Robert Uhland (ed.), 900 Jahre Haus Württemberg. Leben und Leistung für Land und Volk (Stuttgart: W. Kohlhammer, 1984), 163-173.

262 Flacius, Christlicher vnd bestendiger Grundt/Von der Waren/Wesentlichen/Eusserlichen gegenwart vnd muendlicher niessung deß Leibs vnd Bluts Christi/im H. Abendmal/sampt warhafftiger widerlegung der fuernemsten Argument der Sacramentirer/Durch M. Matthiam Flacium Illyricum. Zuuor in Lateinischer Sprach gestelt/vnd nun allen frommen Christen zu gut auch ins Teutsche gebracht (s.1.: 1575; VD16 F 1542), A2r.

263 Flacius' reply to Andreae must have been written in the last few months of his life since it was a reply to Andreae's account of their Strasbourg colloquy that was issued in print in 1574. Andreae's preface is dated on December 1 (VD16 A 2258; German version A 2622). Paul Reinecker published Flacius' text and also added his own preface. In it he accused Andreae of falsely reporting the facts of the colloquium. See Kurtze Widerlegung des Poetischen Dialogi von der Erbsuende Vnd der angehengten Sohrifft/so D. Jacob Andreae inn den Druck ausgesprenget hat Durch den Ehrwirdigen vnd Hochgelehrten Herrn M. Matthiam Flacium Jllyricum. Mit einer Nuetzlichen Vorrede Herrn Pauli Reineckers Pfarherrs zu Grossen Creutzhausen im Steynachischen Gebirge gestelt an den Christlichen Leser zur ... Warnung sich fuer D. Schmidel [nickname for Andreae] ... ernstlich zu hueten (s.1. [Schloss Mansfeld]: 1576; VD16 F 1338). Caspar Heldelin also posthumously published Flacius' defense against Andreae with his own preface, Defensio verae piae ac Lvtheranae, de originali peccato, sententiae: ac Refvtatio sophismatvm simpliciores a vero nosce teipsum, abstrahentium, opposita commentitio colloquio caeterisque adiunctis scriptis a D. Iacobo Andraea nuper aeditus, 
On March 10, 1575 Daniel Flacius called pastors Hartman Beyer and Matthias Ritter to serve the Holy Communion to his father on his deathbed in Frankfurt. That same evening the Frankfurt city physician Adam Lonicer ${ }^{264}$ visited him and gave him a dose of Laudanum. Flacius died peacefully on March 11,1575 , eight days after his $55^{\text {th }}$ birthday, surrounded by his family and a few friends ${ }^{265}$ and his last spoken words were: »Jesus Christ, Son of God, have mercy upon me« (Iesu Christe, fili Dei, miserere mei). As Hartmann Beyer reported in a letter to Lampridio Frideland, a medical doctor in Lübeck, Flacius was buried on March 13. ${ }^{266}$

The place of his grave is unknown. Speculations about the site include St. Peter's Cemetery or the grounds of the Weißfrauenkloster. Others assume that Flacius was buried by his friends and followers outside the Frankfurt city walls, because the Frankfurt city council refused to grant him a proper church burial due to his controversial theology. Johannes Fraxineus from Trügleben by Gotha wrote an epitaph for Flacius that was printed in the Leichenpredigt. ${ }^{267}$ Even though Flacius did not have a steady job during the latter part of his life and was constantly on the move, he still amassed a considerable

per Reverendvm Virum D. M. Matthiam Flacivm Illyricum (Mühlhausen: Georg Hantzsch, 1575; VD16 F 1337), A1r-K4v.

264 For more about Lonicer, see Karl Mägdefrau, »Lonicerus, Adam, « in NDB 15 (1987), 147-148. His younger brother, Philipp Lonicer was a rector of the Frankfurt Gymnasium until July 1576 and also a lay theologian who published together with Hartmann Beyer and Petrus Patiens, Vnterricht Vom hochwirdigen Abendmal Christi... (Frankfurt, 1575; VD16 G 677). He was later pastor in Friedberg, Hesse and superintendent in Königstein im Taunus.

265 Those present included pastors Hartmann Beyer, Matthias Ritter and Jacob Bernoulli from Antwerp. Preger II, 526.

266 The entire letter, dated in Frankfurt on April 1, 1575 is reprinted in Ritter, Eigentliche und umstaendliche, 252-253; see also 256.

267 Heldelin, Eine Christliche predigt..., Rk2v. See also, Ritter, Eigentliche und umstaendliche, 262-263. For more on his commitment to Flacius' theology, see Rudolf Ehwald, »Johannes Fraxineus, ein verschollener Freund des Flacius Illyrikus [sic!], « Mitteilungen der Vereinigung für Gothaische Geschichte und Altertumforschung (1922): 36-50. Fraxineus was Flacius' student in Jena. He matriculated at the university in the first semester of 1558 as »Joh. Eschveus, Gotan." Afterwards he was a professor in Lauingen on the Danube for about five years, where his colleaugue was Caspar Melissander. Both of them were dismissed from their posts because of Flacianism. In 1571 he received a master's degree at the University of Jena, this time as Joh. Fraxineus, Tyring. Mentz (ed.), Die Matrikel der Universität Jena, 94; 566. In 1573 he was in Magdeburg. He refused to sign the Formula of Concord and was constantly moving from city to city. Fraxineus was involved in numerous polemics, one of them being against Gotha Superintendent Johannes Wolfferam from 1588 until Wolfferam's death. Fraxineus published some of Flacius' letters and a short work by Flacius against Compendium Theologiae by Jakob Heerbrand, issued in Tübingen in 1573 (VD16 H 965), both of which he claims he found in the library of Johannes Crailsheim zu Morstein. See, Gravissima Iohannis Marbachii S. Literarum Doctoris, harumdemque in Argentinensi Academia Professoris Epistola qua Matthiae Flacio Illyrico integrates constantiae, \& quod ab haeresi Manichaeorum prorsus alienus exstiterit, praeclarum datur testimonium (Oberursel: Nikolaus Henricus d.Ä., 1601; VD17 12:108435Y); »Censvra M. Flacii Illyrici contra nouum Compendium Theologiae« in Fraxineus' In Compendivm Theologiae Iacobi Heerbrandi S. Theologiae Doctoris \& 
amount of savings. After his death his possessions included money in gold in different foreign coins: 316 French and 100 Italian crowns, 102 Portuguese cross ducats, 52 Hungarian ducats and 81 German Guilder. ${ }^{268}$

In October 1577, two and a half years after Flacius died, his wife Magdalena married Heinrich Petreus, ${ }^{269}$ the Frankfurt grammar school director and committed Flacian, ${ }^{270}$ who in 1597 sold most of Flacius' personal library to Duke Heinrich-Julius of Braunschweig-Lüneburg. ${ }^{271}$ The collection also included Flacius' correspondence, lectures, personal notes, as well as many other manuscripts. Among them were some of his unpublished works, which were ready for printing but never appeared in a book form (these included commentaries on the books of Genesis, Exodus and Leviticus), as well as unfinished handwritten material covering the Old Testament books of first and second Samuel, first and second Kings, and much more, including even the commentary on the Epistle of James and the Book of Revelation. ${ }^{272}$ All of these manuscripts deserve intensive study and publication.

Professoris quondam in Academia Tubingensi (Oberursel: Nikolaus Henricus d.Ä., 1601; VD17 12:108417A), 87-94.

268 Alexander Dietz, Frankfurter Handelsgeschichte, vol. 3 (Frankfurt: Knauer, 1921), 192.

269 Petreus was a jurist, philologist and later became a Wolfenbüttel court official. A poem for the wedding was composed by the well-known Frankfurt jurist Johann Fichard. For Petreus' biography, see Paul Zimmermann, »Petreus, Heinrich, « in ADB 25 (1887), 519-520; Reinhard Frost, »Petreus, Heinrich, « in Wolfgang Klötzer (ed.), Frankfurter Biographie 2: M-Z. Personengeschichliches Lexikon [Veröffentlichungen der Frankfurter Historischen Kommission 19/1] (Frankfurt am Main: Waldemar Kramer, 1996), 131.

270 See Petreus' personal statement consisting of seventeen points concerning original sin, »Bekandtnu(e) $\beta$ des Articulus von der Erbsu(e)nde. Henrici Petrei, Hardesiani, Scholae Francoford. Rector,« in Johann Balthasar Ritter, M. Matthiae Flacii, Illyrici, Ehemahls beru(e)hmt und gela(e)hrten Theologi in Teutschland. Leben und End: Aus theils bekannt, theils unbekannten Uhrkunden, Schrifften und Brieffen, anderer und seiner selbst/Zur Erkla(e)uterung der Kirchen-Historie/Des XVI. Seculi, Mit sonderbarem Fleiß beschrieben Von Johann Balthasar Ritter, Evangelischen Predigern in Franckfurth am Mayn. Zweyte vermehrt und verbesserte Aufflage (Frankfurt and Leipzig: Johann Conrad, Maximilian Ziegler, 1725), 386-398.

271 See the contract of sale dated on April 20, 1597 in Otto von Heinemann, »Kaufkontrakt über die flacianische Bibliothek, « in Die herzogliche Bibliothek zu Wolfenbüttel, 1550-1893: Ein Beitrag zur Geschichte deutchser Büchersammlungen mit einem Anhang von Dokumenten und Archivstücken. Zweite, völlig neugearbeitete Auflage (Wolfenbüttel, 1894; reprint Amsterdam: Gérard Th. Van Heusden, 1969), 285-286. For a discussion of both printed and hand-written books (»incunabulas«) in Flacius' library (907 at the time of the acquisition), see Wolfgang Milde, »The Library at Wolfenbüttel, from 1550 to 1618, "The Modern Language Review 61/1 (1971): 101-112 and particularly section II entitled »The Acquisition of the Library of Matthias Flacius Illyricus, « on pages 104-110. For a reconstruction of the actual contents of the library, see Martina Hartmann, Humanismus und Kirchenkritik, 80-115; 221-258.

272 Flacius, Commentarius in Epistolam Jacobi et in Apocalypsam, HAB, Helmst. 741,2. This manuscript contains 198 pages on 99 folios. See Mirković, Matija Vlačić Ilirik, 410-411. For a catalogue of manuscripts at HAB, see Otto von Heinemann and others, Die Handschriften der Herzoglichen Bibliothek zu Wolfenbüttel [Kataloge der Herzog-August-Bibliothek], 9 vols. (Wolfenbüttel: 1884-1903). 


\section{Concluding Remarks on Flacius' Final Phase of Radicalization}

The lack of willingness to compromise that came to characterize Flacius ever stronger from his Magdeburg years onward meant that he irreversibly damaged his reputation and as a result partially destroyed the very network he had been building up so carefully over his life. Consequently, the circle of those who still tolerated or supported him shrank rapidly. Flacius' obsession with original sin overshadowed everything in this final phase, although he still produced academic work and published three significant tomes while in Strasbourg. In spite of the downward spiral, his brief stay and involvement in the Lutheran congregation in Antwerp was a partly positive experience, even though he managed to stir up antagonism in the city. However, the controversies were taking too much of his time and attention and were increasingly consuming his life.

The last phase of radicalization was characterized by two parallel but equally strong developments. Flacius was facing the inevitable outcomes of his radical theology and desperately grasped at every attempt to clear his name. At the same time, he wanted to accomplish getting rehabilitated by sharpening his theological statements even further. This paradoxical approach, which once again underlined the fact that he had no interest in reaching a consensus or accepting theological formulations he did not agree with to their full extent, drove him to isolation, poverty, exile and eventually to physical exhaustion, which all ultimately contributed to his illness and death. 


\section{Conclusion}

The detailed study of the life and theology of Matthias Flacius Illyricus in this monograph has focused on his progressive theological radicalization as the central theme of investigation. In addition to charting the major turning points in Flacius' theological biography, various factors that ultimately contributed to the growing radicalization of his theology, as he began taking increasingly more radical stances on certain issues, have also been examined. Among the important reinforcing elements were the religious and confessional politics of the Holy Roman Empire, their impact on Flacius and his involvement in them, along with the growing persecution of Protestants south of the Alps, including in his homeland.

One of the central research questions asked which specific events in Flacius' personal life, together with the way in which he interpreted them, impacted and shaped his theology. On the basis of the findings, the process of Flacius' theological radicalization has been mapped out, taking into account both his theological ouvre and his experiences. The progression has been divided into a pre-radicalization phase and three clearly identifiable phases of radicalization, each of which corresponds to various stages of his career, marked by significant life-changing events.

The first chapter explored the pre-radicalization phase. The time period between 1536 and 1548 began with the event of young Flacius leaving Labin, the town of his birth and childhood, and setting out on a journey that would last a lifetime. The formal education Flacius received in Venice, together with other formative influences stemming from his experiences there, played an important role in preparing him for his further studies. Particularly Venetian humanism left a mark on him. Flacius then used the time he spent in Basel and Tübingen for further learning, and together with his brief stay in Augsburg, for meeting key people and beginning to build up a personal network that he maintained. Flacius spent the final portion of his pre-radicalization phase as a student and budding lecturer in Wittenberg. Living at the center of the Lutheran Reformation, being taught by Luther and Melanchthon, and experiencing first a spiritual crisis, then a breakthrough, altered young Flacius forever. His encounter with the saving grace of God in the moment when he felt assaulted by doubts about his new faith and struggled with loneliness, depression and even thoughts of suicide made God's grace central for him. The theological and personal bonds that he established with Luther and Melanchthon during his stay in Wittenberg developed in vastly differing directions but both followed him throughout his career. 
The first phase of Flacius' radicalization took place between 1548 and 1557. It was ushered in by Flacius taking certain theological positions in reaction to a series of political and military developments in the Holy Roman Empire of the German Nation, which in turn had been prompted by the spread of the evangelical faith in many territories and more importantly, among territorial rulers. In the aftermath of the Smalcaldic War, in which the evangelical princes suffered defeat, Flacius rejected the Augsburg Imperial Interim that followed it because it reintroduced some Roman Catholic practices. Positioning himself in opposition to this document and to the authorities involved in its negotiation, he moved to the city of Magdeburg in 1549, where through a large number of anti-Interim publications he established himself as a wellknown polemicist.

During this time period Flacius began to formulate his own theological positions out of a perspective of resistance - a method that remained characteristic of him for the rest of his life. He continued to be intensely involved in disputations concerning a wide range of issues, often being critical of those exercising power, either in church or state. Flacius' first phase of radicalization was marked by his participation in the adiaphoristic controversy, arguing that certain things in the theology and practice of the church are non-negotiable and should remain so especially in times of extreme trial and persecution. He also got involved in the Majoristic debate, which focused on the necessity of good works for salvation - something that Flacius vehemently opposed because it undermined the significance of the grace of God. For Flacius, such teaching came too close to Roman Catholic interpretation and also echoed Schwenckfeld and a number of Anabaptists who denied that faith without works could possibly be a saving faith. In contrast, Flacius claimed that he remained true to Luther's teaching of sola fide on this subject and that he interpreted him correctly. The Osiandrian controversy, also concerning the topic of salvation, provided yet another opportunity for Flacius to express his views in writing. Further written polemics, for example with Schwenckfeld, or Flacius' involvement in the second Eucharistic controversy, marked his time in Magdeburg.

It was also during these same years that Flacius launched some of his most ambitious projects. Both resulting works reflected a Protestant (re-) interpretation of the history of the church. Catalogus testium veritatis provided biographical sketches of a long list of »witnesses to the truth, « who since the beginnings of Christianity stood up against corruption within the church and tyranny, while representing pure, Biblical faith. Historia Ecclesiastica, commonly known as The Magdeburg Centuries, intended to present all of ecclesiastical history from the birth of the church up to the sixteenth century. Flacius gathered a team around himself; he divided up the tasks, which involved working with primary sources, and employed new methods 
in approaching his subject matter. Both of these enterprises aimed to provide legitimation for resistance to the Roman Catholic Church and for establishing Protestantism as the true faith in accordance with the apostolic tradition. At the same time, they were also meant to comfort those who were being persecuted for the »true " Gospel. These themes resonated with readers as they held relevance in light of contemporaneous developments.

In addition to what was taking place in the German-speaking territories, two further occurrences were of particular importance for Flacius. On the one hand, Venetian persecution of those following the new teachings of the Protestant Reformation intensified. This impacted many people in Flacius' homeland. Even his own relative, for whom Flacius tried to garner the support of prominent political and ecclesiastical leaders to appeal for clemency to the Senate of Venice, fell victim to the Inquisition in 1556. Among other bad news coming from the southern and eastern parts of the continent was the ongoing military expansion and rule of the Ottoman Turkish Empire under Suleiman I, known as »the Magnificent « - of which Flacius was kept abreast also through personal correspondence. Such developments naturally heightened Flacius' already existent apocalyptic frame of reference, which also impacted his interpretation of contemporary events. This in turn contributed to the urgency that characterized his polemical writings, which could already be observed during this first phase of radicalization.

Flacius' growing conviction that only his own theological positions were correct and his increasingly visible unwillingness for any kind of compromise did not resonate well with a number of theologians and church leaders who held more accommodating and conciliatory positions. At times lacking fine diplomatic skills, Flacius was quickly alienating a growing circle of political decision makers as well, who were keen on reaching compromise concerning theological differences and therefore maintaining peace in their territories. On the other hand, Flacius was able to build an extensive network of supporters, raise considerable amounts of money for his church history projects, and gather a research team that cooperated with him. All of this proves that he possessed outstanding organizational abilities and was able to convince others to follow his lead. The fact that Flacius made a name for himself as an emerging oppositional figure in Magdeburg had its bright side, too. $\mathrm{He}$ received some recognition and a few specific job offers from territorial rulers and ended up accepting a professorial and ecclesiastical appointment in Jena.

With Flacius' move to Jena in 1557 began the brief but crucial second phase of his theological radicalization. The move signified a great shift for him, as he transitioned from opposition to recognition. He was given a position by Johann Friedrich II of Ernestine Saxony to lecture at the faculty of theology at the Collegium Jenense, which soon after Flacius' arrival was elevated to the level of university. In addition to having to overcome challenges 
as a newcomer, Flacius made things more difficult as he immediately began getting involved in the confessional politics of Ernestine Saxony at the time. Owing in part to the fact that he was not yet fully established in the city and as a result also not very influential, at the beginning he had very little success in trying to sway ecclesio-political decisions in the direction he preferred. As time passed, his ability to persuade the Duke and his courtiers seems to have strengthened and he used his position of influence to shape a Book of Confutation, which was supposed to lay out correct doctrine that should be followed by all Christians in the Ernestinian territories. Belligerent in tone and content and accepting no compromise, the Konfutationsbuch ended up making more foes and creating greater problems for Flacius than producing his desired outcome, namely to unify the territory theologically and at the same time denounce a number of heresies - as defined by Flacius. Instead, in the end Flacius had to stand trial together with Johannes Wigand and was banned from teaching and publishing in the Ducal Saxon territories. The Jena years, although outwardly successful at the beginning with Flacius' rise through the ranks of the church and academia, ended with his fall from grace.

Leaving Jena ushered in the third and final phase of Flacius' radicalization, which lasted from 1562 until his death in 1575. Flacius first found refuge in Regensburg, where he remained until 1566 . He had been thrust into a position of having to defend himself and was now trying to clear his name from the accusation of causing discord. In addition, Flacius' doctrine of original sin was seen by many as heretical, so that he was also trying to vindicate himself theologically. The difficulties he was experiencing, however, did not dampen his zeal for making missionary plans of reaching out to his fellow South Slavs through wanting to establish theological training schools in Regensburg and in Klagenfurt and getting marginally involved in the publication of Protestant materials translated into Croatian and Slovenian.

Being uprooted from Jena impacted not only Flacius but also his growing family. After all, he had experienced the highest level of stability there that he had known, and from this point onward he never held a steady job, nor did he ever stay in one place longer than a few years. While in Regensburg, Flacius' first wife died giving birth to their twelfth child. Flacius later remarried and had six more children, which meant that he was always under pressure to provide for a large family. His argumentative nature often took the best of him, and he further got embroiled in a number of polemics. He also used his personal network and connections to try to have an effect on the confessional politics in the free imperial cities of Nuremberg and Danzig. The favor he received from the city council in Regensburg was revoked by an order of Emperor Maximilian II, and Flacius was forced once again to look for a new home for himself, while his family stayed behind. Among his 
most significant publications written in this period was Clavis Scripturae Sacrae, his hermeneutical magnum opus. He also used this work for clarifying and explaining in detail his doctrine of original sin and thereby providing a response to his critics.

In late 1566 Flacius moved to Antwerp, where he was asked to advise the evangelical church on ecclesiastical matters. Welcomed by the city senate, he did receive recognition and contributed to shaping the Antwerp Confession, which in turn impacted other evangelical churches from Aachen to Amsterdam. The upturn in Flacius' fortunes ended abruptly after only a few months, when the city was overrun by Spanish troops in the spring of 1567. Flacius found himself on the move again and ended up in Strasbourg, where his family joined him in 1568. Experiencing antagonism from the political leadership of the city from almost the beginning, Flacius felt compelled to write his doctrinal defense. The resulting work reflected the crystallization of his doctrine on original sin. Just as in his previous treatise on the subject, Flacius was far from trying to soothe his opponents' criticism. Instead, he held on rigidly to the same ideas and formulations that had already received wide disapproval. This was typical of this advanced stage of radicalization: even with everything to lose and in a very precarious situation, Flacius did not think about how to redeem himself but held on firmer than ever to his convictions, unwilling to reconsider, or even just rephrase, any of them. Remarkably, even in this situation and after years of having produced a long line of theological opponents through his sharp-tongued polemics, he still had some supporters and sympathizers left. In Strasbourg Flacius brought to completion his last major work, Gloss on the New Testament, but in 1573 he was expelled from the city as a result of the theological controversies that surrounded him. The only place that offered him asylum was a convent in Frankfurt am Main, even though the city council did not welcome him and he had to leave again the next year. Even when he reached this level of having alienated almost everyone around him and becoming completely dependent on mercy shown by others, Flacius remained resolute in believing that he held the right and only correct (that is, truly Biblical and truly Lutheran) theological stances. Soon after returning from almost an entire year of travels he died in early 1575 . The city denied him an evangelical funeral.

Until now, the development of Flacius' theological radicalization has not been reconstructed by employing a chronological approach. The present work therefore represents a contribution by examining his life and charting his theological course as two realms closely intertwined with each other and mutually influencing one another. In contrast to the works of previous Flacius biographers, a greater emphasis was placed on exploring Flacius' early years, his renaissance humanist education in Venice and the studies he conducted in Basel and Tübingen. Among the significant outcomes emerging 
from this study is the demonstration of the important role these influences played not only prior to his arrival in Wittenberg but also throughout his life. Furthermore, it has been revealed that beginnings of Flacius' rigidity in doctrinal matters were already observable at the end of his time in Wittenberg, thereby preparing him for the first phase of radicalization taking place in Magdeburg. Concerning the importance of Flacius' Wittenberg experiences, this book strives to achieve a more balanced and nuanced representation of the relationships he developed with Luther and Melanchthon, while discussing the specific ways in which Flacius was appropriating their theology.

As the title of the monograph - »Theologian of Sin and Grace « - already suggests, the doctrine of sin, and particularly that of original sin, eventually emerged as the linchpin for much of Flacius' theological work. In his later years and with the advancement of the radicalization of his theology, sin occupied the center of his arguments and became the primary lens through which he viewed and evaluated the theological claims presented by others. This is clearly visible from his disputations and other writings. At the same time, his extreme emphasis on sin was based on an equally heightened awareness of God's grace. Only this grace, which Flacius understood to be unlimited, could provide within his theological system a counterpoint to the complete corruptness of human beings: through God's boundless grace can people gain salvation and receive a new life that replaces their corrupted nature. As became clear particularly in his argumentation against the adiaphorists and Osiander, Flacius was also a theologian for whom grace was of fundamental importance. For his theological positioning of original sin Flacius was constantly returning to Luther's De servo arbitrio and to his lectures on Genesis, which young Flacius witnessed as a student in Wittenberg. This radical view of sin should therefore be approached in light of his understanding of grace.

The study of a large number of primary sources, many of which were authored by Flacius, has resulted in delivering new findings of various aspects of Flacius' life. The present research has thereby uncovered and reconstructed the wide-reaching personal and professional networks built up by Flacius. It has been able demonstrate some of the ways in which he utilized his connections for diverse purposes. Furthermore, this work has resulted in uncovering more about Flacius' role and his behind-the-scenes engagement in the confessional politics and the ensuing territorial confessionalization, in addition to his impact on the Lutheran identity formation through the Gnesio-Lutheran and Flacian (Flacianer) groups. Flacius' tireless pursuit of authority in this realm became more evident through the reconstruction of some of his important relationships. Therefore, in addition to the impact that ecclesio-political decisions had directly on Flacius, his contributions to and involvement in such matters are also emphasized. For example, research for this monograph has uncovered new information about Flacius' vast networks 
in the free imperial cities of Antwerp, Augsburg, Danzig, Frankfurt, Nuremberg, Regensburg, and Strasbourg. The information gleaned also illustrates the breadth of Flacius' academic interests, as he built relationships with people from diverse disciplines, as well as his strategy for creating a base of support - be it theological, ideological or financial.

The underscoring of Flacius' multifaceted competences in a number of different academic fields is yet another dominant observation emerging from the present research. His prolific writings and the breadth of the issues over which he got involved in controversies suggest that he was far from being reduced to a single-issue theologian. Flacius' writings reveal not only the depth of his theological reflection but also a remarkable familiarity with philosophy and classical literature, in addition to his knowledge of a number of languages.

It is also important to consider that in the background of Flacius' growing theological radicalization stood the situation of the Protestants in his homeland, where they were being fiercely persecuted. Flacius' works were placed on the Index librorum prohibitorum, ${ }^{1}$ which made it impossible for him to return to live and work there. Conceivably he interpreted this as the price he had to pay in order to practice and defend the new faith he had found.

Overall, the findings show that Flacius was a complex figure, a person with diverse interests and abilities, and a wide-ranging network of contacts. Accordingly, aspects of the process of Flacius' theological radicalization have been examined through taking into account the intricate interplay of outward influences, which often resulted in getting him exiled. Ultimately, Flacius' radical theology contributed to a public downfall but he did have some measure of success at times and even attracted a considerable number of followers for shorter periods of time. In the posthumously published funeral sermon the uncompromising character of Flacius' theology was perceived by his adherents in a positive sense: they had referred to him as a new prophet Jonah, sent to Germany. According to them, within the context of the First Book of Kings 18:21, »How long will you waver between two opinions? If the LORD is God, follow him, but if Baal is God, follow him, « Flacius had made the right decision in his life and theology. To establish whether this claim was true did not fall into the scope of the present research. Instead, this monograph has striven to present a more detailed and more compre-

1 Flacius' writings were banned by the first Roman Index of January 1559 and in the subsequent editions of the Index from 1564 and 1582. Index avctorvm, et Librorum, qui ab Officio Sanctae Rom. et Vniuersalis Inquisitionis caueri ab omnibus et singulis in uniuersa Christiana Republica mandantur, sub censuris contra legentes, uel tenentes libros prohibitos in Bulla, quae lecta est in Coena Domini expressis, et sub alijs poenis in Decreto eiusdem Sacri officy contentis (Rome: Antonio Blado, 1559), F4r. 
hensive view at Flacius' life that can contribute to enriching the existing research landscape with new information on this contentious figure and his role in the process of confessionalization in the latter half of the sixteenth century. 


\section{Bibliography}

\section{Manuscripts $^{1}$}

Aurifaber, Johannes, Matthias Flacius Illyricus et al. Ein ander Bedencken der Theologen auff den Franckfurdischen abschiedt. 1558. Heidelberg, Universitätsbibliothek. Cod. Palatinus Germanicus $155,52 \mathrm{r}-53 \mathrm{v} ; 83 \mathrm{r}-90 \mathrm{v}$.

Flacius, Matthias Illyricus. Ankündigung seiner Vorlesung über den Römerbrief. April 28, 1557. FBG, Chart. B 213, 331r-332r.

-. Refutatio Samaritani Interim, in quo vera Religio cum Sectis \& corruptelis scelerate et perniciose confunditur. 1558. HAB, Cod. Guelf. Helmst. 81, 139r-144v.

- . Grund und Ursach warumb das Frankfurdische Interim in keinem Wege anzunemen sey. 1558. HAB, Cod. Guelf. 79. Helmst., 384v-391r.

Heller, Joachim. Relation vnd bericht M. Joachim Hellers in Causa Sacramenti. 1562. Nuremberg, Staatsarchiv. Reichsstadt Nürnberg. Repertorium 15a, Ratskanzlei A-Laden, 182, Nr. 2.

Johann Friedrich II, Herzog von Sachsen. Ad lectionem publicam \& Superintendentiam universalem. 1556. HAB, Cod. Guelf. 79 Helmst., 117r-v.

-. Der Fvrsten zv Sachsen Recvsation schriefft widder den Franckfordisschen Abschiedt. Anno 1558. Heidelberg, Universitätsbibliothek. Cod. Palatinus Germanicus 155, 56r-60v.

Otto Heinrich von Pfalz. Othonis epistola vocatoria ad D. Illyricum. Sept. 19, 1556. StAR, Eccl. I, 15, nr. 121, 8726-8727.

Regensburg City Council. Ratsprotokoll über die Verhandlung mit Fl. Illyrikus, welcher ein »Trostbüchlein für die verfolgten und geplagten Christen « hier drucken lassen wollte. March 6, 1562. StAR, Eccl. I, 17, 21, 10508-10515.

\section{Primary Sources}

Andreas Gerhard Hyperius Briefe 1530-1563. Gerhard Krause, ed. [Beiträge zur historischen Theologie 64]. Tübingen: J.C.B. Mohr (Paul Siebeck), 1981.

Bekendtnus Derer Kirchen binnen Antorff / so der waren Augspurgischen Confession zugethan. Aus dem Lateinischen ins hoch Deutsch gebracht. Sampt einer Vorrhede M. Cyria: Spangenberg. Schmalkalden: Michael Schmuck, 1567.

1 The bibliographical information relating to the letters by Flacius and others as well as particular library signatures of certain primary sources referred to in the book are mentioned in the corresponding footnotes and are not included in this bibliography. 
Bericht Burgermeister vnd Rhat / der Statt Lindaw. I. Von wegen ettlicher daselbsten / enturlaubten Predicanten. II. Sampt dem Gespra(e)ch / vom Artickel der Erbsu(e)nde / vber dem new arweckten Streit / in dem Monat Augusto, Anno 1575. Auff dem Rhathauß / in grosser Anzal der Personen gehalten. III. Mit angehengten / vnnd daru(e)ber ergangnen/reiner Christlichen Kirchen / Augspurgischer Confession / Vrtheiln vnnd Erkanntnussen. IIII. Auch gantzem Proceß / wie mit den jrrigen Predicanten / von anfang / bis zur irer Enturlaubung gehandelt. In wo(e)lchem die Lehre von der Erbsu(e)nde / vermo(e)g Gottes Worts /... eigentlich erkla(e)ret I vnnd die Kirch Gottes / vor den newen falschen lehrern trewlich gewarnet würde. Tübingen: Georg Gruppenbach, 1576.

The Book of Concord: The Confessions of the Evangelical Lutheran Church. Robert Kolb and Timothy J. Wengert, eds. Translated by Charles Arand et al. Minneapolis: Fortress, 2000.

Briefsammlung des hamburgischen Superintendenten Joachim Westphal aus den Jahren 1530 bis 1575. Sillem, Carl Hieronymus Wilhelm, ed. 2 vols. Hamburg: Lucas Gräfe \& Sillem, 1903.

Catechismus Oder Christlicher Vnderricht / wie der in Kirchen vnd Schulen der Churfuerstlichen Pfaltz getrieben wirdt. Heidelberg: Johann Mayer, 1563.

Confessie oft Bekentenisse der Dienaren Jesu Christi in de Kercke binnen Antwerpen die welcke der Confessie van Ausborch toeghedaen is. Beter ouersien ende gheemendeert nae de latijnsche copije. S. 1: 1567.

Confession des Ministres de Iesv Christ, en Eglise d'Anuers, qui consent à la Confession d'Ausbourg. S. 1: 1567.

The Correspondence of Erasmus: Letters 142-197 (1501-1514). R.A.B. Mynors and Douglas F.S. Thomson, eds. Vol. 2. Toronto: University of Toronto Press, 1975.

De Locorvm Theologicorvm D. Philippi Melanthonis Orthodoxa Pvritate et Vtilitate, adsertio et subscriptio praecipuorum aliquot Doctorum. Frankfurt: Paul Reffeler, 1579; Görlitz: Ambrosius Fritsch, 1580.

Die Amerbachkorrespondenz IX/2: 1. Juli 1554 - Ende 1555. Beat Rudolf Jenny, ed. Basel: Verlag der Universitätsbibliothek, 1983.

Enchiridion Geistliker Leder vnd Psalmen / vppet nye gebetert. Mart. Luther. Mit einem nyen Calender schoen thogericht. Gedrueckt tho Magdeborch / Jn der Belagerung / Jn grother vahr / Dar ys dith vulendet gar / Den XXX. May / Dat ys war. Magdeburg: Hans Walther, 1550/51.

Formula Concordiae oder Notel der Kirchen Zu Dantzigk. S. 1: 1652.

Gruendlicher Gegenbericht... Widerlegung der Formulae Concordiae oder Notel / so alle Prediger zu Dantzigk.... Danzig: Jakob Rhode, 1567.

The Heidelberg Catechism. Translated into English by the Christian Reformed Church. Grand Rapids: CRC Publications, 1988.

Index avctorvm, et Librorum, qui ab Officio Sanctae Rom. et Vniuersalis Inquisitionis caueri ab omnibus et singulis in uniuersa Christiana Republica mandantur, sub censuris contra legentes, 
uel tenentes libros prohibitos in Bulla, quae lecta est in Coena Domini expressis, et sub alijs poenis in Decreto eiusdem Sacri officy contentis. Rome: Antonio Blado, 1559.

Melanchthon deutsch III: Von Wittenberg nach Europa. Günther Frank and Martin Schneider, eds. Leipzig: Evangelische Verlagsanstalt, 2011.

Ratschlag etliche des verlognen, auffruehrischen Manns Matthaei Flacii Jlirici Caluminias wider ein Erbarn Rath vnd gemeine Statt allhie betreffendt. Nuremberg, 1564. In Beyträge zur Litteratur besonders des sechzehnten Jahrhunderts 1/20 (1785): 407-412.

Svpplicatio qvorvndam Theologorvm, qvi, post obitvm Lvtheri P[hilipp]. M[elanchthon]. corruptelis \& Sectis, voce aut scriptis contradixerunt, pro libera, Christiana, \& legitima Synodo, ad Illustrissimum Principem, D.D. Iohannem Fridericum II. Ducem Saxoniae \&c. eiusque C. Fratres, ac alios pios Principes \& Status Angustanam Confessionem amplectentes. S. 1: 1560 .

Acontius, Melchior and Matthias [Garbitius] Illyricus. Erotica / Georgii Sabini / Brandeburgensis. Dvo Epithalamaia. / Alterum Latinis versibus a Melchiore / Acontio, Alterum Graecis a Matthia Illyrico / scriptum. Wittenberg: Josef Klug, 1536.

Amsdorf, Nikolaus von. Das Doctor Pomer vnd Doctor Maior mit jren Adiaphoristen ergernis vnnd zurtrennung angericht / Vnnd den Kirchen Christi vnueberwintlichen schaden gethan haben. Derhalben sie vnd nicht wir zu Magdeburg vom Teuffel erwegt sein / wie sie vns schmehen vnd lestern. Niclas von Amsdorff Exul. Magdeburg: Michael Lotter, 1551.

- . »Sendbrieff Herrn Nicolai Ambsdorffij von der vnschuld vnd reiner ler M. Fl. Ill.« In Matthias Flacius Illyricus, ed. Erzehlung. Wie der Hochwichtig vnnd langwirige Religionstreit / Victorini in Thueringen / endlich geschlichtet worden sey / durch die Mitler beschriben / Allen liebhabern der Warheit / sehr nützlich zulesen. Jetzo vonn newem mit fleis Corrigirt / vnnd an vilen orthen gemehrt vnd gebesert. Regensburg: Heinrich Geißler, 1563.

Andreae, Jakob. Bericht von der Erbsünde. Darinn der vnderscheid zwischen der verderbten Natur deß Menschen nach dem fahl vnnd der Erbsünde bewisen vnd erklert Vnd dem einfaltigen Layen ein richtiger weg angezeigt wie er sich vermög Gottes Worts ... Durch Jacobum Andree D. Probst zu Tübingen. Tübingen: Georg Grupenbach, 1575.

- . Colloquium de Peccato originis. Inter D. Iacobvm Andreae, et M. Matthiam Flaccivm Illyricum Argentorati Anno 1571. institutum. Cvi Adivncta svnt allia quoque, Scripta, sicut sequens pagina docebit. In qvibvs Doctrina et Controversia de Peccato originis perspicuem explicata, \& compendiaria via ad piam pacem, \& litis huius expeditam compositionem monstratur. Tübingen: Georg Gruppenbach, 1574.

Aurifaber, Johannes, ed. M. Ioannis Stolsii Concionatoris Avlici Ducum Saxoniae Refutatio propositionum Pfeffingeri de Libero arbitrio, cum Praefatione M. Ioannis Aurifabri. Matth: Fla: Illyrici de eadam controuersia. Jena: Thomas Rebart, 1558.

Bembo, Pietro. History of Venice. Vol. 3, Books IX-XII. Edited and translated by Robert W. Ulery, Jr. [The I Tatti renaissance Library 37]. Cambridge, MA: Harvard University Press, 2009.

Biandrata, Giorgio. Georgii Blandratae confession Antitrinitaria. In Heinrich Philipp Conrad Henke, Opuscula academica theologici potissimum argumenti. Leipzig: Crusius, 1802, $257-263$ 
Bolziano, Urbano. Vrbani Bellvnensis, Institvtionum Linguae Graecae libri Dvo ... Basel: Hieronymus Curio and Heinrich Petri, 1548.

Brenz, Johannes, Nikolaus Gallus and Matthias Flacius Illyricus. Bekentnis Brentij vnd andern Wirtebergischen Theologen von der Rechtfertigung. Mit einer Vorreden M. Illyr. vnd Nic. Galli an die Preusische Kirchen. Magdeburg: Christian Rödinger d.Ä., 1553.

Bucer, Martin. In Sacra Qvatvor Evangelia, Enarrationes Perpetvae... Basel: Johannes Herwagen d.Ä., 1536.

Buchholzer, Georg and Matthias Flacius Illyricus. Ein Prophetische / Buspredigt für die jenigen / So / den erkanten vnd bekanten Christum mit / dem Antichrist vnd seinem hauffen verfolget haben / oder noch verfolgen. / Mit einer Vorrede Matt. Fla. Illy. / G.B. Propst zu Berlin. Magdeburg: Christian Rödinger, 1550.

Bugenhagen, Johannes. Eine Christliche Predigt / vber der Leich vnd begraebnis / des Ehrwirdigen D. Martini Luthers / durch Ern Johan Bugenhagen Pomern / Doctor / vnd Pfarrher der Kirchen zu Wittemberg / gethan. Wittenberg: Georg Rhau, 1546.

Bullinger, Heinrich, trans. Einhaelligkeit Der Dienern der Kilchen zue Zürich vnd herren Joannis Caluinj dieners der Kirchen zue Genff / deren sy sich im handel der heyligen Sacramenten gaegen andern erklaert vnd vereinbared habend. Zurich: Rudolf Wyssenbach, 1551.

-. Heinrich Bullinger Briefwechsel 13: Briefe des Jahres 1543. Rainer Henrich, Alexandra Kess and Christian Moser, eds. Zurich: Theologischer Verlag, 2008.

-. In Acta Apostolorum Heinrychi Bullingeri Commentariorum libri VI. Zurich: Christoph Froschauer d. Ä., 1540.

- . In Sacrosanctvm Iesu Christi Domini nostri Euangelium secundum Matthaeum Commentariorum libri XII. Zurich: Christoph Froschauer d.Ä., 1542.

Calvin, John. Defensio Sanae et Orthodoxae Doctrinae de Sacramentis, eorumque natura, ui, fine, usu, \& fructu: quam pastores \& ministri Tigurinae Ecclesiae \& Geneuensis antehac breui Consensionis mutuae formula complexi sunt: unà cum refutatione probrorum quibus eam indocti \& clamosi homines infamant. Iohanne Calvino authore. Zurich: Christoph Froschauer d. ̈̈., 1555.

- . Erklaerung, wie es der Religion halben im Heiligen Reich bis zu Austrag des gemeinen Concilii gehalten werden soll / Interim / Advltero/ Germanvm. / Cui adiecta est. / Vera Christianae pacificationis / \& Ecclesiae reformandae ratio. / Per Iohannem Caluinium. Magdeburg: Michael Lotter, 1549.

- . trans. L'Accord passe et conclvd Tovchant la Matiere des Sacraments, entre les Ministre de l'Eglise de Zurich, \& Maistre Iohan Caluin Ministre de l'Eglise de Geneue. Geneve: Johann Crespin, 1551.

Camerarius, Joachim. Das Leben Philipp Melanchthons. Translated by Volker Werner [Schriften der Stiftung Luthergedenkstätten in Saschen-Anhalt 12]. Leipzig: Evangelische Verlagsanstalt, 2010 .

- . De Philippi Melanchthonis ortu, totius vitae curriculo et morte de Philippi Melanchthonis ortv, Totivs Vitae Cvrricvlo et Morte, Implicata Rervm Memorabilivm Temporis Illivs Hominumque mentione atque indicio, cum expositionis serie cohaeentium: Narratio Diligens est Accvrata Ioachimi Camerarii Pabeperg. Leipzig: Ernst Vögelin, 1566.

- . Libellus nouus, Epistolas et alia qvaedam Monvmenta Doctorvm Superioris et huius Aetatis Complectens. Editus studio Joachimi Camerarij Pabeperg. Anno Christi. M. D. LXIII. Leipzig: Hans Rambau d.Ä., 1568. 
Canisius, Petrus. Beati Petri Canisii, Societatis Iesu, Epistulae et Acta, Volumen Quartum. 15631565. Braunsberger, Otto, ed. Freiburg in Breisgau: Herder, 1905.

Colerus, Jakob. Historia Dispvtationis sev potivs Colloqvii, inter Iacobvm Colervm et Mathiam Flacivm Illyricvm, de Peccato originis, habitae in arce Langenavv Silesiorum 12. Maij Anno 1574. Pavlo ante Obitvm Illyrici. Berlin: Nikolaus Voltz, 1585.

Crusius, Martin. Martin Crusii Schwaebischer Chronick. Translated by Johann Jakob Moser. Frankfurt: Metzler and Erhard, 1733.

Dávid, Ferenc and Giorgio Biandrata. Refvtatio scripti Georgii Maioris, in qvo Devm Trinvm in Personis, et Vnvm in Essentia: Vnicum deinde eius Filium in persona, \& duplicem in naturis, ex lacunis Antichristi probate conatus est. Avthoribvs. Francisco Dauidis, Superintendente, et Georgio Blandrata, Doctore. Klausenburg (Kolozsvár): Kaspar Heltus, 1569.

Die Confessie oft Belydinghe des Gheloofs / die den onuerwinlycken Keyser Carolus de. V. inden Rijcxdach van Ausborch ouerghegheuen is / Int Jaer M.D.XXX. Nu eerst wten latine int nederduytsch op daldernerstichste ende ghetrouwelycste ouerghesedt. Psal. CXIX. Ick sprack van uwe ghetuygenissen voor die Coningen / ende ick en werde niet bechaemt. 1566. Antwerp: Hans de Laet and Gillis Coppens 1566.

Eber, Paul. Calendarium historicum. Wittenberg: Johannes Kraft d.Ä., 1571.

Erasmus, Desiderius. Des Erasmi Rot. Opervm Sextus Tomvs Novvm Testamentvm Complactens ... Basel: Hieronymus Froben and Nicolaus Episcopius, 1542.

- . ed. Diui Ambrosii episcopi Mediolanensis, Comentarii in omnes Diui Pauli epistolas, ex restitution Desiderii Erasmi Roterodami diligenter recogniti. Adiecta Est Avtem Noviter inuenta ad Hebraeos epistola, eisduem Autoris comentariis illustrate. Antwerp: Johannes Steelsius and Johannes Grapheus, 1540.

- . NEA $\triangle \mathrm{I} \Theta H K H$. Novvm Testanementvm. Basel: Hieronymus Froben, 1545.

Erastus, Thomas. Bestendige Ableinung der Vngegruendten beschuldigung / damit D. Johann Marbach / das buechlein Thomae Erasti Medici, vom verstand der wort Christi / Das ist mein Leib letc. vnterstehet verdechtig zu machen. Heidelberg: Johann Mayer, 1565.

- . Erzelung Etlicher vrsachen / warumb das hochwirdig Sacrament des Nachtmals vnsers Herrn und Heylandts Jesu Christi, nicht solle ohne das Brotbrechen gehalten werden. Heidelberg: Johannes Mayer, 1563.

Fabri, Johannes. Antwort / Auff das vnnu(e)tz / vnrain / jrrig geschwetz Mathie Flaccij Jllyrici / so er geschriben wider das bu(e)chlein / genant Rechter weg. Vnd auff seine dreyvndzwaintzig sectische Argument / so er geschriben an Osterreich vnnd Bayern / wider die Euangelische Meß. Mit einer vorgehenden Epistel / ... Durch D. Johannem Fabri von Hailbrunn / Thumprediger zu Augspurg / mit bestendigem grund / allen Christglaubigen zu trost / ganz trewlich beschrieben. Dillingen: Sebald Mayer, 1558.

-. Was die Euangelisch Mesz sey / Grundtliche vnnd Christenliche anzaigung / auß der hailigen geschrifft / vnnd auß den alten hayligen Kirchen lerern / zue trost vnd sterckung der Glaubigen. Durch D. Johannem Fabri von Hailbrun / Thumbprediger zue Augspurg. Dillingen: Sebald Mayer, 1555.

Flacius, Matthias Illyricus. Angelvs tenebrarum detectus. Qvod Accidentarii, Scholasticorvm pelagianismum, a Luthero P. M. destructum, reaedificent instaurentque. Qvod Scholastici Ivsticiam illam essentialem, homini in creatione inditam, eiusque contrariam iniustitiam animaduerterint: sed per suas ratiocinationes euanescentes, temere ad comminiscendam 
accidentariam iustitiam aberrauerint. Matth.. Fl.: Illyricus. Oberursel: Nikolaus Henricus d.Ä., 1572.

- . Antwort Matth. Fl. Jllyr. auff etliche Beschueldigung D. Gei. Maiors / vnd D. Pomers. Magdeburg: Christian Rödinger d.Ä., 1551.

- . Apologia Matthiae Flacij Illyrici ad Scholam Vitebergensem in Adiaphororum causa. Eiusdem Epistola de eadem materia ad Philip. Melantho. Item quaedam alia eiusdem / generi .... Magdeburg: Michael Lotter, 1549.

-. Apologia M. Fl. Jllyrici / auff zwo vnchristliche Schrifften Justi Menij / Darinnen von den grewlichen Verfelschungen der Adiaphoristerey vnd Maioristerey allerley nuetzlichs angezeigt wird. Gebessert. Erfurt: Merten von Dolgen, 1558.

- . Bericht M. Fla. Jllyrici / Von etlichen Artikeln der Christlichen Lehr / vnd von seinem Leben / vnd endlich auch von den Adiaphorischen Handlungen / wider die falschen Geticht der Adiaphoristen. Lutherus spricht.... Jena: Thomas Rebart, 1559.

- . Beweisung das nicht die vnsere Christi / Sonder die Papistische Religion / new vnd auffruerisch / vnd ein vrsach alles vngluecks sey. Wider das Gotteslesterisch buch Marani, oder des schwartzen Munchs zu Augspurg, von dem itzigen krieg geschrieben. Durch Matth.Flacium Jllyricum. Magdeburg: Christian Rödinger d.Ä., 1553.

-. Bvlla Antichristi de Retrahendo populo Dei in ferream Aegiptiacae seruitutis fornacem, Maguntini Rabsaces blasphemis literis consona, Ex qua facile animaduerti potest, quid Satan per utranque suam uirtutem, scilicet, per parricidiale bellum contra Ecclesiam Dei suscep tum, \& per mendacia Concilium, Interim, Adiaphora \& Chorrook efficere conetur. Magdeburg: Michael Lotter, 1549.

-. Catalogvs Testium ueritatis, qui ante nostram aetatem Pontifici Romano, eiusque erroribus reclamarunt: iam denuo longe quam antea, \& emendatior \& auctior editus. Opus varia rerum ... Cum Praefatione Matthiae Flacii Illyrici, qua Operis huius \& ratio \& usus exponitur. Strasbourg [Basel]: Paul Messerschmidt and Johannes Oporinus, 1562.

- . Catalogus testivm veritatis, qvi ante nostram aetatem reclamarunt Papae. Opus uaria rerum, hoc praesertim tempore scitu dignissimarum, cognitione refertum, ac lectucum primis utile atque necessarium. Cum Praefatione Mathiae Flacii Illyrici, qua operis huius \& ratio \& usus exponitur. Basel: Johannes Oporinus and Michael Martin Stella, 1556.

- . Catalogvs Testivm Veritatis: Historia der zeugen/Bekenner vnd Maerterer/so Christum vnd die Euangelischewarheitbiss hieher/auch etwa mitten im Reich derfinsternus/warhafftigerkennet/ Christlich vnd auffrichtig bekennet / vnd dem Baepstlichen vermeinten Primat/jrrthumen / ergerlichem leben vnd lastern / erstlich widersprochen / Auch mehrertheils uber solchem Christlichen kampff / unbillichem Hasz / grewliche verfolgung / harte gefencknus / vnd den todt selber / ritterlich außgestanden vnd erlidten haben. Jetzt neulich dem teutschen Leser zu gutem /... auß dem Latein in vnsere gemeine Teutsche sprach gebracht vnd verfertigt / Durch Conradum Lautenbach von Mutißlar / Pfarherrn zu Hunaweiler. Frankfurt: Johann Schmidt, 1573.

- . Christlicher vnd bestendiger Grundt / Von der Waren/Wesentlichen / Eusserlichen gegenwart vnd muendlicher niessung deß Leibs vnd Bluts Christi / im H. Abendmal / sampt warhafftiger widerlegung der fuernemsten Argument der Sacramentirer / Durch M. Matthiam Flacium Illyricum. Zuuor in Lateinischer Sprach gestelt / vnd nun allen frommen Christen zu gut auch ins Teutsche gebracht. S. 1: 1575.

- . Clavis Scriptvrae S., seu de Sermone Sacrarum literarum, Authore Matthia Flacio Illyrico. Pars Prima: in qva singvlarvm vocvm atqve locotionum S. Scripturae usus ac ratio Alphabetico ordine explicatur. Basel: Eusebius Episcopius, 1580.

- . Clavis Scriptvrae, seu de Sermone Sacrarum literarum, plurimas generales Regulas continens, Altera Pars. Avthore Matthia Flacio Illyrico Albonense. Basel: Eusebius Episcopius, 1581. 
-. Confessio VValdensium de plerisqve nvnc controversis dogmatibus ante 134. annos contra claudicantes Hussitas scripta.... Basel: Johannes Oporinus, 1568.

- . Confvtatio Catechismi laruati Sydonis Episcopi, Autore Matthia Flacio Illyrico. Magdeburg: Michael Lotter, 1549.

- . [Johannes Hermanus]. Das man in diesen geschwinden laufften / dem Teuffel vnd Antichrist zugefallen / nichts in den Kirchen Gottes vorendern soll. Durch Johannem Hermannum. Magdeburg: Michael Lotter, 1548.

-. De mystica sacramentalique seu externa praesentia et manducatione corporis et sanguinis Christi in sacra coena. Avtore Matthia Flacio Illyrico. Oberursel: Nikolaus Henricus d.Ä., 1574 .

-. De occasionibvs vitandi errorem in essentia iniustitiae originalis. Item, de eximia vtilitate summaque necessitate doctrinae de essentia imaginis Dei ac diaboli, iustitiaeque ac iniustitiae originalis. Per Matth. Flaccium Illyricum. Nunc primùm in lucem edita. Basel: Pietro Perna, 1569 .

- . De Translatione Imperii Romani ad Germanos. Item de Electione Episcoporum, quod aequem ad plebem pertineat. Matthia Flaccio Illyrico Avtore. Basel: Pietro Perna, 1566.

- . De Vocabvlo Fidei / Et Aliis Quibvsdam / Vocabvlis, Explicatio uera \& utilis, sum[p]ta ex / fontibus Ebraicis. Scripta a Matthia Flacio Illyrico. Cum praefatione Phil Mel. Abacuc 2. Anno M.D. XLIX. Wittenberg: Veit Kreutzer, 1549.

- . De Voce et Re Fidei, contra Pharisaicvm Hypocritarum fermentum. Autore Matthia Flacio Illyrico. Cum praefatione Philippi Melanchthonis. Abacuc 2. Anno M.D. LV. Mense Martio. Basel: Johannes Oporinus, 1555.

-. Defensio sanae doctrinae de originali iustitia ac iniustitia, aut peccato, Matth. Flac. Illyri. Basel: Pietro Perna, 1570.

-. Des h. Hulrichs etwa vor sechshundert jaren Bischoffs zu Augspurg Schrifft. Magdeburg: Michael Lotter, 1553.

- . Ein buch / von waren vnd falschen Mitteldingen / Darin fast der gantze handel von Mitteldingen erkleret wird / widder die schedliche Rotte der Adiaphoristen. Durch Matth.Flacium Jllyr. Magdeburg: Christian Rödinger d.Ä., 1550.

-. [Johannes Waremundus]. Ein gemine protestation vnd Klagschrifft aller frommen Christen wieder das Jnterim vnnd andere geschwinde anschlege vnd grausame verfolgung der wiedersacher des Euangelij / allen Gotfuerchtigen gewissen / zu dieser betruebten zeit / vberaus sehr nuetzlich vnnd troestlich zu lesen. Durch Joannem waremundum. Magdeburg: Michael Lotter, 1548 .

-. [Theodorus Henetus]. Ein kurtzer bericht von Jnterim / darauss man leitlich kan die leer vnd Geist desselbigen Buchs erkennen / Durch Theodorum Henetum allen fromen Christen zu dieser zeit nützlich vnnd tröstlich. Magdeburg: Michael Lotter, 1548.

-. Ein rechter lesteriger Rabsakes brieff / geschrieben von einem Bischoff an einen Christlichen Fuersten / in welchem er ihn vermanet das er sol von der erkanten warheit Christi zu dem Antichrist abfallen / Daraus man sehr woll kan mercken wie gut es die Antichristische Wolffe mit den armen Schefflein Christi meinen. Magdeburg: Christian Rödinger d.Ä., 1549.

- . Ein register der hundert beschwerungen / damit Deudschland von dem Bapst vnd den seinen jemmerlich beschwert / vnd vberladen / ja gentzlich verterbt wird / auffm Reichstage zu Nu(e) rnberg Anno 1523. von dem Reich dem Bapst vbersendet. Mit einer kurtzen Vorrede Matth: Fla. Illyr: Magdeburg: Christian Rödinger d.̈̈., 1551. 
- . [Publius Aesquillius]. Ein Sendbrieff, / P.Aesquillij von dem tode Pauli / des dritten Babsts dieses namens, Jtem / Was jhm nach seinem tode / begegnet ist. Mit zweien Vorreden. Magdeburg: Christian Rödinger d. Ä., 1550.

-. Ein vermanung zur bestendigkeit / in bekentnis der warheit / Creutz / vnd Gebett / in dieser betruebten zeit sehr nuetzlich vnd troestlich / durch M. Matthiam Flacium Jllyricum / Hebreischen leser zu Wittenberg. Magdeburg: Michael Lotter, 1550.

- . Eine vberaus nützliche Historien / wie zur zeit des H. Augustini / die Bepste mit dem VI. Carthaginensischen Concilio / von jrem Primat oder Gewalt haben gestritten / vnd vberwunden sind worden / aus warhafftigen alten schrifften zusamen gelesen / Durch Matth. Flac. Jllyr. Magdeburg: Michael Lotter, 1555; 2nd edition, Oberursel: Nikolaus Henricus d.Ä., 1562.

- . Eine entschueldigung Mathiae Flacij Jllirici / an einen Pfarher. Jtem desselben / was da sey die Kirchen verlassen / odder nicht verlassen. Durch M. Fla. Illy. Jtem zween Trewme Philippi. Magdeburg: Christian Rödinger d.Ä., 1549.

- . ed. Eine Erschreckliche Historia von einem / [Franz Spira] den die feinde des Evangelij inn welsch Land gezwungen haben / den erkanten Chrjstum zuvorleugnen. Magdeburg: Michael Lotter, 1549.

- . Eine prophetische abkonterfeiung des Tridentischen Conciliabuli. Durch D. Martinum Lutherum. Mit einer erklerung M. Fl. Jllyr. Magdeburg: Christian Rödinger d.Ä., 1551.

- . Einfeltige Christliche Vnterweisunge der gewachssenen Jugend in den noetigsten Stuecken des Christichen Glaubens / so auff den kleinen Catechismum folgen solt / Sampt Anzeigung der jetzigen widerwertigen Jrthumen / auff das sie erkenne beide das Gute / zur erwehlung / vnd auch das Boese / zur vermeidung. M. Matthias Flacius Jllyricus. Oberursel: Nikolaus Henricus d.Ä., 1577.

- . Entschueldigung Matthiae Flacij JIlyrici / geschrieben an die Vniuersitet zu Wittemberg / der Mittelding halben. Item sein brieff an Philip. Melanthonem / sampt etlichen andern schrifften dieselbige sach belangend. Verdeudscht. Magdeburg: Christian Rödinger d.Ä., 1549.

- . Erklerung der schendlichen Suende der jenigen / die durch das Concilium / Jnterim / vnd Adiaphora / von Christo zum Antichrist fallen / aus diesem Prophetischen gemelde / des 3. Eliae seliger gedechtnis / D. M. Luth. genomen. Durch Matth. Fla. Illyr. Magdeburg: Christian Rödinger d.Ä., 1550.

-. Etliche greiffliche gewisse vnnd scheinbarliche warzeichen / Daraus ein jeder wie geringes verstands er sey / Wo er nur zu erforschung der warheit geneiget ist / vormercken kann / das die Lehre der Euangelischen des Herrn Christi Leher selbst ist / vnd das der Papisten Lehr falsch / Gottloss vnd vom Antichrist erfunden ist. Auss einer lateinischen schrifft M. Matthie Flacij Jllyrici verdeutschet. Magdeburg: Christian Rödinger d.Ä., 1549.

-. Etliche klare vnd treffliche Zeugnussen / D. Martini Luthers / von dem bo(e)sen Wesen / Essentia, Bild, Form oder Gestalt des jrdischen todten Adams / vnd von der Wesentlichen transformation / oder Verwandelung des Menschen: Aus welchen die Verkerung der Wo(e)rter / vnd der Sache auch die falsche Lere der Sophisten / vnd des Papistischen Accidens kan vberaus wol ero(e)rtert werden. Matth. Flac: Illyr: S. 1: 1574.

- . Etliche troestliche vermanungen / in Sachen das heilige Goettliche Wort betreffend: Zu dieser betruebten Zeit/sehr nuetzlich vnd troestlich zu lesen / D. Martinus Luther / Anno. M.D.XXX. Wieder aussgelegt zu Magdeburg An. 1550. Magdeburg: Christian Rödinger d.Ä., 1550; 2nd edition, Jena: Thomas Rebart, 1558.

- . Excvsatio Matthiae Flacij Illyrici, contra calvmnias adversariorvm, qvod praesentivm calamitatvm Ecclesiae Brabantiae cavsa fverit. S. 1: 1568. 
-. Gnwqu seautov. De essentia originalis iustitiae et iniustitiae seu Imaginis Dei et contrariae. Avthore Matth. Flacio Illyrico. Basel: Pietro Perna, 1568.

- . Gregorii Tvronici Historiae Francorvum. Libri Decem. Basel: Pietro Perna, 1568.

- . Gründliche verlegung aller schedlichen Schwermereyen des Stenckfelds / zur vnterricht vnd warnung der einfeltigen Christen. Geschrieben durch Matthiam Flacium Illyricum, M. D. LVII. Nuremberg: Jonann vom Berg and Ulrich Neuber, 1557.

-. Gruendliche verlegung aller Sophisterey so D. Pfeffinger mit den andern Adiaphoristen das Leiptzigsche Jnterim zubeschoenen gebraucht. Durch Matth. Fla. Jllyricum. Magdeburg: Christian Rödinger d.Ä., 1551.

-. Gruendliche verlegung aller Sophisterey so Juncker Jssleb D. Jnterim Morus Pfeffinger D. Geitz in seinem gruendlichen bericht vnd jhre gesellen die andere Adiaphoristen das Leipsische Jnterim zu beschoenen gebrauchen. Durch Matth. Fla. Illyricum. Magdeburg: Christian Rödinger d.Ä., 1550 .

- . ed. Ioannis Hus, et Hieronymi Pragensis Confessorvm Christi Historia er Monvmenta, Partim Annis Svperioribvs Pvblicta, Partim Nvnc demum in lucem prolata \& edita, cum scriptis \& testimonijs multorum ... (Altera Pars. Additae svnt Narrationes de Condemnatione Inivsta, et Indign Svpplicio Ioannis Hvs, et Hieronymi Pragensis, ab incertis Avthoribus ...) Narrationes de condemnatione iniusta et indigno supplicio Johannis Hus et Hieronymi Pragensis. Nuremberg: Johann vom Berg and Ulrich Neuber, 1558.

- . Kurtze antwort M. Fla. Jllyr. auff des Laruen Bischoffs von Sydon Holhiplerey / Damit er seinen Antichristischen Catechismum vertedingen wil. Jtem etliche oeffentliche verfelschung Gottes worts aus des Sidonij Buechern. Jtem ein stueck aus einer schrifft des hochgelarten Gersonis. Magdeburg: Christian Rödinger d.Ä., 1553.

- . Matthiae Flacij Illyrici, de voce \& re Fidei, quodque sola fide iustificemur, contra Pharisaicum hypocritarum fermentum, Liber. Eiusdem, De Iusticia Christiana, Site Iustificatione, \& noua obedientia, Disputatio multa accuratius alijs quibusdam explicans. Item, De Velamine Mosis, eiusque detractione. De uestigijs ueri usus Legis. De nomine IEHOVA. Cum rerum \& verborum in his omnibus praecipue memorabilium copioso Indice. Basel: Johannes Oporinus, 1563.

- . Missa Latina, quae olim ante Romanam circa 700. Domini annum in usu fuit, bona fide ex uetusto authenticoque Codice descripta. Item quedam de uetustatibus Missae scitu ualde digna. Adivncta est Beati Rhenani Praefatio in Missam Chrysostomi à Leone Tusco, Anno Domini 1070. Uersam. Strasbourg: Christian Mylius, 1557.

- . Omnes Libelli Mathiae Fl. Illrici, hactenvs in sacramentaria controversia editi. Quibus accessit valde copiosa Appendix nouarum demonstrationum. In hoc opere multae admodum arduae quaestiones dilucide explicantur, in quibus plaerique disputantes hactenus haesitarunt. Frankfurt: Peter Braubach, 1567.

- . Omnia Latina Scripta Matthiae Flacii Illyrici, hactenus sparsim contra Adiaphoricas fraudes \& errores aedita, \& quaedam prius non excusa, catalogum uersa pagina indicabit. Magdeburg: Michael Lotter, 1550.

- . ed. Otfridi Evangeliorvm Liber .... Basel: Heinrich Petri, 1571.

-. Paralipomena Dialectices. Libellus lectu dignissimus, et ad Dialecticam Demonstrationem certius cognoscendam, cuius etaim in Praefatione prima quedam principia proponuntur, apprime utilis. Basel: Jakob Kündig, 1558.

-. Quid sit Ecclesiam deferere aut non deferere per Math. Flacium Illyricum. Magdeburg: Michael Lotter, 1549.

-. Qvod hoc tempore nvlla penitvs mvtatio in Religione sit in gratiam impiorum facienda. Per Matth. Flacium Illiric.... Magdeburg: Hans Walther, 1549. 
- . Refvtatio confessionis Arianae Blandratae. In Heinrich Philipp Conrad Henke, Opuscula academica theologici potissimum argumenti. Leipzig: Crusius, 1802, 263-284.

- . Refvtatio Missae. Widerlegung des Sophistischen Buechs des Schwartzen Münchs von der Opffer Meß / Anno 1555. außgangen. Jtem die beschreibung der Mesz oder Communion dreyer alten vaetter / als Justini / welcher zue Rhom vngefaehr 150. Jar nach Christo gelebt / Clementis /... Dionisij / ... Durch Matth. Flac. Jllyricum.... Strasbourg: Samuel Emmel, 1557.

-. Refvtatio propositionum Pfeffingeri de Libero arbitrio ... M. Fla. Illyrici de eadem materia controversia. Jena: Thomas Rebart, 1558.

-. Solida Refvtatio vanissimorum Sophismatum, calumniarum \& figmentorum, atquem adeo etiam deterrimorum errorum Antidoti, \& aliorum Neopelagianorum Scriprotum. Avthore Math. Flac. Llyrico. S. 1: 1573.

- . Tēs tou Hyiou Theou Kainēs Diathēkēs hapanta. Novvm Testamentvm Iesv Christi Filii Dei, ex versione Erasmi, innvmeris in locis ad Graecam veritatem, genuinumque sensum emendata. Glossa compendiaria M. Matthiae Flacij Illyrici Albonensis in nouum Testamentum. Cum multiplici indice tum ipsius sacri Textus, tum etiam glossae. Basel: Pietro Perna and Theobald Dietrich, 1570.

- . Trewe Warnung vnd Vermanung / das man das heilige Testament des hochwirdigen Nachtmals / vnsers Herrn Jesu Christi vnuerfelscht / vnd in seinem rechten eigentlichen verstande / rein behalten sol / Jn dieser vnserer zeit wider so manicherley Verfuerer/Sophisterey vnd Betriegerey/ Sehr nuetzlich zu lesen. Jtem / Widerlegung vier Predigten eines Sacramentirers / mit zunamen Oleuianus. Jtem / Beweisung / Das auch die vnwirdigen den Leib vnd Blut Jesu Christi im Abendmal empfahen / Wider ein Schwenckfeldisch Buechlein / so newlich ohne Namen durch den Druck ausgestrewet worden. M. Flacius Illyricus. Oberursel: Nikolaus Henricus d.Ä., 1564.

-. Troestliche Gegenspruech des Ernwirdigen Herren Doctoris Martini Lutheri / vnd Matthie Jllyrici / wider des Rabe Osiandri Primarij spruch. Wittenberg: Hans Lufft, 1552; Magdeburg: Christian Rödinger d.Ä., 1552.

-. Troestliche Vermanungen an die Christen / so vmb GOTTES Worts willen verfolgt werden. Durch / Doctor Martin Luther gestelt/ Anno. 1530. S. 1: 1562.

-. Verlegung der Apologiae Sydonij / damit er seinen Catechismus verteidinget. Matth. Flacius Jllyricus. Magdeburg: Christian Rödinger d.Ä., 1553.

-. Von Ankunfft des Roemischen Keyserthumbs an die Deudschen. Von der Herkunfft der Sieben Churtfuersten. Verdeudschet durch M. Wolffgang Waldner. Jtem / Von der Wahl der Prelaten. Ob Petrus zu Rohm gewesen sey. Durch M. Matth. Flacium Jllyricum. Oberursel: Nikolaus Henricus d.Ä., 1567.

-. Von dem fürnembsten stücke / punct / oder artickel der Schwenckfeldischen schwermerey. Durch Matthiam Flacium Jllyricum. Strasbourg: Samuel Emmel, 1554.

- . Von der Disputation / oder Religionstreit / zwischen M. Matthia Flacio Jllyrico / vnd den Jesuitischen Doctoren zu Fulda / dieses 1573. Jar geschehen ... Jtem / von Vneynigkeit der Papisten vnter sich selbs. Oberursel: Nikolaus Henricus d.Ä., 1574.

-. Von der Erbsünde / Freyen Willen / Bekerung vnd Widergeburt / Antwort Matt. FI. Jllyrici auff etliche Schrifften Christophori Lasij des Jnterimisten. Oberursel: Nikolaus Henricus d.Ä., 1568.

- . Von der Gerechtigkeit wider Osiandrum / nuetzlich zu lesen. Durch Matth. Flacium Illyr. Magdeburg: Christian Rödinger d.Ä., 1552.

- . Von der h. Schrifft vnd jrer wirckung / widder Caspar Schwenckfeld / Durch Matthiam Flacium Jllyricum. Mit einer vermanung Nicolai Galli das ampt Gottlichs worts in ehren zuhaben. 
Magdeburg: Michael Lotter, 1553; 2nd revised edition, Strasbourg: Samuel Emmel, 1554. In CS 13: $397-448$.

- . Von der Messe vnd jhrem Canone Magistri Johannis Agricolae Eysleben / Lhere vnd schrifft / Welche er auff dem Reichstag zu Speyer in der Epistel zu den Collossern geprediget / vnd folgend Anno M.D.XXVII. zu Wittenbergk im Druck offentlich hat ausgehen lassen / Dem Interim so er ytzt hat helffen stellen / gantz entgegen / Daraus sein geyst zuuermercken. Magdeburg: Christian Rödinger d.Ä., 1548.

-. Widder die Goetter in Preussen... Ein kurtzer / heller vnnd klarer bericht von verdienst vnd gerechtigkeit Christi. Durch M. Fla. Jlly.... Magdeburg: Michael Lotter, 1552.

-. Widder die newe Reformation D. Pfeffingers des Meisnischen Thumbherrn. Durch Matth. Fl. Jllyr. Magdeburg: Christian Rödinger d.Ä., 1550.

- . Widder die vnchristliche Vermanungschrifft / des Bisthumbs zu Naumburg / Durch Matth. Flacium Jllyricum. Magdeburg: Christian Rödinger d.Ä., 1550.

- . Widder drei Gottislesterische vnnd Sophistische Argumenta des Funckens / welche er newlich in Preussen widder das tewre blut Christi vnter die Leute gestrewet hat. Matth. Fl. Jllyr. Magdeburg: Michael Lotter, 1555.

-. Widderlegung der Predigten von der allerheiligsten Antichristische Missa des frembden Bischoffs von Sydon / Meintzischen Weihbischoff. durch Matthiam Flacium Jllyricum. Magdeburg: Christian Rödinger d.Ä., 1550.

-. Widderlegung des Catechismi des Larven Bischoffes von Sidon / durch Matthiam Flacium Jllyricum. Magdeburg: Michael Lotter, 1550.

- . [Christianus Lauterwar]. Wider Das Interim. Papistische Mess / Canonem / vnnd Meister Eissleuben / durch Christianum lauterwar / zu dieser zeit nützlich zu lesen. Anno. 1549. Magdeburg: Michael Lotter, 1549.

-. Wider den Euangelisten des heiligen Chorroks / D. Geitz Maior. Matth. Flac. Jlly. »Basel« [Magdeburg: Michael Lotter], 1552.

-. [Carolus Azarias]. Wider den Schnöden Teuffel / der sich jtzt abermals in einen Engel des liechtes verkleidet hat / das ist wider das newe Interim / Durch Carolum Azariam Gotsburgensem. M.D. XLIX. Magdeburg: Christian Rödinger d.Ä., 1549.

- . Widerlegung / eines kleinen Deutschen / Calvinischen Catechismi / so in disem M.D.Lxiij. Jar / sampt ethlichen andern jrrigen Tractetlin ausgangen. Item / Beweisung / Das auch die vnwirdigen den waren Leib vnd Blut Jesu Christi im Abendmal empfahen / Wider ein Schwennckfeldisch Buechlein / so newlich on namen durch den Druck ausgestrewet worden. M. Flacius Jllyricus. Regensburg: Heinrich Geißler, 1563.

- . Widerlegung vier Predigten eines Sacramentirers / mit zunamen Oleuianus. Jtem / Beweisung / Das auch die vnwirdigen den Leib vnd Blut Jesu Christi im Abendmal empfahen / Wider ein Schwenckfeldisch Buechlein / so newlich ohne Namen durch den Druck ausgestrewet worden. Oberursel: Nikolaus Henricus d.Ä., 1564.

- . WJe das Aldenburgisch Colloquium zergangen. Nuremberg: Christoph Heußler, 1569.

-. Wonderfull newes of the death of Paule the III. last byshop of Rome: and of diuerse thynges that after his death haue happened, wherein is trulye set the abominable actes of his most misceuous life. Written in Latin by P. Esquillus, [Matthias Flacius Illyricus] and Englyshed by W. B. Londoner. Translated into English by William Baldwin. London: Thomas Gualtier, 1552.

Flacius, Matthias Illyricus et al. Kirchenagend / oder Form vnd Gestalt / Wie es mit den Sacramenten vnd Ceremonien gehalten wird / in der Kirchen der Augspurgischen Confession zu 
Andorff. Durch die Ehrwirdigen Herrn vnd Predicanten daselbst gestelt / Welcher Namen am Ende gesetzt werden. S. 1: 1567.

Flacius, Matthias Illyricus and Caspar Heldelin. Defensio verae piae ac Lvtheranae, de originali peccato, sententiae: ac Refvtatio sophismatvm simpliciores a vero nosce te ipsum, abstrahentium, opposita commentitio colloquio caeterisque adiunctis scriptis a D. Iacobo Andraea nuper aeditus, per Reverendvm Virvm D. M. Matthiam Flacivm Illyricum. Mühlhausen: Georg Hantzsch, 1575.

Flacius, Matthias Illyricus and Balthasar Houwaert. Defensio Confessionis Ministrorvm Iesv Christi, Ecclesiae Antuerpiensis, quae Augustanae Confessioni adsentitur, contra Ivdoci Tiletani uaria Sophismata. Cvm Praevia Adhortatione ad seriam poenitentiam, et ardentes preces, in praesentibus difficultatibus et periculis. Addita est in fine et Altera Adhortatio ad piam constantiam in praesenti cruce, ac Satanae cribratione. Basel: Bartholomaeus Franck, 1567.

Flacius, Matthias Illyricus and Nikolaus Gallus. Verlegung des Bekentnis Osiandri von der Rechtfertigung der armen sunder durch die wesentliche Gerechtigkeit der Hohen Maiestet Gottes allein. Durch Matth. Fla. Jllyr. Mit vnterschreibung Nicolai Gallj / darin der grund des jrthums Osiandri sampt seiner verlegung auffs kuertzest verfast ist. Magdeburg: Christian Rödinger d.Ä., 1552.

Flacius, Matthias Illyricus and Paul Reinecker. Demonstrationes evidentissimae doctrinae de essentia imaginis dei \& Diaboli, iustitiaeque ac iniustitiae originalis, vna cum testimonijs veterum ac recentium theologorum. Methodica probatio propositionis, Quod peccatum originale sit substantia, Per D. M. Paul. Rei. V. VV. Basel: Pietro Perna, 1570.

Flacius, Matthias Illyricus, the Younger. Amolitio XX. Errorvm, qvos Heshvsivs Illyrico falso obiicit. Examen novae D. Mvsaei de peccato originali sententiae. Eisleben: Andreas Petri, 1572 .

-. Elegia de febri. Scripta à Matthia Flacio Illyrici filio. S. 1: 1571.

Fraxineus, Johannes. Gravissima Iohannis Marbachii S. Literarum Doctoris, harumdemque in Argentinensi Academia Professoris Epistola qua Matthiae Flacio Illyrico integrates constantiae, \& quod ab haeresi Manichaeorum prorsus alienus exstiterit, praeclarum datur testimonium. Oberursel: Nikolaus Henricus d.Ä., 1601.

-. In Compendivm Theologiae Iacobi Heerbrandi S. Theologiae Doctoris \& Professoris quondam in Academia Tubingensi. Oberursel: Nikolaus Henricus d.Ä., 1601.

Gallus, Nikolaus. Auff des Herrn D. Maiors verantwortung vnd Declaration der Leiptzigischen Proposition / wie gute werck zur seligkeit noetig sind / zum zeugnis seiner vnschult / das er mit der Leiptzigischen handlung nichts zu thun habe. Antwort. Nicolai Galli. »Basel« [Magdeburg: Michael Lotter], 1552.

-. Einer Christlichen Stad vnthertenigk antwort / auff das von Key. Ma. vberschickt Jnterim. Vnnd ein Radtschlag der Predicanten der selbigen Stadt. Magdeburg: Michael Lotter, 1548.

-. Vera excusatio M. Fl. Ill. contra novam quandam criminitationem ab Adiaphorists sparsam. Regensburg, 1568.

Garbitius, Matthias Illyricus. Aeschyli Prometheus, cum interpretatione Mathiae Garbitii Illyrici, Graecae linguae \& Moralis philosophiae professoris ordinarij in Academia Tubingensi.... Basel: Johannes Oporinus, 1559.

-. et al. Epitaphia / qvaedam non inscita partim graeca partim / latina iam primum Tubingae aedita. Anno M.D.XL.III. die Augusti VI. Tübingen, 1543. 
Gasser, Pirmin Achilles. Annales civitatis ac rei publicae Augstburgensis. Frankfurt am Main: Christian Egenolff (Erben), 1595.

Hamelmann, Hermann. Sententiae Omnivm Fere Patrvm, tam recentiorum, quam antiquiorum, de primarijs Augustanae Confessionis articulis, in primis uero de sola fide iustificante. Autore \& collectore Hermanno Hamelmanno. Cum Praefatione Philippi Melanthonis, \& Matthiae Flacij Illyrici. Marburg: Andreas Kolb, 1557.

Haubold, Hieronymus. Formvla Veritatis. Warhafftige vnd gruuendliche Außfuehrung / des hohen vnnd wichtigen Religionsstreits von der Erbsuende .... Nuremberg: Nikolaus Knorr, 1582.

Heerbrand, Jakob. Compendium Theologiae, Qvaestionibvs Methodi Tractatvm. Tübingen: Georg Gruppenbach, 1573.

Heldelin, Caspar d.J. Eine Christliche predigt vber der Leiche des Ehrnwürdigen vnd hochgelerten Herrn M. Matthiae Flacij Illyrici / Weiland getrewen Dieners vnd bestendigen Merterers Jesu Christi Fromen Hertzen zu gut gestellet. Durch M. Gasparem Heldelinum Lindauiensem. Jtem $/$ Summarischer Bericht / der Handlungen vnd Streitsachen Herrn Matthiae Flacij Jllyrici / von jm selbst verzeichnet. Oberursel: Nikolaus Henricus d.Ä., 1575.

Helding, Michael. Brevis institvtio ad pietatem Christianam secundum Doctrinam Catholicam continens. ... Defensio adversus calumnias cuiusdam Matthiae Illyrici. Mainz: Ivo Schöffer, 1552 .

Heller, Joachim. Prognosticon M. Joachim Hellers / Manßfeldischen Astronomi auff das 1565 Jar / nach der Geburt ... Jesu Christi / darin aus anzeigung etlicher grosser wunderzeichen ... . Eisleben: Joachim Heller, 1565.

Heshusius, Tilemann. Bekenntnus von dem Nachtmahl des Herrn Jhesu Christi (1559). In Nikolaus Gallus, Confvtationes Etzlicher gegenwertiger Secten vnd Curruptelen / Magistri Nicolai Galli, Pharrherr vnd Superintendenten / der Stad Regenspurg. Jena: Thomas Rebart and Donat Richtzenhan, 1562, C6v-E5v.

- . Epistola D. Tilemani Heshvsii ad M. Matthiam Flacivm Illyricvm De controuersia. An peccatum Originis sit substantia. Item analysis argvmentorvm quibus D. Illyricus nititur. Jena: Christian Rödinger d.J., 1570.

-. Trewe Warnung fuer den Heidelbergischen Caluinischen Catechissmum / sampt wierderlegung etlicher jrthumen desselben. D. Tilemnnus Hesshusius Exul Christi. Eisleben: Urban Gaubisch, 1564.

Hus, Jan. Enarratio Psalmorum (Ps. 109-118). In Jana Nechutová et al (eds.) [Corpvs Christianorvm: Continuatio Mediaeulis 253]. Turnhout: Brepols, 2013.

Irenaeus, Christoph. Contrafet Vnd Spiegel des Menschen. Mit seinen eigentlichen Farben aus Gottes Wort/illuminirt vnd ausgestriechen. Daraus erscheinet / Das der Mensch ausser Christo / on Glauben vnd H. Geist / vor der Widergeburt / nach anklage des Gesetzes / das scheusslichste Monstum / gro(e)ster Grewel fu(e)r Gott / vnd die elendste Creatur auff Erden sey. Sampt dem Trostspiegel. Daraus klar vnd offenbar. Das Gottes Son selbs hat mu(e)ssen Mensch werden / das Gesetz erfu(e)llen / leiden vnd sterben ... Oberursel: Nikolaus Henricus d.Ä., 1582.

- . Erzehlung vnd Widerlegung etlicher vnchristlichen / ergerlichen vnd abschewlichen Reden D. Jacobs vnd seiner Accidens Bru(e)der. In Examen Des ersten Artickels vnd des Wirbel Geists $/$ Jm newen Concordien Buch. Vnd Einfeltiger Beweis / das darinne der Artickel von der Erbsuüde wider sich selbs ist/vnd sich selbs widerlegt. M. Christoph: Jreneus exul Christi. S. 1: 1581, $\mathrm{P} 3 \mathrm{r}-\mathrm{Aa} 2 \mathrm{v}$. 
Johann Friedrich II, Herzog von Sachsen. Des Durchleuchtigen Hochgebornen Fuersten vnd Herrn/ Herrn Johans Friderichen des Mittlern / Hertzogen zu Sachssen / Landgrauen in Dueringen / vnd Marggrauen zu Meissen / fuer sich selbs / Vnd von wegen seiner F. G. Bruedere / Hertzog Johans Wilhelmen / vnd Hertzog Johans Friderichen des Juengern zu Sachssen etc. in Gottes wort / Prophetischer vnnd Apostolischer schrifft / gegruendete Confutationes / Widerlegungen vnd verdammung etlicher ein zeit her / zu wider demselben Gottes wort / vnd heiliger Schrifft / auch der Augspurgischen Confession Apologien / vnd den Schmalkaldischen Artickeln / Aber zu fuerderung vnd wider anrichtung des Antichristischen Bapstums eingeschlichenen / vnd eingerissenen Corruptelen / Secten vnd Jrrthumen / Wie dieselben vnterschiedlich / vnd in Specie / namhafftig angezeigt werden / An ihrer F. G. getrewe Landstende / Vnterthanen vnd Verwanten ausgangen / Damit sie sich durch Goetliche verleihung / dafuer zu hueten / Auch in Gottes worts / vnd der Christlichen Religion Sachen / gemelter Auspurgischen Confession / Apologien / Vnd den Schmalkaldischen Artickeln gemes (dabey denn ihre F. G. durch Goettliche gnad / bis an derselben ende zuuerharren willens vnd entschlossen) zu halten wissen vnd haben. Jena: Thomas Rebart, 1559.

- . Illvstrissimi Principis Ac Domini, Domini Iohannis Friderici Secvndi, Dvcis Saxoniae, Landgrauij Thuringiae, \& Marchionis Misniae, suo ac Fratrum D. Iohannis Vuilhelmi, et D. Iohannis Friderici natu Iunioris nomine, solida \& ex Verbo Dei sumpta Confutatio \& condemnatio praecipurarum Corruptelarum, Sectarum, \& errorum, hoc tempore ad instaurationem \& propagationem Regni Antichristi Rom. Pontificis aliarumque fanaticarum opinionum, ingruentium \& grassantium, contra ueram sacrae Scripturae, Confeßionis Augustanae \& Schmalkaldicorum Articulorum Religionem, ad suae Celsit. \& Fratrum suorum subditos cuiuscunque Ordinis scripta \& edita, ut auxiliante deo illas satane technas cauere, \& in puritate Verbi Dei praedictaque Christiana agnita, recepta, \& confessa Religione( in cutus Confessione \& ipsorum Celsitudines, Dei beneficio, constants ad extremum usque altae spiritum perseuerare decreuerunt) illi quoque permanere possint, quemadmodum et debent. Jena: Thomas Rebart, 1559.

-. Ordenung vnd summarischer Process des Fu(e)rstlichen Sechsischen Consistorij. Auffgerichtet in dem jar. M.D.LXI. Jena: Thomas Rebart, 1561.

Judex, Matthaeus, ed. Das Kleine Corpvs Doctrinae. Das ist / Die Heuptstuecke vnnd summa Christlicher lere / fuer die Kinder in Schulen vnd Heusern ... gestellet / durch Matthaevm Ivdicem. Rostock: Stephan Möllemann, 1564.

-. ed. Dat cleyne Corpus Doctrinae. Dat is: Die hooftstucken en Somma der Christelijcke leereinge voor die kinderen in den Scholen ende buysen opt Simpleste gbestelt, door: Mattheum Iudicem. Wesel: Hans de Braeker, 1564.

- . Der Ewigen / Allmechtigen Goettlichenn Mayest. Mandat / vnd ernstlicher befelch / wes sich ein yeder Christ / nach seinem berueff vnnd stande / gegen dem offenbarten Antichrist / das gantze Babstumb / halten solle / widerholet vnd erkleret / Durch Mattheum Judicem. S. 1: 1561.

Kausler, Eduard von and Theodor Schott, eds. Briefwechsel zwischen Christoph, Herzog von Württemberg und Petrus Paulus Vergerius [Bibliothek des litterarischen Vereins in Stuttgart 74]. Tübingen: H. Laupp, 1875.

Krell, Sebastian, ed. Otrozhia Biblia. Ein Handtbuechlein / Darinn ist vnter anderm der Catechismus Von fünfferlei sprachen. Regensburg: Johann Burger, 1566. Facsimile edition [Monumenta Litterarum Slovenicarum 20]. Ljubljana: Mladinska knjiga, 1987.

Lang, Andreas and Hieronymus Haubold. Richtige vnd in Gottes Wort gegruendte Bekentnis von der Erbsvnde. Herrn Andree Langen etwan Pfarrers zu Clagenfurd in Kaerndten Vnd M. 
Hieronymi Hauboldi auch etwan Rectoris der Landtschafft Schulen daselbst. Der warheit zum Zeugnuss / vnd fromen Christen zum unterricht / in druck verfertiget. S. 1: 1576.

Lasius, Christoph. Fundament Warer vnnd Christlicher Bekerung / Wider die Flacianische Klotzbus / aus vier Jrthumen widers Fundament ersetz / klerlich erwisen / vnd gründlich widerlegt. Durch M. Christophorum Lasium. Frankfurt an der Oder: Johann Eichorn, 1568.

- . Praelibatio Flaciani dogmatis, de prodigiosa conversione hominis, ad gustum totius contoversiae proposita. Wittenberg: Peter Seitz d.J., 1568.

Liebler, Georg. Oratio lugubris, Post funerationem Clarissimi, \& omni Virtutum \& Doctrinarum genere spectatissimi viri, Dn. M. Matthiae Garbitii Illyrici, vtrivsqve lingvae, et philosophiae moralis, in inclyra Tubingensi Academia Professoris celebratissimi fidelissimique: in Ferijs DD. Apostolorum Philippi \& Jacobi, Anno 1559. cum Discipulis suis, insigni dexteritate, zeloque; plane divino, summa cum admiratione explicaret Textum, Jo: 14. Tübingen: Johann Alexander Cellius, 1614

Lonicer, Philipp, Hartmann Beyer and Petrus Patiens. Vnterricht Vom hochwirdigen Abendmal Christi... Frankfurt, 1575.

Luther, Martin. Aliqvot epistolae reverendi patris piae memoriae D. Martini Lutheri quibusdam Theologis ad Augustana comitia. Anno 1530. scriptae, de conciliationibus Christi et Belial disserentes, ex quibus multa remedia praesentibus Ecclesiae morbis salutaria, peti possunt. Et quedam alia lectu digna. Matthias Flacius Illyricus, ed. Magdeburg: Michael Lotter, 1549.

- . Etliche Brieffe / des Ehrwirdigen Herrn D. Martini Luthers seliger gedechtnis / an die Theologos auff den Reichstag zu Augspurg geschrieben / Anno M.D.XXX. Von der vereinigung Christi vnd Belials / Aufs welchen man viel nützlicher Lehr in gegenwertiger gefahr der Kirchen nemen kan. Verdeutscht. Item, etliche andere schrifften, nuetzlich vnd troestlich zu Lesen. Matthias Flacius Illyricus, ed. Magdeburg: Christian Rödinger, 1549; 2nd edition, Jena: Thomas Rebart, 1558.

Major, Georg. Auff des Ehrenwirdigen Herren Niclas von Ambsdorff schrifft, so jtzundt neulich Mense Nouembri Anno 1551. wider Georgen Maior oeffentlich im Druck ausgegangen. Antwort Georg: Maior. Wittenberg: Georg Rhau, 1552.

-. Auslegung des Glaubens / Welcher das Symbolum Apostolicum genand wird / den einfeltigen Pfarherrn vnd allen Hausuetern zu dienste in XX. Predig verfasset. Durch D. Georg. Maior. Mit einer Vorrede / des M. Flacij Jllyrici schreien vnd schreiben belangend. Wittenberg: Georg Rhau, 1550; 2nd edition, Wittenberg: Veit Kreutzer, 1554.

-. Commonefactio D. Georgii Maioris, ad ecclesiam catholicam, orthodoxam, de fugiendis \& execrandis blasphemijs Samosatenicis, Arianis, Eunomianis, \& alijs, quae hoc tempore a Francisco Dauidis, \& quodam Italo Georgio Blandrata, \& nonnullis alijs, ab Orco \& Stygia palude reuocantur, \& paßim sparguntur. Wittenberg: Hans Lufft, 1569.

- . De Origine et Avtoritate Verbi Dei, \& quae Pontificum, Patrum \& Conciliorum sit autoritas, admonitio hoc tempore, quo de Concilio congregando agitur, ualde necessaria. Additvs est Catalogus Doctorum Ecclesiae Dei, a mundi initio, usque ad haec tempora. Georgio Maiore Avtore. Basel: Andreas Cratander (Erben), 1551.

-. Refvtatio horrendae prophanationis Coenae Domini, collecta ex Evangelio et sinceris antiqvae ecclesiae testimoniis a Georgio Maiore. Cum praefacione Philip. Melanth. Wittenberg: Veit Kreutzer, 1551; 2nd edition, Wittenberg: Veit Kreutzer, 1555; 3rd edition, Wittenberg: Veit Kreutzer, 1557; 4th edition, Wittenberg: Veit Kreutzer, 1561.

Marbach, Johann. Christlicher / vnd warhaffter vnderricht / von den worten der einsatzung des heyligen Abendmals Jesu Christi / vnsers Heylandts / sampt gruendtlicher widerlegung der 
Sacramentierer hieuon jrrigen Lehr / vnd meynung. Gestellet durch Johan Marbach / der h. Schrifft Doctorn / vnd der Kirchen zu Straßburg Superintendenten. Strasbourg: Christian Müller d.Ä., 1565.

Marulus, Marco [Marulić, Marko]. Libar Marca Marula Splichianina V chomse sdarsi Istoria Sfete udouice Iudit u uersih haruacchi slosena chacho ona ubi uoiuodu Olopherna Posridu uoische gnegoue i oslodobi puch israelschi od ueliche pogibili. Venice: Guglielmo da Fontaneto, 1521.

Medler, Nikolaus. Eine Predigt vber Das Euangelion Luce xiiij. Von dem Wassersuechtigen / So man list den Siebenzehenden Sontag nach Trinitatis wieder das INTERIM. Geschrieben an einem guden freundt. Durch Doctorem Nicolaum Medlerum. Magdeburg: Michael Lotter, 1548.

Medler, Nikolaus and Matthias Flacius Illyricus. Ein wunderlich gesicht newlich bey Braunschweig am hiemel gesehen / beschrieben durch den hochgelerten hern Doctorem Nicolaum Medlerum / Superattendententem zu Braunschweig. Magdeburg: Pankratz Kempff, 1549.

Meister, Joachim. Metamorphosis Flacii Illyrici in truncum. Görlitz: Ambrosius Fritsch, 1578.

Melanchthon, Philipp. Bedencken vom Synodo aller Chur und Fürsten und Stände Augsburgischer Confession. 1558. In CR 9: 462-478.

- . Melanchthons Briefwechsel, 12: Texte 3127 - 3420a (1543). Dall'Asta, Matthias, Heidi Hein and Christine Mundhenk, eds. Stuttgart / Bad Cannstatt: Frommann-Holzboog, 2011.

- . Ivdicivm D. Philippi Melanchthonis, de controuersia Coenae Domini, ad Illustrisimum Princepem, ac D. D. Fridericum, Comitem Palatinum Rheni, Sacri Romani Imperij Archidapiferum, Electorem, Bauariae Ducem, \&c. Heidelberg: Ludwig Lucius, 1560.

- . Oratio in fvnere Reverendi viri D. Martini Lvtheri, recitata Vitebergae a Philippo Melanchthone. Wittenberg: Josef Klug 1546.

- . De Philosophia oratio pronunciata, cum decerneretur gradus Magisterij quibusdam doctis \& honestis iuuenibus. Philippi Melanth. 1536. In CR 11: 278-284.

Melissander, Caspar. Klarer Bericht Von der Erbsuende / Ob sie ein Substantz, oder ein Accidens sey / vnd was fuer ein Accidens sie eigentlich sey? Daraus der einfeltige Deudsche Mann den rechten Grund des gantzen Handels / sowol wider das Pelagianische vnd Synergistische Accidens, Als wider die Manicheische Gottslesterliche Substantz / auffs deutlichste zuuernemen ... Jtzt in Druck gegeben Durch D. Casparum Melisandrum, Pfarrern vnd Superintendentem zu Aldenburg in Meissen. Wittenberg: Simon Gronenberg, 1581.

Merckel, Heinrich. Warhafftiger Avssfuerlicher vnd gruendlicher Bericht / von der Altenstadt Magdeburgk Belagerung / so die Roem: Key: May: Carolus Quintus / sampt Churfuersten / Fuersten vnd Stenden des Heiligen Roemischen Reichs etc. Anno 50 am 16 Septembris angefangen / vnd bis auff den 9. Nouembris Anno 51 Continuirt: Vnd wie endlich die Stadt vortragen vnd zur Aussoenung wieder kommen / Durch Heinrichen Merckeln / Secretarium der Altenstadt Magdeburgk beschrieben. Magdeburg: Paul Donat, 1587.

Morgenstern, Benedict, Johannes Wigand et al. Widerlegung der Notel / damit die Sacramentirer zu Dantzig / jhren Jrthumb vnd Verfolgung / verkleistern vnd bedecken wollen... Sampt zweien Vorreden: Eine der Prediger in der Herrschafft Mansfeldt / an die Diener Go(e)ttliches Worts zu Dantzig vnd Thorn. Die andere / An einen Erbaren ... Rath / der Ko(e)niglichen Stad Thorn ... Eisleben: Andreas Petri, 1567.

Mörlin, Joachim. Wider die Landluegen der Heidelbergischen Theologen. Joachimus Moerlin D. Eisleben: Andreas Petri, 1565.

- and Matthias Flacius Illyricus. Antwort auff das Buch des Osiandrischen schwermers in Preussen / M. Vogels / darinnen er sein beduncken anzeiget von der fürgefallenen zwispalt / vnd meinen Brieff an jn. Joachimus Moerlin D. Jtem Matth. Fl. Jllyrici von dem Gebet einer Osiandrischen Person / vber den lxxj. Psalm. Magdeburg: Ambrosius Kirchner d.Ä., 1557. 
Musaeus, Simon, ed. Dispvtatio de originali peccato et libero arbitrio, inter Matthiam Flacium Illyricum et Victorinum Strigelium publice Vinariae per integram hebdomadam, praesentibus Illustriss. Saxoniae Princibus, Anno 1560. initio mensis Augusti habita.... Basel: Johannes Oporinus, 1562.

- . ed. Disputatio De Originali Peccato Et Libero Arbitrio, Inter Matthiam Flacium Illyricum, \& Victorinum Strigelium, Publice Vinariae Per Integram Hebdomadam, Praesentibus Illustriss. Saxoniae Principibus, Anno 1560. Initio Mensis Augusti, Contra Papistrarum \& Synergistarum Corruptelas Habita. Basel: Johannes Oporinus, 1563.

Muzio, Girolamo. Le Vergeriane del Mvtio Ivstinopolitano. Discorso se si convenga ragvnar concilio. Trattato della Comvnione de' Laici; \& delle mogli de’ Cherici. Venice: Gabriel Giolitto de Ferrari e fratelli, 1551.

Olevianus, Caspar. Kurtze Summ vnd jnnhalt Ettlicher Predigten vom H. Abendmal vnsers Heilands Jesu Christi. Darinn allein auß Gottes wort vnd nicht auß der vernunft noch menschen Lehr / der rechte einfeltige verstandt / frucht vnd nutz des H. Abendmals / one alle bitterheyt vnnd gezaenck wirdt fürgetragen. Gepredigt zu Heidelberg / durch Casparum Oleuianum / Anno 1563. Heidelberg: Johannes Mayer, 1563.

Opitz, Josua. Eine Christliche Leichpredigt. Bey dem Begrebnuß des Ehrwirdigen vnnd Hochgelehrten Herrn Nicolai Galli / Pfarrhers / vnd Superintendenten der Christlichen Gemein zu Regenspurg / gethan am tag Johannis Baptistae. Durch M. Iosvam Opitivm / Predigern in der Newen Pfarr daselbst. Regensburg: Johann Burger, 1570.

- . Protestation wider den unseligen Abfall M. Hieronymi Pereisterij / von erkanter vnd bekanter warheit / vnd seine durch den Druck außgegangene Retraction / oder Widerruff. Von M. Iosua Opitio. Zu rettung seiner Christlichen Lehre vnd Bekantnis / vnd seinem Zuhoeren zur warnung gestelt. S. 1: 1578.

Osiander, Andreas d.Ä. Gesamtausgabe. Schriften und Briefe September 1551 bis Oktober 1552 sowie Posthumes und Nachträge. Vol. 10. Gerhard Seebass, ed. Gütersloh: Gütersloher Verlagshaus, 1997.

-. Von dem Einigen Mjtler Jhesu Christo vnd Rechtfertigung des Glaubens. Bekantnus Andreas Osiander. Königsberg: Hans Lufft, 1551.

Pagnino, Santes. Hoc Est, Thesavrvs Linvae Sanctae: Sic Enim Inscribere placuit lexicon hoc Hebraicum ... Lyon: Sebastian Gryphius, 1529.

Pantaleon, Heinrich. Der dritte vnd letste Theil Teutscher Nation Heldenbuch: Jn diesem werden aller Hochberuempten Teutschen Personen Geistlicher vnd Waelticherhohen vnd nideren staths Leben vnd nam̃haffte tathen gantz waarhafftig beschriben ... vnder den vier letsten Keyseren Maximilian I. Carolo V. Ferdinando vnd Maximilian II. von dem 1500 biß auff das lauffende 1570 jar ... Erstlich durch den Hochgelehrten Herren Heinrich Pantaleon zum theil auß vieler voelckeren Historien ... in Latein zusamen gebracht vnd mit sampt vieler personen bildnussen fürgestellet. Jetzmalen aber von dem Authore selbs verteutschet reichlich gemehret geenderet vnd gebesseret. Basel: Nikolaus Brylinger (Erben), 1570.

Patiens, Petrus, Heinrich Petreus and Christian Egenolff. Accesit Narratio de vita \& obitu M. Hartmanni Beyeri, Ecclesiastis Francofurtensis Primarii. Avthore Petro Patiente, Ecclesiaste Francofurtensi. Frankfurt: Franz and Nikolaus Basse, 1577.

-. Historia Mag. Hartmann Beyers / seligen / weylandt Euangelischen Predicanten zu Franckfort am Mayn / wie es vmb sein gantzes Leben vnd Wesen gethan / vnd wie er von diesem Jammerthal seliglich abgeschieden. Vor diser zeit in Latein beschriben / durch Petrum Pati- 
entem / Euangelischen Predicanten daselbst / vnd nun durch denselben auch verteutsch / vnd gemehret. In der Vorrede wirt auch das Christlich Leben vnnd Ende Frauw Marien / Herrn Antony Elers / alten Burgermeisters Haußfrauwen / seligen / kürtzlich vnd gantz troestlich beschrieben. Frankfurt: Paul Reffeler, 1578.

Peristerius, Hieronymus. Retractation Gentzliche Auffhebung vnnd verwerffung. Der Anno 1574 gestelten vnd getruckten kurtzen Antwort vnd Berichts. M. Hieronymi Peristerii. Von der Hauptfrage des gegenwertigen Streits von der Erbsuende. Vnd Wie er sich mit der Euangelischen Kirchen vnd Gemeine/des heiligen Roeomischen Reichs Freystat Regenspurg Christlich versoenet vnd mit derselben Bekantnuß wider die newen Manicheer gentzlich vereiniget habe. Regensburg: Hans Burger, 1578.

- and Matthias Flacius Illyricus. Christliche Confession vnd Bekentnus / auch Antwort vnd Bericht / auff den fuergelegten Extract eines Erbarn Camerer vnd Rhats der loeblichen Stadt Regenspurg von dem gegenwertigen Streitte / der Erbsuende / gezogen vnd genomen aus den Schrifften der Propheten vnd der Apostel. M. Hieronymus Peristerius. Jtem / Matthiae Flacij Jllyrici von der besten Schlichtung dieses Streitts von der Erbsuende / sampt seinem Beschlus. Oberursel: Nikolaus Henricus d.Ä., 1574.

Pfeffinger, Johannes. De libertate voluntatis humanae qvaestiones qvinqve. D. Iohannes Pfeffinger. Leipzig: Georg Hantzsch, 1555.

Porthaise, Jean. De Verbis Domini, Hoc Facite, Pro Oecvmenico Concilio Tridentino, aduersus Sophisticas nebulas Matthiae Flaccij Illyrici. Antwerp: Emanuel Philips Tronaesius, 1567.

Ravesteyn, Josse van. Catholicae confvtationis prophanae illivs et pestilentis confessionis, (quam Antuerpiensem Confessionem appellant Pseudoministri quidam) contra varias \& inanes cauillationes Mat. Flacci Illyrici, APOLOGIA seu defensio. Authore Ivdoco Ravesteyn Tiletano, Doctore Theologo in Academia Lovaniensi. Leuven: Pierre Zangre, 1568.

- . Confessionis Siue doctrinae, quae nuper edita est a Ministris, qui in Ecclesiam Antwerpiensem irrepserunt, \& Augustanae Confessioni se assentiri profitentur, succincta Confutatio. Leuven: Pierre Zangre, 1567.

Reinecker, Paul and Matthias Flacius Illyricus. Kurtze Widerlegung des Poetischen Dialogi von der Erbsu(e)nde Vnd der angehengten Sohrifft / so D. Jacob Andreae inn den Druck ausgesprenget hat / Durch den Ehrwirdigen vnd Hochgelehrten Herrn M. Matthiam Flacium Jllyricum. Mit einer Nu(e)tzlichen Vorrede Herrn Pauli Reineckers / Pfarherrs zu Grossen Creutzhausen im Steynachischen Gebirge / gestelt an den Christlichen Leser / zur Trewhertzigen Erinnerung / Vermanung vnd Warnung / sich fu(e)r D. Schmidel vnd Allen denen / die dem Accidens Teuffel zu Hofe reithen / vleissig vnd ernstlich zu hu(e)ten. S. 1. [Schloss Mansfeld], 1576.

Reu, Johann Michael, ed. Quellen zur Geschichte des Katechismus-Unterrichts: Mitteldeutsche Katechismen. Vol 2/2: Texte [Quellen zur Geschichte des kirchlichen Unterrichts in der evangelischen Kirche Deutschlands zwischen 1530 und 1600]. Gütersloh: C. Bertelsmann, 1911.

Rhenanus, Beatus. Avtores Historiae Ecclesiasticae ... Basel: Hieronymus Froben and Nicolaus Episcopius, 1544

Ritter, Johann Balthasar, ed. Eigentliche und umstaendliche / Beschreibung / Des / Lebens / Handels und Wandels / der Streiten und Schrifften, wie auch / endlich des Todes / M. Mat. Flacii / Illyrici, / Ehemals beruehmten und sehr gelaehrten / Theologi in Teutschland: / Aus theils bekannten, theils bißher unbekannten / Uhrkunden, Schrifften und Brieffen, anderer / und seiner selbst / Zur Beleuchtung der Kirchen-Historie / Des XVI. Seculi, / Derfertiget, auch 
auff verschiedener Begehr... / zum Druck ueberlassen / Von / Johann Balthasar Ritter / Evangelischen Predigern in Franckfurth am Mayn. Frankfurt: Wolffgang Christoph Multzen, 1723.

- . M. Matthiae Flacii, Illyrici, Ehemahls beru(e)hmt und gela(e)hrten Theologi in Teutschland. Leben und End: Aus theils bekannt, theils unbekannten Uhrkunden, Schrifften und Brieffen, anderer und seiner selbst / Zur Erkla(e)uterung der Kirchen-Historie / Des XVI. Seculi, Mit sonderbarem Fleiß beschrieben Von Johann Balthasar Ritter, Evangelischen Predigern in Franckfurth am Mayn. Zweyte vermehrt und verbesserte Aufflage. Frankfurt and Leipzig: Johann Conrad, Maximilian Ziegler, 1725.

Sarcerius, Erasmus. In Matthaevm Evangelistam ivsta docta Scholia, per omnes rhetoricae artis ... Basel: Bartholomaeus Westheimer, 1544.

- . In Marcum evangelistam iusta scholia ... Basel: Bartholomaeus Westheimer, 1541.

- . Lvcae Evangelion cvm ivstis scholijs, per omnes circumstantias, Methodica forma consriptum ... Basel: Bartholomaeus Westheimer, 1540.

- . In D. Pavli Epistolas Ad Corinthios, eruditae ac piae meditations. Strasbourg: Wendel Rihel, 1544.

Schegk, Jakob. Philosophiae Natvralis (qvae Acroamata solitus fuit appellare Aristoteles) omnes disputations, ac uniuersa tractatio, duobus libris comprehensa ... Ad Iacobvm Schegkivm / Matthias Illyricus. Tübingen: Ulrich Morhardt d.Ä., 1538.

Schlüsselburg, Conrad, ed. Catalogi Haereticorum, Conradi Schlüsselbvrgii, SS. Theologiae Doctoris Et Professoris, ac in Ecclesia \& Gymnasio Stralesundensi, in Pomerania, Superintendentis, Liber XIII. \& vltimus. In qvo incredvlorvm Adiaphoristarum, \& fugitiuorum Interimistarum errores, apostasiae collusiones cum Antichristo Romano, \& argumenta repetuntur \& refutantur, cum assertione verae sententiae quam Catholica complextitur Ecclesia. Frankfurt: Johann Saurius, 1599.

Schober, Bartholomäus. Kurtze vnd klare richtige Antwort / des Herrn Bartel Schoebers / weiland Burgers zu Regenspurg / Auff D. Caspars Melisanders / Pfarherrs zu Aldenburg / etc. vnklaren Bericht von der Erbsuende / damit Melisander die Einfeltigen je lenger je mehr verirret vnnd verwirret. Anno/ 1581. S. 1: 1581.

Schwenckfeld, Caspar. Der Wittenbergischen vnd Leiptzischen Theologen Judicium vnd zeügknus von dem frommen manne Jllyricus vnnd seinem gesellen N. Gallus. Mit auffdeckung ettlicher jhrer jrrthumb / Vnd widerlegung des buechlins wider Chaspar Schwenckfelden geschrieben. Ulm: Hans Varnier, 1553.

- Vom worte Gottes. Das khein ander wort Gottes sei / aigentlich zureden / denn der Suen Gottes Jesus Christus / Bewerung. Damit auch auff Matthie Flacij Jllyrici schmachbuechlen / mit auffdeckung seiner vilfaltigen Jrrthumb wirt geanthwurt. Jtem / Judicium vber Osianders leere von der Iustification. Durch Caspar Schwenckfeldt von Ossing. Augsburg: Hans Gegler, 1554.

- . Von der hailigen Schrifft / jrem Jnnhalt / Ampt / rechtem Nutz / Brauch vnd miszbrauch. Jtem / Vom vnderschaide der diener vnd prediger der hailigen Schrifft / vnd des worts Gottes. Was auch recht aigentlich Gottes wort sei. Hagenau: Sigmund Bund, 1551.

Serrarius, Johann. Das die Euangelischen Prediger gute wercke nicht verbieten noch verwerffen / wie sich Herr Boneuentur, Thomasprediger zu Dantzk in seinen Predigten zum oftermal hoeren lesst / ein kurtzer Bericht durch Joannem Serrarium. Mit einer Vorrede Matth. Flac. Jlli. Magdeburg: Michael Lotter, ca. 1555.

Siber, Paul. Epitaphivm Illvstrissimi Principis, ac Domini, D. Ioannis Friderici IIII. Filii Illvstriss: Principis, D. Ioan: Fridericii II. Dvcis Saxoniae, Landgravii Thvringae, Marchionis Misniae, Scriptvm a Pavlo Sibero. Jena: Donat Richtzenhan, 1560. 
Simler, Josias. Bibliotheca Institvta et collecta primvm a Conrado Gesnero, Deinde in Epitomen redacta \& nouorum Librorum accessione locupletata, iam vero postremo recognita, \& in duplum post priores editiones aucta, per Iosiam Simlerum Tigurinum. Zurich: Christoph Froschauer d.J., 1574.

Spangenberg, Cyriacus. Agenda. Christliche Kirchenordnung der Gemeine Gottes / so in Antdorff der waren / reinen / vnuerfelschten Augspurgischen Confession zugethan. Schmalkalden: Michael Schmuck, 1567.

- . Von dem Lindauwischen Colloquio / zwischen Doctor Jacob Andreen / vnd Herrn Tobia Ruppio / Anno 1575. Jm Augusto gehalten. M. Cyriacus Spangenberg. Oberursel: Nikolaus Henricus d.Ä., 1577.

Staphylus, Friedrich. Defensio pro Trimembri Theologia M. Lutheri, Contra Aedificatores Babylonicae Tvrris. Phil. Melanthonem. Shwenckfeldianum Longinum. And.

Musculum. Mat. Flacc. Illyricum. Iacobum Andream Shmidelinum. Authore Friderico Staphylo. Dillingen: Sebald Mayer, 1559.

-. Synodvs Sanctorvm Patrvm Antiquorum contra noua dogmata Andreae Osiandri. Nuremberg: Paul Fabricius, 1553.

Stifel, Michael. Von der Christfermigen / rechtgegründten leer Doctoris Martini Luthers / ain überuß schoen kunstlich Lied / sampt seyner neben außlegung. / Bruder Michael Styfel, Augustiner von Esszlingen. Augsburg: Erhard Oeglin, 1522.

Thaurer, Benedikt. Speculum coniugis ex capite 31. Proverbiorum Salomonis, in honorem sacri nuptialis, reuerendi ac docti viri, D. magistri Caspari Heldelini pastoris ecclesiae Cronbergensis, et castissimae uirginis Magdalenae, clarissimi viri D. magistri Cyriaci Spangenbergii filiae, carmine politum. Eisleben: Andreas Petri, 1577.

Timann, Johannes. Farrago Sententiarvm Consentientivm In Vera Et Catholica doctrina, de Coena Domini, quam firma assensione, \& uno spiritu, iuxta diuinam uocem, Ecclesiae Augustanae confessionis amplexae sunt, sonant \& profitentur: Ex Apostolicis scriptis: Praeterea ex Orthodoxorum tam ueterum, quam recentium perspicuis testimonijs, contra Sacramentariorum dissidentes inter se opiniones, diligenter \& bona fide collecta. Per Ioannem Timmanvm Amsterodamum, Pastorem Bremensem, in Ecclesia Martiniana. Vnà cum Indice rerum memorabilium. Frankfurt: Peter Brubach, 1555.

Truber, Primus. Catechismus / In der Windischenn Sprach / sambt einer kürzten Außlegung / in gesang weiß. Item die Litanai / vnd ein predig vom rechten / Glauben, gestelt, durch / Philopatridum / Illiricum. Anu kratku Poduuzhene skaterim / vsaki zhlouik more vnebu / pryti. Tübingen: Ulrich Morhart d.Ä., 1550.

Ursinus, Zacharias. Antapokrisis ad Heshusii et Flacii sectae responsa. 1564. In Quirinus Reuter and David Pareus, eds. Zacahriae Ursini ...Professoris in Academia Heidelberg et Neustadiana. Operum Theologicorum Tomi Duo. Heidelberg: Jonah Rosa, 1612.

- . Gründtlicher bericht Vom heiligen Abendmal vnsers Herren Jesu Christi / aus einhelliger Lere I der heiligen Schrifft / der alten rechtglaeubigen Christlichen kirchen / Vnd auch der Augspurgischen Confession. Gestellt Durch der Vniuersitet Heydelberg Theologen. Heidelberg: Johann Mayer, 1564.

Vergerio, Pietro Paolo, the Younger. A Brief Narrative of the Last Days and Awful Death of Francis Speira, Counsellor at Law. By the Right Rev: Peter Paul Vergerius, Bishop of Justinopolis. John H. Bernheim, ed. Elizabethtown, PA: W. M. Baxter, 1834. 
- . Epistola de morte Pauli Tertij Pont. Max. deque iis qvae ei post mortem eivs accidervnt. Basel: Johannes Oporinus, 1549.

-. Hevs Germani / Cognoscite ex hac epistola quid de uobis sentiat \& praedicet beatissimus Papa. Tum etiam uidete quale consilium / cum suis creaturis celebraturus sit. En tibe me hostem inquit Dominus exercituum, qui subducam fimbrias tibi supra faciem tuam, \& ostendam gentibus pudenda tua, renisque foeditatem tuam. Basel: Johannes Oporinus, 1551.

-. Was / vnnd wie man sich zue dem künfftigen Concilium zue Trydent / versaehen moege. Auch was gůtts dauon zue verhoffen. Bern: Matthias Apiarius, 1551.

Wagner, Marcus. Thüringer Königreichs / Das es für vnd nach Christi geburth in Pagos getheilet gewesen / wahrhafftiger / ... Mit einer beglaubten Vorrede / M. Cyriaci Spangenberg, Durch Marcvm VVagnervm Frimariensem Historicvm.... Jena: Tobias Steinmann, 1593.

Waldner, Wolfgang. Abfertigung / vnd gruendliche Widerlegung des vngegruendten Gegenberichts M. Josue Opitij / so er von der Erbsuende / seiner enturlaubung / von etlichen Specialhendeln / wider eines Erbarn Camerer vnd Raths der Stadt Regenspurg warhafften Bericht / am ende des 1578. Jars / hat meuchelisch in Druck außgehen lassen. Wolffgangus Waldner Kirchendiener zu Regenspurg. Regensburg: Johann Burger, 1580.

- . Antwort auff des Osianders Schmeckbier. S. 1: 1552.

- . Christlicher vnd Gruendtlicher bericht / Von der Rechtfertigung des Glaubens / Einwonung Gottes vnd Christi in vns. Der Ehrwirdigen / Gottseligen Herrn vnnd Euangelischer warheyt Lehrern. D. Martini Luthers heyliger gedechtnuß / Johannis Brentzij Ein seer schoene vnd troestliche predig / von der Rechtfertigung des glaubens ... vnnd Vrbani Regij Seligen ... von der Rechtfertigung. Nuremberg: Hans Daubman, 1550.

- . Ein Historia: Wie der Antichrist zu Rhom in diesem 1553. jar / abermal zween Christen jaemerlich ermoerdet hat. verdeutscht durch H. Wolfgangum Waldner. Coburg: Cyriacus Schnauß, 1554 .

Westphal, Joachim, ed. Confessio Fidei de Evcharistiae Sacramento, in qva Ministri Ecclesiarum Saxoniae solidis Argumentis sacrarum Literarum astruunt Corporis et Sanguinis Domini nostri Iesv Christi, praesentiam in Coena sancta, et de libro Ioannis Caluini ipsis dedicato respondent. Magdeburg: Ambrosius Kirchner d.Ä., 1557.

- . Farrago Confvsanearvm et inter se Dissidentivm Opinionum De Coena Domini, ex Sacramentariorum libris congesta, Per. M. Ioachimum westphalum, Past. Hamb. Magdeburg: Christian Rödinger d.Ä., 1552.

- . Loci Praecipvi, de VI, vsv, et Dignitate Salvtiferi Baptismi ex Euangelistis \& Apostolis collecti à Magistro Ioachimo Vuestphalo, Ecclesiae Hamburgensis Pastore. Strasbourg: Blasius Fabricius, 1556.

- . Recta Fides de Coena Domini, ex verbis Apostoli Pauli, \& Euangelistarum demonstrata ac communita, per Magistrum Ioachimum Vvestphalum Ecclesiae Hamburgensis Pastorem. Magdeburg: Michael Lotter, 1553.

Westphal, Joachim and Wolfgang Waldner. Confessio / oder Bekantnuss dess Glaubens vnd der Lehr / von dem Hochwirdigen Sacrament / dess waren Leibs vnnd Bluts Jhesu Christi / gestellet vnnd geschriben von den Christlichen Lehrern der Saechsischen Kirchen / auff das Buch Johannis Caluini / das er jnen dedicirt vnd zugeschriben hat. Erstlichen im Druck Lateinisch ausgegangen / jetzt aber trewlichen verteutschet. Durch Walffgangum Waldner. Regensburg: Heinrich Geißler, 1558.

- . Der rechte vngefelschte Glaub / von dem Hochwirdigen Sacrament des waren leybs vnd bluts vnsers Herrn Jesu Christi / bede auß den worten der heyligen Euangelisten / vnd des lieben 
Apostels Pauli / erstlich im Latein angezeygt vnd beschrieben. Durch. M. Joachimum Westphalum / Pfarrhern zu Hamburg. Jetzt aber auffs treulichste verdeutscht / von Wolffgango Waldner / der Christlichen Kirchen diener zu Nu(e)rnberg. Nuremberg: Georg Merkel, 1554; 2nd revised edition, Nuremberg: Georg Merkel, 1555.

Wigand, Johannes. De Manichaeismo Renovato. D. Iohannes VVigandvs Episcopus Pomezaniensis. Leipzig: Henning Grosse, 1587.

-. Gnwql seautov. Hoc est, De Homine Integro. Corrupto. Renato. Glorificato : Et de vicinis rebus, Simplex, dilucida, \& solida doctrina, ordine tradita in Academia Ienensi. Frankfurt: Peter Braubach, 1562. Translated by Basilius Faber, Erkenne dich selbst. Das ist Heyisame / nu(e) tzliche vnd no(e)tige Lere / von dem Menschen ... Erfurt: Georg Baumann d.Ä., 1563.

-. Von Zweyen Grewlichen / Gottslesterlichen Jrrthuemben / der Newen Manicheer... Regensburg: Johann Burger, 1574.

-. and Mattheus Judex. Octaua Centuria Ecclesiasticae Historiae, Continens Descriptionem Amplissimarvm Rervm in Regno Christi, quae Octauo post eius natiuitatem seculo acciderunt: cum Imperium Romanum gubernarent.... Basel: Johannes Oporinus and Johannes Herwagen, d.J., 1564.

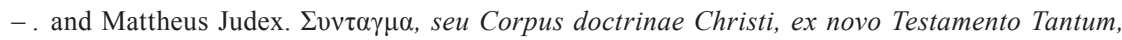
Methodica ratione, singulari fide \& diligentia congestum: per Iohannem Vvigandvm, et Matthaevm Ivdicem. Basel: Johannes Oporinus, 1558.

Wissenburg, Wolfgang and Matthias Flacius Illyricus. Antilogia Papae: hoc est, de corrupto Ecclesiae statu, \& totius cleri Papistici peruersitate, Scripta aliquot ueterum authorum, ante annos plus minus CCC, \& interea: nunc primùm in lucem eruta, \& ab interitu uindicata. Cum praefatione D. Vvolfgani Vuissenburgij Theologi Basiliensis. Basel: Johannes Oporinus, 1555.

Wittich, Hieronymus and Matthias Flacius Illyricus. Kurtze vnnd gru(e)ndtliche widderlegung der vier Schlusreden die Johan Sigmund / Werner / etwa Pfarherr zu Lignitz aus Schwenckfeldts $B u(\mathrm{e})$ chern gezogen / gestalt / vnd gericht hat wider die Christliche lehre vom dienst des Go(e) ttlichen worts vnd der hochwirdigen Sacrament Jesu Christi des Sons Gottes. durch Hieronymum Wittich. Jtem eine kurtze schrifft Matth. Flacij Illyrici. Magdeburg, 1555.

Witzel, Georg. Pvblicvm Ecclesiae Sacrvm. Von der Warheit der Altkyrchischen Liturgy vnd Opfferung das ist Catholischer Missen Antwort Georgij Wicelij Orthodoxi wider den Matthis Jllyric. zu Magdenburg. Köln: Johann Quentel, 1551.

Zigerius, Emerich and Matthias Flacius Illyricus. Epistola Cvivsdam Pii Concionatoris, ex Turcia, ad M. Illy. missa, qualis nam status Euangelij, \& Ecclesiarum sub Turco sit indicans, cum Praefatione Illyrici. Magdeburg: Christian Rödinger d.Ä., 1549.

- . Ein schrifft / eines fromen Predigers aus der Tuerckey an Jllyricum geschrieben / Darinnen angezeiget wird / wie es dort mit der Kirche vnd dem Euangelio zugehet. Magdeburg: Michael Lotter, 1550.

\section{Secondary Literature}

Andernach, Dietrich. »Beyer, Hartmann.« Neue Deutsche Biographie 2 (1955), 203.

Backus, Irena. Reformation Readings of the Apocalypse: Geneva, Zurich, and Wittenberg [Oxford Studies in Historical Theology]. New York: Oxford University Press, 2000. 
Bahlmann, Paul. »Wesling, Andreas.« Allgemeine Deutsche Biographie 42 (1897), 139.

Bahr, Ernst. »Brandes, Johann.« Neue Deutsche Biographie 2 (1955), 521.

Balázs, Mihály. Ungarländische Antitrinitarier IV: Ferenc Dávid [Bibliotheca Dissidentium: Répertoire des non-conformistes religieux des seizième et dix-septième siécles 26]. BadenBaden / Bouxwiller: Valentin Koerner, 2008.

Ballerstedt, Maren, Peter Petsch and Matthias Puhle, eds. Magdeburger Drucke des 16. Jahrhunderts. Ein Bestandeverzeichnis mit einer Einleitung von Michael Schilling. Halle: Mitteldeutscher Verlag, 2009.

Barnes, Robin Bruce. Prophecy and Gnosis: Apocalypticism in the Wake of the Lutheran Reformation. Stanford, CA: Stanford University Press, 1988.

Barton, Peter F. Um Luthers Erbe, Studien und Texte zur Spätreformation, Tilemann Heshusius (1527-1559) [Untersuchungen zur Kirchengeschichte 6]. Witten: Luther Verlag, 1972.

Bauch, Gustav. Valentin Trozendorf und die Goldberger Schule [Monumenta Germaniae Paedagogica 57]. Berlin: Weidmann, 1921.

Bauer, Karl. »Der Bekenntnisstand der Reichsstadt Frankfurt a. M. im Zeitalter der Reformation. V.«Arichv für Refomationsgeschichte 22 (1924): 39-101.

Baum, Wilhelm. »Der Klagenfurter Universitätsplan des Flacius Illyricus (1562) und der Flacianismus in Kärnten.« In Wilhelm Baum, ed. Kollegium, Lyzeum, Gymnasium. Vom »Collegium Sapientiae et Pietatis« zum Bundesgymnasium Völkermarkter Ring, Klagenfurt. Die Geschichte des ältesten Gymansiums Österreiches. Klagenfurt: Kärtner Druck- und Verlag, 1991, 33-44.

-. et al., eds. Konziliarismus und Humanismus: Kirchliche Demokratisierungbestrebungen im Spätmittelalterlichen Österreich. Wien: Turia and Kant, 1996.

Baumgarten, Hermann. Sleidans Briefwechsel. Strasbourg: Karl J. Trübner, 1881.

Baur, Jörg. »Flacius - Radikale Theologie.« Zeitschrift für Theologie und Kirche 72 (1975): $365-380$.

Bautz, Traugott, ed. »Flimmer, Johannes.« In Biographisch-Bibliographisches Kirchenlexikon 2 (1990), 60.

Bayle, Pierre. »Egnatius (Jean Baptiste).« In Dictionnaire Historique et Critique, Par Mr. Pierre Bayle. Cinquieme Edition. Vol. 2: C-I. Amsterdam et al., 1740, 345-346.

Beck, Hans-Georg. Der Vater der deutschen Byzantinistik. Das Leben des Hieronymus Wolf von ihm selbst erzählt [Miscellanea Byzantina Monacensia 29]. München: Institut für Byzantinistik und Neugriechisch, 1984.

Becker, Eduard Edwin. Die Riedesel zu Eisenbach: Geschichte des Geschlechts der Riedesel Freiherrn zu Eisenbach, Erbmarschälle zu Hessen. Vol. 3: Vom Tode Hermanns III. Riedesel 1501 bis zum Tode Konrads II. 1593. Offenbach am Main: Wilhelm Gerstung, 1927.

Berndorff, Lothar. Die Prediger der Grafschaft Mansfeld. Eine Untersuchung zum geistlichen Sonderbewusstsein in der zweiten Hälfte des 16. Jahrhunderts. Potsdam: Universitätsverlag, 2010.

Beuningen, Petrus Theodorus van. Wilhelmus Lindanus als inquisiteur en Bisschop: Bijdrage tot zijn biografie (1525-1576). Assen: van Gorcum, 1966.

Bezzel, Irmgard. »Joachim Heller (ca. 1520-1580) als Drucker in Nürnberg und Eisleben.« Archiv für die Geschichte des Buchwesens 37 (1992): 295-330.

-. Leonhard Heußler (1548-1597), Ein vielseitiger Nürnberger Drucker und Verbreiter von Neuigkeitsberichten [Buchwissenschaftliche Beiträge aus dem Deutschen Bucharchiv München 62]. Wiesbaden: Harrassowitz, 1999. 
Bibl, Viktor. »Der Briefwechsel zwischen Flacius und Nidbruck. Aus den Handschriften 9737 b, $\mathrm{i}$ und k der k. u. k. Hofbibliothek in Wien.« Jahrbuch der Gesellschaft für die Geschichte des Protestantismus in Österreich 17 (1896): 1-24; 18 (1897): 201-238; 19 (1898): 96-110; 20 (1899): 83-116.

- . »Melanchthon und Nidbruck. Aus der Handschriften 9737 i und k der k.k. Hofbibliothek in Wien.« Jahrbuch der Gesellschaft für die Geschichte des Protestantismus in Oesterreich 18 (1897): 34-47.

- . »Nidbruck und Tanner. Ein Beitrag zur Entstehungsgeschichte der Magdeburger Centurien und zur Charakteristik König Maximilians II.« Archiv für österreichische Geschichte 85 (1898): $379-430$.

Bierma, Lyle D., ed. An Introduction to the Heidelberg Catechism: Sources, History and Theology with a Translation of the Smaller and Larger Catechisms of Zacharias Ursinus [Texts and Studies in Reformation and Post-Reformation Thought]. Grand Rapids: Baker, 2005.

- . »What Hath Wittenberg to do with Heidelberg? Philip Melanchthon and the Heidelberg Catechism.« In Karin Maag, ed. Melanchthon in Europe: His Work and Influence Beyond Wittenberg [Texts and Studies in Reformation and Post-Reformation Thought]. Grand Rapids: Baker, 1999, 103-121.

Bietenholz, Peter G. »Simon Grynaeus of Veringendorf, c 1494 - 1 August 1541.« In Peter G. Bietenholz, ed. Contemporaries of Erasmus. 2 vols. Toronto: University of Toronto Press, 1986, 2: $142-146$.

- . ed. The Correspondence of Erasmus: Letters 594 to 841 (1517 to 1518). Vol. 5. Toronto: University of Toronto Press, 1979.

Bilokapić, Ante. »Die Erbsünde in der Lehre des M. Flacius Illyricus.« In Josip Matešić, ed. Matthias Flacius Illyricus: Leben \& Werk [Internationales Symposium, Mannheim, Februar 1991; Südosteuropa-Studien 53]. München: Südosteuropa-Gesellschaft, 1993, 43-52.

Blendinger, Friedrich. »Gasser (Gassarus), Achilles Pirminius.« Neue Deutsche Biographie 6 (1964), 79-80.

Bollbuck, Harald, ed. Historische Methode und Arbeitstechnik der Magdeburger Zenturien. Edition ausgewählter Dokumente [Editiones Electronicae Guelferbytanae 11]. Wolfenbüttel: Herzog August Bibliothek, 2012. http://diglib.hab.de/wdb.php?dir=edoc/ed000086.

Bonhoeffer, Dietrich. »Irrlehre in der Bekennenden Kirche? Gutachten, Stettin, Juni 1936.« In Eberhard Bethge, ed. Dietrich Bonhoeffer, Gesammelte Schriften II: Kirchenkampf und Finkenwalde. Resolutionen, Aufsätze, Rundbriefe 1933 bis 1943. München: Chr. Kaiser Verlag, 1959, 246-275.

Böhl, Eduard. Beiträge zur Geschichte der Reformation in Österreich. Hauptsächlich nach bisher unbenutzten Aktenstücken des Regensburger Stadtarchivs. Jena: Gustav Vischer, 1902.

Brady, Thomas A. Jr. German Histories in the Age of Reformations, 1400-1650. Cambridge: Cambridge University Press, 2009.

Brandy, Hans Christian. »Jakob Andreaes Fünf Artikel von 1568/69.« Zeitschrift fur Kirchengeschichte 98 (1987): 338-351.

Brodrick, James. Saint Petrus Canisius. Chicago: Loyola Press, 1988.

Bucsay, Mihály. »Ein Brief von Imre Eszéki an Flacius.« In Tibor Bartha, ed. Studia et Acta Ecclesiastica III. Budapest: A Magyarországi Református Egyház Zsinati Irodájának Sajtóosztálya, 1973, 905-910. 
Bunting, Ian D. »The Consensus Tigurinus.« Journal of Presbyterian History 44 (1966): 45-61.

Burchill, Christopher J. »In the Shadow of a Titan: Johann Marbach and the origins of confessional orthodoxy in Strasbourg, 1553-1563.« Unpublished paper presented at the Sixth International Congress of Luther Research. Erfurt, 1983.

- . »On the Consolation of a Christian Scholar: Zacharias Ursinus (1534-83) and the Reformation in Heidelberg.« Journal of Ecclesiastical History 37/4 (1986): 1-20.

Burckhardt, Andreas. Johannes Basilius Herold. Kaiser und Reich im protestantischen Schrifttum des Basler Buchdrucks um die Mitte des 16. Jahrhunderts [Basler Beiträge zur Geschichtswissenschaft 104]. Basel / Stuttgart: Helbing \& Lichtenhahn, 1967.

Burmeister, Karl Heinz. Achilles Pirmin Gasser 1505-1577: Arzt und Naturforscher, Historiker und Humanist. 3 vols. Wiesbaden: Guido Pressler, 1970-1975.

- . »Achilles Pirmin Gasser (1505-1577) as Geographer and Cartographer.« Imago Mundi 24 (1970): 57-62.

- . »Gasser (Gassarus), Achilles Pirmin.« In Wilhelm Kühlmann et al., eds. Frühe Neuzeit in Deutschland 1520-1620. Literaturwissenschaftiches Verfasserlexikon 1: Aal, Johannes - Chytraeus, Nathan. Berlin: De Gruyter, 2011, 528-535.

Bushbeck, Herman. »Des Matthias Flacius Illyricus Religionsgespräche auf Burglehnhaus und Schloss Lengenau im Jahre 1574.« Jahrbuch des Vereins für schlesische Kirchengeschichte 24 (1934): 3-23.

Buscher, Hans. Heinrich Pantaleon und sein Heldenbuch [Basler Beiträge zur Geschichtswissenschaft 26]. Basel: Helbing \& Lichtenhahn, 1946.

Campi, Emidio. »Zanchi, Hieronymus.« In Hans Dieter Betz et al., eds. Religion in Geschichte und Gegenwart. 4th ed. Tübingen: Mohr Siebeck, 2005, 8: 1780.

Campi, Emidio and Ruedi Reich, eds. Consensus Tigurinus (1549). Die Eingung zwischen Heinrich Bullinger und Johannes Calvin über das Abendmahl. Werden-Wertung - Bedeutung. Zurich: Theologischer Verlag, 2009.

Cavazza, Silvano. »Pier Paolo Vergerio e Flacio Illirico per Baldo Lupetino.« Quaderni giuliani di storia 26/1 (2005): 127-141.

Christman, J. Robert. Doctrinal Controversy and Lay Religiosity in Late Reformation Germany: The Case of Mansfeld [Studies in Medieval and Reformation Traditions]. Leiden / Boston: Brill, 2012.

Clemen, Otto. »Kaspar von Niedbruck als Büchersammler.« Zentralblatt für Bibliothekswesen 49 (1942): 168-169.

- . Kleine Schriften zur Reformationsgeschichte (1897-1944). Vol. 6. In Ernst Koch, ed. Leipzig: Zentralantiquariat der DDR, 1985.

- . »Zwei Briefe von Tübinger Universitätsprofessoren an Melanchthon.« Zeitschrift für Württembergische Landesgeschichte 4 (1940): 76-82.

Considine, John P. Dictionaries in Early Modern Europe: Lexicography and the Making of Heritage. New York: Cambridge University Press, 2008.

Coufal, Dušan. »Einletung.« In Jana Nechutová et al, eds. Magistri Iohannis Hus Enarratio Psalmorum (PS. 109-118) [Corpvs Christianorvm: Continuatio Mediaeulis 253] Turnhout: Brepols, 2013, IX-LXXI. 
Deutsch, Vlado L. »Flacijevci u slovenskoj reformaciji.« In Branko Lovrec, ed. Blizu ti je riječ: Spomen zbornik uz 75. obljetnicu života Josipa Horaka. Zagreb: Duhovna stvarnost, 1988, $105-124$.

Diener, Ronald E. »Johann Wigand (1523-1587).«In Jill Raitt, ed. Shapers of Religious Traditions in Germany, Switzerland, and Poland 1560-1600. New Haven: Yale University Press, 1981, 19-38.

-. The Magdeburg Centuries: A Bibliothecal and Historiographical Analysis. PhD diss., Cambridge, MA: Harvard Divinity School, 1979.

Diestelmann, Jürgen. Joachim Mörlin: Luthers Kaplan - „Papst der Lutheraner." Ein Zeit- und Lebensbild aus dem 16. Jahrhundert. Neuendettelsau: Freimund-Verlag, 2003.

Dieter, Theodor. Der junge Luther und Aristoteles. Eine historisch-systematische Untersuchung zum Verhältnis von Theologie und Philosophie [Theologische Bibliothek Töpelmann 105]. Berlin: Walter de Gruyter, 2001.

Dietz, Alexander. Frankfurter Handelsgeschichte. Vol. 3. Frankfurt: Knauer, 1921.

Dingel, Irene. »An patres et concilia possint errare. Georg Majors Umgang mit den Vätern.« In Leif Grane, Alfred Schindler and Markus Wriedt, eds. Auctoritas Patrum II, Neue Beiträge zur Rezeption der Kirchenväter im 15. und 16. Jahrhundert [Veröffentlichungen des Instituts für Europäische Geschichte Mainz 44]. Mainz: Philipp von Zabern, 1998, 51-66.

-. »Calvinism at the Borders of the Empire: Johannes Wigand and the Lutheran Reaction to Calvinism.« In Amy Nelson Burnett, ed. John Calvin, Myth and Reality: Images and Impact of Geneva's Reformer. Eugene: Cascade Books, 2011, 139-161.

-. Concordia Controversa. Die öffentlichen Diskussionen um das lutherische Konkordienwerk am Ende des 16. Jahrhunderts [Quellen und Forschungen zur Reformationsgeschichte 63]. Gütersloh: Gütersloher Verlagshaus, 1996.

- . »Die Bibelausgabe des Matthias Flacius Illyricus - ein Geschenk an Gasser.« In Bibliotheca Palatina: Katalog zur Ausstellung vom 8. Juli bis 2. November 1986, Heiliggeistkirche Heidelberg. Heidelberg: Edition Braus, 1986, 407-408.

- . »Die Kultivierung des Exulantentums im Luthertum am Beispiel des Nikolaus von Amsdorf.» In Irene Dingel, ed. Nikolaus von Amsdorf (1483-1565) zwischen Reformation und Politik [Leucorea-Studien zur Geschichte der Reformation und der Lutherischen Orthodoxie 9]. Leipzig: Evangelische Verlagsanstalt, 2008, 153-175.

-. »Flacius als Schüler Luthers und Melanchthons.« In Graf Gerhard, ed. Vestigia Pietatis. Studien zur Geschichte der Frömmigkeit in Thüringen und Sachsen. Festschrift für Ernst Koch [Herbergen der Christenheit 5]. Leipzig: Evangelische Verlagsanstalt, 2000, 77-93.

- . »Melanchthons Einigungsbemühungen zwischen den Fronten: der Frankfurter Rezeß.«In Jörg Haustein, ed. Philipp Melanchthon. Ein Wegbereiter für die Ökumene [Bensheimer Hefte 82]. Göttingen: Vandenhoeck \& Ruprecht, 1997, 119-141.

- . ed. Reaktionen auf das Augburger Interim: Der Interimistische Streit (1548-1549). [Controversia et Confessio. Theologische Kontroversen 1548-1577/80: Kritische Auswahledition. Vol. 1]. Göttingen: Vandenhoeck \& Ruprecht, 2010.

- . »The Culture of Conflict in the Controversies Leading to the Formula of Concord (1548-1580).« In Robert Kolb, ed. Lutheran Ecclesiastical Culture, 1550-1675. [Brill Companions to the Christian Tradition 11]. Leiden: Brill, 2008, 15-64. 
- . »The Preface of The Book of Concord as a Reflection of Sixteenth-Century Confessional Development.« Lutheran Quarterly 15/4 (2001): 373-395.

- . trans. »Vorrede zur Schrift des Matthias Flacius Illyricus »De voce et re fidei« ()Vom Wort und der Sache des Glaubens $\iota$ ) 1549/1563.« In Michael Beyer, Armin Kohnle and Volker Leppin, eds. Melanchthon deutsch IV: Melanchthon, die Universität und ihre Fakultäten. Leipzig: Evangelisches Verlagsanstalt, 2012, 175-184.

- . »Westphal, Joachim.« Theologische Realenzyklopädie 35 (2003), 712-715.

- . »Wigand, Joachim.« Theologische Realenzyklopädie 36 (2004), 33-38.

Dingel, Irene and Günther Wartenberg, eds. Georg Major (1502-1574). Ein Theologe der Wittenberger Reformation [Leucorea-Studien zur Geschichte der Reformation und der Lutherischen Orthodoxie 7]. Leipzig: Evangelische Verlagsanstalt, 2005.

-. eds. Politik und Bekenntnis. Die Reaktion auf das Interim von 1548 [Leucorea-Studien zur Geschichte der Reformation und der Lutherischen Orthodoxie 8]. Leipzig: Evangelische Verlagsanstalt, 2006.

Dilthey, Wilhelm. Studien zur Geschichte des deutschen Geistes. Gesammelte Schriften. Book III. Leipzig / Berlin: Tuebner, 1927.

Distel, Theodor. Der Flacianismus und die Schönburg'sche Landesschule zu Geringswalde. Leipzig: Johann Ambrosius Barth, 1879.

- . »Haubold, Hieronymus.« Allgemeine Deutsche Biographie 11 (1880), 42-43.

Döllinger, Ignaz, von. Die Reformation, ihre innere Entwicklung und ihre Wirkungen im Unfange des Lutherischen Bekenntnisess. 2 vols. Regensburg: Verlag von G. Joseph Manz, 1848.

Dorchenas, Ingeborg. «Johannes Pappus.« In Biographisch-Bibliographisches Kirchenlexikon 6 (1993), 1497-1502.

Edwards, Mark U., Jr. Luther's Last Battles: Politics and Polemics, 1531-46. Ithaca and London: Cornell University Press, 1983.

Ehmann, Johannes. Luther, Türken und Islam. Eine Untersuchung zum Türken- und Islambild Martin Luthers (1515-1546) [Quellen und Forschungen zur Reformationsgeschichte 80]. Gütersloh: Gütersloher Verlagshaus, 2008.

Ehmer, Hermann. »Bonifatius Wolfhart, ein reformatorischer Theologe aus Buchen.« In Rainer Trunk, Helmut Brosch, Karl Lehrer, eds. 700 Jahre Stadt Buchen. Beiträge zur Stadtgeschichte. Buchen: Verlag Odenwälder, 1980, 211-231.

- . »Erhard Schnepf. Ein Lebensbild.« Blätter für württembergische Kirchengeschichte 87 (1987): 72-126.

- . »Erhard Schnepf(f).« Neue Deutsche Biographie 23 (2007), 320-321.

Ehwald, Rudolf. »Johannes Fraxineus, ein verschollener Freund des Flacius Illyrikus.« Mitteilungen der Vereinigung für Gothaische Geschichte und Altertumforschung (1922): 36-50.

Elze, Theodor Ludwig. Die Universität Tübingen und die Studenten aus Krain: Festschrift zur vierten Säcularfeier der Eberhard-Karls-Universität. Tübingen: Franz Fues, 1877; reprint in [Geschichte, Kultur und Geisteswelt der Slowenen 14]. München: Rudolf Trofenik, 1977.

-. Geschichte der protestantischen Bewegungen und der Deutschen evangelischen Gemeinde in Venedig. Bielefeld: Druck von Velhagen und Klasing, 1883. 
- . »Skalich, Paul.« Allgemeine Deutsche Biographie 34 (1892), 443-444.

Erbe, Michael. François Bauduin (1520-1573). Biographie eines Humanisten [Quellen und Forschungen zur Reformationsgeschichte 46]. Gütersloh: Gerd Mohn, 1978.

Faselius, Johann Adolph Leopold. Neueste Beschreibung der herzoglich Sächsischen Residenzund Universitäts-Stadt Jena. Jena: Prager, 1805.

Feine, Hans Erich. »Gremp von Freudenstein, Ludwig.» Neue Deutsche Biographie 7 (1966), $44-45$.

Ficker, Johannes and Otto Winckelmann. Handschriftenproben des sechzehnten Jahrhunderts nach Strassburger Originalen. Zweiter Band. Tafel 47-102. Zur geistigen Geschichte. Strasbourg: Karl J. Trübner, 1905.

-. Kleine Ausgabe: 35 Tafeln in Lichtdruck mit Transcriptionen und biographischen Skizzen. Strasbourg: Karl J. Trübner, 1906.

Fine, John Van Antwerp. When Ethnicity Did Not Matter in the Balkans: A Study of Identity in PreNationalist Croatia, Dalmatia, and Slavonia in the Medieval and Early-Modern Periods. Ann Arbor, MI: University of Michigan Press, 2006.

Fligge, Jörg Rainer. Herzog Albrecht von Preussen und der Osiandrismus, 1522-1568. Bonn: Friedrich Wilhelm University, 1972.

Förstemann, Karl Eduard, ed. Album Academiae Vitebergensis. Vol. 1: 1502-1560. Tübingen: Max Niemeyer, 1976.

Fraenkel, Pierre. »Matthias Flacius Illyricus and his Gloss on Hebrews 9.« The Journal of Medieval and Renaissance Studies 14/1 (1984): 97-111.

Frank, Christina Beatrice Melanie. Untersuchungen zum Catalogus testium veritatis des Matthias Flacius Illyricus. PhD diss., Tübingen: Eberhard-Karls-Universität, 1989.

Frank, Gustav. »Opitz, Josua.« Allgemeine Deutsche Biographie 24 (1886), 369-370.

Frensdorff, Ferdinand. „Gasser, Achilles Pirmin.« Allgemeine Deutsche Biographie 8 (1878), 396-397.

Fricke, Friederike. Luthers Kleiner Katechismus in seiner Einwirkung auf die katechetische Litteratur des Reformationsjahrhunderts. Göttingen: Vandenhoeck \& Ruprecht, 1898.

Friedensburg, Walter. »Die Anstellung des Flacius Illyricus an der Universität Wittenberg.« Archiv für Reformationsgeschichte 11 (1914): 302-310.

- . »Ein Brief Aurifabers an Flacius (1549).« Archiv für Reformationsgeschichte 20 (1923): 62-65.

Friedrich, Markus. »Orthodoxy and Variation: The Role of Adiaphorism in Early Modern Protestantism. . In Randolph C. Head and Daniel Christensen, eds. Orthodoxies and Heterodoxies in Early Modern German Culture: Order and Creativity 1500-1750 [Studies in Central European Histories 42]. Leiden / Boston: Brill, 2007, 45-68.

Frost, Reinhard. »Beyer, Hartmann.« In Wolfgang Klötzer, ed. Frankfurter Biographie 1: $A-L$. Personengeschichliches Lexikon [Veröffentlichungen der Frankfurter Historischen Kommission 19/1]. Frankfurt: Waldemar Kramer, 1994, 68-69.

-. »Petreus, Heinrich.« In Wolfgang Klötzer, ed. Frankfurter Biographie 2: M-Z. Personengeschichliches Lexikon [Veröffentlichungen der Frankfurter Historischen Kommission 19/2]. Frankfurt: Waldemar Kramer, 1996, 131. 
Gadamer, Hans-Georg. »Die Universalität des hermeneutischen Problems.« Philosophisches Jahrbuch 73 (1966): 215-225.

Gantet, Claire. »Dreams, Standards of Knowledge and `Orthodoxy८ in Germany in the Sixteenth Century.« In Randolph C. Head and Daniel Christensen, eds. Orthodoxies and Heterodoxies in Early Modern German Culture: Order and Creativity 1500-1750 [Studies in Central European Histories 42]. Leiden / Boston: Brill, 2007, 69-87.

Gehrt, Daniel. Ernestinische Konfessionspolitik. Bekenntnisbildung, Herrschaftskonsolidierung und dynastische Identitätsstiftung vom Augsburger Interim 1548 bis zur Konkordienformel 1577 [Arbeiten zur Kirchen- und Theologiegeschichte 34]. Leipzig: Evangelische Verlagsanstalt, 2011.

- . »Zum besseren vnd gründtlicheren verstandt des Catechismi Lutheri. Das Kleine Corpus Doctrinae des Matthäus Judex.« In Gerlinde Huber-Rebenich, ed. Lehren und Lernen im Zeitalter der Reformation [Spätmittelalter und Reformation 68]. Tübingen: Mohr Siebeck, 2012, 149-199.

Gehrt, Daniel and Volker Leppin, eds. Paul Eber (1511-1569): Humanist und Theologe der zweiten Generation der Wittenberger Reformation [Leucorea-Studien zur Geschichte der Reformation und der Lutherischen Orthodoxie 16]. Leipzig: Evangelische Verlagsanstalt, 2014.

Gensichen, Hans-Werner. We Condem: How Luther and 16th-Century Lutheranism Condemned False Doctrine. Translated by Herbert J. A. Bouman. St. Louis: Concordia, 1967.

Gindely, Anton. Böhmen und Mähren im Zeitalter der Reformation I: Geschichte der Böhmischen Brüder. Vol. 2: (1564-1609). Prague: Carl Bellmann, 1858.

- Quellen zur Geschichte der Böhmischen Brüder vornemlich ihren Zusammenhang mit Deutschland betreffend. Vol. 2. Wien: Kaiserlich-Königlich Hof- und Staatsdruckerei, 1859.

Goeters, Johann Friedrich Gerhard. »Caspar Olevianus als Theologe.« Monatshefte für Evangelische Kirchengeschichte des Rheinlandes 37/38 (1988/1989): 287-344.

- . »Ein Brief des Grafen Hermann von Neuenahr an den lutherischen Theologen Matthias Flacius Illyricus.« Monatshefte für evangelische Kirchengeschichte des Rheinlandes 9 (1960): 54-58.

Goetz, Walter and Leonhard Theobald, eds. Beiträge zur Geschichte Herzog Albrechts V. und der sog. Adelsverschwörung von 1563 [Briefe und Akten zur Geschichte des sechzehnten Jahrhunderts mit besonderer Rücksicht auf Baierns Fürstenhaus 6]. Leipzig: Tuebner, 1913.

Grbac, Vilim. Crkva rođenja Blažene Djevice Marije. Labin: Matthias Flacius, 1988.

Gunnoe, Charles D., Jr. Thomas Erastus and the Palatinate: A Renaissance Physician in the Second Reformation [Brill's Series in Church History 48]. Leiden: Brill, 2011.

Hagen, Kenneth G. «)De Exegetica Methodo〈: Niels Hemmingsen’s De Methodis.« In David Steinmetz, ed. The Bible in the Sixteenth Century [Duke Monographs in Medieval and Renaissance Studies]. Durham, NC: Duke University Press, 1996, 181-196.

- Hebrews Commenting from Erasmus to Bèze, 1516-1598 [Beiträge zur Geschichte der biblischen Exegese 23]. Tübingen: Mohr Siebeck, 1981.

Haikola, Lauri. Gesetz und Evangelium bei Matthias Flacius Illyricus: Eine Untersuchung zur lutherischen Theologie vor der Konkordienformel [Studia Theologica Lundensia 1]. Lund: CWK Gleerup, 1952.

Hannemann, Kurt. »Der Humanist Georg Fabricius in Meissen, das Luthermonotessaron in Wittenberg und Leipzig und der Heilandpreaefatiokodex aus Naumburg a.d. Saale. « Annali Sezione Germanica 17: Filologica Germanica. Napels: Ed. Intercontinentalia, 1974: 7-109. 
Hartmann, Martina. »Die Magdeburger Centurien und ihre wissenschaftliche Bedeutung.» In Eckhart W. Peters, ed. Die Magdeburger Centurien, vol. 1: Die Kirchengeschichtsschreibung des Flacius Illyricus. Dössel, Saalkreis: Janos Stekovics, 2007, 55-80.

-. Humanismus und Kirchenkritik: Matthias Flacius Illyricus als Erforscher des Mittelalters [Beiträge zur Geschichte und Quellenkunde des Mittelalters 19]. Stuttgart: Jan Thorbecke, 2001.

- . »Matthias Flacius Illyricus, die Magdeburger Centuriatoren und die Anfänge der quellenbezogenen Geschichtsforschung.« In Arno Mentzel-Reuters and Martina Hartmann, eds. Catalogus und Centurien: Interdisziplinäre Studien zu Matthias Flacius und den Magdeburger Centurien [Spätmittelalter, Humanismus, Reformation 45]. Tübingen: Mohr Siebeck, 2008, 1-17.

Hase, Karl Alfred von. »Morgenstern, Benedict.« Allgemeine Deutsche Biographie 22 (1885), $228-230$.

- . »Paulus Scalichius, der falsche Markgraf von Verona (1561-1565).« In Karl A. von Hase, Herzog Albrecht von Preussen und sein Hofprediger: eine Königsberger Tragödie aus dem Zeitalter der Reformation. Leipzig: Breitkopf und Härtel, 1879, 287-330.

Hase, Hans Christoph von. Die Gestalt der Kirche Luthers. Der casus confessionis im Kampf des Matthias Flacius gegen das Interim von 1548. Göttingen: Vandenhoeck \& Ruprecht, 1940.

-. Der status confessionis in den Streitschriften um das Augsburger Interim von 1548. STM thesis. New York City: Union Theological Seminary, 1934.

Hasse, Hans-Peter. »Georg Major als Professor der Leucorea. Identifikation mit der Wittenberger Reformation.« In Irene Dingel and Günther Wartenberg, eds. Georg Major (1502-1574). Ein Theologe der Wittenberger Reformation [Leucorea-Studien zur Geschichte der Reformation und der Lutherischen Orthodoxie 7]. Leipzig: Evangelische Verlagsanstalt, 2005, 41-68.

Hauser, Angelika. Pietro Paolo Vergerios protestantische Zeit. PhD diss., Tübingen: EberhardKarls-Universität,1980.

Haußleiter, Johannes. »Matthias Flacius als Herausgeber von Luthers Koburger Briefen und Trostsprüchen (1530).« Neue Kirchliche Zeitschrift 28 (1917): 149-187.

Heijting, Willem. Profijtelijke boekskens. Boekcultuur, geloof en gewin. Historische Studies. Hilversum: Verloren, 2007.

Heinemann, Otto von et al. Die Handschriften der Herzoglichen Bibliothek zu Wolfenbüttel [Kataloge der Herzog-August-Bibliothek]. 9 vols. Wolfenbüttel, 1884-1903.

- . Die herzogliche Bibliothek zu Wolfenbüttel, 1550-1893: Ein Beitrag zur Geschichte deutchser Büchersammlungen mit einem Anhang von Dokumenten und Archivstücken. Zweite, völlig neugearbeitete Auflage. Wolfenbüttel, 1894. [Reprint, Amsterdam: Gérard Th. Van Heusden, 1969.]

Hendel, Kurt K. Introduction to and translation of A Christian Sermon over the Body and at the Funeral of the Venerable Dr. Martin Luther, Preached by Mr. Johann Bugenhagen Pomeranus, Doctor and Pastor of the Churches in Wittenberg. Atlanta: Pitts Theology Library, 1996.

Herrmann, Axel and Arnd Kluge, eds. Nikolaus Medler (1502-1551): Reformator-PädagogeMathematiker. Hof (Saale): Nordostoberfränkischer Verein für Natur-, Geschichts- und Landeskunde, 2003.

Herrmann, Rudolf. Thüringische Kirchengeschichte II. Weimar: Hermann Böhlaus Nachfolger, 1947 [reprint Waltrop: Hartmut Spenner, 2000].

Hertel, Gustav. »Zur Geschichte der heshusianischen Bewegung in Magdeburg.« GeschichtsBlätter für Stadt und Land Magdeburg: Mitteilungen des Vereins für Geschichte und Altertumskunde des Herzogtums und Erzstifts Magdeburg 34 (1899): 72-151. 
Hillerbrand, Hans J., ed. The Oxford Encyclopaedia of the Reformation. 4 vols. New York/Oxford: Oxford University Press, 1996.

Hirschmann, Gerhard. »Die zweite Nürnberger Kirchenvisitation 1560/61.« Zeitschrift für bayerische Kirchengeschichte 32 (1963): 111-132.

- . Kirchenvisitation im Landgebiet der Reichsstadt Nürnberg 1560/1. Quellenedition [Einzelarbeiten aus der Kirchengeschichte Bayerns 68]. Neustadt a.d. Aisch: Degener, 1994.

Hofmann, Siegfried. »Petrus Canisius und die Widerlegung der Magdeburger Centurien.« In Karl Batz, ed. Die Jesuiten in Ingolstadt: 1549-1773. Ausstellung des Stadtarchivs, der Wissenschaftlichen Stadtbibliothek und des Stadtmuseums Ingolstadt [12. Oktober 1991 bis 12. Januar 1992]. Ingolstadt: Stadtarchiv, 1991, 20-28.

Hofmann, Norbert. Die Artistenfakultät an der Universität Tübingen, 1534-1601 [Contubernium: Beiträge zur Geschichte Eberhard-Karls-Univesität Tübingen 28]. Tübingen: Mohr Siebeck, 1982.

Hollaender, Alcuin. »Der Theologe Matthias Flacius Illyricus in Strassburg in den Jahren 15671573.« Deutsche Zeitschrift für Geschichtswissenschaft, Neue Folge 2 (1898): 203-224.

Holtzmann, Heinrich. »Lasius, Christoph.« Allgemeine Deutsche Biographie 17 (1883), 733.

- . »Marbach, Johann.« Allgemeine Deutsche Biographie 20 (1884), 289-290.

- . »Niedbruck, Kaspar von.« Allgemeine Deutsche Biographie 52 (1906), 621-629.

Horning, Wilhelm. Dr. Johann Pappus von Lindau: 1549 - 1610: Münsterprediger, Universitätsprofessor und Präsident des Kirchenkonvents zu Straßburg; aus unbenuetzen Urkunden und Manuskripten. Strasbourg: J.H.E. Heitz, 1891.

- . Dr. Johannes Marbach, Pfarrer zu St. Nikolai, Münsterprediger, Professor und Präsident des lutherischen Kirchenkonvents in Straßburg 1545-1581. Strasbourg: C.A. Vomhoff, 1887.

Hubert, Friedrich. Vergerios publizistische Thätigkeit nebst einer bibliographischen Übersicht. Göttingen: Vandenhoeck \& Ruprecht, 1893.

Hund, Johannes. Das Wort ward Fleisch: Eine systematisch-theologische Untersuchung zur Debatte um die Wittenberger Christologie und Abendmahlslehre in den Jahren 1567 bis 1574 [Forschungen zur systematische und ökumenischen Theologie 114]. Göttingen: Vandenhoeck \& Ruprecht, 2006.

-. »Kryptocalvinismus oder Kryptophilippismus? Die Wittenberger Abendmahlslehre und Christologie in den Jahren 1567-1574.« In Irene Dingel and Armin Kohnle, eds. Philipp Melanchthon. Lehrer Deutschlands, Reformator Europas [Leucorea-Studien zur Geschichte der Reformation und der Lutherischen Orthodoxie 13]. Leipzig: Evangelische Verlagsanstalt, 2011, 271-288.

Hund, Johannes and Henning P. Jürgens. »Pamphlets in the Theological Debates of the Later Sixteenth Century: The Mainz Editorial Project `Controversia et Confessio〈.« In Malcolm Walsby and Graeme Kemp, eds. The Book Triumphant. Print in Transition in the Sixteenth and Seventeenth Centuries [Library of the Written Word 15 - The Handpress World 9]. Leiden / Boston: Brill, 2011, 158-177.

Husner, Fritz. »Die Editio princeps des »Corpus Historiae Byzantinae.« Johannes Oporin, Hieronymus Wolf und die Fugger.« In Festschrift Karl Schwarber. Beiträge zur schweizerischen Bibliotheks-, Buch und Gelehrtengeschichte. Basel: B. Schwabe, 1949, 143-162.

Hülße, Friedrich Adolf. »Selbstbiographie eines Magdeburgers aus dem 16. Jahrhundert (Albert Rolevink). « Archiv des Vereins für Geschichte und Alterthümer der Herzogthümer Bremen und Verden und des Landes Hadeln zu Stade 10 (1884): 86-104. 
Ilić, Luka. »Beza and Flacius in the Sacramentarian Controversy.« In Irena Backus, ed. Théodore de Bèze (1519-1605): Actes du colloque de Genève (septembre 2005) [Travaux d'Humanisme et Renaissance 424]. Genève: Droz, 2007, 353-365.

-. »Bullingerjev vpliv na slovensko reformacijo « [Bullinger's Influence on the Reformation in Slovenia]. Stati inu obstati. Revija za vprašanja protestantizma 1-2 (2005): 72-81.

- . »Der heilige Mann und thewre held«: Flacius' View of Luther.« In Marina Miladinov in cooperation with Luka Ilić, eds. Matija Vlačić Ilirik III: Proceedings of the Third International Conference on Matthias Flacius Illyricus, Labin/Croatia, 2010. Labin: Grad Labin, 2012, 294-314.

- . »Flacius' Status Confessionis as an Inspiration for von Hase, Bonhoeffer and the Confessing Church in the Third Reich.« Unpublished paper delivered at the annual meeting of the American Academy of Religion in Chicago, November 3, 2008.

- . »Praeceptor Humanissimus et duo Illyri: Garbitius et Flacius.« In Irene Dingel and Armin Kohnle, eds. Philipp Melanchthon. Lehrer Deutschlands, Reformator Europas [LeucoreaStudien zur Geschichte der Reformation und der Lutherischen Orthodoxie 13]. Leipzig: Evangelische Verlagsanstalt, 2011, 65-79.

- . »Primus Truber (1508-1586), the Slovenian Luther.« Lutheran Quarterly 22/3 (2008): 268-277.

-. The Understanding of Sin in the Theology of Matthias Flacius Illyricus. Master of Arts thesis. Amsterdam: Vrije Universiteit, 2005.

Jacobs, Eduard. »Reiffenstein.« Allgemeine Deutsche Biographie 27 (1888), 691-693.

Jager, H. de. »Attestatie voor de predikanten van de Augsburgsche Confessie te Antwerpen, afgegeven door prins Willem I.« Studiën en Bijdragen op 't gebied der historische theologie 3 (1876): 550-551.

Janse, Wim. Albert Hardenberg als Theologe: Profil eines Bucer-Schülers [Studies in the History of Christian Thought 57]. Leiden: Brill, 1994.

-. »Die Melanchthonrezeption des Nonkonformisten Wilhelm Klebitz (ca. 1533-1568).« In Günter Frank and Herman J. Selderhuis, eds. Melanchthon und der Calvinismus [Melanchthon-Schriften der Stadt Bretten 9]. Stuttgart / Bad Cannstatt: Frommann-Holzboog, 2005, 257-289.

- . »Joachim Westphal's Sacramentology.« Lutheran Quarterly 22/2 (2008): 137-160.

- . »Non-conformist Eucharist Theology: The case of the alleged »Zwinglian Polemicist« Wilhelm Klebitz (c. 1533-68).« Nederlands Archief voor Kerkgeschiedenis / Dutch Review of Church History 81/1 (2001): 5-25.

- . »The Controversy between Westphal and Calvin on Infant Baptism, 1555- 1556.« Perichoresis 6/1 (2008): 3-43.

Janssen, Wibke. »Wir sind zum wechselseitigen Gespräch geboren« Philipp Melanchthon und die Reichsreligionsgespräche von 1540/41 [Forschungen zur Kirchen- und Dogmengeschichte 98]. Göttingen: Vandenhoeck \& Ruprecht, 2009.

Jauernig, Reinhold. »Forster, Johann.« Neue Deutsche Biographie 5 (1961), 304.

Junghans, Helmar. »Aurifaber, Johannes.« Theologische Realenzyklopädie 4 (1979), 752-55.

- . »Kryptocalvinismus.« Theologische Realenzyklopädie 20 (1990), 123-129.

- . »Major (Maier), Georg.« Neue Deutsche Biographie 15 (1987), 718-719. 
-. „Verzeichnis der Rektoren, Prorektoren, Dekane, Professoren und Schloßkirchenprediger der Leucorea vom Sommersemester 1536 bis zum Wintersemester 1574/75.« In Irene Dingel and Günther Wartenberg, eds. Georg Major (1502-1574) - Ein Theologe der Wittenberger Reformation [Leucoreastudien zur Geschichte der Reformation und der Lutherischen Orthodoxie 7]. Leipzig: Evangelische Verlagsanstalt, 2005, 235-270.

Jürgens, Henning P. »Die Beteiligung der beiden Preußen an den nachinterimistischen Streitigkeiten."Zeitschrift für Geschichte und Altertumskunde Ermlands: Beiträge zur Kirchen- und Kulturgeschichte des Preussenlands 55 (2011): 30-63.

- . »Druckschriften in den theologischen Debatten des späteren 16. Jahrhunderts: Die Datenbank der Mainzer Quellenedition zur Bekenntnisbildung und Konfessionalisierung (1458-1580).« In Irene Dingel and Günther Wartenberg, eds. Georg Major (1502-1574). Ein Theologe der Wittenberger Reformation [Leucorea-Studien zur Geschichte der Reformation und der Lutherischen Orthodoxie 7]. Leipzig: Evangelische Verlagsanstalt, 2005, 125-138.

- . »Hardenberg, Albert (Rizaeus).« In Martin Tielke, ed. Biographisches Lexikon für Ostfriesland. Aurich: Ostfriesische Landschaft, 2007, 182-186.

-. »Intra-Protestant Conflicts in 16th Century Poland and Prussia - The Case of Benedict Morgenstern. » In R. Ward Holder, ed. Calvin and Luther: The Continuing Relationship [Refo500 Academic Studies 12]. Göttingen: Vandenhoeck \& Ruprecht, 2013, 143-162.

- . Johannes a Lasco, 1499-1560 - Ein Europäer des Reformationszeitalters. Wuppertal: Foedus, 2004.

- . Johannes a Lasco in Ostfriesland. Der Werdegang eines europäischen Reformators [Spätmittelalter und Reformation 18]. Tübingen: Mohr Siebeck, 2002.

Karabaić, Iva. Posvetno pismo Matije Grbića prijevodu Eshilova Okovanog Prometeja. Undergraduate thesis, Department of Philosophy, The University of Zagreb, 1996.

Karo, Georg. »Das Lindauer Gespräch. Ein Beitrag zur Geschichte der Concordienformel.« Zeitschrift für Wissenschaftliche Theologie 45 (1902): 513-564.

Kattermann, Gerhard. »Ein Buchgeschenk des Flacius Illyricus aus dem Kreis der Otfried-Textüberlieferung und andere Überreste der Bücherei A. P. Gassers in der Badischen Landesbibliothek.« Neue Heidelberger Jahrbücher, Neue Folge (1939): 84-89.

Kaufmann, Thomas. Das Ende der Reformation. Magdeburgs »Herrgotts Kanzlei« (1548-1551/2) [Beiträge zur historischen Theologie 123]. Tübingen: Mohr Siebeck, 2003.

- . »Die Anfänge der Theologischen Fakultät Jena im Kontext der innerlutherischen Kontroversen zwischen 1548 und 1561.« In Volker Leppin, Georg Schmidt, and Sabine Wefers, eds. Johann Friedrich I. - der lutherische Kurfürst [Schriften des Vereins für Reformationsgeschichte 204]. Gütersloh: Gütersloher Verlaghaus, 2006, 209-258.

- . »Erfahrungsmuster in der frühen Reformation. «In Paul Münch, ed. »Erfahrung « als Kategorie der Frühneuzeitgeschichte [Historische Zeitschrift. Beiheft 31]. München: Oldenbourg, 2001, 281-306.

- . »Recess of Frankfurt.« In Klaus Ganzer and Bruno Steimer, eds. Dictionary of the Reformation. Translated by Brian McNeil [The Encyclopedia of Theology and Church]. New York: Crossroad, 2004, 119-120.

- . »WWie die Bücher und Schrifften ... Lutheri nützlich zu lesen.< Joachim Mörlins Anweisung zum Lutherstudium von 1565 und ihr historischer Kontext.« In Notger Slenczka and Walter Sparn, eds. Luthers Erben: Studien zur Rezeptionsgeschichte der reformatorischen Theologie Luthers. Festschrift für Jörg Baur zum 75. Geburtstag. Tübingen: Mohr Siebeck, 2005, 25-72. 
- . ») Our Lord God’s Chancery« in Magdeburg and Its Fight against the Interim.« Church History 73 (2004.): 566-582.

-. »Theologische Auseinandersetzungen an der Universität Königsberg im 16. und 17. Jahrhundert.« In Klaus Gerber, Manfred Komorowski and Axel E. Walter, eds. Kulturgeschichte Ostpreußens in der Frühen Neuzeit [Studien und Dokumente zur deutschen Literatur und Kultur im europäischen Kontext; Frühe Neuzeit 56]. Tübingen: Max Niemeyer, 2001, 243-318.

- . »Türckenbüchlein«: Zur christlichen Wahrnehmung »türkischer Religion« in Spätmittelalter und Reformation [Forschungen zur Kirchen- und Dogmengeschichte 97]. Göttingen: Vandenhoeck \& Ruprecht, 2008.

Kaul, Theodor. »Peter Patiens, der hierzulande `unübliche Papst‘.« Blätter für pfälzische Kirchengeschichte und religiöse Volkskunde 37/38 (1970-1971): 373-443.

Kawerau, Gustav. »Aurifaber, Johannes (Vratislaviensis).« Realenzyklopädie für protestantische Theologie und Kirche 3/2 (1897), 288-290.

-. »Eine Episode aus dem Kampfe der Flacianer mit den Melanchthonianern.« Theologische Studien und Kritiken. Eine Zeitschrift für das gesamte Gebiet der Theologie 55/1. Gotha: Friedrich Andreas Perthes, 1882, 324-343.

Keller, Rudolf. »Das Schriftverständnis bei Georg Major.« In Reinhold Mokrosch and Helmut Merkel, eds. Humanismus und Reformation: Historische, theologische und pädagogische Beiträge zur deren Wechselwirkung [Arbeiten zur Historischen und Systematischen Theologie 3]. Münster: Lit, 2001, 123-135.

- . Der Schlüssel zur Schrift. Die Lehre vom Wort Gottes bei Matthias Flacius Illyricus [Arbeiten zur Geschichte und Theologie des Luthertums, Neue Folge 5]. Hannover: Lutherisches Verlagshaus, 1984.

- . »Gnesiolutheraner.« Theologische Realenzyklopädie 13 (1984), 512-519.

Kess, Alexandra. Johann Sleidan and the Protestant Vision of History [St. Andrews Studies in Reformation History]. Aldershot / Burlington, VT: Ashgate, 2008.

Kidner, A. Gordon. »Antonio del Corro.« In André Séguenny, ed. Éloy Pruystinck, Sebastian Franck, Antonio del Corro [Bibliotheca Dissidentium: Répertoire des non-conformistes religieux des seizième et dix-septième siécles 7]. Baden-Baden / Bouxwiller: Valentin Koerner, 1986, 121-176.

Kittelson, James M. »Marbach vs Zanchi: The Resolution of Controversy in Late Reformation Strasbourg.« Sixteenth Century Journal 8 (1977): 31-44.

- . Toward an Established Church: Strasbourg from 1500 to the Dawn of the Seventeenth Century [Veröffentlichungen des Instituts für Europäische Geschichte 182]. Mainz: Philipp von Zabern, 2000.

Kluge, Rolf-Dieter. »Zum 500. Geburtstag des slowenischen Reformators Primus Truber.« Tübinger Blätter 94 (2007/2008): 26-34.

Klüpfel, Karl August. »Garbitius, Matthias.« Allgemeine Deutsche Biographie 8 (1878), 367.

Knoblich, Augustin. Chronik von Lähn und Burg Lähnhaus am Bober: Urkundliche Beiträge zur Geschichte der Städte, Ritterburgen, Fürsten und Adelsgeschlechter Schlesiens. Breslau: Aderholz, 1863.

Koch, Ernst. »Gnesiolutheraner.« In Religion in Geschichte und Gegenwart $3^{4}$ (2000), 1043; (2010), 29-36.

- . »Judex (Richter), Matthäus.« In Religion in Geschichte und Gegenwart $4^{4}$ (2001), 643. 
- . »Strigel, Victorin(us).« Theologische Realenzyklopädie 32 (2001), 252-255.

- . »Victorin Strigel (1524-1569). Von Jena nach Heidelberg.« In Heinz Scheible, ed. Melanchthon in seinen Schülern. Wiesbaden: Harrassowitz, 1997, 391-404.

Kohl, Wilhelm. »Thomas Illyricus (Th. v. Osimo, Th. Elysius, ital. Tommaso Illirico).« In Biographisch-Bibliographisches Kirchenlexikon 11 (1996), 1388-1390.

Kolb, Robert. »Andreae, Jakob.« In The Oxford Encyclopedia of the Reformation 1: 36-38.

-. Bound Choice, Election, and Wittenberg Theological Method: from Martin Luther to the Formula of Concord [Lutheran Quarterly Books]. Grand Rapids / Cambridge: Eerdmans, 2005.

- . »Dynamics of Party Conflict in the Saxon Late Reformation: Gnesio-Lutherans vs. Philippists.« The Journal of Modern History 49/3 (1977): 1289-1305.

-. For All the Saints: ChangingPerceptions of Martyrdom and Sainthood in the Lutheran Reformation. Macon, GA: Mercer University Press, 1987.

- . »Georg Major as Controversialist: Polemics in the Late Reformation." Church History 45/4 (1976): 455-468.

- . Martin Luther as Prophet, Teacher, and Hero: Images of the Reformer, 1520-1620 [Texts and Studies in Reformation and Post-Reformation Thought]. Grand Rapids: Baker, 1999.

- . »Matthaeus Judex's Condemnation of Princely Censorship of Theologians' Publications." Church History 50/4 (1981): 401-414.

-. »Matthias Flacius' Glossa Compendiaria: The Wittenberg Way of Exegesis in Its Second Generation.« In Marina Miladinov in cooperation with Luka Ilić, eds. Matija Vlačić Ilirik III: Proceedings of the Third International Conference on Matthias Flacius Illyricus, Labin $/$ Croatia, 2010. Labin: Grad Labin, 2012, 72-89.

- . »Musculus, Andreas.« In The Oxford Encyclopedia of the Reformation 3: 103.

- . »Nikolaus Gallus' Critique of Philip Melanchthon's Teaching on the Freedom of the Will.» Archiv für Reformationsgeschichte 91 (2000): 87-109.

- . Nikolaus von Amsdorf (1483-1565): Popular Polemics in the Preservation of Luther's Legacy [Bibliotheca Humanistica \& Reformatorica 26]. Nieuwkoop: B. De Graaf, 1978.

- . »Philipp's Foes, but Followers Nonetheless: Late Humanism among the Gnesio-Lutherans.« In Manfred P. Fleischer, ed. The Harvest of humanism in Central Europe: Essays in Honour of Lewis W. Spitz. St. Louis: Concordia, 1992, 159-177.

- . »Spangenberg, Cyriakus (1528-1604).«In The Oxford Encyclopaedia of the Reformation 4: 99-100.

-. »The Braunschweig Resolution: The Corpus Doctrinae Prutenicum of Joachim Morlin and Martin Chemnitz as an Interpretation of Wittenberg Theology.« In John M. Headley et al., eds. Confessionalization in Europe, 1555-1700: Essays in Honour of Bodo Nischan. Aldershot / Burlington, VT: Ashgate, 2004, 64-89.

- . »The First Protestant >Biblical Theology.< The Syntagma of Johannes Wigand and Matthaeus Judex.« In Torbjörn Johansson, Robert Kolb and Johann Anselm Steiger, eds. Hermeneutica Sacra. Studien zur Auslegung der Heiligen Schrift im 16. und 17. Jahrhundert-Studies of the Interpretation of Holy Scripture in the Sixteenth and Seventeenth Centuries [Historia Hermeneutica. Series Studia 9]. Berlin: Walter de Gruyter, 2010, 189-206.

Kopp, Manfred. Die Druckerei zu Ursel 1557-1623. Oberursel im Taunus: Stadt Oberursel, 1990.

- . Nicolaus Henricus und Cornelius Sutor: Bürger und Drucker zu Ursel. Oberursel: PharmaDruck Inge Hartmann, 1964. 
Kordić, Ivan. Hermeneutika Matije Vlačića Ilirika. Zagreb: August Šenoa, 1992.

-. „Vlačićev Gnothi seauton.« Prilozi za istraživanje hrvatske filozofske baštine 1-2 (1994): $137-155$.

Kos, Vedran. »Podlabin.« Istarska Enciklopedija. Zagreb: Leksikografski zavod Miroslav Krleža, $2005,603$.

Kostrenčić, Ivan, ed. Urkundliche Beiträge zur Geschichte der protestantischen Literatur der Südslaven in den Jahren 1559-1565. Wien: Carl Gerold's Sohn, 1874.

Körbler, Đuro. »Humanista Matija Grbić (Mathias Garbitius Illyricus).« In Rad Jugoslavenske akademije znanosti $i$ umjetnosti, Knjiga 145 [Razredi filologijsko-historijski i filosofijskojuridički 55]. Zagreb: Knjižara Jugoslavenske akademije, 1901.

Köstlin, Julius. Die Baccalaurei und Magistri der Wittenberger philosophischen Facultät 1518 1537 und die ordentlichen Disputationen 1536-1537. Aus der Facultätsmatrikel veröffentlicht. Halle: Max Niemeyer, 1888.

-. Die Baccalaurei und Magistri der Wittenberger philosophischen Fakultät 1538-1546 und die öffentlichen Disputationen derselben Jahre. Aus der Facultätsmatrikel veröffentlicht. Halle: Max Niemeyer, 1890.

Kötz, Gustav. Die Danziger Konkordienformel über das Heilige Abendmahl, Notel genannt, und ihre Apologie (1561-1567). Königsberg: H. Jaeger, 1901.

Krabbe, Otto. David Chyträus. Rostock: Adler's Erben, 1870.

Krabbel, Gerta. Paul Skalich. Ein Lebensbild aus dem 16. Jahrhundert [Geschichtliche Darstellungen und Quellen 1]. Münster: Borgmeyer, 1916.

Krause, Karl Ernst Hermann. »Henninges, Friedrich.« Allgemeine Deutsche Biographie 11 (1880), 778.

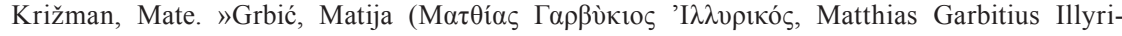
cus; Garbicius, Grbac, Ilirik).« In Trpimir Macan, ed. Hrvatski biografski leksikon 5, Gn-H. Zagreb: Leksikografski zavod Miroslav Krleža, 2002, 138-139.

Kropatscheck, Hans. Das Problem theologischer Anthropologie auf dem Weimarer Gespräch von 1560 zwischen Matthias Flacius Illyricus und Viktorin Strigel. ThD diss., Göttingen: GeorgAugust-Universität, 1943.

Krüger, Thilo. Empfangene Allmacht: die Christologie Tilemann Heshusens (1527-1588) [Forschungen zur Kirchen und Dogmengeschichte 87]. Göttingen: Vandenhoeck \& Ruprecht, 2004.

Kurihara, Ken. Wunderzeichen and Society in Late Reformation Germany: Lutheran Clergy and Celestial Wonders. PhD diss., New York City: Fordham University, 2010.

Leeb, Rudolf. »Der Einfluss von Cyriakus Spangenberg auf die habsburgischen Erblande und das Erzstift Salzburg. «In Stefan Rhein and Günther Wartenberg, eds. Reformatoren im Mansfelder Land: Erasmus Sarcerius und Cyriakus Spangenberg [Schriften der Stiftung Luthergedenkstätten in Sachsen-Anhalt 4]. Leipzig: Evangelische Verlagsanstalt, 2006, 259-277.

- . »Der Missionsgedanke bei Hans Ungnad von Sonneck, Primus Truber und in der lutherischen Reformation. . In Sašo Jerše, ed. Vera in hotenja: študije o Primožu Trubarju in njegovem času. Ljubljana: Slovenska matica, 2008, 256-272.

- . »Regensburg und das evangelische Österreich.« In Peter Schmid and Heinrich Wanderwitz, eds. Die Geburt Österreiches. 850 Jahre Privilegium minus [Regensburger Kulturleben 4]. Regensburg: Schnell und Steiner, 2007, 229-249. 
Leppin, Volker. Antichrist und Jüngster Tag. Das Profil apokalyptischer Flugschriftenpublizistik im deutschen Luthertum 1548-1618 [Quellen und Forschungen zur Reformationsgeschichte 69]. Gütersloh: Gütersloher Verlagshaus, 1999.

-. »Bekenntnisbildung als Katastophenverarbeitung. Das Konfutationsbuch als ernestinische Ortsbestimmung nach dem Tode Johann Friedrichs I.« In Volker Leppin, Georg Schmidt, and Sabine Wefers, eds. Johann Friedrich I. - der lutherische Kurfürst [Schriften des Vereins für Reformationsgeschichte 204 ]. Gütersloh: Gütersloher Verlaghaus, 2006, 295-306.

Leu, Urs B. Conrad Gesner als Theologe. Ein Beitrag zur Zürcher Geistesgeschichte des 16. Jahrhunderts [Zürcher Beiträge zur Reformationsgeschichte 14]. Bern: Herbert Lang, 1990.

Loesche, Georg. »Der Briefwechsel des Mathesius.«Jahrbuch der Gesellschaft für die Geschichte des Protestantismus in Oesterreich 11 (1890): 31-33; 49; 57-60.

Lohse, Bernhard. »Dogma und Bekenntnis in der Reformation: Von Luther bis zum Konkordienbuch.« In Carl Andresen, ed. Handbuch der Dogmen- und Theologiegeschichte. Göttingen: Vandenhoeck \& Ruprecht, 1980, 2: 125-129.

Loosjes, Jakob. Geschiedenis der Lutherische Kerk in der Nederlanden. 's-Gravenhage: Martinus Nijhoff, 1921.

Lowry, Martin J.C. »Giambattista Egnazio of Venice, 1473 - 4 July 1553.« In Peter G. Bietenholz, ed. Contemporaries of Erasmus. 2 vols. Toronto: University of Toronto Press, 1986, 1: 424-425.

- . The World of Aldus Manutius: Business and Scholarship in Renaissance Venice. Ithaca: Cornell University Press, 1979.

Loy-Bayreuth, Friedrich. »Der Flacianische Streit in Regensburg.» Zeitschrift für bayerische Kirchengeschichte 1 (1926): 6-29; 67-93.

Lyon, Gregory B. »Baudouin, Flacius, and the Plan for the Magdeburg Centuries.« Journal of the History of Ideas 64/2 (2003): 253-272.

Luciani, Tomaso. Mattia Flacio, Istriano di Albona. Notizie e documenti. Pula: Tipografia G. Seraschin, 1869.

Lund, Eric, ed. Documents from the History of Lutheranism 1517-1750. Minneapolis: Fortress, 2002.

Mahlmann, Theodor. »Melanchthon als Vorläufer des Wittenberger Kryptocalvinismus.« In Günter Frank and Herman J. Selderhuis, eds. Melanchthon und der Calvinismus [MelanchthonSchriften der Stadt Bretten 9]. Stuttgart / Bad Cannstatt: Frommann-Holzboog, 2005, 173-230.

- . »Musäus, Simon.« In Religion in Geschichte und Gegenwart $5^{4}$ (2002), 1591.

Maier, Helmuth. »Der Humanist Mathias Garbitius Illyricus.« Blätter für Württembergische Familienkunde 5, Heft 11/12 (1934): 105ff.

Marnef, Guido. Antwerp in the Age of Reformation: Underground Protestantism in a Commercial Metropolis, 1550-1577 [Johns Hopkins University Studies in Historical and Political Science 114]. Baltimore: Johns Hopkins University Press, 1996.

- . »Multiconfessionalism in a Commercial Metropolis: The Case of 16th-Century Antwerp.«In Thomas Max Safely, ed. A Companion to Multiconfessionalism in the Early Modern World [Brill Companions to the Christian Tradition 28]. Leiden / Boston: Brill, 2011, 75-97.

Massner, Joachim. Kirchliche Überlieferung und Autorität im Flaciuskreis. Studien zu den Magdeburger Zenturien [Arbeiten zur Geschichte und Theologie des Luthertums 14]. Berlin / Hamburg: Lutherisches Verlagshaus, 1964. 
Mayr, Josef Karl. »Michael Eichlers Leichenpredigt auf den Magister Josua Opitz.« Jahrbuch der Gesellschaft für die Geschichte des Protestantismus in Österreich 71 (1955): 68-72.

- . „Vom Geist des Hauses: der lutherische Landhausprediger Josua Opitz.« Jahrbuch der Gesellschaft für die Geschichte des Protestantismus in Österreich 71 (1955): 9-13.

Mägdefrau, Karl. »Lonicerus, Adam.« Neue Deutsche Biographie 15 (1987), 147-148.

Mencken, Johann Burkhard, ed. Scriptores rerum Germanicarum. Vol. 1. Leipzig: Martini, 1728.

Menčik, Ferdinand. »Caspar Nydbruck's Verhältnis zu den Calixtinern in Böhmen.« Jahrbuch der Gesellschaft für die Geschichte des Protestantismus in Oesterreich 18/1-2 (1897): 48-55.

Mennecke-Haustein, Ute. Conversio ad Ecclesiam. Der Weg des Friedrich Staphylus zurück zur vortridentinischen Katholischen Kirche [Quellen und Forschungen zur Reformationsgeschichte 74]. Gütersloh: Gütersloher Verlagshaus, 2003.

Mentz, Georg and Reinhold Jauernig, eds. Die Matrikel der Universität Jena: 1548 bis 1652. Vol. 1. [Veröffentlichungen der Thüringischen Historischen Kommission 1]. Jena: Gustav Fischer, 1944.

Mezger, Georg. «Wolf, Hieronymus.« Allgemeine Deutsche Biographie 43 (1898), 755-757.

Miculian, Antonio. Protestantizam u Istri (XVI.i XVII. stoljeće) u svjetlu novih arhivističkih istraživanja / Protestantismus in Istrien (16. und 17. Jahrhundert) im Lichte der neuesten archivistischen Forschungen. Pula: Zavičajna naklada Žakan Juri, 2006.

Mielke, Heinz-Peter. »Wolfhart, Bonifatius.» in Biographisch-Bibliographisches Kirchenlexikon 29 (2008), 1575.

Miladinov, Marina. »Mittelding or Idolatry? Veneration of Saints in Matthias Flacius Illyricus.» In Marina Miladinov, ed. Matija Vlačić Ilirik II: Papers from the Second International Conference on Matthias Flacius Illyricus, Labin / Croatia, 2006. Labin: Grad Labin, 2008, 75-107.

Milde, Wolfgang. »The Library at Wolfenbüttel, from 1550 to 1618.« The Modern Language Review 61/1 (1971): 101-112.

Miller, Gregory J. »Luther on the Turks and Islam.« In Timothy J. Wengert, ed. Harvesting Martin Luther's Reflections on Theology, Ethics, and the Church [Lutheran Quarterly Books]. Grand Rapids: Eerdmans, 2004, 185-203.

Mirković, Mijo. Matija Vlačić [Biblioteka portreti]. Beograd: Nolit, 1957.

-. Matija Vlačić Ilirik [Djela JAZU 50]. Zagreb: Izdavački zavod Jugoslovenske akademije znanosti i umjetnosti, 1960.

-. Matija Vlačić Ilirik [Istra kroz stoljeća II: 9-10]. 2 vols. Pula: Čakavski sabor - Istarska naklada; Rijeka: Liburnia, 1980.

- . Pokušaj Matije Vlačića Ilirika da osnuje sveučilište u Regensburgu i u Celovcu [Poseban otisak iz 300. knjige rada Jugoslovenske akademije znanosti i umjetnosti]. Zagreb, 1954, 537-573.

Mittler, Elmar. »Achilles Pirmin Gasser.« In Bibliotheca Palatina: Katalog zur Ausstellung vom 8. Juli bis 2. November 1986, Heiliggeistkirche Heidelberg. Heidelberg: Edition Braus, 1986, 398-399.

Moldaenke, Günther. Schriftverständnis und Schriftdeutung im Zeitalter der Reformation, Teil I: Matthias Flacius Illyricus [Forschungen zur Kirchen und Geistesgeschichte 9]. Stuttgart: W. Kohlhammer, 1936.

Moritz, Anja. Interim und Apokalypse. Die religösen Vereinheitlichungsversuche Karls V. im Spiegel der magdeburgischen Publizistik 1548-1551/52 [Spätmittelalter, Humanismus, Reformation 47]. Tübingen: Mohr Siebeck, 2009. 
Moser, Jakob. Schwäbische Chronick. 2 vols. Frankfurt: Metzler und Erhard, 1733.

Mrkonjić, Tomislav. »Slawische Bücher als Geschenke des Matthias Flacius Illyricus.« In Bibliotheca Palatina: Katalog zur Ausstellung vom 8. Juli bis 2. November 1986, Heiliggeistkirche Heidelberg. Heidelberg: Edition Braus, 1986, 408-410.

Mühlpfordt, Günter and Ulman Weiß, eds. Kryptoradikalität in der Frühneuzeit [FriedensteinForschungen 5]. Stuttgart: Franz Steiner Verlag, 2009.

Münnich, Franz. »Theodor Fabricius. Lebensbeschreibung des ersten anhaltischen Superintendenten. Unter Hinzufügung einer deutschen Übersetzung.« Zerbster Jahrbuch 16 (1931/32): 37-94.

Neumaier, Helmut. ')Exules Christi< in Franken - die Herren von Stetten und der Flacianismus. Das Zeugnis des Cyriacus Spangenberg.« Blätter für württembergische Kirchengeschichte 101 (2001): 13-48.

- . »Zum konfessionellen Verhalten der fränkischen Reichsritterschaft: Ort Odenwald im späten 16. Jahrhundert.« Zeitschrift für Württembergische Landesgeschichte 55 (1996): 109-130.

Neuser, Wilhelm H. »Der zweite Abendmahlsstreit.« In Carl Andresen, ed. Handbuch der Dogmen- und Theologiegeschichte: Die Lehrentwicklung im Rahmen der Konfessionalität. Göttingen: Vandenhoeck \& Ruprecht, 1988, 272-285.

- . »Heidelberger Katechismus von 1563.« In Mihály Bucsay, Emidio Campi et al., eds. Reformierte Bekenntnisschriften 2/2: 1562-1569. Neukirchen-Vluyn: Neukirchner Verlag, 2009, 167-212.

- . »Luther und Melanchthon - Ein Herr, verschiedene Gaben.« Luther Digest: An Annual Abridgment of Luther Studies 3 (1995): 60-64.

Newald, Richard. »Briefer, Nikolaus.« Neue Deutsche Biographie 2 (1955), 611.

Nicollier-De Weck, Béatrice. Hubert Languet (1518-1581): Un Réseau politique international de Melanchthon à Guillaume d'Orange [Travaux d'Humanisme et Renaissance 293]. Genève: Droz, 1995.

Niebler, Klaus. Bücher aus der Bibliothek des Augsburger Humanisten Achilles Pirmin Gasser (1505-1577) in der Stadtbibliothek Mainz. Eine Untersuchung von Restbeständen der Bibliotheca Palatina. Köln, 1973.

Nischan, Bodo. Prince, People, and Confession: The Second Reformation in Brandenburg. Philadelphia: University of Pennsylvania Press, 1994.

- . »The >Fractio Panis:« A Reformed Communion Practice in Late Reformation Germany.« Church History 53/1 (1984): 17-29.

Nüssel, Friederike. Allein aus Glauben: zur Entwicklung der Rechtfertigungslehre in der konkordistischen und frühen nachkonkordistischen Theologie [Forschungen zur systematischen und ökumenischen Theologie 95]. Göttingen: Vandenhoeck \& Ruprecht, 2000.

Nyhus, Paul L. »Grynaeus, Simon (1493-1541).« In The Oxford Encyclopedia of the Reformation 2: 200-201.

Olson, Oliver K. »Baldo Lupetino, Venetian Martyr.« Lutheran Quarterly 7 (1993): 7-18.

- . »The >Fractio Panis` in Heidelberg and Antwerp.« In Derk Visser, ed. Controversy and Conciliation: The Reformation and the Palatinate 1559-1583 [Pittsburgh Theological Monographs New Series 18]. Allison Park, PA: Pickwick Publications, 1986, 147-153. 
-. »Matthias Flacius Illyricus." In Jill Raitt, ed. Shapers of Religious Tradition in Germany, Switzerland and Poland, 1560-1600. New Haven / London: Yale University Press, 1981, 1-17.

-. Matthias Flacius and the Survival of Luther's Reform [Wolfenbütteler Abhandlungen zur Renaissanceforschung 20]. Wiesbaden: Harrassowitz, 2002.

Overell, Anne and Scott C. Lucas. »Whose wonderful news? Italian satire and William Baldwin's Wonderfull Newes of the Death of the Death of Paule the III.«Renaissance Studies 26/2 (2012): $180-196$.

Peterson, Luther D. »Johann Pfeffinger's Treatise of 1550 in Defense of Adiaphora: »High Church « Lutheranism and Confessionalization in Albertine Saxony.« In John M. Headley, Hans Joachim Hillerbrand and Anthony J. Papalas, eds. Confessionalization in Europe, 1555-1700. Essays in Honor and Memory of Bodo Nischan. Burlington, VT: Ashgate, 2004, 91-105.

- . »Justus Menius, Philipp Melanchthon, and the 1547 Treatise, Von der Notwehr Unterricht.« Archiv für Reformationsgeschichte 81 (1990): 138-157.

- . »Synergist Controversy.« In The Oxford Encyclopedia of the Reformation 4: 133-135.

Pflanz, Hans-Henning. Johann Stigel als Theologe (1515-1562). PhD diss, Breslau, 1936.

Pierce, Robert A. Pier Paolo Vergerio the Propagandist. [Uomini e dottrine 40]. Rome: Edizioni di storia e letteratura, 2003.

Pohlig, Matthias. »War Flacius Humanist?« In Arno Mentzel-Reuters and Martina Hartmann, eds. Catalogus und Centurien. Interdisciplinäre Studien zu Matthias Flacius und den Magdeburger Centurien [Spätmittelalter, Humanismus, Reformation, 45]. Tübingen: Mohr Siebeck, 2008, $19-52$.

Pont, Johannes W. De Luthersche kerken in Nederland. Vol. 2. Amsterdam: Swets \& Zeitlinger, 1929.

- . »Het kleine Corpus Doctrinae van D. Mattheus Judex opnieuw uitgegeven en van een inleiding en aantekenigen vorzien door Dr. J.W. Pont.« Nieuwe bijdragen tot kennis van de geschiedenis en het wezen van het Lutheranisme in de Nederlanden 4. Amsterdam, 1911.

Posset, Franz. »Marulić, Marko (Marcus Marulus).« Biographisch-Bibliographisches Kirchenlexikon 31 (2011), 942-947.

Preger, Wilhelm. Matthias Flacius Illyricus und seine Zeit. 2 vols. Erlangen: T. Bläsing, 1859-1861 [reprint: Hildesheim: Georg Olms and Nieuwkoop: B. de Graaf, 1964].

Pullapilly, Cyriac K. Caesar Baronius, Counter-Reformation Historian. Notre Dame / London: University of Notre Dame Press, 1975.

Raabe, Wilhelm. Unseres Herrgotts Canzlei. Braunschweig: Georg Westermann, 1862.

Raecke, Jochen. »Primus Truber als Autor und Übersetzer. Betrachtungen zum Thema literarische Originalität.«In Sönke Lorenz, Anton Schindling and Wilfried Setzler, eds. Primus Truber. 1508-1586 Der slowenische Reformator und Württemberg. Stuttgart: W. Kohlhammer, 2011, $119-144$.

Rajhman, Jože. Pisma slovenskih protestantov / Briefe der slowenischen Protestanten [Razred za filološke in literarne vede / Classis II: Philologia et Litterae. Korespondence pomembnih Slovencev / Epistulae Slovenorum illustrium 11]. Ljubljana: Slovenska akademija znanosti in umetnosti / Academia scientiarum et artium slovenica, 1997. 
Rädle, Herbert. »Simon Grynaeus (1493-1541): Briefe.« Basler Zeitschrift für Geschichte und Altertumskunde 90 (1990): 35-118.

Reichert, Ernst-Otto. Amsdorff und das Interim. Kommentierte Quellenedition mit ausführlicher historischer Einleitung. Nach dem maschinenschriftlichen Manuskript der Dissertation aus dem Jahre 1955 digital erfasst, für den Druck eingerichtet und um Register und bibliographische Nachträge ergänzt von Hans-Otto Schneider [Leucorea-Studien zur Geschichte der Reformation und der Lutherischen Orthodoxie 14]. Leipzig: Evangelische Verlagsanstalt, 2011.

Reske, Christoph. Die Buchdrucker des 16. und 17. Jahrhunderts im deutschen Sprachgebiet. Auf der Grundlage des gleichnamigen Werkes von Josef Benzing [Beiträge zum Buch- und Bibliothekswesen 51]. Wiesbaden: Harrassowitz, 2007.

Rhein, Stefan. »Johannes Stigel (1515/1562). Dichtung im Umkreis Melanchthons.« In Heinz Scheible, ed. Melanchthon in seinen Schülern. Wiesbaden: Harrassowitz, 1997, 31-49.

- . »Paul Eber aus Kitzingen: Schüler und Kollege Philipp Melantchthons.« Zeitschrift für bayerische Kirchengeschichte 80 (2011): 239-259.

Richter, Matthias. Gesetz und Heil: Eine Untersuchung zur Vorgeschichte und zum Verlauf des sogenannten Zweiten Antinomische Streits [Forschungen zur Kirchen- und Dogmengeschichte 67]. Göttingen: Vandenhoeck \& Ruprecht, 1996.

Ritter, Johann August von Eisenhart. »Tanner, Georg.« Allgemeine Deutsche Biographie 37 (1894), 382-383.

Roldan-Figueroa, Rady. »Antonio del Corro and Paul as the Apostle of the Universal Redemption.« In R. Ward Holder, ed. A Companion to Paul in the Reformation [Brill's Companions to the Christian Tradition 15]. Leiden / Boston: Brill, 2009, 389-425.

Ross, James Bruce. »Gasparo Contarini and His Friends.« Studies in the Renaissance 17 (1970): $192-232$.

-. „Venetian Schools and Teachers Fourteenth to Early Sixteenth Century: A Survey and a Study of Giovanni Battista Egnazio.« Renaissance Quarterly 29/4 (1976): 521-566.

Roth, F. Wilhelm E. »Des M. Flacius Illyricus Beziehungen zu den Städten Straßburg und Lindau. 1570-1572.«Zeitschrift für wissenschaftliche Theologie 54 (1912): 244-255.

Roth, Friedrich. »Der Augsburger Jurist Dr. Hieronymus Fröschel und seine Hauschronik von 1528-1600.«Zeitschrift des Historischen Vereins für Schwaben und Neuburg 38 (1912): 1-82.

- . »Der markgräfliche Kanzler Dr. Hieronymus Fröschel und sein Bericht über seine Kämpfe gegen die Konkordie und die Ansbacher Konkordisten (1577 und 1578).« Beitrage zur bayerischen Kirchengeschichte 17 (1911): 49-70; 105-123.

Rudersdorf, Manfred. »Herzog Ludwig (1568-1593).«In Robert Uhland, ed. 900 Jahre Haus Württemberg. Leben und Leistung für Land und Volk. Stuttgart: W. Kohlhammer, 1984, 163-173.

Russel, William R. »Aurifaber, Johannes.« In The Oxford Encyclopedia of the Reformation 1: $101-102$.

Scheible, Heinz. »Der Plan der Magdeburger Zenturien und ihre ungedruckte Reformationsgeschichte.«PhD diss., Heidelberg: Ruprecht-Karls-Universität, 1960.

- . ed. Die Anfänge der reformatorischen Geschichtsschreibung: Melanchthon, Sleidan, Flacius und die Magdeburger Zenturien [Texte zur Kirchen- und Theologiegeschichte 2]. Gütersloh: Gerd Mohn, 1966.

- . Die Entstehung der Magdeburger Zenturien. Ein Beitrag zur Geschichte der Methode [Schriften des Vereins für Reformationsgeschichte 183]. Gütersloh: Gerd Mohn, 1966. 
- . »Die Magdeburger Zenturien mit Widmungen für Gasser.« In Bibliotheca Palatina: Katalog zur Ausstellung vom 8. Juli bis 2. November 1986, Heiliggeistkirche Heidelberg. Heidelberg: Edition Braus, 1986, 410-411.

- . »Der Catalogus Testium Veritatis. Flacius als Schüler Melanchthons.« Blätter für pfälzische Kirchengeschichte und religiöse Volkskunde 63/30 (1996): 343-357.

Schilling, Heinz and Heribert Smolinsky, eds. Der Augsburger Religionsfrieden 1555. Wissenschaftilches Symposium aus Anlaß des 450. Jahrestages des Friedensschlusses, Augsburg 21. Bis 25. September 2005 [Schriften des Vereins für Reformationsgeschichte 206]. Gütersloh: Gütersloher Verlagshaus, 2007.

Schimmelpfennig, Adolf von. »Colerus, Jacobus.« Allgemeine Deutsche Biographie 4 (1876), 401-402.

Schindling, Anton. Humanistische Hochschule und Freie Reichstadt: Gymnasium und Akademie in Strassburg 1538-1621 [Veröffentlichungen des Instituts für Europäische Geschichte Mainz 77]. Wiesbaden: Franz Steiner, 1977.

Schmid, Eduard. »Des Flacius Erbsünde - Streit. Historisch-literarisch dargestellt: bis zum weimarischen Convent 1571.« Zeitschrift für die Historische Theologie 19/1 (1849): 3-78; 19/2: $218-279$.

Schmidt, Gustav Lebrecht. Justus Menius, Der Reformator Thüringens. Nach archivalischen und andern gleichzeitigen Quellen. Gotha: Friedrich Andreas Perthes, 1867.

Schmidt-Biggemann, Wilhelm. »Flacius Illyricus' »Catalogus testium veritatis« als kontroverstheologische Polemik.« In Günther Frank and Friedrich Niewöhner, eds. Reformer als Ketzer: Heterodoxe Bewegungen von Vorreformatoren [Melanchthon-Schriften der Stadt Bretten 8]. Stuttgart / Bad Cannstatt: Frommann-Holzboog, 2004, 263-291.

Schmidt-Grave, Horst. Leichenreden und Leichenpredigten Tübinger Professoren (1550-1750): Untersuchungen zur biographischen Geschichtsschreibung in der frühen Neuzeit [Contubernium 6]. Tübingen: Mohr, 1974.

Schneider, Heinrich. »Die Bibliotheksreisen des Marcus Wagner.« Zentralblatt für Bibliothekswesen 50 (1933): 678-682.

Schnelbögl, Fritz. »Sankt Sebald in Nürnberg nach der Reformation.« Zeitschrift für bayerische Kirchengeschichte 32 (1963): 155-172.

Schnurrer, Christian Friedrich. Erläuterungen der Würtembergischen Kirchen- Reformationsund Gelehrten Geschichte. Tübingen: J. G. Cotta'schen Buchhandlung, 1798.

Schornbaum, Karl. »Besold, Hieronymus.« Neue Deutsche Biographie 2 (1955), 179.

- . »Die brandenburgisch-nürnbergische Norma doctrinae 1573.« Archiv für Reformationsgeschichte 19 (1922): 161-193.

Schottenloher, Karl. »Handschriftenschätze zu Regensburg im Dienste der Zenturiatoren (15541562).« Zentralblatt für Bibliothekswesen 34 (1917): 65-82.

- . Das Regensburger Buchgewerbe im 15. und 16 Jahrhundert mit Akten und Druckverzeichnis [Veröffentlichungen der Gutenberg-Gesellschaft 14-19]. Mainz: Verlag der Gutenberg-Gesellschaft, 1920.

- . Pfalzgraf Ottheinrich und das Buch. Ein Beitrag zur Geschichte der evangelischen Publizistik. Mit Anhang: Das Reformationsschrifttum in der Palatina. Münster: Aschendorffschen Verlagsbuchhandlung, 1927.

Schöttgen, Johann Christian. »Leben Marcus Wagners, eines bekannten Thüringischen Historici und Pfarrers zu Buffleben.« Sammlung verschiedener Nachrichten zu einer Beschreibung des Kirchen- und Schulenstaats im Herzogthum Gotha 12. Gotha: Christian Mevius, 1757, 56-91. 
Schulte, Josef Wilhelm. »Beiträge zur Entstehungsgeschichte der Magdeburger Centurien.» Jahres-Bericht der Philomathie 19. Neisse: Graveur, 1877, 51-154.

Schultz, Selina Gerhard. Caspar Schwenckfeld von Ossig (1489-1561). Pennsburg, PA: The Board of Publication of the Schwenkfelder Church, 1977 [4th edition].

Schutte, Anne Jacobson. Pier Paolo Vergerio: The Making of an Italian Reformer [Travaux D'humanisme et Renaissance 160]. Genève: Droz, 1977.

Schwarz, Rudolf. Johannes Calvins Lebenswerk in seinen Briefen. Eine Auswahl von Briefen Calvins in deutscher Übersetzung. Zweiter Band: Die Briefe bis zum Jahre 1564. Tübingen: J.C.B. Mohr and Paul Siebeck, 1909.

Seebass, Gottfried. »Andreas Osiander d.Ä. und der Osiandrische Streit: Ein Stück preußischer Landes- und reformatorischer Theologiegeschichte.« In Dietrich Rauschning and Donata von Nerée, eds. Die Albertus-Universität zu Königsberg und ihre Professoren: Aus Anlaß der Gründung der Albertus-Universität vor 450 Jahren, Jahrbuch der Albertus-Universität zu Königsberg 29. Berlin: Duncker \& Humbolt, 1995, 33-48.

- . »Antichrist IV: Reformation und Neuzeit.« Theologische Realenzyklopädie 3 (1978), 28-43.

- . »Johannes Brenz und Andreas Osiander.« Blätter für württembergische Kirchengeschichte 100 (2000): $162-185$.

Seidel, Peter M. Michael Helding (1506-1561). Ein Bischof im Dienst von Kirche und Reich [Reformationsgeschichtliche Studien und Texte 157]. Münster: Aschendorff, 2012.

Seidel Menchi, Silvana, ed. Ketzerverfolgung im 16. und frühen 17. Jahrhundert [Wolfenbütteler Forschungen 51]. Wiesbaden: Harrassowitz, 1992.

Selle, Götz von. Geschichte der Albertus-Universität zu Königsberg in Preussen. Königsberg: Kanter-Verlag, 1944.

Sieh-Burens, Katarina. Oligarchie, Konfession und Politik im 16. Jahrhundert: zur sozialen Verflechtung der Augsburger Bürgermeister und Stadtpfleger 1518-1618 [Schriften der Philosophischen Fakultäten der Universität Augsburg 29]. München: Ernst Vögel, 1986.

Simon, Wolfgang, Berndt Hamm and Reinhold Friedrich, eds. Martin Bucer Correspondance 8 (April 1532 - August 1532) [Studies in Medieval and Reformation Traditions 153]. Leiden: Brill, 2011.

Simonsfeld, Henry. Der Fondaco dei Tedeschi in Venedig und die deutsch-venetianischen Handelsbeziehungen. Quellen und Forschungen. 2 vols. Stuttgart: Verlag der J.G. Cotta'schen Buchhandlung, 1887.

Sixt, Christian Heinrich. Dr. Paul Eber, der Schüler, Freund und Amtsgenosse der Reformatoren. Ein Beitrag zur Geschichte des Reformations-Zeitalters, mit XLIX Original-Urkunden. Heidelberg: Karl Winter, 1843.

Slenczka, Björn. Das Wormser Schisma der Augsburger Konfessionsverwandten von 1557. Protestantische Konfessionspolitik und Theologie im Zusammenhang des zweiten Wormser Religionsgesprächs [Beiträge zur historischen Theologie 155]. Tübingen: Mohr Siebeck, 2010.

Smedes, Egbert. $» D e$ Lutherse predikant Balthasar Houwaert als vermoedelijk dichter van het Wilhelmus [1525-1578?].« Tijdschrift voor geschiedenis 60/ 2-3 (1947): 129-155.

Smolinsky, Heribert. »Altgläubige Kontoverstheologen und das Interim.« In Irene Dingel and Günther Wartenberg, eds. Politik und Bekenntnis. Die Reaktion auf das Interim von 1548 [Leucorea-Studien zur Geschichte der Reformation und der Lutherischen Orthodoxie 8]. Leipzig: Evangelische Verlagsanstalt, 2006, 51-64.

Spieker, Christian Wilhelm. Lebensgeschichte des Andreas Musculus, General-Superintendent der Mark Brandenburg, Consistorialrath, Doctor und erster Professor der Theologie und 
Pfarrer zu Frankfurt an der Oder. Ein Beitrag zur Reformations- und Sittengeschichte des 16ten Jahrhunderts. Frankfurt an der Oder: Trowitzsch, 1858 [reprint: Nieuwkoop: B. de Graaf, 1964].

Spitz, Lewis W. »Review of Martin Stupperich’s book, Osiander in Preusen, 1549-1552.« Church History 43/3 (1974): 403-404.

- and Barbara Sher Tinsley, eds. Johann Sturm on Education: the Reformation and Humanist Learning. St. Louis: Concordia, 1995.

Stalmann, Joachim. »Schalling, Martin.« In Biographisch-Bibliographisches Kirchenlexikon 8 (1994), 1583-1585.

Steinmann, Martin. »Aus dem Briefwechsel des Basler Druckers Johannes Oporinus.« Basler Zeitschrift für Geschichte und Altertumskunde 69 (1969): 104-203.

-. Johannes Oporinus. Ein Basler Buchdrucker um die Mitte des 16. Jahrhunderts [Basler Beiträge zur Geschichtswissenschaft 105]. Basel / Stuttgart: Helbing \& Lichtenhahn, 1967.

Steitz, Georg Eduard. »Beyer, Hartmann.« Allgemeine Deutsche Biographie 2 (1875), 597-598.

- . »Der lutherische Prädicant Hartmann Beyer. Ein Zeitbild aus Frankfurts Kirchengeschichte im Jahrhundert der Reformation. «Archiv für Frankfurts Geschichte und Kunst 4 (1847): 100-146; 5 (1853): 49-110.

Stemberger, Herman. Labinska povijesna kronika: povijesne skice Kožljaka, Čepića, Kršana i Šumbera. Edited and translated by Tullio Vorano. Labin: Radničko sveučilište i Narodni muzej, 1983.

Stintzing, Roderich von. Georg Tanners Briefe an Bonifacius und Basilius Amerbach 1554-1567. Ein Beitrag zur Geschichte der Novellen-Editionen. Bonn: Adolph Marcus, 1879.

Strobel, Georg Theodor. »Nuernbergischer Ratschlag den unruhigen Flacium betreffend vom Jahr 1564. «In Beyträge zur Litteratur besonders des sechzehnten Jahrhunderts 1/20. Nuremberg / Altdorf: George Peter Monath, 1785, 405-412.

Stupperich, Martin. Osiander in Preussen 1549-1552 [Arbeiten zur Kirchengeschichte 44]. Berlin: Walter de Gruyter, 1973.

Talanga, Josip. »Paralipomena Dialectices des Matthias Flacius Illyricus.« In Josip Matešić, ed. Matthias Flacius Illyricus - Leben \& Werk. Internationales Symposium, Mannheim, Februar 1991 [Südosteuropa-Studien 53]. München: Südosteuropa-Gesellschaft, 1993, 111-138.

Teichmann, Albert. »Gremp von Freudenstein, Ludwig.« Allgemeine Deutsche Biographie 9 (1879), 637-638.

Thompson, John Lee. Reading the Bible with the Dead: What You Can Learn from the History of Exegesis That You Can't Learn from Exegesis Alone. Grand Rapids / Cambridge: Eerdmans, 2007.

Toepke, Gustav, ed. Die Matrikel der Universität Heidelberg. Vol. 1: von 1386 - 1553. Heidelberg: Carl Winter, 1884.

Troxler, Walter. »Ravesteyn, Josse od. Jodokus Tiletanus, Kontroverstheologe.« In BiographischBibliographisches Kirchenlexikon 7 (1994), 1422-1424.

Twesten, August Detlev. Matthias Flacius Illyricus, eine Vorlesung. Mit autobiographischen Beilagen und einer Abhandlung über Melanchthons Verhalten zum Interim von Hermann Rossel. Berlin: G. Bethge, 1844. 
Tylenda, Joseph N. »Calvin and Westphal: Two Eucharistic Theologies in Conflict.« In Wilhelm H. Neuser, Herman J. Selderhuis and Willem Van't Spijker, eds. Calvin's Books: Festschrift Dedicated to Peter De Klerk on the Occasion of His Seventieth Birthday. Heerenveen: J.J. Groen, 1997, 9-21.

-. »The Calvin - Westphal Exchange. The Genesis of Calvin's Treatises against Westphal.« Calvin Theological Journal 9/2 (1974): 182-209.

Ulenberg, Caspar. Geschichte der lutherischen Reformatoren Dr. Martin Luther's, Philipp Melanchthon's, Matthias Flacius Illyricus, Georg Major's und Andreas Osiander's. 2 vols. Mainz: Kirchheim, Schott und Thielman, 1836-1837.

- . Historia de vita, moribus, rebus gestis ac denique morte Praedicantium Lutheranorum, D. M. Lutheri, Ph. Melanchthonis, Matthiae Flacii Illyrici, Georgi Maioris et Andreae Osiandri. Köln: Gualterus, 1622.

Vainio, Olli-Pekka. Justification and Participation in Christ: The Development of the Lutheran Doctrine of Justification from Luther to the Formula of Concord (1580) [Studies in Medieval and Reformation Traditions 130]. Leiden / Boston: Brill, 2008.

Verkamp, Bernard J. »The Limits upon Adiaphoristic Freedom: Luther and Melanchthon.«Theological Studies 36/1 (1975): 52-76.

Vermaseren, Bernard Antoon. »The Life of Antonio del Coro (1527-1591) Before His Stay in England. I. In Spain and France.« Archives et Bibliothèques de Belgique. Archief-en Bibliotheekwezen in België 57 (1986): 530-568.

- .»The Life of Antonio del Coro (1527-1591) Before His Stay in England. II. Minister in Antwerp (Nov. 1566 - April 1567).« Archives et Bibliothèques de Belgique. Archief-en Bibliotheekwezen in België 59 (1990): 175-275.

Visser, Derk. Zacharias Ursinus: The Reluctant Reformer, His Life and Times. New York: United Church Press, 1983.

Vogel, Heinrich J. »The Flacian Controversy on Original Sin.« In Arnold J. Koelpin, ed. No Other Gospel: Essays in Commemoration of the 400th Anniversary of the Formula of Concord 1580-1980. Milwaukee, WI: Northwestern Publishing House, 1980, 1-15.

Vögel, Herfried. »Alberus, Erasmus.« In Wilhelm Kühlmann et al., eds. Frühe Neuzeit in Deutschland 1520-1620. Literaturwissenschaftliches Verfasserlexikon 1: Aal, Johannes - Chytraeus, Nathan. Berlin: De Gruyter, 2011, 87-99.

Voit, Hartmut. Nikolaus Gallus, Ein Beitrag zur Reformationsgeschichte der nachlutherischen Zeit [Einzelarbeit zur Kirchengeschichte Bayerns 54]. Neustadt a.d. Aisch: Degener, 1977.

Vollert, Max. »Basilius Monner, der erste Rechtslehrer an der Universität Jena.« Zeitschrift des Vereins für Thüringische Geschichte und Altertumskunde 30 (1933): 41-51.

Vögel, Herfried. »Alberus, Erasmus.«In Wilhelm Kühlmann et al., eds. Frühe Neuzeit in Deutschland 1520-1620. Literaturwissenschaftliches Verfasserlexikon 1: Aal, Johannes - Chytraeus, Nathan. Berlin: De Gruyter, 2011, 87-99.

Wackernagel, Hans Georg, ed. Die Matrikel der Universität Basel, vol. 2, 1532/33-1600/01. Basel: Verlag der Universitätsbibliothek, 1956. 
Wadl, Wilhelm, ed. Glaubwürdig bleiben: 500 Jahre protestantisches Abenteuer. Wissenschaftlicher Begleitband zur Kärntner Landesausstellung 2011 in Fresach [Archiv für vaterländische Geschichte und Topographie 101]. Klagenfurt am Wörthersee: Geschichtsverein für Kärnten, 2011.

Wagenmann, Julius August. »Heling, Moritz.« Allgemeine Deutsche Biographie 11 (1880), 690.

Waldeck, Oskar. »Die Publizistik des Schmalkaldischen Krieges.« Archiv für Reformationsgeschichte 7 (1909-1910): 1-55; 8 (1911-1912): 44-133.

Walther, Gerrit. Abt Balthasars Mission. Politische Mentalitäten, Gegenreformation und eine Adelsverschwörung im Hochstift Fulda [Schriftenreihe der Historischen Kommission bei der Bayerischen Akademie der Wissenschaften 67]. Göttingen: Vandenhoeck \& Ruprecht, 2002.

Wartenberg, Günther. »Das Augsburger Interim und die Leipziger Landtagsvorlage zum Interim.« In Irene Dingel and Günther Wartenberg, eds. Politik und Bekenntnis. Die Reaktion auf das Interim von 1548 [Leucorea-Studien zur Geschichte der Reformation und der Lutherischen Orthodoxie 8]. Leipzig: Evangelische Verlagsanstalt, 2006, 15-32.

Waschbüsch, Andreas. Alter Melanchthon: Muster theologischer Autoritätsstiftung bei Matthias Flacius Illyricus [Forschungen zur Kirchen- und Dogmengeschichte 96]. Göttingen: Vandenhoeck \& Ruprecht, 2008.

Weigelt, Horst. The Schwenkfelders in Silesia. Pennsburg, PA: Schwenkfelder Library, 1985.

Wendland, Henning, ed. Die Bibelsammlung der Ehemals Reichsstädischen Bibliothek Lindau (Bodensee) [Neujahrsblatt des Museumsvereins Lindau 48/49]. Lindenberg: Josef Fink, 2008.

Wengert, Timothy J. Defending Faith: Lutheran Responses to Andreas Osiander's Doctrine of Justification, 1551-1559 [Spätmittelalter, Humanismus, Reformation 65]. Tübingen: Mohr Siebeck, 2012.

- . »Georg Major (1502-1574). Defender of Wittenberg's Faith and Melanchthonian exegete.« In Heinz Scheible, ed. Melanchthon in seinen Schülern [Wolfenbütteler Forschungen 73]. Wiesbaden: Harrassowitz, 1997, 129-156.

-. Philip Melanchthon, Speaker of the Reformation: Wittenberg's Other Reformer [Variorum Collected Studies Series 963]. Farnham: Ashgate, 2010.

-. Philip Melanchthon's "Annotationes in Johannem « in Relation to its Predecessors and Contemporaries [Travaux d'Humanisme et Renaissance 220]. Genève: Droz, 1987.

- . »Philip Melanchthon's Gift to Caspar von Niedbruck.« Lutheran Quarterly 12 (1998): 485-489.

-. »We Will Feast Together in Heaven Forever: The Epistolary Friendship of John Calvin and Philip Melanchthon.« In Karin Maag, ed. Melanchthon in Europe: His Work and Influence beyond Wittenberg [Texts and Studies in Reformation and Post-Reformation Thought]. Grand Rapids: Baker, 1999, 19-44.

- . »With Friends Like This ... The Biography of Philip Melanchthon by Joachim Camerarius.« In Thomas F. Mayer and D.R. Woolf, eds. The Rhetorics of Life-Writing in Early Modern Europe: Forms of Biography from Cassandra Fedele to Louis XIV [Studies in Medieval and early Modern Civilization]. Ann Arbor: University of Michigan Press, 1995, 115-131.

Westermayer, Albert, Emil Wagner, and Theodor Demmler, eds. Die Grabdenkmäler der Stiftskirche zu St. Georg in Tübingen. Tübingen: Weil, 1912.

Wiechmann, Carl Michael. Das Kleine Corpus Doctrinae. Ein Katechismus aus Mecklenburg. Schwerin: Bärensprung, 1865.

Wotschke, Theodor. Geschichte der Reformation in Polen [Studien zur Kultur und Geschichte der Reformation 1]. Leipzig: Verein für Reformationsgeschichte, 1911. 
Zedler, Johann Heinrich. Grosses vollständiges Universal-Lexicon aller Wissenschaften und Kunste. Vol. 32: Ro-Rz. Halle / Leipzig: Johann Heinrich Zedler, 1742.

Zimmermann, Paul. »Petreus, Heinrich.« Allgemeine Deutsche Biographie 25 (1887), 519-520.

Zoepffel, Richard Otto. »Pappus, Johannes.« Allgemeine Deutsche Biographie 25 (1887), 163-164.

Zschäbitz, Gerhard. »Die Auswirkungen der Lehren Philipp Melanchthons auf die fürstenstaatliche Politik in der zweiten Hälfte des 16. Jahrhunderts.« In Philipp Melanchthon 1497-1560. Humanist, Reformator, Praceptor Germaniae. Berlin: Akademie-Verlag, 1963, 190-226.

Zuck, Lowell H., ed. Documents in Free Church History Christianity and Revolution: Radical Christian Testimonies 1520-1650. Philadelphia: Temple University Press, 1975.

Zwanepol, Klaas. »Lutheran-Reformed Unity in the Netherlands.«Lutheran Quarterly 11/4 (1995): 419-451.

\section{Website}

www.falcius.net 



\section{Index}

The numbers in italics refer to mentions occurring in the footnotes.

\section{Index of Names ${ }^{1}$}

Acontius, Melchior (1515-1569) 55

Aepinus, Johannes (1499-1553) 89, 114

Aeschylus (ca. $525 \mathrm{BC}-$ ca. $456 \mathrm{BC}$ ) 54

Agricola, Johannes(1494-1556) 32f., $75,77,90,90,95$

Agricola, Stephan (1491-1547) 40

Alard, Frans $(\dagger 1578) \quad 196$

Alber, Erasmus (ca. 1500-1553) 24, $88,88,114$

Albrecht of Brandenburg-Ansbach, Duke of Prussia (1490-1568, r. 1525-1568) 102, 108f., 108f., $113,182,182$

Albrecht VII, Count of MansfeldHinterort (1480-1560, r. 15011560) 102

Alighieri, Dante (1265-1321) 121

Altieri, Baldassare (ca. 1500-1550) 82f., $82 f$., 84

Ambrosiaster (ca. 366/384) 61

Amerbach, Bonifacius (1495-1562) 43, 125

Amsdorf, Nikolaus von, Bishop of Naumburg (1483-1565, r. $1542-$ 1546) 23f., $71,75,88,98,98 f$. .,
$102,102,110,114,129,136,138$, 162,162

Andreae, Jakob (1528-1590) 39, 46, $48,114,114,115,130,167,188,188$, 199, 202, 202, 213, 213, 219, 219, 225,225

Anna Sophia of Prussia, Duchess of Mecklenburg (1527-1591) 109

Aquila, Caspar (1488-1560) 75, 90, 143,144

Aristotle (384 BC-322 BC) 55, 68f., $68 f ., 125$

Ascerius, Franciscus 35

Asclepius Barbatus, Nikolaus (†1571) 203

Athanasius of Alexandria, Saint (ca. 296-373) 199

August I, Elector of Saxony (15261586, r. 1553-1586) 125, 143, 156f., 187, 200, 220, 220

Augustine, Bishop of Hippo (Aurelius Augustinus) (354-430, r. 395430) $169,189,203,205,211,220$

Aurifaber (Goldschmid; Vratislaviensis), Johannes (1517-1568) 87, 87, 110, 143f., 159f., 180, 182, 182

Aurifaber (Goldschmid; Vimariensis), Johannes (1519-1565) 143, 144f., $148,148,155,159$

1 Names of biblical persons, mythological figures and contemporary authors have not been included. Dates of birth, death and duration of reign are provided to the extent possible. This index does not include references to Matthias Flacius Illyricus, since his name appears on almost every page. 
Baier, Johann 41

Baldwin, William († 1563) 32, 81

Balsaráti Vitus, Johannes (15291575) 128

Bäris (Baerisius), Michael (15211571) 52

Barthen, Jakob von (ca. 1505-ca. 1565) 181,181

Barthold von Mandelsloh (†1580) 221

Baudoin, François (1520-1573) 125, 125

Baumgartner (Baumgärtner), Hieronymus (1498-1565) 54, 54

Baumgartner, Johannes (mentioned 1557) 129

Bembo, Pietro (1470-1547) 29

Bengel, Johann Albrecht (16871752) 215

Berg (Montanus), Johann vom († 1563) 101, 116

Bernhard of Lippe VIII, Count (15271563) 113

Bernoulli, Jacob (mentioned 1575) 226

Besler (Peßler), Michael (15121576) 176, 176, 178, 179

Besold (Petzolt), Hieronymus (15221562) 112, 178, 178f., 182

Beyer, Hartmann (1516-1577) 119, 119, 122f., 122f., 128, 195, 220, 226, 226

Beyer, Johann Hartmann (15631625) 183

Beza (de Bèze), Theodor (Théodore) (1519-1605) 104, 172, 184f., 201, 217

Bezold, Georg (1538-1598) 222
Biandrata, Giorgio (ca. 1515-ca. 1588) 104,104

Bibl, Viktor (1870-1947) 44

Bibliander, Theodor (1505-1564) 219

Bidenbach, Wilhelm (1538-1572) 199

Birkicht (Bürkicht), Andreas $\left({ }^{\circ} 1510\right)$ 88

Bodeker, Johannes († 1564) 128

Bodenstein, Anton (1517-1572) 181, 183

Boerhave, Marcus (1599-1654) 120

Bolzanio, Urbano (1443-1524) 61

Bonhoeffer, Dietrich (1906-1945) 131, 133

Bonomo, Pietro, Bishop of Trieste (1458-1546, r. 1502-1546) 80

Bonus, Joachim (†after 1577) 128

Brandes, Johann (1503-1577) 182

Brenz, Johannes (1499-1570) 94, $95,112,114,114,115,128,167,182$, 198, 202, 202

Bresnitzer, Alexius (1504-1581) 144

Bridget (Birgitta) of Sweden (13031373) 121

Briefer, Nikolaus (1484-1548) 50, 50

Brück, Christian (1517-1567) 150, 154

Brück, Gregor von (1484-1547) 31

Bucer, Martin (1491-1551) 40, 61, 203

Buchholzer, Georg (1503-1566) 32

Bugenhagen, Johannes (1485-1558) $64,66,75,95,96,96,98,98,100$, 100, 106 
Bullinger, Heinrich (1504-1575) 60, $83,83,126,167,173,184,201,202$, 219

Burchard, Franz $(† 1590) \quad 183,183$

Calvin, Johannes (Jean Cauvin) (1509-1564) 43, 45, 77, 89, 90, $90,114,125,126,126,127,127,146$, $169,170,172,177,177,181,184,219$

Camerarius, Joachim (1500-1574) $50,53,54,56,56,57,58,59,62,64$, $67,69,69,105,179$

Canisius, Petrus (1521-1597) 141, 167,167

Carpaccio, Vittore (ca. 1465-1526) 37

Casa, Giovanni della (1503-1556) 81

Cellarius, Johannes 52

Cellarius (Borrhaus), Martin (14991564) 52

Charles V, Emperor (1500-1558, r. 1519-1556) $67,78,80,91,94$, 121, 139, 142

Chemnitz, Martin (1522-1586) 128, 180, 203, 209

Chizzola, Ippolito (1522-1565) 11, 42

Christian III, King of Denmark and Norway (1503-1559, r. 1534-1559) 104

Christoph, Duke of Württemberg (1515-1568, r. 1550-1568) 57, 70, $85,114,143,196,225$

Chytraeus, David (1530-1600) 114, 129

Cicero, Marcus Tullius (106 BC$43 \mathrm{BC}) 36$

Colerus, Jacob (1537-1612) 222, 222
Colerus, Mathias (1530-1587) 160

Consul (Konzul), Stephan (Stipan) of Istria (1521- ca. 1579) 165

Contarini, Gasparo (1483-1542) 37, 37,70

Copus (Köppe), Martin († 1581) 124, 125

Corro, Antonio del (1527-1591) 198, 198

Crailsheim, Johannes von (15241594) $220,221,226$

Cranmer, Thomas, Archbishop of Canterbury (1489-1556, r. 15331556) 70

Crell, Paul (1531-1579) 101

Cruciger, Caspar, the Elder (15041548) 86,95

Crusius, Martin (1526-1607) 57

Curzolo, Jacopo 82

Dalmata (Dalmatin), Anton (ca. 15001579) 165

Dávid, Ferenc (1510-1579) 104, 104

Dietrich, Veit (1506-1549) 56, 63, 83,174

Dilthey, Wilhelm (1833-1911) 188

Dionysius the Areopagite, Saint (ca. 1st century) 222

Donà (Donato), Francesco, Venetian Doge (ca. 1468-1553, r. 15451553) 81

Dürfeld, Christoph († 1583) 153

Dürnhofer, Laurentius (1532-1595) 176

Eber, Paul (1511-1569) 77, 77, 86f., 100, 101, 137 
Eck, Johannes (1486-1543) 180

Edward VI, King of England (15371553, r. 1547-1553) 102

Egenolff, Christian (1519-1598) 119

Eggerdes, Petrus (Peter) ( $†$ after 1593) 24

Egnazio, Giovanni Battista (Giambattista Cipelli) (ca. 1478-1553) 35f., 35-37, 61, 84f.

Epiphanius, Bishop of Salamis, Saint (ca. 315-403, r. 367-403) 67, 67f.

Erasmus of Rotterdam, Desiderius (1466-1536) 35f., 36, 50, 61, 215f., 216,217

Erastus (Lüber), Thomas (1524-1583) 172,172

Estienne, Robert (1503-1559) 216

Eusebius of Caesarea (260/264-339/ 340) 118

Faber, Aegidius (1490-1558) 115

Faber, Basilius (1520-1576) 204

Fabri, Johannes (1504-1558) 93, 93

Fabricius, Andreas (1530-1577) 149

Fabricius, Theodore (1501-1570) 106, 106, 108, 108

Fagius, Paul (ca. 1504-1549) 39

Farnese, Alessandro $\rightarrow$ Paul III

Farnese, Alessandro, the Younger (1520-1589) 84

Faust(us), Michael (ca. 1483-1561) 64,64

Ferdinand I, Archduke of Austria, King of the Holy Roman Empire of the German Nation (1503-1564, r. 1521-1564, 1558-1564) 138, 142

Fichard, Johann (1512-1581) 227
Finck, Solomon (1566-1629) 172

Flacius Illyricus, Matthias, the Younger (1547-1593) 58, 68, 68, 87,221

Flacius, Anna (married 1577) 178

Flacius, Daniel († after 1597) 23, 222, 226

Flacius (neé Faust), Elisabeth († 1564) 64, 67, 87, 88

Flacius (neé Ilbeck), Magdalena († 1579) 186, 220, 227

Flinner, Johannes (1520-1578) 199, 199

Forster (Förster), Johannes (14961556) $58,58,61$

Forwerck, Gregor († 1576) 178

Franck, Sebastian (ca. 1499-ca. 1543) 169

Fraxineus (Eschner), Johannes († 1606) 226, 226

Frecht, Martin (1494-1556) 115

Frede, Henning (mentioned 1557) 128

Frideland, Lampridio (mentioned 1575) 226

Friedensburg, Walter (1855-1938) 31,87

Friedrich III, Elector Palatinate (15151576, r. 1559-1576) 166f., 167, $168,170,200$

Friedrich II, Duke of Liegnitz und Brieg (1480-1547, r. 14991547) 115,135

Fröschel, Hieronymus (1527-1602) $46,46,48$

Fröschl, Josef von Marzoll (mentioned 1563) 179 
Fuchs, Leonhart (1501-1566) 58, 58

Fugger, Johann Jakob (1516-1575) 48

Fugger, Ulrich (1526-1584) 48, 72

Funck, Johannes (1518-1566) 182, 182

Gadamer, Hans-Georg (1900-2002) 188

Gallus (Hahn), Nikolaus (15161570) 24, 88, 88f., 98, 103-105, 105f., 108, 113, 114, 114, 116f., 129, $136,160,160,162,164,167,177$, 178, 186, 186f., $197 f$.

Gamersfelder, Sigmund (1547-1603) 178

Garbitius (Grbac, Grbić), Matthias (Matija) (ca. 1505-1559) 31, 31, 53-57, 53-57, 58, 61, 65, 67, 71

Garbitius, Christoph (mentioned 1554) 56

Garbitius, Magdalene (1555-1616) 57

Garbitius, Margarete (married 1538) 56

Garbitius, Matthias, the Younger (1547-1591) 56

Gasser, Achilles Pirmin (1505-1577) 11, 39, 44-46, 44-46, 47f., 48, 160, 214

Gentili, Valentin († 1566) 104

Georg II, Duke of Liegnitz and Brieg (1523-1586, r. 1547-1586) 115

Georg III, Prince of Anhalt-Dessau (1507-1553, r. 1530-1549) 100

Gerlach, Conrad († 1596) 106, 106

Gerson, Jean Charlier de (13631429) 91
Gessner, Conrad (1516-1565) 51f., 52,125

Goldstein, Killian, the Elder (14991568) 61

Goulart, Simon (1543-1628) 120

Granvella, Nicolas Perrenot (14861550) 180

Grau, Johannes (1483-1559) 143

Gremp von Freudenstein, Ludwig (1509-1583) 58, 58

Grevenstein, Anton $(\dagger 1572) \quad 128$

Gribaldi, Matteo Moffa (ca. 15051564) 82

Gromann, Peter (mentioned 1574) 222

Grumbach, Wilhelm von (1503-1567) 186

Grynaeus (Grynäus), Simon (14931541) 50, 50, 51f., 52, 71, 71

Gučetić (Gozze), Petar (1493-1564) 30

Gugger, Philipp (mentioned 1562) 165

Guttich, Matthias (mentioned 1544) 83

Gwalther, Rudolf (1519-1586) 219

Haintzel, Johann Baptist (15241581) 41, 41, 43f., 43f.

Haller (Hallerstein), Joachim von (1524-1570) 174

Haller, Wolfgang († after 1587) 162, 162

Hamelmann, Hermann (1526-1595) 196

Hardenberg (Rizaeus), Albert (15101574) $128,128,154$ 
Harsdörfer (Harsdörffer), Christoph (1505-1578) 178, 178

Harsdörfer (Harsdörffer), Maria $(\dagger 1619) \quad 178$

Hartmann, Joachim (mentioned 1567) 196

Hartmann, Wolfgang (mentioned 1595) 48

Harvell, Edmund, »Sigismund « $(† 1550) \quad 83$

Hase, Hans Christoph von (19072005) 131f., 132, 133f.

Haubold, Hieronymus (ca. 15351579) 187,187

Havemann, Christian (mentioned 1557) 128

Heerbrand, Jakob (1521-1600) 226

Heinrich-Julius, Duke of Braunschweig-Lüneburg und Prince of Braunschweig-Wolfenbüttel (15641613, r. 1589-1613) 227

Heldelin, Caspar (1505-1558) 39f., 202f., 225

Heldelin, Caspar, the Younger (ca. $1552-\dagger$ after 1577) 38, 39

Helding, Michael (1506-1561) 90, 90f., 99, 141

Heling, Moritz (1522-1595) 174, 176,176

Heller, Joachim (1518-1590) 174, 174, 176, 176, 177-179, 179

Henninges, Friedrich (ca. 14951563) 89

Henry VIII, King of England and Ireland (1491-1547, r. 1509-1547, 1541-1547) 83

Herberstein, Sigismund von (14861566) 44
Herbst, Chrétienne 50

Hermann of Neuenahr and Moers, Count (1520-1578, r. 1552-1578) 196

Herwart, Wolfhart Peter (15141585) $11,41,41,42$

Heshusius (Hesshus), Tilemann (1527-1588) 24, 46, 48, 166, 167, $167,173,201,209,221 f$.

Heusenstamm, Sebastian von (15081555) 31,90

Heußler (Häussler, Hausler), Christoph $(\dagger 1578) \quad 176$

Heußler, Leonhard (1548-1597) 176

Hildegard of Bingen (1098-1179) 121

Hilten, Johann (1425-1507) 121

Hiltner, Johannes (1485-1567) 162, 162

Hidfeld (Hitfeld), Ambrosius (mentioned 1557) 128

Hoffmeister, Johannes (1509-1547) 137

Hosius, Stanislaus (1504-1579) 114, 167,167

Houwaert, Balthasar (1525-1578?) 196, 197, 197

Hügel, Andreas (1499-1572) 139, 143, 145, 147, 148, 153

Hus (Huss), Jan (Johann) (ca. 13691415) $101,101,121$

Hyperius (Gerhard), Andreas (15111564) $43,125,125$

Ilbeck (Ilpeck), Erasmus (mentioned 1567) 186,186

Irenaeus, Christoph (1522-1595) 24, 178, 202, 204 
Irenaeus (Ehrenfried), Wolfgang (married in 1577) 178

Irtenberger (Irrtenberger), Thomas $(† 1590) \quad 178,178$

Israel, Georg (1505-1588) 101

Jerome of Prague (1379-1416) 101

Jerome, Saint (ca. 347-420) 53, 53, 188

Joachim Fiore from Calabria (ca. 1135-1202) 121

Joachim I Nestor, Elector of Brandenburg (1484-1535, r. 14991535) 75

Joachim II Hector, Elector of Brandenburg (1505-1571, r. 15351571) 143

Joachim von Ortenburg (15301600) 179

Johann Albrecht I, Duke of Mecklenburg (1525-1576, r. 15471576) $109,109,182$

Johann Friedrich I, »John the Magnanimous «, Elector and Duke of Saxony (1503-1554, r. 1532-1547, 1547-1554) 21, 31, 67, 78, 83f., 137,146

Johann Friedrich II, Duke of Saxony (1529-1595, r. 1554-1567) 121, 135f., 138f., 140, 140, 143-145, 153$155,155,162,186,231$

Johann Friedrich III, Duke of Saxony $(1538-1565$, r. 1557-1565) 121, 136,138

Johann Friedrich IV, Duke of Saxony (1559-1560) 153

Johann Georg, Elector of Brandenburg (1525-1598, r. 1571-1598) 221
Johann Wilhelm I, Duke of Saxony (1530-1573, r. 1554-1572) 121, 136,138

Johannes de Rupescissa (Jean Roquetaillade) (ca. 1310-1366) 121

Johannes Teckler (1525-1580) 221

John Chrysostom, Archbishop of Constantinople, Saint (ca. 347407) 137

Jonas, Justus (1493-1555) 95, 95

Jud, Leo (1482-1542) 219

Judex (Richter), Matthaeus (15281564) 124, 124f., 128, 148, 148, 149, 154f., 154f., 160, 167

Julius, Duke of Braunschweig-Lüneburg und Prince of BraunschweigWolfenbüttel (1528-1589, r. 15681589) 221

Karlstadt, Andreas Bodenstein von (1486-1541) 51, 52, 171

Kawerau, Gustav (1847-1918) 102, 106

Kingsattler (König), Johannes (14861534) 56

Klebitz, Wilhelm (ca. 1533-1568) 167,168

Klingenbeck, Conrad (1526-1567) $176,176,179$

Klombner, Matthias (Matija) (ca. 1520-1569) 164, 164f.

Knorr, Bonaventura ( $\dagger$ after 1563) 184,187

Koch (Coccius), Huldrich (15251585) 201

Krage, Tilemann (1520-1577) 128

Krell (Krelj), Sebastian (15381567) 49, 160, 164, 164, 165, 223 
Kreutzer (Creuzer), Georg († 1587) 200

Kreutzer, Veit $(\dagger 1578) \quad 70,86,99,102$

Kyber, David (1525-1553) 199

Kyber, Elias († 1569) 199, $199 f$.

Kyber, Lucius $(† 1554) 199$

Lagus, Josua (ca. 1535- † after 1583) 166

Lampadius, Auctor (ca. 15001559) 79

Lando, Pietro (1462-1545) 81, 83, 83

Lang, Andreas (†1583) 187

Langemak, Gregor (1671-1731) 222

Languet, Hubert (1519-1582) 67, $104,125,125$

Lasco (Łaski), Johannes à (Jan) (14991560) $126,128,181$

Lasius, Christoph (1504-1572) 49, 49

Lautenbach, Conrad (1534-1595) 163

Lescher(us), Martin (mentioned 1557) 129

Liebler, Georg (1524-1600) 55, 55

Lindt, William Damasus van der, »Lindanus«, Bishop of Roermond (1525-1588, r. 1562-1588) 197

Lonicer (Lonitzer), Adam (15281586) 203, 226

Lonicer (Lonitzer), Philipp (15321599) 226

Loosjes, Jakob (1874-1935) 195

Lossius, Lucas (Lukas) (15081582) 203

Lotter, Michael (1499-1556) 71, 89, 89
Luciani, Jacobea (Jakovica) 34f.

Luciani, Luciano $34 \mathrm{f}$.

Ludwig (Louis III), Duke of Württemberg (1554-1593, r. 15681593) 225,225

Ludwig IV, Landgrave of HesseMarburg (1539-1604, r. 15671604) 33

Ludwig, Duke of Stolberg (1505-1574, r. 1535-1574) 52

Lufft, Hans (1495-1584) 113, 120

Lupetino (Lupetina), Baldo (15021556) 34f., 38f., 41, 71, 80, 82, 83, $84 \mathrm{f} ., 85,86$

Lupetino (Lupetina), Ivanka $34 \mathrm{f}$.

Luther, Martin (1483-1546) 17f., 20-22, 22, 23, 30, 39, 40, 54f., 60, 62f., 62f., 64-66, 68f., 69, 71, 73, 76, 83, 83, 84, 93-95, 95, 96f., 97, 103, 106, 109f., 111, 116, 120f., 129f., 130, 131, 142, 145, 152, 168f., 179, 181, 191f., 200f., 203, 205, 207, 212, 218f., 223, 229f., 234

Machiavelli, Niccolò (1469-1527) 121

Magdeburg, Joachim (1525-1587) 24,128

Major (Maier), Georg (1502-1574) $20,65,77,86,89,93,97-101,98$ 101, 102-104, 103f., 108, 117, 120, $129,141,143,145,167,217$

Mandelsloh, Barthlold von (15211593) 221

Manutius (Manuzio), Aldus (Aldo) (1450-1515) 35f., 36

Marbach, Johannes (1521-1581) 48, 166, 172, 199f., 219 
Margaret, Duchess of Parma, Governor of the Netherlands (15221586 , r. 1559-1567, 1578-1582) 196, 197

Marulus (Marulić), Marcus (Marko) (1450-1524) 38

Mathesius, Johannes (1504-1565) $43,87,87$

Maurice (Moritz), Duke and Elector of Saxony, »Judas of Meissen« (1521-1553, r. 1541-1547, 15471553) $76,78,80,101,105 f ., 220$

Maximilian II, Archduke of Austria, King of the Holy Roman Empire of the German Nation (1527-1576, r. 1564-1576) $186,200,212,232$

Meckhart, Georg (1533-1592) 49

Medler, Nikolaus (1502-1551) 67, 67, $68,77-79,78$

Meerfeld (Mörfeld, Mehrfeld), Katharina von $(\dagger 1588) \quad 220,223$

Meienschein, Johann (mentioned 1564) 178

Meister, Joachim (1532-1587) 65

Melanchthon (Schwarzerdt), Philipp (1497-1560) 15, 17f., 31, 33, 36, $36,38,38,40,41,44,51,53-55,53-$ 55, 56f., 57, 58f., 59, 60, 62, 64-67, 64-67, 68-70, 69f., 71, 75, 83, 83, $86,86,87,90,93,95,95,96,98$, 99, 102f., 103-105, 110f., 112-114, 112-114, 120, 123, 124f., 129, 137f., 140-142, 142, 147-149, 149, 167f., 170, 170, 174, 179, 180, 180f., 201, 203, 206-208, 215, 229, 234

Melanchthon, Anna (1522-1547) 55, 55

Melissander (Bieneman), Caspar (1540-1591) 163, 226
Mencke, Johann Burckhardt (16741732) 48

Menius, Justus (1499-1558) 70, 77, 86, 103, 103f., 145

Menzel, Hieronymus (1517-1590) 39

Merckel (Marcellus), Heinrich (Hinricus) († after 1585) $\quad 88,88$

Merckel (neé Hahn (Gallus), Margarethe (mentioned 1564) 88

Meshov, Arnold (1591-1667) 35

Meyenburg, Michael (1491-1555) 149

Micyllus, Jacob (1503-1558) 54

Mirković, Mijo (1898-1963) 18, 30, $33,34,35,50,57,67,113,155,160$, 164,186

Molitor, Caspar († 1562) 154

Monner, Basilius (ca. 1500-1566) $46,140,140$

Morgenstern, Benedict (1525-1599) 181, 181, 182f., 183

Mörlin, Joachim (1514-1571) 114, 114, 141, 166, 180, 182, 182, 209

Mörlin, Maximilian (1514-1581) $143,144,145,154$

Möstel, Wolfgang (1497-1575) 144

Münster, Sebastian (1488-1552) 51

Musaeus (Musäus), Simon (15211576) $64,143,145,148,148$, 149f., 154, 162, 221

Musculus, Andreas (1514-1581) 114, 221,221

Muzio, Girolamo (1496-1576) 85

Myconius (Molitor), Oswald (14881552) 51f.

Necker, Georg (†1574) 151, 161, 200f., 201 
Neuber, Ulrich $(\dagger 1571) \quad 178$

Niedbruck (Nidbruck), Caspar (Kaspar) von (1525-1557) 43f., 43f., $52,52,118,125,126,202$

Nuber, Veit (Vitus) $(† 1576)$ 180f., $180 f$.

Oecolampadius, Johannes (1482-1531) $51 \mathrm{f}$.

Ohmes, Otto († after 1568) 129

Olevian(us), Caspar (1536-1587) $168,172,172,173,182,186$

Opitz, Joshua (1543-1585) 186f., 187, 188

Oporinus (Herbst), Johannes (15071568) 33, 44, 50f., 50f., 52, 53f., 56, $61,70,120,124,126,150,163,222$

Oertel (Örtel, Winsheim), Veit (Vitus) (1501-1570) 62

Örtel, Andreas (mentioned 1564) 178

Osiander, Andreas (1496-1552) 20, 77, 108f., 109, 110f., 111, 112-114, 114, 115, 129f., 143, 178, 178f., 182, 234

Osiander, Katharina (1526-1562) 178

Osiander, Lucas, the Elder (15341604) 114

Osteradt, Heinrich (mentioned 1557) 128

Otfrid von Weißenburg (ca. 790875) 45

Ottheinrich, Elector Palatinate (15021559, r. 1556-1559) 136f., 136f., 143

Otto (Otho), Anton (1501-1588) 114, 128
Pagnino (Pagnini), Santes (14701541) 61, 61

Pantaleon, Heinrich (1522-1595) 35, $50,52,52,62,222$

Pappus, Johannes (1549-1610) 200, 200

Pareus (Wängler), David (1548-1622) 173

Patiens (Gedultig), Petrus (15301584) 119,226

Paul III, Pope (Alessandro Farnese) (1468-1549, r. 1534-1549) 32, 70, $81,81,84,90$

Peck, Jacob († 1571) 178, 178

Pericles (ca. 495 BC-429 BC) 55

Peristerius, Hieronymus(† 1587) 187, 187

Petrarca, Francesco (1304-1374) 121

Petreus, Heinrich (1546-1615) 119, 227, 227

Peucer (Beucker), Caspar (15251602) 149

Pfeffinger, Johannes (1493-1573) 91, 91, 117, 148

Pflug, Julius of, Bishop of Naumburg-Zeitz (1499-1564, r. 15421564) 76,91

Philipp I, Landgrave of Hesse (15041567, r. 1509/1518-1567) 143

Philipp II, Landgrave of Hesse-Rheinfels (1541-1583, r. 1567-1583) 73

Philipp II, King of Spain and Portugal (1527-1598, r. 1554-1598) 198

Phillip IV, Count of Nassau-Weilburg (1542-1602, r. 1559-1574) 139

Photius I, Patriarch of Constantinople (ca. 820-893) 121

Pisano, Aloysius 81 
Pistorius, Friedrich (1486-1553) 53, 112

Pius V, Pope (1504-1572, r. 15661572) 167

Plato (428/427 BC-348/346 BC) 68, 68,203

Poach, Andreas (1515-1585) 206

Polentz, Georg von (1478-1550) 182

Pollicarius, Johannes (1515-1562) 112,114

Porthaise, Jean (1520-1602) 198, 198

Praetorius (Schultze), Abdias (Gottschalk) (1524-1573) 124, 125

Preger, Johann Wilhelm (18271896) $18,29,63,70,141,160,163$, 216

Probst, Jakob (1486-1562) 128

Rabus, Ludwig (1523/1524-1592) 202

Ravesteyn, Josse van, »Tiletanus« (1506-1570) 197, 197

Reiffenstein, Johann Wilhelm von (ca. 1520-1575) 52, 52

Reinecker, Paul († after 1576) 204, 225

Renata, Duchess of Ferrara (René de France) (1510-1574) 85

Reuter, Quirinus (1558-1613) 173

Rhenanus, Beatus (1485-1547) 61, 137

Riedesel, Adolf Hermann, Baron $\mathrm{zu}$ Eisenbach in Hesse (15281582) $46,203,203,220$

Ritter, Matthias (1526-1588) 226, 226
Rödinger, Christian, the Elder $(† 1557) \quad 21,23$

Rolevinck, Albert (1530-1607) 69, 69

Rosenthal, Lukas (1497-1559) 128

Röser (Rosaria), Magdalene (15211555) 56

Rosinus, Bartholomaeus (1520-1586) 154

Roth, Matthias (†1575) 35, 46, 200f., 201

Roting, Michael (1494-1588) 114, 179,179

Rudiger, Adam († 1569) 144

Rupp, Tobias (1538-1588) 45f., 46, 200, 201, 202

Sabina, Duchess of Württemberg (1492-1564) 55

Sabinus (Schuler), Georg (15081560) 55,55

Socrates (469 BC-399 BC) $\quad 68,68$

Saliger (Beatus), Johannes ( $\dagger$ after 1577) 196

Sarcerius, Erasmus (1501-1559) 61, $61,128,141,145$

Sarcerius, Wilhelm (ca. 1536-1582) 39

Savonarola, Girolamo (Hieronymus) (1452-1498) 121

Schalling, Martin, the Younger (15321608) 177,177

Scheffler, Sebald (1540-1583) 201, 202

Schegk (Degen), Jakob (15111587) 55,58

Schelhammer, Johannes (1527-1605) 174,176 
Schepff, Johannes († after 1596) 46, 225

Schleiermacher, Friedrich (17681834) 62

Schneidewein, Heinrich (1510-1580) 154

Schnepf(f), Erhard (1495-1558) 49, 53, 114, 135, 138, 138, 139f., 143, 145,147

Schober (Schöber), Bartholomaeus († after 1582) 163f., 163f., 179, 179

Schröter, Johannes (1513-1593) 139, 139

Schütz, Christian (1526-1592) 149

Schwenckfeld von Ossig, Caspar (1489-1561) 20, 77, 85, 85, 99, 99, 115f., 116, 117f., 130, 136, 137, 146, $170,178,182,217,222,230$

Scotus, John Duns (ca. 1266-1308) 121

Sebaldus of Nuremberg, Saint $183 f$.

Seebass, Gotfried (1937-2008) 114

Segebade, Elard ( $\uparrow$ after 1571) 128

Selnecker, Nikolaus (1530-1592) 219

Selst, Johann (mentioned 1557) 128

Seneca, Lucius Annaeus (ca. 4 BC65) 153

Serrarius, Johannes (mentioned 1555) 184

Siber, Paul (mentioned 1560) 153

Sichard, Johannes (1499-1552) 57

Sigismund, Holy Roman Emperor (1368-1437, r. 1433-1437) 121

Simler (Simmler), Josias (1530-1576) 51

Skalich (Skalichius, Scaliger, Skalić) Paul (1534-1575) 24, 124f., 182, 182
Sleidan, Johannes (1506-1556) 43

Sophocles (ca. 496 BC-405/406 BC) 55

Spalatin, Georg (1484-1545) 95

Spangenberg, Cyriacus (1528-1604) 46, 46, 48, 48, 196, 202

Spangenberg, Johannes (1484-1550) 49, 102

Spangenberg, Magdalena (married 1577) 39

Speratus, Paul (1484-1551) 182

Sperber, Erhard (1529-1608) 180, 180, 181

Speziale (Speciale), Pietro (14781554) 83,85

Spiera, Francesco (ca. 1502-1548) 81f., 82

Stabenau, Michael von († 1595) 222

Stancaro, Francesco (1501-1574) 147

Staphylus, Friedrich (1512-1564) 87, 114,167

Stifel, Michael (1487-1567) 96

Stoltz, Johann (1514-1556) 64, 148

Stopler, Johann $(† 1553) \quad 54$

Stössel, Johann (1524-1576) 140, $143,144,145,148,154 \mathrm{f}$.

Strele, Bartholomaeus ( $\dagger$ after 1565) 129

Strigel(ius), Victorin (Viktorin) (1524-1569) 137-139, 139, 140, 143, 145, 147-150, 152f., 162, 193

Stupanus, Johannes Nikolaus (15421621) 222

Suetonius, Gaius Tranquillus (ca. 69122) 36

Suleiman I, Sultan of the Ottoman Empire, »the Magnificent« (14941566, r. 1520-1566) 231 
Sulzer, Simon (1508-1585) 52, 201f., 220

Szigeti (Zigerius), Imre (Emericus; Emerich), Eszéki († after 1551) $21 f$.

Tanner, George (ca. 1520-ca. 1584) $68,125,125$

Tauler, Johannes (ca. 1300-1361) 121

Teckler, Johannes (ca. 1525-1580) 221

Thangel, Lukas († 1590) 154

Thaurer, Benedikt (mentioned 1577) 39

Thomas Illyricus (1484-1528) 30

Thucydides (ca. 460 BC-ca. 400 BC) 203

Timann, Ditmar 128

Timann, Johann »Amsterdamus« (1500-1557) 128

Toledo, Fernando Álvarez de, 3rd Duke of Alba (1507-1582) 197

Trevisano, Marc Antonio (ca. 14751554) 85

Tronaesius, Emanuel Philips (mentioned 1567) 198, 198

Truber (Trubar), Primus (Primož) (1508-1586) 24, 94, 94, 130, 165

Tucher, Anna (ca. 1511-1565) 88

Tucher, Stephan (ca. 1510-1550) 88, 88

Twesten, August Detlev (1789-1876) $62 \mathrm{f}$.

Ulenberg, Caspar (1549-1617) 35

Ulrich I, Duke of Württemberg (1487-1550, r. 1498-1519, 15341550) 56
Ungnad, Hans III, Baron of Sonnegg (1493-1564) 156, 164, 164, 165

Ursinus, Zacharias (1534-1584) 166, $168,170,173$

Valla, Lorenzo (ca. 1407-1457) 121

Vergerio, Giovanni Battista, Bishop of Pula (ca. 1492-1548, r. 15321548) 80f., 81

Vergerio, Pietro Paolo, the Younger, Bishop of Modruš and Capodistria (1498-1565, r. 1536-1549) 11, 24, 32f., 41, 42, 57, 70, 80, 82, 84f.

Vermigli, Peter Martyr (1500-1562) 203

Vida, Ottonello († 1551) 85

Viereckel, Wolfgang (mentioned 1574) 187, 187

Vlačić, Andrija (ca. † 1532) 34

Vollrad (Volrath) V of Mansfeld, Count (1520-1578, r. 1560-1578) 204, 221

Vorstius, Johannes († 1599) 196

Wagner, Marcus (1528-1597) 124, 124f., 159

Waldner, Wolfgang (ca. 1519-1583) 114, 129, 129, 177, 177-179, 188

Waldo, Peter (ca. 1140-ca. 1218) 122

Wallenrod, Matthes von (†1572) 154

Walther, Philipp $(†$ 1553) 85

Weichßner (Weixer), Hans (mentioned 1553) 116

Weickersreutter, Johannes (ca. 15481622) 57

Werner, Johann Sigismund (14911554) 115 
Wesenbeck, Matthias (1531-1586) 154

Wesling, Andreas († 1577) 110

Westphal, Joachim (1510-1574) 49, $89,126-129,127,177,196$

Wieland, Israel (1543-1633) 55

Wiener, Paul (1495-1554) 24

Wigand, Johannes, Bishop of Pomerania and Samland (1523-1587, r. $1575 / 1577-1587) \quad 20,39,45,45$, $46,48,70,124,124 f$., $128,148,148$, 149, 154f., 159, 160, 167, 187, 204, 209, 232

Wilhelm IV, Landgrave of Hesse-Kassel (1532-1592, r. 1567-1592) 33

Willer, Georg (mentioned 1574) 222

William (Wilhelm) I, Prince of Orange, Count of Nassau-Dillenburg (1533-1584, r. 1544-1584) 195, 195, 197, 197

William, Duke of Jülich-Cleves-Berg (1516-1592, r. 1539-1592) 195

Winter, Balthasar (†1561) 148, $153 f$.

Wissenburg, Wolfgang (ca. 14961575) 52,52

Wittich, Hieronymus (†1553) 115, 115
Witzel, Georg (1501-1573) 91, 91

Wolf, Hieronymus (1516-1580) 48, 48

Wolff, Martin (ca. 1515-1578) 144, 196

Wolfferam, Johannes (1530-1598) 226

Wolffhart (Lycosthenes), Conrad (1518-1561) 50

Wolfgang, Count of Palatinate-Zweibrücken $\quad(1526-1569$, r. $1532-$ 1569) 11, 143, 185

Wolfhart (Lycostenes), Bonifacius (ca. 1490-1543) 40, 40, 50

Zanchi, Girolamo (1516-1590) 200

Zanettini, Dionisio de, »il Grechetto«, Bishop of Chironissa and Melopotamos (r. 1538-1549) 84

Zedlitz, Sebastian von $(1521-\dagger$ after 1596) 115, 115, 221f., 222

Ziegler, Bernhard (1494-1552) 114

Zwinger, Theodor, the Elder (15331588) 50

Zwingli, Huldrych (Huldreych, Huldreich, Ulrich) (1484-1531) 127, 130, 146, 219 


\section{Index of Places}

Aachen 196, 233

Albona $\rightarrow$ Labin

Altenburg 144, 176, 219

Althausen 46

Altzelle 101

Amberg 136, 143

Amsterdam 36, 124, 153, 196, 227, 233

Anhalt 67, 79, 105, 106, 113

Antwerp 17, 20, 47, 61, 195-198, 195-198, 213, 226, 228, 233, 235

Augsburg 19, 21, 23, 24, 29, 32, 40f., 40f., 43, 43, 44, 44f., 46, 46, 48-50, 48-50, 57, 59, 63, 67, 70f., 75, 75, 76-78, 86, 90-95, 96, 100, 105, 108, 114, 115, 118., 130, 132f., 140, 142f., 159, 167, 170, 173, 173, 184, 202, 229f., 235

Austria 80, 129, 163, 164, 164, 165, $187,187,213$

Bad Windsheim 162

Barby 106, 108

Basel 19, 24, 29, 32, 32, 33f., 34f., 41, 43f., 46, 48, 50-53, 50-54, 56, 59f., $61,63,70,71,73,120,120,124,126$, 150, 163, 178, 196, 197f., 201f., 204, 212, 213, 216, 220, 229, 233

Bavaria 42, 164

Berlin 39, 44, 62, 69, 109, 113, 124, $167,172,188,221,221 f$.

Bern 33, 50, 52

Bienbach 204

Bingen 53, 121

Bohemia 101, 122, 164, 187

Bologna 38
Brač (Bracia) 37

Brandenburg 75f., 108, 221

Braunschweig 21, 33, 67f., 68, 69, 75, 77, 88f., 106, 128, 141, 182

Breda 197

Bremen 128, 128, 154

Breslau $\rightarrow$ Wrocław

Brieg (Brzeg) 115, 115

Brussels 198

Buda 22

Bufleben 159

Calabria 121

Calw 56

Canterbury 70

Capodistria $\rightarrow$ Koper

Carinthia (Kärnten) 164f., 164f., 213

Chiavenna 86

Citadella 81, 85

Coburg 94f., 145, 154, 178

Cologne 91, 91, 196

Constantinople 121

Cottbus 221

Cres (Cherso) 37, 80, 82

Croatia 16, 18, 21, 30, 34, 37f., 38, 80,212

Cyprus 67

Dabrun 64, 87

Dalmatia $30,37,61,81$

Danzig (Gdańsk) 174, 180f., 180f., 182f., 183, 184, 232, 235

Denmark $104,124,130$ 
Dessau 100, 101

Diest 195

Dubrovnik (Ragusa) 30, 37

Ebersbach im Taunus 39, 48

Efferdingen 187

Eisenach 70, 103, 162, 206

Eisenbach (Castle in Oberhessen) 203

Eisfeld 143

Eisleben $39,64,102,128,166,179-$ $181,204,221$

England 102, 121

Ermland (Warmia) 114

Ferrara 85

France 30, 85

Frankfurt am Main 20, 33, 40, 48, $52,57,65,82,89,119,119,126,126$, $128,142-145,163,163,173,186$, 195, 196, 197, 198, 202, 204, 218, 220, 220, 222f., 225-227, 226f., 233,235

Frankurt an der Oder 49, 221

Friedberg (Hesse) 226

Fulda 159, 220

Geneva $83,89,126,126,170,177$, 184,216

Gengenbach in Baden 199

Geringswalde 187

Germany $18,24,26,31,39,43,53$, 67, 75, 80, 97, 131-134, 149, 171, 183, 202, 212, 221, 235

Goldberg (Złotoryja) 222

Göppingen 85
Görlitz 65

Gotha 15, 102-104, 125, 137, 159, 226, 226

Graubünden 33

Gross Kreuzhausen 204

Halberstadt $\quad 11,79$

Hamburg 49, 49, 89, 106, 126, 128 , 154, 196

Hannover 115,128

Heidelberg $16,45,51,54,54,72,77$, 123, 136, 136f., 144, 166f., 167, 171173, 172f., 214

Heilbronn 93

Helbra 196

Heldburg 140, 154

Helfta 196

Helmstedt 104

Hermannstadt (Sibiu) 24

Hesse 16, 33, 67, 83f., 139, 143, 220, 226

Hildesheim 18, 128

Holland (The Netherlands) 130, 197, 197

Hoorn 120

Hungary 21f.

Husum in Schleswig-Holstein 128

Hvar (Lesina) 37

Ingolstadt 93, 164, 166, 167

Istria $29,29,30,33 f ., 37,53,53,62$, $70,80,80,165$

Italy $54,63,83 f ., 165$

Jena $9,18,20,33,39,43,46,49 f$., 64 , $66,69,73,88,95 f ., 129,135-137$, 
135-137, 138-141, 139-141, 143f., 144-146, 146-149, 148f., 153f., 153f., 155, 159f., 160, 164, 164, 167, 177, 178f., 186, 201, 204, 226, $231 \mathrm{f}$.

Jerusalem 31

Kahla 144

Kemberg 64

Klagenfurt $\quad 165,165,187,232$

Königsberg(Kaliningrad) 108,108f., $111,180,182,182$

Königstein im Taunus 226

Koper $70,80,84 f ., 85$

Köthen $\quad 67,105 f .$, 105f., 107f., 113, 113

Krk (Veglia) 81

Kronberg im Taunus 39

Küstrin 49

Kvarner Gulf (Quarnaro) 80

Kwidzyn 182

Labin 9, 16, 30, 33f., 33f., 35, 85, 97, 165,229

Lähn (Wleń) 222, 222

Lähnhaus, Castle (Zamek Wleń) 222

Laibach $\rightarrow$ Ljubljana

Langenau (Czernica) 222

L'Aquila (Aquilla) 82

Lauingen 226

Leiden $36,41,98,115,117,120,128$, 140, 147, 172, 191, 197f.

Leipe (Lipin) 222

Leipzig $\quad 20,24,36,48,53 f ., 56,56$, $58 f ., 61,64,67,69-71,77,77,89,91$, 97, 101, 104, 117, 127, 136, 148, 148, 179, 181f., 187f., 227

Liegnitz (Legnica) 115
Lindau am Bodensee $16,39,45,46$, 46, 47, 70, 151, 161, 200f., 200-202

Ljubljana 16, 24, 49, 106, 107, 164f., 164f., 223, 229

Louvain (Leuven) 30, 36, 197, 197

Löwenberg (Lwówek Śląski) 183

Lübeck 128, 163, 226

Lucca 200

Lüneburg 89,128

Lyon 61,122

Magdeburg 17, 19, 21, 23, 23f., 31, $32,32,38,41,43,49,49,52,62$, 65-67, 68-70, 69f., 71, 75f., 76, 77, $78,81,82,82,87 \mathrm{f} ., 88,89,90 f ., 92 \mathrm{f}$. , 93-97, 98, 98, 99, 101-103, 105f., 105f., 108, 108-110, 113f., 113-115, $116,116,118 \mathrm{f} ., 126-128,126-129$, $130,130,131,135,136,137,148 f$. , $160,167,178 f ., 183,184,184,222$, 226, 228, 230f., 234

Mainz 15f., 31, 35, 58, 90, 91, 98, 120,162

Mansfeld 39, 46, 102, 128, 141, 145, 179, 187, 195, 195f., 204, 221, 225

Mansfeld-Hinterort 102

Marburg 43, 113, 125, 125, 141, 157

Marienwerder $\rightarrow$ Kwidzyn

Mecklenburg 109

Meissen 101

Merseburg 91, 98, 99, 101, 141

Milan 35, 35, 85

Moers 196

Mömpelgard (Montbéliard) 213

Morstein (Hohenlohe) 220, 226

Mulhouse 52, 226

Munich 167

Mühlberg 80 
Mühlhausen $\rightarrow$ Mulhouse

Nassau 16

Naumburg an der Saale 46, 159, 160

Neukirch an der Katzbach (Nowy Kościół nad Kaczawa) 115, 221f.

New York 132

Nordhausen $128,149,149$

Norway 104

Nuremberg 53, 54, 54, 63, 108, 112, $114,116,127,129,129,159 f ., 160$, $163,174,174,175-179,176-179$, 182f., 183, 184, 232, 235

Obersulz 187

Oettingen 204

Orlamünde 154

Oxford 215

Padua $38,81,82,164$

Palatinate (Pfalz) 136f., 137, 143, 166f., 170, 186

Paris 30,216

Parma 196, 197

Pićan (Pedena) 53f.

Poland 115, 130, 167, 181

Pomerania (Pomorze) 98

Pomesania 182f.

Prague 101, 101, 162

Prussia (Royal, Polish, Ducal) 45, 108f., 109, 113, 113, 114, 180, 180f., 182, 182-184

Pula (Pola) 18, 29, 34, 80, 80, 81, 185, 212

Rab (Arbe) 37
Regensburg 16, 20,33, 45, 49-51, 59, $105,105,116,129,130,136,139$, 159f., 160, 162f., 162f., 164f., 165f., $175,177,177,178 \mathrm{f} ., 180,182,184-$ 188, 186-188, 212, 220, 232, 235

Riesenburg (Prabuty) 182f.

Rijeka (Fiume) 81

Rome 23, 70, 86, 91, 98, 121f., 235

Römhild 144

Rostock 68, 110, 110, 124, 181, 183

Rothenburg ob der Tauber 94

Rudolstadt 159,178

Salzburg 163

Samland, Bishopric in Prussia 109, 182, $182 f$.

Saxony, Albertine 78, 80, 91, 139, 149

Saxony, Ernestine 20, 139f., 144, 148, 156, $231 \mathrm{f}$.

Schwerin 110,128

Scotland 124

Sélestat 137

Šibenik (Sebenico) 81

Siebenbürgen (Transylvania) 24, 104, 104

Silesia (Schlesien) 115, 183, 221, $221 f$.

Slovenia 80,130

Spain 198, 198

Split 38

Staffelstein (Bad Staffelstein in Franken) 174

Steyr 129

Stolberg 52

Ston 30 
Strasbourg (Argentoratum) 20, 40, 40, 43, 45, 45f., 50f., 58, 61, 93, 116, $116,125,136,137,163,166,172$, 198-200, 199f., 201, 204, 213, 213, 219f., 222, 225, 228, 233, 235

Stuttgart 25, 41, 50f., 57, 85, 94, 122, $168,174,191,198,225$

Styria (Steiermark) 213

Sulzbach 143

Sülzfeld in Franken 179

Swabia (Schwaben) 114, 114, 115

Sweden 121

Switzerland 33, 202

Teutleben 204

Thorn (Toruń) 181, 181, 183

Thuringia (Thüringen) 136,160

Trent (Trento) 33, 38, 38, 81, 93, 97, 111, 141, 198

Treviso 83,83

Trieste 80

Trogir (Tragurium) 81

Trügleben 226

Tübingen 19, 22-24, 30, 30, 41, 43, 51, 53, 53, 55-58, 55-58, 59f., 61, $63,64,70,71,71,76,85,94,109 f$., $114,124-126,165,188,200,202$, $213,218,219,226,229,233$

Udine (Weiden) 54

Ulm 117, 202

Urach (Bad Urach) 156, 165, 165

Utrecht 36

Val Bregaglia 33

Vatican 48
Venice 19, 29, 29, 30, 33f., 35, 35, 37f., 37f., 39-41, 63, 70, 71, 80, 82, 83f., 83f., 85f., 85f., 215, 229, 231, 233

Vicenza 83, 83, 84

Vienna 21, 43, 44, 52, 68, 124, 125 , $126,139,164,186,200$

Weida 144

Weimar 46, 136, 138, 140f., 143f., 144, 145, 148, 150f., 153, 154-156, $156,159,160,162,163,189,193,204$

Weißenburg (Wissembourg) 45

Weißenfels 112

Weißenhorn 72

Wismar 109, 128

Wittenberg 19-21, 22, 30f., 31, 34, 39, 40, 41, 49, 53, 54f., 55, 56, 58f., 59, 60f., 61, 62-64, 64, 65f., 66, 67-70, 69f., 71, 73, 75-78, 84, 8688, 87f., 89, 91, 93-96, 96, 97f., 99, 100f., 101f., 103, 104f., 105f., 106, 109f., 110, 112f., 114, 115, 117, 120, $125,125,130,137,137,138,144$, $146,149,149,156,163,174,177 f$., 179, 180, 180, 181, 201, 219, 221, $222,229,234$

Woerden 196

Wolfenbüttel $26,60,227$

Worms 139-142, 141, 156, 197

Wrocław 87, 115, 144

Württemberg $16,24,55,56,57,70$, 85, 114, 114, 139, 143, 165f., 196, $213,219,225,225$

Ypres 125 
Zerbst 106, 106

Zurich 51, 60f., 83, 83, 126, 127, 173, $173,184,219$

Zweibrücken 143,185 